JOSÉ FILOMENO DE MORAES FILHO

\title{
CONGRESSO CONSTITUINTE, CONSTITUIÇÃO DIRIGENTE E ESTADO DE BEM-ESTAR
}

Doutorado em Direito Econômico e Financeiro

Orientador: Prof. Dr. Gilberto Bercovici

FACULDADE DE DIREITO - UNIVERSIDADE DE SÃO PAULO

SÃO PAULO 


\section{CONGRESSO CONSTITUINTE, CONSTITUIÇÃO DIRIGENTE E ESTADO DE BEM-ESTAR}

Tese apresentada à Faculdade de Direito como requisito parcial para a obtenção do título de Doutor.

Área de concentração: Direito Econômico e Financeiro

Orientador: Professor-Doutor Gilberto Bercovici 


\section{FOLHA DE APROVAÇÃO}

José Filomeno de Moraes Filho

Congresso Constituinte, constituição dirigente e Estado de bem-estar

Tese apresentada à Faculdade Direito da Universidade de São Paulo para a obtenção do título de Doutor.

Área de concentração: Direito Econômico e Financeiro

Orientador: Prof. Dr. Gilberto Bercovici

Aprovada em:

BANCA EXAMINADORA

Prof. Dr. Gilberto Bercovici (Orientador)

Instituição: Universidade de São Paulo-SP

Assinatura:

Prof. Dr.

Instituição:

Assinatura:

Prof. Dr.

Instituição:

Assinatura:

Prof. Dr.

Instituição:

Assinatura:

Prof. Dr.

Instituição:

Assinatura: 
Para Goretti, principalmente, e para as nossas primícias, Bernardo, Maria de Fátima e Tomás. Para Paulo Bonavides e Fernando Ximenes.

Para Marcelo Caracas Linhares e Ruy Vidal Gomes da Silva, com saudade. 


\section{AGRADECIMENTOS}

Este doutorado certamente não existiria sem a contribuição, direta ou indireta, remota ou recente, de um conjunto de pessoas e instituições. Destarte, com a manifestação de reconhecimento, faz-se imperioso o registro de presenças, que, de diversas maneiras, mas todas relevantes, concorreram para que o objetivo se convertesse em realidade.

Agradeço aos Professores-Doutores que, em aceitando a incumbência de participar da banca examinadora, a sobrevalorizaram.

A prestimosidade de Eneas de Oliveira Matos e as orientações da minha colega Luciana Costa tornaram a vida mais fácil durante a minha residência - laboriosa, mas intelectualmente prazerosa - na cidade de São Paulo.

Ao professor Gilberto Bercovici cabe o reconhecimento especial pela oportunidade que concedeu de receber-me como orientando e pela dedicada, prestativa e compreensiva presença como orientador. Exemplo de competência intelectual e seriedade profissional, Gilberto Bercovici tornou-se credor, também, dos graus de liberdade que me permitiu na elaboração deste trabalho.

Ao professor Martonio Mont'Alverne Barreto Lima, cuja amizade e diálogo intelectual, continuados, só me engrandecem, devo o enorme incentivo para que este doutorado se realizasse.

Ao Programa de Pós-Graduação em Direito da Universidade de Fortaleza, na pessoa do seu ex-coordenador, o professor Martonio, na da atual Coordenadora, professora Lilia Maia de Morais Sales, e nas dos demais colegas do Programa, externo a minha homenagem pela amizade e companheirismo que me deferem.

Ainda na Unifor, a minha homenagem é extensiva aos colegas do Centro de Ciências Jurídicas, o que faço na pessoa do seu Diretor, professor Francisco Otávio de Miranda Bezerra. Por sua vez, apresento os meus agradecimentos à professora Núbia Maria Garcia 
Bastos, Supervisora de Monografia do Curso de Direito, pelos conselhos e sugestões referentes ao rigor técnico e estético da tese.

Tenho também a minha dívida fundada de gratidão para com a Universidade Estadual do Ceará, especialmente para com os meus colegas professores do seu Curso de Ciências Sociais. Ademais, ao professor Manassés Claudino Fonteles, ex-reitor da Uece, agradeço o estímulo continuado no que concerne à minha titulação universitária.

Registro o meu reconhecimento aos meus alunos dos cursos de graduação e pósgraduação, no Ceará e fora do Ceará, com quem, ao longo da minha carreira universitária, tenho aprendido mais do que ensinado.

A Procuradoria Geral do Estado do Ceará, a cujos quadros funcionais honrosamente pertenço, tem o meu reconhecimento pelo apoio que recebi para a realização do doutorado na Universidade de São Paulo.

Para com a Faculdade de Direito da Universidade de São Paulo, só tenho palavras de atenção por me acolher no seu Programa de Doutorado em Direito Econômico e Financeiro. Sou grato aos professores das Arcadas cujas preleções freqüentei. Com eles e com os meus colegas de estudo muito pude aprender, refletindo, de maneira larga, sobre grandes problemas jurídico-constitucionais, político-constitucionais e econômicoconstitucionais.

É escusado dizer que sou o único responsável pelos senões formais e materiais presentes no trabalho, dos quais isento totalmente, inclusive, o orientador. 
[...] E quem quiser ver o presente para onde há de olhar? [...] Digo que olhe juntamente para um e para outro espelho. Olhai para o passado e para o futuro, e vereis o presente. [...].

Padre Antônio Vieira 


\section{RESUMO}

MORAES FILHO, José Filomeno de. Congresso Constituinte, constituição dirigente e

Estado de bem-estar. 2009. 299p. Tese (Doutorado) - Faculdade de Direito, Universidade de São Paulo, São Paulo, 2009.

A presente tese tem por objetivo a análise da decisão sobre a "constituição econômica", no âmbito da realização da "constituição dirigente" e da instituição do Estado Democrático e Social de Direito no Brasil, por meio do processo constituinte levado a efeito nos anos de 1987 e 1988. Partindo da constatação de que a literatura jurídico-constitucional brasileira não dá a necessária atenção à problemática constituinte nem à articulação entre Estado, Constituição e Política e tendo em vista a "constituição econômica" presente no texto constitucional de 1988, o trabalho articula os temas do poder constituinte, da constituição dirigente-econômica e da reconstrução do Estado, utilizando-se do instrumental da teoria constitucional, da teoria do Estado e da história constitucional. Avalia-se, pois, que a manifestação do poder constituinte se inscreve como locus privilegiado para a observação da correspondência entre Estado, Constituição e Política, demonstrado pela observação das suas manifestações no Brasil, em diversos momentos, nomeadamente em 1987/1988. De fato, na esteira da convocação estabelecida pela Emenda Constitucional n. 26, de 27 de novembro de 1985, o Brasil viveu um dos mais importantes momentos de ativação política da sociedade civil organizada, que dava continuidade ao processo de mudança política, o qual, iniciando-se em meados da década de 70 e prolongando-se pelos anos 80, ocasionou a inflexão do regime militar, a construção de instituições representativas e multipartidárias e a realização de uma nova Constituição. Assim, se o ritmo cadenciado das mudanças e as negociações entre os agentes que pressionavam pela abertura política e os líderes do regime burocrático-autoritário sugeriram a existência de um tipo especial de transição, denominado "transição pela transação", e apesar das limitações constantes do ato convocatório do Congresso Constituinte, o produto final do esforço constituinte ficou mais próximo das aspirações democráticas e progressistas. Constata-se que, nas duas últimas décadas, apesar das transformações que ocorreram no capitalismo, com a desconstrução do padrão regulatório keyenesiano, a expansão dos mercados, a relativização do Estado, 
enfim, a ameaça neoliberal, o caráter dirigente da Constituição brasileira, todavia, mantémse intacto. Por tudo isso, decorridos vinte anos da promulgação da Constituição Federal, conformação normativa de uma "ordem econômica, fundada na valorização do trabalho humano e na livre iniciativa", com o fim de "assegurar a todos existência digna, conforme os ditames da justiça social" (CF, art. 170, caput), representa um salto de qualidade no constitucionalismo nacional e está a desafiar a realização conjunta da democracia política, da sociedade de bem-estar e do desenvolvimento econômico.

Palavras-chave: Congresso Constituinte. Poder constituinte. Constituição Federal. Constituição econômica. 


\section{ABSTRACT}

MORAES FILHO, José Filomeno de. Brazilian Constituent Congress, Directive Constitution and Welfare State. 2009. 299p. Thesis (Doctoral) - Faculdade de Direito, Universidade de São Paulo, São Paulo, 2009.

This thesis has as its objective an analysis of the decision on the "economic constitution", within the ambit of the "directive constitution" and the establishment of the Social and Democratic State of Law in Brazil, through the constituent process carried out during the years of 1987 and 1988. In view of the fact that legal and constitutional Brazilian literature does not give the necessary attention to the problem nor the linkage between constituent State, Constitution and Politics and in view of the "economic constitution" laid out in the constitutional text of 1988, this paper articulates the themes of constituent power, "economic directive constitution" and the reconstruction of the State, using the tools of constitutional theory, theory of the state and constitutional history. So, it has been assessed that the manifestation of the constituent power comes as privileged locus for the observation of the correlation between State, Constitution and Politics, demonstrated by observing its manifestations in Brazil, at different times, particularly in 1987/1988. In fact, in the wake of the call established by the $26^{\text {th }}$ Constitutional Amendment, from November $27^{\text {th }} 1985$, Brazil experienced one of its most important moments of political awakening of organized civil society, which had been pushing for political change, from the mid-70's and into the 80 's, that led to the fall of the military regime, the building of representative institutions and the founding of multiparty system and a new constitution. Thus, if the rhythmical pace of change and the negotiations between the players that struggled for political opening and the leaders of the political and bureaucratic-authoritarian regime suggested the existence of a special type of transition, called "transition through the transaction", and despite the limitations of the call for the Constituent Congress, the final product of the effort was closer to the constitutional democratic and progressive aspirations. It appears that in the past two decades, despite the changes that have occurred in capitalism, with the abandonment of Keynes' regulatory standard, the expansion of markets, the relativization of the state, in other words, the neoliberal threat, the leading 
character of the Brazilian Constitution, however, remains intact. It can be concluded that after twenty years of the enactment of the Federal Constitution, conformation of a normative "economic order, based on the enhancement of human labor and free enterprise", in order to "ensure a dignified livelihood for all, according to the dictates of social justice" (Federal Constitution, art. 170, caput), it represents a great leap in national constitutionalism and challenges a joint realization of political democracy, social welfare and economic development.

Key-words: Brazilian Constituent Congress. Constituent Power. Federal Consitution. Economic Constitution. Welfare State. 


\section{RIASSUNTO}

MORAES FILHO, José Filomeno de. Congresso Costituente, Costituzione Dirigente e Stato di Benessere. 2009. 299p. Tesi (Dottorato) - Facoltà di Diritto, Università di São Paulo, São Paulo, 2009.

La presente tesi ha come obiettivo l'analisi della decisione sulla "costituzione economica", nell'ambito della realizzazione della "costituzione dirigente" e dell'istituzione dello Stato Democratico e Sociale di Diritto in Brasile, per mezzo del processo costituente avvenuto negli anni 1987 e 1988. Partendo dalla costatazione che la letteratura giuridicocostituzionale brasiliana non dà la necessaria attenzione alla problematica costituente e nemmeno alla correlazione tra Stato, Costituzione e Politica e considerando la "costituzione economica" presente nel testo costituzionale del 1988, il lavoro analizza i temi del potere costituente, della costituzione dirigente-economica e della ricostruzione dello Stato, utilizzando gli strumenti della teoria costituzionale, della teoria dello Stato e della storia costituzionale. Si valuta, quindi, che la manifestazione del potere costituente si iscrive come locus privilegiato per l'osservazione della corrispondenza tra Stato, Costituzione e Politica, dimostrato dall'osservazione delle sue manifestazioni in Brasile, in diversi momenti, principalmente nel 1987/1988. Di fatto, sulla scia della convocazione stabilita dall'Emenda Costituzionale no 26, del 27 novembre 1985, il Brasile ha vissuto uno dei più importanti momenti dell'attivazione politica della società civile organizzata, che dava continuità al processo di cambiamento politico, il quale, iniziandosi nella metà degli anni 70 e continuando negli anni 80, ha portato all'incrinatura del regime militare, alla costruzione di istituzioni rappresentative e multipartidarie e alla realizzazione di una nuova Costituzione. Così, se il ritmo cadenzato dei cambiamenti e le trattative tra gli agenti che pressionavano per l'apertura politica e gli esponenti del regime burocratico-autoritario hanno suggerito l'esistenza di un tipo speciale di transizione, denominato "transizione mediante transazione", e nonostante le limitazioni costanti nell'atto di convocazione del Congresso Costituente, il prodotto finale dello sforzo costituente è rimasto più vicino alle aspirazioni democratiche e progressiste. Si costata che, negli ultimi due decenni, nonostante le trasformazioni che hanno interessato il capitalismo, con lo sgretolarsi del 
modello regolatore keynesiano, l'espansione dei mercati, la relativizzazione dello Stato, infine, la minaccia neoliberale, il carattere dirigente della Costituzione brasiliana, tuttavia, si mantiene intatto. Per tutto questo, trascorsi venti anni dalla promulgazione della Costituzione Federale, conformazione normativa di un "ordine economica, fondata sulla valorizzazione del lavoro umano e sulla libera iniziativa", con la finalità di "assicurare a tutti uma esistenza degna, conforme i precetti della giustizia sociale" (Costituzione Federale, art. 170, caput), rappresenta un salto di qualità nel costituzionalismo nazionale ed è una sfida alla realizzazione congiunta della democrazia politica, della società del benessere e dello sviluppo economico.

Parole chiave: Congresso Costituente. Potere costituente. Costituzione Federale. Costituzione economica. Stato di Benessere. 


\section{LISTA DE ABREVIATURAS E SIGLAS}

$\mathrm{AC}$

ACNUR

$\mathrm{AD}$

$\mathrm{AL}$

$\mathrm{AL}$

AI

AIB

$\mathrm{AM}$

ANC

Anpocs

Arena

ARP

BA

$\mathrm{CC}$

$\mathrm{CD}$

CE

Cebrap

CED

CEE

$\mathrm{CF}$

CIDE

CICV

Clacso

$\mathrm{CN}$

CNBB

Comp.

Coord.

CPDOC

CR
Ato Complementar

Alto Comissariado das Nações Unidas para Refugiados

Aliança Democrática

Aliança Liberal

Estado de Alagoas

Ato Institucional

Ação Integralista Brasileira

Estado do Amazonas

Assembléia Nacional Constituinte

Associação Nacional de Pós-Graduação e Pesquisa em Ciências Sociais

Aliança Renovadora Nacional

Agência Reguladora de Petróleo

Estado da Bahia

Congresso Constituinte

Câmara dos Deputados

Estado do Ceará

Centro Brasileiro de Análise e Planejamento

Centro de Ensino à Distância

Centro de Estudos Estratégicos

Constituição Federal

Centro de Investigación y Docencia Económicas

Comitê Internacional da Cruz Vermelha

Consejo Latinoamericana de Ciencias Sociales

Congresso Nacional

Conferência Nacional dos Bispos do Brasil

Compilador

Coordenador

Centro de Pesquisa e Documentação de História Contemporânea do Brasil Costa Rica 


\begin{tabular}{|c|c|}
\hline CUE & Conselho da União Européia \\
\hline CUT & Central Única dos Trabalhadores \\
\hline CPEC & Comissão Provisória de Estudos Constitucionais \\
\hline $\mathrm{CS}$ & Comissão de Sistematização \\
\hline DF & Distrito Federal \\
\hline Difel & Difusão Européia do Livro \\
\hline $\mathrm{DCN}$ & Diário do Congresso Nacional \\
\hline $\mathrm{DN}$ & Diário do Nordeste \\
\hline DNPM & Departamento Nacional da Produção Mineral \\
\hline $\mathrm{EC}$ & Emenda à Constituição ou Emenda Constitucional \\
\hline ED & Esquerda Democrática \\
\hline Ed. & Editor ou editora \\
\hline ed. & edição \\
\hline Eduerj & Editora da Universidade do Estado do Rio de Janeiro \\
\hline Edusp & Editora da Universidade de São Paulo \\
\hline Eletrobrás & Centrais Elétricas Brasileiras S.A. \\
\hline Faperj & Fundação de Amparo à Pesquisa do Estado do Rio de Janeiro \\
\hline FCBR & Fundação Casa de Rui Barbosa \\
\hline FIESP & Federação das Indústrias do Estado de São Paulo \\
\hline FGTS & Fundo de Garantia de Tempo de Serviço \\
\hline FGV & Fundação Getúlio Vargas \\
\hline FSP & Folha de São Paulo \\
\hline GO & Estado de Goiás \\
\hline Idesp & Instituto de Estudos Econômicos, Sociais e Políticos de São Paulo \\
\hline Ioce & Imprensa Oficial do Estado do Ceará \\
\hline IIDH & Instituto Interamericano de Derechos Humanos \\
\hline Iuperj & Instituto Universitário de Pesquisas do Rio de Janeiro \\
\hline LC & Lei Constitucional \\
\hline LEC & Liga Eleitoral Católica \\
\hline LGDJ & Librairie Générale de Droit et de Jurisprudence \\
\hline JB & Jornal do Brasil \\
\hline $\mathrm{MCT}$ & Ministério da Ciência e Tecnologia \\
\hline MDB & Movimento Democrático Brasileiro \\
\hline MG & Estado de Minas Gerais \\
\hline
\end{tabular}


Estado do Mato Grosso

MUT

Movimento Unificado dos Trabalhadores

NLB

National Library Board

Nuclebrás

Empresas Nucleares Brasileiras S.A.

$\mathrm{OAB}$

Ordem dos Advogados do Brasil

OESP O Estado de São Paulo

Org. Organizador

PA

Estado do Pará

PAEG Plano de Ação Econômica do Governo

PCB Partido Comunista Brasileiro

PCdoB Partido Comunista do Brasil

PCUS Partido Comunista da União Soviética

PD Partido Democrático

PDC Partido Democrata Cristão

PDS Partido Democrático Social

PDT Partido Democrático Trabalhista

PE $\quad$ Estado de Pernambuco

PEC Proposta de Emenda à Constituição

Petrobrás Petróleo Brasileiro S.A.

PFL Partido da Frente Liberal

PI Estado do Piauí

PL Partido Liberal

PMB Partido Municipalista Brasileiro

PMDB Partido do Movimento Democrático Brasileiro

PN Partido Nacional

PR Partido Republicano ou Estado do Paraná

PRL Partido Republicano Liberal

PRM Partido Republicano Mineiro

PRP Partido Republicano Paulista

PSC Partido Social Cristão

PSD Partido Social Democrático

PT Partido dos Trabalhadores

PTB Partido Trabalhista Brasileiro

PSP Partido Social Progressista 


\begin{tabular}{|c|c|}
\hline PUC & Pontifícia Universidade Católica \\
\hline PUF & Presses Universitaires de France \\
\hline Radiobrás & Empresa Brasileira de Comunicação \\
\hline RBEP & Revista Brasileira de Estudos Políticos \\
\hline RIANC & Regimento Interno da Assembléia Nacional Constituinte \\
\hline RJ & Estado do Rio de Janeiro \\
\hline $\mathrm{RS}$ & Estado do Rio Grande do Sul \\
\hline RT & Revista dos Tribunais \\
\hline SE & Estado de Sergipe \\
\hline Senac & Serviço Nacional de Aprendizagem Comercial \\
\hline SP & Estado de São Paulo \\
\hline STF & Supremo Tribunal Federal \\
\hline s.d. & sem data \\
\hline $\mathrm{S} / 1$. & Sem lugar \\
\hline s.p. & sem página \\
\hline TSE & Tribunal Superior Eleitoral \\
\hline Typ. & Typographia \\
\hline $\mathrm{UCN}$ & União Cívica Nacional \\
\hline UDN & União Democrática Nacional \\
\hline UDR & União Democrática Ruralista \\
\hline Uece & Universidade Estadual do Ceará \\
\hline UFC & Universidade Federal do Ceará \\
\hline UFF & Universidade Federal Fluminense \\
\hline UFJF & Universidade Federal de Juiz de Fora \\
\hline UFRJ & Universidade Federal do Rio de Janeiro \\
\hline UFSC & Universidade Federal de Santa Catarina \\
\hline Unam & Universidad Autónoma de México \\
\hline UnB & Universidade de Brasília \\
\hline Unesp & Universidade Estadual Paulista \\
\hline Unicamp & Universidade Estadual de Campinas \\
\hline Unifor & Universidade de Fortaleza \\
\hline Unisinos & Universidade do Vale do Rio dos Sinos \\
\hline USP & Universidade de São Paulo \\
\hline
\end{tabular}




\section{SUMÁRIO}

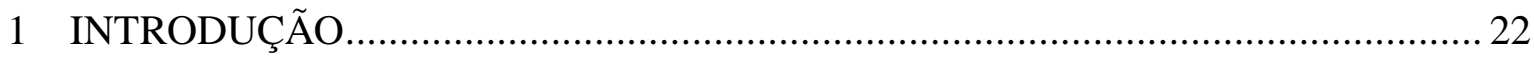

2 CONSTITUINTES E CONSTITUIÇÕES BRASILEIRAS, E ORDEM

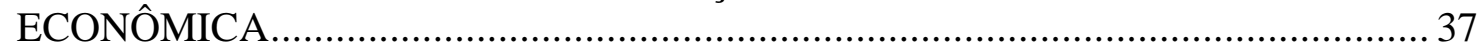

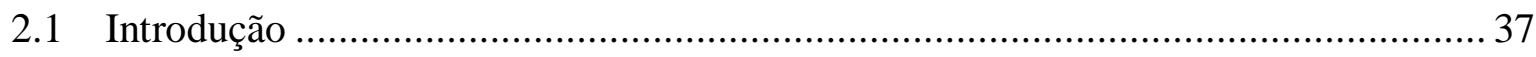

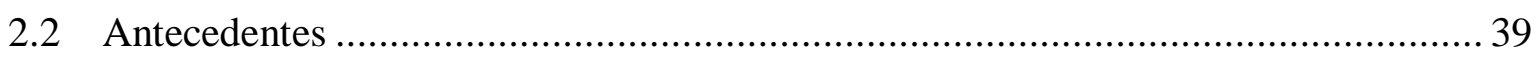

2.3 A Assembléia Constituinte de 1823 ........................................................................... 42

2.3.1 A problemática da constituição econômica............................................................. 48

2.3.2 A Constituição do Império …………………………………………………….... 50

2.4 Primeiras constituinte e constituição republicanas ………………………………........5

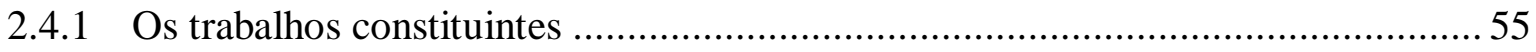

2.4.2 Os partidos políticos na Assembléia de 1891 ........................................................56

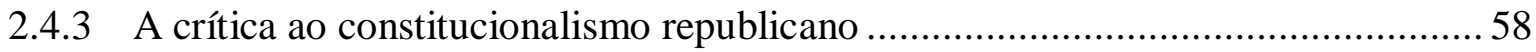

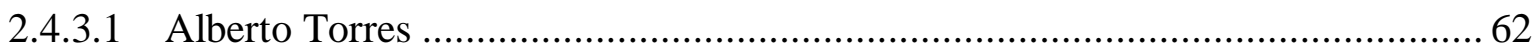

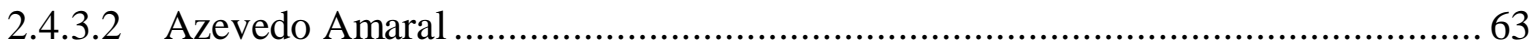

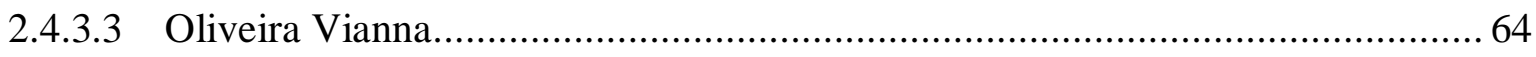

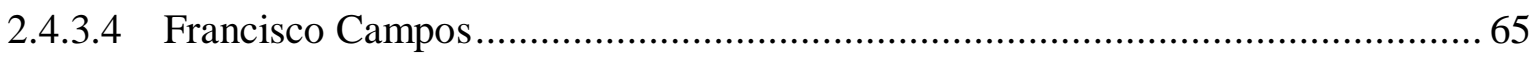

2.4.4 A "campanha do revisionismo" e a revisão constitucional de 1926..........................67 67

2.5 A Constituinte de 1933/1934 e a Constituição de 1934 ................................................. 68

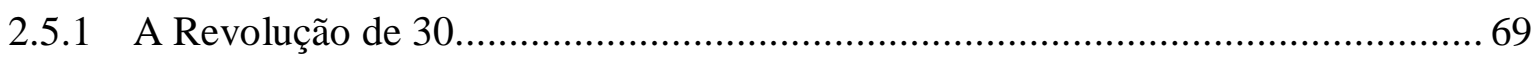

2.5.2 A institucionalização da Revolução de 30 ............................................................ 70

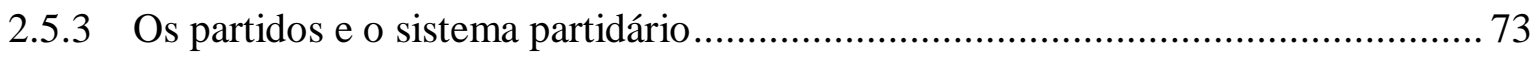

2.5.4 A luta pela Assembléia Nacional Constituinte e os seus obstáculos ........................ 76

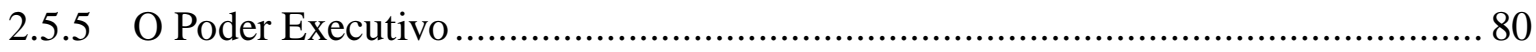

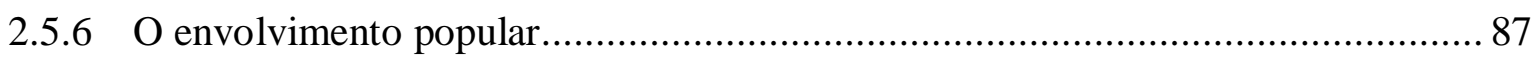


2.5.7 A evolução dos trabalhos constituintes

2.5.8 A representação popular na Constituinte .................................................... 91

2.5.9 A Assembléia Constituinte e a questão social e econômica ................................ 93

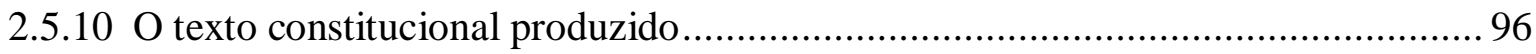

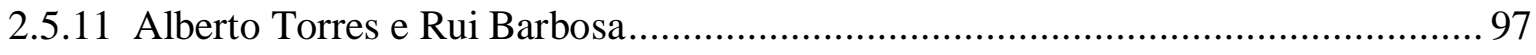

2.6 A Constituinte e a Constituição de 1946 ............................................................ 99

2.6.1 A convocação da Assembléia Nacional Constituinte ......................................... 99

2.6.2 Partidos e sistema partidário na conjuntura constituinte................................... 102

2.6.3 Partidos nacionais e hegemonia liberal-conservadora na Assembléia Nacional Constituinte

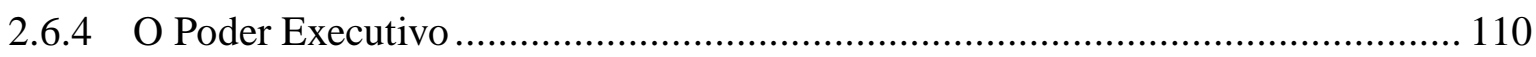

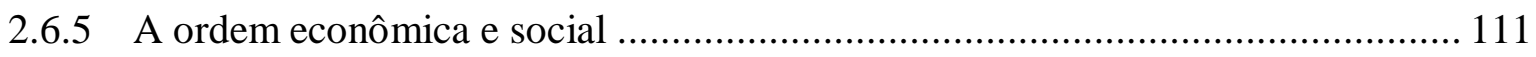

2.6.6 A representação popular na Constituinte de 1946 ............................................ 113

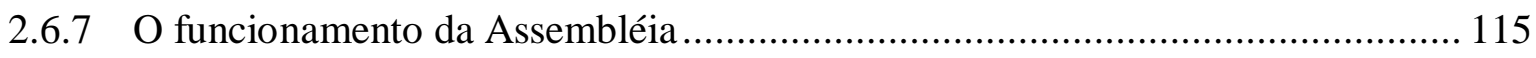

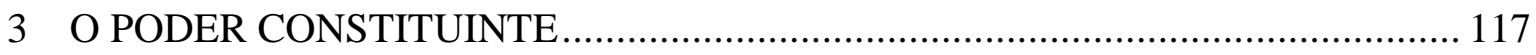

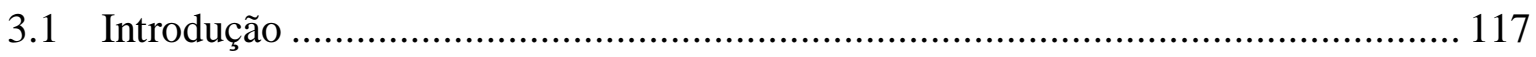

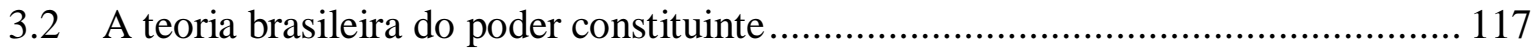

3.3 Subsídios para uma teoria brasileira do poder constituinte ................................ 121

3.3.1 Afonso Arinos de Melo Franco e a "constituinte instituída" ............................. 121

3.3.2 As eleições e a assembléia constituinte como elementos identificadores do

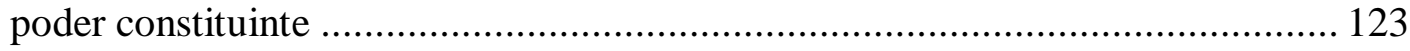

3.3.3 A disciplina jurídica do poder econômico ................................................... 124

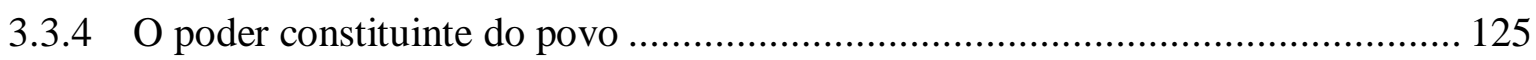

3.3.5 O poder constituinte como manifestação da elite política ................................ 126

3.3.6 Considerações a partir de Sieyès .............................................................. 127

3.3.7 O poder constituinte como "antiimaginário elitista" ..................................... 128

3.3.8 Transferência do político: da "elite" para o "povo" ........................................ 130

3.4 A retórica do retorno ao Estado Democrático de Direito ................................... 131 
3.5 O poder constituinte no Brasil e o Congresso Constituinte

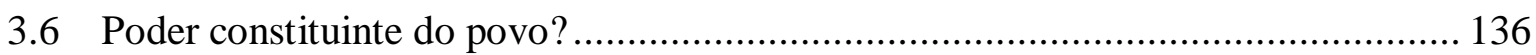

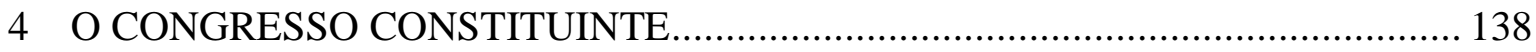

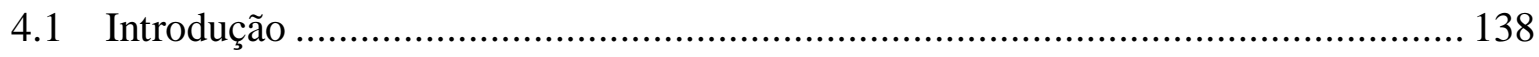

4.2 A "transição por transação" e o Congresso Constituinte ......................................... 138

4.3 Distensão, abertura e redemocratização........................................................ 140

4.4 A reativação da sociedade civil ............................................................... 145

4.5 A devolução do poder constituinte ao povo..................................................... 149

4.6 A Comissão Provisória de Estudos Constitucionais ................................................ 152

4.6.1 Os trabalhos da Comissão Afonso Arinos ...................................................... 154

4.6.2 A Comissão e o Congresso Nacional................................................................ 155

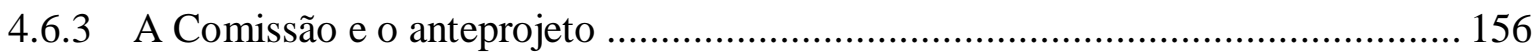

4.7 O Congresso Constituinte e o "paradoxo do êxito"............................................. 159

4.8 O debate sobre os limites dos poderes do Congresso Constituinte ........................ 162

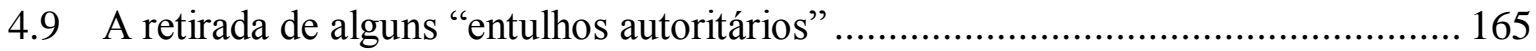

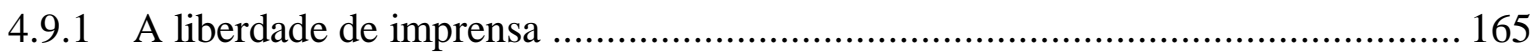

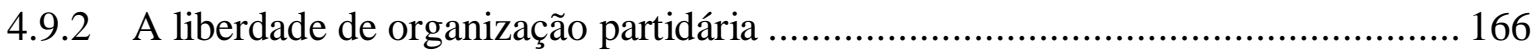

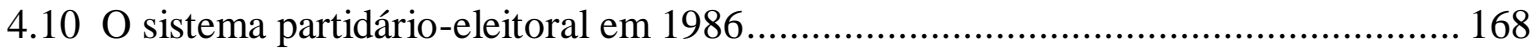

4.11 As eleições para o Congresso Constituinte .................................................... 169

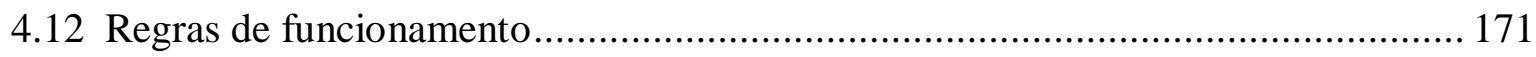

4.12.1 Conflitos e consensos na Comissão de Sistematização .................................... 173

4.12.2 O consenso originado das sessões plenárias e das votações nominais ................. 174

4.13 Interpretações sobre o trabalho constituinte.................................................. 175

5 EM BUSCA DA CONSTITUIÇÃO ECONÔMICA …........................................ 178

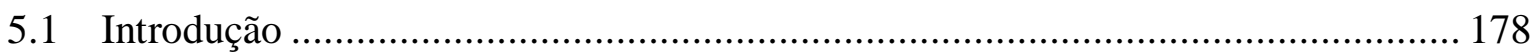

5.2 A agenda da transição e a constituição econômica .............................................. 179

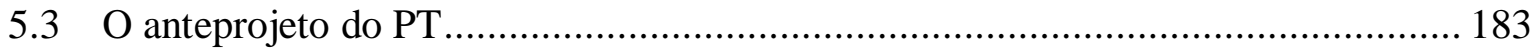


5.4 O anteprojeto da Comissão Provisória de Estudos Constitucionais e a "constituição econômica"

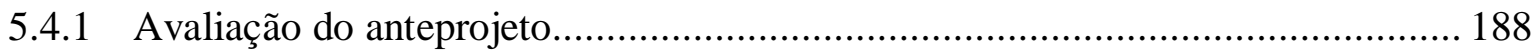

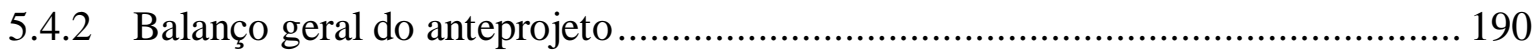

5.5 Perfil dos deputados constituintes em relação à "constituição econômica" ............ 191

5.6 A ordem econômica no debate constituinte-parlamentar .................................... 192

5.7 A construção da "constituição econômica" no texto constitucional ....................... 205

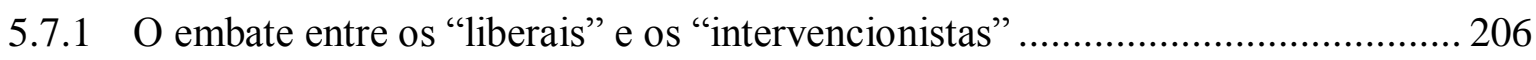

6 ESTADO DE BEM-ESTAR, DESENVOLVIMENTO E DIREITOS SOCIAIS ... 214

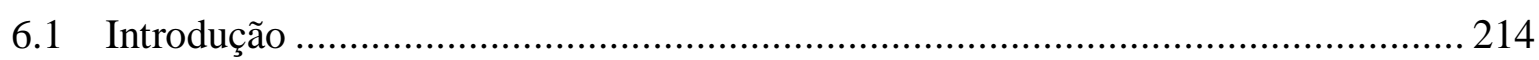

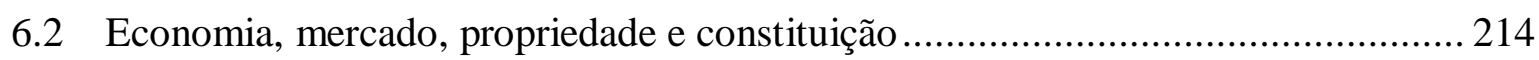

6.2.1 O mercado como instituição jurídica ........................................................ 216

6.2.2 Constituição econômica e "autonomia" do Estado.............................................. 218

6.3 A ordem econômica nas constituições brasileiras ................................................ 219

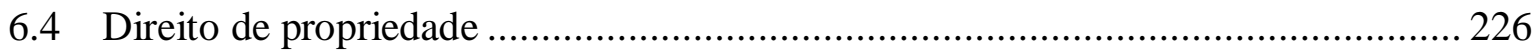

6.5 A "constituição econômica" e as emendas constitucionais .................................... 228

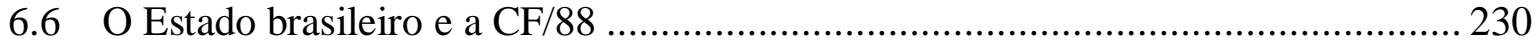

6.7 O "mal-estar da Constituição" e as "incertezas epistêmicas da directividade

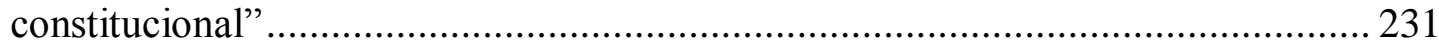

6.8 Constituição econômica e constituição financeira ............................................... 233

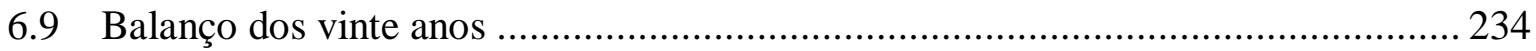

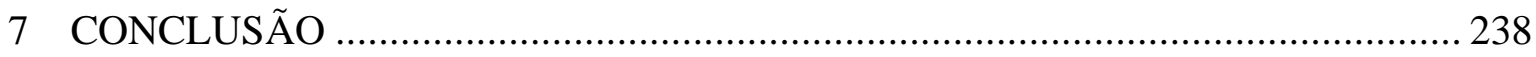

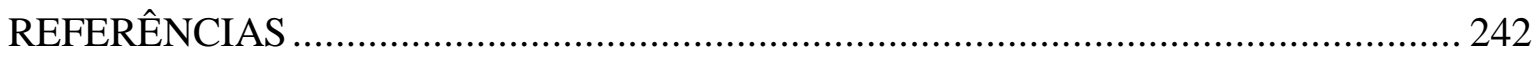

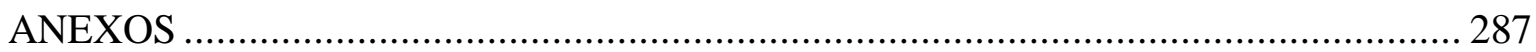




\title{
1 INTRODUÇÃO
}

\author{
[...] \\ Esta Constituição, o povo brasileiro me autoriza a \\ proclamá-la. Não ficará como bela estátua inacabada, \\ mutilada ou profanada. \\ O povo brasileiro nos mandou aqui para fazê-la, não para \\ ter medo. \\ Viva a Constituição de 1988! \\ Viva a vida que ela vai defender e semear!
}

Ulysses Guimarães

A Constituição Federal acaba de completar vinte anos de promulgação. É a terceira constituição brasileira em grau de durabilidade, após a Constituição do Império e a primeira Constituição Republicana, e visto que a Constituição de 1946 foi desnaturada a partir de abril de 1964. Ademais, não é temerário afirmar que é a mais efetiva de todas as que já se teve.

A Constituição de 1988 consagra, a partir do seu Preâmbulo, a idéia de um Estado Democrático e Social de Direito. Ali, os constituintes proclamaram-se reunidos para instituir

\footnotetext{
um Estado Democrático, destinado a assegurar o exercício dos direitos sociais e individuais, a liberdade, a segurança, o bem-estar, o desenvolvimento, a igualdade e a justiça como valores supremos de uma sociedade fraterna, pluralista e sem preconceitos, fundada na harmonia social e comprometida, na ordem interna e internacional, com a solução das controvérsias. ${ }^{1}$
}

A soberania, a cidadania, a dignidade da pessoa humana, os valores sociais do trabalho e da livre iniciativa e o pluralismo político foram erigidos como fundamentos do Estado Democrático de Direito (art. $1^{\circ}$ ), proclamando-se que o poder emana do povo, que o exercerá por meio de representantes eleitos ou diretamente.

${ }^{1}$ BRASIL. Constituição (1988). Constituição da República Federativa do Brasil. Brasília: Senado Federal, 1988. 
Carregado de programaticidade ${ }^{2}$ e diretividade, ${ }^{3}$ o texto constitucional de 1988 estabeleceu como "objetivos fundamentais da República Federativa do Brasil" a construção de uma sociedade livre, justa e solidária, a garantia do desenvolvimento nacional, a erradicação da pobreza e da marginalização e a redução das desigualdades sociais e regionais e a promoção do bem de todos, sem preconceitos de origem, raça, sexo, cor, idade e quaisquer outras formas de discriminação. No capítulo "dos direitos sociais", foram erigidos como direitos pertinentes à sociedade como um todo, a educação, a saúde, o trabalho, o lazer, a segurança, a previdência social, a proteção à maternidade e à infância, bem como a assistência aos desamparados.

Ademais, ao tratarem da "ordem econômica e financeira", os constituintes consignaram que "a ordem econômica, fundada na valorização do trabalho humano e na livre iniciativa, tem por fim assegurar a todos existência digna, conforme os ditames da justiça social”, observando-se os seguintes princípios: I - soberania nacional; II propriedade privada; III - função social da propriedade; IV - livre concorrência; V - defesa do consumidor; VI - defesa do meio ambiente; VIII - busca do pleno emprego; IX tratamento favorecido para as empresas de pequeno porte. ${ }^{4}$

${ }^{2}$ A expressão "carregados de programaticidade" está em CANOTILHO, J. J. Gomes. "Brancosos" e interconstitucionalidade: itinerários dos discursos sobre a historicidade constitucional. Coimbra: Almedina, 2005a, p.104.

${ }^{3}$ Ver, entre outros, CANOTILHO, J. J. Gomes. Constituição dirigente e vinculação do legislador: contributo para a compreensão das normas constitucionais programáticas. 2. ed. Coimbra: Coimbra Editora, 2001; e CANOTILHO, J. J. Gomes, op. cit., 2005a; BERCOVICI, Gilberto. A problemática da constituição dirigente: algumas considerações sobre o caso brasileiro. Revista de Informação Legislativa, Brasília, n.142, p.35-51, 1999; e BERCOVICI, Gilberto. A constituição dirigente e a crise da teoria constitucional. In: SOUZA NETO, Cláudio Pereira de; BERCOVICI, Gilberto; MORAES, Filomeno; LIMA, Martonio Mont'Alverne Barreto. Teoria da constituição: estudos sobre o lugar da Política no Direito Constitucional. Rio de Janeiro: Lumen Juris, 2003, p.75-150; BERCOVICI, Gilberto; MASSONETO, Luís Fernando. A constituição dirigente invertida: a blindagem da constituição financeira e a agonia da constituição econômica. Separata do Boletim de Ciências Económicas, Coimbra, 2006; COUTINHO, Jacinto Nelson de Miranda (Org.). Canotilho e a constituição dirigente. Rio de Janeiro: Renovar, 2003. Grosso modo, as teses de J. J. Gomes Canotilho sobre a "constituição dirigente" podem ser assim sumariadas: a) intensidade vinculativa das normas constitucionais impostas - imposições constitucionais e normas programáticas - "As imposições constitucionais são permanentes mas concretas; as normas determinadoras de tarefas ou definidores de fins são imposições permanentes mas abstractas"; b) os direitos fundamentais a prestações não devem confundir-se com as normas programáticas e com as imposições constitucionais; c) o programa constitucional de governo concebe-se também como programa em conformidade com a Constituição, devendo distinguir-se de outras figuras afins com as quais anda sistematicamente confundido (programa eleitoral e partidário, acordo partidário-governamental e acordo programático governamental"; d) a historicidade da Constituição significa apenas que os homens, através de acções materiais, tentam conformar o futuro, de acordo com os condicionalismos das circunstâncias concretas (lógica da situação)".

${ }^{4}$ BRASIL. Constituição (1988), op. cit., 1988. A Emenda Constitucional no 42, de 19 de dezembro de 2003, modificou os incisos VI e IX do art. 170, dando-lhes as seguintes redações: "VI - defesa do meio ambiente, inclusive mediante tratamento diferenciado conforme o impacto ambiental dos produtos e serviços e de 
Conforme acentua Eros Roberto Grau, “[...] a Constituição do Brasil é - tem sido uma Constituição dirigente, e vincula o legislador. E, ainda que tenha sido múltiplas vezes emendada, seu cerne, que identifico fundamentalmente nos preceitos dos seus arts. $3^{\circ}, 1^{\circ} \mathrm{e}$ 170, resta intocado". ${ }^{5}$ Por sua vez, Gilberto Bercovici ressalta que a Constituição de 1988 "contém em seu texto as bases de um projeto nacional de desenvolvimento, em que torna possível a reestruturação do Estado brasileiro para conduzir as transformações sociais necessárias para a superação do subdesenvolvimento". ${ }^{6}$ Neste diapasão, pois, é que a "constituição econômica" contida no texto constitucional vigente assume particular relevância.

Efetivamente, o Estado moderno ${ }^{7}$ nasce sob a vocação de atuar no campo econômico, ${ }^{8}$ desenvolvendo-se, grosso modo, em etapas que constituem o absolutismo, o

seus processos de elaboração e prestação"; "IX - tratamento favorecido para as empresas de pequeno porte constituídas sob as leis brasileiras e que tenham sua sede e administração no País". BRASIL. Constituição (1988). Emenda Constitucional $\mathrm{n}^{\circ}$ 42, de 19 de dezembro de 2003, Disponível em: <http://www.presidencia.gov.br/legislacao>. Acesso em: 5 out. 2008.

${ }^{5}$ GRAU, Eros Roberto. A ordem econômica na Constituição de 1988. 10. ed. São Paulo: Malheiros, 2005 , p.366.

${ }^{6}$ BERCOVICI, Gilberto. Constituição econômica e desenvolvimento: uma leitura a partir da Constituição de 1988. São Paulo: Malheiros, 2005, p.9.

${ }^{7}$ Ver, entre outros, ALVES, Alaor Caffé. Estado e ideologia: aparência e realidade. São Paulo: Brasiliense, 1987; ANDERSON, Perry. Lineages of the absolutist state. London: NLB, 1974; BERCOVICI, Gilberto. Soberania e constituição: para uma crítica do constitucionalismo. São Paulo: Quartier Latin, 2008; BOBBIO, Norberto. Teoria geral da política: a filosofia política e as lições dos clássicos. Rio de Janeiro: Campus, 2000; BOBBIO, Norberto et al. O marxismo e o Estado. 2. ed. Rio de Janeiro: Graal, 1979; BONAVIDES, Paulo. Do Estado liberal ao Estado social. 6. ed. São Paulo: Malheiros, 1996; BURDEAU, Georges. O Estado. São Paulo: Martins Fontes, 2005; DALlARI, Dalmo de Abreu. O futuro do Estado. São Paulo: Saraiva, 2001; DUVERGER, Maurice. Institutions politiques et droit constitutionnel. 12. ed. Paris: PUF, 1970; ELIAS, Norbert. O processo civilizador. Rio de Janeiro: Jorge Zahar, 1994; FINNER, S. E. The history of government: empires, monarchies and the modern State. Oxford: Oxford University Press, 1997. v.III; GIDDENS, Anthony. O Estado-nação e a violência. São Paulo: Edusp, 2001; HELLER, Hermann. Teoría del Estado. Buenos Aires: Fondo de Cultura Económica, 1992; HOBSBAWN, Eric. O novo século: entrevista a Antonio Polito. São Paulo: Companhia das Letras, 2000; JELLINEK, George. Teoría general del Estado. México-DF: Fondo de Cultura Económica, 2000; LAMENATZ, John Petrov. Man and society: a critical examination of some important social and political theories from Machiavelli to Marx. London: Longman, 1963; MALBERG, R. Carré de. Teoría general del Estado. México-DF: Fondo de Cultura Económica, 2001; KELSEN, Hans. Teoria geral do direito e do Estado. 5. ed. São Paulo: Martins Fontes, 2005; MIRANDA, Jorge. Teoria do Estado e da constituição. Rio de Janeiro: Forense, 2002; MORAES, Filomeno. Poder. In: BARRETTO, Vicente de Paulo (Coord.). Dicionário de Filosofia do Direito. São Leopoldo-RS: Unisinos; Rio de Janeiro: Renovar, 2006, p.640-642; NEGRI, Antonio; HARDT, Michael. O trabalho de Dioniso: para a crítica do Estado pós-moderno. Juiz de Fora: UFJF; Pazulin, 2004; O’DONNELL, Guillermo. Pensamientos retrospectivos sobre el Estado, la democratización y la democracia. In: EMMERICH, Gustavo Ernesto (Coord.). Ellos y nosotros: democracia y representación en el mundo actual. México-DF: Demos, 2006, p.17-22; RUFFÍA, Paolo Biscaretti di. Introducción al derecho constitucional comparado. México: Fondo de Cultura Económica, 1975; SKINNER, Quentin. The foundations of modern political thought. Cambridge: Cambridge University Press, 1978. 2v.; MANIN, Bernard. The principles of representative government. Cambridge: Cambridge University Press, 1997.

${ }^{8}$ Ver, entre outros, GRAU, Eros Roberto. A ordem econômica na Constituição de 1988. 10. ed. São Paulo: Malheiros, 2005; FERRARESE, Maria Rosaria. Diritto e mercato. Torino: G. Giappiachelli Editore, 1992; FORGIONI, Paula A. Análise econômica do direito: paranóia ou mistificação? In: COUTINHO, 
liberalismo, o intervencionismo e a veleidade neoliberal, ${ }^{9}$ que não são as mesmas, evidentemente, do Estado latino-americano e, em especial, do Estado brasileiro. ${ }^{10}$

O Estado nacional (ou Estado moderno ou Estado capitalista) é fruto de complexo processo que passa a ter visibilidade a partir da segunda metade do século XV. E é a primeira forma de dominação política que, a partir de determinado momento da sua evolução, postula o seu fundamento na igualdade de todos os sujeitos nos limites de um território. Esses sujeitos são cidadãos e o Estado capitalista é normalmente um Estado de cidadãos. ${ }^{11}$ A postulação da igualdade dos indivíduos diferencia, pois, o Estado capitalista das formas pré-capitalistas de Estado, a saber, o escravista e o feudal, nos quais as suas

Jacinto Nelson de Miranda; LIMA, Martonio Mont'Alverne Barreto (Org.). Diálogos constitucionais: Direito, neoliberalismo e desenvolvimento em países periféricos. Rio de Janeiro: Renovar, 2006, p.419442; GARGARELLA, Roberto. As pré-condições econômicas do autogoverno político. In: BORON, Atilio A. Filosofia politica: controvérsias sobre a civilização, império e cidadania. Buenos Aires: Clacso; São Paulo: Departamento de Ciência Política da USP, 2006, p.279-294; IRTI, Natalino. L'ordine giuridico del mercato. 4. ed. Roma/Bari: Laterza, 2001; POLANYI, Karl. A grande transformação: as origens da nossa época. 5. ed. Rio de Janeiro: Campus, 2000; TORRE-SCHAUB, Marthe. Essai sur la construction juridique de la categórie de marché. Paris: LGDJ, 2002.

9 O neoliberalismo - que surge no segundo Pós-Guerra, como reação teórica e política ao Estado intervencionista e do bem-estar - é, no entanto, fenômeno distinto do liberalismo clássico. Tem como base teórica originária obra dada a lume por Friedrich August von Hayek, em 1944, a qual constitui ataque frontal contra qualquer limitação - denunciada como ameaça letal à liberdade econômica e também política - dos mecanismos de mercado por parte do Estado. Ver HAYEK, Friedrich von. The road to serfdom. London: Routledge \& Paul Kegan, 1979. Todavia, há ser qualificado nas suas acepções fundamentais, a saber, nos países capitalistas centrais, refere-se a um conjunto de proposições de ações contrárias a estrutura político-econômica ao Estado de Bem-Estar; na América Latina e, especialmente, no Brasil, diz respeito ao programa de ação vinculado às normas de ajuste monetário e fiscal do Fundo Monetario Internacional e do Banco Mundial. Assim, "para os países periféricos, sobretudo o Brasil, o primeiro sentido do neoliberalismo reproduz-se no discurso político apenas como metáfora. Nem no Brasil, nem em qualquer outro país da América Latina, existiu um regime efetivo de regulação de capital a partir de mecanismo de seguridade social, tal como se consolidou na Europa do pós-guerra. Por isso o discurso neoliberal aqui perde qualquer especificidade. De fato, os argumentos neoliberais em favor do mercado e do Estado mínimo não se distanciaram demasiadamente da retórica comum do discurso liberal, usualmente proclamado pela burguesia brasileira". BALTAR, Ronaldo. Empresariado, transição e o papel do Estado na ordem econômica e social. Tese (Doutorado em Sociologia). São Paulo, Faculdade de Filosofia, Letras e Ciências Humanas da Universidade de São Paulo, 1996, p.113-114.

${ }^{10}$ Ver, entre outros, COLLIER, David (Org.). O novo autoritarismo na América Latina. Rio de Janeiro: Paz e Terra, 1982; MÉNDEZ, Juan E. et al. Democracia, violência e injustiça: o não-Estado de Direito na América Latina. São Paulo: Paz e Terra, 2000.

${ }^{11}$ Ver MORAES, Filomeno. Direitos e garantias fundamentais e a realidade brasileira. In: TRINDADE, Antônio Augusto Cançado (Ed.). A incorporação das normas internacionais de proteção dos direitos humanos no direito brasileiro. San José-Costa Rica: IIDH;ACNUR;CIVC;CUE, 1996, p.471-484. Segundo Max Weber, somente no Ocidente, desenvolveu-se um capitalismo racional, com fenômenos culturais caracterizados de modo "universal em seu valor e significado", a par de um Estado como "entidade política, com uma 'Constituição' racionalmente redigida, um Direito racionalmente ordenado, e uma administração orientada por regas racionais, as leis, e administrado por funcionários especializados". WEBER, Max. A ética protestante e o espírito do capitalismo. 4. ed. São Paulo: Pioneira, 1985, p.1 e 4. O "momento maquiavélico" comporta as articulações diversas entre Estado burocrático, economia capitalista e sociedade civil. Ver POCOCK, John Greville Agard. The machiavellian moment. 2. ed. Princeton: Princeton University Press, 2003. 
instituições tinham como base a crença de que, em decorrência do nascimento ou posição na sociedade, os indivíduos eram desiguais.

No Cone Sul da América Latina e, especialmente, no Brasil, com todas as suas ambigüidades e indefinições, contradições e possibilidades, sem negar o papel da influência do pensamento constitucional europeu e norte-americano, a evolução do Estado nacional dá-se obedecendo a uma lógica oligárquica, populista e autoritário-burocrática, ${ }^{12}$ seguindo-se a transição para as novas democracias. ${ }^{13}$

De todo modo, tanto alhures como aqui, o Estado não prescinde das estruturas de direito, que fixam os seus contextos e constituem o seu arcabouço, formando assim o que se denomina de "ordem jurídica." Tais estruturas reguladoras compõem o que, entre outros, já no século XVI, Jean Bodin ${ }^{14}$ denominava o "direito da república", Thomas Hobbes $^{15}$ e John Locke, ${ }^{16}$ no século XVII, e Jean-Jacques Burlamaqui ${ }^{17}$ e Jean-Jacques Rousseau, ${ }^{18}$ no século XVIII, chamavam "direito político". ${ }^{19}$ A existência de um "direito

${ }^{12}$ O’DONNELL, Guillermo. Modernización y autoritarismo burocrático. Buenos Aires: Paidós, 1972.

${ }^{13}$ Ver, entre outros, ABRANCHES, Sérgio. Presidencialismo de coalizão: o dilema institucional brasileiro. Dados - Revista de Ciências Sociais, Rio de Janeiro, v.31, n.1, p.5-34, 1988; CAMARGO, Aspásia; DINIZ, Eli. (Org.). Continuidade e mudança no Brasil da Nova República. São Paulo: RT, 1989; CARDOSO, Fernando Henrique. Autoritarismo e democratização. Rio de Janeiro: Paz e Terra, 1975; JAGUARIBE, Hélio et al. Brasil, sociedade democrática. Rio de Janeiro: José Olympio, 1985; ENCINAR, José Juan Gonzalez et al. El proceso constituyente. Enseñanzas a partir de cuatro casos recientes: España, Portugal, Brasil y Chile". Cadernos do Idesp, São Paulo, n.37, 1991; FAORO, Raymundo. A república inacabada. São Paulo: Globo, 2007; e Constituinte: a verdade e o sofisma. In: SADER, Emir (Org.). Constituinte e democracia no Brasil de hoje. São Paulo: Brasiliense, 1985, p.7-16; FARIA, José Eduardo. A crise constitucional e a restauração da legitimidade. Porto Alegre: Sergio Antonio Fabris Editor, 1985; FERREIRA FILHO, Manoel Gonçalves. A democracia possível. 3. ed. São Paulo: Saraiva, 1976; FERREIRA FILHO, Manoel Gonçalves. Nova perspectiva do processo constitucional. Revista Brasileira de Estudos Políticos, Belo Horizonte, n.60/61, p.127-145, 1985; FERREIRA FILHO, Manoel Gonçalves. O anteprojeto dos notáveis. São Paulo: Saraiva, 1987; O`DONNELL, Guillermo; SCHMITTER, Philippe (Ed.). Transições do regime autoritário. São Paulo: Vértice/RT, 1988. 3v.; e Transição do regime autoritário: primeiras conclusões. São Paulo: Vértice/RT, 1988; LAFER, Celso. O sistema político brasileiro. São Paulo: Perspectiva, 1975; LINZ, Juan; STEPAN, Alfred. Problems of democratic transition and consolidation. Baltimore: John Hopkins Press, 1996; MORAES, Filomeno; LIMA, Martonio Mont'Alverne Barreto. Partidos políticos y elecciones: la Justicia electoral en la construcción de la democracia brasileña. In: EMMERICH, Gustavo Ernesto (Coord.). Ellos y nosotros: democracia y representación en el mundo actual. México-DF: Demos, 2006, p.213-230; STEPAN, Alfred. Os militares: da abertura à "Nova República". Rio de Janeiro: Paz e Terra, 1986; VIANNA, Luiz Werneck. Travessia: da abertura à constituinte. Rio de Janeiro: Taurus, 1986.

${ }^{14}$ BODIN, Jean. Los seis libros de la república. 3. ed. Madrid: Editorial Tecnos, 1997.

15 HOBBES, Thomas. Do cidadão. São Paulo: Martins Fontes, 1992 e HOBBES, Thomas. Leviathan. London: Penguin Classics, 1985.

${ }^{16}$ LOCKE, John. Second treatise of government. Indianapolis-Indiana: Hackett Publishing Company, 1980.

17 BURLAMAQUI, Jean-Jacques. The principles of natural and political law. Indianapolis - Indiana: Liberty Fund, 2006.

${ }^{18}$ ROUSSEAU, Jean-Jacques. Du contrat social précédé de discours sur l'économie politique et de du contrat social première version et suivi de fragments politiques. Paris: Éditions Gallimard, 1964.

19 Friedrich Müller acentua que "Rousseau, em texto de época, Du Contrat Social, já havia mencionado sinteticamente a teoria constitucional e o direito constitucional com o subtítulo 'Principes du Droit 
político”, constituído pelas normas que regem a organização institucional da política e o seu funcionamento no âmbito por ela determinado e delimitado, ${ }^{20}$ tem o significado, por conseguinte, de que a política não se reduz unicamente a relações de força.

Particularmente no que concerne à "constituição econômica", consiste ela no cabedal de normas que versam o econômico, regulando a infra-estrutura societal, inclusive, com pretensões de discipliná-la e de limitar o poder econômico. Como ressalta Manoel Gonçalves Ferreira Filho,

[...] esta constituição aparece nos textos escritos como uma espécie de complemento, ou apenso da constituição política. Isto, porém, é um fenômeno decorrente da história, visto que, bem antes de surgir a preocupação de controlar o poder econômico, já era o poder político objeto de disciplinamento constitucional. ${ }^{21}$

Todavia, se somente a partir do século $\mathrm{XX}$ os textos constitucionais passaram a explicitar e sistematizar a matéria econômica, as anteriores - mesmo quando não possuíam "normas que visassem diretamente à disciplina da econômica" -, ou tinham "regras de

Politique'. Direito constitucional é o direito do político. Insistir nisso não tem relação alguma com o 'decisionismo' (aquele de Carl Schmitt ou de outros juristas conservadores). Schmitt desprezava os textos normativos da Constituição democrática (como a Constituição da República de Weimar, na Alemanha), e os concebia como 'mera lei constitucional', superestimando-os por meio de uma mistificadora e irracional 'decisão fundamental'”. MÜLLER, Friedrich. Prefácio. In: SOUZA NETO, Cláudio Pereira de; BERCOVICI, Gilberto; MORAES, Filomeno; LIMA, Martonio Mont'Alverne Barreto. Teoria da constituição: estudos sobre o lugar da política no direito constitucional. Rio de Janeiro: Lumen Juris, 2003, p.XI.

${ }^{20}$ Sobre o desenvolvimento do constitucionalismo, ver, entre outros, ACKERMAN, Bruce. We the people. Cambridge-Massachusetts; London: The Belknap Press of Harvard University Press, 1993a; BANNING, Lance. Jefferson \& Madison: three conversations from the Founding. Madison: Madison House, 1995; BAGEHOT, Walter. The English constitution. Oxford: Oxford University Press, 2001; BORON, Atilio A. Filosofia política marxista. São Paulo: Cortez; Buenos Aires: Clacso, 2003 (principalmente o capítulo 3 - "O constitucionalismo norte-americano e as tradições políticas do liberalismo e do socialismo"); DAHL, Robert A. How democratic is the american constitution? New Haven and London: Yale Nota Bene, 2003; DUGUIT, Léon. La separación de poderes y la Asamblea Nacional de 1789. Madrid: Centro de Estudios Constitucionales, 1996; GOYARD-FABRE, Simone. Os princípios filosóficos do direito político moderno. São Paulo: Martins Fontes, 1999; LANE, Jan-Erik. Constitutions and political theory. Manchester and New York: Manchester University Press, 1996; LOSURDO, Domenico. Democracia ou bonapartismo: triunfo e decadência do sufrágio universal. Rio de Janeiro: UFRJ; São Paulo: Unesp, 2004; MCILWAIN, Charles Howard. Constitutionalism, ancient and modern. Ithaca: Cornell University Press, 1947; HAMILTON, Alexander; MADISON, James; JAY, John. The federalist papers. New York: Signet Classics, 2003. KETCHAM, Ralph (Ed.). The anti-federalist papers and the constitutional Convention debates. New York: Signet Classics, 2003. Sobre o constitucionalismo latinoamericano, ver, entre outros, CARPIZO, Jorge. La Constitución mexicana de 1917. 2. ed. México-DF: Unam, 1973; FIX-ZAMUDIO, Hector. La evolución del derecho internacional de los derechos humanos en las constituciones latino-americanas. In: TRINDADE, Antônio Augusto Cançado; VOLIO, Lorena González (Comp.). Estudios básicos de derechos humanos II. San José-Costa Rica: IIDH, 1995, p.51-66. Sobre as perspectivas fundamentais da "constituição", a sociológica, a política e a normativa, ver, principal e respectivamente, LASSALLE, Ferdinand. A essência da constituição. Rio de Janeiro: Liber Juris, 1995; SCHMITT, Carl. Teoría de la constitución. Madrid: Alianza Editorial, 1992; KELSEN, Hans. Teoria pura do direito. 7 ed. São Paulo: Martins Fontes, 2006.

${ }^{21}$ FERREIRA FILHO, Manuel G. Direito constitucional econômico. São Paulo: Saraiva, 1990, p.7. 
repercussão econômica", ${ }^{22}$ ou a matéria econômica se fazia presente exatamente pelo silêncio normativo. Anais de assembléias constituintes, aqui e alhures, documentam a preocupação com a matéria econômica. No caso, a presença se dava pela ausência, ${ }^{23}$ ou pela presença direta ou indireta de aspectos concernentes à matéria econômica, tais como o direito de propriedade, a liberdade de comércio e de indústria, a livre concorrência, entre outros. $^{24}$

De fato, da segunda metade do século XVIII, quando vieram à luz, até os dias atuais, quando se marcam pela diretividade, as constituições escritas compreendem um "conjunto de normas compreensivo de uma ordem econômica, ainda que como tal não formalmente referido". ${ }^{25}$ As transformações por que o direito passou - como mecanismo de harmonização de conflitos, de legitimação do poder e, mais recentemente, de instrumento de realização de políticas públicas - fizeram com que, mais e mais, abarcasse normas de conteúdo econômico, a fazerem das constituições estatuto do poder político e estatuto do poder econômico.

De modo geral, a "constituição econômica" atém-se às pedras angulares da organização jurídica da economia. Sua explicitação remonta ao esforço constituinte mexicano, na esteira revolucionária de $1910,{ }^{26}$ prosseguindo com o texto constitucional de Weimar, de $1919,{ }^{27}$ e adquirindo pompa e circunstância com os textos constitucionais de Portugal, de $1976,{ }^{28}$ da Espanha, de $1978,{ }^{29}$ e do Brasil, de $1988 .{ }^{30}$ Destarte, a atividade

${ }^{22}$ Ibid., 1990, p.7.

23 “[...] A Constituição Econômica não é uma inovação do 'constitucionalismo social' do século XX, mas está presente em todas as Constituições, inclusive nas liberais dos séculos XVIII e XIX. Durante o liberalismo, a visão predominante era da existência de uma ordem econômica natural, fora das esferas jurídica e política, que, em tese, não precisaria ser garantida pela Constituição. No entanto, todas as Constituições liberais possuíam disposições econômicas em seus textos. A Constituição Econômica liberal existia para sancionar o existente, garantindo os fundamentos do sistema econômico liberal, ao prever dispositivos que preservavam a liberdade de comércio, a liberdade de indústria, a liberdade contratual e, fundamentalmente, o direito de propriedade". BERCOVICI, Gilberto, op. cit., 2005, p.32.

${ }^{24}$ Certamente, a passagem da ordem liberal para a ordem intervencionista não configura uma ruptura, mas o "desígnio de se aprimorar, tendo-se em vista a sua defesa", pois "a transformação [...] se dá no instante em que as precedentes ordens econômicas (mundo do dever-ser) passam a instrumentar a implementação de políticas públicas. Vale dizer: no instante em que a ordem econômica - parcela da ordem jurídica -, já instalada no nível constitucional, passa a predicar o aprimoramento da ordem econômica (mundo do ser), visando à sua preservação". GRAU, Eros Roberto, op. cit., 2005, p.75-74.

${ }^{25}$ Ibid., 2005, p.17.

${ }^{26}$ Ver, entre outros, CARPIZO, Jorge. La constitución de 1917. 2. ed. México-DF: Unam, 1973; HELÚ, Jorge Sayeg. El constitucionalismo social mexicano. México: Fondo de Cultura Económica, 1972.

${ }^{27}$ Ver, entre outros, BERCOVICI, Gilberto. Constituição e estado de exceção permanente: atualidade de Weimar. São Paulo: Azougue Editorial, 2004a; ARAÚJO, Cícero. Apresentação. In: BERCOVICI, Gilberto, op. cit., 2004a, p.9-17.

${ }^{28}$ Além de outros autores portugueses citados ao longo deste trabalho, ver também ANDRADE, José Carlos Vieira de. Os direitos fundamentais na Constituição Portuguesa de 1976. Coimbra: Almedina, 1987. 
econômica como objeto explícito das constituições escritas é acontecimento recente, datando-se da passagem do Estado liberal para o Estado social, ${ }^{31}$ isto é, a partir da segunda década do século XX, quando, em decorrência de uma multiplicidade de causas econômicas, políticas, sociais e culturais, cuidou-se de colocar no texto constitucional propriamente dito "um corpo de normas destinado a reger o fato econômico". ${ }^{32}$ Com a

${ }^{29}$ Sobre a Constituição da Espanha de 1978, ver, entre outros, LUNO, Antonio-Enrique Perez. Derechos humanos, estado de derecho y constitución. 9. ed. Madrid: Tecnos, 2005.

${ }^{30}$ Tal corpo de normas que cuida do fato econômico tanto pode agrupar-se no texto constitucional (constituição econômica formal) quanto estar composto, além das normas constitucionais, das infraconstitucionais (constituição econômica material). Ver, entre outros, BERCOVICI, Gilberto, op. cit., 2005; COMPARATO, Fábio Konder. O indispensável direito econômico. Revista dos Tribunais, São Paulo, n.353, p.14-26, 1965; FERRARESE, Maria Rosaria, op. cit., 1992; GRAU, Eros Roberto, op. cit., 2005; MOREIRA, Vital. Economia e constituição: para o conceito de constituição económica. 2. ed. Coimbra: Coimbra Editora, 1979; PACHECO, Pedro Mercado. El análisis económico del derecho: una reconstrucción teórica. Madrid: Centro de Estudios Constitucionales, 1994; SOUZA, Washington Peluso Albino de. Teoria da constituição econômica. Belo Horizonte: Del Rey, 2002; TAVARES, André Ramos. Direito constitucional econômico. 2. ed. São Paulo: Método, 2006.

${ }^{31}$ Ver, principalmente, BONAVIDES, Paulo, op. cit., 996.

${ }^{32}$ MENDES, Gilmar Ferreira et al. Curso de direito constitucional. São Paulo: Saraiva, 2007, p.1.288. Ainda para estes autores, a principal causa para a existência da constituição econômica foi a "exacerbação do capitalismo e a sua conseqüente confrontação com o operariado, dando origem à Questão Social, a exigir uma constituição econômica ou um direito especial da economia, em que o Estado, embora não se substituísse ao mercado, interviesse minimamente nas suas disputas, através de normas e/ou institutos que, embora assegurassem o direito de propriedade, a liberdade de empresa e a liberdade de trabalho - como direitos fundamentais econômicos -, não permitissem abusos no seu exercício". Ibid., 2007, p.1.289. Nas palavras de Eros Roberto Grau: "[...] conjunto de normas que define, institucionalmente, um determinado modo de produção econômica. Assim, ordem econômica, parcela da ordem jurídica (mundo do dever-ser), não é senão o conjunto de normas que institucionaliza uma determinada ordem econômica (mundo do ser)". GRAU, Eros Roberto, op. cit., 2005, p.72. Diferentemente da antiguidade greco-romana, a propriedade no Ocidente passou, sobretudo a partir do século XIX, a ter um sentido essencialmente econômico. De fato, o direito burguês a concebeu como poder direto e absoluto sobre a coisa, em função dos seus valores de uso e de troca. Na passagem da Idade Média para a modernidade, procedeu-se à reversão da disjunção entre propriedade imóvel e propriedade móvel. A res mobilis passa também a ser considerada importante, com o capitalismo nascente, umbilicalmente ligado ao comércio, à economia monetária e à urbanização. A partir de então, a riqueza mobiliária, isto é, constituída de moedas e metais preciosos, passa a proprocionar poder político. Concomitantemente, a criação dos papéis comerciais, dos títulos-valores e dos diferentes sistemas de contas mercantis completou o instrumento necessário à eclosão e ao desenvolvimento da revolução industrial. COMPARATO, Fábio Konder. Função social da propriedade dos bens de produção. Revista de Direito Mercantil, São Paulo, n.63, p.71-89, jul./set. 1986; COMPARATO, Fábio Konder. Direito empresarial: estudos e pareceres. São Paulo: Saraiva, 1990. Desde o século XVII, uma gama importante de pensadores tem-se debruçado sobre a problemática da propriedade. Embora com diferenças, de modo geral, o pensamento do século XVII e XVIII baseou-se no direito natural e no contrato social para justificar o direito de propriedade. Indivíduo, igualdade e autonomia tornam-se categorias - em substituição a comunidade, hierarquia e dependência - que orientam a nova ideologia econômica e política. DUMONT, Louis. Essays on individualism: modern ideology in anthropological perspective. Chicago: University of Chicago Press, 1986. O homo aequalis toma o lugar do homo hierarchicus. John Locke é pioneiro na construção do argumento segundo o qual a interação entre indivíduos com igualdade e autonomia faz surgir a ordem social. Décadas depois, Adam Smith acaba por trazer à luz o fundamento moral necessário ao pleno exercício do auto-interesse. Se o direito de propriedade se origina do instinto humano de auto-conservação, advindo de Deus, as coisas da natureza são úteis, quando são apropriadas. ver SMITH, Adam Teoria dos sentimentos morais, ou ensaio para uma análise dos princípios pelos quais os homens naturalmente julgam a conduta e o caráter, primeiro de seus próximos, depois de si mesmos, acrescida de uma dissertação sobre a origem das línguas. São Paulo: Martins Fontes, 2002. Assim, Locke associa à propriedade o valor "trabalho", vinculando o direito de propriedade, em boa medida, à propriedade produtiva. Não somente a propriedade, mas também os seus 
idéia de encaminhamento das tensões presentes entre duas instituições inseparáveis, a saber, o Estado e o mercado.

Logo, se o mercado é uma instituição jurídica, visto que criação histórica, política e social, ele não é um locus naturalis, mas um locus artificialis, isto é, uma instituição que nasce graças a determinadas reformas institucionais, operando com fundamento em normas jurídicas que o regulam, o limitam e o conformam; ${ }^{33}$ portanto busca uma ordem garantidora da regularidade e previsibilidade de comportamentos. Assim, a intervenção do Estado na vida econômica tem o condão de estabelecer o beneficio do cálculo de previsão, reduzindo os riscos,${ }^{34}$ buscando uma justiça correta ${ }^{35}$ e entronizando o princípio da segurança. ${ }^{36}$

A passagem do Estado liberal para o Estado que intervém assistiu à mudança do paradigma constitucional. Passou-se, então, das constituições estatutárias ou orgânicas, que

frutos, oriundos do trabalho, deveriam ter a proteção do Estado: “[...] As much land as a man tills, plants, improves, cultivates, and can use the product of, so much is his property. He by his labour does, as it were, inclose it from the common. Nor will it invalidate his right, to say every body else has an equal title to it; and therefore he cannot appropriate, he cannot inclose, without the consent of all his fellow-commoners, all mankind. [...] He that [...] subdued, tilled and sowed any part of it, thereby annexed to it something that was his property, which another had no title to, nor could without injury take from him". LOCKE, John, op. cit., 1980, p.21.

${ }^{33}$ Ver, a propósito, IRTI, Natalino. L’ordine giuridico del mercato. 4. ed. Roma/Bari: Laterza, 1998; NUNES, António José Avelãs. Os sistemas económicos: o capitalismo - génese e evolução. Coimbra: Serviço de Acção Social da Universidade de Coimbra, 2003; GRAU, Eros Roberto, op. cit., 2005. Para Eros Roberto Grau, em suma: 1. a sociedade capitalista é essencialmente jurídica e nela o direito atua como mediação específica e necessária das relações de produção que lhes são próprias; 2. tais relações de produção não poderiam estabelecer-se nem poderiam reproduzir-se sem a forma de direito posto pelo Estado; 3. tal direito posto pelo Estado surge para disciplinar os mercados. GRAU, Eros Roberto, op. cit., 2005. Como substrato ideológico, em torno do que se justificou o mercado, observa-se que Bernard Mandeville já se orgulhava de "haber demostrado que ni las cualidades amistosas ni los afectos simpáticos que son naturales en hombre, ni las virtudes reales que sea capaz de adquirir por razón y la abnegación, son los cimientos de la sociedad". Porém, "por el contrario, lo que llamamos mal en este mundo, sea moral o natural, es el gran principio que hace de nosotros seres sociables, la base sólida, la vida y el sostén de todos los oficios y profesiones, sin excepción: es ahí donde hemos de buscar el verdadero origen de todas las artes y ciencias, y en el momento en que el mal cese, la sociedad se echará a perder si no se disuelve completamente". Assim, "los vicios privados, manejados diestramente por un hábil político, pueden trocarse en beneficios públicos". MANDEVILLE, Bernard. La fábula de las abejas o los vicios privados hacen la prosperidad pública. México: Fondo de Cultura Económica, 2001, p.248. Na esteira de Bernard Mandeville, no século seguinte, qualificando o argumento, Adam Smith afirmará que, no plano da atividade econômica e da busca pela propriedade, os vícios privados, sobretudo o egoísmo, constituem elemento positivo, se a busca do interesse de um não for impedimento para busca do interesse do outro. $\mathrm{O}$ egoísmo está, pois, para a economia assim como a simpatia está para moral, pois, "todo homem é por natureza primeiro e principalmente recomendado a seus próprios cuidados, e como é mais adequado para cuidar de si mesmo do que qualquer outra pessoa, é adequado que faça assim" SMITH, Adam, op. cit., 2002, p.102-103. Na verdade, aquilo que o ser humano tem em vista é o seu próprio benefício e não o da sociedade, todavia, ao fim e ao cabo, "são conduzidos (os proprietários) por uma mão invisível a fazer quase a mesma distribuição das necessidades da vida que teria sido feita, caso a terra fosse dividida em porções iguais a todos os seus moradores". Assim, "sem intenção, sem saber, promovem os interesses da sociedade, e oferecem meios para multiplicar a espécie". SMITH, Adam, op. cit., 2002, p. 226.

${ }^{34}$ WEBER, Max. Economía y sociedad. 15. ed. Buenos Aires: Fondo de Cultura Económica, 2004.

${ }^{35}$ Ver LASSALLE, Ferdinand. A essência da constituição. Rio de Janeiro: Liber Juris, 1995.

${ }^{36}$ Ver NUNES, José António Avelãs, op. cit., 2003 b. 
definem o estatuto do poder, que se formulam como instrumento of government, estabelecendo competências, estruturando o poder político e regulando os processos políticos em sentido estrito, para as constituições diretivas. Nestas últimas, a ordem econômica mais do que pressuposta é posta. Assim, como diz Vital Moreira, a constituição econômica, própria dos últimos tipos de constituição, pode ser definida como "o conjunto de preceitos e instituições jurídicas que, garantindo os elementos definidores de um determinado sistema económico, instituem uma determinada forma de organização e funcionamento da economia e constituem, por isso mesmo, uma determinada ordem econômica" (sic)..$^{37}$

No Brasil, o processo constituinte de 1987/1988 e a constituição dirigente dele originada tiveram na devida conta todas as funções estatais reconhecidas modernamente, ${ }^{38}$ pois dirige ao Estado os objetivos fundamentais de "construir uma sociedade livre, justa e solidária", "garantir o desenvolvimento nacional", "erradicar a pobreza e a marginalização e reduzir as desigualdades sociais e regionais" e "promover o bem de todos, sem preconceitos de origem, raça, sexo, cor, idade e quaisquer outras formas de discriminação". Curiosamente, o tiveram em momento em que o egoísmo e a competição como motores da atividade econômica, nos termos de Adam Smith, ${ }^{39}$ recuperados por Friedrich von Hayek ${ }^{40}$

${ }^{37}$ Citado por GRAU, Eros Roberto, op. cit., 2005, p.79.

38 A atividade estatal pode ser organizada nos seguintes escaninhos: 1. constituir e preservar o modo de produção capitalista; 2. complementar o mercado; 3. substituir o mercado; 4. compensar as disfunções do processo de acumulação. Ver HABERMAS, Jürgen. A crise de legitimação do capitalismo tardio. Rio de Janeiro: Tempo Brasileiro, 1980. Substancialmente, tal atividade evoluiu no que concerne à concepção liberal, a qual, segundo um dos seus mais conspícuos teóricos, consistiria em que, de acordo com "o óbvio e simples sistema da liberdade natural", "o soberano tem apenas três deveres a cumprir: três deveres de grande importância, na verdade, mas simples e perceptíveis para o senso comum: em primeiro lugar, o dever de proteger a sociedade da violência e das invasões de outras sociedades independentes; em segundo lugar, o dever de proteger, tanto quanto possível, todos os membros da sociedade da injustiça ou opressão de qualquer outro membro, ou o dever de estabelecer uma administração exacta da justiça; e, em terceiro lugar, o dever de criar e preservar certos serviços públicos e certas instituições públicas que nunca poderão ser criadas ou preservadas no interesse de um indivíduo ou de um pequeno número de indivíduos, já que o lucro jamais reembolsaria a despesa de qualquer indivíduo ou pequeno número de indivíduos, embora possa, muitas vezes, fazer mais do que reembolsar esse lucro a uma grande sociedade". SMITH, Adam. Inquérito sobre a natureza e as causas da riqueza das nações. 3. ed. Lisboa: Fundação Calouste Gulbenkian, 1999. v. II, p.284-285.

${ }^{39}$ Ver, principalmente, SMITH, Adam, op. cit., 1999. v.II.; SMITH, Adam, op. cit., 2002. Ver também NUNES, António José Avelãs. A filosofia social de Adam Smith. Separata do Boletim de Ciências Económicas, Coimbra, v.XLIX, 2005.

${ }^{40}$ HAYEK, Friedrich von, op. cit., 1979. 
e instrumentalizados por Milton Friedman ${ }^{41}$ e seus Chicago's Boys, buscavam novamente a hegemonia. ${ }^{42}$

$\mathrm{Na}$ verdade, no "momento constituinte" ${ }^{43}$ brasileiro, já se espraiava por muitos rincões o "desejo de constituição" que fazia contraponto à utopia keynesiana, ao welfare state e à vigência dos direitos sociais, econômicos e culturais. ${ }^{44}$ Todavia, enquanto o capitalismo e o mercado reivindicavam graus de liberdade então inexistentes, e em outros países o processo constituinte acompanhava a maré montante, ${ }^{45}$ o Brasil construía uma

${ }^{41}$ Ver, entre outros, FRIEDMAN, Milton. Essays in positive economics. Chicago: University of Chicago Press, 1953; FRIEDMAN, Milton; FRIEDMAN, Rose. Free to choose: a personal statement. New York: Harcourt Brace Jovanovich, 1980.

${ }^{42}$ Ver, entre outros, CASTEL, Robert. Les metamorphoses de la question sociale: une chronique du salariat. Paris: Fayard, 1995; GOLDTHORPE, John H. (Ed.). Order and conflict in contemporary capitalism: studies in the political economy of Western European nations. Oxford: Clarendon Press, 1988; HAGGARD Stephen; KAUFMAN, Robert. The politics of economic adjustments: international constraints, distributive politics and the State. Princeton: Princeton University Press, 1992; HOBSBAWM, Eric. The age of extremes: A history of the world, 1914-1991. New York: Pantheon Books, 1994; HUTTON, Will; GIDDENS, Anthony (Ed.). Global capitalism. New York: The New Press, 2001; KORPI, Walter. The democratic class struggle. London: Routledge \& Kegan Paul, 1983; ORDOÑEZ, Jaime; VÁZQUEZ, Enrique (Org.). Derechos económicos y desarrollo en América Latina. San José CR: IIDH, 1991; PEREIRA, L. C.; MARAVALL, J. M.; PRZEWORSKI, Adam. Economic reforms in new democracies. Cambridge: Cambridge University Press, 1993; PRZEWORSKI, Adam. Estado e economia no capitalismo. Rio de Janeiro: Relume-Dumará, 1995; SANTOS, Boaventura de Sousa. Pela mão de Alice: o social e o político na pós-modernidade. São Paulo: Cortez, 1995; SMITH, William; ACUÑA, Carlos H. T.; GAMARRA, Eduardo (Ed.). Latin American political economy in the age of neo liberal reform: theoretical and comparative perspectives for the 1990s. New Brunswide: Transaction Press, 1994, e SMITH, William; ACUÑA, Carlos H. T.; GAMARRA, Eduardo. Democracy, markets, and structural reform in Latin America: Argentina, Bolivia, Brazil, Chile and México. New Brunswide: North-South Center/Transaction Press, 1994; SOLA, Lourdes (Org.). Estado, mercado e democracia: Política e economia comparadas. São Paulo: Paz e Terra, 1993; FIORI, José Luís; MEDEIROS, Carlos (Org.). Polarização mundial e crescimento. Petrópolis: Vozes, 2001; FAUCHER, Philippe. Políticas de ajuste ou erosão do Estado no Brasil? Dados - Revista de Ciências Sociais, Rio de Janeiro, v.36, n.3, p.393-418, 1993; NUNES, António José Avelãs. Neoliberalismo e direitos humanos. Rio de Janeiro: Renovar, 2003a; LOSURDO, Domenico. Contra-história do liberalismo. Aparecida-SP: Idéias \& Letras, 2006; CANOTILHO, J. J. Gomes. O Estado adjetivo e a teoria da constituição. Revista LatinoAmericana de Estudos Constitucionais, Belo Horizonte, n.5, p.139-154, 2005b; MILIBAND, David (Org.). Reinventando a esquerda. São Paulo: Unesp, 1997.

43 ACKERMAN, Bruce. Neo-federalism? In: ELSTER, Jon; SLAGSTAD Rune. Constitutionalism and democracy. Cambridge: Cambridge University Press, 1993b, p.153-193.

${ }^{44}$ Quando da feitura da CF, iniciava-se "um mundo que nos pegou de surpresa", convivente com três processos interligados - globalização, destradicionalização e reflexividade social. Ver GIDDENS, Anthony. Para além da esquerda e da direita. O futuro da política radical. São Paulo: Unesp, 1996. Segundo Giddens, a globalização - refere-se à "ação à distância", ou seja, os efeitos globais e rápidos de decisões isoladas. Relacionado com o desenvolvimento dos meios de comunicação global instantânea e dos transportes de massa, o seu crescimento recente é cada vez mais e mais intenso. A par da criação de sistemas em ampla escala, a globalização se refere também à transformação de contexto da experiência social, na medida em que atividades do cotidiano são cada vez mais influenciadas por eventos ocorrendo em outros lugares, às vezes muito distantes, e em que hábitos locais de estilo de vida passam, muitas vezes, a ter conseqüências globais. A destradicionalização refere-se não ao fim da tradição, mas à demanda de que ela seja justificada. Finalmente, a reflexividade social constitui a crescente demanda de que as pessoas sejam mais e mais bem informadas e tomem decisões por si mesmas.

${ }^{45} \mathrm{Na}$ Colômbia, v. g., "las elites criollas encontraron en la formulación de la Constitución la mejor herramienta para consolidar, legislar y legitimar el proyecto económico y político del neoliberalismo. De hecho lograron que las disposiciones políticas que abogaban por un espíritu democratizador no se 
constituição que ia de encontro a tal realidade. ${ }^{46}$ Não deixa de ser relevante, pois, a observação de tal conjuntura constituinte.

Evidentemente, como observa J. J. Gomes Canotilho, as instâncias de temporalidade “deverão ser convocadas numa teoria da Constituição temporalmente adequada". Uma constituição é o "presente do passado", pois "não deixa de ser "memória na história" mesmo quando propõe rupturas (revolucionárias ou não) com o passado"; é o "presente do presente", já que "ela dedica sempre uma indispensável atentio à conformação da ordem jurídica actual"; é presente do futuro, "ao proclamar tarefas e fins para o futuro, mas sobretudo, ao antecipar expectativas de se converter em lei para as gerações futuras". ${ }^{47}$ Tudo, com o sentido de fugir da "negação da possibilidade e pensabilidade de uma constituição divorciada do Estado e da Nação". ${ }^{48}$

Nos anos 30, Mirkine-Guetzévitch já acentuava que "os homens novos, que chegam ao poder, se pensam no futuro, pensam ainda mais no passado". ${ }^{49}$ Mais recentemente, Miguel Carbonnell também acentua:

[...] La constitución de nuestro tiempo convive con el pasado - renunciando a
su repetición en algunos casos, como lo demuestran las cláusulas de
inmodificabilidad de la constitución alemana, destinadas a decir 'nunca más' a
experiencias como las vividas bajo el régimen nazi -, pero se constituye sobre
todo como una aspiración de futuro, es decir, como una especie de 'utopía

constituyeran en obstáculos para la implementación del nuevo paradigma de desarrollo neoliberal. Es más, a través del uso de diversos dispositivos normativos y de las tecnologías políticas del neoliberalismo, han logrado hacer converger su proyecto económico del libre mercado con su proyecto político de una democracia liberal-elitista, tecnocrática y delegativa". MARTíN, Carolina Jiménez. Momentos, escenarios y sujetos de la producción constituyente. Aproximaciones críticas al proceso constitucional de los noventa. Análisis Político, Bogotá, n.58, p.156, 2006.

${ }^{46} \mathrm{Na}$ era da globalização, "o problema de constitucionalizar uma ordem política e económica através do direito continua a residir na assimetria entre a 'responsabilidade' imposta ao Estado de direito democrático no plano político, social e económico, e as suas reais capacidades de actuação, agora num contexto global crescentemente compressor da modelação jurídico-política estatal quanto à segurança, à liberdade e ao próprio direito". CANOTILHO, J. J. Gomes, op. cit., 2005a, p.22. Sobre a problemática, ver, entre outros, ARANTES, Paulo. Extinção. São Paulo: Boitempo, 2007; AGAMBEN, Giorgio. Estado de exceção. São Paulo: Boitempo, 2004; ANDERSON, Perry. Balanço do neoliberalismo. In: SADER, Emir; GENTILI, Pablo (Org.). Pós-neoliberalismo: as políticas sociais e o Estado democrático. São Paulo: Paz e Terra, 1995, p.9-23; NUNES, António José Avelãs, op. cit., 2003a; BOBBIO, Norberto. Destra e sinistra: ragioni e significati di una distinzione politica. Roma: Donzelli, 1994; FARIA, José Eduardo. Os direitos humanos e o dilema latino-americano às vésperas do século XXI. Boletim da Sociedade Brasileira de Direito Internacional, São Paulo, n.93/94, p.43-60, 1994; HOBSBAWM, Eric. O novo século: entrevista a Antonio Polito. São Paulo: Companhia das Letras, 2000; BELLUZZO, Luiz Gonzaga de Mello. Ensaios sobre o capitalismo no século XX. São Paulo: Unesp; Campinas: Unicamp, 2004.

${ }^{47}$ CANOTILHO, J. J. Gomes. "Brancosos" e interconstitucionalidade: itinerários dos discursos sobre a historicidade constitucional. Coimbra: Almedina, 2005a, p.26.

${ }^{48}$ Ibid., p.201.

49 MIRKINE-GUETZÉVITCH, B. As novas tendências do direito constitucional. São Paulo: Nacional, 1933, p. 25 . 
concreta' para usar el concepto recordado por Jürgen Habermas o como una 'carta de navegación' si recurrimos a la imagen que propuso Carlos S. Nino. ${ }^{50}$

De igual modo, Gustavo Zagrebelski demonstra que:

[...] La constitución de la Revolución miraba solamente hacia adelante. La constitución de la Conservación miraba solamente hacia atrás. Las constituciones de nuestro tiempo miran al futuro teniendo firme el pasado, es decir, el patrimonio de experiencia histórico-constitucional que quieren salvaguardar y enriquecer. Incluso se podría decir: pasado y futuro se ligan en una única línea y, como los valores del pasado orientan la búsqueda del futuro, así también las exigencias del futuro obligan a una continua puntualización del patrimonio constitucional del pasado y por tanto a una continua redefinición de los principios de la convivencia constitucional. La 'historia' constitucional no es un pasado inerte sino la continua reelaboración de las raíces constitucionales del ordenamiento que nos es impuesto en el presente por las exigencias constitucionales del futuro. ${ }^{51}$

De fato, uma constituição é um modelo de vida orientado para o futuro, algo de "utopia concreta" ou de uma "carta de navegação". Assim, a orientação finalista do estatuto constitucional, no que concerne às esperanças refletidas do poder constituinte, a buscar caminhos sociais, econômicos, políticos e culturais diferentes do status quo, ou seja, "van mas allá de registrar solamente las relaciones de poder existentes", pois

\begin{abstract}
[...] Tales objetivos de la constitución son la relación de una humanidad real en la convivencia social, el respecto de dignidad humana, el logro de justicia social sobre la base de la solidaridad y en el marco de la igualdad y de la libertad, la creación de condiciones socioeconómicas para la libre autorrealización y emancipación humana, así como el desarrollo de una conciencia política general de responsabilidad democrática. Estos contenidos de la constitución, la mayoría de las veces, no están presentes en la realidad, sino que siempre están pendientes de una futura configuración política [...] la constitución [...] se produce activamente y se transforma en praxis autónomamente en virtud de la participación democrática en las decisiones estatales. ${ }^{52}$
\end{abstract}

Como afirma Miguel Carbonell, “[...] un sistema constitucional no es ni puede ser, en la práctica, solamente revolución o solamente conservación, aunque a veces esto se olvide por los defensores de una u otra óptica". ${ }^{53}$ Fazendo reverberação de Rui Barbosa,${ }^{54}$ também João Mangabeira já acentuava que “todas elas (as constituições) representam

${ }^{50}$ CARBONELL, Miguel. Zagrebelsky y el uso de la Historia por el derecho constitucional. In: ZAGREBELSKY, Gustavo. Historia y constitución. Buenos Aires: Editorial Trotta, 2005, p.9-10.

${ }^{51}$ ZAGREBELSKY, Gustavo. Historia y constitución. Madrid: Editorial Trotta, 2005, p.90-91.

${ }^{52}$ SCHNEIDER, Hans Peter. Democracia y constitución. Madrid: Centro de Estudios Constitucionales, 1991, p.49.

${ }^{53}$ CARBONELL, Miguel, op. cit., 2005, p.11.

54 “[...] uma codificação não pode ser a expressão absoluta de um sistema, vitória exclusiva de uma doutrina. Toda obra de legislação em grande escala há de ser obra de transação. Do ponto de vista de cada teoria extrema, tudo o que por ela se não moldar servilmente incorrerá nas suas invectivas. Radical, o código seria monstruoso, para os reacionários. Reacionário, passaria por monstruoso entre os radicais. E não podendo ser, a um tempo, radical e reacionário, será, necessariamente, monstruoso aos olhos dos radicais e dos reacionários. Destes escolhos não há fugir”. MANGABEIRA, João. Em torno da constituição. São Paulo: Nacional, 1934, p.10. 
compromisso e transação entre partidos adversos de idéias dessemelhantes, interesses divergentes". ${ }^{55}$ Assim, "se [...] um código de tais escolhos não pode fugir, muito menos a eles fugirá uma constituição, instrumento essencialmente político, e, por isso mesmo, de composição, estabilidade e equilíbrios entre forças que se opõem ou interesses que se chocam". ${ }^{56}$

Obviamente, a observação da feitura de uma constituição é tarefa múltipla. Em primeiro lugar, porque as constituições foram, pelo menos no Brasil, frutos de acontecimentos muito marcantes. Assim, o advento da República exigiu a elaboração da segunda constituição brasileira, e a Revolução de 30, o Estado Novo, a redemocratização pós-45, o golpe de 64, o reforço autoritário de 1968-1969 e a passagem do governo militar para o civil também deram azo, cada fato a seu tempo, às Constituições de 1934, 1937, 1946, 1967, 1969 e 1988. Em segundo lugar, a compreensão eficiente do texto constitucional depende da sua inscrição no jogo político das linguagens em disputa naqueles momentos, da definição de seus personagens, dos seus interesses e pontos privilegiados, e das suas intenções ${ }^{57}$ Ademais, uma constituição assenta-se numa tradição, mormente uma tradição rica como a brasileira, por meio de sucessivas re-interpretações, re-significações e recepções que, se acaba por dar à luz um texto eminentemente prescritivo, também interpreta e reordena uma realidade concreta, que é vista de tal modo e que se propõe seja vista de outro.

55 Ibid., 1934, p.10. O mesmo João Mangabeira ressaltava: “[...] Quando se encontra um jurista político é ouro sobre o azul. Mas um professor de direito poderá ser incompetente para formular uma constituição. Quando uma constituição obedece exclusivamente às nossas idéias, como juristas, ela não resiste aos embates da vida. A prova disso encontramos na Constituição austríaca, traçada por um dos maiores doutrinadores da atualidade. A obra de Kelsen não resistiu, porque não representava a realidade da Áustria, a cuja vida era inadequada. O grande teorista do Direito não tinha o tino político, o tato do estadista, o tato antigo, profundo e diário com as forças econômicas e as correntes de opinião que formava o meio social de sua pátria". Acta da $51^{\mathrm{a}}$ sessão da Subcomissão Constitucional. In: AZEVEDO, José Afonso de Mendonça. Elaborando a constituição nacional: atas da Subcomissão elaboradora do anteprojeto 1932/1933. Brasília: Senado Federal, Conselho Editorial, 2004, p.1.029. Ainda sobre o pensamento desse "juristapolítico", ver MANGABEIRA, João. Idéias políticas de João Mangabeira. Brasília: Senado Federal; Rio de Janeiro: FCRB, 1980. 3 v.

${ }^{56}$ MANGABEIRA, João, op. cit., 1934, p.50.

57 Ver, entre outros, JASMIM, Marcelo. Francisco Campos e a crítica das constituições liberais. Caxambu-MG: paper apresentado durante o XXV Encontro Anual da Associação Nacional de PósGraduação e Pesquisa em Ciências Sociais - Anpocs, 2001. O caso do Chile é excepcional, pois, "no es usual que una constitución dictada por un gobierno autoritario se convierta en el medio para que la oposición lo obligue a entregar el poder y en el marco legal fundamental para el nuevo gobierno democrático". Assim, tal "peculiaridad de la transición chilena es especialmente paradójica dada la estrechez y dureza del régimen autoritario de Pinochet, [...] y no es de esperar que este tipo de régimen tan unipersonal e impermeable a toda influencia genere una constitución que después sirva para constituir un gobierno de transición a la democracia”. VALENZUELA, J. S. La constitución de 1980 y el inicio de redemocratización en Chile. Working Paper (Kellog Institute), n.242, Indianopolis-Indiana, 1997, p.1. 
Caracterizando-se como uma das conjunturas mais cruciais da história constitucional brasileira, a dos anos de 1987/1988, é relevante observar a dinâmica que permitiu a formulação da "constituição econômica" e como se deu a dialética da construção de um texto constitucional com afinidades eletivas decididas em relação ao Estado desenvolvimentista e às suas potencialidades, possibilidades e desafios. Pode-se estabelecer, assim, discurso acadêmico que articula Estado, Constituição e Política, não sendo necessário insistir em que Estado, Constituição e Política hão de ser sempre entendidos em conjunto e que a manifestação do poder constituinte se inscreve como locus privilegiado de observação de tal correspondência.

Efetivamente, a Constituição Federal, promulgada em 5 de outubro de 1988, como constituição dirigente econômica e social - possível em virtude da manifestação peculiar que tomou o poder constituinte na conjuntura de funcionamento do Congresso Constituinte - tem fundamentalmente na "constituição econômica" um dos sustentáculos de um projeto de construção nacional. Na verdade, a transição brasileira do autoritarismo-burocrático, ultrapassando a lógica "lenta, gradual e segura", acabou por encontrar no Congresso Constituinte a tentativa de construção de um Estado de bem-estar, por isso, "ao revés do que dizem os seus inimigos", a CF/88 é a "melhor das Constituições brasileiras de todas as nossas épocas constitucionais". ${ }^{58}$

Afinal de contas, é verdade que nunca houve uma manifestação na inteireza do poder constituinte do povo, ${ }^{59}$ de modo a tornar mais relativa a crise constituinte brasileira intrínseca ao processo político nacional ${ }^{60}$ Ou é razoável perguntar se o processo constituinte de 1987/1988 rompeu com tal paradigma, senão para o refazimento institucional desde os seus desde os seus fundamentos, pelo menos proporcionar-lhes um salto de qualidade?

\footnotetext{
${ }^{58}$ BONAVIDES, Paulo. Teoria constitucional da democracia participativa. São Paulo: Malheiros, 2001. p.204.

${ }^{59}$ MÜLLER, Friedrich. Fragmento (sobre) o poder constituinte do povo. São Paulo: RT, 2004.

${ }^{60}$ A propósito, ver, principalmente, SALDANHA, Nelson. Formação da teoria constitucional. Rio de Janeiro: Forense, 1983; e SALDANHA, Nelson, op. cit., 1986; BONAVIDES, Paulo, op. cit., 2006; BERCOVICI, Gilberto. O poder constituinte do povo no Brasil: um roteiro de pesquisa sobre a crise constituinte. In: COUTINHO, Jacinto Nelson de Miranda; LIMA, Martonio Mont'Alverne Barreto (Org.). Diálogos constitucionais: direito, neoliberalismo e desenvolvimento em países periféricos. Rio de Janeiro: Renovar, 2006, p.215-224; SILVA, José Afonso da. Poder constituinte e poder popular: estudos sobre a Constituição. São Paulo: Malheiros, 2002; LIMA, Martonio Mont'Alverne Barreto; BERCOVICI, Gilberto. Entrevista com Friedrich Müller. Seqüência - Revista do Curso de Pós-Graduação em Direito da UFSC, Florianópolis, n.51, p.9-30, 2005.
} 


\section{CONSTITUINTES E CONSTITUIÇÕES BRASILEIRAS, E ORDEM ECONÔMICA}

[...] O que há no Brasil de liberal e democrático vem de suas constituintes, e o que há no Brasil de estamental e elitista vem das outorgas, das emendas e dos atos de força. [...]

Raymundo Faoro

\subsection{Introdução}

O capítulo presente objetiva traçar a evolução constitucional do Brasil, destacando as assembléias constituintes, bem como as constituições advindas de tais assembléias constituintes. Observar-se-á, pois, a evolução do constitucionalismo brasileiro a partir dos quatros momentos privilegiados - 1823, 1890/1891, 1933/1934 e 1946 - da feitura de constituições. Para tanto, ter-se-á em conta o processo eleitoral, a organização partidária e de opinião e a organização interna, tudo no sentido de buscar continuidades e descontinuidades nos quase duzentos anos de constitucionalismo liberal-democrático brasileiro, e situar-se-á, inclusive, a problemática da "constituição econômica", pois se "as constituições que formam a primeira geração do constitucionalismo não continham normas para disciplinar a atividade econômica", "havia, é certo, nessas constituições, e, mormente, nas declarações de direitos, que as precediam ou acompanhavam, normas de repercussão econômica".

\footnotetext{
${ }^{1}$ FERREIRA FILHO, Manoel Gonçalves. Direito constitucional econômico. São Paulo: Saraiva, 1990, p.3. Ver, a propósito de uma "leitura econômica", BEARD, Charles Austin. An economic interpretation of the Constitution of the United States. Mineolo - New York: Dover Publications, 2004. Aliás, uma leitura econômica, desta feita do poder constituinte, é procedida por Domenico Losurdo, quando afirma que "[...] a Convenção convocada para a Filadélfia é quase exclusivamente composta 'de homens extremamente conservadores', os quais, trabalhando em rigoroso segredo e indo muito além do mandato recebido, que prevê apenas uma obra de reforma dos 'Artigos' da Confederação, elaboram um texto constitucional totalmente novo, reforçando enormemente o poder central: 'realizado por Napoleão, chamar-se-ia um coup d'État' [...]" e que "[...] a virada político-constitucional não estava legitimada nem pela ordem jurídica existente nem pelo apelo à soberania popular, mas pela absoluta necessidade de poupar ao país os ataques à propriedade, o caos e a anarquia que sobre ele pendiam ameaçadoramente". LOSURDO, Domenico. Democracia ou bonapartismo: triunfo e decadência do sufrágio universal. Rio de Janeiro: UFRG; São
} 
Entre as constituintes, além da de 1988, aconteceram duas constituintes congressuais, compostas de deputados e senadores, as de 1891 e 1946, as quais, findada a tarefa constituinte, passaram automaticamente a funcionar como Poder Legislativo ordinário. A única Constituinte exclusiva, ou quase-exclusiva, foi a de 1933/1934, que, promulgado texto constitucional em 16 de julho de 1934 e terminada a sua tarefa no dia seguinte, com a eleição indireta e posse do presidente da República, transformou-se em Câmara dos Deputados, acumulando as funções do Senado Federal, até que, no ano seguinte, tomassem posse os novos deputados e senadores e a atividade legislativa ordinária tivesse curso.

Quer realmente iniciais, como a Constituinte de 1823, quer recriadoras de realidades jurídicas ab-rogadas ou derrogadas, as manifestações do poder constituinte originário têm as suas peculiaridades nacionais, como se vê ao longo do capítulo. Em geral, as constituintes têm o significado mais do que a mera revisão de parâmetros jurídicos tout court, funcionando como momentos de construção de novos arranjos de poder. No Brasil, têm funcionado tanto para a saída de autoritarismos "revolucionários", como em 1891 e 1934, quanto de autoritarismos "contra-revolucionários", como em 1946.

Assim, a história política brasileira é fértil em matéria de assembléias constituintes, tendo sido instaladas em 1823, 1890, 1933, 1946 e 1987. Constituições, além das provenientes das assembléias constituintes, as de $1891,{ }^{2} 1934,{ }^{3} 1946^{4}$ e 1988 , existiram mais ainda as oriundas das sístoles autocráticas de ocasião: a Constituição de $1824,{ }^{5}$ já que Pedro I dissolvera a Assembléia Constituinte instalada após a Independência, foi a primeira da série de ordenamentos constitucionais autoritários; $1937^{6}$ assistiu a outra manifestação do autoritarismo no processo constitucional; em 1967 se editou nova carta, ${ }^{7}$ a qual, embora

Paulo: Unesp, 2004, p.98. Tenha-se em conta também que os "federalistas" norte-americanos viam a propriedade como a causa da "division of the society into different interests and parties", dado que "the diversity in the faculties of men, from which the rights of property originate, is the first insuperable obstacle to a uniformity of interests". Logo, "the protection of these faculties is the first object of government". HAMILTON, Alexander; MADISON, James; JAY, John. The federalist papers. New York: Signet Classics, 2003, p.73.

2 BRASIL. Constituição (1891). Constituição da República dos Estados Unidos do Brasil. Disponível em: <http://www.presidencia.gov.br/legislacao〉. Acesso em: 10 jan. 2008.

${ }^{3}$ BRASIL. Constituição (1934). Constituição da República dos Estados Unidos do Brasil. Disponível em: <http://www.presidencia.gov.br/legislacao〉. Acesso em: 10 jan. 2008.

4 BRASIL. Constituição (1946). Constituição dos Estados Unidos do Brasil. Disponível em: <http://www.presidencia.gov.br/legislacao〉. Acesso em: 10 jan. 2008.

5 BRASIL. Constituição (1824). Constituição Política do Império do Brasil. Disponível em: <http://www.presidencia.gov.br/legislacao〉. Acesso em: 10 jan. 2008.

6 BRASIL. Constituição (1937). Constituição dos Estados Unidos do Brasil. Disponível em: <http://www.presidencia.gov.br/legislacao〉. Acesso em: 10 jan. 2008.

${ }^{7}$ BRASIL. Constituição (1967). Constituição da República Federativa do Brasil. Disponível em: <http://www.presidencia.gov.br/legislacao〉. Acesso em: 10 jan. 2008. 
passando pelo Congresso Nacional, não se livrou do travo da imposição; finalmente, em 1969 se coroou, com a impropriamente chamada Emenda Constitucional (EC) $\mathrm{n}^{\mathrm{o}} 1,{ }^{8} \mathrm{o}$ conjunto de constituições outorgadas no Brasil.

Os frutos advindos das assembléias constituintes representam, assim, contrapontos importantes aos surtos de autoritarismo que, periodicamente, marcaram a história políticoconstitucional brasileira. No seu tempo, tais assembléias estabeleceram arenas privilegiadas da participação política da sociedade, mesmo se se impuser um nível de exigência maior em relação às mesmas. A propósito, merece atenção a assertiva de Raymundo Faoro, trazida a lume antes da Constituinte de 1987/1988, segunda a qual nunca o Poder Constituinte conseguira, nas suas quatro tentativas, "vencer o aparelhamento de poder, firmemente ancorado ao patrimonialismo de Estado, mas essas investidas foram as únicas que arvoraram a insígnia da luta, liberando energias parcialmente frustradas". ${ }^{9} \mathrm{De}$ fato, "todos os passos, insuficientes na verdade, no caminho das liberdades e da democracia, nos quase 160 anos de país independente, foram dados pelas constituintes, que legaram à sociedade civil as bandeiras, frustradas e escamoteadas, de sua emancipação". ${ }^{10}$

\subsection{Antecedentes}

A rigor, as idéias do Constitucionalismo começaram a ter consequiências institucionais para o Brasil ${ }^{11}$ a partir dos desdobramentos da chamada Revolução Liberal do Porto, que, em Portugal, exigia que o rei renunciasse aos seus poderes absolutos e jurasse de antemão a Constituição que se queria elaborada. A notícia da insurreição constitucionalista, iniciada na cidade do Porto, em 24 de agosto de 1820, só chegaria ao Brasil dois meses depois e dava conta de que juristas e letrados, ostensivamente apoiados por comerciantes e militares, exigiam uma Constituição que reproduzisse as linhas mestras da Carta da Espanha, de 1812, restaurada em março de 1820.

\footnotetext{
${ }^{8}$ BRASIL. Constituição (1967). Emenda Constitucional n. 1, de 17 de outubro de 1969. Disponível em: <http://www.presidencia.gov.br/legislacao>. Acesso em: 10 jan. 2008.

9 FAORO, Raymundo. A república inacabada. São Paulo: Globo, 2007, p.257.

10 Ibid., 2007, p.258.

11 "Em conseqüência, antes que a independência rompesse o compromisso do Brasil com as instituições judiciais e administrativas do antigo regime, Portugal já havia começado a mudá-las (carta de lei de 11 de julho de 1822), pela separação da atividade administrava da função judicial, pela centralização política e administrativa que abandonava - ao menos na superfície - o regime da monarquia concelhia de extração medieval e pela transformação do Rei em primeiro administrador do Estado. As novas idéias, vindas da França, tiravam do Monarca o poder de fazer a lei, prerrogativa das Cortes; compensavam-no, contudo, dando-lhe a administração do Estado, fornida dos despojos das autoridades locais (judiciais e administrativas)". BORJA, Célio. Introdução. In: URUGUAI, Visconde de. Ensaio sobre o direito administrativo. Brasília: Ministério da Justiça, 1997, [s.p.].
} 
João VI decidiu convocar as velhas Cortes portuguesas que se haviam reunido pela última vez em 1698. Segundo o decreto real, elas estariam autorizadas a emendar, alterar e dispor, que a sanção real já estaria assegurada, "segundo os usos, costumes e lei fundamentais da monarquia". Os anseios dos insurretos do Porto, porém, alcançaram Lisboa e, daí, todo o reino português, ganhando terreno a luta pela soberania nacional. Afinal, em vez das velhas Cortes do agrado do monarca, se instituíram as Cortes Extraordinárias e Constituintes da Nação Portuguesa, a que o rei forçadamente teve de aderir, tais as pressões que se montaram aquém e além mar. Foi nessa oportunidade que os brasileiros, pela primeira vez, tiveram ocasião de eleger, enviando-os em seguida a Portugal, deputados constituintes.

Totalizando 75, dos quais consta que somente cerca de cinqüenta compareceram a Portugal, os deputados constituintes brasileiros formavam minoria na Assembléia Constituinte, vez que os portugueses se representavam por 130 deputados. ${ }^{12}$ Ademais, o movimento liberal português mantinha intactos os planos colonialistas da metrópole em relação ao Brasil, o que caracterizava a presença dos representantes brasileiros como extremamente problemática. ${ }^{13}$ Os mandatários à assembléia portuguesa eram, de modo geral, herdeiros do ideário da Revolução Francesa, e pensavam que a soberania deveria residir na nação. E, embora associando a soberania do Estado luso-brasileiro à soberania de um corpo de cidadãos, no contexto pós-Congresso de Viena, acreditavam ser possível conciliar tais princípios com o da legitimidade dinástica. ${ }^{14}$

Entre as divergências de várias ordens que se estabeleceram em torno do projeto para alcançar aquela soberania, dada a não-referência ainda a uma sociedade de massas, os mandatários entendiam que o corpo de cidadãos que deveria compor a nação era formado pelos súditos de um mesmo rei e os fundamentos para a sua soberania confundiam-se com os princípios da própria nobreza. A única nação reconhecida pelos constituintes de Lisboa era a portuguesa, cuja soberania era defendida pelos representantes tanto de Portugal como do Brasil.

${ }^{12}$ CARVAlHO, Manuel Emílio Gomes de. Os deputados brasileiros nas Cortes Gerais de 1821. Brasília: Senado Federal, Conselho Editorial, 2003; DEIRÓ, Eunápio. Fragmentos de estudos da história da Assembléia Constituinte do Brasil. Brasília: Senado Federal, Conselho Editorial, 2006.

${ }^{13}$ MORAES, Filomeno. As constituintes brasileiras: retrospectiva e tendência. DN Cultura, Fortaleza, n.156, p.4-5, 29 set. 1985.

${ }^{14}$ BERBEL, Márcia Regina. Deputados do Brasil nas Cortes Portuguesas de 1821-22. Novos Estudos Cebrap, São Paulo, n.51, p.189-202, 1998. 
A Constituinte teve distintas fases, mas a integração nacional, com "os portugueses de ambos os hemisférios", segundo as Bases da Constituição, aprovadas em março de 1821, deveria ocorrer no Legislativo (composto por uma única Câmara, que se reuniria em Lisboa), no Executivo (exercido unicamente pelo rei, residente em Lisboa) e no Judiciário (todos os julgamentos de última instância deveriam ser realizados em Lisboa). ${ }^{15}$ Os representantes das províncias do Brasil, entretanto, eram portadores de mais de um projeto político, pois, enfáticos na defesa da unidade da nação portuguesa, divergiam quanto à forma de estabelecê-la, ${ }^{16}$ caracterizando-se a diversidade de bancadas brasileiras. Uma questão, por exemplo, parece ter impedido o acordo entre pernambucanos e integracionistas de Portugal: ${ }^{17}$ a idéia da representação provincial. Os últimos achavam que a representação da nação, integrada no Congresso, não pressupunha a existência de delegações provinciais. De acordo com essa concepção, ainda que os deputados tivessem sido eleitos nas províncias, eram representantes da nação e poderiam decidir sobre qualquer assunto das outras unidades provinciais. Os pernambucanos foram de encontro a essa formulação, quando solicitaram a espera dos delegados fluminenses para decidir sobre o envio de tropas ao Rio de Janeiro. ${ }^{18}$

Para os baianos, as províncias deveriam ter um Executivo eleito, as leis deveriam ser feitas a partir da representação provincial e sua aplicação seria de inteira responsabilidade dessas, propondo, assim, uma espécie de "confederação nacional", que se opunha frontalmente à "nação integrada" dos portugueses, confederação tal que poderia ser conciliada com a integração econômica. No entanto, antes que esse acordo se realizasse, a chegada dos paulistas, em fevereiro de 1822, alterou mais uma vez o quadro do Congresso de Lisboa. A deputação de São Paulo foi a única a levar instruções, consubstanciadas no documento Lembranças e Apontamentos do Governo Provisório de São Paulo aos

\footnotetext{
15 Ibid., 1998, p.195. Como observa Paulo Ferreira Cunha, "as Cortes não tinham somente o mandato imperativo de fazer um texto mais liberal que o de Espanha", mas, assumindo o papel legislativo, "a Assembléia aboliu a Inquisição por unanimidade [...], introduziu diversas reformas administrativas, decretou várias amnistias e perdões [...], aboliu alguns privilégios monopolistas em diversos produtos [...], instituiu a liberdade do ensino etc., etc.”. CUNHA, Paulo Ferreira. Para uma história constitucional do direito português. Coimbra: Almedina, 1995, p.289. Sobre as Bases da Constituição, diz o mesmo autor que, como "os trabalhos de discussão da Constituição propriamente dita eram bastante lentos, a Assembléia votou [...] a aprovação prévia das Bases da Constituição, a fim de que o rei regressado pudesse jurar qualquer coisa. O que viria realmente a suceder. As Bases eram quase uma tradução de artigos da Constituição Espanhola [...]”. Ibid., 1995, p.289.

${ }_{17}$ Ibid., 1995, p.191.

${ }^{17}$ Alexandre Valentim classificou os deputados portugueses em integracionistas e moderados, não se ocupando, todavia, dos deputados brasileiros. VALENTIM, Alexandre. Os sentidos do Império: questão nacional e questão colonial na crise do antigo regime português. Porto: Afrontamento, 1993.

${ }^{18}$ Ibid., 1993, p.196.
} 
Deputados da Província. ${ }^{19}$ Segundo Oliveira Lima, tais instruções eram "compreensivas e notáveis, cuja autoria cabe sem dúvida a José Bonifácio, porque, nas mesmas, se encontram estampadas idéias que a muito poucos então preocupavam, como as da abolição da instituição servil e catequese dos indígenas". ${ }^{20}$ Outro aspecto das Lembranças... é o inquérito realizado antes da confecção do documento, como registra M. E. Gomes de Carvalho:

\begin{abstract}
A atitude [...] dos mandatários de São Paulo promanava [...] também das instruções recebidas do governo na mesma província. Empenhada em conhecer o sentir do povo [...], a junta paulista julgara avisadamente que nada haveria de mais acertado do que ouvir as câmaras municipais. Pediu-lhes informação de suas conveniências locais e perguntou-lhes quais eram, ao seu parecer, as providências úteis ao Brasil e as apropriadas a cimentarem a união do reino americano com a metrópole. Estribada nas memórias e apontamentos das municipalidades, organizou o famoso regimento para os deputados, o qual constituía vasto programa político. [...]. ${ }^{21}$
\end{abstract}

Os sucessos políticos que ocorriam no Brasil, com o mal-estar causado, de modo geral, pela presença da representação do Brasil nas Cortes portuguesas, acabaram por proporcionar que o esforço constituinte se transferisse para a Assembléia inaugurada em maio de 1823.

\title{
2.3 A Assembléia Constituinte de $\mathbf{1 8 2 3}$
}

[...] o projeto de Constituição que eu lhe hei de breve apresentar; que será duplicadamente mais liberal, do que a extinta Assembléia acabou de fazer.

Pedro I

${ }^{19}$ SILVA, José Bonifácio de Andrada e. Projetos para o Brasil. Organização de Miriam Dolhnikoff. São Paulo: Companhia das Letras; Publifolha, 2000.

${ }^{20}$ LIMA, Oliveira. O movimento da Independência: 1821-1822. 6. ed. Rio de Janeiro: Topbooks, 1997, p. 154. O historiador observa ainda: "A qualidade da representação brasileira nas Cortes de Lisboa prova que o Brasil se achava maduro para a vida independente, sendo de notar que a procura de lugares não foi grande, antes eram poucos os que se prestavam a aspirar a uma honraria que não era um cargo e que trazia no bojo incômodos certos e glórias problemáticas". E que a comissão constitucional brasileira foi formada de luminares da representação, com o parecer com que foram apresentados os resultados dos seus trabalhos correspondendo ao "mérito dos que o elaboraram, obedecendo à inspiração geral das instruções dadas aos deputados paulistas por José Bonifácio". SILVA, José Bonifácio de Andrada e, op. cit., 2000, p.149 e 345. Muito tempo depois, Renato Archer, que foi um dos líderes da "Ala Moça" do Partido Social DemocráticoPSD, diria: "Esta mesma foi a postura que levou o reformista José Bonifácio a viabilizar o surgimento do Estado brasileiro através da transmissão da coroa de pai para filho, ao mesmo tempo que propunha em projeto de Constituição o estatuto do índio, a abolição da escravatura e a reforma agrária [...]". ARCHER, Renato. Prefácio. In: HIPPOLITO, Lúcia. De raposas e reformistas: o PSD e a experiência democrática brasileira, 1945-1964. Rio de Janeiro: Paz e Terra, 1985, p.19.

${ }^{21}$ CARVALHO, Manuel Emílio Gomes de. Os deputados brasileiros nas Cortes Gerais de 1821. Brasília: Senado Federal, Conselho Editorial, 2003, p.161. 
A primeira Assembléia Constituinte efetivamente brasileira, embora convocada antes mesmo do Sete de Setembro, somente se instalou após a Independência, precisamente em maio de 1823, com a finalidade de apresentar projeto e dar a primeira constituição ao País recém independente. ${ }^{22}$ A Constituinte de 1823 refletia na sua composição as condições sociais, econômicas e políticas em que vivia um país eminentemente agrário, de população disseminada por um extensíssimo território, de centros urbanos rarefeitos e de economia baseada na mão-de-obra escrava. Compunha-se de "26 bacharéis em direito e cânones, 22 desembargadores, 19 clérigos entre os quais um bispo, e 7 militares entre os quais 3 marechais de campo e dois brigadeiros". ${ }^{23}$

O colégio eleitoral que escolheu os deputados constituintes era severamente limitado. Considerava-se cidadão brasileiro, por conseguinte com direito de voto, o brasileiro nato ou o português que optasse pela nacionalidade brasileira. Mas mecanismos copiados do sistema eleitoral vigente em Portugal restringiam a cidadania política. As eleições foram indiretas, realizadas através de quatro escrutínios, a saber, as freguesias elegiam seus eleitores compromissários; estes elegiam os eleitores paroquiais; os eleitores paroquiais elegiam os eleitores de comarca que, por seu turno, escolhiam os deputados constituintes. Nos dois primeiros turnos, o voto não era secreto e, a partir do segundo, quando se escolhiam os eleitores paroquiais, o voto era censitário, isto é, os eleitores de comarca, os eleitores de província e os deputados constituintes teriam de dispor de uma renda mínima fixada pela lei. O sistema eleitoral excluía a maioria da população, visto que não desfrutavam de liberdade política nem os homens livres pobres, nem as mulheres, nem a massa escrava. Segundo Maria Beatriz Nizza da Silva,

Depois de vários movimentos constitucionais em Portugal e no Brasil a imprensa
divulgou as diversas opções para o novo sistema político que iria surgir com a
queda do Antigo Regime. Constituições várias foram publicadas, desde a
republicana dos Estados Unidos às monárquicas de 1812 em Espanha e de 1814
em França. Não havia dúvidas quanto à opção feita por D. Pedro, mas a elite

22 Para uma análise da "cultura política" na conjuntura pré-constituinte, ver NEVES, Lúcia Maria Bastos Pereira das. Corcundas e constitucionais: a cultura política da Independência (1820-1822). Rio de Janeiro: Revan; Faperj, 2003. Sobre a vida e ação dos principais atores políticos presentes na formação do Estado brasileiro, ver SOUSA, Octávio Tarquínio de. História dos fundadores do Império do Brasil. Rio de Janeiro: José Olympio, 1957. 10 v. Sobre outros aspectos da formação do Estado brasileiro, ver, entre outros, LIMA, Martonio Mont'Alverne Barreto. Judiciário e Estado no Brasil: tribunais superiores e juízes na formação do Estado brasileiro. Revista da Escola Superior do Ministério Público do Distrito Federal e Territórios, Brasília, n.6, p.171-199, 1995; URICOECHEA, Fernando. A formação do Estado brasileiro no século XIX. Dados - Revista de Ciências Sociais, Rio de Janeiro, n.14, p.85-109, 1977; e URICOECHEA, Fernando. O minotauro imperial. Rio de Janeiro: Difel, 1978.

23 MELLO, F. I. Marcondes H. de. A constituinte perante a história. Brasília: Senado Federal, 1996, p.4. 
brasileira hesitava entre vários caminhos constitucionais, caminhos esses barrados com a Constituição de $1824 .^{24}$

Logo na fala inaugural da Assembléia Constituinte, o Imperador antecipou a expectativa que tinha em relação à mesma, acentuando:

Como imperador constitucional, e mui especialmente como defensor perpétuo deste império, disse ao povo no dia $1^{\circ}$ de dezembro do ano próximo passado, em que fui coroado e sagrado, que com a minha espada defenderia a pátria, a nação e a Constituição, se fosse digna do Brasil e de mim. Ratifico, hoje, mui solenemente perante vós esta promessa, e espero que me ajudeis a desempenhála, fazendo uma constituição sábia, justa, adequada e executável, ditada pela razão e não pelo capricho, que tenham vista tão-somente a felicidade geral, que nunca pode ser grande sem que esta constituição tenha bases sólidas, bases que a sabedoria dos séculos tenha mostrado, que são as verdadeiras, para darem uma justa liberdade aos povos, e toda a força necessária ao Poder Executivo. [... $]^{25}$

Além de reivindicar "toda a força necessária ao Poder Executivo", o Imperador apresentava o seu entendimento sobre a separação de poderes nos seguintes termos:

Uma constituição em que os três poderes sejam divididos, de forma que não possam arrogar direitos que não lhes compitam, mas que sejam de tal modo organizados e harmonizados, que se lhes torne impossível, ainda pelo decurso do tempo, fazerem-se inimigos, e cada vez mais concorrerem de mãos dadas para a felicidade geral do Estado. Afinal uma constituição, que pondo barreiras inacessíveis ao despotismo, quer real, quer aristocrático, quer democrático, afugente a anarquia, e plante a árvore daquela liberdade, a cuja sombra deve crescer a união, tranqüilidade e independência deste império, que será o assombro do mundo novo e velho. ${ }^{26}$

Herdeiro da tradição ideológica advinda da Santa Aliança, Pedro I rechaçava a herança do constitucionalismo revolucionário da segunda metade do século XVIII, tachando-o de teorético e metafísico, quando dizia:

Todas as instituições, que, à maneira de 1791 e 92, têm estabelecido as suas bases, e se têm querido organizar, a experiência nos tem mostrado que são totalmente teoréticas e metafísicas, e por isso inexequíiveis; assim o prova a França, Espanha, e ultimamente Portugal. Elas não têm feito, como deviam, a felicidade geral; mas sim, depois de uma licenciosa liberdade, vemos que em alguns países já apareceu, e em outros ainda não tarda a aparecer o despotismo em um, depois de ter sido exercitado por muitos, sendo conseqüência necessária, ficarem os povos reduzidos à triste situação de presenciarem, e sofrerem todos os horrores da anarquia. ${ }^{27}$

${ }^{24}$ SILVA, Maria Beatriz Nizza da. Prefácio. In: NEVES, Lúcia M. B. P. das. Corcundas e constitucionais: a cultura política da Independência (1820-1822). Rio de Janeiro: Revan; Faperj, 2003, p.14.

${ }^{25}$ Fala do Trono na sessão de abertura da Constituinte, em 3/5/1823. In: BONAVIDES, Paulo; AMARAL Roberto. Textos políticos da história do Brasil. 3. ed. Brasília: Senado Federal, Conselho Editorial, 2002. v. I, p.727-728.

26 Ibid., 2002, p.728.

27 Ibid., 2002, p.728. 
Por fim, encarecia a receita de constituição apropriada "à localidade, e civilização do povo brasileiro", a saber:

Longe de nós tão melancólicas recordações; elas enlutariam a alegria e o júbilo de tão fausto dia. Vós não as ignorais, e eu, certo, que a firmeza nos verdadeiros princípios constitucionais, que têm sito sancionados pela experiência, caracteriza cada um dos deputados que compõem esta ilustre assembléia, espero, que a Constituição, que façais, mereça a minha imperial aceitação, seja tão sábia e tão justa, quanto apropriada a localidade, e civilização do povo brasileiro; igualmente, haja de ser louvada por todas as nações, que até os nossos inimigos venham a imitar a santidade e sabedoria de seus princípios, e que por fim a executem. $^{28}$

No discurso do presidente da Constituinte, Dom José Caetano da Silva Coutinho, em resposta à Fala do Trono, em linguagem afirmativa, também se enviaram mensagens antecipatórias do entrechoque que logo se daria entre o Imperador e a Assembléia Constituinte, a saber:

[...] O Brasil civilizado já não podia perfeitamente constituir-se e organizar-se, senão adotando as formas e estabelecendo as garantias e criando as instituições políticas que têm feito a felicidade e a opulência dos povos mais ilustrados do mundo.

A distinção dos poderes políticos é a primeira base de todo o edifício constitucional; estes poderes se acham já distintamente no recinto augusto desta sala; a sabedoria coletiva da nação; a autoridade constituinte e legislativa; o chefe do poder Executivo. Mas é este mesmo recinto apertado e estreito que eu considero como a imagem mais viva e enérgica daquele laço apertado e indissolúvel que deve ligar todos os membros do corpo político, daquela doce harmonia que deve dirigir para um só fim todos os supremos poderes, aliás distintos e independentes nos limites de sua esfera. Essa doce harmonia dos poderes é objeto mais claro, e precioso dos mais puros votos do nosso coração e de todos os cidadãos amantes da pátria e amigos da humanidade. Esta doce harmonia dos poderes não pode ser somente a obra dos talentos e das luzes que hoje se têm difundido por toda a parte, ela se espera principalmente, e com todo o fundamento se espera das altas virtudes liberais que residem no generoso coração de Vossa Majestade, e igualmente se espera das virtudes patrióticas, que estão animando a todos os ilustres representantes do povo brasiliense. ${ }^{29}$

Dias depois, o voto de graças da Assembléia, redigido por Antônio Carlos, ressaltava que a Assembléia não

terá o ardimento de invadir as prerrogativas da coroa, que a razão aponta como complemento do ideal da monarquia; a assembléia não ignora que elas, quando

${ }^{28}$ Fala do Trono na sessão de abertura da Constituinte, em 3/5/1823. In: BONAVIDES, Paulo; AMARAL Roberto, op. cit., 2002. v.I, p.728.

${ }^{29}$ Resposta do Presidente da assembléia geral à fala do Trono. In: BONAVIDES, Paulo; AMARAL Roberto, op. cit., 2002, p.730-731. 
se conservam nas raias próprias, são a mais eficaz defesa dos direitos do cidadão e o maior obstáculo à erupção da tirania de qualquer denominação que seja. ${ }^{30}$

A Assembléia não era rousseauniana, mas burkeana. ${ }^{31}$ A propósito, lembre-se Antônio Carlos, que assim se referia ao falar da "liberdade": "um dos mais sinceros amigos dela, o célebre Burke, que apregoou e vitoriosamente demonstrou que o gênio da liberdade detesta igualmente quimeras exageradas como o baixo servilismo, a pôs fora do alcance da contestação". ${ }^{32} \mathrm{Na}$ sessão de 6 de maio de 1823, o mesmo Antônio Carlos sublinhava os limites dos poderes da Coroa e, por conseguinte, a amplitude dos poderes da Assembléia Constituinte. Veja-se:

A nação [...] elegeu um Imperador Constitucional, deu-lhe o poder executivo e o declarou chefe hereditário: nisto não podemos nós bolir; o que nos pertence, é estabelecer as relações entre os poderes, de forma porém que se não ataque a realeza. $^{33}$

A Assembléia de 1823 foi levada a um processo de radicalização e de confronto. De um lado, os deputados nativistas exigiam que o Imperador reconhecesse a soberania da Assembléia, através de um juramento antecipado da Constituição em processo de elaboração; do outro, aquele, irredutível quanto aos seus poderes, acabou por considerar a Assembléia "indigna" de si e, manu militari, dissolveu-a. Fechada a Assembléia Constituinte, o Imperador convocou comissão de notáveis para, sob a sua direção, redigir a Constituição. ${ }^{34}$

${ }^{30}$ MELLO, Barão Homem de. A constituinte perante a história. Brasília: Senado Federal, 1996, p.7.

31 Ao invés de considerar a sociedade e o Estado como resultante de relações contratuais, o romantismo viaos como unidade espiritual, preferindo as mudanças imperceptíveis, que se acumulam silenciosamente, às transformações violentas provocadas pelas rebeliões. O conservadorismo liberal de Burke observava, porém, que "um Estado sem meios de alguma mudança não dispõe de meios para conservar-se". Ver principalmente BURKE, Edmund. Reflexões sobre a revolução em França. 2. ed. Brasília: UnB, 1998.

32 Apud MELLO, Barão Homem de, op. cit., 1996, p.18.

33 Ibid., 1996, p.19.

34 MORAES, Filomeno, op. cit., 1985, p.4. Há interpretações alternativas sobre a dissolução da Assembléia Constituinte, p. ex., Agenor de Roure observa: "Os documentos publicados na íntegra e em resumo ou apenas citados n'esta Memória deixam tão claro o pensamento constante do nosso primeiro Imperador a favor do governo constitucional, que uma única razão se encontra para explicar a dissolução da Constituinte de 1823 - o medo! A análise psicológica dos fatos históricos, para conhecimento das causas que os determinaram [...] levarão ao espírito dos que acompanharem este estudo até o fim, a convicção de que: $1^{\circ}$, na obra da formação constitucional do Brasil, o papel de Pedro I foi importantíssimo; $2^{\circ}$, na dissolução da Constituinte não entrou a ambição de mando absoluto nem como elemento auxiliar quanto mais decisivo; $3^{\circ}$, que como deputados encarregados de elaborar uma constituição, os três Andrada agiram com grande sabedoria e prudência, não podendo a sua ação parlamentar justificar o golpe de 12 de Novembro, obtido por meio de pressão e assinado, a contragosto, graças exclusivamente a esse fantasma de que fala Gustave Le Bon, quando trata do papel político do Medo e afirma que a maior parte dos grandes acontecimentos do passado foram realizados sob a influência de Fantasmas. [...]". ROURE, Agenor de. Formação constitucional do Brasil. Rio de Janeiro: Tipografia do Jornal do Comércio, 1914, p.11-12. Já Kenneth Maxwell dirá que Pedro I “era um rei demasiado 'liberal' para os padrões da Santa 
Para Paulo Bonavides e Paes de Andrade, o liberalismo de Pedro I, no discurso de abertura dos trabalhos constituintes, fora estritamente o do liberalismo já então conservador; ${ }^{35}$ uma espécie de precipitação ideológica das tendências que haviam banido a onda radicalizadora de 1793 e selado o pacto da monarquia constitucional. ${ }^{36}$ Thomas Flory, contudo, observa:

Es difícil saber qué significaba exactamente el liberalismo para Pedro I, porque como muchos contemporáneos suyos usó ese término de modo como un símbolo, sin definición. Cualquiera que fuera su punto de vista, la mayoría de los miembros de la Asamblea Constituyente de 1823 estuvieron en desacuerdo con él. [...] En lugar del anteproyecto que los electores habían estado discutiendo, prometió promulgar una constitución 'dos veces más liberal. ${ }^{37}$

De qualquer modo, ainda para Thomas Flory,

la nueva constitución no resultó muy desagradable ni siquiera para los enemigos de Don Pedro. En algunas cosas no llegaba suficientemente lejos para los radicales, pero la mayoría de los brasileños estuvo de acuerdo en que era un documento bastante vago como para acomodar sus propias ideas de un Brasil Constitucional. ${ }^{38}$

Para Oliveira Vianna, a Constituinte de 1823 foi da mais alta conta, por reunir os "maiores do País pelo prestígio da cultura, da inteligência, do caráter ou da situação social”, visto que "os grandes estadistas que consolidaram o Império e construíram o poder político da nação saíram dela ou nela estiveram, com exceção de Feijó e Bernardo de

\footnotetext{
Aliança na Europa, mas muito 'despótico' para muitos brasileiros, sobretudo para os republicanos de Pernambuco que se insurgiram em duas ocasiões para repudiá-lo. Seu papel, conforme o perfil traçado pela historiografia portuguesa, é o de um defensor do 'constitucionalismo', uma imagem totalmente incompatível com aquela traçada pela historiografia brasileira, onde ele foi o governante que rejeitou a constituição e demitiu José Bonifácio e seus irmãos, líderes da pequena minoria de brasileiros que queriam reformas fundamentais". MAXWELL, Kenneth. Por que o Brasil foi diferente? O contexto da independência. In: MOTA, Carlos Guilherme (Org.). Viagem incompleta: a experiência brasileira (15002000): formação: histórias. São Paulo: Senac, 2000, p.186.

${ }^{35}$ A respeito do liberalismo no Brasil, ver, entre outros, SANTOS, Wanderley Guilherme dos. Ordem burguesa e liberalismo político. São Paulo: Duas Cidades, 1978; PAIM, Antonio. História do liberalismo brasileiro. São Paulo: Mandarim, 1998; FLORES, Alberto Vivar. El liberalismo constitucional en la fundación del Imperio brasileño. Revista Electrónica de Historia Constitucional, Oviedo-España, n.6, 2005. Disponível em: 〈http://hc.rediris.es/06/articulos〉. Acesso em: 10 set. 2007.

${ }^{36}$ BONAVIDES, Paulo; ANDRADE, Paes de. História constitucional do Brasil. Brasília: Paz e Terra, 1989, p.40. A monarquia constitucional é, na verdade, uma criação do século XIX, representando "el compromiso histórico entre el principio monárquico y las pretensiones irreversibles de libertad de la ciudadanía. A diferencia de la parlamentaria, la monarquía constitucional descansaba sobre la idea de una autolimitación voluntaria del gobernante, en este caso, de tipo jurídico, consagrado en un documento constitucional, en una constitución. Algunas de estas constituciones fueron 'otorgadas' con fundamento en la plena autoridad del soberano. [...] Otras constituciones tuvieron un origen de 'constituciones pactadas', más próximas al modelo iusnaturalista del contrato político: mediante un contrato entre el príncipe y los representantes de los estamentos, así por ejemplo, la Constitución del Reino de Wurttemberg, del 25 de septiembre de 1819". ZIPPELIUS, Reinhold. Teoría general del Estado. 2. ed. México-DF: Editorial Porrúa/Unam, 1989, p.155.

${ }^{37}$ FLORY, Thomas. El juez de paz y el jurado en el Brasil imperial. México-DF: Fondo de Cultura Económica, 1996, p.20.

${ }^{38}$ Ibid., 1996, p.21.
} 
Vasconcelos". E que "eles tinham, ao demais, a imensa autoridade de um mandato verdadeiramente nacional - pois eram realmente, não ficticiamente, 'representantes da nação". ${ }^{39}$ Contrariamente, segundo John Armitage,

[...] cada um se possuiu de idéias exageradas de sua própria importância, combinada na maior parte com a mais completa ignorância da tática usada nas assembléias deliberativas; excetuados os três Andradas [...], havia entre todos muito poucos indivíduos, se é que os havia, acima da mediocridade. ${ }^{40}$

\title{
2.3.1 A problemática da constituição econômica
}

$\mathrm{Na}$ promoção de projetos e indicações, no recebimento e estudo de petições e representações, a Assembléia teve papel importante, revendo a economia, estudando a situação financeira, examinando as condições da sociedade. Evidentemente, "ela não pretendia, pela grande maioria de seus constituintes, mudar basicamente a estrutura econômica e social", ${ }^{41}$ vigorando muito mais o propósito da continuidade do que de mudança, como ressalta José Honório Rodrigues:

\begin{abstract}
Ao final, se reconhecerá que são modestas as alterações, apesar do desejo manifestado por alguns de romper as tradições caducas. Não obstante tenha Carneiro de Campos sustentado a caducidade das leis portuguesas e a capacidade revolucionária do novo Estado, a verdade é que a resistência à mudança foi muito forte; e, na Assembléia, que reunia a elite de duas classes, isto é, a dos senhores rurais com os grandes latifundiários e fazendeiros, e a média e superior urbana, pouco se pode fazer no sentido social, ou reformista-econômico. ${ }^{42}$
\end{abstract}

Também a dissolução, em relação a que a maioria das interpretações da época ou posteriores vincula a motivos políticos, tem "alguma motivação econômica que, se não fosse a causa principal, houvesse concorrido para a decisão". ${ }^{43}$ Ainda de acordo com José Honório Rodrigues, "aos perigos do crescente nacionalismo político se somavam os receios do nacionalismo econômico que os Andradas e seus aliados defendiam no seio da Assembléia". ${ }^{44}$

No que diz respeito ao "nacionalismo econômico", objeto de discussão na Assembléia Constituinte, não pode ser olvidado o papel de José Bonifácio que, “como

\footnotetext{
${ }^{39}$ VIANNA, Oliveira. O idealismo na constituição. Rio de Janeiro: Terra de Sol, 1927, p.19-20.

${ }^{40}$ ARMITAGE, John. História do Brasil. 3. ed. Rio de Janeiro: Tecnoprint, 1965, p.78.

${ }^{41}$ RODRIGUES, José Honório. A Assembléia Constituinte de 1823. Petrópolis: Vozes, 1974, p.162.

42 Ibid., 1974, p.199.

${ }^{43}$ Ibid., 1974, p.199.

${ }^{44}$ Ibid., 1974, p.200. "Já vimos, no exame da atividade legislativa da Assembléia, que o projeto de extinção do juízo dos defuntos e ausentes deve ter pesado na balança, pois atingia a fundo interesses econômicos portugueses, tentando travar a remessa de capitais para Portugal e liberando para uso brasileiro recursos de ausentes e defuntos em grande parte portugueses". Ibid., 1974, p.99.
} 
cientista, como pensador imbuído das idéias da Ilustração, como membro da elite colonial, [...] e como estadista", pensou a nação de maneira global, possibilitando a emergência de "um projeto nacional coerente e articulado, embora não sistematizado" ${ }^{45}$ Como acentua Miriam Dolhnikoff,

\begin{abstract}
Se a substituição da mão-de-obra escrava pela assalariada e a integração dos indígenas eram necessárias para alcançar a homogeneidade e conformar a identidade nacional, também, o eram para criar outras condições indispensáveis à existência da nação. Somente através dessas reformas se poderia preservar a ordem interna (liquidando os principais focos de tensão), conquistar o desenvolvimento econômico e construir o Estado nacional, segundo os padrões modernos. Este último ponto perpassa todo o pensamento de José Bonifácio. [...] ${ }^{46}$
\end{abstract}

De fato, na busca de um Estado moderno, capaz de gerenciar os conflitos e de implantar um plano civilizador, José Bonifácio apresentou à Assembléia Constituinte de 1823 projeto de emancipação gradual da escravatura, em que, inclusive, as relações escravistas fossem mediadas pelo Estado durante tal emancipação gradual. A intervenção estatal na relação senhor/escravo apresentava-se como o mecanismo regulador a retirar dos grandes proprietários o arbítrio sobre a vida dos seus cativos e a formular as condições de trabalho dos escravos, impondo restrições à exploração de menores e de mulheres, delimitando a jornada diária e determinando que o senhor fornecesse alimentação e vestuário adequados, com a prescrição de que deveriam ficar a cargo do poder público, e não dos proprietários, o processo e a punição dos escravos infratores. Além do que,

[...] Era preciso restringir os latifúndios e incentivar a pequena e média propriedade. Caminho seguro para a produtividade agrícola, mas também para a penetração do Estado no interior da nação, na medida em que diminuiria o poder dos grandes latifundiários e também permitiria o povoamento do território, acabando com o isolamento em que vivia a maior parte da população. [...]. ${ }^{47}$

Na verdade, a "Representação à Assembléia Geral Constituinte e Legislativa do Império do Brasil sobre a escravatura" - com a busca de um modelo de Estado intervencionista na propriedade e na sociedade, com tarefas a exercitar - preconizava já um conjunto de medidas que somente o constitucionalismo do século seguinte deu conta.

\footnotetext{
${ }^{45}$ DOLHNIKOFF, Miriam. Introdução. In: SILVA, José Bonifácio de Andrada e. Projetos para o Brasil. Organização de Miriam Dolhnikoff. São Paulo: Companhia das Letras; Publifolha, 2000, p.6.

${ }^{46}$ Ibid., 2000, p.9.

${ }^{47}$ Ibid., 2000, p.9-10.
} 
Pode-se dizer que José Bonifácio foi quem, pela primeira vez, pensou na "constituição econômica" brasileira. ${ }^{48}$

\subsubsection{A Constituição do Império}

Dissolvida a Assembléia Constituinte, somente em 1824, através da outorga imperial, o Brasil teve a sua primeira constituição. O projeto de que se originou a Constituição outorgada em 1824 teve como inspirador José Joaquim Carneiro de Campos, membro da extinta Assembléia Constituinte e ministro demissionário da Pasta do Império no auge da crise da dissolução. Publicado em 20 de dezembro de 1823, o mesmo projeto, encomendado ao Conselho de Estado, era fiel ao rascunho introduzido por Pedro I e tinha como fonte oculta o antigo projeto de Constituição, elaborado basicamente por Antônio Carlos. $^{49}$

Instituição fadada a ser, durante os dois Reinados, a pedra angular da controvérsia política concernente à definição da esfera e alcance dos poderes constitucionais, no momento constituinte as variações de fundo ${ }^{50}$ entre os dois projetos gravitaram especialmente em torno da introdução do Poder Moderador no projeto do Conselho de

48 Conforme observa Kenneth Maxwell, "intelectuais, traficantes e patriotas brasileiros [...] estavam amargamente divididos quando se tratava de abolir ou não a escravidão. Podiam abraçar o liberalismo, mas seu zelo 'revolucionário' ficava estritamente limitado a um desejo de acesso aos mercados, à proteção da propriedade e a garantias de que as dívidas seriam pagas. Nesse quadro, o centralismo, a monarquia e a continuidade eram fundamentais. Os 'patriotas' do Brasil eram realistas e não podiam ir além da sua base de apoio social. Aqueles que assim o fizeram, como José Bonifácio, foram logo descartados". MAXWELL, Kenneth. Por que o Brasil foi diferente? O contexto da independência. In: MOTA, Carlos Guilherme (Org.). Viagem incompleta: a experiência brasileira (1500-2000): formação: histórias. São Paulo: Senac, 2000, p.192.

${ }^{49}$ BONAVIDES, Paulo; ANDRADE Paes, op. cit., 1989, p.77. Entretanto, em debate parlamentar, em junho de 1841, Antônio Carlos exprimiu o seu juízo crítico sobre a Carta de 1824 da seguinte forma: "Senhores, a Constituição foi feita às carreiras; quanto mais nela medito, mais me persuado que quem a fez não entendia o que fazia". Apud NABUCO, Joaquim. Um estadista do Império. 5. ed. Rio de Janeiro: Topbooks, 1997. v.I, p.89. Segundo Octavio Tarquínio de Souza, o projeto do Conselho de Estado "repetiu, muitíssimas vezes, o da Assembléia dissolvida". Por sua vez, o próprio Antonio Carlos aduziu certa feita: "Os Senhores Conselheiros de Estado, que entraram a fazer a Constituição, não fizeram senão inserir poder moderador, elemento federativo, colocar alguns artigos diferentemente e no mais copiaram meu Projeto". Apud PORTO, Walter Costa. Prefácio. In: AZEVEDO, José Afonso de Mendonça. Elaborando a constituição nacional: atas da Subcomissão elaboradora do anteprojeto 1932/1933. Brasília: Senado Federal, Conselho Editorial, 2004, p.XII.

${ }^{50}$ Outra variação substancial entre o projeto Antônio Carlos e a Constituição outorgada era a vitaliciedade do Senado. Sobre a compreensão do Senado vitalício, destaquem-se as palavras do Conselheiro Nabuco de Araújo, no discurso do uti possidetis: “[...] o Senado não pode fazer política, que o Senado não se pode envolver na torrente das parcialidades militantes, sem provocar conflito com a Câmara dos Deputados, sem derrogar o principio conservador que o coloca entre a coroa e o povo, entre a imobilidade e o progresso, entre a ordem e a liberdade”. NABUCO, Joaquim, op. cit., 1997. v. I., p.432. 
Estado. ${ }^{51}$ Ademais, era uma contribuição inovadora ao constitucionalismo em desenvolvimento, com a adoção da principiologia de Benjamin Constant, ${ }^{52}$ em detrimento das idéias de Montesquieu invocadas tanto pela Convenção da Filadélfia quanto por constituições francesas. ${ }^{53}$ Segundo Paulo Bonavides e Paes de Andrade, embora já se tenha atribuído a Martim Francisco a idéia do Poder Moderador, a história constitucional até hoje não determinou com exatidão quem lembrou, sugeriu ou fez introduzir o quarto poder que não constava do Projeto Antônio Carlos - na Carta de 25 de março de $1824 .{ }^{54}$ À Constituição Imperial foi concedida legitimação consensual pelas câmaras municipais, na época, a mais importante base de representatividade, ${ }^{55}$ num plebiscito municipalista indireto com "uma quase unanimidade de vozes em favor do juramento e do pedido de outorga imediato". ${ }^{56}$

${ }^{51}$ João Camilo de Oliveira Torres resenha as variações fundamentais e o debate doutrinário e político travado no Império em torno do Poder Moderador. TORRES, João Camilo de Oliveira. A democracia coroada: teoria política do Império do Brasil. Rio de Janeiro: José Olympio, 1957. Sobre o rico material doutrinário relativo ao tema, produzido durante o Império, ver principalmente SOUZA, Braz Florentino Henriques de. Do poder moderador: ensaio de direito constitucional contendo a análise do título $\mathrm{V}$, capítulo $\mathrm{I}$, da constituição política do Brasil. Brasília: Senado Federal, 1979; VASCONCELOS, Zacarias de Góes e. Zacarias de Góes e Vasconcelos. Organização e introdução de Cecília Helena de Salles Oliveira. São Paulo: Ed. 34, 2002 (principalmente "Da natureza e limites do Poder Moderador"); URUGUAI, Visconde de. Ensaio de direito administrativo. Brasília: Ministério da Justiça, 1997. SÃO VICENTE, José Antônio Pimenta Bueno, Marquês de. José Antônio Pimenta Bueno, Marquês de São Vicente. Organização e introdução de Eduardo Kugelmas. São Paulo: Ed. 34, 2002. Sobre a crucial questão da centralização versus descentralização do poder, ver FERREIRA, Gabriela Nunes. Centralização e descentralização no Império: o debate entre Tavares Bastos e Visconde de Uruguai. São Paulo: Editora 34/Departamento de Ciência Política da USP, 1999.

${ }^{52}$ Ver CONSTANT, Benjamin. Escritos de política. São Paulo: Martins Fontes, 2005 (principalmente os "Princípios de política aplicáveis a todos os governos representativos e em particular à Constituição atual da França"). O Visconde de Uruguai, dissertando sobre "o que é Poder Moderador, Real ou Neutro", acentuava que o mesmo "não é criação de Benjamim Constant, o qual reconhece haver colhido o gérmen da idéia nos escritos de Clermont Tonnerre", não fazendo aquele "mais do que desenvolver a idéia, e separar, debaixo do nome de um poder distinto, várias atribuições, que não pertencendo, nem devendo, por sua natureza e fim, pertencer ao Executivo, tinham estado até então mais ou menos envolvidas nele, mistura que já muitos publicistas tinham notado". URUGUAI, Visconde de, op. cit., 1997, p.255.

${ }^{53}$ De fato, e ainda de acordo com o Visconde de Uruguai, "as Cartas Constitucionais Francesas de 1814, e de 1830, não tinham Poder Real, Neutro ou Moderador distinto. As funções deste poder, não consideradas como delegaçoes da Nação, estavam fundidas com outras no Poder Executivo". Assim, "quem o mostrou [...], quem o delineou , quem o criou realmente [...] foi o Sr. Dr. Pedro I, primeiramente no art. 98 da nossa Constituição, depois no art. 71 da Carta Constitucional da Monarquia Portuguesa. URUGUAI, Visconde de, op. cit., 1997, p.255.

${ }^{54}$ BONAVIDES, Paulo; ANDRADE, Paes de, op. cit., 1989, p.78.

${ }^{55}$ Evidentemente, como ressalta Oliveira Vianna, a ausência do povo não diminui o papel das câmaras no período colonial. "Não se veja, nem se alegue - como prova da presença do povo-massa e da sua influência nestas corporações municipais do período colonial - a vida agitada, às vezes, que estas corporações revelavam, a importância que adquiriram e o papel que exerceram ou pretenderam exercer naquele tempo. Esta vivacidade - observável através da Atas de todas estas Câmaras do norte ao sul - não podia provir do povo-massa, que, como acabamos de ver, nestas não tinha participação, mas, da nobreza da terra, desta aristocracia privilegiada, inscrita "nos livros de S. Majestade"'. VIANNA, Oliveira. Instituições políticas brasileiras. Belo Horizonte: Itatiaia/USP/UFF, 1987. v.1, p.119-120.

${ }^{56}$ A nota destoante adveio da Câmara de Itu, em que vieram a lume as Reflexões sobre o Projeto da Constituição, redigidas por Feijó. E, em Pernambuco, onde Caneca, "o Frade Carmelita, revolucionário da 
A Constituição de 1824 terminaria com a vontade anunciada na Fala do Trono, quando da abertura da Constituinte: uma Constituição outorgada que, liberal em matéria de direitos individuais, se mostraria centralizadora e autoritária na soma dos poderes que concedia ao monarca constitucional. ${ }^{57}$

Em relação aos aspectos sociais envolvidos no processo constituinte de 1823, merece atenção a figura do Frei Caneca, o qual, segundo Alcindo Guanabara, destaca-se "com a grandeza de um pensador profundo e com a força de um estadista capaz de organizar”, cuja "análise à Constituição não é obra de crítica vã" e cujos "ataques originam-se de suas opiniões sobre o direito constitucional a criar". ${ }^{58}$ De todo modo, como ressalta Nelson Saldanha:

O direito público no Brasil, formado em alto nível intelectual a partir do
surgimento dos primeiros comentários da Constituição de 1824 , sem embargo
das diferentes posturas doutrinárias dos respectivos autores, foi formado,
também, por um episódio particular: o debate em torno do chamado Poder
Moderador. Em meados do século, dominou a cena um conservadorismo
filosoficamente pouco expressivo (com poucas exceções): em sua segunda
metade, Tobias Barreto desencadeou um sério movimento crítico, basicamente
filosófico, mas com repercussões na literatura e no Direito. No final do século,

Confederação do Equador, na época o maior constitucionalista do País, verberou as nascentes absolutistas da futura Carta [...]", para quem "o Poder Moderador de nova invenção maquiavélica é a chave mestra da opressão da nação brasileira e o garrote mais forte da liberdade dos povos". Ver BONAVIDES, Paulo; ANDRADE Paes de, op. cit., 1989, p.79-80. Ver também CANECA, Frei Joaquim do Amor Divino. Frei Joaquim do Amor Divino Caneca. Organização e introdução de Evaldo Cabral de Melo. São Paulo: Ed. 34, 2001; MELLO, Evaldo Cabral de. A outra independência: o federalismo pernambucano de 1817 a 1824. São Paulo: Editora 34, 2004.

${ }^{57}$ A Constituição do Império teve única emenda, advinda de onda liberal, por meio do Ato Adicional de 1834, que, entre outras medidas, suprimiu o Conselho de Estado; instituiu as assembléias legislativas provinciais, dotando-as, para a época e para uma forma de Estado unitário, de considerável autonomia; e fortaleceu o poder do Regente, que se tornou "a figura dissimulada de um chefe republicano, de um Presidente da República", com a sua investidura passando a ser feita pelos eleitores da respectiva legislatura, reunidos nos seus colégios. Tais eleitores votavam em dois brasileiros natos, nascidos em províncias diferentes, através de escrutínio secreto. BONAVIDES, Paulo; ANDRADE Paes de, op. cit., 1989, p.120. Ver também BENEVIDES, J. M. Corrêa de Sá e. Análise da constituição política do império do Brasil. São Paulo: Tipografia King, 1890. Para um panorama da circulação das elites e da dinâmica política durante a quadra imperial, ver CARVALHO, José Murilo de. A construção da ordem: a elite política imperial; Teatro de sombras: a política imperial. 2. ed. Rio de Janeiro: UFRJ; RelumeDumará, 1996.

${ }^{58}$ GUANABARA, Alcindo apud FREIRE, Felisbelo. História constitucional da República dos Estados Unidos do Brasil. Rio de Janeiro: Typ. Aldina, 1895. v.III, p.XXI. Segundo ainda Alcindo Guanabara: "[...] Caneca aparece-nos, pois, como o primeiro pensador brasileiro formulando a solução do nosso problema político pela república federal e presidencial. Essa solução veio a tomar corpo posteriormente no projeto da Constituição que foi debatido pela constituinte da República de Piratinim e no qual a forma federal e a forma presidencial, se ainda não se apresentavam com o rigor preciso com que surgiram no Congresso Constituinte de 1891, delineavam-se já assaz frisantemente, incorporando as aspirações latentes ou expressas da época. Porque se o desejo de assumir autonomia pela federação trabalhava de longa data no país, o desgosto causado pelo regime parlamentar era fato sobre o qual não iludiam, nem se calavam os principais homens políticos dos antigos partidos". Ibid., 1895, p.XXII. 
com o advento da República e da Constituição de 1891, arregimentou-se de novo os nossos publicistas em torno de um texto constitucional. ${ }^{59}$

Exegeta e apologista da Carta de 1824, o Marquês de São Vicente observa: "Nosso Direito Público positivo é a sábia Constituição política, que rege o Império: cada um de seus belos artigos é um complexo resumido dos mais luminosos princípios do Direito Público filosófico, ou racional." 60

Mesmo José Antônio Pimenta Bueno, discutindo a igualdade e definindo-a como igualdade perante a lei, revela a preocupação social com as bases materiais em que se aplicava a Constituição do Império, e critica "a horrível desigualdade material", acentuando que "é uma desgraça e um perigo ver ao lado de uma opulência espantosa, de gozo e luxo requintados, uma multidão de seres humanos mortos de fome". ${ }^{61}$

De fato, advindo das plagas européias, o pensamento liberal brasileiro, como já bem destacado por Raymundo Faoro, era mais marcado pelo absolutismo ilustrado do marquês de Pombal do que pelas lutas afirmativas de segmentos inconformados com o ancien régime francês. ${ }^{62}$ Iniciavam-se, no constitucionalismo, "as idéias fora do lugar", pois, como já destacado por Roberto Schwarz, talvez com certo exagero, mas não sem razão, "ao longo de sua reprodução social, incansavelmente o Brasil põe e repõe idéias européias, sempre em sentido impróprio", ${ }^{63}$

Eduardo Kugelmas acentua que "as elites ilustradas do universo luso-brasileiro da década de 1820" eram, em boa medida, herdeiras da tradição de que fala Raymundo Faoro, logo se tornando evidentes

as aproximações e sintonias entre estas elites e o moderadíssimo liberalismo dos teóricos franceses da época, preocupados em encontrar o equilíbrio entre o absolutismo de outrora, legitimado pelo direito divino dos reis, e a visão de soberania popular identificada com o período jacobino da Revolução Francesa e considerada rousseauniana. ${ }^{64}$

${ }^{59}$ SALDANHA, Nelson. Prefácio. In: VARELA, Alfredo. Direito constitucional brasileiro: reforma das instituições nacionais. Brasília: Senado Federal, Conselho Editorial, 2002, p.XII-XIII.

${ }^{60}$ SÃO VICENTE, José Antônio Pimenta Bueno, Marquês de, op. cit., 2002, p.58.

${ }^{61}$ Ibid., 2002, p.508. Sobre tal preocupação, João Camilo de Oliveira Torres veria mais uma "posição cristã do que apenas liberal". TORRES, João Camilo de Oliveira. Os construtores do Império. São Paulo: Nacional, 1968, p.146.

${ }^{62}$ Ver FAORO, Raymundo. Existe um pensamento político brasileiro? In: A república inacabada. São Paulo: Globo, 2007, p.25-165.

${ }^{63}$ SCHWARZ, Roberto. Ao vencedor as batatas. São Paulo: Duas Cidades; Ed. 34, 2000, p.29.

${ }^{64}$ KUGELMAS, Eduardo. Pimenta Bueno, o jurista da Coroa. In: SÃO VICENTE, José Antônio Pimenta Bueno, Marquês de, op. cit., 2002, p.39. 
$\mathrm{Na}$ verdade, uma definição restritiva de cidadania e uma hierarquização dos direitos políticos dos cidadãos eram vistos à época como compatíveis com uma noção limitada de liberalismo. ${ }^{65}$

\subsection{Primeiras constituinte e constituição republicanas}

Está tudo errado; é preciso desfazer o que está feito [...].

Gaspar da Silveira Martins

Uma passeata militar, sob o olhar bestializado ${ }^{66}$ do povo, levou de roldão a Constituição do Império e promoveu a derrocada da experiência político-constitucional iniciada setenta e cinco anos antes. ${ }^{67}$

A primeira constituição republicana foi produto de dois poderes constituintes originários, a saber, o poder constituinte do Governo Provisório, fático, na plenitude do exercício de todas as competências, e o poder constituinte do Congresso Nacional, poder de direito, com a tarefa de fazer a Constituição dentro das linhas mestras do movimento republicano e federativo, de que o Governo Provisório fora a personificação. ${ }^{68}$ O Governo Provisório desempenhou essa função através de decretos, os quais, em seu conjunto, formaram verdadeira constituição a reger o país, tracejando as novas instituições políticas, nomeadamente a república e a federação (art. $1^{\circ}$ do Decreto $\mathrm{n}^{\circ} 1$, de 15 de novembro de 1889). ${ }^{69}$

${ }^{65}$ Ibid., 2002, p.39-40.

${ }^{66}$ Ver BALEEIRO, Aliomar. Constituições brasileiras: 1891. Brasília: Senado Federal; CEE/MCT, 2001; CARVALHO, José Murilo de. Os bestializados. São Paulo: Companhia das Letras, 1987. Segundo Carlos Maximiliano, "dissipado o estupor originado pela surpresa violenta, não explodiu reação nenhuma: o Brasil em peso aderiu ao facto consummado". MAXIMILIANO, Carlos. Comentários à constituição brasileira. 3. ed. Porto Alegre: Globo, 1929, p.85.

${ }^{67}$ José de Alencar, um dos mais agudos observadores da constituição do Império, em sentido largo, apostrofava a experiência do Segundo Reinado, acentuando as "alforrias" em que deveria haver empenho, a saber, "a alforria do voto, cativo do Governo; a alforria da justiça, cativa do arbítrio; a alforria do cidadão, cativo da Guarda Nacional; e finalmente [...] a alforria do País, cativo do absolutismo, cativo da prepotência do Governo pessoal". Discurso na Câmara dos Deputados, sessão de 13/7/1871. In: ALENCAR, José de. Discursos parlamentares de José de Alencar. Brasília: Câmara dos Deputados, 1977, p.226. De todo modo, como acentua Ernest Hambloch, não faltaram opiniões favoráveis à monarquia brasileira, como a de Rojas Paul, presidente da Venezuela, que, tomando conhecimento da queda, exclamou: "Este é o fim da única república que jamais existiu na América". HAMBLOCH, Ernest. Sua majestade o presidente do Brasil: um estudo do Brasil constitucional (1889-1934). Brasília: UnB, 1981, p.45.

${ }^{68}$ BONAVIDES, Paulo; ANDRADE, Paes de. História constitucional do Brasil. Brasília: Paz e Terra, 1989, p.210.

${ }^{69}$ BRASIL. Decreto n. 1 , de 15 de novembro de 1889. Disponível em: <http://www.senado.gov.br/legislacao〉. Acesso em: 10 abr. 2008. 


\subsubsection{Os trabalhos constituintes}

A Assembléia Constituinte, convocada por decreto de 21 de dezembro de 1889 , eleita em 15 de setembro e instalada em 15 de novembro de 1890, era composta de 205 deputados e 63 senadores (três por Estado). Presidida por Prudente de Morais, concluiu os trabalhos em 24 de fevereiro de 1891.

O decreto por meio de que se convocou a Assembléia Constituinte estabelecia uma só câmara, mas a lei pela que se realizaram as eleições entrou em contradição com o decreto, compondo-se, por fim, de duas câmaras. Por meio do Decreto ${ }^{\circ} 510$, de 22 de junho de $1890,{ }^{70}$ o Governo Provisório estabeleceu a nova constituição, mandando-a vigorar desde logo no tocante à dualidade das câmaras, à sua composição e à sua eleição.

Diz Felisbelo Freire que "poucas incompatibilidades figuraram na lei e ainda menores as que foram observadas no pleito. Assim, tiveram entrada na representação cidadãos investidos dos cargos de governadores, ministros, chefes de polícia, comandantes de armas, etc." ${ }^{71}$ Segundo ainda Felisbelo Freire, tiveram assento "médicos, juristas, bacharéis em direito, engenheiros civis e militares, literatos, jornalistas, militares de mar e terra", todavia, "outro fator que não deixou de preocupar nossa atenção foi a latitude que teve o elemento militar na constituinte", pois "crescido foi o número de militares que nela tiveram assento". ${ }^{72}$ Segundo ainda Felisbelo Freire,

\footnotetext{
O liberalismo a Spencer, o positivismo, os excessos federalistas, o individualismo social contra o protecionismo do Estado, e muitos outros sistemas, tiveram seus ardentes e sinceros defensores. Somente não se ouviram opiniões contra o regímen republicano em si e a federação. ${ }^{73}$
}

Segundo Raymundo Faoro, a Assembléia Constituinte, "perdida a memória dos dias em brasa de 1823", instalou-se "sob a indiferença do povo da Capital Federal". ${ }^{74}$ Foi criada comissão, que ficou conhecida como a Comissão dos Cinco, formada por Joaquim Saldanha Marinho, presidente; Américo Brasiliense de Almeida Melo, vice-presidente; Antônio Luiz dos Santos Werneck, Francisco Rangel Pestana e José Antonio Pereira de

\footnotetext{
${ }^{70}$ BRASIL. Decreto n. 510, de 22 de junho de 1890. Disponível em: 〈http://www.senado.gov.br/legislacao〉. Acesso em: 10 abr. 2008.

${ }^{71}$ FREIRE, Felisbelo. História constitucional da República dos Estados Unidos do Brasil. Rio de Janeiro: Typ. Aldina, 1895. v. III, p.9.

72 Ibid., 1895. v.III, p.VI. "Do Congresso, composto de 205 membros, tiveram assento 46 militares". Ibid., 1895, p.VIII.

${ }^{73}$ Ibid., 1895, p.VI.

${ }^{74}$ FAORO, Raymundo. Os donos do poder: formação do patronato político brasileiro. 10. ed. São Paulo: Globo; Publifolha, 2000. v.2, p.167.
} 
Magalhães Castro, com o encargo de elaborar o anteprojeto da primeira constituição federal. Cumprida a tarefa, o trabalho foi entregue ao Governo Provisório, para que este fizesse a revisão - que coube precipuamente a Rui Barbosa ${ }^{75}$ - antes de enviá-lo ao Congresso Constituinte. Ao cabo, era um projeto "baseado nas constituições americana e argentina, com algumas idéias da Suíça, [...] retocado pelo Sr. Rui Barbosa". ${ }^{76}$

\subsubsection{Os partidos políticos na Assembléia de 1891}

Ainda com o testemunho de Felisbelo Freire, historiador e membro da Constituinte, outro aspecto a destacar foi a "falta de partidos organizados", pois

[...] Com a revolução política dissolveram-se os dous partidos do império e muito cedo funcionou ela para que tivesse partidos organizados, com programas bebidos nas novas instituições. Muito poucos foram os políticos do império que n'ela tiveram assento. A grande maioria compôs-se de moços pertencentes ao partido republicano histórico que fizeram a propaganda. Foi deste partido que saiu o maior contingente. ${ }^{77}$

75 Aurelino de Araújo Leal relata que, tendo Rui Barbosa finalizado a revisão do projeto e entregando-o a Deodoro para a sua assinatura, ocorreu o seguinte diálogo: "O Chefe do Governo folheou o documento, minuciou-lhe as páginas, e não achando o que procurava, perguntou: 'Onde está o artigo que autoriza o Presidente a dissolver o Parlamento?' O Sr. Rui explicou-lhe que tal dispositivo não era de molde a figurar numa Constituição Presidencialista, ao que Deodoro objetou: 'Pois bem. Mas o senhor há de sair um dia do Congresso, como Antonio Carlos, em 1823, tirando o seu chapéu à majestade do canhão’ e assinou o decreto". LEAL, Aurelino de Araújo. História constitucional do Brasil. Brasília: Senado Federal, Conselho Editorial, 2002, p.214-215. Segundo Aliomar Baleeiro, Deodoro "queria a unidade da magistratura, poder de o Presidente da República dissolver o Congresso, enfim, disposições incompatíveis como Presidencialismo federativo do figurino norte-americano ou da cópia argentina de 1853, obra de Alberdi”. BALEEIRO, Aliomar. Constituições brasileiras: 1891. Brasília: Senado Federal; CEE/MCT, 2001, p.29.

${ }^{76}$ ROURE, Agenor de. A constituinte republicana. Rio de Janeiro: Imprensa Nacional, 1920. v.1, p.12. Segundo Walter Costa Porto, "a Assembléia Constituinte amalgamava democratismo francês, liberalismo inglês e federalismo americano”. PORTO, Walter Costa. Prefácio. In: CAVALCANTI, João Barbalho Uchôa. Constituição Federal Brasileira, 1891: comentada. Brasília, Senado Federal, Conselho Editorial, 2002, p.XII. A influência do constitucionalismo norte-americano não deve ser descurada, inclusive, porque antes o Decreto n. 848, de 11 de outubro de 1890, já dispusera que "os estatutos dos povos cultos e especialmente os que regem as relações jurídicas na República dos Estados Unidos da América do Norte, os casos de common law e equity, será também subsidiários da jurisprudência e processo federal". BRASIL. Decreto n. 848, de 11 de outubro de 1890. Disponível em: <http://www.senado.gov.br/legislacao>. Acesso em: 10 abr. 2008. Amaro Cavalcanti também acentua a influência do constitucionalismo dos Estados Unidos: "o projeto que se discute, todos sabemos, não é uma obra original. Elaboração da política experimental, ele nos apresenta o texto da Constituição Federal da República Norte-Americana, completado com algumas disposições das Constituições suíça e argentina". Prudente de Moraes também acentuou que "a nossa Pátria, de hoje em diante, tem uma Constituição livre e democrática com o regime da mais larga federação, única capaz de mantê-la unida, de fazer com que possa desenvolver-se, prosperar e corresponder, na América do Sul, ao seu modelo da América do Norte". CARONE, Edgar. A república velha (instituições e classes sociais). 4. ed. Rio de Janeiro: Difel, 1978, p.288.

77 PORTO, Walter Costa, op. cit., 2002, p.XI. 
Assim,

De duzentos e sessenta e oito membros de que se compunha o congresso, vê-se que 131 pertenciam ao partido republicano histórico.

Estes diversos elementos de que ele se compunha, republicanos, federalistas, conservadores e liberais no império, republicanos positivistas, e militares, conformam aquilo que atrás dissemos - a impossibilidade de definir claramente o congresso como um corpo político.

Por isso mesmo que não possuía homogeneidade política, foi sempre impossível ver a influência de disciplina dominando os seus trabalhos. Não se ressentia da influência de chefes, de leaders, atendendo entretanto às opiniões e esclarecimentos dos competentes, nas graves questões que discutia. ${ }^{78}$

Mas, mesmo o Partido Republicano, "ele não apresenta-se no seio da constituinte como um partido organizado". Assim,

[...] Nem ele mesmo resistiu à ação dissolvente da revolução. Em seu seio começa a operar-se a cisão de seus membros, colocando-se eles em pontos opostos e situações adversas, em períodos posteriores de nossa vida republicana.

Esse resultado era inevitável. Como partido de propaganda, que o era, não poderia deixar de cindir-se, passando à fase de partido de governo em que os interesses e os intuitos são de ordem e natureza muito diversos. ${ }^{79}$

Conclusivamente, Felisbelo Freire vê, na ausência de partidos, "em grande parte o ter a constituinte chegado ao termo de sua obra”, visto que

Compreende-se facilmente que se os homens da constituinte de Novembro de 1890 se separassem pelas responsabilidades inerentes às organizações partidárias e dominados pelos hábitos entre nós inveterados do parlamentarismo, da demagogia parlamentar, graves atritos levantar-se-iam contra ela e o governo. ${ }^{80}$

As eleições para o Congresso Constituinte basearam-se no disciplinamento traçado por meio do Decreto n ${ }^{\circ}$ 510, de 22 de junho 1890, conhecido como Regulamento Alvim.

As eleições para o Congresso Constituinte, mesmo com a vitória esmagadora do governo, "não significou a eleição de um corpo legislativo dócil". Havia republicanos de todos os tipos: antigos, novos e de poucos dias. A Assembléia Constituinte procurou primeiro definir sua soberania com relação ao Poder Executivo, visto que o Governo Provisório concentrava os poderes executivo e legislativo. No entanto, os poderes do Executivo continuaram como estavam e os representantes deveriam cuidar apenas de elaborar a nova constituição. O tema central da elaboração constitucional foi a organização

\footnotetext{
${ }^{78}$ FREIRE, Felisbelo, op. cit., 1895. v. III, p.12.

${ }^{79}$ FREIRE, Felisbelo, op. cit., 1895. v. III, p.XI.

${ }^{80}$ FREIRE, Felisbelo, op. cit., 1895. v. III, p.XII.
} 
do Estado, a partir da dialética, de um lado, da corrente do federalismo exacerbado e, de outro, do federalismo domesticado. ${ }^{81}$

De todas as assembléias constituintes brasileiras, a de 1890/1891 foi a mais exígua e apressada, concluindo o seu projeto em pouco mais de três meses, para o que "[...] colaborou o desejo de votar, logo, a Constituição, 'para que o País entrasse, quanto antes, no regime legal', como explicaria De Roure", mas valeu de igual modo “o temor da febre amarela. E, também, um outro temor, com relação ao Chefe do Governo Provisório, Deodoro, já descontente com o andamento dos trabalhos". 82

\subsubsection{A crítica ao constitucionalismo republicano}

A primeira constituinte republicana teve o liberalismo econômico como ideologia, separando o Estado da sociedade. A propósito, observa Gustavo Franco:

[...] A latitude das mudanças não conhecia precedente, sendo que, para algumas regiões e atividades mais diretamente dependendo do chamado 'elemento servil', ou de privilégios associados à monarquia, a Abolição e a República assinalavam o desfecho de uma lenta agonia, ou a aceleração de um vigoroso processo de modernização que se desenhava no limiar da década de 1890. A Abolição, conforme um relato da época, tinha sido como uma 'faísca elétrica que destrói talvez, mas purifica o ambiente', ou seja, 'destruição criadora', como tantas outras reformas e inovações nos anos que se seguiram. ${ }^{83}$

Convém também destacar que a constituição do Estado Nacional implicou o efeito de distanciamento entre o "público" e o "privado". Aquele, concebido como mais moderno que este; na República, o "privado" acabou por apropriar-se do "público", marcando-o com o sentido particularista dos seus interesses, no caso a agricultura capitalista cafeeira. Acaba-se por ver que o Estado, apesar da ortodoxia liberal do texto constitucional de 1891,

\footnotetext{
${ }^{81}$ Ver LESSA, Renato. A invenção republicana. 2. ed. Rio de Janeiro: Topbooks, 1999.

${ }^{82}$ PORTO, Walter Costa, op. cit., 2002, p.XV.

${ }^{83}$ FRANCO, Gustavo. Prefácio. In: BARBOSA, Rui. O papel e a baixa do câmbio: um discurso histórico, 1891. Rio de Janeiro: Reler, 2005, p.11-12. De outra parte, como observa Joseph L. Love: "O Brasil nadava contra a corrente centralizadora quando a Constituição de 1891 [...] outorgou poderes fiscais e financeiros inusitados aos estados da federação. Na Argentina e no México, muitos anos antes da virada do século, o poder de fato, contrário ou não aos pressupostos constitucionais, havia começado a pender na direção central dessas nações. Na Colômbia, a centralização havia triunfado decididamente em 1886". LOVE, Joseph L. A república brasileira: federalismo e regionalismo (1889-1937). In: MOTA, Carlos Guilherme (Org.). Viagem incompleta: a experiência brasileira (1500-2000): a grande transação. São Paulo: Senac, 2000, p.123.
} 
se faz progressivamente interventor em matéria econômica, a fim de defender a valorização dos preços internacionais do café, como no Convênio de Taubaté (1906). ${ }^{84}$

Para um dos seus construtores, Manuel Ferraz de Campos Salles,

a obra legislativa da Constituinte está representada nesse monumento imperecível, que é a Constituição de 24 de fevereiro, na qual foram vazadas as aspirações democráticas do povo brasileiro, que vinha lutando, desde os tempos coloniais, para destruir os opressivos aparelhos da monarquia centralizada. ${ }^{85}$

Todavia, de modo geral, o fruto do trabalho da primeira constituinte republicana não agradou, iniciando-se de logo a elaboração da sua crítica a partir da própria sessão em que foi promulgada, com o conclamar para a sua revisão. ${ }^{86}$ Segundo Ernest Hambloch,${ }^{87}$ essa reforma foi procrastinada pelas oligarquias, e o resultado dessa demora foi tal que, quando se decidiu levá-la adiante, já não bastava uma reforma constitucional, pleiteava-se uma revolução que acabasse com todos os vícios oligárquicos. Gilberto Amado resumiu assim o destino da Constituição de 1891: “A Constituição republicana sobre o restante do País exerce a mesma função nominal que exercia a Monarquia". ${ }^{88}$

Certamente, o primeiro passo da longa marcha da "democracia brasileira, representativa, laica e republicana", foi dado com "o primeiro voto na eleição de deputados à Assembléia Constituinte de 1891" ${ }^{89}$ Todavia, a organização social, econômica e política subjacente à Constituição de 1891, isto é, a República Velha, foi muito bem caracterizada por Robert Levine como um período de "cidadania limitada", em que "os brasileiros [...]

${ }^{84}$ Ver VIANNA, Luiz Werneck. Travessia: da abertura à constituinte. Rio de Janeiro: Taurus, 1986. No Império, a regulação econômica do Estado fazia-se sentir no comércio e indústria, com praticamente tudo a depender do governo, com autorizações, favores, tarifas protecionistas e concessões. Ver FAORO, Raymundo. Os donos do poder: formação do patronato político brasileiro. 10. ed. São Paulo: Globo; Publifolha, 2000. v.2. No próprio Manifesto Republicano, de 3 de dezembro de 1870, falava-se de "a liberdade econômica suprimida por uma legislação restritiva”. In: BONAVIDES, Paulo; AMARAL, Roberto, op. cit., 2002. v.II, p.485. Ademais, "do ponto de vista jurídico, esta fase também mereceu um relevo todo especial, porque é aquele em que nasceu o Código Comercial [...]; o regulamento 737, relativo ao processo civil e comercial [...], e a lei de terras de 1850. É também desse período a introdução no direito administrativo do regime de concessão, inspirado no direito europeu, para obras e serviços públicos". VENANCIO FILHO, Alberto. A intervenção do Estado no domínio econômico: o direito público econômico no Brasil. Rio de Janeiro: FGV, 1968, p.27.

${ }^{85}$ SALES, Manuel Ferraz de Campos. Da propaganda à presidência. Brasília: UnB, 1983, p.31.

86 Neste sentido foi o discurso de Leopoldo Bulhões, constituinte goiano. In: BONAVIDES, Paulo; AMARAL, Roberto, op. cit., 2002, v.4, p.26.

${ }^{87}$ HAMBLOCH, Ernest. Sua majestade o presidente do Brasil: um estudo do Brasil constitucional (18891934). Brasília: UnB, 1981.

${ }^{88}$ AMADO, Gilberto. Grandes discursos 2. Brasília: Instituto Tancredo Neves, 1988, p.59.

${ }^{89}$ SANTOS, Wanderley G. dos. O paradoxo de Rousseau: uma interpretação democrática da vontade geral. Rio de Janeiro: Rocco, 2007, p.13. O sistema representativo no Império pode ser caracterizado pelo "sorites" de Nabuco de Araújo: “[...] o Poder Moderador pode chamar a quem quiser para organizar Ministérios; esta pessoa faz a eleição porque há de fazê-la; esta eleição faz a maioria. Eis aí o sistema representativo no nosso país!’. Discurso de Sorites apud NABUCO, Joaquim, op. cit., 1997. v.I, p.764. 
não gozavam nem de uma democracia nem de mais oportunidades para melhorar de vida". Assim,

\begin{abstract}
Em 1889, o governo do Brasil passou de monarquia constitucional a república federativa secular, fundamentada nos princípios ortodoxos do liberalismo econômico e comandada de forma ditatorial durante quase toda a primeira a década de sua existência. Os presidentes civis que governaram após 1896 o fizeram sob a ameaça constante de uma intervenção militar. A estabilidade chegou depois de 1898 sob o comando dos paulistas, e o governo federal expandiu-se com a república. De 1900 a 1930, as despesas do governo central aumentaram mais de 5\% ao ano, três vezes a taxa de 1930-45, apesar de todos os novos departamentos criados por Vargas. ${ }^{90}$
\end{abstract}

No período, na sua maior parte, "a cidadania, na prática, estendia-se apenas à elite" e "abusos contra os direitos humanos eram lugar-comum":

[...] Mesmo durante os períodos em que não havia censura formal, os editores de jornais instintivamente amenizavam, ou excluíam totalmente, notícias sobre greves, especialmente aquelas contra grandes proprietários de terras (como no caso da greve de 1931 contra as fazendas de café de Albuquerque Lins) e contra ferrovias de propriedade estrangeira. Os militares chefiavam campos de concentração para prisioneiros políticos, num dos quais, em Clevelândia do Norte, no distante Amapá, descobriram-se décadas depois túmulos cheios de cadáveres de prisioneiros que receberam injeções de morfina ou haviam sido forçados a ingerir grandes quantidades de vidro moído. Excetuando-se as atividades religiosas, a sociedade tinha poucas oportunidades de se reunir. A vida nos vilarejos, prejudicada pelo poder dos proprietários de terras, carecia da tradição de autonomia que gozavam os vilarejos no México ou no Peru. ${ }^{91}$

A obra constituinte de 1890/1891 "mereceu dois [...] tipos de análise": 1. daqueles que, tendo participado, de algum modo, do esforço constituinte, procuraram detalhar o processo de sua elaboração, o propósito de seus legisladores, o alcance de seus dispositivos, comparando o texto com o de cartas então vigentes em todo o mundo, entre os quais se situam Agenor de Roure ${ }^{92}$ e João Barbalho ${ }^{93}$; 2. dos que, entre os quais se destacam Oliveira Vianna ${ }^{94}$ e Ernest Hambloch ${ }^{95}$, depois de passado largo tempo da aplicação da Constituição, lamentaram a distância entre as intenções expressas no documento e a realidade do país. ${ }^{96}$

\footnotetext{
${ }^{90}$ LEVINE, R. M. Pais dos pobres? O Brasil da era Vargas. São Paulo: Companhia das Letras, 2001, p.20.

${ }^{91}$ Ibid., 2001, p.21.

${ }^{92}$ ROURE, Agenor de. A constituinte republicana. Rio de Janeiro: Imprensa Nacional, 1920. v.1

${ }^{93}$ CAVALCANTI, João Barbalho Uchôa. Constituição Federal Brasileira, 1891: comentada. Brasília: Senado Federal, Conselho Editorial, 2002.

${ }^{94}$ Ver, principalmente, VIANNA, Oliveira. O idealismo na constituição. Rio de Janeiro: Terra de Sol, 1927.

${ }^{95}$ Ver HAMBLOCH, Ernest, op. cit., 1981.

${ }^{96}$ PORTO, Walter Costa. Prefácio. In: CAVALCANTI, João Barbalho Uchoa, op. cit., 2002, p.XI.
} 
Cumpre destacar que, com a Constituição de 1891, forma-se no Brasil uma tradição de pensamento das mais fecundas. Decididamente autoritário e encontrando em Alberto Torres, Oliveira Viana, Azevedo Amaral e Francisco Campos os seus expoentes, ${ }^{97}$ tal pensamento tinha por objetivo persuadir as elites culturais da época, sobretudo, para a necessidade de, com o instrumental científico-sociológico, munir-se de antídotos contra o constitucionalismo formal, de fortalecer o poder público central e incrementar o nacionalismo. Talvez, constitua mesmo como "a formação de um sistema ideológico orientado no sentido de conceituar e legitimar a autoridade do Estado como princípio tutelar da sociedade". A "estrutura narrativa de tais autores, "invariavelmente se inicia com amplas reflexões histórico-sociológicas sobre a formação colonial do país, estende-se no diagnóstico do presente - no caso, a República Velha - e culmina na proposição de algum modelo alternativo de organização político-institucional".98

De modo geral, os críticos da Constituição republicana insistiam na necessidade de adaptar as instituições à realidade nacional e afirmavam o contraste do "país legal" em relação ao "país real", isto é, a parcial ou total inadequação das instituições a partir de 1891 à evolução do Brasil. Por conta do dedutivismo jurídico-formal, o constitucionalismo republicano seria vítima da reificação institucional, ou seja, da aceitação do ponto de vista segundo o qual as mesmas instituições acarretam sempre os mesmos efeitos políticos, independentemente da ordem econômica e social em que se inscrevem. ${ }^{99}$

\footnotetext{
${ }^{97}$ Além desses pensadores, sobretudo na década de 30, um conjunto de trabalhos também cuidou da crítica às instituições da República Velha, entre os quais se incluem, DUARTE, Nestor. A ordem privada e a organização política nacional. Brasília: Ministério da Justiça, 1997; ALMEIDA, Martins de. Brasil errado: ensaio político sobre os erros do Brasil como país. Rio de Janeiro: Civilização Brasileira, 1932; ROSA, Virgínio Santa. A desordem: ensaio de interpretação do momento. Rio de Janeiro: Schmidt, 1932; e ROSA, Virgínio Santa. O sentido do tenentismo. Rio de Janeiro: Schmidt, 1933; SODRÉ, Alcindo. A gênese da desordem. Rio de Janeiro: Schmidt, 1933.

98 LAMOUNIER, Bolívar. Formação de um pensamento político autoritário. FAUSTO, Boris (Org.). História geral da civilização brasileira: sociedade e instituições (1889-1930). Rio de Janeiro: Difel, 1977. 2v., p.345 e 356. Para o mesmo autor, a "ideologia de Estado", presente no pensamento crítico da Primeira República e nos ideólogos da Revolução de 30, “[...] não é, porém, apenas a exponenciação do antiindividualismo [...]. É sobretudo a constituição [...] de uma visão do mundo político na qual são afugentadas todas as representações conducentes à noção de um 'mercado político', exorcizado em proveito das representações fundadas no princípio da autoridade e em supostos consensos valorativos". Ibid., 1977, p.357.

${ }^{99}$ Felisbelo Freire, pelo contrário, considera que a República “constitui uma tradição histórica em nossa vida política", afirmando "a convicação que toma corpo justamente no fato incontestável de que a República teve suas causas de origem, de desenvolvimento, suas fases e seus períodos históricos, sofrendo a influência cultural do meio e reagindo sobre ele”. FREIRE, Felisbelo, op. cit., 1895. v.1, p.9.
} 


\subsubsection{Alberto Torres}

Para Alberto Torres, a Constituição Federal de 1891 fora "fruto de uma revolta sem cultivo prévio na opinião e sem preparo organizador - surgida, inesperadamente, das trevas da conspiração política, para a realidade, por força de um trabalho subterrâneo". ${ }^{100}$ Tal revolta fora favorecida por alguns acidentes da política imperial, a saber, a abolição dos escravos e a moléstia do monarca, principalmente prenunciando este último, a aproximação do terceiro reinado antipático, em geral, ao sentimento popular, de modo que o texto constitucional republicano "não é senão uma roupagem de empréstimo, vestindo instituições prematuras". ${ }^{101}$ Segundo ainda Alberto Torres, todas as nações possuem um regime constitucional ostensivo e um regime constitucional verdadeiro, mas subterrâneo, com "o terrível problema da arte política" consistindo em conciliar a realidade com a abstração. Assim, o regime ideal seria aquele em que os dois planos se confundissem, de modo que um regime constitucional evoluísse na medida em que o plano inferior se aproximasse da concepção legal. Louvando o texto promulgado em 24 de fevereiro de 1891 e reconhecendo-lhe a perfeição técnica, assinala:

[...] Como obra de estética e de ideal político, é talvez o mais notável documento de cultura jurídica contemporânea; não sei que haja outra onde as definições e as classificações, o rigor e o cuidado no desenvolver regras e funções, tenham atingido a tanta perfeição; nenhuma levou tão longe o empenho de proclamar as mais avançadas conquistas da liberdade humana e da democracia. ${ }^{102}$

Todavia, a "perfeição técnica" discrepa substancialmente das "necessidades positivas" e das "formas de vida real":

Desde que se sai [...] do terreno puramente abstrato e da contemplação da forma, começam a surgir as lacunas, as imperfeições e incoerências do sistema. Não tendo por fim regular fatos da vida pública do povo e do país, atender ás suas necessidades positivas, faltou ao legislador o critério prático, próprio de um trabalho legislativo assentado sobre o terreno da observação e da experiência, único que pode dar às leis uma feição inteligível, porque reflete as formas da vida real. $^{103}$

\footnotetext{
${ }^{100}$ TORRES, Alberto. A organização nacional. 4. ed. São Paulo: Nacional; Brasília: UnB, 1982, p.34.

${ }^{101}$ Ibid., 1982, p.35.

${ }^{102}$ Ibid., 1982, p.80.

${ }^{103}$ Ibid., 1982, p.80.
} 
Alberto Torres propunha a instituição de um "Poder Coordenador", ${ }^{104}$ semelhante ao Poder Moderador imperial, porém, com funções mais amplas. Embora tal poder nunca tenha se institucionalizado, observa Barbosa Lima Sobrinho que

\begin{abstract}
grande parte das atribuições que Alberto Torres lhe conferia insere-se hoje na atividade de vários órgãos administrativos, como o Ministério do Trabalho, o Conselho de Águas e Energia, o Ministério da Economia, a Justiça Eleitoral, o Supremo Tribunal Federal, os órgãos legislativos, o Ministério da Agricultura, para não citar senão os mais importantes..$^{105}$
\end{abstract}

No seu livro principal, A organização nacional, Alberto Torres anexou um "projeto de revisão constitucional", em que se vislumbra um esboço de "constituição econômica", alheia ao figurino liberal do texto constitucional de 1891, "para tornar efetivas as garantias constitucionais à liberdade, à segurança e à propriedade, assegurar aos cidadãos bem-estar, prosperidade e educação, direito ao trabalho e a seus instrumentos, bem como à justa remuneração de seus frutos", "para garantir a liberdade comercial, apoiar a produção e assegurar aos consumidores a aquisição de tudo quanto interessar à vida, à saúde, à educação e à prosperidade, por seu justo preço". ${ }^{106}$

\title{
2.4.3.2 Azevedo Amaral
}

Já para Azevedo Amaral, o regime inaugurado pelo movimento de 1889 e depois concretizado na Carta Política de 1891 representou progresso considerável no sentido da aproximação da ordem política com a realidade nacional, principalmente, com a adoção do presidencialismo. O Executivo também sai fortalecido com a adoção do presidencialismo, deixando de ser criação do Poder Moderador para emanar da vontade geral. Assim, o

\footnotetext{
${ }^{104}$ A idéia de um "poder coordenador" tornar-se-á, mutatis mutandi, recorrente no debate constituinte brasileiro, como em proposições de Fábio Konder Comparato e Goffredo Telles Jr. Para o primeiro, a proposta de "o planejamento na estrutura institucional do Estado brasileiro [...] criar órgãos autônomos de elaboração e fiscalização dos planos de desenvolvimento, tanto na União, quanto nos Estados". Inclusive, "a Superintendência Nacional de Planejamento tem o dever de propor, perante o Tribunal Constitucional, ação de invalidade de leis e atos do Poder Executivo que contrariem os planos de desenvolvimento". Para o segundo, a criação de uma "Assessoria ilustre", totalmente apartidária e ligada diretamente ao presidente da República, o Conselho do Planejamento Nacional. Ver, respectivamente, COMPARATO, Fábio Konder. Muda Brasil! Uma constituição para o desenvolvimento democrático. 4. ed. São Paulo: Brasiliense, 1987, p.26; e TELLES JR., Goffredo. O povo e o poder. 2. ed. Porto Alegre: Juarez de Oliveira, 2006.

${ }^{105}$ LIMA SOBRINHO, Barbosa. A presença de Alberto Torres: sua vida e pensamento. Rio de Janeiro: Civilização Brasileira, 1968, p.363. Segundo o mesmo autor, "O Estado forte que Alberto Torres desejava, não tinha nada de comum com o Estado discricionário dos fascismos. Era, antes de tudo, um Estado de direito, armado dos poderes necessários para enfrentar as poderosas oligarquias financeiras, os argentários, como ele os denominava. Mas Alberto Torres exaltava os direitos individuais, o que hoje se denominaria a Dignidade da Criatura Humana, e levava tão longe essa preocupação, que criava um Poder Coordenador para defender os direitos individuais nos Estados. [...]". Ibid., 1968, p.514.

${ }^{106}$ Ver Projeto de revisão constitucional. In: TORRES, Alberto, op. cit., 1982, p.301-331.
} 
presidencialismo prestou ao Brasil dois serviços de extrema relevância: a) tornou possível a consolidação da república, ao impedir que, na confusão criada pela revivescência dos saudosismos monarquistas e das ambições caudilhescas, se precipitasse uma crise de desagregação da nacionalidade; b) a possibilidade - que fora dele não teria existido - de uma ação administrativa que, apesar de erros e desfalecimentos ocasionais, permitiu avanço no progresso econômico do país. ${ }^{107}$ Todavia, reforçava o entendimento segundo o qual os erros da Carta de 1891 advinham da transplantação, para o meio brasileiro, de instituições que haviam sido criadas em uma ambiência social e sob as injunções de problemas políticos profundamente diferentes dos nossos, no caso os Estados Unidos da América.

\subsubsection{Oliveira Vianna}

Oliveira Vianna também acentuou a disjunção entre o "país legal” e o "país real", ${ }^{108}$ como a base do diagnóstico do caráter utopicamente liberal das instituições jurídicopolíticas levadas a termo com a Constituição de 1891, em contraste com o caráter clânicooligárquico das instituições sociais. A seu ver, os "bons rapazes, que se haviam adestrado em atirar pedras no governo, colhidos de surpresa para a grave missão de estadistas, tiveram que improvisar às pressas um programa de construção", ${ }^{109}$ ademais, de terem uma mentalidade cujo traço mais distintivo

era a crença no poder das fórmulas escritas. Para esses sonhadores, pôr em letra de forma uma idéia era, de si mesma, realizá-la. Escrever no papel uma Constituição era fazê-la para logo uma cousa viva e atuante: as palavras tinham o poder mágico de dar realidade e corpo às idéias por elas representadas. ${ }^{110}$

\footnotetext{
${ }^{107}$ Ver AMARAL, Azevedo. O Estado autoritário e a realidade nacional. Brasília: UnB, 1981. No entanto, Azevedo Amaral considerava que, "exercendo uma influência desagregadora, menos perceptível talvez na aparência, mas de resultados muito mais profundos e irreparáveis, ocorria uma causa de ordem econômica de formidáveis possibilidades", ou seja, "o erro mais grave e mais imperdoável dos constituintes de 1891 foi não terem assegurado por meio de um dispositivo explícito a unidade do mercado nacional (eliminação de todas as restrições de intercâmbio interno). Esse foi corrigido pela Carta de 1937'. Ibid., 1981, p.40.

${ }^{108}$ Conforme observa Bolívar Lamounier, "a disjunção entre o 'país real' e o 'país legal' é uma forma narrativa extremamente comum em todos os países onde se verificou uma reação forte contra o iluminismo e o constitucionalismo abstrato do liberalismo francês do século XVIII”. LAMOUNIER, Bolívar. Formação de um pensamento político autoritário. In: FAUSTO, Boris (Org.). História geral da civilização brasileira: sociedade e instituições (1889-1930). Rio de Janeiro: Difel, 1977. v.2, p.354.

${ }^{109}$ VIANNA, Oliveira, op. cit., 1927, p.23-24.

${ }^{110}$ Ibid., 1927, p.25. A República Velha era dominada pelo bacharelismo do Direito Privado, "eram todos civilistas e comercialistas. Este era o Direito que importava. Nada de Direito Público, o qual, não tendo o prestígio das academias jurídicas, também não merecia o respeito devido pelos governantes. Havia Rui Barbosa, com o gigantismo de sua palavra e de sua vida política, mas ele era também desiludido com a República e apontava os desvios da política em relação ao ideário dos republicanos históricos. Rui estaria, também, na oposição à República Velha. O Direito Público nas mãos da oligarquia era mais um
} 
Assim,

os republicanos da Constituinte construíram um regímen político baseado no pressuposto da opinião pública organizada, arregimentada e militante. Ora, esta opinião não existia, e ainda não existe entre nós: logo, ao mecanismo idealizado pelos legisladores de 91 faltava o sopro inspirador do seu dinamismo. Daí a sua falência. 111

Prossegue Oliveira Vianna afirmando que o erro dos reformadores políticos foi querer realizar no Brasil uma democracia do tipo inglês, o que, segundo ele, seria coisa totalmente impossível, porque, "seja qual for a pregação dos novos Rui do futuro, estaremos condenados a jamais ser ingleses". ${ }^{112}$

\subsubsection{Francisco Campos}

Francisco Campos, a la Glumpowicz, não deixava de ver no Estado um componente essencialmente violento. Entre os ensaístas brasileiros, "é provavelmente [...] o que mais se aproxima da visão glumpowcziana". ${ }^{113}$ Todavia, sem e contra o liberalismo político, internaliza a noção de Estado de Direito advinda do constitucionalismo liberal. Na verdade, o autor da Constituição de 1937 foi o mais importante defensor intelectual do corporativismo autoritário, rejeitando categoricamente a democracia liberal por julgar que a entrada das massas na vida política exigia medidas repressivas, pois poderia degenerar em luta de classes, numa "inundação moscovita” e em anarquia. Assim é que Francisco Campos defendia um Estado forte e centralizado que servisse ao país todo, não a interesses

instrumento para a utilização do Poder, do que a condição necessária para o seu exercício. Essa é a explicação do fato de como, em uma República dominada pelos bacharéis, havia tanta fraude nas eleições, tanto desvirtuamento das instituições, o clima, enfim, que levou ao ciclo revolucionário, cujo epílogo está em 1930”. POLETTI, Ronaldo. A Constituição de 1934. Brasília: CED, 1987, p.4.

111 VIANNA, Oliveira, op. cit., 1927, p.43.

112 VIANNA, Oliveira. Instituições políticas brasileiras. Brasília: Itatiaia/USP/UFF, 1987, p.124.

${ }^{113}$ LAMOUNIER, Bolívar. Formação de um pensamento político autoritário. In: FAUSTO, Boris (Org.), op. cit., 1977, p.367. Rogerio Dultra dos Santos traça bem o perfil de Francisco Campos: "Campos foi um dos políticos mais ativos na configuração do Estado brasileiro durante o século XX. Responsável pela reorganização dos sistemas educacional, legal e constitucional durante a Revolução de 1930 e no Estado Novo, elaborou também o Ato Institucional $n^{\circ} 1$, que deu origem ao regime militar (1964-1985). De 1935 até 1937, quando deixou o cargo de secretário de Educação do antigo Distrito Federal para elaborar o Projeto da Constituição outorgada, Campos já era o jurista mais influente na política nacional, articulando com os integralistas o apoio a Vargas. De 1937 a 1942, ocupou o cargo de ministro da Justiça e Negócios Interiores, colaborando diretamente para a consolidação do regime. Como personagem do Estado Novo, foi responsável pela reforma dos Códigos de Processo Civil, Penal e Processo Penal. Criou a Lei Orgânica dos Estados, que pretendia limitar seus poderes legislativo e administrativo, vinculando-os ao poder central; a Lei de Crimes contra a Economia Popular, a Lei de Segurança Nacional; as Leis de Naturalidade (naturalização, repressão política a estrangeiros, expulsão, extradição e imigração); a regulação da cobrança da dívida ativa da União; o Decreto-Lei contra o loteamento de terrenos; a Lei de Fronteiras etc. [...]". SANTOS, Rogerio Dultra dos. Francisco Campos e os fundamentos do constitucionalismo antiliberal no Brasil. Dados - Revista de Ciências Sociais, Rio de Janeiro, v.50, n.2, p.391-320, 2007. 
de classes. Ao Estado cabia o papel de guiar, não de controlar. O trabalho deveria ser organizado segundo um eixo vertical, dos sindicatos locais às confederações nacionais, representando organicamente não só os trabalhadores, mas a administração, os produtores e o Estado. ${ }^{114}$

Não se veja, entretanto, na crítica ao liberalismo da República Velha, da verdadeira hostilidade à organização de interesses no nível da sociedade civil, qualquer incentivo ou concessão à mobilização plebiscitária por parte da "ideologia de Estado" que vai num crescendo. Nada de partido único integrador, nem de qualquer modalidade de messianismo político, pelo contrário, "um cultivadíssimo realismo mescla-se aqui com a percepção elitista da irracionalidade dos menos esclarecidos, dando como resultado uma inclinação essencialmente não mobilizadora do processo político". Assim,

[...] Atenta à solidez, senão à funcionalidade, das estruturas de poder privado, a razão de Estado requer apenas uma captação controlada de recursos e energias da sociedade, sem exageros e sem componentes emocionais ou míticos capazes de perturbar o metabolismo social. A integração política totalitária, poder-se-ia escrever explicitando um pouco mais o pensamento de Francisco Campos, implica na anulação do próprio Estado como expressão de um modo parcial de integração política, e portanto do próprio objetivo da atividade política, que é uma integração apenas parcial da sociedade humana. A ideologia autoritária é uma ideologia de Estado neste duplo sentido: ela visa a integração político-social sob a égide tutelar do Estado, e não a integração mobilizadora que desfaz a demarcação jurídica e burocrática entre Estado e Sociedade; e teme o inevitável corolário da mobilização de massa - a 'aparição de César' - que dissolve o Estado como unidade jurídica impessoal em favor da autocracia plebiscitária. ${ }^{15}$

Por outro lado, Francisco Campos posta-se em oposição tanto ao liberalismo como ao fascismo e ao socialismo: no primeiro, por conceber a realidade política segundo a imagem do "mundo forense"; no fascismo e no socialismo, por pretender a integração total. Reforça o ponto de vista de que "a integração política totalitária" não elimina

${ }^{114}$ CAMPOS, Francisco. O Estado nacional: sua estrutura, seu conteúdo ideológico. Brasília: Senado Federal, Conselho Editorial, 2001.

115 Ainda segundo Bolívar Lamounier: "[...] O caso de Francisco Campos ilustra de maneira absolutamente gráfica esse pensamento: a opção pelo Rechstaat, pelo ideal de ordenação jurídica consagrado pelo constitucionalismo liberal, mas desta vez contra o liberalismo político. Enquanto se preserva, no terreno jurídico, a intenção "civilizatória" da elite cosmopolita, a racionalidade da esfera política é mais uma vez concebida como dominação cautelosa ou, para retomar a imagem de Oliveira Vianna, como adaptação às boas qualidades do país, extirpando-lhe as más. Boas qualidades seriam, no caso, aquela racionalidade sóbria, aquele sentimento das limitações humanas que os ensaístas da época discerniam no "caráter nacional". Da mesma maneira que impede a organização conflitiva de interesses nas formas que lhe sejam potencialmente hostis, o Estado pode e deve igualmente dispensar as que se empenhem na sua exaltação". Ibid., 2001, p.369-370. 
completamente as tensões políticas internas. Se o fizesse o Estado deixaria de existir, pois não passaria de "um modo parcial de integração política das massas humanas". ${ }^{116}$

\subsubsection{A "campanha do revisionismo" e a revisão constitucional de 1926}

Até agora, a política brasileira quer a Constituição inalterada, para se violar. Nós a queremos reformada, para se conservar.

Rui Barbosa

Conforme anota Barbosa Lima Sobrinho, em 1926, a Constituição de 1891 deixou de

ser tabu, derrogada pelas emendas que o Poder Executivo sugerira e o Poder Legislativo se apressara em aprovar. Era a conclusão de um longo esforço, que datava das primeiras manifestações de inconformidade registradas, por assim dizer, no dia seguinte ao da promulgação da Constituição. ${ }^{117}$

Efetivamente, um conjunto de manifestações, políticas e doutrinárias, denotavam aquilo que Campos Sales denominou de "obsessão revisionista", considerando "precipitada, inoportuna e antipatriótica essa propaganda que se agita contra a Constituição republicana". ${ }^{118}$ Em 1908, Joaquim Francisco de Assis Brasil apresenta um programa revisionista. ${ }^{119}$ Aurelino de Araújo Leal também dá notícia de projetos de reforma apresentados, entre os quais, o do Conselho Municipal de Petrópolis, em 1903. ${ }^{120}$ Por sua vez, já em 1899, Alfredo Varela trouxe à luz o seu Direito constitucional brasileiro, que começa com um estudo sobre as reformas constitucionais que considerava indispensáveis. ${ }^{121}$

${ }^{116}$ Ibid., 2001, p.36. Para uma interpretação recente do legado teórico de Francisco Campos, ver SANTOS, Rogerio Dultra dos, op. cit., 2007.

${ }^{117}$ LIMA SOBRINHO, Barbosa, op. cit., 1968, p.483.

${ }^{118}$ Campos Sales observava: "[...] ninguém pôde ainda dar com o verdadeiro rumo desses reformadores. O que todos vêem é que falta aos apóstolos da nova seita a condição essencial de força na propaganda: a fé, a sinceridade da crença. Ninguém apreende, no vago das declamações, o que pretendem esses propagandistas, pois que eles mesmos não o sabem nem o dizem; o que, porém, não escapa à observação do bom senso popular, é que, na quase totalidade, eles vão abraçando a nova fé à medida que vão perdendo as posições que conseguiram à sombra dessas mesmas instituições que ora combatem [...]”. SALES, Manoel Ferraz de Campos, op. cit., 1983, p.128.

${ }^{119}$ BRASIL, Assis Joaquim Francisco. Da democracia representativa na república (antologia). Brasília: Senado Federal, 1998.

${ }^{120}$ LEAL, Aurelino de Araújo. História constitucional do Brasil. Brasília: Senado Federal, Conselho Editorial, 2002.

${ }^{121}$ VARELA, Alfredo. Direito constitucional brasileiro: reforma das instituições nacionais. Brasília: Senado Federal, Conselho Editorial, 2002. Seguiu-se um conjunto de trabalhos em que a matéria da revisão é ferida. Ver, entre outros, CORREA, Serzedello. A revisão constitucional. Rio de Janeiro: Companhia Litho-typographia, 1904; CASTRO, Araújo. A reforma constitucional. Rio de Janeiro: L. Ribeiro 1924; NUNES, José Castro. Jornada revisionista: os rumos, as idéias, o ambiente: estudo crítico da 
Por fim, advindas de mensagem do presidente Arthur Bernardes, ${ }^{122}$ onze emendas foram discutidas e aprovadas, entre as quais, as de $n^{\circ} 6$ e $n^{\circ} 7$, que, de interesse mais próximo à "constituição econômica", trataram, respectivamente, da "proibição da transferência a estrangeiros de minas e de jazidas minerais ou das terras em que elas existissem" 123 e da "restrição da liberdade de comércio". Barbosa Lima Sobrinho resume bem o resultado da reforma constitucional de 1926:

[...] E o certo é que a reforma de 1926 não deteve a revolução, que se vinha elaborando pela acumulação de males, que correspondiam ao nosso desajustamento social e aos vícios e iniqüidades de nossa estrutura econômica. A preocupação de defender o regime se transformava no fortalecimento do Poder Executivo e não no fortalecimento do Estado. Fortalecer o Estado seria armá-lo para resolver os problemas da nacionalidade, problemas econômicos e sociais que se avolumavam e exigiam solução imediata. [...]. Fortalecer apenas o Poder Executivo era criar um ambiente de Ditadura, com todos os desfechos que ela acarreta, [...]. E fortalecer o Estado para fortalecer as oligarquias que o dominam, acaba sendo uma farsa com que se acobertam interesses espúrios de grupos financeiros. ${ }^{124}$

\subsection{A Constituinte de 1933/1934 e a Constituição de 1934}

Nós estamos construindo um edifício para os vivos, e não um túmulo para os mortos.

Virgílio de Melo Franco

constituição. Rio de Janeiro: Almeida Marques, 1924; LESSA, Pedro. A reforma constitucional. Rio de Janeiro: Brasileira Lux, 1925.

${ }^{122}$ Procedeu-se à Reforma de 1926 apesar da, na terminologia atual, "limitação circunstancial" ocasionada pelo estado de sítio durante o governo de Artur Bernardes. Todavia, segundo Barbosa Lima Sobrinho, é "verdade que Artur Bernardes não agiu como um ditador. Não preparou projetos, não intimidou parlamentares, não tomou atitudes ostensivas de patrão ou comandante. Limitou-se, numa Mensagem de abertura aos trabalhos parlamentares, a indicar os pontos onde a reforma lhe parecia necessária à vista de realidades que estavam presentes aos olhos de todos. [...]”. LIMA SOBRINHO, Barbosa, op. cit., 1968, p.488.

${ }^{123}$ Na motivação de tal dispositivo, está certamente o contencioso que se estabeleceu em torno da produção de aço, em que se envolveu Percival Farquhar, empresário norte-americano, a partir da presidência de Epitácio Pessoa. Como observa John D. Wirth, "o plano de Farquhar era grandioso, mas bem concebido. Após consultar o Presidente Epitácio Pessoa, que estava ansioso por iniciar a produção de aço e a exploração de petróleo no Brasil, Farquhar propôs a exportação de minério de ferro de Itabira e a simultânea instalação de uma moderna usina siderúrgica em condições de fabricar produtos básicos de aço. O norteamericano deseja minerar cerca de dez milhões de toneladas anuais de hematita de alta qualidade e embarcar esse minério via Santa Cruz, uma [...] cidadezinha pesqueira no Espírito Santo [...]. Na viagem de retorno, os navios cargueiros de Farquhar trariam carvão norte-americano e europeu de alta qualidade para a usina. Tratava-se do famoso Contrato Itabira de 1920". Todavia, com algum tempo, "os nacionalistas mineiros sustentavam que Farquhar havia iludido Epitácio Pessoa a fim de apoderar-se do minério deles, e que nunca iria instalar espontaneamente uma usina de aço". Mais tarde, "José Américo de Almeida mandou investigar o contrato da Itabira e tudo fez para declará-lo nulo". WIRTH, John D. A política do desenvolvimento na era de Vargas. Rio de Janeiro: FGV, 1973, p.59, 61 e 66.

${ }^{124}$ Ibid., 1973, p.493. 


\subsubsection{A Revolução de 30}

A Revolução de 1930 definiu de forma aguda o impasse político-constitucional que caracterizou a República Velha, com as fortes críticas que, desde a promulgação da Constituição de 1891, ${ }^{125}$ eram veiculadas. A cidadania restrita e a hegemonia das oligarquias já eram objeto das revoltas tenentistas dos anos 20, das cisões interoligárquicas e das demandas relativas ao sistema eleitoral, ao respeito pelo voto, ao reconhecimento dos candidatos eleitos, além da organização do movimento operário, ${ }^{126}$ que se manifestava, inclusive, pela emergência de greves a partir da segunda década. Assim, o movimento que culminou com a Revolução de 1930, a crer nos discursos e manifestos da Aliança Liberal (AL), tinha como finalidade o restabelecimento da legitimidade da forma representativa de poder, abalada pelos desvios, distorções e degenerações do presidencialismo e das práticas eleitorais que desfiguravam a manifestação da vontade popular. ${ }^{127}$

A conjuntura pós-30 pode ser desdobrada em três etapas, a saber, a eclosão revolucionária, que se estende até o final do Governo Provisório; a constitucionalização,

\footnotetext{
${ }^{125}$ Durante o processo constituinte que se deu em decorrência da Revolução de 30, veio à tona de maneira exponencial a questão da centralização política. Porta-voz dos interesses dos tenentes e secretário-geral da Subcomissão do Itamarati, Temístocles Brandão Cavalcanti sintetiza bem o espírito da discussão, quando observa: "A federação, como existia entre nós, e o individualismo foram os dois processos de desassociação que nos trouxe a Constituição de 1891. A primeira ia nos desagregando politicamente; o segundo criou este espírito de dissolução social que nos priva, até hoje, de qualquer sentimento coletivo, tão necessário à própria existência da nação. Impõe-se, por isso mesmo, uma tendência para a unidade, mas de maneira que a subsistência da forma federativa não se torne incompatível com a organização de um Estado, integral em sua acepção mais genérica, que seja a expressão da unidade nacional". CAVALCANTI, Temístocles Brandão. À margem do anteprojeto. Rio de Janeiro: Irmãos Pongetti, 1933, p.8.

${ }^{126}$ De todo modo, convém pensar com Evaristo de Moraes Filho, que já observava: “[...] constitui exagero e grave ofensa aos trabalhadores brasileiros a constante afirmativa de que nada existiu antes de 1930, que toda a legislação a favor dos operários lhes fora graciosamento outorgada, sem nenhuma luta, nem manifestação expressa dos mesmos de que a desejavam. Justiça seja feitos aos grandes idealistas, intelectuais e juristas, que tomaram o partidos dos operários; justiça se faça àquelas massas anônimas, que, mesmo sem imposto sindical, sem proteções ministeralistas, sem falsos líderes sindicais, apresentavam muito mais consciência de classe do que os atuais sindicatos, presos ao Ministério do Trabalho, sem o menor espírito de iniciativa. Se movimento social houve no Brasil, à maneira da história da Inglaterra, da França, dos Estados Unidos, esse movimento se deu exatamente nesses primeiros períodos adversos. A classe operária e seus líderes sabiam bem o que queriam". MORAES FILHO, Evaristo de. O problema do sindicato único no Brasil: seus fundamentos sociológicos. 2. ed. São Paulo: Alfa-Ômega, 1978, p.196197.

${ }^{127}$ Segundo Ernest Hambloch, "foi contra as tendências autocráticas da Constituição de 1891-1926, que a Revolução de 30 foi ostensivamente feita. Foi para aboli-las que a Constituição foi ab-rogada pelos revolucionários de 1930. E foi para perpetuá-las e acentuá-las que a composição da Assembléia Nacional Constituinte de 1933-34 foi tão sagaz e metodicamente pré-arranjada pelo Governo Provisório que a Revolução de 1930, de maneira inteiramente fortuita, colocara no poder". HAMBLOCH, Ernest, op. cit., 1981, p.90.
} 
que redefine as bases de um novo pacto legal entre as forças em litígio, e, por fim, a erosão institucional, que mina as bases do pacto recentemente formulado, acelerando os preparativos para o golpe que se deu em novembro de $1937 .{ }^{128} \mathrm{O}$ ante, o durante e o pós processo constituinte é pleno de dificuldades e tropeços, ambigüidades e indefinições, e, na primeira etapa, é marcado pelo confronto entre os tenentes e os oligarcas, com o compromisso constitucional significando "problemas políticos mascarados, ou reforçados, por discussões jurídicas e conteúdo técnico." ${ }^{129}$

\subsubsection{A institucionalização da Revolução de 30}

O Governo Provisório foi instituído por meio do Decreto $\mathrm{n}^{\circ} 19.938$, de 11 de novembro de 1930. ${ }^{130}$ Tal decreto, com força constituinte similar à do Decreto $\mathrm{n}^{\circ} 1$, do primeiro governo republicano, estabelecia que o Governo Provisório passava a exercer discricionariamente todas as funções e atribuições do Poder Executivo, como também do Poder Legislativo, até que, eleita a Assembléia Constituinte, se restabelecesse a organização jurídica do país.

Somente em 14 de maio de 1932, o Governo Provisório expediu o Decreto $n^{\text {o }} 21.402$, ${ }^{131}$ que determinava o dia 3 de maio do ano seguinte para a realização das eleições à Assembléia Nacional Constituinte (ANC), assim como criava, sob a presidência do ministro da Justiça e dos Negócios Interiores, comissão incumbida de elaborar o anteprojeto da Constituição.

Quase um ano depois, em cinco de abril de 1933, foi editado o Decreto $\mathrm{n}^{\mathrm{o}} 22.621,{ }^{132}$ que tratava da convocação da Assembléia Constituinte, aprovava o seu regimento interno e prefixava o número de deputados. $\mathrm{O}$ art. $2^{\circ}$ do decreto estabelecia que

a Assembléia Nacional Constituinte terá poderes para estudar e votar a nova
Constituição dos Estados Unidos do Brasil, devendo tratar exclusivamente de
assuntos que digam respeito à respectiva elaboração, à aprovação dos atos do

${ }^{128}$ CAMARGO, Aspásia. Prefácio. In: GOMES, Angela Maria de Castro (Coord.). Regionalismo e centralização política: partidos e constituinte nos anos 30. Rio de Janeiro: Nova Fronteira, 1980.

${ }^{129}$ Ibid., 1980, p.16.

${ }^{130}$ BRASIL. Decreto n. 19.938, de 11 de novembro de 1930. Disponível em: <http://www.senado.gov.br/legislacao>. Acesso em: 10 abr. 2008.

${ }^{131}$ BRASIL. Decreto n. 21.402, de 14 de maio de 1932. Disponível em: <http://www.senado.gov.br/legislacao>. Acesso em: 10 abr. 2008.

${ }^{132}$ BRASIL. Decreto n. 22.621, de 5 abril de 1933. Disponível em: 〈http://www.senado.gov.br/legislacao〉. Acesso em: 10 abr. 2008. 
Governo Provisório e à eleição do Presidente da República - feito o que se dissolverá. ${ }^{133}$

Quando Antunes Maciel assume o Ministério da Justiça, é criada a Subcomissão do Itamarati, encarregada de dar início aos trabalhos de confecção do anteprojeto e em cuja composição estavam presentes, além de "notáveis", diversos ministros do Governo Provisório. Entre outros, compunham a Subcomissão do Itamarati Afrânio de Melo Franco (ministro das Relações Exteriores), presidente e representante do Ministro da Justiça; Temístocles Brandão Cavalcanti, secretário-geral; Assis Brasil, ministro da Agricultura; Osvaldo Aranha, ministro da Fazenda; José Américo de Almeida, ministro da Viação de Obras Públicas; Carlos Maximiliano; Antonio Carlos de Andrada, ex-presidente do Estado de Minas Gerais; Arthur Ribeiro; Prudente de Moraes Filho; Agenor de Roure; João Mangabeira; Oliveira Viana e o general Góes Monteiro. ${ }^{134}$

\footnotetext{
${ }^{133}$ Ibid., 2008. Hans Kelsen emitiu parecer, datado de 14 de outubro de 1933, sobre a "competência" da Assembléia Nacional Constituinte, respondendo aos quesitos formulados "não do ponto de vista político ou de direito natural", "mas exclusiva e unicamente do ponto de vista do direito positivo", e concluindo que "para a situação e competência da Assembléia Nacional Constituinte não pode ser considerada outra norma de direito que o Regimento 22.621, de 7 de abril de 1933", baixado pelo Governo Provisório. Para o parecerista, "a Assembléia Nacional não possui outros direitos além dos que lhe foram outorgados pelo Regimento de 7 de abril de 1933. Por isso ela não tem o direito de revogar o regimento e substituí-lo por outro. O regimento obriga a Assembléia Nacional Constituinte no sentido em que lhe regula a função e especialmente lhe determina a competência. O regimento é um elemento essencial da organização naquele tempo vigente. Em relação àquela organização, a chamada Assembléia Nacional Constituinte não tem o caráter de criadora da Constituição, mas de executora da elaboração da Constituição. Ofendendo as disposições do regimento, ofenderá assim a organização em vigor. Em dependência das circunstâncias poderá valer isso como um tentativa para, por meio da revolução, tornar-se um órgão sob todos os pontos de vista constituinte, isso é originário e supremo criador da Constituição". KELSEN, Hans. A competência da Assembléia Nacional Constituinte de 1933/34. Revista Trimestral de Direito Público, São Paulo, n.9, p.5-8, 1995, p.5-6. Em relação a tal estudo, Ari Marcelo Solon observa que, no plano teórico, "ele suscita problemas curiosos se levarmos em conta que, pela periodização habitual da obra kelseniana, nos encontramos no auge da fase neo-kantiana que culminará justamente com a publicação no mesmo ano da Teoria Pura do Direito", principalmente porque "a metamorfose do poder fático em jurídico, a primazia do elemento fatual já denotam indícios de abandono do contraste fundamental entre ser e dever-ser”. Assim, "o leitor do parecer [...] terá razão ao se perguntar como se conciliam estas investigações com as posições metodológicas precisadas na teoria de que o direito somente podia ser objeto de estudo normativo". SOLON, Ari Marcelo. Um texto de Kelsen sobre o Brasil. Revista Trimestral de Direito Público, São Paulo, n.9, p.8-11, 1995, p.8 e 10. Ver também VASCONCELOS, Arnaldo. Teoria pura do direito: repasse crítico de seus principais fundamentos. Rio de Janeiro: Forense, 2003.
}

${ }^{134}$ BRASIL. Decreto n. 21.402, de 14 de maio de 1932. Disponível em: <http://www.senado.gov.br/legislacao>. Acesso em: 10 abr. 2008.

Perfil detalhado da Subcomissão do Itamarati foi proporcionado por Afonso Arinos de Melo Franco: "Percorrendo-se as opiniões manifestadas nos debates, nota-se a existência de uma espécie de inclinação fascistizante nos espíritos revolucionários dos mais jovens. Góis Monteiro exprimia um nacionalismo militarista, desconfiando das tradições liberais e da técnica de democracia clássica, que, de resto, conhecia muito pela rama. Oliveira Vianna - grande figura intelectual - tinha as convicções sociologicamente aristocráticas e autoritárias, que compendia em toda a sua obra de discípulo dileto de Alberto Torres. José Américo e Osvaldo Aranha flutuavam nas indecisas aspirações de uma justiça social e de uma organização estatal influenciadas pelos novos modelos ditatoriais da Europa. João Mangabeira era o ilustre jurista e insigne orador de sempre: como sempre brilhante e impetuoso, cedendo, às vezes, às perigosas impressões do momento, que vestia com as roupagens sedutoras de sua dialética e de sua contraditória cultura, ao 
Por sua vez, o Decreto $\mathrm{n}^{\mathrm{o}} 22.364$, de 17 de janeiro de 1933, ${ }^{135}$ cuidou dos casos de inelegibilidade, entre os quais são arrolados o chefe do Governo Provisório, os interventores federais, os ministros de Estado, os ministros do Supremo Tribunal Federal (STF), do Supremo Tribunal Militar, do Superior Tribunal de Contas e do Superior Tribunal de Justiça Eleitoral, e os chefes e subchefes dos Estados-Maiores do Exército e da Armada.

O Decreto $\mathrm{n}^{\mathrm{o}} 22.621$, de 5 de abril de 1933, demonstra que a direção do processo constituinte coube ao Governo Provisório. Tal diploma, a par de definir a convocação e a composição da Assembléia, estabelece o seu regimento interno. Cabia à Assembléia, além de elaborar a nova Constituição, julgar os atos do Governo Provisório e eleger o presidente da República, dissolvendo-se depois. O decreto em tela também dispunha sobre a composição da Assembléia - 254 deputados eleitos na forma da lei ${ }^{136}$ e mais quarenta representantes classistas, ${ }^{137}$ eleitos por sindicatos reconhecidos pelo Ministério do Trabalho -, e regulava a inviolabilidade dos deputados constituintes e criava controle de suas presenças nas sessões da Assembléia.

Por fim, o Governo Provisório editou ainda o Decreto $n^{\circ} 22.653$, de 20 de abril de $1933,{ }^{138}$ que fixava o número e estabelecia o modo de escolha dos deputados classistas, e o

mesmo tempo liberal à maneira de Rui e esquerdista à maneira da filosofia marxista. Surpreendente é o equilíbrio de Antônio Carlos. O que faltava ao Andrada em preparação intelectual sobrava em finura, sensatez e experiência. Francamente, [...] considero acima da expectativa a firmeza e o acerto de muitas de suas atitudes, na discussão de temas delicados, atitudes que ele disfarçava com um ar de displicente bonomia. Temístocles Cavalcanti dava, então, os primeiros passos na carreira de cultor do Direito Público em que, depois, se notabilizou. Àquele tempo suas opiniões pareciam fortemente coloridas da influência autoritária a que há pouco aludi. O esforço de Melo Franco, quase sempre bem sucedido, era o de coordenar os debates, esclarecer as obscuridades, contornar habilmente os choques, afastar, quando necessário, os desatinos, aceitar as inovações úteis ou inevitáveis, reunir tudo, enfim, no notável projeto que pôde ser submetido à Constituinte". FRANCO, Afonso Arinos de Melo. Um estadista da República. Rio de Janeiro: Nova Aguilar, 1976, p.1.044.

${ }^{135}$ BRASIL. Decreto n. 22.364, de 17 de janeiro de 1933. Disponível em: <http://www.senado.gov.br/legislacao>. Acesso em: 10 abr. 2008.

${ }^{136}$ Pela primeira vez, contou-se com a participação de uma deputada, Carlota Pereira.

${ }^{137}$ Sobre a representação classista, inclusive, sobre a sua atuação na Assembléia Constituinte, ver BARRETO, Alvaro Augusto de Borba. Representação das associações profissionais no Brasil: o debate dos anos 1930.

Revista de Sociologia e Política, Curitiba, n.22, p.119-133, 2004; GOMES, Angela Maria de Castro. A representação de classes na Constituinte de 1934. In: (Coord.). Regionalismo e centralização política: partidos e constituinte nos anos 30. Rio de Janeiro: Nova Fronteira, 1980, p.427-491; VIANNA, Luiz Werneck. Liberalismo e sindicato no Brasil. Rio de Janeiro: Paz e Terra, 1976.

${ }^{138}$ BRASIL. Decreto n. 22.653, de 20 de abril de 1933. Disponível em: <http://www.senado.gov.br/legislacao>. Acesso em: 10 abr. 2008. 
Decreto $n^{\circ} 22.696$, de 11 de maio de 1933, que aprovava as instruções para a execução daquele. ${ }^{139}$

\subsubsection{Os partidos e o sistema partidário}

Na conjuntura, é importante buscar o movimento de mobilização e reorganização político-partidária e de campanha eleitoral que antecedeu a instalação da Constituinte de 1933/1934, com a emergência de novos partidos e das suas ligações com os interventores estaduais e com o governo central, quanto ao desenvolvimento dos trabalhos constituintes, observando-se os temas cruciais, tanto para os interesses das principais forças políticas em questão quanto para o próprio debate político-constitucional que dominou a década de $30 .{ }^{140}$

Acentue-se que o processo de reconstitucionalização, que tem seu ápice na feitura do novo texto constitucional, tem antecedentes imediatos decisivos, como a Revolução Constitucionalista de 1932. Um dos seus efeitos, além de possibilitar a convocação da Assembléia Nacional Constituinte, foi o de debilitar o tenentismo.

No tocante aos partidos políticos, assiste-se, no início dos anos 30, a um intenso movimento de criação de agremiações. Em primeiro lugar, a tentativa, fracassada, por parte de setores do movimento tenentista de fundar o Partido Nacional (PN) que, afastando definitivamente dos regionalismos, derruísse as oligarquias do Centro-Sul. As veleidades tenentistas, no entanto, acabam por conseguir alguma concretização com a formação da União Cívica Nacional (UCN), com certa penetração nos Estados nortistas e nordestinos.

\footnotetext{
${ }^{139}$ O Decreto n. 22.653 dispunha que "tomarão parte na Assembléia Constituinte, com os mesmos direitos e regalias que competirem aos demais de seus membros, quarenta representantes de associações profissionais, tocando vinte aos empregados e vinte aos empregadores; nestes incluídos três por parte das profissões liberais e, naqueles, dois por parte dos funcionários públicos" (art. $1^{\circ}$ ). Ademais, como indicador da "cidadania regulada". Estabelecia que "só terão direito de voto na eleição determinada no art. $1^{\circ}$ os sindicatos que houverem sido reconhecidos pelo Ministério do Trabalho, Indústria e Comércio até o dia 20 de maio de 1933 e as associações de profissões liberais e de funcionários públicos que estiverem organizadas legalmente até a mesma data" (art. $3^{\circ}$ ). A propósito do reconhecimento sindical pelo Estado e do "direito a voto", isto é, a "cidadania regulada", ver SANTOS, Wanderley Guilherme dos. Cidadania e justiça: a política social na ordem brasileira. Rio de Janeiro: Campus, 1979.

${ }^{140}$ GOMES, Angela Maria de Castro. Introdução. In:___ (Coord.), op. cit., 1980, p.41-131. Segundo o Código Eleitoral de 1932, “consideram-se partidos políticos para os efeitos deste decreto: 1) os que adquirirem personalidade jurídica, mediante inscrição no registro a que se refere o art. 18 do Código Civil; 2) os que, não a tendo adquirido, se apresentarem para os mesmos fins, em caráter provisório, com um mínimo de 500 eleitores; 3) as associações de classe legalmente constituídas". (art. 1º, caput). Ademais, "uns e outros deverão comunicar por escrito ao Tribunal Superior e aos Tribunais Regionais das regiões em que atuarem a sua constituição, denominação, orientação política, seus órgãos representativos, o endereço de sua sede principal, e o de um representante legal pelo menos" (art. $1^{\circ}$, par. ún.).
} 
Em segundo lugar, constrói-se um rol significativamente extenso de agremiações para concorrer às eleições de 3 de maio de 1933, entre as quais a Liga Eleitoral Católica (LEC), a qual teve forte atuação em tais eleições, sensibilizando o eleitorado católico em geral e o feminino, em particular. De outra parte, rearticulam-se as oligarquias decaídas com as suas agremiações tradicionais, como, em São Paulo, o Partido Republicano Paulista (PRP) e o Partido Democrático (PD), quer em agremiações novas, como, em Minas Gerais, o Partido Republicano Mineiro (PRM) e, no Rio Grande do Sul, o Partido Republicano Liberal (PRL). ${ }^{141}$

O regionalismo partidário da República Velha ressurgia, agora, porém, como resultado do fortalecimento das interventorias e das forças políticas locais a estas integradas, com o poder político central crescentemente inclusivo. De fato, nos meses finais de 1932 e iniciais de 1933, despontava uma miríade de partidos nos Estados, sob a direção dos interventores. Essas agremiações constituíam uma espécie de "PRs" da década de 30, com o mesmo caráter dos "PRs" da República Velha. Incontestavelmente,

\begin{abstract}
alguns indicadores básicos atestavam um processo de reformulação da estrutura político-partidária do país - e não a conservação pura e simples dessa estrutura. A figura do interventor, com sua posição política oficial de delegado do Poder Executivo, dá, em grande medida, a linha das alterações sofridas. ${ }^{142}$

Neste sentido, é importante assinalar que, de fato, a Assembléia Nacional Constituinte de 1934 apresentou-se organizada por bancadas estaduais onde muitas vezes dominava um só partido, a exemplo da República Velha. A presença desta dimensão regionalista de organização partidária, bem com como a falência das tentativas de formação de um Partido Nacional são, inclusive, para muitos analistas do período, o grande problema que a Constituinte vai enfrentar como reflexo das insuficiências do processo revolucionário inaugurado em 1930. $[\ldots]^{143}$
\end{abstract}

O Partido Comunista Brasileiro (PCB), fundado em 1922, requereu o registro para concorrer às eleições de 1933. Mas, o recém criado Tribunal Superior Eleitoral (TSE) denegou o pedido nos seguintes termos:

O Sr. Presidente (ministro Hermenegildo de Barros) lê um requerimento do secretário-geral do Partido Comunista, pedindo urgência para o julgamento do registro do mesmo partido e reclamando contra a coação que diz sofrerem os correligionários no saguão do tribunal [...].

\footnotetext{
${ }^{141}$ SILVA, Hélio. 1934 - A constituinte. Rio de Janeiro: Civilização Brasileira, 1969; CARONE, Edgard. A república nova (1930-1937). Rio de Janeiro: Difel, 1976.

${ }^{142}$ GOMES, Angela Maria de Castro. Confronto e compromisso no processo de constitucionalização (19301935). In: FAUSTO, Boris (Org.) História geral da civilização brasileira: sociedade e política (19301964). 2. ed. Rio de Janeiro: Difel, 1983. 3v., p.32.

${ }^{143}$ Ibid., 1983, p.33.
} 
O Sr. Miranda Valverde relata o processo 279 (registro do Partido Comunista) e vota no sentido de ser negado registro ao Partido Comunista porque, como filiado à $3^{a}$ Internacional de Moscou, é uma associação para fins ilícitos e, como tal, nula de pleno direito. No mesmo sentido votam os srs. Eduardo Espínola, José Linhares, Renato Tavares. O Sr. Carvalho Mourão, embora considerando o Partido Comunista como sociedade para fins ilícitos, manifesta-se pela incompetência do tribunal para declarar essa nulidade, o que deverá ser feito pela justiça ordinária. Também assim entendeu o Sr. Monteiro de Sales, manifestando-se pela necessidade de ser ouvida a parte interessada. O tribunal negou registro ao Partido Comunista por quatro votos contra dois. ${ }^{144}$

Realizadas as eleições em 3 de maio e proclamados os eleitos em 26 de junho de 1933, os resultados deram substancial vitória aos situcionismos estaduais, com a vitória dos novos partidos regionais e a conseqüente hegemonia governamental na Assembléia Nacional Constituinte. Apesar das acusações de fraude e da anulação das eleições nos Estados Santa Catarina, Mato Grosso e Espírito Santo, o processo eleitoral foi bem conduzido.

Não se pode deixar de levar em conta, no caldeirão de tendências políticas e de entrechoques ideológicos, a verdadeira ojeriza ao liberalismo, advindo tanto à esquerda quanto à direita do espectro político-ideológico.

A título de amostragem, um dos porta-vozes do catolicismo, ${ }^{145} \mathrm{o}$ advogado Heráclito Fontoura Sobral Pinto, em meados de 1931, verberava que a verdadeira causa da Revolução de 1930 estava no mal-estar que invadiu o organismo nacional e se apoderou dele, resultado de erros que haviam desviado a política dos princípios cristãos, e punha no "miserável liberalismo", que, segundo ele, aniquilava a personalidade individual e era responsável pela rejeição da "moral dogmática, a única coisa capaz de ordenar os procedimentos de governantes e governados".

\footnotetext{
${ }^{144}$ Ata da $25^{\text {a }}$ sessão do TSE, ocorrida em 31 de março de 1933 apud NOGUEIRA, Octaciano. A Constituinte de 1946. Getúlio, o sujeito oculto. São Paulo: Martins Fontes, 2005, p.51. "Com o registro negado, o PCB valeu-se do que fora concedido à União Operária e Camponesa para participar do pleito no Rio de Janeiro, onde nada menos do que vinte partidos e duzentos candidatos concorreram às dez vagas existentes. Todos os eleitos eram candidatos ligados ao governo e ao Movimento Tenentista. Nenhum representante da esquerda logrou êxito. A despeito de impedidos de participar com sua própria legenda, os comunistas conseguiram ser representados na Assembléia Constituinte de 1933 pelo deputado Zoroastro Gouveia, eleito pelo Partido Democrático de São Paulo, e que na primeira intervenção no plenário fez profissão de fé marxista". Ibid., 2005, p.51.

${ }^{145}$ Pontes de Miranda sintetiza bem a inflexão da ideologia católica: "A doutrina católica esperou realizar, por meio do imperativo moral, a melhor distribuição dos bens da vida. Não o conseguiu e provavelmente não o conseguirá nos países em que ainda predomina. Mas, desde que reconheçam os crentes, católicos ou não, [...] que 'os direitos do homem à sua subsistência passam à frente dos seus direitos à propriedade', única compatível com o Cristianismo, as dificuldades cessam, e é possível uma civilização cristã no momento e no futuro". MIRANDA, Pontes de. Comentários à Constituição de 1946. 2. ed. Rio de Janeiro: Max Limonad, 1953. v.IV, p.464.
} 
Em relação ao esforço constituinte, Sobral Pinto acentuava que os novos governantes não haviam realizado um só ato de prudência enérgica e de visão sensata, culpando a "anarquia" na mentalidade nacional e concluindo que a solução não estava no anúncio de uma nova Constituição.

Em um dos primeiros números de A Razão, jornal publicado em São Paulo por Plínio Salgado e Francisco San Tiago Dantas, opositores intelectuais do liberalismo e da rápida constitucionalização, Sobral Pinto recomendava às figuras públicas que abandonassem a covardia e atacassem o liberalismo, que havia sido exaltado por muitas gerações. ${ }^{146}$

Por outro lado, o processo de constitucionalização pós-30 tem um componente que não pode ser olvidado, qual seja, a influência que, antes, e durante a Constituinte, foi exercida pelo integralismo, por conta das "complexas relações entre o Catolicismo e o Integralismo". ${ }^{147}$ Criada em 1932 a Ação Integralista Brasileira (AIB), a sua ideologia "nasce do processo de convergência das idéias autoritárias de direita numa sociedade em transição, sob o impacto da nova situação internacional, marcada pela revolução soviética e a contra-revolução fascista". ${ }^{148}$

Em relação à elite política emergente com a Revolução de 30, "as posições do integralismo alternam-se entre o cortejo, a cumplicidade e o ódio". ${ }^{149}$ Apesar das tendências ideológicas contraditórias no seu interior, a AIB metaboliza um conjunto de componentes, em que se destacam nacionalismo e espiritualismo, a par da luta contra o liberalismo e o socialismo, constituindo o primeiro movimento de massa no Brasil.

\subsubsection{A luta pela Assembléia Nacional Constituinte e os seus obstáculos}

A convocação, a instalação e o funcionamento da Assembléia Constituinte foram cercados dos perigos dos "tempos sombrios", ${ }^{150}$ pois

\footnotetext{
Desde o início que pairava no ar uma constante ameaça ao funcionamento da Assembléia Nacional Constituinte. Os trabalhos de sua instalação haviam transcorrido num ambiente de grande tensão política. A corrente revolucionária pelo tenentismo, fora contrária à convocação da constituinte, preferindo

${ }^{146}$ DULLES, John W. F. Sobral Pinto: a consciência do Brasil. Rio de Janeiro: Nova Fronteira, 2001, p.58.

${ }^{147}$ LINZ, Juan. Prefácio à segunda edição. In: TRINDADE, Hélgio. O integralismo (o fascismo brasileiro na década de 30). 2. ed. Rio de Janeiro: Difel, 1979, p.XV.

${ }^{148}$ TRINDADE, Hélgio. O integralismo (o fascismo brasileiro na década de 30). 2. ed. Rio de Janeiro: Difel, 1979, p. 277.

${ }^{149}$ Ibid., 1979, p.278.

${ }^{150}$ Tomo a expressão emprestada de ARENDT, Hanna. Men in dark times. New York: Harcourt, 1967.
} 
prolongar o período discricionário, sob a alegação de que o programa da revolução não tinha sido completado. Mais de uma vez, o Clube 3 de Outubro fizera pronunciamentos nesse sentido. Nem outra era a significação das repetidas ameaças de chefes militares como Manuel Rabelo e Góis Monteiro, no Palácio Tiradentes. A documentação da época comprova a conspiração militarista que tentou conquistar a presidência da Assembléia para um elemento simpático aos tenentes, Virgílio de Melo Franco ou Cristóvão Barcelos. Seria, assim, o passo inicial para a candidatura de Osvaldo Aranha à Presidência constitucional. ${ }^{151}$

A Assembléia Constituinte foi objeto de conspirações que, no limite, programavam o seu fechamento. Um dos movimentos conspiratórios envolveu, inclusive, o ministro da Guerra e o chefe do Estado-Maior do Exército, general Góis Monteiro.

\begin{abstract}
Simbolicamente, um importante documento, enviado pelo comandante da $7^{\mathrm{a}}$ Região Militar sediada em Recife a Góes Monteiro, marca o início das confabulações e traça o seu significado e objetivo. Trata-se de um manifesto 'resultante de entendimentos nos meios militares - propondo que Exército e Marinha intervenham no processo constitucional, 'em nome da nação', evitando as 'explorações políticas desencadeadas em torno da Assembléia Nacional Constituinte'. Para tanto, deveria ser adotada, imediatamente, a constituição de Júlio de Castilhos. A reação militar visava basicamente a Constituinte, com suas diretrizes políticas liberais, e não tanto a figura de Vargas enquanto chefe da nação. No entanto, a situação evolui a tal ponto, envolvendo inúmeros chefes de regiões militares, que chega a ser considerada ameaçadora à ordem legal, exigindo uma intervenção direta do próprio Vargas. ${ }^{152}$
\end{abstract}

De fato, temendo a volta dos "políticos" ao poder, a realização das eleições em maio e a convocação da Assembléia para novembro não foram do agrado dos tenentes, que consideravam prematura a reconstitucionalização do país, assim como fora do seu desagrado a instituição do Código Eleitoral. ${ }^{153}$ Sobretudo, porque não houve renovação apreciável nos quadros representativos, nem na mentalidade daqueles que se dividiram em 1929, na sucessão de Washington Luis. Em relação aos políticos, pode-se dizer que, “nos

\footnotetext{
${ }^{151}$ SILVA, Hélio; CARNEIRO, Maria Cecília R. A lei e a revolta, 1934-1936. São Paulo: Três, 1975, p.87.

${ }^{152}$ GOMES, Angela Maria de Castro. Introdução, op. cit., 1980, p.52. "Muito bem informado de todos os movimentos realizados dentro do Exército, dispondo de fidelidade irrestrita da maioria dos interventores do Norte, do Rio Grande do Sul e Minas Gerais, tendo sólidos apoios em seu ministério - Juarez Távora (Agricultura), Antunes Maciel (Justiça), Protógenes Guimarães (Marinha) e outros, e possuindo uma incrível capacidade política de aguardar o momento oportuno, Vargas consegue vencer o movimento conspiratório sem provocar impactos, quer nos meios militares, quer nos meios políticos. Góes Monteiro é mantido no Ministério da Guerra durante todo o período da sucessão presidencial, sem que se abra um confronto aberto entre ele e Vargas, já que, se sua permanência no cargo lhe dava recursos de poder, permitia igualmente a Vargas uma proximidade útil, bem como a exigência de uma postura pública de comprometimento". Ibid., 1980, p.55.

${ }^{153}$ No dia seguinte à edição do Código Eleitoral, ocorreu o empastelamento do Diário Carioca, jornal favorável à Assembléia Constituinte. Os desdobramentos do fato ocasionaram a "crise dos demissionários gaúchos", isto é, dos ministros gaúchos no Governo Provisório, entre os quais o próprio ministro da Justiça, Maurício Cardoso, decididamente favorável à constitucionalização. Ver SILVA, Hélio. 1931 - Os tenentes no poder. 2. ed. Rio de Janeiro: Civilização Brasileira, 1972; GOMES, Angela Maria de Castro. Introdução, op. cit., 1980.
} 
campos opostos, com poucas exceções, quase todos apostolavam as mesmas idéias e praticavam atos semelhantes". ${ }^{154}$

As duas principais forças que propiciaram a Revolução de 30, os tenentes e as oligarquias dissidentes, cedo explicitaram o conflito político que os colocavam em antagonismo, com a manifestação de cosmovisões opostas e a disputa pelos de loci de poder. Destarte, os anos pré-constituintes são marcados pela vinda a lume de um leque extensíssimo de propostas ideológicas, de modelos políticos, de receitas institucionais, como pouco se tem visto no evoluir da história político-constitucional brasileira, que não escondiam o significado de luta pela direção política do país. A ofensiva tenentista está presente tanto na disputa por cargos na administração pública civil e militar nos planos federal quanto na disrupção da guerra civil.

[...] articulando-se em torno do Clube 3 de Outubro, procurando criar as suas próprias bases organizacionais de mobilização social (referimo-nos às tentativas de organização das Legiões Revolucionárias) e definindo melhor seu programa político de ação, os tenentes realizam o esforço de conjugar a influência que então exerciam no aparelho de Estado com a constituição de um sólido e autônomo instrumento de representação política. [.... ${ }^{155}$

Com um cabedal formidável de recursos políticos, possibilitados pela legislação excepcional editada na esteira do golpe de 3 de outubro, além das interventorias, do fechamento das assembléias legislativas e das câmaras de vereadores, da censura à imprensa, entre outros, o movimento tenentista avançava profundamente por sobre o domínio das oligarquias. Por seu turno, as oligarquias afastadas ou preteridas se rearticulavam. Como diz Angela Maria de Castro Gomes:

[...] É dentro deste contexto político que se deve entender o debate em torno da constitucionalização do país, anunciado desde 1931 pela própria legislação do Governo Provisório e alimentada pela ação de diversas facções das oligarquias regionais que procuravam mobilizar a opinião pública nacional pelo retorno do país à ordem legal. É ainda dentro do mesmo contexto que se pode avaliar a importância das tentativas de reorganização partidária e a variedade de programas políticos que emergem no momento imediatamente posterior ao encerramento da guerra civil, situando o fim do governo revolucionário de exceção. ${ }^{156}$

A luta político-ideológica em busca da, ou contra $a$, reconstitucionalização acaba por tornar-se o nó górdio a desatar no confronto entre tenentes e oligarcas e a direção do processo iniciado em 1930. Deste modo,

\footnotetext{
${ }^{154}$ SILVA, Hélio, op. cit., 1972, p.30.

${ }^{155}$ GOMES, Angela Maria de Castro. Introdução, op. cit., 1980, p.27.

${ }^{156}$ Ibid., 1980, p.27.
} 
A campanha pela constitucionalização ganha assim uma dimensão e um significado político e ideológico central para a década. Para certos setores oligárquicos, afastados do poder a nível estadual e nacional, ou frustrados na expectativa de participação política em âmbito federal, o retorno do país à ordem legal passa a significar a possibilidade de retomada das posições políticas que julgavam ter direito. Desta forma, o objetivo mais imediato da constitucionalização era o desalojamento dos elementos tenentistas dos postos que então detinham, através de um movimento de contestação do regime de força vigente. $\mathrm{O}$ instrumento para tal ação seriam, sem dúvida, a reorganização e reativação das máquinas político-partidárias oligárquicas, cujo poder essencial continuava residindo no controle exercido sobre o eleitorado rural. $[\ldots]^{157}$

Em relação ao tenentismo, Edgard Carone destaca as frustrações que se lhe sucederam com a derrota das suas bandeiras frente às "tendências oligárquicas e conservadoras" que constituem a maioria da Assembléia Nacional Constituinte:

O Tenentismo, apesar de sua força de pressão e programa, não conseguiu impor a sua ideologia, pois as tendências oligárquicas e conservadoras são maioria na Assembléia Nacional Constituinte. Os diálogos ásperos dos deputados tenentistas, apoiados pela presença constante do Clube 3 de Outubro nas galerias não impedem que a maior parte de seus projetos seja derrotada. Dois pontos, entretanto, marcam o seu pensamento, que é a nacionalização de riquezas do subsolo e de águas, e a representação de classe. ${ }^{158}$

Ainda sobre o tenentismo, e ao seu lema vitorioso da nacionalização das riquezas do subsolo e das águas, aduz Edgard Carone:

É a partir de 1930 que o tenentismo retoma os temas e, desde os manifestos iniciais do movimento Brasil - Novo, Legião Revolucionária de São Paulo e do Clube 3 de Outubro, se fala em decretação dos Códigos de Água e de Minas, além do Florestal etc. A pressão é tão grande e a ênfase sobre o problema é tão aguda que os deputados tenentistas vencem e é incluído na Constituição, art. $5^{\circ}$, parágrafo XIX, no item de competência privativa da União - o seu direito de legislar sobre 'bens do domínio federal, riquezas do subsolo, mineração, metalurgia, águas, energia hidrelétrica, florestas, caça e pesca e a sua exploração'. ${ }^{159}$

Ainda sobre o tenentismo, observa John D. Wirth que havia descompasso entre a sua direção, adepta de alguma forma de economia regulada pelo Estado, e "a elite política e industrial da nação" que não partilhava "a convicção dos jovens reformadores quanto à eficácia dos empreendimentos econômicos do governo". ${ }^{160}$ Assim é que

\footnotetext{
${ }^{157}$ Ibid., 1980, p.28.

${ }^{158}$ CARONE, Edgard. A república nova (1930-1937). Rio de Janeiro: Difel, 1976, p.180-181.

${ }^{159}$ Ibid., 1976, p. 181.

${ }^{160}$ WIRTH, John D. A política do desenvolvimento na era de Vargas. Rio de Janeiro: FGV, 1976, p.66. Ainda segundo este autor, "os tenentes, responsáveis pela segunda onda de nacionalismo depois de 1930, objetivavam antes de tudo moralizar a política e a administração do país. Mas, se se pode dizer que tinham um programa de desenvolvimento econômico, este consistia em centralizar a legislação e regular as concessões. Assim é que Juarez Távora (Ministro da Agricultura) colocou a prospecção, concessão de licenças e serviços estatísticos sobre o controle do recém-criado Departamento Nacional da Produção
} 
[...] Roberto Simonsen, o industrial, afirmou inequivocamente que o Estado devia ser um regulador, mas nunca um produtor. Távora tencionava nacionalizar os recursos naturais e a mineração através de legislação nos moldes do código italiano de 1927, mas a Assembléia Constituinte de 1933-34 diluiu as suas propostas as estabelecer que só as jazidas de minério e as fontes de potencial hidráulico não exploradas na época pertenceriam ao Estado. Em consequiência, muitas minas de propriedade estrangeira, inclusive a Itabira, escaparam, apesar do código de minas de 1934, que restringia a propriedade estrangeira. ${ }^{161}$

Permaneciam intocados os currais eleitorais sob o mando dos chefes políticos locais, fundado no latifúndio e nas condições que reduziam o trabalhador rural à condição análoga à de escravo. Enfim, permaneciam os mecanismos de repressão e de sedução próprios da República Velha, que deram azo à busca da "justiça e representação" contida na plataforma da Aliança Liberal.

A aglutinação de diversos fatores, como a ruína dos cafeicultores, o sopro das idéias sociais, o sentimento nacionalista e a "feroz crítica que buscava desmoralizar a autoridade dos parlamentos livres e patentear sua incapacidade para solver a crise das instituições de governo", favoreceu a continuidade do poder pessoal. Tais fatores passaram a

[...] ascender no ânimo de seu titular o desejo já dificilmente simulado de garantir, sob tais escusas, o exercício indefinido de suas prerrogativas de governo absoluto, com poderes excepcionais completamente desatados de vínculos com o Estado de Direito. Não havia, pois, uma vontade política clara de retornar logo aos moldes clássicos de funcionamento regular das instituições mediante o restabelecimento da coparticipação do ramo parlamentar de governo. ${ }^{162}$

\subsubsection{O Poder Executivo}

$\mathrm{Na}$ esteira dos acontecimentos que levaram Getúlio Vargas à presidência da República, foi editado o Decreto no 19.398 , de 11 de novembro de 1930, verdadeira "lei orgânica", ${ }^{163}$ institucionalizando os poderes do Governo Provisório, o qual passou a exercer

\footnotetext{
Mineral (DNPM), enquanto José Américo de Almeida (Ministro dos Transportes) mandou investigar o contrato da Itabira e tudo fez para declará-lo nulo”. Ibid., 1976, p.66.

${ }^{161}$ Ibid., 1976, p.66-67.

${ }^{162}$ GOMES, Angela Maria de Castro. Introdução, op. cit., 1980, p.28.

${ }^{163}$ O Decreto n. 19.398, de 10/11/30, que instituiu o "Governo Provisório da República dos Estados Unidos do Brasil”, estabeleceu: “Art. $1^{\circ}-$ O Governo Provisório exercerá discricionariamente, em toda a sua plenitude, as funções e atribuições, não só do Poder Executivo, como também do Poder Legislativo, até que, eleita a Assembléia Constituinte, estabeleça esta a reorganização constitucional do país. [...] Art. $2^{\circ}$ É confirmada, para todos os efeitos, a dissolução do Congresso Nacional, das atuais Assembléias Legislativas (quaisquer que sejam as suas denominações), das Câmaras ou Assembléias Municipais, e quaisquer outros órgãos legislativos ou deliberativos, existentes nos Estados, nos Municípios, no Distrito Federal ou no Território do Acre, e dissolvidos os que ainda o não tenham sido de fato". BRASIL. Decreto n. 19.398, de 11 de novembro de 1930. Disponível em: 〈http://www.senado.gov.br/legislacao〉. Acesso em: 10 abr. 2008.
} 
as funções tanto do Poder Executivo quanto do Legislativo, "até que, eleita a Assembléia Constituinte, estabeleça esta a reorganização constitucional do país" (art. $\left.1^{\circ}\right) .^{164}$

Com base no mesmo decreto, fecharam-se todas as Câmaras Legislativas do país, do Congresso Nacional às Câmaras Municipais, e conferiu o Poder Legislativo federal ao chefe da Nação. No mesmo ato, Getúlio demitiu os presidentes de todos os Estados da Federação (que haviam sido eleitos antes de 30), e os substituiu por interventores federais, aos quais atribuiu o Poder Executivo e o Poder Legislativo, com competência sobre as suas respectivas unidades federativas. ${ }^{165}$

Observe-se também que a derrota dos "constitucionalistas" paulistas de 1932 levou o Governo Provisório a expulsar do país importantes lideranças que lhe faziam oposição. Ademais, a figura do exílio interno ou externo fez com que lideranças, como Borges de Medeiros e Arthur Bernardes, fossem postas fora da atividade política ostensiva. ${ }^{166}$ Além do mais, as restrições estabelecidas pela "lei das inelegibilidades" faziam com que, no dizer de Raul Fernandes, "por esmagadora maioria”, a Assembléia fosse composta de “deputados partidários do golpe de outubro de 1930”. 167

Destarte, pelas próprias circunstâncias "revolucionárias", tanto a convocação e instalação quanto o funcionamento da Assembléia Constituinte estiveram umbilicalmente ligados à agenda do Executivo, como a seqüência de fatos e decisões o demonstram. Cumpre ressaltar, todavia, que a convocação da Assembléia Constituinte esteve presente, desde o primeiro momento, na retórica da nova política.

Aos interventores cabe o dever de arregimentação e unificação das forças políticas estaduais, decaídas e emergentes, no sentido de incorporá-las aos desideratos da nova política central. ${ }^{168}$ Afinal, a frustração na organização de um partido político nacional compensava-se através da integração pelo alto das organizações nacionais. Getúlio Vargas

\footnotetext{
${ }^{164}$ Ibid., 2008.

${ }^{165 ، \text { Art. }} 4^{\circ}$ Continuam em vigor as Constituições federal e estadual, as demais leis e decretos federais, assim como as posturas e deliberações e outros atos municipais, todos, porém, inclusive as próprias Constituições, sujeitos às modificações e restrições estabelecidas por esta Lei ou por decretos ou atos ulteriores do Governo Provisório ou de seus delegados na esfera de atribuições de cada um”. Ibid., 2008.

${ }^{166}$ Somente pelo Decreto n. 24.297, de 28 de maio de 1934, foi concedida a anista aos participantes da Revolução de 1932. Por sua vez, o Decreto n. 24.776, de 14 de julho de 1934, suspendeu a censura à imprensa.

${ }^{167}$ Discurso de saudação a Getúlio Vargas na Assembléia Constituinte apud GOMES, Angela Maria de Castro, op. cit., 1980, p.29.

${ }^{168}$ Em São Paulo, o PD e o PRM da República Velha unem-se e, com mais outros partidos, formam a "Chapa Única por São Paulo", com o sentido inicial de oposição ao Governo Provisório e defesa do federalismo.
} 
estava atento à questão, alertando os interventores para o fato de que, "quando a luta [...] se transfere do prélio das armas para o das urnas é [...] lógico que o mesmo espírito de combatividade os mantém como parte da contenda". Diz mais o chefe do Governo Provisório que "aos interventores deixo inteira liberdade na escolha da conduta a seguir", todavia, também, "a responsabilidade pelas conseqüências daí resultantes", pois "ninguém deve desinteressar-se pela organização política do país, principal objetivo das próximas eleições". ${ }^{169}$

Em $1^{\circ}$ de novembro de 1932, o Governo Provisório edita o Decreto $\mathrm{n}^{\mathrm{o}} 22.040,{ }^{170} \mathrm{com}$ o objetivo de apressar e regular os trabalhos da Comissão Constitucional, criada para a elaboração do anteprojeto de Constituição, a ser dirigido pelo Governo Provisório à Assembléia Constituinte. A Comissão - criada em 14 de maio de 1932 e composta de "tantos membros quantos fossem necessários à elaboração do referido projeto e por forma a serem nela representadas as correntes organizadas de opinião e de classe, a juízo do Chefe do Governo" - é uma tentativa de dar resposta à efervescência que fez deflagrar, dois meses depois, a Revolução Constitucionalista.

É oportuno também acentuar que, por determinação presidencial de fevereiro de 1931, estabeleceu-se comissão - formada por Joaquim Francisco de Assis Brasil, João Crisóstomo da Rocha Cabral e Mário Pinto Serva e destinada ao estudo e à revisão da legislação vigente -, tendo em vista a apresentação de projeto de Código Eleitoral. ${ }^{171}$ Por fim, por meio do Decreto n. 20.076, de 24 de fevereiro de 1932, foi instituído o Código

${ }^{169}$ Carta de Getúlio Vargas a Carneiro de Mendonça, interventor do Ceará apud GOMES, Angela Maria de Castro. Introdução, op. cit., 1980, p.31.

${ }^{170}$ BRASIL. Decreto n. 22.040, de $1^{\text {o }}$ de novembro de 1932. Disponível em: <http://www.senado.gov.br/legislacao>. Acesso em: 10 abr. 2008.

${ }^{171}$ O Decreto n. 19.459, de 6 de dezembro de 1930, instituiu Comissão Legislativa, sob "a presidência de honra do ministro de Estado da Justiça", com o fito de "elaborar os projetos de revisão ou reforma da legislação civil, comercial, penal, processual da justiça federal e do Distrito Federal, de organização judiciária do Distrito Federal, e de outras matérias indicadas pelo mesmo ministro". A Comissão "dividirse-á em subcomissões de três membros, incumbida cada uma de determinado projeto de lei, podendo também designar-se relatores individuais para o mesmo fim". Ademais, dispunha também que "as subcomissões e os relatores individuais receberão e apreciarão todas as sugestões que lhes forem enviadas, e, logo que concluídos, farão publicar os anteprojetos elaborados, a fim de sofrerem críticas e observações, que serão apreciadas fundamentalmente e atendidas, como merecerem, nos projetos definitivos. Os projetos definitivos, à proporção que forem concluídos, serão remetidos, por intermédio do consultor geral da República, ao ministro de Estado da Justiça, para serem promulgados por decreto, com as modificações que o governo possa julgar necessárias". Por fim, estabelecia que "todos os decretos assim expedidos entrarão em vigor, nos prazos que determinarem, mas serão submetidos oportunamente à aprovação do Congresso Constituinte". BRASIL. Decreto n. 20.076, de 24 de fevereiro de 1932. Disponível em: <http://www.senado.gov.br/legislacao>. Acesso em: 10 abr. 2008. 
Eleitoral, ${ }^{172}$ para regular "em todo o país o alistamento eleitoral e as eleições federais, estaduais e municipais" (art. $1^{\circ}$ ), com o que se procedia à institucionalização de princípios e demandas que orientaram a Revolução de 30. Segundo acentuava o chefe do Governo Provisório em relação à "nova política do Brasil, "o Governo é provisório, a Revolução é definitiva". ${ }^{173}$

O Código Eleitoral proporcionou profundas mudanças, como o estabelecimento do sufrágio universal e do voto direto e secreto, a instituição da Justiça Eleitoral (com “funções contenciosas e administrativas") em substituição às comissões legislativas de verificação de poderes, ${ }^{174}$ enfim, um conjunto de alterações que consistiam nas propostas da Aliança Liberal, no seu lema "justiça e representação". Ademais, o Código Eleitoral de 1932 ampliava o colégio eleitoral, à medida que, embora mantendo a idade de vinte e um anos prevista também no texto constitucional de 1891 (art. 70, caput), estabelecia "que é eleitor o cidadão maior de 21 anos, sem distinção de sexo, alistado na forma deste Código". ${ }^{175}$

Para as eleições para a Câmara dos Deputados e as Assembléias Legislativas, passava-se a obedecer ao sistema de representação proporcional, ${ }^{176}$ ultrapassando-se um debate recorrente desde a época do Império entre majoritaristas e proporcionalistas.

\footnotetext{
${ }^{172}$ Ver, entre outros, CABRAL, João C. da Rocha. Código Eleitoral da República dos Estados do Brasil. 3. ed. Rio de Janeiro: Freitas Bastos, 1934; FERREIRA, Manoel Rodrigues. A evolução do sistema eleitoral brasileiro. Brasília: Senado Federal, Conselho Editorial, 2001.

${ }^{173}$ VARGAS, Getúlio. A nova política do Brasil. Rio de Janeiro: José Olympio, 1938. v.I, p.109-128.

${ }^{174}$ Uma das pedras angulares da República Velha, a verificação de poderes pela Câmara dos Deputados foi mecanismo instituído durante o governo de Campos Sales, favorecendo o poder das oligarquias contra as tentativas de oposição e organizando "uma maioria arregimentada e resoluta", no dizer de Campos Sales. De fato, a verificação de poderes, como bem observou Assis Brasil, "substituiu-se à eleição. E que reconhecimentos! As crônicas autênticas da época, as próprias atas dos corpos legislativos exibem casos de se fazer um representante da nação por simples emenda, mandando trocar um nome por outro. E não simplesmente isso, mas um nome que aparecia virtualmente sem votos por outro que os ostentava nos papéis eleitorais. A única atenuante era - não se tratar verdadeiramente de averiguar quem era mais votado, porque ninguém o era: as eleições figuravam na consciência pública como simples fantasmagoria". BRASIL, Joaquim Francisco de Assis. Idéias políticas de Assis Brasil. Brasília: Senado Federal; Rio de Janeiro: FCRB, 1990. 3v., p.140. Ver, também, AMADO, Gilberto. Eleição e representação. Brasília: Senado Federal, 1999.

${ }^{175} \mathrm{O}$ art. $4^{\circ}$ do Código Eleitoral estabelecia: "Não podem alistar-se eleitores: a) os mendigos; b) os analfabetos; c) as praças de pré, excetuados os alunos das escolas militares de ensino superior. [...]". Por sua vez, a qualificação fazia-se ex officio ou por iniciativa do cidadão. Qualificavam-se ex officio: "a) os magistrados, os militares de terra e mar, os funcionários públicos efetivos; b) os professores de estabelecimentos de ensino oficiais ou fiscalizados pelo Governo; c) as pessoas que exerçam, com diploma científico, profissão liberal; c) os comerciantes com firma registrada e os sócios de firma comercial registrada: e) os reservistas de $1^{\text {a }}$ categoria do Exército e da Armada, licenciados nos anos anteriores" (art. 37).

176، Art. 38. [...] § $2^{\circ}$ Na eleição do Presidente da República, dos Governadores dos Estados, dos membros do Conselho Federal, ou para o preenchimento de vagas nas Câmaras Legislativas, prevalecerá o princípio majoritário".
} 
Incluiu-se também no Código Eleitoral a representação classista, fruto das pressões tenentistas, por meio do Clube 3 de Outubro. ${ }^{177}$

O significado do Código Eleitoral, no que se refere ao processo de reconstitucionalização, foi enfatizado por Getúlio Vargas em discurso na sessão solene de abertura da Assembléia Nacional Constituinte, em 15 de novembro de 1933:

\begin{abstract}
O governo revolucionário, responsável pelo saneamento dos costumes políticos contra os quais a Nação se rebelou, não poderia cogitar de reorganizá-la constitucionalmente, antes de aparelhá-la para manifestar, de modo seguro e inequívoco, a sua vontade soberana. A reforma eleitoral que era, para mim, compromisso de candidato [...] tornou-se imposição inadiável ao assumir a chefia do governo revolucionário. De como cumpri esse compromisso de honra, resistindo e sobrepondo-me à pressão dos acontecimentos, atesta-o o Código Eleitoral, já qualificado 'carta de alforria do povo brasileiro', e o pleito de 3 de maio, do qual se disse, unanimemente, ser a eleição mais livre e honesta realizada, até hoje, no Brasil. ${ }^{178}$
\end{abstract}

A emergência da nova legislação eleitoral acabou por ter impacto sobre as eleições para a Assembléia Constituinte, impactos esses reconhecidos mesmo por críticos severos da democracia liberal. Azevedo Amaral destacou:

\begin{abstract}
A Constituinte da segunda República foi incontestavelmente o primeiro exemplo, em toda a nossa história política, de uma assembléia cujos membros podiam ser encarados como autênticos representantes do eleitorado. $\mathrm{O}$ elemento de fraude que porventura maculou o processo eleitoral foi tão diminuto que de modo algum afetou o caráter verídico do pleito considerado em conjunto. A Nação teve assim oportunidade do poder apreciar e julgar o valor da democracia do sufrágio universal promíscuo e da eleição direta em condições que, para o meio brasileiro, podiam ser consideradas ideais. Além das garantias de independência proporcionadas ao eleitor pelo voto secreto e pela atitude de impecável imparcialidade do governo durante o pleito, bem como da apuração honesta dos resultados das urnas pela justiça eleitoral, outro fator imprimiu à eleição da Constituinte um caráter inequivocamente democrático, no sentido dado à expressão pelos partidários da democracia liberal. O eleitorado fora consideravelmente reforçado e as facilidades ao alistamento ex-ofício ainda engrossaram as fileiras dos cidadãos habilitados a levar os seus sufrágios às urnas. ${ }^{179}$
\end{abstract}

Algo inusitado foi a presença de ministros, embora sem direito a voto, nas sessões da Assembléia Nacional Constituinte. ${ }^{180} \mathrm{Na}$ primeira sessão de trabalho da Assembléia,

\footnotetext{
177،“Art. 142. No decreto em que convocar os eleitores para a eleição de representantes à Constituinte, o Governo determinará o número de representantes nacionais que a cada Estado caiba eleger, bem como o modo e as condições de representação das associações profissionais".

${ }^{178}$ Mensagem lida à Constituinte de 1933. In: VARGAS, Getulio, op. cit., 1938. v. III, p.29.

${ }^{179}$ AMARAL, Azevedo. O Estado autoritário e a realidade nacional. Brasília: UnB, 1981, p.73.

${ }^{180} \mathrm{O}$ Regimento Interno (Decreto n. 22.621/1933) estabelecia que "aos Ministros de Estado é reconhecido o direito de comparecer às sessões da Assembléia Nacional sempre que o entenderem, ou quando forem destacados pelo Chefe do Governo para assistirem ou tomarem partes nos debates. Em hipótese alguma, terão direito a voto, embora permaneçam no recinto, ocupando a bancada ministerial [...]." (art. 53, § $5^{\circ}$ ).
} 
Osvaldo Aranha, então ministro da Fazenda, foi investido na liderança da maioria. Por conseguinte, nos trabalhos da Assembléia tinha voz de comando quem, sequer, fora eleito constituinte. No seu primeiro discurso na Assembléia, o líder da maioria salientou que "o Governo Provisório, pela presença e pela palavra do seu grande chefe, acaba de dar-vos o testemunho dessa segurança e dessa autoridade, entregando-vos, sem reservas, a elaboração do estatuto fundamental e o exame dos seus próprios atos."

E enfatizou que "foi-se a hora em que o líder trazia para a subserviência das assembléias os ucases presidenciais" e que "não tem, nem terá o Governo a menor intervenção, nem na ordem, nem na orientação da elaboração constitucional”. Todavia, sibilinamente, advertia aos constituintes que, embora

esta deve ser obra vossa, feita com brevidade, porque estes são os reclamos da opinião. [...] Nesse labor, que hoje iniciamos, [...] nenhum de vos será capaz de desviar o seu mandato de sua luta e patriótica finalidade para outras que não digam com as funções mesmas da Assembléia [...].

Pois,

[...] Se tal suceder, por ação interna ou perturbação externa, pode o povo ter a certeza de que, em sua quase unanimidade, [...] haveremos de cumprir nosso dever, dando ao Brasil uma Constituição que não seja madrasta do povo, mas a mãe comum dos concidadãos. ${ }^{181}$

Algum tempo depois, a exoneração de Oswaldo Aranha do Ministério da Fazenda, com a repercussão na liderança da Assembléia, é um fato conflituoso, já que o nome escolhido por Getúlio Vargas para a liderança da maioria - o do deputado do Partido Social Democrático (PSD) baiano Medeiros Neto, foi entendido como interferência indevida nos trabalhos constituintes. De qualquer forma, Medeiros Neto, apesar das restrições que lhe foram feitas, acabou sendo proclamado líder da maioria.

Todavia, nem tudo era pressão e ameaça em direção à Assembléia Constituinte. $\mathrm{O}$ Governo Provisório e, sobretudo, Getúlio Vargas, também era alvo da pressão e ameaça em sentido contrário. A Assembléia, além de decidir sobre os atos governamentais, detinha um trunfo de muita importância: a ela caberia eleger o presidente da República.

A presidência da Assembléia Constituinte revelou-se motivo de grande preocupação e foi objeto de cuidadosos arranjos políticos. Para tanto, auxiliado por Flores da Cunha e Juraci Magalhães, interventores, respectivamente, do Rio Grande do Sul e da Bahia,

\footnotetext{
${ }^{181}$ Apud SILVA, Hélio. 1934 - A constituinte. Rio de Janeiro: Civilização Brasileira, 1969, p.36.
} 
Getúlio Vargas acabou por anular a manobra tenentista que queria pôr um dos seus na presidência e, assim, garantir, num futuro próximo, a eleição do presidente da República.

Ademais, frustrou-se a conspiração militar, que visava a impor a candidatura Góis Monteiro à presidência constitucional, buscando repetir o que acontecera em 1891, durante a primeira Constituinte republicana, ocasião em que Deodoro foi feito presidente da República. ${ }^{182}$ A presidência da Assembléia acabou preenchida por Antônio Carlos de Andrada, o oligarca dissidente da política de Washington Luís e um dos pró-homens da Aliança Liberal.

Entre as decisões/não-decisões tomadas pela Assembléia que significavam algum rasgo de independência, autonomia, e agenda diferente das intenções do Governo Provisório, dos tenentes e de Getúlio Vargas, a mais eloqüente certamente foi a resistência à subversão da pauta dos trabalhos constituintes, no sentido de antecipar a eleição presidencial.

No discurso como presidente constitucional, pronunciado em 20 de julho de 1934, na Assembléia Constituinte, dirá este:

\begin{abstract}
Ora, quem examinar atentamente a matéria da nova Constituição verificará, desde $\log$, que ela fragmenta e dilui a autoridade, instaura a indisciplina e confunde, a cada passo, as atribuições dos Poderes da República. [...] A Constituição de 1934, ao revés da que se promulgou em 1891, enriquece os elos da Federação: anula, em grande parte a ação do Presidente da República, cerceando-lhe os meios imprescindíveis à manutenção da ordem, ao desenvolvimento normal da administração: acoroçoa as Forças Armadas à prática do facciosismo partidário, subordina a coletividade, as massas proletárias e desprotegidas ao bel-prazer das empresas poderosas; coloca o indivíduo acima da comunhão. ${ }^{183}$
\end{abstract}

Por tudo, talvez Getúlio Vargas, ao receber a notícia de que acabava de ser votada a nova Constituição, teria dito: "Serei o primeiro revisionista". ${ }^{184}$ De modo geral, a Constituição repetia o dilema já anotado por Mirkine-Guetzévitch, segundo o qual

As crises econômicas e financeiras exigem soluções rápidas. Mas o Executivo é fraco, e por mais poderoso que seja nos textos legais, o Legislativo, peado pela lutas dos partidos muitas vezes sem experiência e sem prática parlamentar, tornase, na realidade, um poder fraco e incapaz. Assim, nem o Executivo, nem o

\footnotetext{
${ }^{182}$ Ibid., 1969; GOMES, Angela Maria de Castro. Confronto e compromisso no processo de constitucionalização (1930-1935). In: FAUSTO, Boris (Org.), op. cit., 1983.

${ }^{183}$ Apud GOMES, Angela Maria de Castro. Confronto e compromisso no processo de constitucionalização (1930-1935). In: FAUSTO, Boris (Org.), op. cit., 1983, p.36.

${ }^{184}$ SILVA, Hélio, op. cit., 1963, p.563.
} 
Legislativo estão em condições de satisfazer às necessidades do estado e garantir o funcionamento normal dos serviços públicos. ${ }^{185}$

A Assembléia se reuniu sob um clima de apreensão, para não dizer de intimidação e desconfiança, bem como de ressentimento, com a censura impedindo a imprensa de acompanhar os seus trabalhos. A influência de Getúlio Vargas na Constituinte fica patente com a elaboração de certos preceitos da Carta, p.ex., o art. 18 do Ato das Disposições Transitórias, que aprovava todos os atos do Governo Provisório, dos interventores federais e dos delegados do mesmo governo, além de excluir os seus efeitos de "qualquer apreciação judiciária". ${ }^{186}$

\subsubsection{O envolvimento popular}

Observa-se um envolvimento talvez inusual para os tempos, conforme se pode extrair das palavras de Carlos Maximiliano ao observar que, "quando se reuniu a Comissão de 91, um livro de título impressionante, La Politique Expérimentale, de Léon Domat, dominava as ruas e o recinto das Assembléias"; agora, no início dos anos 30, o autor da moda "é Mirkin Guetsevitch, para a direita e para a esquerda". Observa ainda relator do projeto de constituição:

Ora, exatamente como ele publicou os textos das Constituições do mundo, vejo nos bondes, nos hotéis, nos ônibus, os livros dele em todas as mãos e as Constituições alemã e austríaca, e que sei, reboam nos ouvidos da gente de manhã até a noite. [...].

\footnotetext{
${ }^{185}$ MIRKINE-GUETZÉVITCH, B. As novas tendências do direito constitucional. São Paulo: Nacional, 1933 , p. 26.

${ }^{186}$ BRASIL. Constituição (1934). Constituição da República dos Estados Unidos do Brasil. Disponível em: 〈http://www.presidencia.gov.br/legislacao>. Acesso em: 10 jan. 2008. Deve-se observar que, quando do lançamento do programa da Aliança Liberal, no Rio de Janeiro, em janeiro de 1930, Getúlio Vargas já tomara em conta o problema social, afirmando que "não se pode negar a existência da questão social no Brasil" e que se trata" um dos problemas que terão de ser encarados com seriedade pelos poderes políticos, pois, "tanto o proletariado urbano como o rural necessitam de dispositivos tutelares" e "o programa é mais do povo do que uma visão de conjunto". Ver WOLKMER, Antônio Carlos. Constitucionalismo e direitos sociais no Brasil. São Paulo: Acadêmica, 1989, p.43. Todavia, confrontados o programa da Aliança Liberal com o de Júlio Prestes, "a diferença é mínima”, diz CARONE, Edgard. A república velha (evolução política). São Paulo: Difel, 1971, p.410. Especificamente sobre Getúlio Vargas, lembra Robert Levine: "Não sabemos ao certo até que ponto Vargas sofreu a influência das ideologias fascistas das décadas de 20 e 30 . O corporativismo brasileiro, emprestado do fascismo europeu, também influenciou o New Deal. De maneira geral, porém, embora Vargas fosse um nacionalista, ele confiava mais no pragmatismo do que na ideologia, o que contribuía para a imprevisibilidade que o caracterizava. Mudava de direção com freqüência, assim como seu contemporâneo Franklin D. Roosevelt. E, como o outro Roosevelt, Theodore, era um herege ortodoxo e um reformista conservador". LEVINE, Robert M. Pais dos pobres? O Brasil da era Vargas. São Paulo: Companhia das Letras, 2001, p.15. Ver também LOEWENSTEIN, Karl. Brazil under Vargas. New York: Macmillan, 1942.
} 
[...] Dessas consultas apressadas, simplesmente aos textos, resulta um mal formidável, que já tenho apurado nos numerosos projetos de constituições integrais ou parciais, que me chegaram e estão chegando às mãos todos os dias.

O Brasil é o País em que todo mundo sabe Direito, todo mundo discute Direito, todo mundo fala sobre Direito. Eu recebi projetos integrais de constituições, escritos por militares, engenheiros, médicos, farmacêuticos e advogados. Ontem, ainda recebi dois. Todos os dias me chegam às mãos.

Vejo que são exatamente outras tantas vítimas de Mirkin Guetsevitch. ${ }^{187}$

Entre os subsídios apresentados à Assembléia Constituinte, deve ser destacado o de Borges de Medeiros, que anexou um anteprojeto detalhado de constituição no livro $\mathbf{O}$ Poder Moderador na república presidencial, trazido à luz em 1933. ${ }^{188}$ Fundamentandose em Hans Kelsen e em Mirkine-Guetzevitch, entre outros, o esboço de constituição oferecido por Borges Medeiros trata, no Título II, da problemática "Dos Direitos Sociais", com os capítulos seguintes: A Família; As Associações; A Educação; O Trabalho; A Propriedade; A Economia Nacional; Os Nacionais.

Afinal, apesar do envolvimento da sociedade, "nos bondes, nos hotéis, nos ônibus" e a problemática constitucional a reboar "nos ouvidos da gente de manhã até a noite", inclusive, com a apresentação de "numerosos projetos de constituições integrais ou parciais", "escritos por militares, engenheiros, médicos, farmacêuticos e advogados", de que falava Carlos Maximiliano, o momento final da Assembléia Nacional Constituinte reverteu as expectativas que provocara, conforme anota Hélio Silva:

Quando, em 16 de julho de 1934, o Palácio Tiradentes acendeu as luminárias, engalanado de flores, povoado de homens solenes e representativos, para a promulgação da nova Carta, os mais lúcidos sentiram que havíamos perdido a grande oportunidade e atirado pela janela a única revolução da Revolução.

\footnotetext{
${ }^{187}$ Discurso de Carlos Maximiliano pronunciado em novembro de 1933 apud SILVA, Hélio, op. cit., 1969, p.62-64. Traduzido no Brasil por Cândido Motta Filho, o livro As novas tendências do direito constitucional. São Paulo: Nacional, 1933 mereceu elogioso prefácio de Vicente Ráo, em que destaca que o método utilizado pelo autor "é, entre todos, o mais valioso. Por duas principais razões: - primeira, a autenticidade direta e imediata de suas fontes; segunda, a precisão e evidente honestidade de suas conclusões". RÁO, Vicente. Mirkine-Guetzévitch e sua obra. In: MIRKINE-GUETZÉVITCH, B. As novas tendências do direito constitucional. São Paulo: Nacional, 1933, p.8.

${ }^{188}$ Em confronto com a concepção castilhista de República, de que tinha sido o artífice mais continuado, Borges de Medeiros agora defendia o seguinte ponto de vista: "Em nossa concepção, o rol do presidente consistirá em presidir a República como o seu primeiro magistrado, e não como o seu primeiro leader político", pelo que, "separado dos poderes executivo, legislativo e judiciário, ele constituirá o quarto poder do Estado, o poder moderador da República". MEDEIROS, Borges de. O poder moderador na república presidencial. Brasília: Senado Federal, Conselho Editorial, 2004, p.67-68. Na verdade, no grupo que ascendeu ao poder com a Revolução de 30, liderado por Getúlio Vargas, houve componentes adeptos de transplantar ao plano nacional a experiência rio-grandense. A propósito, ver, entre outros, RODRIGUEZ, Ricardo Vélez. Castilhismo: uma filosofia da República. Brasília: Senado Federal, Conselho Editorial, 2000; FREITAS, Décio. O homem que inventou a ditadura no Brasil. 3. ed. Porto Alegre: Sulina, 1999.
} 
O pesquisador de História relê, com pesar, o juízo que os fundadores do novo regime deixaram, testemunhando a sua desilusão. Não era a República dos sonhos de nenhum deles... ${ }^{189}$

\subsubsection{A evolução dos trabalhos constituintes}

Instalada em 15 de novembro de 1933, a Assembléia Constituinte promulgou a Constituição em 16 de julho de 1934. No dia seguinte, elegeu Getúlio Vargas presidente da República. No entremeio, um dos mais complexos momentos da vida institucional, com continuidades e descontinuidades, de salto para o futuro e permanências no passado, de anseios e de ressentimentos. Afinal, a realização da Assembléia Constituinte estava presa, em boa medida, ao resultado da guerra civil em que o Governo Provisório arrancara a vitória pelas armas, mas sucumbira perante a maré montante das exigências aos parâmetros da legalidade.

Em 16 de novembro, a Assembléia recebeu o anteprojeto da Subcomissão do Itamarati, como ponto de partida dos debates parlamentares. Desde então, apesar das vicissitudes e incertezas do processo político, há o cumprimento de certo cronograma de trabalho. A primeira etapa diz respeito à atuação da Comissão Constitucional, a denominada Comissão dos 26, com a apresentação das emendas dos deputados em sessões plenárias. Seus trabalhos realizaram-se entre novembro de 1933 e março do ano seguinte, com a entrega de substitutivo ao anteprojeto da Subcomissão do Itamarati.

$\mathrm{Na}$ busca da racionalização dos trabalhos, a Comissão Constitucional, a dos 26, acaba atribuindo tarefas a sub-relatores de partes do substitutivo. A "Comissão dos Três" presidente, vice-presidente e relator-geral - passa a reunir-se com os relatores parciais. A tarefa não deixa de ser vista como tendente a apressar os trabalhos, como manobra para realizar-se, logo, a eleição presidencial.

Ainda em janeiro de 1934, começam a realizar-se as reuniões da Comissão de Revisão, para o exame dos substitutivos parciais. Em 24 de fevereiro, é apresentado à Comissão dos 26 projeto de substitutivo, que, a partir de então, tem tarefa de redação do projeto constitucional. Em 7 de março, o Diário da Assembléia publicou o parecer e o substitutivo apresentados à Comissão de Revisão. Em 11 de março, publicou-se a Resolução $\mathrm{n}^{\mathrm{o}} 3$, pela qual se reformava o Regimento Interno, com o fim de acelerar o

\footnotetext{
${ }^{189}$ SILVA, Hélio, op. cit., 1969, p.24.
} 
trabalho constituinte. No início de abril, o Projeto $\mathrm{n}^{\mathrm{o}}$ 1-a/34 (substitutivo constitucional) é discutido, com a aposição de várias emendas. ${ }^{190}$

A partir de então, inicia-se nova etapa dos trabalhos constituintes. Observa-se a articulação das bancadas no interior da Assembléia, com o objetivo de aprovar em plenário as propostas, formando-se, então, dois grandes blocos, a saber, o das grandes bancadas, com o predomínio de Minas Gerais, Rio Grande do Sul, Bahia e São Paulo, e o das pequenas bancadas.

Em 7 de maio, vota-se, em segundo turno, o projeto 1-B da Constituição, com as emendas.

Em 5 de junho, a Constituinte aprova os atos do Governo Provisório.

Em 16 de julho, a segunda constituição republicana é promulgada. Todavia, a Assembléia eleita em 1933 prorrogou os seus trabalhos, agora como legislatura ordinária, até outubro, quando foram expedidos os diplomas dos deputados eleitos já na vigência do novo texto constitucional.

O historiador Hélio Silva descreve a expectativa que cercou o início dos trabalhos constituintes, inclusive, comparando-o com o da Assembléia Constituinte de 1946, nos seguintes termos:

Para os que viram a solenidade de instalação da Assembléia Nacional
Constituinte, de 15 de novembro de 1933 , aquela Casa se havia preparado para o
Momento supremo. E nunca mais teria a grandeza que foi abandonando o
plenário, os gabinetes, os corredores, as escadarias. Em 1946, o prodígio não se
reproduziu. O Momento Supremo nunca se repete. Porque, naquela primeira data
longínqua, todo um povo, a nação inteira, acreditava na restauração da
democracia (como se alguma vez tivesse sido instaurada). Em 1946, malgrado o

\footnotetext{
${ }^{190}$ João Mangabeira criticou acerbamente o projeto da Assembléia Constituinte, formulado pela Comissão dos Três, acentuando que, "onde [...] o projeto requinta o seu reacionarismo, é no capítulo da ordem social", pois "aí tudo é garantia, carinho e conchego para os ricos. Escárnio, desprezo e impiedade para os pobres". Salienta que "todo surto revolucionário deve ser, por definição, um movimento para a esquerda, procurando atender, por soluções políticas traduzidas afinal em fórmulas jurídicas, os interesses, as necessidades, os sofrimentos das massas, espoliadas pelas minorias venturosas". Todavia, "o pecado mortal do projeto é o seu reacionarismo. A sua [...] consideração para os ricos e o seu desprezo para os pobres", daí que "como projeto de uma revolução é um contra-senso! Porque ele se confunde no tom férreo da mais decidida reação. É um projeto ancien régime". Ao "derredor da intervenção nos estados (para garantia das prerrogativas judiciárias segundo o anteprojeto) e da Ordem Econômica e Social é que se reuniriam, solidários no combate, todos os verdadeiros reacionários - ou adoradores do regulismo estadual e do capitalismo insaciável”. MANGABEIRA, João. Em torno da constituição. São Paulo: Nacional, 1934, p.166, 270, 171 e 32 .
} 
silêncio radioso da Paz mundial, transmudava-se apenas a ditadura do Estado Novo, nas metástases recentes das oligarquias estaduais. [...]. ${ }^{191}$

\title{
2.5.8 A representação popular na Constituinte
}

Joaquim Nabuco observa que, no Segundo Reinado,

\begin{abstract}
já sob o ministério Itaboraí, podia-se distinguir a separação entre os liberais, a faixa radical. Um homem novo começava a aparecer na política, e revelava, desde os seus primeiros atos, uma independência, uma força, uma audácia, como decerto ainda não se tinha visto, batendo às suas portas em nome de um direito até então desconhecido: o do povo. Era Silveira Martins. [...] É o Sansão do Império.
\end{abstract}

Todavia, observa também que, “anos depois ele será, talvez, dos nossos políticos o mais conservador". ${ }^{192}$

Desde a entrada do "povo" na política, referida por esse, até a Constituinte de 1933/1934, no Brasil, por conta da representação classista, o povo ingressava pessoalmente no foro constituinte. Em 16 de novembro de 1933, durante a primeira reunião de trabalho da Assembléia Constituinte, Zoroastro Gouveia, antes filiado ao Partido Democrático (PD) de São Paulo e eleito como socialista, faz profissão de fé no socialismo marxista, apesar de considerar o possível isolamento no colegiado, visto as idéias marxistas serem novas no Brasil. ${ }^{193}$ De outra parte, a Constituinte teve a presença da representação da classe operária, com vinte representantes, numa bancada que totalizava quarenta votos. ${ }^{194}$ Todavia, "estes se somavam à maioria, salvo as exceções apontadas. Não havia reivindicações das várias classes. Seus componentes não tinham nem o traquejo parlamentar, nem, em sua maioria, a autoridade da cultura ou do relevo social que as outras bancadas exibiam". ${ }^{195}$ Não é outro o

\footnotetext{
${ }^{191}$ SILVA, Hélio, op. cit., 1969, p.21-22.

${ }^{192}$ NABUCO, Joaquim. Um estadista do Império. 5. ed. Rio de Janeiro: Topbooks, 1997. v. II, p.814-815.

${ }^{193}$ SILVA, Hélio, op. cit., 1969, p.32. Afonso Arinos de Melo Franco também registra: “[...] na Constituinte, surgem, talvez pela primeira vez, na nossa história constitucional, os representantes de um pensamento socialista consciente e, reivindicador. Deputados como Acir Medeiros e Vasco de Toledo (representantes classistas da categoria dos empregados) ou Zoroastro Gouveia e Lacerda Werneck, eleitos pelo Partido Socialista de São Paulo, falam, na Assembléia, outra língua, a língua do operariado e do intelectual reformista, se não revolucionário. Ao lermos os seus discursos, nos Anais, sentimos a presença de qualquer coisa de novo nos debates. [...] Sem dúvida essas vozes perdem-se, ainda, abafadas na caudal da oratória jurídica, política, ou teoricamente econômica e inconfundível. Zoroastro Gouveia e Lacerda Werneck são os melhores representantes parlamentares das novas aspirações socialistas”. FRANCO, Afonso Arinos de Melo. Curso de direito constitucional brasileiro. Rio de Janeiro: Forense, 1960. v.II, p.189.

${ }^{194}$ O Decreto n. 22.653, de 20 de abril de 1993, estabelecia: "Art. 1'. Tomarão parte na Assembléia Constituinte, com os mesmos direitos e regalias que competirem aos demais de seus membros, quarenta representantes de associações profissionais, tocando vinte aos empregados e vinte aos empregadores, nestes incluídos três por parte das profissões liberais e, naqueles, dois por parte dos funcionários públicos".

${ }^{195}$ SILVA, Hélio, op. cit., 1960, p.66.
} 
reconhecimento de Martins e Silva, representante da classe dos empregados, quando se apresentou ao plenário da Assembléia:

\begin{abstract}
A voz de um representante, genuinamente operário, talvez não possa interessar a uma Câmara de eruditos, se a encarnamos pelo lado da ilustração; se, porém, essa voz proletária for tomada pela sua sinceridade, tem que ser ouvida não só com atenção, mas com o mais absoluto respeito. ${ }^{196}$
\end{abstract}

Na ocasião, Martins e Silva ponderou também que bancada proletária tinha como pontos a defender a representação de classe, a aprovação das leis trabalhistas já editadas, a manutenção dos princípios de assistência social constantes do anteprojeto, a liberdade absoluta da manifestação do pensamento, a justiça trabalhista e a unificação do ensino, com a sua gratuidade, além da manutenção de salário igual para trabalho igual, já prevista no Anteprojeto. Ademais, defendia que a lei deve assegurar, nas cidades e nos campos, salário mínimo capaz de satisfazer as condições de existência, as necessidades normais de vida dos trabalhadores chefes de família. Enfatizou também a questão social, como um dos problemas mais importantes para a pacificação da família brasileira, com a edição de legislação capaz de solucionar a questão social, sem entrechoques violentos e sem derramamento de sangue.

No entanto, o representante das classes trabalhadoras, vindo do Estado do Pará, recebeu a contradita do socialista Zoroastro Gouveia - deputado por São Paulo e proprietário de banca de advocacia -, para quem "os trabalhadores nacionais hão de estar, forçosamente, contra a organização capitalista, porque somente a luta contra o capitalismo representa a libertação do trabalho universal" e que "o trabalhador brasileiro é sempre um escravo do capitalismo, dos cacauais da Bahia, dos cafezais de São Paulo e das fábricas de Pernambuco".

Para Martins e Silva, em total contraponto ao deputado marxista, haveria de "criar a política proletária brasileira, unida pela idéia da pátria, sem importação estrangeira que é o nosso mal”, "não perturbar essa obra estupenda que se realiza no Brasil, aliás, com o próprio concurso do Governo revolucionário" e "fazer para a nossa Pátria uma legislação social perfeita com um projeto constitucional que sirva de exemplo a todas as nações civilizadas do mundo". ${ }^{197}$

\footnotetext{
${ }^{196}$ Apud SILVA, Hélio, op. cit., 1969, p.69-70.

${ }^{197}$ Apud SILVA, Hélio, op. cit., 1969, p.69-70.
} 
Mas, em suma, o que foi o processo constituinte de 1933/1934 e a sua resultante? Dilo Pontes de Miranda, ressaltando a "contradição dolorosa" nas "três almas diferentes" em seu texto:

\begin{abstract}
Na Constituição de 1934 refletiram-se as tendências divergentes do nosso tempo: se bem que liberal, preocupou-se demasiado com a segurança, e daí ter pendido para o fascismo; posto que democrática, temeu as lutas, e se prestou a ser manejada contra a Democracia. Três almas diferentes confundiam-se nela: a democracia norteamericana, a das Constituições novas da Europa e a dos exemplos italiano e alemão recentes. [...] ${ }^{198}$
\end{abstract}

\title{
2.5.9 A Assembléia Constituinte e a questão social e econômica
}

A Constituição de 1934 introduziu a questão social e econômica, com os seus consectários, nos textos constitucionais brasileiros. Já na segunda sessão da Subcomissão Constitucional, encarregada de confeccionar anteprojeto a ser submetido à Assembléia Nacional Constituinte, João Mangabeira pontuou a alternativa entre a "revolução" e a "reação" que se antepunha na conjuntura, qual seja: “[...] todas as constituições modernas têm como orientação acabar com as desigualdades sociais. Se a constituição brasileira não marchar na mesma direção, deixará de ser revolucionária para se tornar reacionária. $[\ldots] " .199$

Os debates ocorridos durante as reuniões da Subcomissão do Itamarati demonstram a disposição dos seus componentes em torno de formular um anteprojeto concorde com o constitucionalismo social. Buscava a organização da ordem econômica com fulcro nos princípios da justiça e nas necessidades da vida nacional, como o fito de garantir a todos "uma existência digna do homem". A "liberdade econômica do indivíduo" deveria se conformar a tais parâmetros..$^{200}$

\footnotetext{
${ }^{198}$ MIRANDA, Pontes. Comentários à constituição de 1946. 2. ed. Rio de Janeiro: Max Limonad, 1953, p. 466-467.

${ }^{199}$ Acta da segunda sessão da Sub-comissão Constitucional, presidência do sr. Mello Franco. In: AZEVEDO, José Afonso de Mendonça. Elaborando a constituição nacional: atas da Subcomissão elaboradora do anteprojeto 1932/1933. Brasília: Senado Federal, Conselho Editorial, 2004, p.20. Da mesma ata, consta ainda que "o sr. José Américo manifesta-se no mesmo sentido. O sr. Góes Monteiro diz que terá de fazer observações à medida que o Presidente conduzir a discussão do projeto do ilustre relator. Apóia o ponto de vista dos srs. João Mangabeira e José Américo sobre a 'justiça social', que a liberdade deve ser subordinada à ordem e igualdade sociais". Ibid., 2004, p.20.

${ }^{200}$ “Art. $1^{\circ}$. A ordem econômica deve ser organizada conforme os princípios da justiça e as necessidades da vida nacional, de modo a garantir a todos uma existência digna do homem. Dentro desses limites, é assegurada a liberdade econômica do indivíduo".
} 
Quando da apreciação do artigo referente às "empresas ou concessões de serviços públicos", dissertando sobre o Estado brasileiro, pela União Federal e os Estadosmembros, Oswaldo Aranha observa que

a legislação universal, contatando a situação privilegiada das mesmas, tem evoluído, no sentido de fazer com que o Estado - que lhes favorece esses lucros, porque as coloca nas suas atividades, dentro do comércio, numa situação especial, decorrente da concessão que lhes deu - compartilha dos lucros em excesso, que elas obtiveram, segundo norma limitativa traçada como básica ${ }^{201}$

E dava como exemplo, o da São Paulo Railway:

Tal que todo o café de S. Paulo é obrigado a transitar por ela. Ora, não é justo que o Estado, que, em virtude dos seus poderes, investiu determinada empresa de tal situação privilegiada, não participe desses lucros, na maior parte, decorrentes da atribuição especial ou concessão que ele lhe dá. ${ }^{202}$

Conforme assinala João Mangabeira, "o anteprojeto não se alistou no socialismo. Ao contrário, reconheceu, proclamou e garantiu a propriedade privada", ficando "com a carta de Weimar, com a torrente de pensadores contemporâneos, que todos eles rejeitam a concepção individualista da propriedade”. Por conseguinte,

[...] O anteprojeto [...] não foi para a esquerda, nem para a direita. Não aboliu a propriedade, nem lhe conferiu, também, o cunho individualista, peculiar ao direito romano e ao liberalismo burguês. Como sempre, ficou no meio termo. Não retrogradou ao passado; não antecipou o futuro. Permaneceu no presente, considerando que a propriedade tem uma função social, que à lei compete regular. Nisto combinam, nisto se acordam filósofos, juristas, economistas, historiadores e sociólogos modernos, numa dessas unanimidades consagradoras dos fatos evidentes e inevitáveis. ${ }^{203}$

A Subcomissão do Itamarati utilizou como modelo de trabalho a Constituição de 1891, mas como esta não incorporava os temas mais em voga do constitucionalismo moderno, foi dada a alguns dos seus integrantes a relatoria de capítulos e disposições especiais, como a relativa à ordem econômica e social, atribuída a Oswaldo Aranha. ${ }^{204}$ No final, no discurso de encerramento dos trabalhos da Subcomissão do Itamarati:

A Subcomissão fez o possível, visando esse objetivo. Cada qual transigiu, cada
qual cedeu, conciliando sua doutrina com a situação atual do Brasil, com as
condições peculiares do nosso meio, da nossa raça, da nossa civilização e da
nossa história. Uma Constituição é forçosamente, inelutavelmente uma obra de

${ }^{201}$ Acta da $38^{\text {a }}$ Sessão da Sub-Comissão elaboradora do anteprojeto de Constituição. In: AZEVEDO, José Afonso de Mendonça, op. cit., 2004, p.730.

${ }^{202}$ Ibid., 2004, p.730.

${ }^{203}$ MANGABEIRA, João, op. cit., 1934, p.218-219.

${ }^{204}$ Ibid., 1934, p.9. Ver também HILTON, Stanley. Oswaldo Aranha: uma biografia. Rio de Janeiro: Objetiva, 1994 (especialmente, "V - Reconstitucionalização e Desencanto, 1932-1934”). 
transação, entre as várias correntes e forças que formam a estrutura da sociedade a que ela vem servir. É sobretudo e antes de tudo uma obra de políticos e não de juristas. $[\ldots]^{205}$

Em 1934, o constitucionalismo nacional passou a atribuir nova regulação à propriedade, ${ }^{206}$ dispondo que "a Constituição assegura a brasileiros e a estrangeiros residentes no País a inviolabilidade dos direitos concernentes à liberdade, à subsistência, à segurança individual e à propriedade". E, embora "garantido o direito de propriedade", tal não poderia "ser exercido contra o interesse social ou coletivo, na forma que a lei determinar", devendo os Poderes Públicos verificar, periodicamente, o padrão de vida nas várias regiões do país.

No que diz respeito à "Ordem Econômica e Social", reconhecia-se o papel ativo do Estado, com a conseqüente intervenção nas órbitas da política econômica e social. As palavras de João Mangabeira, citadas acima, na segunda sessão da Subcomissão do Itamarati, por meio das quais expusera o dilema da "revolução" versus "reação", isto é, "todas as constituições modernas têm como orientação acabar com as desigualdades sociais. Se a constituição brasileira não marchar na mesma direção, deixará de ser revolucionária para se tornar reacionária”. ${ }^{207}$ Em completa diferença com o texto constitucional de 1891, a matéria fora aceita pela Subcomissão do Itamarati, pelo

${ }^{205}$ Acta da $51{ }^{\text {a }}$ Sessão da Sub-Comissão elaboradora do anteprojeto de Constituição. In: AZEVEDO, José Afonso de Mendonça, op. cit., 2004, p.1.029. Temístocles Brandão Cavalcanti considerou que o anteprojeto “orienta-se por um caminho que não se afasta das nossas perspectivas mais próximas e fornece aos homens que vão governar o país um sistema bastante maleável para, dentro dele, orientar a solução dos problemas econômicos" e que, "embora acentuada a orientação liberal do projeto, no que diz com a liberdade individual em tudo o que se refere à ordem econômica ou social, faz a afirmação do princípio da intervenção do Estado [...] dando à propriedade o seu verdadeiro conceito social, admitindo a intervenção do Estado nas empresas de serviço público ou particular, criando, enfim, um novo direito de tendências socialistas". Destarte, "o anteprojeto muito realizou num país que ainda sofre a influência das idéias escravocratas". CAVALCANTI, Temístocles Brandão. À margem do anteprojeto constitucional. Rio de Janeiro: Irmãos Pongetti, 1933, p.139, 140 e 146.

${ }^{206}$ A Constituição de 1891 assegurava "a brasileiros e a estrangeiros residentes no País a inviolabilidade dos direitos concernentes à liberdade, à segurança individual e à propriedade" e que "o direito de propriedade mantém-se em toda a sua plenitude, salva a desapropriação por necessidade ou utilidade pública, mediante indenização prévia", além do que "as minas pertencem aos proprietários do solo, salvas as limitações que forem estabelecidas por lei a bem da exploração deste ramo de indústria" (art. 72, caput e § 17). A Constituição do Império estatuía "a inviolabilidade dos Direitos Civis, e Políticos dos Cidadãos Brasileiros, que tem por base a liberdade, a segurança individual, e a propriedade", garantindo-se "[...] o Direito de Propriedade em toda a sua plenitude. Se o bem público legalmente verificado exigir o uso, e emprego da Propriedade do Cidadão, será ele previamente indenizado do valor dela. A Lei marcará os casos, em que terá lugar esta única exceção, e dará as regras para se determinar a indenização" (art. 179, XXII). Ademais, responsabilizava os Ministros de Estado, entre outras hipóteses, "pelo que obrarem contra a Liberdade, segurança, ou propriedade dos Cidadãos" (art. 136, V).

${ }^{207}$ Acta da segunda sessão da Subcomissão Constitucional, presidência do sr. Mello Franco. In: AZEVEDO, José Afonso de Mendonça. Elaborando a constituição nacional: atas da Subcomissão elaboradora do anteprojeto 1932/1933. Brasília: Senado Federal, Conselho Editorial, 2004, p.20. 
substitutivo da Assembléia Constituinte e, por fim, pela própria Constituição de 1934 (contida no Título IV - arts. 115 a 143).

\title{
2.5.10 O texto constitucional produzido
}

O advogado Levi Carneiro, representante das profissões liberais, alertava já em discurso pronunciado, em 6 de maio de 1934, na Assembléia Constituinte:

\begin{abstract}
A preocupação do meio-termo conduzirá a Assembléia a votar uma Constituição inadaptável às realidades históricas, políticas e sociais do país. A seu critério, ela se apresenta ditatorial e haurida na autoridade daqueles dois poderes, (Poder Executivo e Poder Legislativo) ameaçando arrastar-nos a um sistema que seria fatalmente rompido em um golpe de Estado. ${ }^{208}$
\end{abstract}

De fato, "a Carta de 1934 não pôde, sequer, ter a duração do documento de 1891 ". ${ }^{209}$ A Intentona Comunista de 1935 foi o pretexto que se teve para pôr fim à Constituição de $1934 .{ }^{210}$ A Carta de 1937 acabou por englobar as sucessivas medidas de exceção que, num crescendo, respondiam ao clima social de medo, possibilitando a sua exploração por parte da burguesia brasileira, no que se refere ao comunismo. Ademais, para os vitoriosos de 1937, em boa parte calcados na ideologia do constitucionalismo antiliberal, ${ }^{211}$ o texto de 1934 não se coadunava com os novos tempos. De qualquer modo, apesar do diagnóstico/advertência de Gilberto Amado, segundo o qual "não há mais lugar para os liberais", visto que "o mundo, hoje, está dividido entre revolucionários, a extrema esquerda e reacionários, a extrema direita", ${ }^{212}$ as elites políticas na Assembléia Constituinte recalcitravam em tal liberalismo. O mais grave, todavia, é que era "a hora das tendências fascistas". ${ }^{213}$

[...] Desta forma, poderíamos caracterizar a Constituinte de 1934 não como um fruto da revolução e sim como uma exigência da contra-revolução. Num primeiro momento, portanto, a luta pela constituinte vai funcionar como pólo

\footnotetext{
${ }^{208}$ CARNEIRO, Levi. Pela nova constituição. Rio de Janeiro: A. Coelho Branco Filho (Editor), 1936, p.83. Ver também SERVA, Mário Pinto. Problemas da constituinte. São Paulo: Casa Siqueira Sales Oliveira, 1933.

${ }^{209}$ SILVA, Hélio, op. cit., 1969, p.24.

${ }^{210}$ Para Azevedo Amaral, a Constituição de 1934 “é um monstro em que, aliás como se poderia prever, se amalgamaram em verdadeiro pandemônio ideológico as doutrinas mais contraditórias, as tendências mais antagônicas e os pontos de vista mais irreconciliáveis". AMARAL, Azevedo. O Estado autoritário e a realidade nacional. Brasília: UnB, 1981, p.74.

${ }^{211}$ A propósito do constitucionalismo antiliberal brasileiro nos anos 30, ver, sobretudo, CAMPOS, Francisco. O Estado nacional: sua estrutura, seu conteúdo ideológico. Brasília: Senado Federal, Conselho Editorial, 2001.

${ }^{212}$ AMADO, Gilberto. Gilberto Amado, discursos parlamentares. Brasília: Câmara dos Deputados, 1979. p. 268.

${ }^{213}$ LIMA SOBRINHO, Barbosa. A presença de Alberto Torres: sua vida e pensamento. Rio de Janeiro: Civilização Brasileira, 1968, p.497.
} 
aglutinador, reunindo desde elementos explicitamente contrários à Revolução de 1930, até elementos nitidamente revolucionários, dentre os quais figuravam até mesmo partidários do governo Vargas. Somente num segundo momento é que o Governo Provisório encampa esta proposta, esvaziando-a de seu conteúdo oposicionista e colocando-a como intenção legítima de toda a nação, defendida e encaminhada por aqueles que estão no poder, particularmente o próprio Vargas. 214

Talvez a palavra-chave para explicar a Constituinte de 1933/1934 seja: contrarevolução. Isto a diferencia das constituintes republicanas de 1891 e 1946, consequiência imediata dos fatos que ocasionaram a queda da monarquia e a derrocada do Estado Novo. Por conseguinte, a Constituinte dos anos 30 tem três momentos distintos: a retórica dos que derrubaram a República Velha; as pressões das oligarquias derrubadas em 1930 em coalizão formal ou informal dos setores que, mesmo tendo participado do esforço "revolucionário", encontravam-se marginalizados; a encampação do fato pelo Governo Provisório, mais precisamente por Getúlio Vargas, que, vitorioso pelas armas na Revolução Constitucionalista de 1932, não pode mais sopitar a maré montante constituinte. Era inevitável, doravante, aquilo que Raul Fernandes, relator-geral da Assembléia Constituinte, chamou "a sanção moral da legalidade", isto é, "o batismo da legalidade vindo cobrir com o manto da sua majestade a obra de força realizada em outubro de $1930 " .{ }^{215}$

\subsubsection{Alberto Torres e Rui Barbosa}

Se a Constituinte de 1891 teve em Rui Barbosa ${ }^{216}$ o seu principal guia intelectual, a Constituinte de 1933/1934, pelo menos da perspectiva de uma das suas forças atuantes - os tenentes -, o substituiu por Alberto Torres. Foi este quem, em 1933 e 1934, "presente ao

${ }^{214}$ GOMES, Angela Maria de Castro. Confronto e compromisso no processo de constitucionalização (19301935). In: FAUSTO, Boris (Org.). História geral da civilização brasileira: sociedade e política (19301964). 2. ed. Rio de Janeiro: Difel, 1983, p.13-14.

${ }^{215}$ FERNANDES, Raul apud GOMES, Angela Maria de Castro. Introdução, op. cit., 1980, p.29. “O estatuto político de 16 de julho de 1934, elaborado por aquela Constituinte, tão inequivocamente representativa da vontade das massas eleitorais expressa em sufrágio direto, é um monstro em que, aliás como se poderia prever, se amalgamaram em verdadeiro pandemônio ideológico as doutrinas mais contraditórias, as tendências mais antagônicas e os pontos de vista mais irreconciliáveis. A Constituição de 1934 reúne de fato, na mais estranha convivência, as correntes de pensamento político mais disparatadas. [..] A Constituição elaborada por aquela assembléia não era um estatuto orgânico nacional, mas uma espécie de tratado que abrangia na sua órbita enorme todas as coisas divinas e humanas. Realmente, a Constituição de 16 de julho, que começava ocupando-se de teologia, encerrava a sua interminável cadeia de artigos prescrevendo regras ortográficas [...].” AMARAL, Azevedo, op. cit., 1981, p.74-75.

${ }^{216}$ Ver, entre outros, BARBOSA, Rui. Pensamento e ação de Rui Barbosa. Brasília: Senado Federal, 1999. 
debate e à ansiedade dos tenentes", ${ }^{217}$ teve as suas obras como livros de cabeceira dos reformadores do momento.

Em A desordem: ensaio de interpretação do momento, publicado em 1932, Virgínio Santa Rosa, por exemplo, vê em Alberto Torres o modelo que se opõe a Rui Barbosa, em quem faltaria tudo "como pensador e sociólogo, sobrando-lhe unicamente os dons de um estilo rico e poderoso que teria operado milagres, se traduzisse acaso as verdades dum Alberto Torres". ${ }^{218}$ Evidentemente, um estrato social que cultivava naqueles anos a hostilidade aos "carcomidos" e a tudo que se aproximasse dos métodos e comportamento políticos, os tenentes viam em Rui Barbosa o modelo a ser exorcismado. Como diz Barbosa Lima Sobrinho,

[...] Abaixo os políticos! Era um protesto unânime que crescia diante de Rui Barbosa, que eles consideraram mais culpado pelo fato de não haver aproveitado melhor os dons excepcionais que, se aplicado de outra forma, poderia ter encontrado a palavra de ordem da redenção nacional, desde que se não extraviassem no formalismo das questões jurídicas, nos descaminhos da erudição, na selva selvagem das polêmicas implacáveis. E o vício maior, que esterilizava o Brasil, era a ausência de um contato direto com a realidade, contato que Alberto Torres procurava de todos os modos, sacrificando a esse esforço o êxito de sua carreira política, as ambições de homem público, as horas de lazer, as preocupações de prestígio e de prosperidade. ${ }^{219}$

Convém afirmar, todavia, que merece recuperação o "industrialismo" de Rui Barbosa, a partir da crítica desenvolvimentista. ${ }^{220}$ Se é certo que tinha afeição pelo

${ }^{217}$ LIMA SOBRINHO, Barbosa, op. cit., 1968, p.507. Angela Maria de Castro Gomes, tratando da problemática da centralização versus descentralização, e à busca de um papel afirmativo para a União Federal, também observa: "Lideravam tal tendência as forças políticas vinculadas ao tenentismo. Tais forças, apesar de uma série de divergências em termos de medidas concretas, harmonizavam-se neste nível mais geral da análise e do encaminhamento político. No interior dessa temática, deve ser ressaltada a forte recorrência ao pensamento de Alberto Torres como base de respaldo crítico e como recurso de autoridade na defesa de determinadas soluções alternativas. A presença deste nome é tão palpável que sua simples menção em plenário acabaria por se transformar, no folclore político da época, em símbolo de identificação com a orientação política dos tenentes". GOMES, Angela Maria de Castro, op. cit., 1983, p.58.

${ }^{218}$ ROSA, Virgínio Santa. A desordem: ensaio de interpretação do momento. Rio de Janeiro: Schmidt, 1932, p.59.

${ }^{219}$ LIMA SOBRINHO, Barbosa, op. cit., 1968, p.506. No programa revolucionário do Clube 3 de Outubro, editado em 1932, observa-se: “A República passada foi toda uma mentira. Estudos e indagações determinaram, nitidamente, os principais fatores da falência do regime político inaugurado em 89: a falta de cultura do povo e o divórcio entre a Constituição de 24 de fevereiro e a realidade brasileira. Apurando bem, a responsabilidade maior deve caber ao pacto de 91. Houvesse, na lei das leis, dispositivos que cuidassem, precavida e eficientemente, da educação do povo, problema primordial, outros teriam sido a evolução e o desenvolvimento da primeira república". UNIVERSIDADE DE BRASÍLIA. A revolução de 30: textos e documentos. Brasília: UnB, 1982, p.84.

${ }^{220}$ "Seu industrialismo, outrora muito acusado, em seguida se recuperando aos olhos de uma crítica desenvolvimentista, foi desmontado, a pretexto de fracassar em meio a uma grande crise, a do Encilhamento. O principal demolidor: Joaquim Murtinho, liberal econômico principalmente contra o protecionismo às empresas nascentes, em nome de um cruel darwinismo social (mero poder do mais forte) que não admitia sequer a previdência social (quanto ao socialismo, nem falar, não passaria da 'volta da sociedade à escravidão'), mas bem que Murtinho soube ajudar a agricultura tradicional, ao defender a 
liberalismo vitoriano, ${ }^{221}$ ainda no final do Império já proclamava a necessidade da liberdade religiosa, da democratização do voto, da desoligarquização do Senado, da desenfeudação da propriedade e da federação. ${ }^{222}$

Depois, quando da campanha formulava um programa mais ousado de intervenção social e econômica, para responder à questão - "mas somos uma nação agrícola. E por que não também uma nação industrial?”, ressaltando um plano de reformas em que se destacavam: 1. casas de operários; 2. trabalho de menores; 3 . horas de trabalho; 4. regalias às mães operárias; 5. garantia de seguro aos acidentes do trabalho, com inclusão dos trabalhadores agrícolas, cuja omissão "brada aos céus"; 6. seguro operário; 7. igualdade dos sexos ante o trabalho; 8. salário mínimo fixado em lei para os menores; 9. extinção ou redução do trabalho noturno; 10. trabalho em domicílio; 11. garantia de salário durante certo prazo de gravidez e depois do parto; 12 . armazéns de venda aos operários. ${ }^{223}$

\title{
2.6 A Constituinte e a Constituição de 1946
}

\begin{abstract}
Nas Constituintes de 1823, 1891 e 1934, havia, entre os que nelas se congregaram, um sentimento de fé profunda na perenidade das obras a que se dedicavam.

Creio que esta é a mais cética, a mais melancólica das Assembléias Constituintes que já se reuniram no Brasil. Nenhum de nós parece que acredita estar construindo para os séculos.
\end{abstract}

Aliomar Baleeiro

\subsubsection{A convocação da Assembléia Nacional Constituinte}

Ainda sob a direção de Getúlio Vargas, a partir do início de 1945, começou-se a promover a distensão política. ${ }^{224}$ Primeiramente, por meio do Ato Adicional (Lei

redução das taxas sobre as exportações do café. Afinal de contas, quem o fez Ministro da Fazenda era Campos Sales com os interesses paulistas que representava”. CHACON, Vamireh. Vida e morte das constituições brasileiras. Rio de Janeiro: Forense, 1987, p.113. Ver também MANGABEIRA, João. Rui: o estadista da República. Brasília: Conselho Editorial, Senado Federal, 1999.

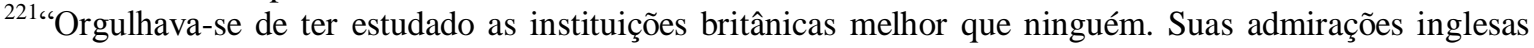
maiores: o economista John Stuart Mill e o estadista William Gladstone, protótipos máximos do liberalismo vitoriano, sombras imensas do fim do século XIX que preparou o espírito de Rui e o acolheu no desterro". CHACON, Vamireh, op. cit., 1987, p.108.

${ }^{222}$ MANGABEIRA, João, op. cit., 1999.

${ }^{223}$ Ibid., 1999, p.317.

${ }^{224}$ Escrevendo sobre o "espírito da Constituição de 1946”, Hermes Lima assinalava que "a Constituinte de 46 trabalhou com o mesmo espírito da de 34. Essencialmente, nada inovou. Se cotejarmos as duas Cartas, verificaremos que, embora existam diferenças, a verdade é que a base da organização política, a base da organização institucional e o espírito dessa organização são idênticos, numa e noutra Constituição". 
Constitucional n. 9, de 28 de fevereiro de 1945), estabeleceu-se que, no prazo de noventa dias, seriam fixadas as datas das eleições para a presidência da República, Câmara dos Deputados e Conselho Federal, ${ }^{225}$ governadorias dos Estados e Assembléias Legislativas. Por conseguinte, deixava-se para trás o plebiscito previsto pela Constituição de $1937 .{ }^{226} \mathrm{De}$ acordo ainda com a Lei Constitucional n. 9/45, instaladas as casas legislativas, o presidente perderia a faculdade de legislar por leis constitucionais e decretos-leis, e as casas legislativas passariam a emendar a Constituição de 1937 e a legislar ordinariamente.

Ademais, a Lei Constitucional n. 9, de 28 de fevereiro de 1945, considerava que "a eleição de um Parlamento dotado de poderes especiais para, no curso de uma legislatura, votar, se o entender conveniente, a reforma da Constituição, supre com vantagem o plebiscito de que trata o art. 187 desta última" e, também, que “o voto plebiscitário implicitamente tolheria ao Parlamento a liberdade de dispor em matéria constitucional”.

Depois, promoveu-se a anistia de todos os presos políticos, por meio do Decreto-lei n. 7.474, de 18 de abril. ${ }^{227}$ Em 28 de maio, conforme o prazo estipulado pela Lei Constitucional n. 9/45, editou-se o Decreto-lei n. 7.586, ${ }^{228}$ que marcou as eleições para 2 de dezembro do mesmo ano.

Enquanto isso o movimento "queremista" ganhava as ruas, estimulado pelo próprio presidente da República e apoiado, inclusive, pelo PCB, a defender a "Constituinte com Vargas".

Acrescentava que, "tanto a Constituinte de 34, como a de 46, foram Assembléias preocupadas sobretudo em impedir que um Executivo avassalador, de tendências discricionárias, dominasse a cena pública". LIMA, Hermes. O espírito da Constituição de 1946. In: INSTITUTO DE DIREITO PÚBLICO E CIÊNCIA POLÍTICA. Estudos sobre a constituição brasileira. Rio de Janeiro: FGV, 1954, p.14 e 16.

${ }^{225}$ A Constituição de 1937 estabelecia: “Art. 50 - O Conselho Federal compõe-se de representantes dos Estados e dez membros nomeados pelo Presidente da República. A duração do mandato é de seis anos. Parágrafo único - Cada Estado, pela sua Assembléia Legislativa, elegerá um representante. O Governador do Estado terá o direito de vetar o nome escolhido pela Assembléia; em caso de veto, o nome vetado só se terá por escolhido definitivamente se confirmada a eleição por dois terços de votos da totalidade dos membros da Assembléia". A LC nº 9/45 deu a seguinte redação: “Art. 50. O Conselho Federal compõe-se de dois representantes de cada estado e do Distrito Federal, eleitos por sufrágio direto. A duração do mandato é de seis anos." BRASIL. Constituição (1937). Constituição dos Estados Unidos do Brasil. Disponível em: 〈http://www.presidencia.gov.br/legislacao>. Acesso em: 10 jan. 2008.

226،A Art 187 - Esta Constituição entrará em vigor na sua data e será submetida ao plebiscito nacional na forma regulada em decreto do Presidente da República". Ibid., 2008.

${ }^{227}$ BRASIL. Decreto-lei n. 7.474, de 18 de abril de 1945. Disponível em: <http://www.senado.gov.br/legislacao>. Acesso em: 10 abr. 2008.

${ }^{228}$ BRASIL. Decreto-lei n. 7.586, de 28 de maio de 1945. Disponível em: <http://www.senado.gov.br/legislacao>. Acesso em: 10 abr. 2008. 
O TSE, em 2 de outubro, resolvera sobre duas consultas, uma formulada pelo recém criado Partido Social Democrático (PSD) e outra pela Ordem dos Advogados do Brasil $(\mathrm{OAB})$-Distrito Federal. A primeira pedia resposta para a seguinte questão: "quais os poderes reais que competirão ao futuro parlamento?’. A outra solicitava esclarecimento sobre "se o parlamento a ser eleito em 2 de dezembro de 1945, além da função legislativa ordinária, exercerá, em face da lei constitucional n. 9, funções de assembléia constituinte”. A decisão, por maioria, deu-se no sentido de conhecer das consultas formuladas e "declarar que o Parlamento nacional que será eleito a 2 de dezembro de 1945, além das suas funções ordinárias, terá poderes constituintes, isto é, apenas sujeitos aos limites que ele prescrever”.

Alguns dias depois, o presidente do TSE e do STF, agora investido na presidência da República, em virtude do golpe que derrubou Getúlio, editava a Lei Constitucional n. 13, de 12 de novembro de 1945, segundo a qual "os representantes eleitos a 2 de dezembro de 1945 para a Câmara dos Deputados e o Senado Federal reunir-se-ão no Distrito Federal, sessenta dias após as eleições, em Assembléia Constituinte, para votar, com poderes ilimitados, a Constituição", ${ }^{229}$

Coube ainda ao presidente José Linhares resolver a questão dos poderes do presidente da República, durante os trabalhos da Assembléia Constituinte, por meio da Lei Constitucional n. 15, de 26 de novembro de 1945. Tal lei, "considerando que, enquanto a Assembléia funcionar como Constituinte, a administração do país não prescindirá de providências de natureza legislativa", estabelecia que "em sua função constituinte terá o Congresso Nacional, eleito a 2 de dezembro próximo, poderes ilimitados para elaborar e promulgar a Constituição do país, ressalvada a legitimidade da eleição do presidente da República" (art. $\left.1^{\circ}\right)$. E que,

\begin{abstract}
enquanto não for promulgada a nova Constituição do país, o presidente da República, eleito simultaneamente com os deputados e senadores, exercerá todos os poderes de legislatura ordinária e de administração que couberam à União, expedindo os atos legislativos que julgar necessários. $\left(\operatorname{art.} 2^{\circ}\right) .^{230}$
\end{abstract}

\footnotetext{
${ }^{229}$ Entre os consideranda, destacava-se que "o Tribunal Superior Eleitoral interpretou como sendo constituintes os poderes que, nos termos da lei constitucional $n^{\circ} 9$, de 28 de fevereiro de 1945 , a Nação vai outorgar ao Parlamento, nas eleições convocadas para 2 de dezembro de 1945", bem como "a conveniência de pôr termo às controvérsias então suscitadas a respeito do julgado, em torno da legitimidade e da extensão dos poderes que a Nação delegará ao parlamento". Decidia-se, também, que, "promulgada a Constituição, a Câmara dos Deputados e o Senado Federal passarão a funcionar como Poder legislativo ordinário".

${ }^{230}$ BRASIL. Constituição (1937). Lei Constitucional no 15, de 26 de novembro de 1945. Disponível em: <http://www.senado.gov.br/legislacao>. Acesso em: 10 abr. 2008.
} 
Ademais, jungia também a Assembléia, no que diz respeito a decidir sobre o mandato presidencial, dispondo que "o período presidencial do Presidente eleito a 2 de dezembro de 1945 e a duração da legislatura eleita na mesma data serão os que forem estabelecidos, pela Assembléia Constituinte, para os presidente e legislaturas futuras" (art. $\left.3^{\circ}\right)$.

Pelo Decreto-lei n. 7.586, de 28 de maio de 1945, que regulou, "em todo o país, o alistamento eleitoral e as eleições a que se refere o art. $4^{\circ}$ da Lei Constitucional n. 9, de 18 de fevereiro de 1945", "os lugares não preenchidos com a aplicação do quociente eleitoral e dos quocientes partidários são atribuídos ao partido que tiver alcançado maior número de votos, respeitada a ordem de votação nominal de seus candidatos" (art. 48). ${ }^{231}$

Diferentemente do pleito para a Constituinte dos anos 30, agora, as eleições consistiram em votar em senadores e deputados federais, respectivamente, pelo sistema majoritário e pelo sistema proporcional. Sendo aquele decreto editado com a finalidade de dirigir as eleições que marcaram o restabelecimento do regime democrático, restabeleceu os órgãos da Justiça Eleitoral, extintos na Carta de 1937, confirmou àquela as mesmas atribuições estabelecidas pela Constituição de 1934 e pelo Código Eleitoral de 1935 e trouxe-lhe outras competências, entre as quais ordenar o registro dos partidos políticos e dos candidatos à presidência da República e à Constituinte.

Em 1945, foi estabelecido que os candidatos não poderiam disputar eleições sem o apoio de partidos, alianças ou coligações partidárias, admitindo-se, inclusive, que, nos pleitos majoritários, o candidato pudesse inscrever-se em mais de uma legenda, e tornandose obrigatória a constituição de partidos nacionais.

\subsubsection{Partidos e sistema partidário na conjuntura constituinte}

Conhecidos os resultados eleitorais, o PSD foi o único partido a eleger, sem coligação, deputados em todos os Estados, no Distrito Federal e no Território do Acre, sendo o mais votado em todos os Estados, com exceção do Ceará, Piauí, Paraíba e Bahia.

${ }^{231}$ BRASIL. Decreto-lei n. 7.586, de 28 de maio de 1945. Disponível em: <http://www.senado.gov.br/legislacao>. Acesso em: 10 abr. 2008. 
Minas Gerais, Rio Grande do Sul, São Paulo e Pernambuco detinham as maiores bancadas. $^{232}$

O PSD acabou por deter a presidência da República e a da Assembléia Constituinte. Além do mais, ocupou a presidência e a relatoria da Comissão Constitucional, presidiu oito subcomissões $(88,8 \%)$ e ocupou a relatoria de quatro delas $(44,5 \%)$.

A representação da UDN era composta por muitos "carcomidos", ${ }^{233}$ isto é, remanescentes da República Velha, além de "tenentes", como Juarez Távora e Juraci Magalhães, inconformados com a decretação do Estado Novo. Também,

[...] A ela se filiavam os desiludidos, os deserdados de 30, como Virgílio de Melo Franco, preterido, desprezado e rejeitado, depois de ter sido, ao lado de Osvaldo Aranha, a alma pensante, dínamo e motor da revolução. Estavam também os emergentes do fugaz e efêmero regime de 34, como o mineiro Pedro Aleixo, de quem Getúlio se serviu para desbancar da presidência da Câmara seu parceiro e aliado, ex-presidente de Minas, Antônio Carlos, dirigente máximo da Aliança Liberal [...]. Como o dele, era o caso de Odilon Braga, ministro de Getúlio que, à semelhança de Juraci Magalhães e Flores da Cunha, inconformado com o Estado Novo, rompeu com o ditador, tornou-se seu adversário [...]. A todos, muitos antigos adversários, uniam apenas sentimentos comuns: o ódio de uns, o despeito de outros. ${ }^{234}$

Em suma, a UDN da Assembléia Constituinte de 1946 compunha-se dos membros das oligarquias destronadas a partir de 1930, antigos aliados de Getúlio Vargas, partícipes do Estado Novo, além dos liberais nos Estados e das esquerdas. ${ }^{235}$ A respeito da composição da UDN, Afonso Arinos destacava que "havia duas direitas antidemocráticas aninhadas na UDN: uma que detestava a herança varguista e aspirava à ditadura militar por motivos políticos, e outra que tendia também para a ditadura militar, mas por reacionarismo econômico e hostilidade ao progresso social". 236

${ }^{232}$ HIPPOLITO, Lúcia. De raposas e reformistas: o PSD e a experiência democrática brasileira, 1945-1964. Rio de Janeiro: Paz e Terra, 1985.

${ }^{233}$ Entre os próceres da República Velha na Assembléia Constituinte, destacavam-se, entre outros, o presidente Melo Viana (PSD-MG), que fora o vice-presidente de Washington Luís e apoiara Júlio Prestes; o ex-presidente da República Artur Bernardes (chefe do Partido Republicano-PR); o vice-presidente da Assembléia Constituinte Otávio Mangabeira (UDN-BA), ministro das Relações Exteriores de Washington Luís.

${ }^{234}$ NOGUEIRA, Octaciano. A constituinte de 1946. Getúlio, o sujeito oculto. São Paulo: Martins Fontes, 2005, p.14-15. Sobre a UDN na Constituinte, ver também BENEVIDES. Maria Victoria de Mesquita. A UDN e o udenismo: ambigüidades do liberalismo brasileiro, 1945-1965. Rio de Janeiro: Paz e Terra, 1981.

${ }^{235}$ Ibid., 1981. Ademais, segundo a mesma autora, na combinação de interesses da burguesia, dos militares e dos liberais aliados à esquerda, que levaram à queda de Getúlio Vargas em 1945, deve-se observar "uma série de encontros entre Virgílio de Melo Franco, secretário geral da UDN, e o Gen. Góis Monteiro, visando assegurar as garantias das Forças Armadas de que as eleições se realizariam em 'clima democrático"”. Ibid., 1981, p.56.

${ }^{236}$ Apud BENEVIDES. Maria Victoria de Mesquita, op. cit., 1981, p.15. 
A UDN elegeu 77 deputados, além de um da Esquerda Democrática, e dez senadores. ${ }^{237}$ Ficou em segundo lugar, contando que o PSD fizera 151 deputados e 26 senadores. O comportamento udenista durante a Constituinte foi de uma frente e não de um partido. Assim,

\begin{abstract}
Ao abandonar sua missão ostensivamente oposicionista, passa a expressar a própria ambigüidade na ação política: não age contra nem a favor, na indecisão de princípios que oscilam entre a intransigência original de Virgílio de Mello Franco [...], a fixação juridicista de Prado Kelly e o realismo elegantemente adesista de Otávio Mangabeira e Juraci Magalhães. ${ }^{238}$
\end{abstract}

Um dos seus próprios líderes, Carlos Lacerda, avaliando o papel exercido pela UDN, durante a Assembléia Nacional Constituinte, apontando a tentativa de "recuperação populista do partido", considerou:

E a Constituinte chegou ao seu fim, um pouco melancolicamente, e aí alguns elementos tentaram uma recuperação populista do partido. Em primeiro lugar, inútil, porque não deu certo; em segundo lugar, demagógica, porque não era sincera; em terceiro lugar, incompetente politicamente. Por exemplo, o Paulo Sarazate introduziu um artigo para participação dos operários nos lucros das empresas, artigo que nunca conseguiu regulamentar, porque dependia de regulamentação em lei ordinária, e nunca ninguém chegou a uma fórmula matemática capaz de garantir e de interessar o operário na participação do lucro [...]. Então era medida inócua, puramente demagógica, que não teve a menor influência sobre o operariado em relação à UDN [...]. ${ }^{239}$

O Partido Trabalhista Brasileiro (PTB) fez 22 deputados e dois senadores. Sua representação estava umbilicalmente ligada a Getúlio Vargas, que, por tal legenda, fora eleito senador em São Paulo e deputado no Rio Grande do Sul, Bahia, Rio de Janeiro, Distrito Federal, Paraná e Minas Gerais. ${ }^{240}$ Segundo a legislação vigente, os eleitos tinham, depois de instalada a Assembléia Constituinte, dois meses para proceder à opção pelo mandato mais conveniente. Caso não o fizessem no tempo prescrito, Mesa da Constituinte poderia fazê-lo, tendo preferência o estado e o cargo em que tivessem sido mais votados. Assim, os 116.712 votos de Getúlio como deputado do Distrito Federal acabaram por

\footnotetext{
${ }^{237}$ A UDN englobou, em 1945, os candidatos do PR (chefiado pelo ex-presidente Artur Bernardes) e os da Esquerda Democrática (depois PSB, chefiado por João Mangabeira).

${ }^{238}$ Ibid., 1981, p.70.

${ }^{239}$ LACERDA, Carlos. Depoimento. 3. ed. Rio de Janeiro: Nova Fronteira, 1987, p.89. Para uma análise do dia-a-dia da Assembléia Constituinte, ver LACERDA, Carlos. Na Tribuna da Imprensa: crônica sobre a Constituição de 1946. Rio de Janeiro: Nova Fronteira, 2000.

${ }^{240}$ Eleito senador também pelo PSD-RS, Getúlio Vargas acabou por assumir em tal condição. "Tendo tomado posse no dia 4 de junho, [...] praticamente não participou dos trabalhos da Constituinte. Das 182 sessões ordinárias e extraordinárias, realizadas pela Assembléia, entre $1^{\circ}$ de fevereiro e 19 de agosto, [...] tomou parte de apenas 26 , menos de $15 \%$ do total. Não foi apenas o constituinte mais votado e o menos assíduo. Foi [...] o único que não assinou a Constituição nem compareceu à sessão de promulgação. Não tomou parte em nenhum debate, não apresentou emendas ao projeto constitucional e, com sua atitude, demonstrou ostensivo e solene desprezo pela Constituinte. [...]". NOGUEIRA, Octaciano, op. cit., 2005, p.442.
} 
garantir ao seu partido dez cadeiras, para candidatos que variavam do coronel Rui Almeida, o segundo mais votado, com 3.201 votos, a Barreto Pinto, com 537 votos. Destarte, dezessete dos 22 deputados que o PTB elegeu em todo o território nacional estavam na Constituinte por conta dos votos varguistas. ${ }^{241}$

Se em 1933, durante os trabalhos da Constituinte, o deputado Zoroastro Gouveia fizera a primeira profissão de fé no socialismo marxista no Parlamento, agora, o PCB, fundado em 1922, passava a integrar o foro constituinte.

A Conferência da Mantiqueira, em 1943, constituiu um marco importante na vida do PCB, pelo que significou na sua reorganização. Defendeu-se, a partir desse encontro nacional, a "união nacional em torno do governo" na luta contra o nazi-fascismo, prosseguindo na política de união nacional em torno de Getúlio Vargas, até a sua queda em 29 de outubro de 1945..$^{242}$ O PCB defendeu, inclusive, o adiamento das eleições presidenciais e apoiou o movimento "queremista", da "Constituinte com Getúlio".

Pode-se observar que, dado que as demais organizações de esquerda eram inexpressivas sob o ponto de vista numérico, o PCB passou a ser o partido ideológico de expressão nos trabalhos da Assembléia Constituinte. ${ }^{243}$

De todo modo, a Assembléia Constituinte provava ser um momento de pluralismo político até então inédito no país. O PCB chegava ao Parlamento, com 8,53\% dos votos válidos dados nas eleições de dois de dezembro do ano anterior em todo o país, trazendo quatorze dos 286 deputados. Três de Pernambuco, um da Bahia, dois do Estado do Rio, três do Distrito Federal, quatro de São Paulo e um do Rio Grande do Sul. Além de um senador a representar o Distrito Federal, visto que Luís Carlos Prestes, eleito senador pelo Distrito Federal e deputado pelo Distrito Federal, Pernambuco e Rio Grande do Sul, optara

\footnotetext{
${ }^{241}$ Ver DELGADO, Lucília de Almeida Neves. PTB: do getulismo ao reformismo, 1945-1964. São Paulo: Marco Zero, 1989.

${ }^{242}$ Durante a Assembléia Constituinte, no primeiro debate entre Otávio Mangabeira e Luís Carlos Prestes, em 20 de março de 1946, reivindicou este para o PCB a qualificação de opositor de "qualquer perturbação da ordem pública. Mangabeira reclamou que Prestes, "durante a campanha democrática que fizemos na praça pública, sem medir esforços ou conseqüências, enfrentando a ditadura, V. Excia. nos abandonou, desprezando a causa democrática para fortalecer a ditadura, que era precisamente a reação". Ao que Prestes retrucou: "Havia entre o Partido Comunista e a UDN, algo que os separava profundamente. O Partido Comunista era radicalmente contrário a qualquer perturbação da ordem pública [...] tínhamos certeza de que os golpes armados seriam contra a democracia, contra o proletariado, contra o nosso povo". BENEVIDES, Maria Victoria de Mesquita, op. cit., 1981, p.50-51.

${ }^{243}$ RODRIGUES, Leôncio Martins. O PCB: os dirigentes e a organização. In: FAUSTO, Boris (Org.). História geral da civilização brasileira: sociedade e política (1930-1964). 2. ed. Rio de Janeiro: Difel, 1983. 3v., p.361-443.
} 


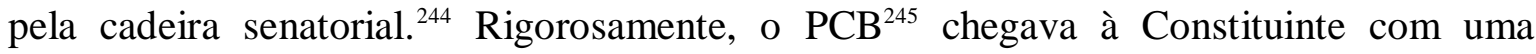
bancada apenas inferior à do PSD, à da UDN e à do PTB.

A formação do PCB, em 1945, denotava um partido ao mesmo tempo de massas e ideológico, capaz de sensibilizar as classes médias e proporcionar, no que diz respeito a filiados e militantes, um corte transversal no país, atraindo, inclusive, numerosos intelectuais. Foi, provavelmente, entre a intelligentsia que o partido obteve maior influência, controlando revistas e outras publicações e entidades culturais. ${ }^{246}$ Sua organização constituía algo diferente para os padrões da época, como diz Leoncio Basbaum:

[...] Desde que Prestes fora posto em liberdade e o Partido devidamente legalizado, houve uma verdadeira enxurrada de adesões de pessoas de todas as classes, em primeiro lugar, de operários. O Partido crescia com uma rapidez tão grande que mal havia tempo para o serviço burocrático de anotar o nome de todos, criar cédulas e organizar uma contabilidade. Brotam 'organismos de base' (nome para antigas células tirado dos Estatutos do PCUS) por todos os lados. ${ }^{247}$

Diz ainda Leoncio Basbaum:

[...] Não somente velhos companheiros e militantes, havia muito afastados das atividades partidárias e políticas. A grande maioria era constituída de gente nova, operários, funcionários, bancários, intelectuais, aí incluídos escritores, artistas plásticos e teatrais, médicos, arquitetos, engenheiros e até advogados. Todos queriam pertencer ao PCB, ao 'Partido do futuro', muitos querendo provar que eram comunistas 'não de agora', mas de muito tempo antes, 'desde a ditadura' etc. $\mathrm{E}$ todos eram bem recebidos, naturalmente, sem mais indagações. ${ }^{248}$

Durante os debates constituintes, os comunistas resistiram à idéia da programaticidade constitucional, por entenderem que uma constituição deve consagrar o já conquistado e não o que é necessário "alcançar e conquistar no futuro", como bem destacou Jorge Amado:

\footnotetext{
${ }^{244}$ Além de Luís Carlos Prestes, da bancada do PCB fazia parte Jorge Amado, que havia ajudado a consagrar nacionalmente a legenda de Prestes com o livro Vida de Luís Carlos Prestes: o cavaleiro da esperança (a primeira edição em português foi publicada em 1945, pela Livraria Martins Editora, do Rio de Janeiro). Formavam a bancada, também, experimentados militantes, tanto ex-militares, como o próprio Prestes, Trifino Correia e Gregório Bezerra, quanto sindicalistas, como Carlos Marighela, Maurício Grabois e João Amazonas, este o líder do partido na Assembléia. Ver RODRIGUES, Leôncio Martins. O PCB: os dirigentes e a organização. In: FAUSTO, Boris (Org.). História geral da civilização brasileira: sociedade e política (1930-1964). 2. ed. Rio de Janeiro: Difel, 1983. 3v.

${ }^{245}$ Os dados estão em RODRIGUES, Leôncio Martins, op. cit., 1983. Sobre a atuação do PCB na Constituinte, ver também, entre outros, SILVA, Hélio. 1945: porque depuseram Vargas. Rio de Janeiro: Civilização Brasileira, 1964 (principalmente "A bancada comunista na Constituinte"); GIOVANNETTI, E. Netto. A bancada do PCB na Assembléia Constituinte de 1946. São Paulo: Novos Rumos, 1986; CHILCOTE, Ronald H. The Brazilian Communist Party. New York: Oxford University Press, 1974.

${ }^{246}$ RODRIGUES, Leôncio Martins, op. cit., 1983.

${ }^{247}$ BASBAUM, Leoncio. Uma vida em seis tempos. São Paulo: Alfa-Ômega, 1976, p. 189.

${ }^{248}$ Ibid., 1976, p. 189-190.
} 
Temos nós comunistas um conceito de Constituição que não é o clássico. O generalíssimo dos vitoriosos exércitos soviéticos, Joseph Stálin, já o definiu com lucidez e clareza admiráveis, e não me furto a ler aqui sua definição de Constituição que também é a nossa. Escreveu Stálin, ao debater o anteprojeto da democrática Constituição da União das Repúblicas Soviéticas Socialistas de 1936, o seguinte:

Uma Constituição não deve confundir-se com um programa. Isto significa que existe uma diferença essencial entre uma Constituição e um programa. Enquanto um programa formula o que ainda não existe, aquilo que é necessário alcançar e conquistar no futuro, uma Constituição, ao contrário, dever tratar do que já existiu, daquilo que já se alcançou e conquistou no momento presente. Um programa refere-se, principalmente, ao futuro; uma Constituição refere-se principalmente ao passado. Esse é [...] o nosso conceito de Constituição. E bem sabemos que nem a de 1891 nem a de 1934 estavam dentro deste conceito. ${ }^{249}$

\subsubsection{Partidos nacionais e hegemonia liberal-conservadora na Assembléia Nacional Constituinte}

O partido majoritário era o PSD, nascido como conjunto de partidos estaduais, organizado em torno dos interventores, a quem a determinação de constituir-se como partido nacional dera o amálgama necessário. ${ }^{250} \mathrm{Na}$ sua primeira convenção nacional, em 17 de junho de 1945, aclamara o general Eurico Gaspar Dutra, então ministro da Guerra, candidato à presidência da República. Ademais, o Conselho Nacional do novo partido, na mesma data, aclamou como presidente da Comissão Diretora a Getúlio Vargas. ${ }^{251}$

Na Assembléia Constituinte, foi o partido político mais poderoso, continuando a sêlo durante todo o regime surgido com a Constituição de 1946, inclusive, funcionando como o principal responsável pela superação das grandes crises políticas do período, constituindo-se ao longo de sua história em "verdadeiro fiador do regime político que

${ }^{249}$ Discurso de Jorge Amado na Assembléia Constituinte apud NOGUEIRA, Octaciano. A constituinte de 1946. Getúlio, o sujeito oculto. São Paulo: Martins Fontes, 2005, p.69. Especificamente sobre a atuação de Prestes na Assembléia Constituinte, ver BRAGA, Sérgio Soares (Org.). Luiz Carlos Prestes; o constituinte, o senador (1946-1948). Brasília: Senado Federal, Conselho Editorial, 2003.

250“Se o PSD não era um partido fortemente centralizado, a articulação entre os seus três níveis - nacional, regional e local - era bastante sólida. Articulação basicamente vertical, o que não evitou a existência de contatos freqüentes entre seções do mesmo nível. Tal incidência, se não impedia o aparecimento de dissidências, permitia maior flexibilidade à estrutura do partido, com reflexo na própria dinâmica das decisões tomadas por ele, dando origem à crença mais ou menos generalizada de que o 'diretório nacional do PSD só se reunia quando estava tudo resolvido"'. HIPPOLITO, Lúcia. De raposas e reformistas: o PSD e a experiência democrática brasileira, 1945-1964. Rio de Janeiro: Paz e Terra, 1985, p.43. A boutade de Tancredo Neves, realçada pela mesma Lúcia Hippolito, acabou por definir bem o PSD na Constituinte e em outros momentos: “Entre a Bíblia e O capital, o PSD fica com o Diário Oficial”. Ibid., 1985, p.36.

${ }^{251}$ Benedito Valladares relata que, quando se comunicou a Getúlio Vargas e ao general Eurico Gaspar Dutra a decisão, o presidente da República não deu "a menor importância à sua eleição, pois já estava com idéia do PTB”. VALLADARES, Benedicto. Tempos idos e vividos: memórias. Rio de Janeiro: Civilização Brasileira, 1966, p.267. 
sucedeu o Estado Novo", ocupando o centro político até fragmentar-se internamente e fragmentar-se o próprio sistema partidário, que entra em colapso em $1964 .^{252}$

Cumpre destacar que, pela primeira vez, representavam-se partidos nacionais no Parlamento brasileiro, ${ }^{253}$ o que caracterizou a assembléia constituinte, para os padrões da sociedade brasileira da época, com grande representatividade. O PSD, a UDN, o PTB, o PCB, o PR (Partido Republicano) e Partido Social Progressista (PSP) foram os partidos com as bancadas mais numerosas e, juntamente com os outros partidos, congregavam getulistas e anti-getulistas, oligarcas e trabalhistas, ex-interventores, socialistas, comunistas e ex-integralistas, uma pluralidade de interesses e de tendências políticas, programáticas e ideológicas de difícil reunião.

$\mathrm{Na}$ verdade, nas eleições para a Assembléia Nacional Constituinte mudava-se a estrutura partidária. Substituíam-se, assim, as eleições tipicamente estaduais da Primeira República. Por outro lado, o caráter de política de elite, com uma baixíssima participação eleitoral (o número de votantes somente atingiu mais de cinco por cento da população em 1930 e somente superou a marca de dez por cento em 1945).

Deve-se ressaltar que PSD (54,7\%) e UDN (26,6\%) perfaziam 81,3\% da composição da Assembléia Constituinte, de modo que, em boa medida, o trabalho constituinte está jungido à visão de mundo, interesses e estratégias de poder das duas agremiações. Destarte, a articulação dentro da Assembléia Constituinte entre os dois partidos transcende os argumentos o mais das vezes utilizados em relação à aglutinação de núcleos oposicionistas que desembocariam na futura União Democrática Nacional (UDN) ou na continuidade das elites políticas ligadas às interventorias estadonovistas e a cúpula dos aparelhos de Estado, que originariam o futuro Partido Social Democrático (PSD). ${ }^{254}$

\footnotetext{
${ }^{252}$ HIPPOLITO, Lúcia, op. cit., 1985, p.27 e 256. Acerca do sistema partidário iniciado em 1945, ver, entre outros, SOUZA, Maria do Carmo Campello de. Estado e partidos políticos no Brasil. São Paulo: AlfaÔmega, 1976; CARVALHO, Orlando. Ensaios de sociologia eleitoral. Belo Horizonte: RBEP, 1958; FRANCO, Afonso Arinos de Melo. História e teoria dos partidos políticos no direito constitucional brasileiro. 2. ed. São Paulo: Alfa-Ômega, 1974; LIMA JR., Olavo Brasil. Os partidos políticos brasileiros - a experiência federal e regional. Rio de Janeiro: Edições Graal, 1983; MORAES, Filomeno. O processo partidário-eleitoral no Brasil: a literatura revisitada. Revista Brasileira de Estudos Políticos, Belo Horizonte, n.86, p.49-84, 1998.

${ }^{253}$ Ibid., 1998, p.34.

${ }^{254}$ MICELI, Sergio. Carne e osso da elite política brasileira pós-1930. In: FAUSTO, Boris (Org.). História geral da civilização brasileira: sociedade e política (1930-1964). 2. ed. Rio de Janeiro: Difel, 1983. 3.v., p.557-596.
} 
A despeito de diversas características em comum, mormente no que se refere à origem social, formação escolar e trajetória ocupacional, Sergio Miceli observa que as diferenças entre os dois grupos originam-se:

[...] de um lado, dos laços que seus integrantes mantêm com setores distintos da elite econômica, bem com da posição relativa que ocupam na hierarquia das profissões liberais e culturais, e, de outro, do grau de proximidade quer em relação aos grupos dirigentes estaduais quer em relação ao poder central ou às 'extensões' em que se desdobrou sua presença no plano estadual. ${ }^{255}$

A propósito, diz ainda Sergio Micelli:

Em 1945, 72\% dos parlamentares federais eleitos no Sudeste eram pessedistas ou udenistas, cifra que se eleva a $89 \%$ em relação aos Estados mais 'atrasados', quer dizer, o desempenho eleitoral desses dois partidos foi sensivelmente melhor nas áreas rurais do que em contexto urbano, e por conseguinte, nos Estados com índices mais baixos de alfabetização e de renda per capita. [...]. ${ }^{256}$

Enfim, levando em consideração a composição social, pode-se resumir o seguinte das duas bancadas: a UDN mantinha equilíbrio entre os representantes dos setores agrários e os bacharéis ilustres dos principais centros urbanos; o PSD recrutou a maioria dos seus parlamentares nos círculos de maior prestígio das profissões liberais e intelectuais, junto às elites de grandes proprietários rurais em alguns Estados nordestinos e nos remanescentes do pessoal político a serviço de antigos clãs oligárquicos já atuantes durante a Primeira República; o PSD valeu-se das alianças que o regime de Vargas celebrou com a liderança patronal do empresariado industrial, do pessoal político constituído ao abrigo das interventorias e de alguns elementos egressos das corporações burocráticas mais dependentes do poder central (militares, p. ex.), buscando ao mesmo tempo preencher seus quadros com figuras de prestígio e experiência em nível local (prefeitos de capitais estaduais e cidades de tamanho médio) e incorporar elementos egressos dos mesmos setores dirigentes que ajudaram a plasmar a UDN. Ademais,

Embora ambos os partidos contassem com figuras de relevo das lideranças agrárias de diversos Estados, o mesmo não ocorreu em relação aos demais setores da elite econômica. O PSD logrou a colaboração quase integral da liderança industrial emergente ao passo que a UDN contou sobretudo com o respaldo de importantes grupos financeiros sediados no Rio de Janeiro, em Minas Gerais e na Bahia. ${ }^{257}$

Em suma,

\footnotetext{
${ }^{255}$ Ibid., 1983, p.562.

${ }^{256}$ Ibid., 1983, p.562.

${ }^{257}$ Ibid., 1983, p.562-563.
} 
A composição política da Constituinte de 1946, entretanto, oferecia um traço inteiramente distinto de quantas assembléias desse gênero se reuniram entre nós, inclusive, mesmo, a Constituinte Imperial. É que as bancadas não mais se situavam por Estados ou partidos regionais, mas por partidos de âmbito nacional, o que, sem dúvida alguma, demonstrava um certo progresso e evolução no sentimento democrático do povo, fruto, naturalmente, da campanha cívica e política travada meses antes pela redemocratização nacional. ${ }^{258}$

Cumpria-se, de algum modo, a necessidade já destacada por Pontes de Miranda, o qual, comentando a Constituição de 1934, dizia que "a formação de partidos nacionais é o caminho único que pode tomar o Brasil constitucional. Sem eles, a vida constitucional, democrática, do Brasil não poderá manter-se". ${ }^{259}$

\title{
2.6.4 O Poder Executivo
}

A Assembléia Constituinte se desenvolveu sob a presidência do marechal Eurico Gaspar Dutra, empossado em 31 de janeiro de 1946. Eleito pela aliança PSD-PTB, com maioria absoluta e com apoio da estrutura do Estado Novo, fora ministro da Guerra de 1936 a 1945, cargo que deixou para candidatar-se a presidente da República. ${ }^{260}$

De todo modo, o presidente Eurico Gaspar Dutra, na Mensagem apresentada ao Congresso Nacional, em 15 de março de 1947, ressaltava:

\begin{abstract}
A Constituição de setembro foi a primeira votada no Brasil sem a mais leve intervenção do Poder Executivo, isto é, sem a apresentação de projeto constitucional, sem a decretação prévia de regimento e sem a presença sequer de Ministros de Estado, no recinto das deliberações, com direito a voto, ou sem ele. Em função dele, não atuou o Governo nem direta, nem indiretamente. Trata-se, portanto, de um diploma emanado genuinamente da soberania popular e cujos dispositivos devem ser rigorosa e exemplarmente observados. ${ }^{261}$
\end{abstract}

${ }^{258}$ LEAL, Hamilton. História das instituições políticas do Brasil. Rio de Janeiro: Imprensa Nacional, 1962, p.577-578.

${ }^{259}$ MIRANDA, Pontes. Comentários à Constituição da República dos E. U. do Brasil. Rio de Janeiro: Guanabara, [s.d.]. v. II, p.303.

${ }^{260}$ Evidentemente, a emergência de uma presidência eletiva não era capaz de escoimar o governo federal da herança repressiva do Estado Novo, como se vê no seguinte episódio: "Na semana que antecedeu o Dia do Trabalho, (o governo) mandou fechar e dissolver, como entidade ilegal, o Movimento Unificado dos Trabalhadores, o MUT, com que o PCB tentava vencer o círculo de ferro dos sindicatos oficiais, havia anos nas mãos dos pelegos. [...] proibiu toda e qualquer manifestação a céu aberto dos sindicatos, permitindo-lhes apenas comemorações em recintos fechados. O chefe de Polícia, Pereira Lira, que algum tempo depois iria ocupar a chefia da Casa Civil de Dutra, publicou nota oficial tornando pública a decisão do governo e, para garantir o ato de força, convocou as Forças Armadas, que ocuparam os principais pontos do Rio de Janeiro [...]”. NOGUEIRA, Octaciano. A constituinte de 1946. Getúlio, o sujeito oculto. São Paulo: Martins Fontes, 2005, p.283-284.

${ }^{261}$ DUTRA, Eurico Gaspar apud SILVA, Hélio. 1945: porque depuseram Vargas. Rio de Janeiro: Civilização Brasileira, 1964, p.368. 
Deve-se ressaltar também que, diferentemente das conjunturas constituintes de 1890/1891, 1933/1934 e 1987/1988, o problema da eleição presidencial não se tornou ponto de conflito agudo. A Constituição de 1937 estabelecia que "o período presidencial será de seis anos" (art. 80). ${ }^{262}$ Como a Assembléia fixou, em 1946, a duração do mandato presidencial em cinco anos, partidários do presidente da República intentaram propor que figurasse, nas Disposições Transitórias, dispositivo estabelecendo que Dutra tivesse a duração de mandato de acordo com o texto vigente à época de sua eleição. Todavia, o "Presidente Eurico Dutra manifestou de imediato o seu desacordo anunciando que, aprovada ou não tal proposição, passaria o Governo a 31 de janeiro de 1951, como de fato passou, "sem mais um ou menos um dia", ao sucessor diplomado pela Justiça Eleitoral. ${ }^{263}$

\title{
2.6.5 A ordem econômica e social
}

Conforme diz Hamilton Leal,

\begin{abstract}
Em grande parte, quase que totalmente mesmo, inspirava-se e baseava-se nas Constituições de 1891 e 1934, aproximando-se a sistemática mais desta que daquela. Não obstante, é preciso salientar que a própria Carta Constitucional de 1937 serviu de fonte ao novo projeto, mormente na parte referente ao Poder Judiciário e à matéria econômico-social. No mais, restabelecia ele o cunho democrático das instituições, com eleições diretas e independência de poderes; com o Poder Legislativo composto de duas Câmaras - Câmara dos Deputados e Senado Federal; o Judiciário plenamente garantido e o Executivo controlado nos limites do regime presidencialista. Como a Constituição de 1934, instituía uma Justiça Eleitoral, devidamente aparelhada e protegida para o cumprimento da missão de dirigir e julgar a manifestação da vontade popular. Enfim, restabelecia as garantias individuais e os direitos sociais de quantos viviam e nasciam em terras do Brasil. ${ }^{264}$
\end{abstract}

Hermes Lima, deputado pela UDN-DF, então pertencente à Esquerda Democrática (ED) e depois um dos fundadores do Partido Socialista Brasileiro (PSB), em discurso pronunciado na Assembléia, em 12 de junho de 1946, deu o tom da problemática econômico-social. Verberando que "a primeira e geral censura que se tem feito ao projeto - a de ser demasiado longo, analítico e minucioso -, censura que podia ser também, com fundamento, irrogada à Constituição de 34 e à Carta outorgada de 37”, considera que “o legislador constituinte deve atentar para que não caia no abuso dos textos declaratórios que consignam princípios e direções sociais e políticas”. Assim, o projeto mereceria duas

\footnotetext{
${ }^{262}$ BRASIL. Constituição (1937). Constituição dos Estados Unidos do Brasil. Disponível em: <http://www.presidencia.gov.br/legislacao>. Acesso em: 10 jan. 2008.

${ }^{263}$ DUTRA, Eurico Gaspar apud SILVA, Hélio, op. cit., 1964, p.365.

${ }^{264}$ LEAL, Hamilton, op. cit., 1962, p.587-588.
} 
censuras, sendo a primeira a "que abusa desses textos, às vezes enunciando detalhes que são mais de natureza administrativa que política". Em segundo lugar,

A outra censura que tenho a fazer ao projeto é que, em matéria econômica e social, as suas declarações pecam antes pela timidez do que pela sua extensão e coragem.

Verificamos essa timidez no dispositivo do $\S 3^{\circ}$ do art. 164 que dá ao Estado a faculdade de monopolizar empresas ou atividades econômicas. Melhor fora que aí estivesse, lealmente, limpamente declarado, o princípio da nacionalização no seu verdadeiro sentido.

\section{$[\ldots]$}

[...] Em matéria de intervenção no domínio econômico do Estado, o que há verdadeiramente é que, na ordem atual, quando a intervenção é a favor dos negócios da classe dominante ou dos grupos dominantes dentro dessa classe, a intervenção é tida como boa. Não põe em perigo a 'ordem'. Quando, porém, a intervenção é favor da maior participação da massa nos benefícios da civilização, que hoje tem a capacidade de ampliar esses benefícios, porque se funda na técnica e na ciência; quando esta intervenção é a favor do povo é que se leva o grande clamor capitalista contra ela.

Ora, [...] no Brasil há um imperativo da intervenção do Estado no domínio econômico, ditado palas condições sociais do povo brasileiro. ${ }^{265}$

A seu tempo, Aliomar Baleeiro (UDN-BA), em discurso na mesma data do de Hermes Lima, observava que o projeto the "parecia conservador e, em alguns pontos, não muito, reacionário e até [...] clerical. E agora não me afasto desta impressão: o projeto é, realmente, conservador”. Considerava, todavia, que a justiça social poderia dar-se por meio da tributação.

[...] O aparelho fiscal pode ser meio idôneo e eficaz para realizar essa revolução branca, sem sangue nem ódios, essa revolução que terá de vir, pela força ou não, mas que virá por sua tendência histórica.

[...] É esta, afinal, a solução que eu apontaria aos constituintes brasileiros de 1946: inscrever expressamente na Constituição que o aparelho fiscal não é apenas um fornecedor de dinheiro para manutenção dos serviços públicos, mas órgão de direção de justiça social. Toda reforma financeira partiria desse postulado. [...]..$^{266}$

\footnotetext{
${ }^{265}$ Discurso de Hermes Lima apud NOGUEIRA, Octaciano, op. cit., 2005, p.383-388.

${ }^{266}$ Ibid., 2005.
} 


\subsubsection{A representação popular na Constituinte de 1946}

Os trabalhos da Assembléia Nacional Constituinte, com a realização da Constituição de 1946, não tiveram equivalentes na história republicana antecedente.267

Ademais, a Constituinte de 1946 reiniciou a vida parlamentar do país, interrompida durante os oito anos do Estado Novo. Como ressalta Octaciano Nogueira,

[...] O período de decisões da Assembléia é curto, entre 12 de agosto e 17 de setembro, quando é aprovada a redação final. Nos sete meses e meio de funcionamento, no Palácio Tiradentes, não se discutiu apenas uma proposta de Constituição. Isso, aliás, foi o que menos se discutiu. Ali se exercitou o aprendizado para a democracia, depois de oito anos de ditadura. Um duro e muitas vezes dramático aprendizado. [...]. ${ }^{268}$

De fato, este aprendizado carecia de grandes esforços, pois, segundo Otávio Mangabeira, "a nova democracia que procuramos estabelecer não é ainda uma árvore que dê abrigo e sombra; é uma planta ainda tenra que exige todo cuidado para medrar e

\footnotetext{
${ }^{267}$ Segundo Hermes Lima, "na Assembléia Constituinte de 1946, vencido o longo período de férias impostas à legalidade democrática pelo Estado Novo, reuniu-se, consagrada pelas urnas, a representatividade da classe política chamada a elaborar a nova Constituição. Assembléia ilustre, de bom nível cultural. A figuras tradicionais, de presença marcante na cena pública [...] - juntavam-se expressões de nova safra de políticos, diversos dos quais atravessaram sofrido aprendizado no correr dos anos da ditadura [...]”. LIMA, Hermes. Travessia: memórias. Rio de Janeiro: José Olympio, 1974, p.155. Um dos signatários da Constituição de 1988, Michel Temer acentua: "A melhor, creio eu, foi a de 1946. [...] foi a mais democrática e tecnicamente perfeita de todas as constituições brasileiras". TEMER, Michel. Entrevista. In: DINES, Alberto; FERNANDES JR., Florestan; SALOMÃ̃, Nelma (Org.). Histórias do poder: 100 anos de política no Brasil. São Paulo: Ed. 34, 2000. v.2, p.312. A mesma opinião é desposada por outro analista: "A própria Constituição de 1946 não tem equivalentes na história brasileira. Foi a mais liberal que tivemos e das mais efetivas historicamente, já que durou quase vinte anos e, na República brasileira, só a de 1891 teve vida mais longa". ALMINO, João. Era uma vez uma constituinte: lições de 1946 e questões de hoje. São Paulo: Brasiliense, 1985, p.8. Ainda sobre a Constituinte e a Constituição de 1946, ver, entre outros, ALMINO, João. Os democratas autoritários: liberdades individuais, de associação política e sindical na Constituição de 1946. São Paulo: Brasiliense, 1980; BALEEIRO, Aliomar. Alguns andaimes da Constituição. Rio de Janeiro: Livraria Principal, 1950; BRAGA, Sérgio Soares. Quem foi quem na Assembléia Constituinte de 1946: um perfil sócio-econômico e regional da Constituinte de 1946. Dissertação (Mestrado em Ciência Política). Departamento de Ciência Política, Campinas-SP, Universidade Estadual de Campinas, 1996. 2 v.; DUARTE, José. A Constituição de 1946. Exegese dos textos à luz dos trabalhos da Assembléia Constituinte. Rio de Janeiro, Imprensa Nacional, 1947. 3v.; DRAIBE, Sonia. Rumos e metamorfoses: Estado e industrialização no Brasil, 1930-1960. 2. ed. Rio de Janeiro: Paz e Terra, 2004; LEAL, Victor Nunes. Coronelismo, enxada e voto: o município e o regime representativo no Brasil. 2. ed. São Paulo: Alfa-Ômega, 1975; INSTITUTO DE DIREITO PÚBLICO E CIÊNCIA POLÍTICA. Estudos sobre a Constituição brasileira. Rio de Janeiro: FGV, 1954; MICELI, Sergio. Carne e osso da elite política brasileira pós-1930. In: FAUSTO, Boris (Org.). História geral da civilização brasileira: sociedade e política (1930-1964). 2. ed. Rio de Janeiro: Difel, 1983. 3.v., p.557596; NOGUEIRA, Octaciano, op. cit., 2005; SILVA, Hélio. 1945: porque depuseram Vargas. Rio de Janeiro: Civilização Brasileira, 1964. VIANNA, Luís Werneck. Liberalismo e sindicato no Brasil. Rio de Janeiro: Paz e Terra, 1976; LIMA SOBRINHO, Barbosa. O direito eleitoral e a constituição de 1946. In: BALEEIRO, Aliomar; LIMA SOBRINHO, B. A constituição de 1946. Brasília: CED, 1987, p.15-31.

${ }^{268}$ NOGUEIRA, Octaciano, op. cit., 2005, p.XVII.
} 
crescer". ${ }^{269}$ A cultura autoritária que permeou, por influência interna e externa, o processo político, o fracasso constitucional dos últimos quinze anos, com duas constituições semânticas, e as Forças Armadas (principalmente o Exército), acoroçoadas "à prática do facciosismo partidário", ${ }^{270}$ traziam muitas dificuldades para a construção de um novo texto constitucional democrático.

Evidentemente, pelos menos desde 1943, ${ }^{271}$ uma sucessão de fatos - entre os quais adquirem relevância a publicação do Manifesto dos Mineiros, a entrevista de José Américo de Almeida ao jornalista Carlos Lacerda, quebrando a censura aos meios de comunicação deu condições à convocação de uma assembléia nacional constituinte e à realização de um novo texto constitucional que exorcismasse o legado do constitucionalismo antiliberal de inspiração, entre outros, de Francisco Campos, o Carl Schmitt brasileiro. Na verdade, a Assembléia Nacional Constituinte foi convocada depois da derrubada de Getúlio Vargas, em 29 de outubro de 1945. As Leis Constitucionais $n^{\circ} 13$, de 12 de novembro, ${ }^{272}$ e n $^{\circ} 15$, de 26 de novembro do mesmo ano, ${ }^{273}$ emitidas durante a presidência de José Linhares, estabeleciam que o Congresso a ser eleito em 2 de dezembro teria a função precípua de elaborar a nova Carta Constitucional, vigorando a Carta de 1937.

As eleições, inclusive as para a Assembléia Constituinte, realizadas em 2 de dezembro de 1945, marcam "a incorporação definitiva dos setores médios e baixos das classes médias no processo político e o advento da participação política das classes trabalhadoras", ${ }^{274}$ em outras palavras, ocasionando o fim da hegemonia da política oligárquica e a sua substituição por uma política poliárquica, com uma participação cada vez maior dos setores populares. Embora, acentua Sergio Miceli, "90\% dos trabalhadores permanecessem excluídos da arena política e sem contarem com porta-vozes próprios entre os representantes no legislativo". ${ }^{275}$ É que:

\footnotetext{
${ }^{269}$ Discurso de Otávio Mangabeira, líder da minoria, na Assembléia Constituinte em 3/4/1946 apud NOGUEIRA, Octaciano, op. cit., 2005, p.264.

${ }^{270}$ Discurso de Getúlio Vargas na Assembléia Constituinte, em 20/7/1934 apud GOMES, Angela Maria de Castro. Confronto e compromisso no processo de constitucionalização (1930-1935), op. cit., 1983, p.36.

${ }^{271}$ Ver, entre outros, ALMINO, João. Os democratas autoritários: liberdades individuais, de associação política e sindical na Constituição de 1946. São Paulo: Brasiliense, 1980.

${ }^{272}$ BRASIL. Constituição (1937). Lei Constitucional n. 13, de 12 de novembro de 1945. Disponível em: <http://www.senado.gov.br/legislacao〉. Acesso em: 10 jan. 2008.

${ }^{273}$ BRASIL. Constituição (1937). Lei Constitucional n. 15, de 262 de novembro de 1945. Disponível em: 〈http://www.senado.gov.br/legislacao〉. Acesso em: 10 jan. 2008.

${ }^{274}$ SOARES, Gláucio Ary Dillon. Sociedade e política no Brasil. Rio de Janeiro: Difel, 1973, p.59.

${ }^{275}$ MICELI, Sergio. Carne e osso da elite política brasileira pós-1930. In: FAUSTO, Boris (Org.), op. cit., 1983, p.563.
} 
[...] Não obstante, 1945 não marcou a participação eleitoral da maioria dos membros das classes trabalhadores: ainda que, pela primeira vez, um a dois milhões de membros das classes trabalhadoras tenham votado; as classes trabalhadoras - inclusive os trabalhadores agrícolas - totalizavam, segundo uma estimativa, aproximadamente dezoito milhões e meio de adultos. Ou seja, a grande maioria (noventa por cento) da classe trabalhadora não participou do processo eleitoral em $1945 .^{276}$

\subsubsection{O funcionamento da Assembléia}

A Assembléia funcionou, com as sessões preparatórias incluídas, de $1^{\circ}$ de fevereiro a 18 de setembro de 1946, data em que foi promulgado o novo texto constitucional, ${ }^{277}$ estruturando-se por meio da Comissão de Polícia (ou Mesa da Assembléia Constituinte), da Comissão de Constituição (subdividida nas seguintes subcomissões: Organização Federal, Discriminação de Rendas, Poder Legislativo, Poder Executivo, Poder Judiciário, Declaração de Direitos, Ordem Econômica e Social, Família, Educação e Cultura, Segurança Nacional e Disposições Gerais e Transitórias), e de Comissões Ordinárias (Comissão de Investigação Econômica e Social, Comissão de Estudo das Indicações, Comissão Parlamentar da Casa Popular, Comissão de Estudo da Situação dos Trabalhadores da Light, Comissão Encarregada de Examinar os Serviços do Departamento Federal de Segurança Pública, Comissão de Inquérito de Casos de Interesse Nacional, Comissão de Inquérito da Campanha da Borracha e Comissão de Amparo e Defesa da Pecuária).

Depois de realizado o Regimento Interno, os líderes partidários designaram os 37 membros da Comissão de Constituição, ou a "Grande Comissão", incumbida de elaborar o projeto de constituição, tendo como presidente Nereu Ramos e vice-presidente, Prado Kelly, os líderes da maioria e da minoria, respectivamente. A Comissão subdividiu-se em subcomissões, com o relator de cada uma destas redigindo uma seção respectiva, após o recebimento de emendas. Tal seção era oferecida à Comissão, cujos membros apresentavam novas emendas, discutidas e votadas.

Depois, cada uma das seções foram juntas no projeto da Comissão de Constituição, o qual foi levado ao Plenário. Neste, o projeto recebeu milhares de emendas, refundindo-se o

\footnotetext{
${ }^{276}$ SOARES, Gláucio Ary Dillon, op. cit., 1973, p.59.

${ }^{277}$ A distribuição partidária dos constituintes - agregados deputados e senadores - era a seguinte: PSD (54,7\%); UDN (26,6\%); PTB (6,8\%); PCB (4,7\%); PR/PSP/PDC/PL/ED (7,2\%). BRAGA, Sérgio Soares, op. cit., 1996. v.1, p.87-92.
} 
projeto com as emendas aprovadas. O texto, então, foi a Plenário, logrando-se a promulgação do texto constitucional em 18 de setembro de 1946.

A Constituição de 1946 tentou restaurar as linhas gerais da Constituição de 1891, adicionando-lhe os direitos sociais que tiveram guarida pela primeira vez na história constitucional brasileira na Lei Fundamental de 1934. E, consagrando os grandes princípios, não cuidou de constitucionalizar - como o fez a Constituição de 1988 - aspectos muitos mais pertinentes à legislação complementar ou ordinária. Como diz Aliomar Baleeiro,

E, realmente, essa tendência restauradora das linhas de 1891 com as inovações aproveitáveis de 1934 (disposições de proteção aos trabalhadores, à ordem econômica, à educação, à família etc.) foi característica do texto que veio a ser promulgado [...] no dia 18 de setembro de $1946 .{ }^{278}$

Evidentemente, as oligarquias cuidaram de dotar a Constituição de salvaguardas severas para conter maiores avanços das reivindicações populares - como a que inviabilizava qualquer tentativa séria de encaminhar a solução para o crucial problema agrário -, ou para evitar a modernização do sistema político, como a que dotava o sistema eleitoral de mecanismos pesados de sobrepresentação na Câmara dos Deputados do eleitorado dos Estados mais subdesenvolvidos. Não faltou quem destacasse o caráter conservador e reacionário da Assembléia Constituinte, e, inclusive, a influência dos representantes das classes dominantes em comum acordo com o imperialismo norteamericano. ${ }^{279}$ Também foi acentuado o "imaginário conservador", do qual se originou "nova ordem excludente", apesar da oposição do PCB e de setores da UDN. ${ }^{280}$ Particularmente, como anotou Sônia Draibe,

Período de formação de uma nova constitucionalidade, este é, sem dúvida, um momento privilegiado para compreender duas questões que remetem diretamente ao problema do controle social e político sobre as decisões de um Executivo que ganhara preeminência e de cuja ação dependeria, em boa medida, a sorte de todos os setores sociais: a questão do planejamento econômico e a questão das relações entre o Poder Executivo e o Poder Legislativo. ${ }^{281}$

\footnotetext{
${ }^{278}$ BALEEIRO, Aliomar. A constituinte e a constituição federal de 1946. In: ; LIMA SOBRINHO, Barbosa. A constituição de 1946. Brasília: CED, 1987, p.1-2.

${ }^{279}$ PEREIRA, Osny Duarte. Que é a constituição (crítica à Carta de 1946 com vistas às reformas de base). Rio de Janeiro: Civilização Brasileira, 1964.

${ }^{280}$ ALMINO, João. Os democratas autoritários: liberdades individuais, de associação política e sindical na Constituição de 1946. São Paulo: Brasiliense, 1980.

${ }^{281}$ DRAIBE, Sônia. Rumos e metamorfoses: Estado e industrialização no Brasil, 1930-1960. Rio de Janeiro: Paz e Terra, 2004, p.246.
} 


\section{O PODER CONSTITUINTE}

[...] A Constituição é um estatuto destinado ao governo e à felicidade de um povo em determinado momento histórico.

João Mangabeira

\subsection{Introdução}

O presente capítulo recupera e discute a problemática do poder constituinte, tendo em conta o debate levado a cabo no período imediatamente anterior ao funcionamento, nos anos 1987/1988, do Congresso Constituinte. Sobretudo, observar-se-ão pontos que mais de perto toquem a perspectiva de construção de um cabedal conceitual e doutrinário autóctone e da tentativa de superação da contradição entre constituição formal e constituição material, tendo em vista, máxime e sempre que possível, a "constituição econômica".

\subsection{A teoria brasileira do poder constituinte}

O "tema nebuloso" do poder constituinte, conforme salienta Gilberto Bercovici, ${ }^{2}$ “[...] é tratado pela doutrina brasileira a partir da transposição da visão européia, notadamente a experiência francesa" e, de modo geral, recebe "tratamento acrítico, formalista e repetitivo", dificultando, por conseguinte, a compreensão das relações complexas entre Estado, constituição, soberania, democracia e política. Ainda de acordo com Gilberto Bercovici, a reflexão original sobre a matéria é, de modo geral, errática,

${ }^{1}$ HORTA, Raul Machado. Direito constitucional. 2. ed. Belo Horizonte: Del Rey, 1999, p. 25.

2 BERCOVICI, Gilberto. O poder constituinte do povo no Brasil: um roteiro de pesquisa sobre a crise constituinte. In: COUTINHO, Jacinto Nelson de Miranda; LIMA, Martonio Mont'Alverne Barreto (Org.). Diálogos constitucionais: direito, neoliberalismo e desenvolvimento em países periféricos. Rio de Janeiro: Renovar, 2006, p.215-224. Assim, "o poder constituinte [...] é tratado pela doutrina brasileira a partir da transposição da visão européia, notadamente a experiência francesa. A monografia de Manoel Gonçalves Ferreira Filho é inteiramente baseada em parte da exposição de Sieyès. Raul Machado Horta recupera, entre outros, Carré de Malberg e Georges Burdeau. Paulo Bonavides, por sua vez, embora tenha uma reflexão original [...] destaca o poder constituinte a partir do pensamento de Sieyès, Carré de Malberg, Eduard Laboulaye e do alemão Egon Zweig, que, no início do século XX, fez uma clássica análise da Assembléia Constituinte Revolucionária francesa. Outros autores buscaram, recentemente, uma explicação teológica de poder constituinte, comparando-o ao poder divino da criação". Ibid., 2006, p.215-216. 
encontrando-se genuinidade no que concerne ao tema, fundamentalmente, em Nelson Saldanha $^{3}$ e Paulo Bonavides. ${ }^{4} \mathrm{O}$ primeiro, pela abordagem que faz sobre o poder constituinte em um país no qual a soberania popular nunca teria se manifestado plenamente, ${ }^{5}$ o outro, ao relevar que a crise constitucional nacional repousa na inadequação do sistema político e da ordem jurídica ao atendimento das necessidades básicas da sociedade. ${ }^{6}$

${ }^{3}$ Ver, principalmente, SALDANHA, Nelson. Formação da teoria constitucional. Rio de Janeiro: Forense, 1983; e SALDANHA, Nelson. O poder constituinte. São Paulo: RT, 1986.

${ }^{4}$ BONAVIDES, Paulo. Curso de direito constitucional. 18. ed. São Paulo: Malheiros, 2006 (principalmente o "Capítulo 4 - O poder constituinte", o "Capítulo 5 - A teoria formal e a teoria material da constituição" e o "Capítulo 11 - O Estado brasileiro e a Constituição de 1988"); e BONAVIDES, Paulo. Constituinte e constituição: a democracia, o federalismo, a crise contemporânea. 2. ed. Fortaleza: Ioce, 1987. À moda de Paulo Arantes (ARANTES, Paulo. Departamento francês de ultramar: estudos sobre a formação da cultura filosófica uspiana. São Paulo: Paz e Terra, 1994), talvez se possa falar também da teoria francesa de ultramar do poder constituinte. Por conseguinte, mutatis mutandi, esquece-se da advertência, segundo a qual "a França é o país onde, mais do que em qualquer outro lugar, as lutas de classe foram sempre levadas à decisão final, e onde, por conseguinte, formas políticas mutáveis nas quais se processam estas lutas e nas quais seus resultados tomam os contornos mais nítidos". ENGELS, Friedrich. Prefácio à terceira edição alemã. In: MARX, Karl. O 18 Brumário e cartas a Kugelmann. 3. ed. São Paulo: Paz e Terra, 1977, p. 12.

${ }^{5}$ Destaca-se em Nelson Saldanha a ênfase no "ponto de vista histórico", que veio a adotar. Diz o autor: “[...] Parece-nos, visto de hoje, que nosso trabalho de 1957 poderia ter recebido uma orientação algo diversa, onde o assunto tivesse um tratamento mais histórico. Com efeito, foi após 1958, com nossa tese sobre As formas de governo e o ponto de vista histórico (reeditada pela RBEP em 1960), quando tentamos superar a perspectiva puramente 'sistemática' na análise das formas de governo, que começamos a usar a perspectiva histórica no tratamento dos temas jurídico-filosóficos, político-sociais, sócio-culturais em geral. Não entendemos por 'ponto de vista histórico' o elementar registro de datas e de eventos - primária concepção 'acontecimental' -, nem adotamos os pretensiosos esquemas cientificistas e dogmáticos dos que procuram encaixar a realidade histórica em estruturas previamente armadas. Por outro lado, ao impor o prisma histórico à experiência política e jurídica, não se deve reduzir o jurídico e o político às "condições" histórico-sociais que os cercam. Trata-se mais de uma junção da perspectiva histórica com a interpretação cultural, com algo sempre de hegelianismo, talvez, e de axiologia também, certo relativismo entretanto'. SALDANHA, Nelson, op. cit., 1986, p.15.

${ }^{6}$ Naturalmente, a "visão francesa" do poder constituinte tem como expoente Emmanuel Joseph de Sieyès, que produziu um documento que enfatiza a ascensão da burguesia, com o discurso constituinte expressando a idéia da soberania nacional. Tendo em conta a crise de legitimidade do absolutismo monárquico e no interior da moldura ideológica jusnaturalista, o terceiro estado - que seria "tudo", tinha sido até então "nada" e pretendia ser "alguma coisa" - significava a própria nação. Ver SIEYÈS, Emmanuel. Qu'est-ce que le tiers état? Genève: Librairie Droz, 1970. Na verdade, no Qu'est-ce que le tiers état?, Sieyès praticamente estabeleceu os termos do choque que se seguiu entre os estamentos privilegiados e a burguesia. Sobre o "pai fundador" da teoria do poder constituinte, diz Steven Englund: “[...] Por algum tempo, em 1789, Sieyès causou o impacto e exerceu o tipo de influência com que a maioria dos filósofos políticos pode apenas sonhar. O ensaio o lançou numa carreira política na Assembléia Nacional [...]. Mas sua carreira, como tantas outras, foi abreviada pela marcha turbulenta da própria Revolução. Um moderado de escol, conseguiu sobreviver ao Terror ('j'ai vécu', sintetizou em frase famosa) tornando-se uma 'toupeira', nas palavras de Robespierre. [...]". ENGLUND, Steven. Napoleão: uma biografia política. Rio de Janeiro: Jorge Zahar Editor, 2005, p.144. Já no século XX, em diálogo com a postulação de Sieyès e acentuando o paradoxo de recusar-se a qualidade de "jurídico" a um poder mediante o qual se cria e se impõe o direito, Georges Burdeau apontou os três caracteres seguintes como essenciais ao poder constituinte: inicial, porque nenhum outro pode existir acima dele; autônomo, porque somente a seu titular cabe decidir qual a idéia de Direito que se fará presente; e incondicionado, por não se subordinar a qualquer regra. Ver BURDEAU, Georges. Traité de science politique. Paris: LGDJ, 1950. t. III (especialmente o "Chapitre III - Le pouvoir constituent"). 
Assim como falta no Brasil uma teoria do Estado consistente e sustentável, não se tem, de igual modo, uma teoria da constituição adequada $^{7}$ nem uma teoria do poder constituinte. ${ }^{8}$ Não somente no Brasil como no constitucionalismo latino-americano, de modo geral, tal lacuna acarreta a compreensão do constitucionalismo nacional e continental como um "desvio" do europeu e do norte-americano. Esquece-se que foi na América Latina, no início do século XIX, que se desenvolveram, pela primeira vez, os governos constitucionais em vários Estados. Até então, existiam apenas as experiências angloamericana e francesa, além das espanhola e portuguesa, e não existia ainda modelo teórico constitucionalista definido, pelo que inúmeras questões continuavam em aberto, tais como soberania popular ou nacional, separação de poderes, representação, eleições. ${ }^{9}$

Boa parte do debate recente em torno do poder constituinte no Brasil deu-se por textos ditos "de ocasião", elaborados durante o processo de redemocratização e reconstitucionalização do país na década de $1980 .{ }^{10}$ Ademais, de modo geral, "uma grande lacuna é a falta de estudos sobre o processo constituinte brasileiro", pois os há, inclusive, "aqueles que, por afirmaram estar tratando de direito constitucional positivo, sequer mencionam o tema do poder constituinte, salvo para mencionar o poder de reforma constitucional e seus limites". ${ }^{11}$

${ }^{7}$ BERCOVICI, Gilberto, op. cit., 2006. Nelson Saldanha adverte que o constitucionalismo na América Latina coincide com o romantismo e o conservadorismo, não com o iluminismo, o que, entre outros fatores, teria gerado um "constitucionalismo sem povo". SALDANHA, Nelson, op. cit., 1983.

${ }^{8}$ Como salientou Hermann Heller, quando da apresentação da sua Teoria do Estado, os reducionismos naturalistas ou idealistas, econômicos ou jurídicos, que a dominavam (e que a dominam) devem ser ultrapassados. Assim, "la realidad social concreta partiendo de la cual debe ser comprendido el Estado real de la actualidad" não está em função da "trivial objeción de que el conjunto de la sociedad civil, como de toda realidad, sólo puede ser captada por el pensamiento dividiéndola en contenidos parciales". Pelo contrario, "desconoce la importancia metódica que tiene, justamente en nuestros tiempos, una acentuación de la realidad social como totalidad". HELLER, Hermann, op. cit., 1992, p.137-138. Respeitadas as coisas que mudam, não é ocioso, também, lembrar Max Weber, quando, na conferência "A política como vocação", "do ponto de vista de um sociólogo", pergunta e responde: "O que é um Estado? Sociologicamente, o Estado não se deixa definir por seus fins. [...] Sociologicamente, o Estado não se deixa definir a não ser pelo específico meio que lhe peculiar [...]”. WEBER, Max. Ciência e política: duas vocações. 16. ed. São Paulo: Cultrix, 2000, p.55-56.

${ }^{9}$ RIVERA, José Antonio Aguilar. En pos de la quimera. Reflexiones sobre el experimento constitucional atlántico. México-DF: CIDE; Fondo de Cultura Económica, 2000. Ver também SAGUIR, Julio ¿Unión o secesión?: los procesos constituyentes en Estados Unidos (1776-1787) y Argentina (1810-1862). Buenos Aires: Prometeo Libros, 2007. Especificamente, sobre a duração das constituições latino-americanas, ver NEGRETTO, Gabriel L. The durability of constitutions in changing environments: explaining constitutional replacements in Latin America. Working Paper (Kellog Institute), n.350, IndianopolisIndiana, 2008.

${ }^{10}$ BERCOVICI, Gilberto, op. cit., 2006.

11 Ibid., 2006, p.215-216. As exceções seriam Nelson Saldanha e Paulo Bonavides, para quem crise constitucional é, na verdade, crise constituinte derivada da inadequação do sistema político e da ordem jurídica ao atendimento das necessidades básicas da ordem social, com o problema constitucional fundandose na contradição entre constituição formal e constituição material. Para uma visão ampla da problemática do 
A questão da teoria do poder constituinte, mutatis mutandi, guarda semelhança com o que observava Oliveira Vianna, para quem, se "o problema da democracia tem sido malposto, é porque tem sido posto à maneira inglesa, à maneira francesa, à maneira americana, mas, nunca, à maneira brasileira". ${ }^{12}$

Cumpre observar que, a partir da erosão do autoritarismo-burocrático ${ }^{13}$ e da conseqüente transição, vieram à luz diversas contribuições doutrinárias relativas ao tema do poder constituinte. Além de Nelson Saldanha e Paulo Bonavides, trataram da problemática, principalmente, Afonso Arinos de Melo Franco, ${ }^{14}$ Raymundo Faoro, ${ }^{15}$ Fábio Konder Comparato, ${ }^{16}$ Dalmo de Abreu Dallari, ${ }^{17}$ Tercio Sampaio Ferraz Jr. ${ }^{18}$ e Manoel Gonçalves Ferreira Filho. ${ }^{19}$ A reflexão de tais autores, refletindo extrações teórico-políticas

poder constituinte na literatura jurídico-constitucional, ver, entre outros, Capítulo II - poder constituinte, em TAVARES, André Ramos. Curso de direito constitucional. São Paulo: Saraiva, 2002.

${ }^{12}$ VIANNA, Oliveira. O idealismo na constituição. Rio de Janeiro: Terra do Sol, 1927, p.13.

${ }^{13}$ No Ato Institucional (depois AI-1), editado em 9 de abril de 1964, assim se declarou o entendimento de "poder constituinte" dos realizadores do golpe de 64: "A revolução vitoriosa se investe no exercício do Poder Constituinte. Este se manifesta pela eleição popular ou pela revolução. Esta é a forma mais expressiva e mais radical do Poder Constituinte. Assim, a revolução vitoriosa, como Poder Constituinte, se legitima por si mesma. [...] Nela se contém a força normativa, inerente ao Poder Constituinte. Ela edita normas jurídicas sem que nisto seja limitada pela normatividade anterior à sua vitória. [...] Os Chefes da revolução vitoriosa, graças à ação das Forças Armadas e ao apoio inequívoco da Nação, representam o Povo e em seu nome exercem o Poder Constituinte, de que o Povo é o único titular". BRASIL. Ato Institucional n. 1, de 9 de abril de 1964. Disponível em: 〈http://www.senado.gov.br/legislacao〉. Acesso em: 10 abr. 2008.

Segundo a historiografia, tal concepção assustou, inclusive, o embaixador norte-americano, com conhecida participação nas tratativas do golpe de Estado: "O Embaixador Gordon ficara muito chocado com o Ato Institucional, particularmente com prólogo, que proclama o direito de uma revolução estabelecer suas próprias regras. O primeiro impulso do embaixador foi recolher-se a Washington, como um gesto de desaprovação, mas desistiu desse intento ante a perspectiva de que fosse eleito presidente o legalista Castello, que utilizaria seus poderes arbitrários com moderação e dentro de poucos meses levaria a nação de volta à legitimidade”. DULLES, John W. Foster. Castello Branco, o presidente reformador. Brasília: UnB, 1983, p.17.

${ }^{14}$ FRANCO, Afonso Arinos de Melo. A constituinte instituída. Revista de Ciência Política, Rio de Janeiro, v.1, n.1, p.3-17, 1982.

15 FAORO, Raymundo. A república inacabada. São Paulo: Globo, 2007, p.257; e FAORO, Raymundo. Constituinte: a verdade e o sofisma. In: SADER, Emir (Org.), op. cit., 1985.

16 COMPARATO, Fábio Konder. Um quadro institucional para o desenvolvimento democrático. In: JAGUARIBE, Hélio et al. Brasil, sociedade democrática. Rio de Janeiro: José Olympio, 1985, p.393432; e COMPARATO, Fábio Konder. Muda Brasil! Uma constituição para o desenvolvimento democrático. 4. ed. São Paulo: Brasiliense, 1987.

${ }^{17}$ DALLARI, Dalmo de Abreu. Constituição e constituinte. 2. ed. São Paulo: Saraiva, 1984.

18 FERRAZ JR., Tercio Sampaio. Constituinte: assembléia, processo, poder. São Paulo: RT, 1985; e FERRAZ JR., Tercio Sampaio. Uma constituinte "lenta, gradual e segura". In: FORTES, Luiz Roberto Salinas, op. cit., 1987, p.241-251.

19 FERREIRA FILHO, Manoel Gonçalves. A democracia possível. 3. ed. São Paulo: Saraiva, 1976; FERREIRA FILHO, Manoel Gonçalves. Nova perspectiva do processo constitucional. Revista Brasileira de Estudos Políticos, Belo Horizonte, n.60/61, p.135-136, 1985; FERREIRA FILHO, Manoel Gonçalves. O anteprojeto dos notáveis. São Paulo: Saraiva,1987; FERREIRA FILHO, Manoel Gonçalves. O poder constituinte. 5. ed. São Paulo: Saraiva, 2007. 
e ideológico-políticas diversas e a partir de textos conjunturais, todavia, acabaram por pontuar, algumas das vezes, questões importantes e inovadoras. ${ }^{20}$

\subsection{Subsídios para uma teoria brasileira do poder constituinte}

Algumas questões inovadoras vieram à tona durante o debate constituinte mais recente, que precedeu a instalação da Assembléia de 1987/1988, como se vê em seguida, com uma amostragem que conjuga subsídios de juristas e de sociólogos.

\subsubsection{Afonso Arinos de Melo Franco e a "constituinte instituída"}

Afonso de Arinos de Melo Franco, analisando as dimensões jurídica e política do poder constituinte, em conferência no Senado Federal, em agosto de 1981, afirmava que "a situação do Brasil se resolverá, [...] e só se resolverá, por meio de uma Assembléia Constituinte Instituída". Tal assembléia, a ser promovida pelo Legislativo, traria "uma solução jurídica, quanto à sua essência, mas política, quanto à sua forma". O aspecto jurídico consistia no fato de o Congresso colocar em um texto "a idéia de direito que a nação desejar", enquanto o caráter político residia no fato de não abalar o "estado de direito existente”. Seria esta a única maneira pacífica para pôr fim à grave crise brasileira, "que é, ante e acima de tudo, uma crise de direito". E propunha, afinal, "a outorga de poderes constituintes ao futuro Congresso Nacional, a ser eleito em 15 de novembro de

${ }^{20}$ Entre outros, Raymundo Faoro chamou a atenção para aspectos importantes da problemática do poder constituinte. Também é interessante a observação que faz acerca da contradição brasileira entre a realidade e a norma: "Edifica-se nas nuvens, sem contar com a razão dos fatos, para que da lei ou do plano saia o homem tal como no laboratório de Fausto, o qual, apesar de seu artificialismo, atende à modernização e ao desenvolvimento do país. A vida social será antecipada pelas reformas legislativas, esteticamente sedutoras, assim como a atividade econômica será criada a partir do esquema, do papel para a realidade. Caminho, este, antagônico ao pragmatismo político, ao florescimento espontâneo da árvore. [...]. FAORO, Raymundo. Os donos do poder: formação do patronato político brasileiro. 10 ed. São Paulo: Globo; Publifolha, 2000. 2v., p.376. A conseqüência é que "entre a tese e a realidade há um abismo: a reforma, ao se institucionalizar, não é, na verdade, a reforma que se propôs: em regra, é uma reforma contra a reforma". FAORO, Raymundo. Constituinte: a verdade e o sofisma. In: SADER, Emir (Org.). Constituinte e democracia no Brasil de hoje. São Paulo: Brasiliense, 1985, p.7. Mais recentemente, também Wanderley Guilherme dos Santos já observou o excesso de "regulação, leis, comandos e diretrizes e planos "no país, violando duplamente a "optimalidade jurídica": "em primeiro lugar, produzindo-se legislação sem demonstrar que o comportamento espontâneo dos indivíduos, submetidos a regras não escritas, é insuficiente ou incerto como gerador de ordem social - de onde se segue o 'confinamento' regulatório da cidadania. Em segundo lugar, mesmo quando a legislação previne algum malefício virtual, ela com freqüência o faz gerando externalidades que comprometem aspectos positivos da situação ex-ante, de tal modo que o resultado final é, no agregado, pior do que a situação original, pré-regulação. Viola-se, finalmente, outro princípio, o da credibilidade da lei, que é o que permite o planejamento individual de cada vida privada e de cada investimento social - seja qual for - de médio e longo prazos". SANTOS, Wanderley Guilherme. Fronteiras do Estado mínimo: indicações sobre o híbrido institucional brasileiro. In: VELloso, João Paulo dos Reis (Coord.). O Brasil e as reformas políticas. Rio de Janeiro: José Olympio, 1992, p.53-54. 
1982", pois a concessão desses poderes constituintes é "a melhor solução, e mesmo a única, em termos jurídicos, para o restabelecimento indispensável da ordem constitucional". ${ }^{21}$

Observando aspectos da forma de concessão dos poderes constituintes a serem exercidos pelo Congresso Nacional, Afonso Arinos de Melo Franco acentuava que poderiam ser instituídos "por um poder anterior existente", o que estaria de acordo com a tradição brasileira. O ponto peculiar, desta vez, seria que o poder constituinte originário caberia ao Legislativo, enquanto nas outras oportunidades coube ao Executivo. Contudo, o Executivo, poder originário instituinte, nunca atuou no desempenho de uma obrigação normativa. Pelo contrário, "sempre procedeu por extensão de suas atribuições inerentes, decidindo em caráter político, para atender a uma emergência política nacional”. Sendo assim, afirma que não existiriam obstáculos para que o Legislativo agisse da mesma maneira. Para tanto, seria elaborado um projeto de resolução legislativa, a ser aprovado pelas duas casas do Congresso Nacional. ${ }^{22}$

$\mathrm{Na}$ discussão se vislumbravam algumas alternativas para a reforma constitucional. ${ }^{23}$ Em primeiro lugar, através de projeto de decreto legislativo, baseado no precedente de 1961, investir-se-iam os então senadores e deputados federais, extraordinária e excepcionalmente, nas funções constituintes, ainda na legislatura que se encerraria em 1983. Mas se apontavam obstáculos de natureza jurídica e ética, tendo em vista a

${ }^{21}$ FRANCO, Afonso Arinos de Melo, op. cit., 1982, p.10. A propósito, ver PILLOUER, Arnaud Le. Les pouvoirs non-constituants des assemblées constituantes: essai sur le pouvoir instituant. Paris: Dalloz, 2005.

${ }^{22}$ FRANCO, Afonso Arinos de Melo., op. cit.,1982, p.10.

${ }^{23}$ Em discurso pronunciado na Câmara dos Deputados, Valmor Giavarina (PMDB-PR), classificou as opiniões sobre a Assembléia Constituinte por meio das seguintes categorias: Posições favoráveis: a) elaboração de uma nova Constituição, através do Congresso Nacional ou de uma Assembléia Constituinte especialmente eleita; b) atribuições de poderes constituintes especiais ao Congresso Nacional; c) o Congresso Nacional a ser eleito teria poderes constituintes especiais; d) os senadores e os deputados federais funcionariam como membros de uma Assembléia Constituinte e do Congresso Nacional; e) o então Congresso Nacional seria imediatamente transformado em Assembléia Constituinte; f) convocação de uma Assembléia Constituinte: i.) sem data marcada; ii.) oportunamente; iii.) a ser eleita em 1982. Posições contrárias: a) desnecessária; b) o presidente Geisel tinha o compromisso de constitucionalizar o país; c) o Governo não aceitaria a convocação de uma Assembléia Constituinte; d) o Congresso Nacional (1979-1982) teria poderes constituintes; e) o então Congresso Nacional já teria poderes constituintes; f) inoportunidade; g) não teria justificativa; h) o problema seria econômico; i) haveria problemas mais importantes a resolver; $\mathrm{j}$ ) eram insatisfatórias as propostas apresentadas; 1) não se modificaria a estrutura vigente. Ver GIAVARINA, Valmor. Constituinte originária e instituída. Disponível em: <http://www.valmorgiavarina.adv.br>. Acesso em: 25 jan. 2003. 
existência de senadores eleitos indiretamente (os "biônicos"), por força da Emenda à Constituição $\mathrm{n}^{\circ} 8$, de 14 de abril de $1977 .{ }^{24}$

Em segundo lugar, por meio de proposta de emenda à Constituição, a ser iniciada em 1985 pelo presidente da República, tendo como precedente a Reforma de 1926 e a frustrada iniciativa do presidente João Batista Figueiredo. O objetivo de dar nova feição jurídica ao Estado brasileiro ocasionaria a mudança da quase totalidade dos dispositivos do texto constitucional então vigente, entretanto, permaneceriam os óbices apontados no que concerne à opção anterior.

Por último, a convocação de uma Assembléia Nacional Constituinte, por meio de proposta de ampla emenda à Constituição, de iniciativa dos congressistas, no uso da competência prevista na Constituição de 1969. Assim, durante a primeira sessão da legislatura a iniciar-se em 1987, o Congresso Nacional realizaria sessões especiais para uma reforma constitucional em profundidade. Tal caminho não encontrava óbices intransponíveis de natureza constitucional, ética, jurídica, legal ou regimental. ${ }^{25}$

\subsubsection{As eleições e a assembléia constituinte como elementos identificadores do poder constituinte}

Conforme Tercio Sampaio Ferraz, "quando os juristas falam em poder constituinte, eles têm uma noção tornada clássica na literatura que é a noção do poder originário”, a qual "é definida, em qualquer manual de Direito Constitucional, em primeiro lugar, como um poder do qual se duvida que ele seja jurídico". Por isso, “os juristas têm um certo pudor em tratar do poder constituinte originário, porque, para muitos, trata-se de uma noção préjurídica". ${ }^{26}$ Assim o é, em primeiro lugar, por ser um poder inicial, portanto iniciador da ordem jurídica e nesse sentido não é precedido de nenhuma organização jurídica; em segundo, porque é um poder autônomo, logo não é delegado de forma nenhuma; e, em terceiro, porque se trata de poder incondicionado.

${ }^{24}$ Redação do art. 41 da Constituição de 1969 dada pela EC n. 8/1977: “Art. 41. [...]. § 1 Cada Estado elegerá três senadores com mandato de oito anos, renovando-se a representação, de quatro em quatro, alternadamente por um e por dois terços. $\S 2^{\circ} \mathrm{Na}$ renovação do terço e, para o preenchimento de uma das vagas, na renovação por dois terços, a eleição far-se-á pelo voto direto e secreto, segundo o princípio majoritário. O preenchimento da outra vaga na renovação por dois terços, far-se-á mediante eleição, pelo sufrágio do colégio eleitoral constituído, nos termos do $\S 2^{\circ}$ do artigo 13 , para a eleição do Governador de Estado, conforme disposto em lei. [...]". BRASIL. Constituição (1967). Emenda Constitucional n. 8, de 14 de abril de 1977. Disponível em: 〈http://www.senado.gov.br/legislacao〉. Acesso em: 10 jan. 2008.

${ }^{25}$ Ver FRANCO, Afonso Arinos de Melo, op. cit., 1982.

${ }^{26}$ FERRAZ, Tercio Sampaio. Uma constituinte "lenta, gradual e segura". In: FORTES, Luiz Roberto Salinas; NASCIMENTO, Milton Meira do (Org.), op. cit., 1987, p.241-242. 
Todavia, conclui, "a primeira observação que podemos fazer a respeito disso é que esta noção, tal como ela é elaborada pelos juristas, é obviamente uma abstração. O poder constituinte não existe. É impossível de ser trazido a alguma forma de realidade". ${ }^{27} \mathrm{Na}$ verdade,

\begin{abstract}
O poder constituinte originário, nem que quiséssemos, não pode ser um poder de fato. Alguma coisa de juridicidade ele sempre tem. Este fato puro é abstração. Ele não é autônomo porque sempre age por alguma forma de delegação. É impossível esta autonomia tal como se imagina. Ele não é inicial e muito menos é incondicionado. Na verdade, o que a gente observa, na formação desse tal poder constituinte originário, são múltiplas tendências e forças se organizando e a noção de soberania que ele procura trabalhar e elaborar também padece dos mesmos caracteres. ${ }^{28}$
\end{abstract}

Assim, "se a noção de poder constituinte originário é uma abstração e é um conceito na verdade operacional, sua função é muito mais operacional”, haverá, no entanto, alguns elementos a identificar o poder constituinte, como as eleições e a própria assembléia. ${ }^{29}$ Por fim, Tercio Sampaio Ferraz vislumbra "uma imensa perversão" no processo constituinte decorrente da "abertura lenta e gradual, e segura":

\begin{abstract}
E, finalmente, esse processo constituinte brasileiro, que estamos vendo agora, às vezes me parece novo, às vezes, uma imensa perversão, e fico meio desenxabido de ver isso. Toda vez que olho o processo constituinte, lembro de uma frase dos nossos presidentes generais, principalmente Geisel, enfim, de toda teoria da revolução de 64, da abertura lenta, gradual. E vendo esse processo constituinte, a gente acaba tendo que reconhecer que eles conseguiram. Estamos numa abertura lenta e gradual, e segura. ${ }^{30}$
\end{abstract}

De todo modo, não deixa de ser relevante a ênfase nos elementos que identificam o poder constituinte, como as eleições para a assembléia e a própria assembléia.

\title{
3.3.3 A disciplina jurídica do poder econômico
}

Para Dalmo de Abreu Dallari, “o grande desafio que se põe para o constituinte de hoje é conseguir disciplinar o poder econômico, para que ele não impeça a construção de uma ordem social em que todos os seres humanos sejam livres e iguais”. Assim,

esse objetivo da Constituição - o controle do poder econômico - já foi percebido e considerado importante na segunda década do século vinte, mas depois disso

\footnotetext{
${ }^{27}$ Ibid., 1987, p.242.

${ }^{28}$ Ibid., 1987, p.243.

${ }^{29}$ Ibid., 1987, p.243. Ver também RIBEIRO, Paulo de Tarso Ramos. Constituinte e decisão jurídica: os paradoxos da legitimação institucional. Dissertação (Mestrado em Direito). São Paulo, Faculdade de Direito da Universidade de São Paulo, 1989.

${ }^{30}$ Ibid., 1987, p.250-251.
} 
cresceu cada vez mais a interferência do poder econômico no exercício do poder político, sem que tenha sido encontrada uma fórmula constitucional eficaz. ${ }^{31}$

Estabelecendo um escorço histórico das constituições, chega ao resultado, segundo o qual, na conjuntura brasileira da época, a "vontade de constituição" era fundamentalmente cuidar da "disciplina jurídica do poder econômico". Pois "o grande desafio do século dezoito, no momento em que foram criadas as Constituições, era a disciplina do poder político" e, "nas perspectivas daquele momento histórico a expressão 'poder político' designava os governantes, que decidiam sobre assuntos de interesse público, separados dos governados, que só tinham poder de decisão sobre as questões de ordem particular de cada um". Assim,

os defensores do direito natural, os liberais, os racionalistas, apoiados pela burguesia rica, demonstraram a existência de valores fundamentais da pessoa humana, entre os quais a liberdade, argumentando com a igualdade essencial de todos os seres humanos para condenar a reserva do poder político a uma classe privilegiada. Com isso foi eliminada a distância que separava o poder político do resto da sociedade, abrindo, formalmente, a possibilidade de acesso ao poder a todos os indivíduos.

Ocorreu, entretanto, que apenas do ponto de vista formal foi estabelecida a igualdade de todos, pois na realidade a imposição de limites aos monarcas absolutos e a grande redução dos privilégios da nobreza só deram possibilidade de participação no poder político àqueles que detinham o poder econômico. É por esse motivo que Lassalle, o grande pensador político do século dezenove, falava sobre a necessidade de incluir os banqueiros entre os "fatores reais do poder" e Galbraith, recentemente, escreveu que os banqueiros constituem a nobreza do capitalismo. ${ }^{32}$

As considerações de Dalmo de Abreu Dallari apontam, pois, no mínimo implicitamente, para a necessidade de uma "constituição econômica" capaz de proporcionar a existência e efetividade dos direitos fundamentais em sentido amplo.

\subsubsection{O poder constituinte do povo}

Sem excepcionar mesmo o processo constituinte de 1987/1988, para Paulo Bonavides, a crise constituinte brasileira

[...] é indicativa da inferioridade ou da insuficiência de soberania das diversas Constituintes, cujas limitações tácitas ou expressas nos conduzem inarredavelmente a irretorquível conclusão de que, em verdade, jamais tivemos uma Assembléia Nacional Constituinte, dotada de liberdade, exclusividade e plenitude de poderes, pelos menos daqueles com que a teoria revolucionária do século XVIII sempre armara esses parlamentos, a fim de que, providos da

\footnotetext{
${ }^{31}$ DALLARI, Dalmo de Abreu. Constituição e constituinte. 2. ed. São Paulo: Saraiva, 1984, p.83.

${ }^{32}$ Ibid., 1984, p.81-82.
} 
suprema vontade da Nação, pudessem refazer as instituições desde os seus fundamentos. ${ }^{33}$

Logo, pelo menos na conjuntura constituinte dos anos 80 no Brasil, a recuperação da legitimidade constituinte na inteireza, "dotada de liberdade, exclusividade e plenitude de poderes", estaria no figurino, segundo o qual

O exercício eficaz do poder constituinte para elaborar uma constituição aberta e pluralista começa com o povo como força de opinião, passa pelo grande canal da Assembléia Constituinte e, finalmente, completando o ciclo de legitimação fundamental, termina com o referendum constituinte do povo soberano. ${ }^{34}$

\subsubsection{O poder constituinte como manifestação da elite política}

Manoel Gonçalves Ferreira Filho, para quem "o titular do Poder Constituinte não é nem a nação nem o povo", "ou só o é na medida em que se imputa à nação ou ao povo um poder que é efetivamente detido e exercido por uma elite", acentua que é a "classe política" 35 "quem rege os destinos do grupo social. Ela é quem vivifica o Poder Constituinte, gerando a Constituinte. E nova Constituição advém quando esta elite muda, ou de cosmovisão, ou de composição". ${ }^{36}$ Ao povo, "no máximo se pode atribuir uma

${ }^{33}$ BONAVIDES, Paulo. Curso de direito constitucional. 18. ed. São Paulo: Malheiros, 2006, p.387.

${ }^{34}$ Id. Constituinte e constituição: a democracia, o federalismo, a crise contemporânea. 2. ed. Fortaleza: Ioce, 1987, p.34. Evidentemente, uma "transição constitucional" chama a atenção para a questão do "procedimento". Conforme acentua J. J. Gomes Canotilho, "a legitimação através do procedimento é uma parte importante para se constatar a "bondade' da constituição". Assim, há dois modelos de relação entre as dimensões materiais e procedimentais do poder constituinte, a saber, o modelo procedimental e o modelo substantivo ou material. Se para o primeiro é bastante o procedimento constituinte estar correto para que o conteúdo também esteja, no segundo o procedimento funciona tão-somente como um meio para se conseguir um conteúdo constitucional justo, logo "o procedimento constituinte justo é uma dimensão estruturante da própria legitimidade da constituição porque, iniciando a 'cadeia de legitimação democrática', dá fundamento a formas de legitimação derivada - legitimação funcional democrática, legitimação democrática organizatória pessoal, legitimação democrática material (exercício do poder de acordo com o conteúdo determinado pelo povo). Assegurando o consenso, as regras de discussão, o diálogo, a publicidade, a crítica e a refutação, a legitimação democrática do procedimento constituinte encerra em si potencialidades de assegurar uma constituição justa”. CANOTILHO, J. J. Gomes. Direito constitucional. 5. ed. Coimbra: Almedina, 1992, p.124.

${ }^{35}$ A propósito, ver MOSCA, Gaetano. La clase política. México-DF: Fondo de Cultura Económica, 1992. Ainda sobre as elites: "Naturalmente, a presença de elites no poder não elimina a diferença entre regimes democráticos e regimes autocráticos. Sabia disso inclusive Mosca, um conservador que se declarava liberal mas não democrático e que imaginou uma complexa tipologia de formas de governo com o objetivo de mostrar que, apesar de não eliminarem jamais as oligarquias no poder, as diversas formas de governo se distinguem com base na sua diversa formação e organização. Mas desde que partir de uma definição predominantemente procedimental de democracia, não se pode esquecer que um dos impulsionadores desta interpretação, Joseph Schumpeter, acertou em cheio quando sustentou que a característica de um governo democrático não é a ausência de elites mas a presenças de muitas elites em concorrência entre si para a conquista do voto popular [...]." BOBBIO, Norberto. O futuro da democracia. 9. ed. Rio de Janeiro: Paz e Terra, 2004, p.39.

${ }^{36}$ FERREIRA FILHO, Manoel Gonçalves. Nova perspectiva do processo constitucional. Revista Brasileira de Estudos Políticos, Belo Horizonte, n.60/61, p.135-136,1985. 
titularidade 'passiva', reconhecendo-se à elite constituinte a titularidade 'ativa': a sua função de agente do Poder Constituinte." ${ }^{37}$ À titularidade "passiva" do povo

\begin{abstract}
resta um papel no processo constituinte: o de dar eficácia (no sentido Kelseniano de cumprimento global das normas) à obra da elite. Eficácia, aliás, que pode ser induzida pela legitimação e que é facilitada pela freqüente indiferença popular em relação ao fenômeno político. Mormente onde preponderam ou a cultura paroquial, ou a cultura de sujeição. ${ }^{38}$
\end{abstract}

Para ele, no entanto, a fonte da proposta de uma nova constituição no Brasil não era "rigorosamente falando, uma nova elite, embora o seu discurso político procure fazer crer nisto". Efetivamente,

abriu-se campo importante para a antiga oposição, inclusive a mais radical, todavia não se pode ocultar que grande parte dos atuais detentores do poder, dele partilharam durante todo o período posterior a 1964. Contudo, o oposicionismo faz parte da elite política e governante, e a preponderância civil não marca simplesmente o advento de uma nova elite. ${ }^{39}$

Diz também Manoel Gonçalves Ferreira Filho no que concerne ao que denomina "oposicionismo":

\begin{abstract}
Mas o seu inconveniente é claro. Ela visa a uma constituição-programa mas Constituição não é programa e sim instrumento de organização, e sobretudo limitação do Poder. O triunfo das idéias que difunde, resultarão ou na decepção popular imediata como o resultado da Constituinte (se esta cuidar de estabelecer uma verdadeira Constituição e não um programa ideal de renovação econômica e social), ou na decepção mediata, (já que, se o papel tolera tudo, a realidade é menos tolerante), e sempre no enfraquecimento da Lei Fundamental no seu aspecto próprio (o de institucionalizar e limitar o Poder). ${ }^{40}$
\end{abstract}

Em suma, na visão desse constitucionalista, a manifestação do poder constituinte é certamente a mesma expressada pelo art. 16 da Declaração dos Direitos do Homem e do Cidadão, de 26 de agosto de $1789 .{ }^{41}$

\title{
3.3.6 Considerações a partir de Sieyès
}

\footnotetext{
${ }^{37}$ Ibid., 1985, p.137.

38 Ibid., 1985, p.137.

${ }^{39}$ Ibid., 1985, p.141.

${ }^{40}$ Ibid., 1985, p.142. Ver, também, FERREIRA FILHO, Manoel Gonçalves. A democracia possível. 3. ed. São Paulo: Saraiva, 1976 (principalmente o cap. II); e FERREIRA FILHO, Manoel Gonçalves. O poder constituinte. 5. ed. São Paulo: Saraiva, 2007.

41 “Art. 16. Toute Société dans laquelle la garantie des Droits n'est pas assurée, ni la séparation des Pouvoirs déterminée, n'a point de Constitution". FRANCE. Déclaration (1789). Déclaration des droits de l'homme y du citoyen. Disponível em: 〈http://www.assemblee-nationale.fr/histoire/dudh/1789.asp>. Acesso em: 8 abr. 2008.
} 
A seu tempo, Eros Roberto Grau vislumbrava no tema da Constituinte um "estímulo ao pensamento crítico" e um "desafio à invenção". Destarte,

Uma das trilhas a caminhar, atendendo ao apelo da revisão da noção de Poder Constituinte do povo - vale dizer, do mito da soberania popular como fonte do Poder Constituinte - abre-se a partir da leitura da obra de Sieyès, Qu'est ce le Tiers État?

Há, seguramente, outras trilhas a seguir. Detenhamo-nos, por ora, em algumas indagações ensejadas pela exposição do "oráculo do Terceiro Estado". ${ }^{2}$

Eros Roberto Grau está intrigado, sobretudo, com a possibilidade de, no Brasil, os constituintes pertencerem aos partidos políticos existentes. A propósito, ressalta:

Não resisto, no entanto, à tentação de, neste passo, introduzir duas questões:

$1^{\text {a }}$. É logicamente justificável que os constituinte sejam eleitos por partidos políticos? Se os tivéssemos como representantes da nação, e não deste ou daquele segmento partidário, não teríamos, então apurável em efetivo grau de pureza a expressão da vontade da nação?

$2^{\mathrm{a}}$. Até que ponto os que responderem negativamente à questão anterior não estarão raciocinando em nome do chamado "interesse de corpo", palco das alianças que levam à fecundação dos inimigos públicos mais temíveis ? $^{43}$

Da reflexão de Eros Roberto Grau, que desposa uma concepção de soberania nacional, extraem-se, por via de conseqüência, duas interrogações cruciais: 1. a representação por indivíduos não-filiados aos corpos intermediários partidários daria uma legitimidade diferente a tais representantes? 2. Por acaso, estariam tais representantes alheios às determinações várias a que os indivíduos, numa situação histórica como a brasileira, estavam?

\subsubsection{O poder constituinte como "antiimaginário elitista"}

Ao mesmo tempo analista e ator da realidade que se desenvolveu naquela quadra, Florestan Fernandes, um dos constituintes, se perguntava:

O que é a Assembléia Nacional Constituinte? O imaginário das elites das classes dominantes ou de seus escribas? Ou uma formação política parida da crise cataclísmica de uma sociedade civil que se tornou inviável para quase cem milhões de excluídos e de oprimidos, ou de trabalhadores que a ela são

${ }^{42}$ GRAU, Eros Roberto. A constituinte e a constituição que teremos. São Paulo: RT, 1985, p.10.

${ }^{43}$ Ibid., 1985, p.18. Observe-se que, com a Emenda à Constituição ${ }^{\circ}$ 25, de 15 de maio de 1985, adquiriu-se ter ampla possibilidade de reorganização partidária, com a abertura da perspectiva de um sistema multipartidário, inclusive, com os partidos comunistas proibidos desde 1947. 
incorporados morfologicamente, mas privados, pelos dinamismos de repressão e de opressão, de peso e voz em sua ordenação e funcionamento? ${ }^{44}$

Respondia Florestan Fernandes, acentuando que, se "os partidos da ordem e os políticos profissionais trabalharam a consciência social desses excluídos", difundindo "a ideologia dos estratos dominantes das classes burguesas" e, assim,

ampliam e aprofundam sua coisificação, iniciada nas fábricas, prolongada nas escolas e nas igrejas, completada nos sindicatos e nos partidos comprometidos com o melhorismo, o obreirismo pacífico, a alienação refinada e aguçada graças ao consumismo de massa e à indústria da comunicação cultural. ${ }^{45}$

A realidade teria feito diferente. Pois, como constata, "a ANC converteu-se em um foco de luz, de esperança - uma promessa que não cabia no imaginário das elites das classes dominantes e no realismo de seus políticos profissionais". Na verdade, ter-se-ia forjado

[...] um antiimaginário contra-elitista, que atravessa a realidade brasileira como um punhal afiado, fundado em suas representações, que não refletem uma imagem invertida de suas condições de vida. Queriam vários tipos de reforma social simultaneamente e, por quererem esses tipos de reforma social, tentaram decifrar a seu modo a ANC e suas tarefas imediatas. É uma ilusão de mandarins supor que a falta de educação ou a ignorância inibiram tal gente e a jogariam no colo dos ricos, no modelo de Constituição que os mandachuvas desejavam e iriam elaborar. ${ }^{46}$

Pode-se extrair que, no entendimento de Florestan Fernandes vocalizado nos anos 80, o poder constituinte tem aparência com a formulação posterior de Antonio Negri, para quem "o poder constituinte não vem depois da política, como atormentada pausa sociológica, como suspensão da realidade institucional, nem pode ser reduzido a uma blitz extemporânea da vontade coletiva, cujos efeitos da constituição da política o trabalho teórico deve limitar". ${ }^{47}$ Para o sociólogo brasileiro, faz-se necessário estabelecer em que consiste "a luta popular pela Constituição da perspectiva dos proletários e o dos oprimidos":

\begin{abstract}
Nesse plano é que se esclarece o que representa a luta popular pela Constituição da perspectiva dos proletários e dos oprimidos. Não se trata de transferir para dentro as 'melhores constituições do mundo'; nem de impor ao Brasil o ônus de possuir a Constituição mais adiantada e completa de nossa era. Mas de estabelecer uma carta constitucional para um país prolongada e profundamente
\end{abstract}

\footnotetext{
${ }^{44}$ FERNANDES, Florestan. A percepção popular da Assembléia Nacional Constituinte. Estudos Avançados, São Paulo, v.2, n.2, 1988, p.86-88.

${ }^{45}$ Ibid., 1988 , p. 86-88.

${ }^{46}$ Ibid., 1988, p. 86-88.

${ }^{47}$ NEGRI, Antonio. O poder constituinte: ensaio sobre as alternativas da modernidade. Rio de Janeiro: DP\&A, 2002, p.7.
} 
destituído de uma sociedade civil civilizada (primeiro, por causa da escravidão; em seguida, por causa das seqüelas da escravidão, da dominação externa, do subdesenvolvimento e do tradicionalismo mandonista e elitista). O impulso de associar a elaboração dos princípios dessa carta fundamental às condições concretas de existência e reprodução da família pobre, do trabalho operário, do movimento sindical, da violentação do trabalhador agrícola, do menor, do indígena, do negro e da mulher, às carências e frustrações que tornam a miséria um universal e a insegurança uma norma, aparece como o nódulo de uma revolução democrática irreversível e permanente. Se ele vingar, o futuro imediato será do presente e o passado perderá o fulcro político de sua repetição inocente. $^{48}$

Destarte, a Assembléia Nacional Constituinte consistiria, sobretudo, em tornar-se o mecanismo capaz de associar a elaboração dos princípios da nova constituição às condições concretas de existência e reprodução das classes subalternas, como parte de "uma revolução democrática irreversível e permanente".

\subsubsection{Transferência do político: da "elite" para o "povo"}

Fernando Henrique Cardoso acentuava:

Há tempo [...] o país entrou num processo constituinte. Antes da campanha das "Diretas, Já". [...] Parte deste contencioso [...] foi sendo dirimida antes da convocação formal da Assembléia Constituinte [...]. Exemplifico: a regulamentação da vida sindical não foi alterada na lei, mas na prática muita coisa mudou, tendo havido o reconhecimento tácito de duas centrais sindicais. Ou ainda: apesar da Lei de Imprensa [...] a liberdade de expressão foi sendo assegurada. $^{49}$

Para Fernando Henrique Cardoso, havia uma "transferência" do político, que saía da “elite" para o "povo".

Todos os grandes políticos deste País nunca emergiam diretamente do povo. Eles vieram das lideranças políticas para o povo [...]. Considero o movimento constituinte com a mesma força que foi a Anistia. Hoje, ele já dominou a intelectualidade, está alcançando a alta classe média e chegando aos líderes sindicais e operários mais politizados. Assim ela está chegando ao povo. [... $]^{50}$

Numa análise retrospectiva, ele define a Assembléia Constituinte como "Assembléia caótica" que

era a expressão do Brasil popular gerado, nas décadas anteriores, pelo e contra o regime autoritário. Pelo regime, porque havia o 'milagre econômico', com mais urbanização, mais migração interna, mais diferenciação de classes. Contra, porque as novas classes, desde o fim dos anos 70, começaram a mobilizar-se e

48 FERNANDES, Florestan. Que tipo de República? 2. ed. Rio de Janeiro: Globo, 2007, p.148.

${ }^{49}$ CARDOSO, Fernando Henrique. A Constituinte: desafio e alternativa. Opinião, São Paulo, p.2, 5 jan.1986.

50 CARDOSO, Fernando Henrique. Brasil: caminhos da transição. Folha de São Paulo (Folhetim), São Paulo, p.3, 29 mar. 1981. 
não encontravam mais posições no mercado e na sociedade, com o início da inflação mais forte e a perda do dinamismo econômico. ${ }^{51}$

Em suma, o Brasil mudara, nas suas variadas instâncias, a saber, a econômica, a social, a política e a cultural. Os trabalhos constituintes de 1987/1988 o demonstrariam.

\subsection{A retórica do retorno ao Estado Democrático de Direito}

Em boa medida, entendia-se o processo constituinte como, essencialmente, o retorno ao Estado Democrático de Direito, tornado precário com as investidas normativas autoritárias, que foram num crescendo desde a edição do AI-1, em 9 de abril de $1964,{ }^{52}$ até a outorga da Constituição de 17 de outubro de $1969 .{ }^{53}$

De fato, o estabelecimento militar-tecnocrático, além de quebrar a legitimidade da ordem jurídica e interromper a caminhada constitucional liberal-democrática reiniciada em 1946, proporcionara a justaposição entre uma "ordem constitucional" e uma "ordem institucional”: a primeira encimada pela Constituição de 1969 e a segunda, sobretudo, pela permanência o AI-5, ${ }^{4}$ que, embora deixasse de vigorar em $1^{\circ}$ de janeiro de 1979, tinha os seus efeitos mantidos e, inclusive, resguardados de qualquer apreciação judicial. ${ }^{55}$

${ }^{51}$ Id. A arte da política: a história que vivi. 3. ed. Rio de Janeiro: Civilização Brasileira, 2006, p.107. FHC ressalta, porém, que "a grande causa da minha geração não foi a da estabilização da economia. Tampouco a do desenvolvimento econômico. Foi a da democracia" e que "a História contemporânea da política brasileira começa nos anos 1970, com as lutas pela volta da democracia". E conclui que "o resultado desse borbulhar da sociedade acabaria sendo a convocação da Assembléia Nacional Constituinte, finalmente eleita em 1986". Ibid., 2006, p.14 -15.

52 BRASIL. Ato Institucional n. 1 , de 9 de abril de 1964 . Disponível em: <http://www.senado.gov.br/legislacao>. Acesso em: 10 jan. 2008.

${ }^{53}$ BRASIL. Constituição (1967). Emenda Constitucional n. 1, de 17 de outubro de 1969. Disponível em: <http://www.presidencia.gov.br/legislacao>. Acesso em: 10 jan. 2008.

54 “Art. 182. Continuam em vigor o Ato Institucional no 5, de 13 de dezembro de 1968, e os demais Atos posteriormente baixados. Parágrafo único. O Presidente da República, ouvido o Conselho de Segurança Nacional, poderá decretar a cessação da vigência de qualquer desses Atos ou dos seus dispositivos que forem considerados desnecessários". A EC n. 1, de 17 de outubro de 1969, dispunha também: “Art. 181. Ficam aprovados e excluídos de apreciação judicial os atos praticados pelo Comando Supremo da Revolução de 31 de março de 1964, assim como: I - os atos do Governo Federal, com base nos Atos Institucionais e nos Atos Complementares e seus efeitos, bem como todos os atos dos Ministros Militares e seus efeitos, quando no exercício temporário da Presidência da República, com base no Ato Institucional $\mathrm{n}^{\circ}$ 12, de 31 de agosto de 1696; II - as resoluções, fundadas em Atos Institucionais, das Assembléias Legislativas e Câmaras Municipais que hajam cassado mandatos eletivos ou declarado o impedimento de governadores, deputados, prefeitos e vereadores quando no exercício dos referidos cargos; e III - os atos de natureza legislativa expedidos com base nos Atos Institucionais e Complementares indicados no item I". Assim, a EC n. 1/1969, ao manter no seu art. 182 a vigência do Ato Institucional $n^{\circ}$ 5, de 13 de dezembro de 1968, e atos posteriores, anulava-se a si própria como carta outorgada. Em relação ao AI-5, ver BRASIL. Ato Institucional n. 5, de 13 de dezembro de 1968. Disponível em: <http://www.senado.gov.br/legislacao>. Acesso em 10 jan. 2008.

${ }^{55}$ A EC n. 11, de 13 de outubro de 1978, dispôs: "Art. $3^{\circ}$ São revogados os atos institucionais e complementares, no que contrariem a Constituição Federal, ressalvados os efeitos dos atos praticados com 
A situação verdadeiramente anárquica, do ponto de vista jurídico, foi observada por Paulo Brossard, que realçou a "desordem" advinda da coexistência da "ordem constitucional" e da "ordem institucional":

\begin{abstract}
Afinal aconteceu o que só por milagre deixaria de acontecer. O regime que pretenderam instituir em nosso País, reunindo, a um tempo e no mesmo documento, a suposta legalidade e o puro arbítrio, a convivência de duas ordens, uma pretensamente constitucional, a outra declaradamente extralegal, tinha de dar no que deu, pela singela razão de que elas são incompatíveis, excluem-se reciprocamente, motivo pelo qual, em verdade, as duas ordens nem são duas, nem são ordens: a desordem é uma só. $[\ldots]^{56}$
\end{abstract}

No mesmo diapasão, Vamireh Chacon verbera a ausência de "qualquer coerência jurídica" do furor normativo que se dá no período:

Desenvolvimento econômico e anticomunismo político, eis a ideologia por trás da sucessão convencional de Constituições (duas), atos institucionais (17) e atos complementares (73), além de milhares de decretos-leis, ditados geralmente pelos tecnoburocratas ao arrepio de qualquer coerência jurídica, num emaranhado pior que o assacado contra o Poder Legislativo tradicional para coibi-lo em nome da organização. Esgotara-se o melhor da geração dos discípulos de Alberto Torres e Oliveira Vianna, adeptos da hegemonia da organização sobre a participação, muito melhor orgânica nos tempos do Estado Novo. $[\ldots]^{57}$

Há, também, os que vislumbravam uma maior dimensão para problemática constituinte. Em texto trazido à estampa em 1985, Fábio Konder Comparato, por exemplo, propõe "gizar os objetivos de uma reforma constitucional", nos quais se observa a conjunção do caráter "jurídico-político" com um caráter mais "econômico-social”, como se vê da seguinte orientação:

base neles, os quais estão excluídos de apreciação judicial”. BRASIL. Constituição (1967). Emenda Constitucional n. 11, de 13 de outubro de 1978. Disponível em: <http://www.senado.gov.br/legislacao>. Acesso em: 15 jan. 2008.

56 Discurso "É tempo de mudar", pronunciado no Senado Federal, em 6/5/1987 apud VALS, Luiz Fernando Montenegro. Brossard: 80 anos na história política do Brasil. Porto Alegre: Artes e Ofícios, 2004, p. 277. No discurso de posse do presidente Emílio Garrastazu Médici, em 1969, já fora vocalizada a coexistência das duas ordens jurídicas, o "plano institucional" e o "plano constitucional": "[...] Vejo o plano institucional, destinado a preservar as conquistas da Revolução, vejo o plano constitucional, que estrutura o Estado e assegura o funcionamento orgânico dos poderes. Estou convencido de que é indispensável a coexistência dessas duas ordens jurídicas, expressamente reconhecida pela Constituição, fundada no imperativo da segurança nacional, e coerente enquanto for benéfica à defesa da democracia e à realidade do bem comum.” BRASIL. Discurso de posse na presidência da República (Emílio Garrastazu Médici). [S/l.]: Departamento de Imprensa Nacional, 1969, p.12.

${ }^{57}$ CHACON, Vamireh. Vida e morte das constituições brasileiras. Rio de Janeiro: Forense, 1987, p.209210. Logo após a edição do "Pacote de Abril", Ernesto Geisel, revertendo as expectativas criadas em torno da redemocratização, proclamou a sua idéia de "democracia relativa". Sobre a qual, dirá depois: "Até hoje, para mim, a democracia é relativa. Tem uma democracia teórica, dos homens do direito, que partem de Montesquieu e na sua imaginação idealizam a democracia. Mas essa democracia só é viável para o homem perfeito [...]". Para ele, “[...] um dos erros que o Brasil tem cometido, ao longo de sua história republicana, é viver nesse sonho de uma democracia no papel, mas que depois, na prática, não se cumpre". D’ARAÚJO, Maria Celina; CASTRO, Célio. Ernesto Geisel. 4. ed. Rio de Janeiro: FGV, 1977, p.392. 
1) Organizar as instituições políticas em função do grande objetivo nacional, que é o desenvolvimento democrático;

2) Compor a distribuição de funções políticas, de modo a combinar poderes ativos e poderes impedientes, não só entre os órgãos estatais, mas também entre Estado e sociedade civil;

3) Reorganizar a aplicação do princípio da separação de Poderes, visando a: a preservar as liberdades individuais; $b$ - assegurar meios de controle eficazes à realização de políticas ou programas de ação; c - evitar a parálise institucional, suscitando-se o impulsionamento dos centros de poder estatal e privado para a realização das liberdades sociais;

4) Integrar o aparelho estatal com o poder tecnológico e o estamento burocrático, em condições de autonomia responsável;

5) Garantir as liberdades políticas, delimitando a defesa de atuação das forças armadas. ${ }^{58}$

De fato, o grande objetivo buscado na conjuntura era a instauração, com a eleição de uma Assembléia Constituinte e a elaboração de uma nova Constituição, da democracia, embora à sombra das ambigüidades e da multiplicidade de sentidos da própria noção de democracia. Como se ponderou à época:

Dos juristas costumamos ouvir alusões à 'colcha de retalhos' a que
corresponderia o aparato legal em vigor, donde surge como objetivo o de
recompor de maneira coerente a legalidade democrática corrompida e
desfigurada por 21 anos de autoritarismo-burocrático. É bastante claro, porém,
que a mobilização em torno da Constituição a ser elaborada se articula com a
percepção, por parte de determinadas forças sócio-políticas, de que ela
representa a oportunidade para avanços rumo a um ideal de democracia
"substantiva" ou social nos quais se alteraria, de alguma forma, a própria
distribuição social de poder. Assim, criam-se, com respeito à Constituinte, não
apenas grandes expectativas, mas expectativas desencontradas.

Assim, como conceber a tarefa da Constituinte, se se parte da distinção entre duas noções de democracia, que definiam de maneira talvez satisfatória o âmbito da multiplicidade de sentidos? De fato, de um lado, tinha-se uma definição "minimalista" de democracia, na qual esta aparece como o conjunto de mecanismos destinados a proteger ou defender as liberdades ou os direitos civis e políticos básicos; do outro lado, uma definição "maximalista" na qual a democracia surge como o conjunto de instituições capazes de

${ }^{58}$ COMPARATO, Fábio Konder. Um quadro institucional para o desenvolvimento democrático. In: JAGUARIBE, Hélio et al., op. cit., 1985a, p.418.

${ }^{59}$ REIS, Fábio Wanderley. Constituição, pacto e poder ou de uma constituição a outra melhor, com engenho e sorte. Revista Brasileira de Ciências Sociais, São Paulo, n.1, 1986, [s.p.]. 
permitir a procura (ativa) do bem público ou comum, incluindo com destaque certo ideal igualitário envolvido nos chamados direitos sociais. ${ }^{60}$

Somente o processo político-constituinte pode dar resposta a tal interrogação.

\subsection{O poder constituinte no Brasil e o Congresso Constituinte}

O caráter de "transição por transação", que marcou a passagem do autoritarismoburocrático para a democracia, nos anos 70 e 80, não evitou a efervescência da sociedade brasileira. ${ }^{61} \mathrm{O}$ conjunto de lutas pela restauração da democracia desembocou na convocação do Congresso Constituinte. ${ }^{62}$ Tais lutas são, por conseguinte, as fontes históricas do novo constitucionalismo brasileiro. Na verdade, no "momento constituinte", ${ }^{63}$ já se demonstrava a existência de um "desejo de constituição" que extrapolava os limites das elites políticas e dos juristas, ganhando a preocupação de setores mais amplos da sociedade.

${ }^{60}$ Ibid., 1986, [s.p.].

${ }^{61}$ A literatura especializada ressalta que os processos de transição política na América Latina, em sua maioria, se consolidaram com mudanças constitucionais. Conforme observam Richard Bellamy e Dario Castiglione, as constituições "desempenham um papel vital na política". BELLAMY, Richard; CASTIGLIONE, Dario. Introduction: constitutions and politics. In: (Ed.). Constitutionalism in transformation: European and theoretical perspectives. Oxford: Blackwell Publishers, 1996, p.1. Por isso, aqui e alhures, de uma parte são instrumentos de governo que limitam, restringem e permitem o controle do exercício do poder político, no melhor sentido de prevenir, bem como evitar a recomposição do abuso do poder. Ver MONTESQUIEU. De l'esprit des lois. Paris: Éditions Gallimard, 1995; PAINE, Thomas. Rights of man. New York: Penguin Books, 1984. Uma constituição é fundamentalmente uma moldura de governo, ou, como disse Giovanni Sartori, "sem uma carta de direitos, uma constituição ainda é uma constituição; mas se ela não está centralizada numa moldura de governo, não é uma constituição". SARTORI, Giovanni. Engenharia constitucional: como mudam as constituições. Brasília: UnB, 1996, p.211. Evidentemente, o caráter de marco na transição do regime autoritário "[...] implicou um difícil contexto de elaboração que [...] deu-se diante de uma sociedade bastante mobilizada e disposta a trazer seus conflitos para o texto constitucional". MAUÉS, Antonio Gomes Moreira. Poder e democracia: o pluralismo na Constituição de 1988. Porto Alegre: Síntese, 1999, p.21.

${ }^{62}$ Quando um Estado surge, é restaurado ou sofre uma transformação radical da sua estrutura, dota-se de uma constituição. De uma constituição material e, em seguida, de uma constituição formal, ou de uma constituição material ou constituição formal concomitantemente. A revolução é a manifestação mais patente de poder constituinte, pois, segundo Jorge Miranda, "nada se afigura, na verdade, mais gerador de Direito do que uma revolução; nada há talvez de mais eminentemente jurídico do que o facto ou acto revolucionário". Assim, "a revolução não é o triunfo da violência; é o triunfo de um Direito diferente ou de um diverso fundamento de validade do sistema jurídico positivo do Estado. Não é antijurídica; é apenas anticonstitucional por oposição à anterior Constituição - não em face da Constituição in fieri que, com ela, vai irromper". A seu tempo, a outra fonte é a transição constitucional. Se na revolução há uma sucessão de constituições materiais e formais, na transição, faz-se presente um dualismo, pois, enquanto se prepara a nova constituição formal, subsiste a anterior. Pelo que, "nada impede que o mesmo órgão funcione simultaneamente (foi o caso do Brasil) como órgão de poder constituído à sombra da Constituição prestes a desaparecer e como órgão de poder constituinte com vista à Constituição que a vai substituir". MIRANDA Jorge. Teoria do Estado e da constituição. Rio de Janeiro: Forense, 2002, p.362 e 365.

${ }^{63}$ ACKERMAN, Bruce. Neo-federalism? In: ELSTER, Jon; SLAGSTAD, Rune, op. cit., 1983b. 
Efetivamente, por mais que o caráter da transição limite a manifestação do poder constituinte, este não se comporta mais como ao longo de outras manifestações da vida político-constitucional brasileira. Como diz Gilberto Bercovici:

[...] As constituições do século XX não representam mais a composição pacífica do que já existe, mas lidam com conteúdos políticos e com a legitimidade, em um processo contínuo de busca de seus conteúdos, de compromisso aberto de renovação democrática. [...] A constituição é vista como um projeto que se expande para todas as relações sociais. O conflito é incorporado aos textos constitucionais, que não representam mais apenas as concepções de classe dominante: pelo contrário, torna-se um espaço onde ocorre a disputa políticojurídica. A discussão sobre soberania e sobre poder constituinte retorna com força. ${ }^{64}$

No entanto, como ressalta Gilberto Bercovici, aqui,

o problema central, ignorado pela maior parte de nossos doutrinadores, é o fato de que a soberania brasileira, como soberania de um Estado periférico, é uma 'soberania bloqueada', ou seja, enfrenta severas restrições externas e internas que a impedem de se manifestar em toda sua plenitude. ${ }^{65}$

Logo, aqui, não há falar nos mesmos termos da teoria clássica do poder constituinte, a saber, poder autônomo, incondicionado, livre, juridicamente desvinculado, pois, o "poder constituinte do povo" funcionou mais como símbolo formal, referendando os conteúdos do poder constituinte das "forças reais de poder" ${ }^{67}$ e bloqueando a tentativa de fundar o "político" com base no poder constituinte do "social". ${ }^{68}$ Aqui, a "inferioridade" ou "insuficiência de soberania das diversas Constituintes" ${ }^{69}$ - a crise constituinte - dá-se fundamentalmente por conta dos "bloqueios à manifestação da soberania plena no Brasil".

${ }^{64}$ BERCOVICI, Gilberto. Soberania e constituição: para uma crítica do constitucionalismo. São Paulo: Quartier Latin, 2008, p.294-295. Tratando mais sobre a ação constituinte e a linguagem constitucional, especialmente perante o processo político, ou, simplesmente, a relação entre texto e realidade constitucional, Karl Loewenstein classifica as constituições em três tipos básicos: "normativas", "nominalistas" e "semânticas". As constituições "normativas" seriam aquelas que direcionam realmente o processo de poder, de tal maneira que as relações políticas e os agentes de poder ficam sujeitos às suas determinações de conteúdo e ao seu controle procedimental. As constituições "nominalistas", embora contendo disposições de limitação e controle da dominação política, não teriam ressonância no processo real de poder, inexistindo suficiente concretização constitucional. Já as constituições "semânticas" seriam simples reflexos da realidade do processo político, servindo, ao contrário das "normativas", como mero instrumento dos "donos do poder", não para sua limitação e controle. Ver LOEWENSTEIN, Karl. Teoría de la constitución. 2. ed. Barcelona: Editorial Ariel, 1976. Obviamente, trata-se "de conceitos típico-ideais no sentido de Weber, de tal maneira que na realidade social haveria vários graus de 'normatividade', 'nominalismo' e 'semantismo' constitucional, caracterizando-se a respectiva constituição pela predominância de um desses aspectos". NEVES, Marcelo. A constitucionalização simbólica. São Paulo: Acadêmica, 1994, p. 95.

${ }_{65}^{65}$ BERCOVICI, Gilberto, op. cit., 2006, p.220.

${ }^{66}$ Ver MÜLLER, Friedrich. Fragmento (sobre) o poder constituinte do povo. São Paulo: RT, 2004.

${ }^{67}$ Ver LASSALLE, Ferdinand. A essência da constituição. Rio de Janeiro: Líber Júris, 1995.

${ }^{68}$ Ver NEGRI, Antonio, op. cit., 2002.

${ }^{69}$ BONAVIDES, Paulo, op. cit., 2006. 
Destarte, não é temerário apontar a correspondência entre a idéia de poder constituinte e a interrupção da construção nacional pelo golpe de $1964 .^{70}$

\subsection{Poder constituinte do povo?}

Afinal de contas, pode-se afirmar que nunca houve uma manifestação na inteireza do poder constituinte do povo, ${ }^{71}$ ou que, pelo menos em 1987/1988, o processo constituinte tornou relativa a crise constituinte intrínseca ao processo político nacional? ${ }^{72}$ Parece razoável afirmar o processo constituinte de 1987/1988 rompeu com o paradigma recorrente ao longo do funcionamento das outras assembléias constituintes, senão para "refazer as instituições desde os seus fundamentos", ${ }^{73}$ pelo menos para proporcionar-lhes um salto de qualidade. Na verdade, a chave para o entendimento do processo constituinte formal de 1987/1988 começa pela participação popular, pela ativação da sociedade, na revolta silenciosa contra o caráter excludente, desmobilizador, do autoritarismo-burocrático. ${ }^{74}$

${ }^{70}$ BERCOVICI, Gilberto, op. cit., 2006. Sobre a construção nacional interrompida, ver, entre outros, FURTADO, Celso. A fantasia desfeita. Rio de Janeiro: Paz e Terra, 1989; e FURTADO, Celso. Brasil -A construção interrompida. 2. ed. Rio de Janeiro: Paz e Terra, 1992. Ver também CARDOSO, Fernando Henrique; FALETTO, Enzo. Dependência e desenvolvimento na América Latina. Rio de Janeiro: Zahar, 1970; HIRSCHMAN, Albert. A mudança para o autoritarismo na América Latina e a busca de suas determinantes econômicas. In: COLLIER, David (Org.). O novo autoritarismo na América Latina. Rio de Janeiro: Paz e Terra, 1982, p.65-100; SANTOS, Wanderley Guilherme dos. Cidadania e justiça. Rio de Janeiro: Campus, 1979.

${ }^{71}$ MÜLLER, Friedrich. Fragmento (sobre) o poder constituinte do povo. São Paulo: RT, 2004.

${ }^{72}$ A propósito, ver, principalmente, SALDANHA, Nelson. Formação da teoria constitucional. Rio de Janeiro: Forense, 1983; e SALDANHA, Nelson. O poder constituinte. São Paulo: RT, 1986; BONAVIDES, Paulo. Curso de direito constitucional. 18. ed. São Paulo: Malheiros, 2006; BERCOVICI, Gilberto. O poder constituinte do povo no Brasil: um roteiro de pesquisa sobre a crise constituinte. In: COUTINHO, Jacinto Nelson de Miranda.; LIMA, Martonio Mont'Alverne Barreto (Org.), op. cit., 2006; LIMA, Martonio Mont'Alverne Barreto; BERCOVICI, Gilberto. Entrevista com Friedrich Müller. Sequiência - Revista do Curso de Pós-Graduação em Direito da UFSC, Florianópolis, n.51, p.9-30, 2005.

${ }^{73}$ BONAVIDES, Paulo, op. cit., 2006, p.387.

${ }^{74}$ Embora caracterizada por práticas que não deixavam de ser elitistas, a integração populista enfatizava a inclusão seletiva de grupos sociais estratégicos e mobilizados. "O padrão de intervenção estatal, no entanto, era sensível às pressões dos setores da massa urbano-industrial que logravam organizar-se, de modo geral estabelecendo respostas preventivas à reivindicação crescente por direitos políticos e sociais e antecipando-se a demandas mais amplas e evitando a ampliação de direitos políticos. [...] A sobrevinda da ditadura militar, em 1964, acarretou repressão à ação coletiva dos estratos subalternos e intervenção nas suas organizações". O autoritarismo-burocrático, ao contrário do sistema populista, era eminentemente excludente. "A nova coalizão dominante inclui tecnocratas de alto nível, tanto militares quanto civis, e trabalha em estreita associação com o capital estrangeiro. A nova configuração de poder imprime restrições profundas aos mecanismos eleitorais e de organização dos trabalhadores. A política pública, por seu turno, passa a ter como escopo fundamental a promoção da industrialização avançada. Estatismo e privatização são as características básicas em que se funda a intervenção social do Estado autoritário. De um lado, crescimento generalizado da máquina burocrática do Estado na área social, com novas agências, maiores e mais complexas; processo decisório que passa a dar-se no interior da máquina estatal, sob o controle de grupos tecnocráticos; centralização, concentração e, até, personalização do poder. De outra parte, privatização da política social, que se dá com a adoção de critérios de mercado como parâmetro decisivo de comportamento; transferência da provisão de bens e serviços de natureza social para organizações 
Outro aspecto que deve ser mencionado é a confluência benfazeja de uma coalizão que, apesar das suas ambigüidades, ${ }^{75}$ desposava alguma ideologia democrática, com, senão uma "transformação de elites", pelo menos uma "convergência de elites". ${ }^{76}$ Menos Emmanuel Joseph Sieyès e Georges Burdeau, pois. No Brasil de 1987/1988, o poder constituinte pode ser entendido, em boa medida, como a tentativa de, novamente, organizar a fantasia ${ }^{77}$ isto é, buscar o término da construção nacional, por meio de um plano de transformações sociais e do Estado, fundada na visão de um projeto nacional de desenvolvimento ${ }^{78}$ e na perspectiva de que a crise constituinte brasileira se superaria com o cumprimento do projeto constitucional de $1988 .^{79}$

empresariais que operam no mercado econômico; reciclagem do dinheiro público destinado a programas sociais no sistema financeiro; particularização dos programas sociais, acarretando a sua captura por interesses particulares de grupos específicos, tornando-os privilégios corporativos ou ocupacionais, quando não diretamente instrumentos de acumulação de capital". MORAES, Filomeno. A construção democrática. Fortaleza: UFC/Casa de José de Alencar, 1998, p.173-174.

75 Uma "estranha diarquia" foi vislumbrada por Juan Linz na transição brasileira. Contrastando a mesma transição com a espanhola, casos em que o poder autoritário intentou uma autotransformação, concluiu que, na Espanha, todas as instituições se renovaram através de eleições democráticas. No Brasil, pelo contrário, o poder autoritário coexistiu com instituições representativas e eleições democráticas. Ver LINZ, Juan. Lições da Espanha para a democracia: o pacto do rei e as tramas brasileiras. Jornal do Brasil, Rio de Janeiro, Caderno B/Especial, p.1, 15 maio 1983. Bolívar Lamounier, por seu turno, acentuou: "Num panorama mais amplo, que ligasse estes acontecimentos (da transição do Autoritarismo) imediatos aos dados mais profundos da formação histórica brasileira, poder-se-ia talvez falar de uma poliarquia perversa, isto é, uma sociedade que não se deixa enquadrar numa dominação autoritária monolítica, mas que tampouco possui a tradição de organização política pluralista e independente do Estado, típica das verdadeiras poliarquias liberais". LAMOUNIER, Bolívar. "O Brasil Autoritário" revisitado: o impacto das eleições sobre a abertura. In: STEPAN, Alfred. Democratizando o Brasil. São Paulo: Paz e Terra, 1988, p.83-124. Sobre o papel das elites políticas, são importantes as palavras de Juan Linz, analisando o processo político espanhol, que saiu da ditadura franquista e consolidou a democracia em poucos anos: "Nenhum estrutura sociológica ou modelo político são adequados para explicar tal processo, sem referência a agentes políticos específicos tomando decisões do dia-a-dia, encarando crises inesperadas e perturbadoras, as quais poderiam ter arruinado o processo [...]. Em tal contexto, a questão da liderança é central." LINZ, Juan, op. cit., 1983, p.1. Ver, também, BRUNEAU, Thomas C. Brazil's political transition. In: HIGHLEY, John; GUNTHER, Richard (Ed.). Elites and democratic consolidation in Latin America and Southern Europe. Cambridge: Cambridge University Press, 1992, p.257-280.

${ }^{76}$ Ver, entre outros, BRUNEAU, Thomas C. Constitutions and democratic consolidation: Brazil in comparative perspective. Brazil's political transition. In: HIGHLEY, John; GUNTHER, Richard (Ed.) Elites and democratic consolidation in Latin America and Southern Europe. Cambridge: Cambridge University Press, 1992, p.257-280.

${ }_{77}^{7}$ A expressão inspira-se em FURTADO, Celso. A fantasia organizada. Rio de Janeiro: Paz e Terra, 1985.

${ }^{78}$ Ver BERCOVICI, Gilberto, op. cit., 2006.

79 A concretização do projeto constitucional e a conclusão da construção da Nação tornaram-se difícil pela mudança para um contexto de estado de exceção econômico permanente, o que não infirma a "vontade de constituição" contida no texto de 1998. Sobre o estado de exceção ver, entre outros, ARAÚJO, Cícero. Apresentação. In: BERCOVICI, Gilberto. Constituição e estado de exceção permanente: atualidade de Weimar. São Paulo: Azougue Editorial, 2004, p.9-17; AGAMBEN, Giorgio. Estado de exceção. São Paulo: Boitempo, 2004; ARANTES, Paulo. Extinção. São Paulo: Boitempo, 2007; BERCOVICI, Gilberto. Constituição e estado de exceção permanente: atualidade de Weimar. São Paulo: Azougue Editorial, 2004; e BERCOVICI, Gilberto. Estado de exceção econômico e a periferia do capitalismo. Separata do Boletim de Ciências Económicas, Coimbra, n.XVLII, 2004; BERCOVICI, Gilberto; MASSONETO, Luís Fernando. A constituição dirigente invertida: a blindagem da constituição financeira e a agonia da constituição econômica. Separata do Boletim de Ciências Económicas, Coimbra, 2006. 


\section{O CONGRESSO CONSTITUINTE}

O Estado legítimo é o Estado de Direito, e o Estado de Direito é o Estado constitucional.

Goffredo Telles Jr.

\subsection{Introdução}

Este capítulo aborda a instituição e o funcionamento do Congresso Constituinte, inclusive os seus antecedentes mais próximos, com a recuperação de momentos importantes relativos à "transição por transação" brasileira.

Em boa medida, a passagem de mais de duas décadas de governos militares fazia fluir no debate político-institucional, além da configuração dos aspectos poliárquicos do sistema político, destronados pelo golpe de 1964 e pelos seus desdobramentos, os anseios e as propostas de configuração do Estado, com, além da conformação dos direitos civis e políticos, a dos direitos sociais, econômicos e culturais, interpelando-se a "constituição econômica".

\subsection{A "transição por transaçãa" e o Congresso Constituinte}

$\mathrm{Na}$ esteira da convocação estabelecida pela Emenda Constitucional $n^{0} 26$, de 27 de novembro de $1985,{ }^{1}$ o Brasil viveu um dos mais importantes momentos de ativação política da sociedade civil organizada, que dava continuidade ao processo de mudança política, o qual, iniciando-se em meados da década de 70 e prolongando-se pelos anos 80, ocasionou a inflexão do regime militar, a construção de instituições representativas e multipartidárias e a realização de uma nova constituição. O ritmo cadenciado das mudanças e as negociações entre os agentes que pressionavam pela abertura política e os líderes do

\footnotetext{
${ }^{1}$ BRASIL. Constituição (1967). Emenda Constitucional no 26, de 27 de novembro de 1985. Disponível em: <http://www.senado.gov.br/legislacao〉. Acesso em: 5 jan. 2008.
} 
regime burocrático-autoritário ${ }^{2}$ sugeriram a existência de um tipo especial de transição, denominado "transição pela transação". ${ }^{3}$

Aquilo que se denominou a primeira transição, ou seja, o lapso entre as primeiras medidas liberalizantes e a passagem de governos autoritários para governos democratizantes, obedeceu, no Brasil, a um calendário extremamente lento e gradual, findando-se somente em 1985, com a vitória de Tancredo Neves no Colégio Eleitoral. A segunda transição, aquela que assistiu à consecução de um regime democrático, foi, por seu turno, problemática, a ponto de ser crucial durante algum tempo a interrogação sobre o grau de consolidação da democracia política brasileira, com analistas denominando a situação político-institucional como "democracia vazia", "democracia pobre" ou "democracia delegativa", para expressar a fragilidade da mesma, sobretudo a sua incapacidade para tratar com a crise econômica e com a crise social. ${ }^{4}$

\footnotetext{
${ }^{2}$ O Estado burocrático-autoritário, muito esquematicamente, pode ser resumido nos seguintes pontos: 1. é, primária e fundamentalmente, o aspecto da sociedade global que garante e organiza a dominação exercida através de uma estrutura de classes subordinada às frações superiores de uma burguesia altamente oligopolista e transnacionalizada, que é, em outros termos, sua principal base social; 2 . institucionalmente, é um conjunto de organizações no qual adquirem peso decisivo as especializadas na coerção, bem como as que tentam levar a cabo a "normalização" da economia; 3. é um sistema de exclusão política de um setor popular previamente ativado, o qual submete a severos controles que visam a destruir ou capturar os recursos (especialmente os cristalizados em organizações de classe e movimentos políticos) que sustentavam essa ativação; 4. tal exclusão provoca a supressão da cidadania e da democracia política, e também a proibição do "popular"; 5. também é um sistema de exclusão econômica do setor popular, ao promover uma "normalização" econômica particular e um padrão de acumulação de capital fortemente orientados em benefício das grandes unidades oligopolistas de capital privado e de algumas instituições estatais, que aumenta as desigualdades preexistentes; 6. a partir das suas instituições levam-se a cabo tentativas sistemáticas de "despolitizar" o tratamento de questões sociais, submetendo-se àquilo que se qualifica como critérios neutros e objetivos de racionalidade técnica; 7. seu regime, não formalizado, porém claramente vigente, implica o fechamento dos canais democráticos de acesso e, junto com eles, dos critérios de representação popular ou de classe, ficando o acesso limitado aos ocupantes da cúpula das grandes organizações, especialmente as Forças Armadas e as grandes empresas privadas ou públicas. Ver O’DONNELL, Guillermo. Análise do autoritarismo burocrático. Rio Janeiro: Paz e Terra, 1990, principalmente o capítulo 1.

${ }^{3}$ SHARE, Donald; MAINWARING, Scott. Transitions from above: democratization in Brazil and Spain. Indiana-Indianopolis: Kellogg, 1984; MORAES, Filomeno. A construção democrática. Fortaleza: UFC/Casa de José de Alencar, 1998; SANTOS, Fabiano. Escolhas institucionais e transição por transação: sistemas políticos de Brasil e Espanha em perspectiva comparada. Dados - Revista de Ciências Sociais, Rio de Janeiro, v.43, n.4, p.637-669, 2000. Evidentemente, processos de transição diferentes deram azo a que "processos de normativização de transformações sociais e políticas sejam também substancialmente diversos". CANOTILHO, J. J. Gomes. Videoconferência - 21/02/02 - UFPR (J. J. Gomes Canotilho e Grupo das Jornadas da Fazenda Cainã). In: COUTINHO, Jacinto Nelson de Miranda (Org.). Canotilho e a constituição dirigente. Rio de Janeiro: Renovar, 2003, p.57.

${ }^{4}$ O'DONNELL, Guillermo. Otra institucionalización. La Política - Revista de Estudios sobre el Estado y la Sociedad, Buenos Aires, n.2, p.5-27, 1996; e O’DONNELL, Guillermo. Disonancias: críticas democráticas a la democracia. Buenos Aires: Prometeo Libros, 2007. Especialmente sobre a "democracia delegativa", ver, ainda, O'DONNELL, Guillermo. Delegative democracy? Working Paper (Kellog Institute), n.172, Indiana-Indianopolis, 1992.
} 
Por outra parte, não se pode olvidar o caráter da transição brasileira, e o seu impacto sobre o processo constituinte que dela decorre. Quando uma transição política se dá por ruptura, a latitude das escolhas institucionais é maior, pois o processo decisório é interrompido e os seus agentes deslocados. O mesmo não ocorre quando a transição é feita segundo uma lógica negociada, dado que aqui se opta, de maneira mais ou menos implícita, pela governabilidade e pela diminuição dos custos da mudança em curto prazo, mantendo-se a rotina do processo decisório. ${ }^{5}$

\subsection{Distensão, abertura e redemocratização}

A quebra da ordem jurídica realizada pelo movimento militar de $1964,{ }^{6}$ com a necessidade da sua reconstrução, sempre esteve presente no discurso governamental. A partir do reforço autoritário ocorrido em 1968/1969, com a edição do AI-5 e a outorga de uma constituição (a denominada Emenda Constitucional $n^{\circ} 1$ ), o debate sobre uma nova ordem constitucional para o Brasil veio à tona. Dessa discussão participou, inclusive, o governo, visto que é um dado recorrente no discurso oficial a necessidade de institucionalizar-se, tendo todos os generais-presidentes - retórica ou sinceramente reconhecido a ilegitimidade intrínseca ao regime e acenado com um futuro promissor, em termos de consecução de algum tipo de ordem democrática, para qual o país, naquele momento, não estaria preparado. A interferência militar era vista, assim, como uma espécie de intervenção cirúrgica, passageira, uma espécie de rito de passagem para uma idade política adulta. Destinava-se a intervenção militar à liquidação de um processo, que abrigou as intenções de alguns e os temores de muitos de transbordar os parâmetros capitalistas e as filiações internacionais do país. As Forças Armadas, fiadoras do novo

\footnotetext{
${ }^{5}$ SANTOS, Fabiano. Escolhas institucionais e transição por transação: sistemas políticos de Brasil e Espanha em perspectiva comparada. Dados - Revista de Ciências Sociais, Rio de Janeiro, v.50, n.2, p.281-323, p.638. Ainda sobre a transição brasileira, ver LIMA JR., Olavo Brasil. Instituições políticas democráticas. Rio de Janeiro: Jorge Zahar Editor, 1997; CHAUÍ, Marilena; NOGUEIRA, Marco Aurélio. O pensamento político e a redemocratização do Brasil. Lua Nova - Revista de Cultura e Política, São Paulo, n.71, p.173-228, 2007.

${ }^{6} \mathrm{Na}$ Circular Reservada de 20 de março de 1964, dirigida pelo Chefe do Estado-Maior do Exército, general Humberto de Alencar Castello Branco aos "generais e demais militares do Estado-Maior do Exército e das organizações subordinadas", destacava-se o temor da instalação de uma Assembléia Constituinte: "São evidentes as duas ameaças: o advento de uma Constituinte como caminho para a consecução das reformas de base e o desenvolvimento em maior escala de agitações generalizadas do ilegal poder do CGT (Comando Geral dos Trabalhadores). As Forças Armadas são invocadas em apoio a tais propósitos". Acentuava-se também que "a ambicionada Constituinte é um objetivo revolucionário pela violência com o fechamento do atual Congresso e a instituição de uma ditadura". In: BONAVIDES, Paulo; AMARAL Roberto. Textos políticos da História do Brasil. 3. ed. Brasília: Senado Federal, Conselho Editorial, 2002. v.VIII, p.799-801.
} 
regime, ou da nova ordem, se viam como a cabeça dotada da racionalidade que faltava às outras partes de um corpo acometido de grave doença. ${ }^{7}$

Houve várias tentativas de reconstitucionalização dentro do figurino autoritário. A Constituição de 1967 foi um desses esforços de institucionalização da ordem autoritária em ascensão. O governo Castelo Branco deixa ao seu sucessor nova ordem jurídica, encimada por uma nova Constituição, que incorporava os dispositivos dos atos institucionais, além de uma Lei de Segurança Nacional e de uma Lei de Imprensa.

Outro esforço foi o do general Costa e Silva para a reforma da Constituição herdada de Castelo Branco, base da abertura que pretendia executar, com o levantamento do recesso do Congresso, a reorganização partidária e o fim dos atos de exceção. ${ }^{8}$ A tentativa redundou, afinal, frustrada, em primeiro lugar pelo recrudescimento do autoritarismo em 1968 e, em segundo, pelo impedimento e morte do presidente da República, o afastamento do vice-presidente e a emergência da junta constituída pelos ministros do Exército, da Marinha e da Aeronáutica. ${ }^{9}$ As veleidades de reconstitucionalização, então, sofreram um colapso, dada a outorga da Emenda Constitucional $\mathrm{n}^{\mathrm{o}} 1 .^{10}$

Durante o próprio governo do general Médici, o ministro Leitão de Abreu aventou a necessidade de descompressão, tendo mesmo encomendado um estudo ao cientista político Samuel Huntington. ${ }^{11}$ Também Manoel Gonçalves Ferreira Filho apresentou em 1972, com a primeira edição do seu A democracia possível, um projeto minucioso de institucionalização para o país. Partindo de uma perspectiva inteiramente favorável ao regime militar e à justeza dos pressupostos que tal regime vocalizava, considerava que

7 O’DONNELL, Guillermo. As forças armadas e o Estado autoritário no Cone Sul da América Latina. Dados - Revista de Ciências Sociais, Rio de Janeiro, v.24, n3, p.277-304, 1981.

8 Ver CHAGAS, Carlos. 113 dias de angústia: impedimento e morte de um presidente. Porto Alegre: L\&PM, 1979.

9 Para tanto, foi instituída "Comissão de Alto Nível", convocada e presidida pelo presidente Costa e Silva e composta pelo vice-presidente Pedro Aleixo (relator e organizador da reforma), ministro da Justiça Gama e Silva, chefe do Gabinete Civil Rondon Pacheco, ministro do Planejamento e Coordenação Hélio Beltrão, ministro do Supremo Tribunal Federal Temístocles Brandão Cavalcanti, ex-ministro da Justiça e do STF Carlos Medeiros da Silva e reitor da Universidade de São Paulo Miguel Reale. Ver ALEIXO, José Carlos Brandi. Introdução. In: SENADO FEDERAL. A constituição que não foi: história da emenda constitucional $n^{\circ}$ 1, de 1969. Brasília: Senado Federal, 2002, p.15-29.

${ }^{10}$ Foram quase quarenta as alterações (presumivelmente realizadas por Leitão de Abreu) da Junta Militar em relação à proposta da Comissão de Alto Nível. Entre elas, a disposição segundo a qual o AI-5 e os atos seguintes permaneceriam em vigência, por prazo indeterminado, e a extensão das penas de morte, prisão perpétua, banimento e confisco nos casos de "guerra psicológica adversa, ou revolucionária, ou subversiva". Ver ARAÚJO, Caetano Ernesto Pereira de; MACIEL Eliane Cruxên Barros de Almeida. A comissão de alto nível: história da emenda constitucional $n^{\circ}$ 1, de 1969. In: SENADO FEDERAL, op. cit., 2002, p.31-83.

${ }^{11}$ BRANCO, Carlos Castelo. Liberar sem transferir poder (entrevista). IstoÉ, São Paulo, n.265, p.68-70, 20 jan. 1982. 
[...] a construção política que ora se impõe reclama a elaboração de uma nova Constituição. A de 1967, embora retocada em 1969, pela Emenda Constitucional $\mathrm{n}^{\circ} 1$, não atende às exigências da institucionalização revolucionária. De fato, ela não traz um modelo capaz de realizar a Democracia no Brasil, nem apto a assegurar a continuidade da obra da Revolução de Março. Isto, aliás, salta aos olhos de qualquer um. Tanto assim é que a sobrevivência da Revolução tem sido garantida, segundo muitos pretendem, pelo Ato Institucional $\mathrm{n}^{\mathrm{o}} 5$, que, na verdade, a suspende. $[\ldots]^{12}$

Assim,

\begin{abstract}
A Democracia [...] não se resume num quadro institucional rígido, universalmente válido, para todas os povos. Ao contrário, ela pode e deve ser ajustada para cada caso, para cada nação, para cada tempo. É preciso cuidar cada povo de encontrar sua democracia possível, que concilie a ordem com o progresso. Essa é tarefa política magna: A democracia possível para o Progresso na Ordem. ${ }^{13}$
\end{abstract}

A busca de liberalização do regime autoritário deu-se por decisão interna corporis, não resultando, por conseguinte, de qualquer mudança substancial na correlação de forças entre os protagonistas e oponentes. Assim, o processo seguiu um padrão de movimentos contraditórios em diversas frentes, caracterizando-se pelo fato de que toda concessão do regime ou conquista da oposição é acompanhada por imposição de controles autoritários alternativos. De fato, a iniciativa e o controle do processo, até determinando momento, pertencem ao regime. Tal processo de liberalização se inicia com a emergência do general Ernesto Geisel à presidência da República, o que representa o acesso às posições superiores de mando do setor do regime favorável a uma mudança no sentido da descompressão política. O simples fato de Geisel comprometer-se publicamente com a "distensão" e o seu apelo à "imaginação criadora" dos políticos foram suficientes para transformar o clima político do país. ${ }^{14}$

E, a partir de 1974, quando Ernesto Geisel foi empossado, assiste-se a mudança no padrão de relacionamento entre a presidência da República e o Congresso Nacional, apesar da manutenção das restrições normativas, passando este a ocupar lugar de destaque no debate do processo político-constitucional. Por outro lado, o presidente da República adotou uma série de atitudes que restituíram ao Legislativo algum sentido de participação. A relação Executivo-Legislativo torna-se livre de muitos dos constrangimentos,

\footnotetext{
${ }^{12}$ FERREIRA FILHO, Manoel Gonçalves. A democracia possível. 3. ed. São Paulo: Saraiva, 1976, p.122.

${ }^{13}$ Ibid., 1976, p.129.

${ }^{14} \mathrm{Em}$ 1978, Paulo Brossard alertava: "Houve tempo em que se falava no 'gradual, mas seguro aperfeiçoamento democrático'. Tive ocasião de sustentar então que a normalização haveria de ser feita de uma vez só, por decisão da maioria e da oposição, quer dizer, por decisão nacional, ou não se faria nunca, pois daqui a cem anos não faltaria quem a entendesse prematura". BROSSARD, Paulo. Ainda é tempo. Brasília: Senado Federal, 1978, p.10.
} 
principalmente em decorrência do relacionamento do governo com a Aliança Renovadora Nacional (Arena), que, durante o período Médici, ficara praticamente isolada do núcleo de poder. Com Ernesto Geisel, passavam os parlamentares tanto da Câmara dos Deputados quanto do Senado Federal a ter maior acesso ao presidente da República e ao governo em geral. Ao mesmo tempo, o ministro da Justiça passa a articular-se permanentemente com as lideranças da Arena nas duas casas legislativas.

A atitude conciliatória do governo Geisel teve o condão de fazer com que o Parlamento despertasse do marasmo a que fora reduzido durante os anos do governo Médici. Ademais, o debate político que precedeu as eleições de 1974, a franquia aos candidatos tanto da Arena quanto do Movimento Democrático Brasileiro (MDB) ao rádio e à televisão e a relativa liberdade com que se procedeu às eleições faziam acreditar que o regime realmente estava mudando, embora o presidente da República reiterasse a sua disposição de governar com os "instrumentos de exceção", apesar de preferir vê-los "não tanto em exercício duradouro ou freqüente, antes como potencial de ação repressiva ou contenção enérgica". ${ }^{15}$

Mas os resultados das eleições de 1974 afetaram o próprio modus faciendi do projeto de mudança política, a partir do que decidiram o papel que o Legislativo deveria exercer durante a "transição", bem como a natureza do relacionamento Executivo-Legislativo. A decisão de "abrir" o regime sempre foi vocalizada enfatizando a disposição de o seu controle não ser repartido, devendo constituir, por conseguinte, monopólio do núcleo de poder que ocupava o aparelho de Estado, à frente do qual se situava o grupo que ascendera com o general Geisel.

Com as eleições parlamentares de 1974, o Congresso Nacional, formalmente, adquiriu uma posição importante dentro do sistema decisório, com a oposição passando a ter "poder de veto" em matéria constitucional. Já que as emendas constitucionais necessitavam de 2/3 dos membros de cada casa legislativa e o MDB alcançava mais de 1/3 dos deputados federais (além de adquirir uma bancada de vinte senadores), estas emendas somente poderiam ser aprovadas mediante acordo entre o governo e a oposição, o que, em tese, significava a divisão do controle do processo de transição.

\footnotetext{
${ }^{15}$ COUTINHO, Amélia; GUIDO, M. Cristina. Geisel, Ernesto. In: ABREU, Alzira A. et al. (Coord.). Dicionário histórico-biográfico brasileiro pós-1930. 2. ed. Rio de Janeiro: FGV; Cpdoc, 2001. v.III, p.2.513.
} 
Ademais, os resultados das eleições, à medida que constituíam a primeira manifestação do eleitorado depois de iniciada a "distensão", eram muito significativos para a mensuração da popularidade do regime. Acarretavam mesmo o esboroar da sua autoestima, a prenunciar medidas tendentes a evitar a perda do controle do processo de mudança política. Ou seja, partindo do pressuposto de que a manutenção do controle do processo pelo próprio regime era a condição sine qua non sob a qual repousava a possibilidade de abertura, era bastante previsível a tomada de medidas que evitassem o crescimento da oposição parlamentar e que anulassem os efeitos dos resultados eleitorais.

A rejeição pela oposição parlamentar, no início de 1977, do projeto de reforma do Judiciário foi o pretexto de que o governo se utilizou para refrear o Congresso. O "Pacote de Abril" neutralizou o poder da oposição congressual em matéria constitucional e colocou, mais uma vez, o Congresso à parte das decisões importantes da vida política.

Baixando o quórum para reformas constitucionais de 2/3 para a maioria absoluta de cada um das casas legislativas, instituindo os senadores "biônicos", criando a sublegenda para as eleições dos senadores escolhidos pelo voto popular, ${ }^{16}$ modificando os critérios de eleições dos deputados federais e estendendo a Lei Falcão ${ }^{17}$ às eleições parlamentares de 1978, o governo, por um lado, readquiria o controle sobre o Congresso, enquanto, por outro, colocava limites a possíveis incômodos futuros da oposição nas casas legislativas. Assim, tornava incontrastável o seu poder sobre os limites da "distensão".

O "Pacote de Abril" iniciava os caminhos para a realização das reformas que faziam parte do projeto liberalizante do governo. A partir de então, sem dificuldades, o Congresso aprovou a emenda constitucional que extinguia parcialmente o AI-5 e pôs alguns dos seus dispositivos no texto constitucional de 1969, além da anistia e da reforma partidária. À edição do "Pacote de Abril" se seguiu uma série de outros "pacotes" de medidas casuísticas, os quais o Executivo extraiu do Congresso.

${ }^{16}$ O Decreto-lei n. 1.541, de 14 de abril de 1977, dispunha: "Art. $1^{\circ}$. Os partidos políticos poderão instituir até três sublegendas nas eleições diretas para senador [...]. Parágrafo único. Sublegendas são listas autônomas de candidatos concorrendo a um mesmo cargo em eleição, dentro do partido político a que são filiados. Art. $2^{\circ}$. Os votos do partido serão a soma dos votos atribuídos aos candidatos das sublegendas. $\S$ $1^{\circ}$ Considerar-se-á eleito o mais votado dentre eles. [...]" BRASIL. Decreto-lei n. 1.541, de 14 de abril de 1977. Disponível em: 〈http://www.senado.gov.br/legislacao〉. Acesso em: 10 jan. 2008.

${ }^{17}$ A Lei n. 6.339, de $1^{\circ}$ de julho de 1976, determinou que, na propaganda eleitoral, os partidos se limitassem a mencionar a legenda, o currículo e o número do registro do candidato na Justiça Eleitoral, bem como a divulgar, pela televisão, a sua fotografia, podendo ainda mencionar o horário e o local dos comícios. BRASIL. Lei n. 6.339, de $1^{\circ}$ de julho de 1976. Disponível em: 〈http://www.senado.gov.br/legislacao〉. Acesso em: 10 jan. 2008. 
A cada enfrentamento do Congresso em relação ao Executivo, este respondeu com a imposição de controles que neutralizavam o ato de rebeldia. Tal comportamento perdurou por muito tempo, e os exemplos mais veementes foram a rejeição da extensão da sublegenda às eleições para governadores, que o Executivo respondeu com a imposição da vinculação total dos votos, e a lei da previdência social que, apesar de ter sido aprovada depois de negociação entre todos os partidos políticos com assento no Congresso, foi virtualmente anulada pela edição de decreto-lei que instituiu as medidas que o Congresso rejeitara.

Assim, a conduta do Executivo em relação ao Legislativo, durante o decorrer do processo de "distensão", foi bastante contraditória e potencialmente conflituosa, pois, à medida que o Parlamento aumentou a sua força política, resultou um conseqüente enfrentamento ao Executivo. Por seu turno, este, embora tendo perdido alguns dos instrumentos autoritários, sempre manteve controles e força suficiente para retaliar o Congresso. Cassação de mandatos parlamentares, imposição de "leis", ameaças públicas ou veladas e até o fechamento temporário do Congresso, caracterizaram o padrão de relacionamento Executivo-Legislativo a partir de 1974. ${ }^{18} 19$

\subsection{A reativação da sociedade civil}

No começo da década de 70, foi uma instituição da sociedade civil, a Ordem dos Advogados do Brasil (OAB), que, numa das suas conferências nacionais, ${ }^{20}$ trouxe a baila a

\footnotetext{
${ }^{18}$ Somente com a Emenda Constitucional no 22, de 29 de junho de 1982, deram-se passos importantes na restituição das funções e prerrogativas do Poder Legislativo, com tal emenda proporcionando, embora com muitas restrições, o retorno da imunidade parlamentar, bem como da capacidade fiscalizatória do Congresso Nacional. BRASIL. Constituição (1967). Emenda Constitucional $n^{\circ} 22$, de 29 de junho de 1982. Disponível em: 〈http://www.senado.gov.br/legislacao〉. Acesso em: 5 jan. 2008.

${ }^{19}$ Ibid., 2008.

${ }^{20}$ BASTOS, Aurélio Wander. A Ordem dos Advogados e o Estado democrático no Brasil. Tese (Doutorado em Ciência Política). Rio de Janeiro, Instituto Universitário de Pesquisas do Rio de Janeiro, 2007. Algum tempo depois, tendo na presidência Raymundo Faoro, a OAB mudou de orientação. Como observa Elio Gaspari, "a Faoro interessava iniciar um processo viável de conciliação. Apresentou-o simples, compreensível e quase livre de contradita. Entrincheirou-se na defesa do restabelecimento do habeas corpus, suspenso desde dezembro de 1968. [...] Faoro afastara-se das principais bandeiras da propaganda oposicionista, a convocação de uma Assembléia Constituinte e a promulgação de uma anistia. A primeira surgira em 1971, durante um seminário do MDB no Recife. Servia mais para demarcar a divisão entre 'autênticos' (que a defendiam) e moderados (que a condenavam) do que para mobilizar o partido. Já a anistia ganhava corpo desde que Therezinha Zerbini organizou os primeiros núcleos do Movimento Feminino pela Anistia, em março de 1975. Ao contrário da Constituinte, tinha a força da rua. Colocadas no campo das premissas, anistia e Constituinte pressupunham a queda ou a radical transformação do regime. O representante da OAB transferiu-as para o elenco dos objetivos: 'A Constituinte é um dos caminhos. Mas não é o único. [...] A anistia é um passo desta pacificação. Não é, talvez, um passo prévio'. [...]." Ainda de acordo com Elio Gaspari, "A agenda enxuta do presidente da
} 
necessidade da reconstitucionalização do país, através da convocação de uma assembléia nacional constituinte. Em seguida, o debate constituinte ganhou maior dimensão política com a deliberação, através de uma convenção nacional, do Movimento Democrático Brasileiro. ${ }^{21}$ As novas disposições inseridas na Constituição vigente, por força do "Pacote de Abril", anulavam na prática o aumento da representação do partido oposicionista e bloqueavam o seu poder de veto sobre as emendas à Constituição, na medida em que alteravam as condições para a votação de tais emendas, permitindo que elas fossem aprovadas por maioria simples. Alterava-se, também, a possibilidade de a oposição apresentar emendas constitucionais - um terço da Câmara ou um terço Senado -, colocando-se, em lugar da alternativa, a possibilidade de, apenas em conjunto, Câmara e Senado apresentarem emendas. ${ }^{22}$

Já em 1977, por ocasião do sesquicentenário de criação dos cursos de Direito no Brasil, a Carta aos Brasileiros, ${ }^{23}$ encabeçada por Goffredo Telles Jr., trazia ao debate público a problemática da ilegitimidade da ordem jurídica vigente. Enfatizava-se que, "sendo lei, a Constituição há de ter, também, sua fonte legítima" e que "a fonte legítima da Constituição é o Povo". Por conseguinte, "a Constituição é obra do Poder Constituinte. Mas o que se há de acrescentar, imediatamente, é que o Poder Constituinte pertence ao

OAB retomava a 'estratégia incremental' proposta em setembro de 1973 pelo professor Wanderley Guilherme dos Santos, a qual fora duramente criticada no meio acadêmico e pelos 'autênticos' do MDB. Sugeria que a ordem política fosse descomprimida por etapas, buscando-se evitar os riscos de uma 'recompressão'. Passados quatro anos, o caminho mostrava-se não apenas funcional, mas também inevitável. O 'Pacote de Abril' e a cassação de Lysâneas Maciel e Alencar Furtado haviam neutralizado a vanguarda oposicionista. Um dos primeiros críticos do professor fora o próprio Lysâneas. Ele, como todo o bloco da esquerda parlamentar, supusera possível um restabelecimento da democracia semelhante àquele que, a seu juízo, ocorrera em 1945, com as Forças Armadas derrubando a ditadura. Em 1977 ficou claro que, se os quartéis se movessem, o general Sylvio Frota derrubaria Geisel”. GASPARI, Elio. A ditadura encurralada. São Paulo: Companhia das Letras, 2004, p.450-451. A propósito da "estratégia incremental", ver SANTOS, Wanderley Guilherme dos. Poder e política: crônicas do autoritarismo brasileiro. Rio de Janeiro: Forense Universitária, 1978.

${ }^{21}$ NOBRE, Freitas. Constituinte. Rio de Janeiro: Paz e Terra, 1978.

${ }^{22}$ A CF/1969 estabelecia: “Art. 47. A Constituição poderá ser emendada mediante proposta: I - de membros da Camara dos Deputados ou do Senado Federal; [...]”. Com a Emenda Constitucional n ${ }^{\circ}$ 8, de 1977, o inciso I passou a ter a seguinte redação: "I - de membros da Câmara dos Deputados e do Senado Federal; [...]".

${ }^{23}$ Cronologia publicada em O Estado de São Paulo no dia da promulgação da Constituição de 1988 considerou a Carta aos Brasileiros o ponto de partida da trajetória que proporcionou o retorno do país à democracia e ao Estado de Direito. Segundo Paulo Bonavides e Paes de Andrade, a leitura da carta "foi tão importante para os pródromos constituintes de 1987 quanto o Manifesto dos Mineiros o fora para a Carta de 1946 e a desagregação do Estado Novo". BONAVIDES, Paulo; ANDRADE, Paes de. História constitucional do Brasil. Brasília: Paz e Terra, 1989, p.452. Um conjunto de análises e avaliações sobre a Carta está em SCHUBSBY, Cássio (Org.). Estado de direito já!: os trinta anos da Carta aos Brasileiros. São Paulo: Lettera.doc, 2007. 
Povo, e ao Povo somente", ${ }^{24}$ pois é falacioso "o binômio Segurança e Desenvolvimento". Assim é que

\begin{abstract}
Aprendemos definitivamente que, fora do Estado de Direito, o referido binômio pode não passar de uma cilada. Fora do Estado de Direito, a Segurança, com seus órgãos de terror, é o caminho da tortura e do aviltamento humano; e o Desenvolvimento, com o malabarismo de seus cálculos, a preparação para o descalabro econômico, para a miséria e a ruína.
\end{abstract}

Não nos deixaremos seduzir pelo canto das sereias de quaisquer Estados de Fato, que apregoam a necessidade de Segurança e Desenvolvimento, com o objetivo de conferir legitimidade a seus atos de Força, violadores freqüentes da Ordem Constitucional.

Afirmamos que o binômio Segurança e Desenvolvimento não tem o condão de transformar uma Ditadura numa Democracia, um Estado de Fato num Estado de Direito. $^{25}$

Cumpria, pois, afirmar a primazia do Estado de Direito, renegando-se, por conseguinte, a ideologia da segurança nacional, segundo a qual o crescimento econômico justificava os atentados à ordem constitucional desde 1964:

Declaramos falsa a vulgar afirmação de que o Estado de Direito e a Democracia são 'a sobremesa do desenvolvimento econômico'. O que temos verificado, com freqüência, é que desenvolvimentos econômicos se fazem nas mais hediondas ditaduras.

Nenhum País deve esperar por seu desenvolvimento econômico, para depois implantar o Estado de Direito. Advertimos que os Sistemas, nos Estados de Fato, ficarão permanentemente à espera de um maior desenvolvimento econômico, para nunca implantar o Estado de Direito.

Proclamamos que o Estado de Direito é sempre primeiro, porque primeiro estão os direitos e a segurança da pessoa humana. Nenhuma idéia de Segurança Nacional e de Desenvolvimento Econômico prepondera sobre a idéia de que o Estado existe para servir o homem. ${ }^{26}$

Na Carta, tem-se a grande preocupação de retomar a discussão do direito como condição de legitimidade do processo político. Por que isso?

[...] Porque, anos antes, havia tido, por parte da ditadura, exatamente por ocasião da edição do Ato Institucional $n^{\circ} 5$, uma ênfase fortemente oposta a essa, que era a utilização do direito como instrumento do desenvolvimento econômico. $\mathrm{Ou}$ seja, a visão de que o direito não é um instrumento de segurança, não é um instrumento de segurança jurídica, não é um instrumento de liberdade pública; o direito é, sim, um instrumento de desenvolvimento econômico. Existiu todo um debate por trás da edição do AI-5, no qual alguns ministros que tinham formação jurídica se manifestaram impactados com o alcance avassalador do Ato, no que a equipe econômica respondeu: 'Precisamos do direito como instrumento de

${ }^{24}$ TELLES JR., Goffredo. Carta aos Brasileiros. In: SCHUBSBY, Cássio (Org.), op. cit., 2007, p.24-25.

${ }^{25}$ Ibid., 2007, p.29.

${ }^{26}$ Ibid., 2007, p.29. 
desenvolvimento e vamos usá-lo para aquilo que queremos em termos de um projeto econômico para o País. Sendo autoritários no início, nos legitimaremos pelo resultado, ou seja, na medida em que o Brasil se desenvolver, lhe ofereceremos os resultados. O 'bolo' vai crescer, assim nós nos legitimaremos. $[\ldots]^{27}$

De fato, Albert Fishlow já acentuava que o "milagre" brasileiro:

[...] these economic accomplishments have come to be viewed not only as the direct consequence of the Revolution of 1964 and structural reforms instituted thereafter, but increasingly as evidence of the incompatibility of democratic political institutions and rapid economic development in Brazil and elsewhere. This interpretation has been given special force by the accelerating prosperity since the Fifth Institutional Act of December 1968 further centralized decisionmaking powers. That act was soon rationalized by policy makers in a response to the requirements of economic development. ${ }^{28}$

E, "as evidence of the incompatibility of democratic political institutions and rapid economic development in Brazil", concluía que "the extent of federal government centralization cannot be ignored", cumprindo que "the political framework favorable the short-term resolution of these questions may not be equally felicitous with regard to the long term":

The present Brazilian model is frankly capitalistic, relying upon the private sector and foreign investment. Yet the increase effectiveness of the market, particularly the capital market, owes much to governmental intervention in the form of tax incentives and other policies. The essentially political decision

${ }^{27}$ FARIA, José Eduardo. Depoimento. In: SCHUBSKY, Cássio (Org.). Estado de direito já!: os trinta anos da Carta aos Brasileiros. São Paulo: Lettera.doc, 2007, p.104-105. Um dos mais destacados analistas na imprensa resume bem a ideologia razoavelmente dominante no período de maior expansão econômica do regime militar, no governo Médici, acerca do mercado e do Estado: "A estrutura econômica cresce e consolida-se segundo o modelo da livre empresa, embora sob o impulso do Estado e a ação supletiva estatal nos setores em que o investimento se apresenta insuficiente. $\mathrm{O}$ crescimento se faz, portanto, segundo um modelo conhecido, sendo previsível que num futuro relativamente próximo não haverá mais razões para o debate sobre se o desenvolvimento de uma nação como o Brasil só pode se realizar segundo este ou aquele modelo. Simplesmente o desenvolvimento terá havido e seguindo a linha geral do modelo capitalista moderno sob a orientação do Estado. Tal raciocínio visa justamente a eliminar a inquietação gerada nos diversos setores da vida nacional pelo desmedido controle do Estado sobre as atividades políticas, o qual para alguns seria a conseqüência da excessiva presença do poder público na atividade econômica". Pelo contrário, "tal controle seria puramente emergencial, pois dentro de algum tempo a direção da vida brasileira refletirá a realidade de uma economia forte e em plena expansão. O Estado, que deterá o comando do processo ainda por algum tempo, terá seu papel principal na vigilância da distribuição do produto do esforço coletivo para impedir a distorção favorecida pelo sistema capitalista em prejuízo das classes trabalhadoras. O sistema de política econômico-financeira revela-se, portanto, otimista não só quanto aos resultados específicos da sua área, como em relação à projeção deles no quadro da vida nacional. [...]”. BRANCO, Carlos Castello. Os militares no poder. Rio de Janeiro: Nova Fronteira, 1979. v.III, p.743-744.

${ }^{28}$ FISHLOW, Albert. Some reflections on post-1964 Brazilian economic policy. In: STEPAN, Alfred (Ed.). Authoritarian Brazil: origins, policies, and future. New Haven and London: Yale University Press, 1973, p. 69. Segundo o mesmo autor, por sua vez, o diretor da missão brasileira da Agency for International Development, em fevereiro de 1969, já acentuava: "In terms of general economic policies, I would say if anything there has been a net improvement; the Finance Minister can now do by decree things that before had to go through Congress; they have been passing out decrees left and right and most of them are to the good". Ibid., 1973, p.69. 
concerning the volume of savings and investment, the structure of income distribution, and the extent of federal government centralization cannot be ignored. The political framework favorable the short-term resolution of these questions may not be equally felicitous with regard to the long term. Nor may the developmental consequences keep pace with the impressive rate of advance of gross domestic product. ${ }^{29}$

Em abril de 1984, em mensagem que encaminhava proposta de emenda à Constituição, o então presidente da República, general João Batista de Figueiredo, conclamou os congressistas a uma revisão constitucional. Abruptamente, depois que a Comissão Mista do Congresso emitiu seu parecer e pouco antes da votação da matéria no plenário, o presidente retirou a proposta. Várias emendas à Proposta de Emenda Constitucional n. 11/84, do Poder Executivo, foram apresentadas visando a conferir poderes constituintes ao Congresso Nacional a ser renovado em 1986, uma vez que juristas se pronunciaram no sentido de que só cabia convocação de uma Assembléia Constituinte se houvesse ruptura da ordem institucional. ${ }^{30}$

\subsection{A devolução do poder constituinte ao povo}

Pontes de Miranda observava que, "nas democracias, quando se quebra a linha democrática, tal como aconteceu no Brasil, em 1889, 1930, 1937 e 1964, a reentrega do poder constituinte ao povo, feita pelo que detém o poder de legislar, apenas instrumenta o restabelecimento da democracia constituinte", concluindo:

[...] De modo que é sempre legítimo o ato do governo, mesmo de fato, que restitui ao povo o poder constituinte, se ele é o titular do poder estatal. Mas é preciso que se trate apenas de restituição. O seu legítimo restituir não autoriza a ir-se além das regras de lugar, tempo e formação da Assembléia Constituinte, ainda assim subordinadas à apreciação por essa própria assembléia, inclusive quanto à deliberação - dela - de se dissolver e convocar outra Assembléia Constituinte. ${ }^{31}$

Raymundo Faoro também se debruçou sobre a "a usurpação" e a "devolução" do poder constituinte, considerando que:

[...] o que não é legitimo será reter o Poder Constituinte, prática que nunca se pode compatibilizar à democracia. Contê-lo e, ao mesmo tempo, proclamar no estatuto que o aprisiona que todo poder emana do povo e em seu nome é exercido soa mais do que como uma contradição. Quem abandona a usurpação e devolve o direito ao titular, seja quem for o autor da ação, retorna à legitimidade

\footnotetext{
${ }^{29}$ Ibid., 1973, p.70.

${ }^{30}$ Ver GIAVARINA, Valmor. Constituinte originária e instituída. Disponível em: <http://www.valmorgiavarina.adv.br>. Acesso em: 25 jan. 2003.

${ }^{31}$ MIRANDA, Pontes de. Comentários à Constituição de 1967. São Paulo: RT, 1967. t. I, p.196-197.
} 
e, embora não a adquira, ingressa no período pré-constitucional. Há um passo relevante que ser dado, no caminho que vai da ilegitimidade até a legitimidade. ${ }^{32}$

Também considerou a problemática da "devolução" do poder constituinte como estando jungida às forças políticas da conjuntura e menos ao "plano das abstrações" matemáticas e jurídicas:

A devolução e principalmente a recuperação da legitimidade, que é concomitante ao processo de um caminho em favor da soberania popular, não se desenvolvem no plano das abstrações, as matemáticas e as jurídicas. $\mathrm{O}$ valor que orienta esse trânsito dentro da sociedade, com imediata e fundamental expressão política, vinculado às classes, camadas e demais forças. Essa conexão explica também o fenômeno inverso, a deslegitimação, como a que ocorreu, por exemplo, com a realeza, hoje incompatível com o postulado de que todo poder emana do povo. A composição da sociedade se projeta nas instituições, em certos momentos em busca de privilégios, sacralizando todas as oligarquias e as autocracias. $\mathrm{Na}$ direção liberal e, sobretudo, na inclinação democrática, que afastou a aristocracia e reconheceu os empresários, os agricultores e os operários como atores da história, entendeu-se que cada um desses setores não seria autônomo se reivindicasse um privilégio, mais um entre outros. [...]. ${ }^{33}$

Ademais, observa Raymundo Faoro que "o poder que devolve ao povo o Poder Constituinte sai da ilegitimidade, do governo de fato, entrando no espaço da préconstitucionalidade ou da semilegitimidade". Assim:

Nesse passo surge a questão de quem convoca a constituinte. A experiência histórica do Brasil mostra que o Poder Executivo se incumbiu dessa tarefa, como manifestação inovatória, premido pela opinião pública, para se liberar de um impasse e de uma crise, provocados pela pressão do Poder Constituinte operante na sociedade. Os precedentes das quatro constituintes demonstram que a devolução e a recuperação, como expressões convergentes de uma conquista e de uma concessão, ocorreram em momentos em que não existia o Poder Legislativo. $^{34}$

A conseqüência é o chamamento à ordem do Poder Legislativo, pois,

Hoje, a realidade é outra, e, em lugar do Executivo que absorvia as funções legislativas, a convocação pode nascer primariamente do poder que está naturalmente habilitado a convocá-la. Não, é claro, para se perpetuar como Poder Constituinte derivado, mas para se legitimar no Poder Constituinte puro, sem os subterfúgios e as falácias de um espaço excepcional, dentro de seus condicionamentos, em uma ampliação da reforma e de suas limitações. O que se espera é que o Congresso, liberto de sua tutela, se submeta, ele também, ao império do povo. Esta é sua vez e a sua hora. ${ }^{35}$

Nelson Saldanha também admitia a restituição do poder constituinte ao povo, por diversos meios - o chefe de Estado, o Congresso Nacional, um referendo popular -:

\footnotetext{
${ }^{32}$ FAORO, Raymundo. A república inacabada. São Paulo: Globo, 2007, p.250.

${ }^{33}$ Ibid., 2007, p. 251.

${ }^{34}$ Ibid., 2007, p. 262.

${ }^{35}$ Ibid., 2007, p.262.
} 
O problema, a um tempo político e técnico (jurídico), de saber quem ou qual órgão poderá convocar eleições para uma Assembléia Constituinte - reiterandose a inadmissibilidade de o atual Congresso metamorfosear-se em Constituinte -, não poderá servir de entrave maior. A solução, como, inclusive, o corroboram antecedentes na história nacional [...], pode estar na convocação pelo chefe do Estado, ou pelo próprio Congresso, poder-se-á consultar o Supremo no sentido de convalidar juridicamente o ato, ou ainda respaldá-lo a posteriori através de um referendum popular. [...]. ${ }^{36}$

Críticas muito severas partiram de diversos setores da sociedade no que respeita à maneira como o problema da restituição do poder constituinte foi conduzido, entre outras, as relativas à confusão da Constituinte com o Congresso Nacional, ${ }^{37}$ a nomeação de uma comissão de notáveis para elaborar anteprojeto a ser enviado à Assembléia, a persistência de grande parte do chamado "entulho autoritário", além da admissão, como constituintes, de 1/3 dos membros do Senado eleitos em 1982.

Assim, frustrou-se o movimento com várias reentrâncias sociais, a unir juristas, políticos e organizações da sociedade civil, que apostava em uma Constituinte desvinculada do Congresso Nacional. Todavia, como observa Henry Maksoud,

A despeito de dissidências a nível individual, o que se viu foi a cumplicidade da maioria dos partidos com assento no Parlamento - que para tanto puseram de lado antagonismos de toda ordem - em torno da fórmula de uma Constituinte monopolizada pelo Congresso, afinal aprovada. PMDB, PFL, PDS e PTB asseguraram esse desfecho, contra o qual bateram-se apenas dois partidos minoritários, o PDT e o PT, ambos, por sinal, de orientação ideológica socialista, ou seja, avessos a um sistema de Governo fundado no princípio da liberdade individual. $^{38}$

${ }^{36}$ SALDANHA, Nelson. O poder constituinte. São Paulo: RT, 1986, p.12-13. Sobre outras posições, ver, entre outros, REALE, Miguel. Por uma constituição brasileira. São Paulo: RT, 1985; TELLES JR., Goffredo. A Constituição, a Assembléia Constituinte e o Congresso Nacional. São Paulo: Saraiva, 1986.

${ }^{37}$ No momento, no Brasil, inclusive, como fruto da política deliberada do regime inaugurado em 1964, mais do que nunca se encarnava no Congresso Nacional brasileiro, "a sorte do regime representativo em nosso país", embora envolto na contradição, segundo a qual, na medida em que "os parlamentos se fazem mais representativos e se reclama deles maior soma de trabalho, as assembléias políticas, mais numerosas na sua composição e mais divididas nas correntes que as compõem, se tornam, material e organicamente, menos capazes de desempenhar as suas funções com a urgência requerida". Assim, "em vista dessa contradição fundamental, não é de se estranhar que os inimigos do regime representativo tenham tirado o maior proveito da crise institucional, encobrindo os seus interesses, muitas vezes escusos, com a acusação de incapacidade, irrogada às assembléias, e com o propósito, aparentemente meritório, de dar maior eficiência ao governo pela supressão dos parlamentos ou pela redução da sua participação na tarefa legislativa". LEAL, Victor Nunes. Problemas de direito público e outros problemas. Brasília: Ministério da Justiça, 1997, p.2.

${ }^{38}$ MAKSOUD, Henry. Apresentação. In: MAKSOUD, Henry (Ed.). Constituinte independente e apartidária. São Paulo: Visão, 1986, p.10-11. Diretor da revista Visão, Henry Maksoud defendia uma "Constituinte autônoma, separada do Congresso", "Constituinte apartidária, acima das facções políticas" e “elaboração orgânica da nova Carta, mediante prévia definição de um regime político”. Ibid., 1986, p.10. 
Herman Assis Baeta, então presidente do Conselho Federal da OAB, perguntava: "teremos uma Constituinte livre e soberana, de forma a dotar o país de um novo ordenamento jurídico de acordo com as aspirações populares?” E defendia que

[...] a nova ordem constitucional seja oriunda de uma assembléia especificamente eleita para elaborar a Constituição, garantida a presença e participação de pessoas diretamente representantes dos mais diversos segmentos sociais, atividades profissionais e tendências políticas. Os partidos políticos, evidentemente, não podem e não devem ficar de fora do processo. Mas também não devem agir como camisa de força à vontade nacional, inibindo a participação de candidatos não profissionalmente dedicados ao trabalho político. ${ }^{39}$

Na mesma direção, põe-se Luiz Carlos Madeira, então presidente da OAB-RS:

A conclusão é uma só: o Congresso Nacional não representa o povo brasileiro. E, porque não representa o povo brasileiro, não tem legitimidade para constituir, vale dizer, organizar, o Estado brasileiro, em nome da sociedade brasileira, definindo a competência dos poderes e declarando os direitos dos cidadãos, de forma que todos se sintam obrigados, indiscriminadamente, a aceitar os ônus que lhes resultam do exercício da autoridade. ${ }^{40}$

A convocação do Congresso Constituinte acabou por dar-se através de emenda constitucional originária do Executivo, com a outorga ao Congresso Nacional de poderes constituintes. Apresentada pelo Executivo uma proposta de emenda constitucional, a mesma se transformou na Emenda $n^{\circ} 26$ (nominalmente à Constituição de 1967), que convocava a Assembléia Nacional Constituinte, ${ }^{41}$ com eleições que se realizaram no dia 15 de novembro de 1986 e com a instalação em $1^{\circ}$ de fevereiro de 1987.

\subsection{A Comissão Provisória de Estudos Constitucionais}

Imaginada por Tancredo Neves, quando ainda disputava o governo de Minas Gerais, ${ }^{42}$ que já tinha, inclusive, a lista dos seus componentes, a Comissão Provisória de Estudos Constitucionais foi instituída pelo presidente José Sarney. ${ }^{43}$

${ }^{39}$ BAETA, Hermann Assis. O monopólio do Congresso. In: MAKSOUD, Henry (Ed.), op. cit., 1986, p.2728.

${ }^{40}$ MADEIRA, Luís Carlos. Os limites do poder. In: MAKSOUD, Henry (Ed.), op. cit., 1986, p.101.

${ }^{41} \mathrm{O}$ relator da matéria, deputado Flávio Bierrenbach (PMDB-SP) tentou fazer passar substitutivo que convocava uma Assembléia Constituinte exclusiva, inclusive, com a realização de um plebiscito para que o eleitorado decidisse se transformava o Congresso em Assembléia Constituinte ou se elegia uma Assembléia Constituinte exclusiva. Rejeitado o substitutivo, restaurou-se a proposta original que consagrava o modelo congressual. Ver BIERRENBACH, Flávio. Quem tem medo da constituinte? Rio de Janeiro: Paz e Terra, 1986.

${ }^{42}$ FOLHA DE SÃO PAULO - Guia da Constituinte, São Paulo, p.25, 19 set. 1986. Sobre a Comissão Afonso Arinos, ver, entre outros, REALE, Miguel. Liberdade e democracia (em torno do anteprojeto da Comissão Provisória de Estudos Constitucionais). São Paulo: Saraiva, 1987; PEREIRA, Osny Duarte. Constituinte (anteprojeto da Comissão Arinos). Brasília: UnB, 1987; FERREIRA FILHO, Manoel 
Duramente criticada no seu nascedouro por setores da sociedade civil, entre os quais a OAB, a Central Única dos Trabalhadores (CUT), a Igreja progressista, pelo PT, PDT e por setores do PMDB, teve juristas que não aceitaram a designação para compô-la. ${ }^{44}$ No entanto, depois de encerrado o seu trabalho, a Comissão Afonso Arinos acabou por sofrer a crítica dos conservadores. ${ }^{45}$ Miguel Reale, por exemplo, observou que o esboço de Constituição não correspondia à opinião da totalidade dos membros da Comissão, pois esta deliberava com a presença de apenas 22 destes; na duração de mais de um ano de

Gonçalves. O anteprojeto dos notáveis. São Paulo: Saraiva, 1987; LAMOUNIER, Bolívar. Os trabalhos da "Comissão Afonso Arinos". In: FORTES, Luiz Roberto Salinas; NASCIMENTO, Milton Meira do (Org.). A constituinte em debate. São Paulo: Sofia Editora Saef, 1987, p.83-99. "Tancredo Neves, conta o jornalista Mauro Santayana, pensou pela primeira vez na formação de uma comissão para elaborar um projeto de Constituição quando iniciava sua campanha para o governo de Minas, em 1982. Santayana, que deixava o jornalismo para assessorá-lo, ouviu Tancredo defender a importância de uma comissão com aquela tarefa e prever as dificuldades que ela teria de enfrentar. Ele já imaginava que, qualquer que fosse o projeto final, as críticas viriam violentas. [...]" FOLHA DE SÃO PAULO - Guia da Constituinte, op. cit., 1986, p.3. Segundo José Gomes da Silva, "a CPEC foi constituída [...] a partir de uma lista de 33 personalidades deixadas pelo falecido presidente Tancredo Neves e da qual o então ministro da Justiça, Fernando Lira (PMDB/PE), conseguiu manter 21 nomes. Por unanimidade, a CPEC escolheu como seu presidente o jurista Afonso Arinos de Melo Franco, a quem coube a tarefa de redigir o preâmbulo do documento". SILVA, José Gomes. Buraco negro: reforma agrária na Constituinte de 1987/88. Rio de Janeiro: Paz e Terra, 1989, p.40.

${ }_{43}$ Ver BRASIL. Decreto n. 91.450, de 18 de julho de 1985 . Disponível em: <http://www.senado.gov.br/legislacao>. Acesso em: 10 abr. 2008.

${ }^{44}$ Os juristas Paulo Bonavides, do Ceará, Eduardo Seabra Fagundes, procurador-geral do Estado do Rio de Janeiro à época e filiado ao PDT, e Fábio Konder Comparato, que redigiu o projeto de Constituição assumido pelo PT. Mas, ressalta Fábio Wanderley Reis, como "talvez o grande objetivo buscado, naquela conjuntura brasileira, fosse a instauração, com a eleição de uma Assembléia Constituinte e a elaboração de uma nova Constituição, da democracia", com "o objetivo o de recompor de maneira coerente a legalidade democrática corrompida e desfigurada por 21 anos de autoritarismo", criaram-se, "com respeito à Constituinte, não apenas grandes expectativas, mas expectativas desencontradas, algumas das quais se revelam, por exemplo, na disputa em torno da composição e do papel a ser desempenhado pela comissão criada sob a presidência do professor Afonso Arinos". REIS, Fábio Wanderley. Constituição, pacto e poder ou de uma constituição a outra melhor, com engenho e sorte. Op. cit. Fábio Konder Comparato mudou logo sua opinião sobre o Congresso Constituinte: "Eu não imaginava que houvesse uma reação muito forte. Porque, na verdade, a fórmula escolhida pelo presidente José Sarney e pelos seus conselheiros se afinava muito com o interesse do próprio Congresso, em fazer de conta que se ia realmente mudar o regime, quando, na verdade, se estava apenas trocando seu invólucro. Mas, agora, reconheço que tem surgido uma certa resistência no Congresso a esse tipo de golpe de Estado". COMPARATO, Fábio Konder. A constituinte do nada mudou (entrevista). Senhor, São Paulo, n.239, p.6-8, 16 out. 1985b, p.3.

${ }^{45}$ Ney Prado, membro e secretário-geral da Comissão, alinhou oito grandes críticas ao anteprojeto: "Preconceituoso: porque se preocupou com demasia com o passado, obstinando-se em contrariá-lo; Casuístico: porque nos seus quase 500 artigos, tudo prevê e tudo regula; Elitista: porque extrapola sua função originariamente concebida, de simples repositório de estudo e sugestões, para apresentar-se como modelo de texto constitucional pronto e acabado; Utópico: porque está desvinculado do Brasil real; Demagógico: porque exacerba expectativas distributivas, sem levar em conta a oportunidade, dosagem, e disponibilidade de meios; Socializante: porque, a pretexto de realizar a justiça social, restringe e esclerosa a liberdade de iniciativa econômica e desnecessariamente os Poderes do Estado; Xenófobo: porque discrimina empresa, tecnologia e capitais estrangeiros". PRADO, Ney. Os notáveis erros dos notáveis da Comissão Provisória de Estudos Constitucionais. Rio de Janeiro: Forense, 1987, p.5-6. 
trabalhos, dispositivos foram aprovados com a votação exígua de 13 ou 14 membros, pelo critério da maioria simples entre os membros presentes em cada reunião. ${ }^{46}$

A Comissão Provisória de Estudos Constitucionais, criada em 18 de agosto de 1985 pelo presidente da República, concluiu formalmente, em 18 de setembro de 1986, o seu anteprojeto de Constituição. ${ }^{47}$ Após a solenidade de entrega do documento final ao presidente da República, tornou-se pública a decisão presidencial de não encampar o anteprojeto, nem mesmo a título de sugestão aos constituintes, sob o fundamento de que "a Constituinte é livre e soberana para elaborar o seu próprio projeto e o Executivo não pode interferir nos trabalhos do Legislativo". Assim, foi-lhe dado

\begin{abstract}
o tratamento de um relatório ou documentário e não propriamente de um anteprojeto, qual fora concebido por Afonso Arinos. Ao invés de remetê-lo à futura Constituinte, como era de se esperar, Sarney simplesmente o enviou por despacho presidencial, datado em 24 de setembro de 1986, ao Ministério da Justiça, onde provavelmente ficou arquivado. ${ }^{48}$
\end{abstract}

\title{
4.6.1 Os trabalhos da Comissão Afonso Arinos
}

Acirrado debate travou-se, colocando em posições adversas, de um lado, aqueles que discordavam da idéia de se ter uma comissão, e, de outro, os que pensavam que o processo constituinte deveria convergir diretamente para o seio da Assembléia, que somente aos constituintes caberia elaborar as propostas e somente a eles caberia explorar as diferentes opções. Em boa medida, o debate sobre a necessidade, conveniência e oportunidade da Comissão Provisória de Estudos Constitucionais esteve jungido ao entendimento sobre a própria natureza da Assembléia Constituinte. Por um lado, entendia-se a assembléia constituinte como exclusiva, portanto, sem maiores condicionamentos, "mais 'rousseauísta', como se o Congresso Constituinte devesse ser uma tábua-rasa do país, uma assembléia originária, uma assembléia primeira dos cidadãos". ${ }^{49}$ Por outro lado, havia os que queriam, ou, simplesmente, haviam se acomodado à idéia de um Congresso Constituinte, nomeadamente os congressistas, que se rebelavam contra a existência da Comissão Afonso Arinos.

\footnotetext{
${ }^{46}$ REALE, Miguel. Liberdade e democracia (em torno do anteprojeto da Comissão Provisória de Estudos Constitucionais. São Paulo: Saraiva, 1987.

${ }^{47}$ BRASIL. Anteprojeto constitucional, elaborado pela Comissão Provisória de Estudos Constitucionais. Diário Oficial, Brasília, suplemento especial ao n. 185, 26 set. 1986.

${ }^{48}$ BONAVIDES, Paulo; ANDRADE, Paes de. História constitucional do Brasil. Brasília: Paz e Terra, 1989, p.453-454.

${ }^{49}$ LAMOUNIER, Bolívar. Os trabalhos da "Comissão Afonso Arinos". In: FORTES, Luiz Roberto S.; NASCIMENTO, Milton M. do (Org.), op. cit., 1987, p.84.
} 
Deve-se observar, todavia, que, a partir do instrumento legal que tratou da sua formação, a Comissão Afonso Arinos foi definida como uma comissão de estudos. Diferentemente, por conseguinte, da Comissão dos Cinco, instituída pelo Governo Provisório nos primórdios do regime republicano, pois esta deveria produzir, como de fato produziu, um texto que, inclusive, entrou em vigor antes dos trabalhos constituintes. Tãosomente no aspecto da finalidade de promoção de estudos, a Comissão Afonso Arinos se assemelha, guardadas as coisas que mudam, à Subcomissão do Itamarati.

Os seus trabalhos se desenrolaram em três fases. Na primeira, deu-se ênfase às sugestões da sociedade, cuja "mecânica foi regionalizada - grupo de São Paulo, grupo do Rio de Janeiro, grupo de Brasília, do Nordeste, de Minas - de tal maneira que facilitasse, que se tornasse mais fácil a audiência à sociedade", e "os membros da comissão, individual e coletivamente, tentaram estabelecer comunicações, contatos, com setores os mais variados, remetendo correspondência, divulgando seus trabalhos". ${ }^{50}$ Finda essa primeira fase, que durou, mais ou menos, de setembro a dezembro, a Comissão foi dividida em dez comitês, ${ }^{51}$ cada um trabalhando, de maneira mais técnica, a matéria que lhe estava afeta, dando-lhe forma jurídica e votando-a. Finalmente, votaram-se em plenário os relatórios provenientes dos dez comitês, produzindo-se, então, o relatório final ou esboço do anteprojeto a que se refere o Decreto ${ }^{\circ} 91.450$, de 18 de julho de $1985 .^{52}$

\subsubsection{A Comissão e o Congresso Nacional}

A Comissão Provisória de Estudos Constitucionais sofreu resistências no Congresso Nacional, principalmente do presidente do PMDB e do líder do governo na Câmara, deputado Pimenta da Veiga (PMDB-MG), por conta da sua vinculação ao Executivo, especialmente ao Ministério da Justiça, então ocupado por Saulo Ramos. O objetivo da comissão seria realizar esboço da nova carta constitucional, mas a sua formação sofreria severas críticas da sociedade civil.

Parlamentares dos mais diversos partidos vislumbraram na Comissão um mecanismo capaz de minimizar-lhes a competência de discutir o assunto constituinte, diminuindo o

\footnotetext{
${ }^{50}$ Ibid., 1987, p.91.

51 Comitês da Declaração de Direitos; da Federação, do Legislativo e da Organização Partidária; do Executivo; do Judiciário; da Educação, Cultura e Comunicações Sociais; da Saúde, do Meio Ambiente, Ciência e Tecnologia; da Ordem Social; e da Segurança e Defesa das Instituições Democráticas. Ver MENDES, Cândido. A inconfidência brasileira: a nova cidadania interpela a constituinte. Rio de Janeiro: Forense-Universitária, 1986.

${ }^{52}$ BRASIL. Decreto n. 91.450, de 18 de julho de 1985, op. cit., 2008.
} 
papel do Congresso Nacional. Flávio Bierrenbach, relator da Comissão Mista de Deputados e Senadores para a apreciação da emenda convocatória da Assembléia Nacional Constituinte, enviada ao Congresso pelo presidente da República, criticava a criação da Comissão, afirmando a desnecessidade do anteprojeto que caberia a ela elaborar. ${ }^{53}$

Embora o presidente da República afirmasse que a "Comissão não substituirá o Congresso nem o povo", e membros do governo declarassem que a Comissão dos Notáveis não limitaria os poderes constituintes, visto que os constituintes poderiam aproveitar o anteprojeto, alterá-lo, aprová-lo ou mesmo rejeitá-lo globalmente, cresciam as críticas no Congresso Nacional à iniciativa governamental. Faziam, assim, coro aos protestos que diversos organismos da sociedade civil orquestravam contra a Comissão.

\subsubsection{A Comissão e o anteprojeto}

Segundo Bolívar Lamounier, membro da CPEC, no que se refere à ordem econômica e social, "a crítica ao projeto talvez venha de maneira mais acentuada dos setores mais conservadores da sociedade". Isto porque

[...] tratará de tornar mais nítido que a ordem econômica tem, como pressuposto, como diretriz fundamental, a melhoria das condições de vida, do bem-estar da população; fará referências explícitas à dívida social acumulada, quer dizer, à necessidade de se redistribuir a renda e riqueza no País; insistirá no planejamento governamental como forma inarredável, num país subdesenvolvido, para se alcançar esses objetivos; enfim, será um texto de orientação desenvolvimentista, reformista no sentido social, provavelmente algo nacionalista no que refere ao capital e às empresas estrangeiras. $[\ldots]^{54}$

Encerrados os trabalhos da Comissão, as ressalvas, as restrições e os questionamentos advieram mais dos setores situados à direita do espectro políticoideológico. Um dos seus membros, empresário, ressaltava que, no capítulo referente à ordem econômica, era patente "o forte conteúdo intervencionista e estatizante", demonstrando mais aversão ao capital do que prioridade ao social, pois

[...] o conjunto do articulado apóia-se na premissa de que a acumulação de capital - não importa a forma pela qual foi conseguida, nem o uso que dela é feito - é, em si, um mal e como tal deve ser tratada. Os justos, amplos e liberais direitos e garantias ficam restritos aos indivíduos (enquanto carentes). A propriedade é questionada e condicionada; a rural (ainda que produtiva) está sujeita a desapropriação, o proprietário urbano pode ser compelido (!) a vender sua terra. $[\ldots]$

\footnotetext{
${ }^{53}$ Ver BIERRENBACH, Flávio. Quem tem medo da Constituinte? Rio de Janeiro: Paz e Terra, 1986.

${ }^{54}$ LAMOUNIER, Bolívar. Os trabalhos da "Comissão Afonso Arinos". In: FORTES, Luiz Roberto S.; NASCIMENTO, Milton M. do (Org.), op. cit., 1987, p.93.
} 


\section{$[\ldots]$}

Em síntese os capítulos da ordem econômica e social refletem uma tomada de posição de natureza ideológica, e, por isso, talvez venham a merecer dos constituintes especial atenção. ${ }^{55}$

Outro, de posição ideológica contrária, avaliava que a Comissão Provisória trabalhou de acordo com a vontade popular, porquanto inserira no projeto reivindicações do movimento sindical (direito de greve, pleno emprego e representação em nível de empresa) e também da sociedade, como, por exemplo, viabilização da reforma agrária e urbana, defesa da tecnologia interna, escola gratuita para todos dos seis aos quinze anos, levantamento da procedência e validade da dívida externa, superação das desigualdades sociais e regionais, proscrição da tortura como crime inafiançável, afirmando que "a população, os partidos e a Assembléia Nacional Constituinte recebem uma proposta que não desmerece os que lutaram pela democracia e pelo avanço social". ${ }^{56}$

A crítica dos conservadores ao texto final da Comissão Provisória de Estudos Constitucionais e o afastamento do secretário-geral são indicadores de que a vitória foi dos progressistas. A Comissão Afonso Arinos discutiu bastante a idéia de uma democracia ao mesmo tempo representativa e participatória, todavia não a adotou como princípio fundamental. Os pontos mais importantes de sua proposta foram a adoção do parlamentarismo, o fortalecimento dos partidos políticos, maior inteligibilidade do sistema eleitoral e a criação de uma federação forte. Instrumentos para legislar diretamente, tais como a iniciativa popular, foram aceitos em princípio, com o entendimento de que uma extensa regulamentação por lei se tornava necessária antes que fossem postos em prática.

De modo geral, tem-se tentado forçar a analogia entre a Comissão Provisória de Estudos Constitucionais e a Comissão de cinco juristas, designada por Deodoro da Fonseca, em 1989, e presidida por Saldanha Marinho, e a Subcomissão do Itamarati, de 1932, nomeada por Getúlio Vargas. Exceto pela característica de ambas as comissões terem sido designadas pelo Poder Executivo, as semelhanças tendem a desaparecer.

De fato, a primeira comissão republicana acabou por elaborar anteprojeto que, reelaborado pelo Governo Provisório, nomeadamente, por Rui Barbosa, e editado por decreto de 22 de junho de 1890 como texto constitucional a viger de imediato, embora ad

\footnotetext{
${ }^{55}$ QUINTELLA, Sérgio F. A ordem econômica e social na constituinte. Folha de São Paulo - Guia da Constituinte, São Paulo, p.25, 19 set. 1986.

56 BARELLI, Walter. Sintonia com vontade popular marcou Comissão. Folha de São Paulo - Guia da Constituinte, São Paulo, p.25, 19 set. 1986.
} 
referendum do futuro Congresso Constituinte. A própria composição da Comissão Provisória de Estudos Constitucionais possibilitou a pluralidade de classes e grupos funcionais e de idéias, sepultando, se é que havia, a possibilidade de um texto à imagem e semelhança de um projeto conservador ou continuísta, em relação ao interregno burocráticoautoritário, o que acabou por resultar, inclusive, no próprio arquivamento do texto.

Por sua vez, a Subcomissão do Itamarati, criada pelo Decreto n ${ }^{\circ} 21.402$, de 14 de maio de 1932, embora mais ampla, também estava profundamente jungida ao Governo Provisório. Entretanto, se destacou por um debate que se prolongou por cerca de seis meses. $^{57}$

De modo geral, as potencialidades da CPEC não foram bem entendidas. Todavia, a decisão original do Poder Executivo de apresentar um projeto de Constituição à Assembléia Constituinte apresentava vantagens sobre outras soluções. Como ressaltou, à época, João Almino, “os trabalhos desta Comissão são, sem dúvida, preferíveis à alternativa de se ter um projeto redigido a poucas mãos dentro do Executivo para ser lançado, sem grande preparação e sem prévia discussão, diretamente à Assembléia". ${ }^{58}$

A importância do anteprojeto da Comissão Provisória de Estudos Constitucionais foi intuída mesmo por alguns dos seus críticos. Observou Manoel Gonçalves Ferreira Filho, por exemplo, que o anteprojeto - a cuja análise dedicou um livro inteiro de crítica mordaz ,59 “por polêmico que seja, é o único texto oficioso com que contará a Constituinte". Por conseguinte, "é preciso analisar os seus principais aspectos, dada a repercussão que ele terá, forçosamente, sobre os trabalhos da Assembléia". ${ }^{60}$

\footnotetext{
${ }^{57}$ Ver AZEVEDO, José Afonso de Mendonça. Elaborando a constituição nacional: atas da Subcomissão elaboradora do anteprojeto 1932/1933. Brasília: Senado Federal, Conselho Editorial, 2004.

58 ALMINO, João. O processo político na Constituinte de 1987. In: FORTES, Luiz Roberto S.; NASCIMENTO, Milton M. do (Org.), op. cit., 1987, p.77.

${ }^{59}$ Entre outros aspectos formais e materiais do anteprojeto, critica: entre "as maiorias ocasionais que adotaram os vários capítulos do texto, pode-se duvidar que reflitam a maioria do povo brasileiro"; "como a composição foi estabelecida para dar lugar a representantes dos mais variados setores da sociedade, obviamente nela assumiram um peso desproporcional à sua força na comunidade certas minorias mais extremadas"; "precedido de um 'prólogo' elaborado em estilo condoreiro [...] e de um 'preâmbulo' redigido por Afonso Arinos (aparentemente antes mesmo de estabelecido o anteprojeto), peças a serem examinadas mais por mestres de literatura do que por meros juristas"; "o exame circunstanciado do anteprojeto não permite uma apreciação favorável do seu texto", caracterizando-se como "um vasto programa, não uma Constituição"; dotado de "detalhismo", "verbalismo", "demagogia", "bom-mocismo", "hipocrisia"; "conservadorismo"; "nacionalisteiro"; "desnacionalizante"; "mal escrito". FERREIRA FILHO, Manoel Gonçalves. O anteprojeto dos notáveis. São Paulo: Saraiva, 1987, passim.

${ }^{60}$ Ibid., 1987, p.3.
} 


\title{
4.7 O Congresso Constituinte e o "paradoxo do êxito"
}

\author{
O regime que se consolidou no Brasil a partir de 1968 promoveu inédita
} centralização de poderes no Executivo, deixando o Legislativo à margem da formulação, da decisão e da implementação da política nacional. Relegado a desempenhar papel secundário no sistema político, o Congresso Nacional só deixou de funcionar regularmente por alguns períodos, só que, ao tempo em que lhe foi reservada posição de somenos importância, ampliou-se a ideologia, quando não sobre a sua inutilidade, ${ }^{61}$ pelo menos sobre a impossibilidade de o mesmo ser agente capaz de promover ou facilitar o processo de desenvolvimento. ${ }^{62}$

Assim, diferentemente do autoritarismo dos países vizinhos, que, via de regra, não suportaram a existência da instituição legislativa, no Brasil o comportamento utilizado

${ }^{61}$ Ver, por todos, Roberto Campos, quando considera: “[...] No caso brasileiro, há poucas dúvidas que, antes das modificações constitucionais trazidas pela Revolução de 1964, o Congresso havia se transformado em 'engenho de inflação' ao multiplicar o orçamento de dispêndio, e em 'fator de distorção' de investimentos pela sua hipersensibilidade a pressões regionais capazes de destruir a coerência e o equilíbrio de planos e programas. Destarte, a dupla constrição imposta à atividade legislativa - primeiro, a vedação do acréscimo de despesas e, segundo, a proibição de aprovação de novos projetos sem a correlata especificação das receitas - nasceu das lições úteis da experiência e não do capricho fútil dos tecnocratas [...]”. CAMPOS, Roberto. O Poder Legislativo e o desenvolvimento. In: MENDES, Cândido (Org.). O legislativo e a tecnocracia. Rio de Janeiro: Imago/Conjunto Universitário Cândido Mendes, 1975, p.35-36.

${ }^{62}$ Uma interpretação prestigiosa a respeito do papel do Legislativo no sistema político-constitucional iniciado em 1946 foi desenvolvida por Celso Furtado, para quem as constituições políticas, inclusive a de 1946, foram usadas sempre como uma poderosa arma com a qual a oligarquia agrária buscava manter o seu status de principal força política. E tanto o Senado Federal quanto a Câmara dos Deputados constituíam-se instrumentos a favor das oligarquias, dos setores atrasados e renitentes ao processo de desenvolvimento: a configuração federativa, que conferia demasiados poderes ao Senado, no qual "os pequenos Estados agrícolas e as regiões menos desenvolvidas exercem uma influência decisiva", fazia com o poder legislativo de fato pertencesse "a uma minoria da população habitante de regiões onde os interesses dos grandes proprietários são poderosos”. O princípio de legitimidade do governo padecia de uma contradição inerente, pois, se de um lado havia necessidade de o governo adequar-se à Constituição, por outro, o presidente da República, para contentar a maioria que o elegeu, era levado a perseguir objetivos incompatíveis com os limites impostos a seu poder pelo Congresso, em virtude da Constituição. Uma contradição entre os dois princípios de legitimidade estabelecia-se: agir de acordo com os parâmetros constitucionais ou agir para satisfação da vontade popular. Manifestando-se como traço da política brasileira durante a República Populista e como o sintoma visível de um conflito interior importante, a corromper todo o processo político, estava, por via de conseqüência, a luta entre os presidentes da República e o Congresso Nacional, este funcionando como centro do poder das classes dominantes tradicionais. FURTADO, Celso. O Brasil ou os entraves ao desenvolvimento. Paz e Terra, Rio de Janeiro, n.4, p.174-175, 1967. Wanderley Guilherme dos Santos, ao analisar a crise de 1964, concorda que ela foi resultado de um estado de imobilismo político, porém tal imobilismo não seria decorrência de um impasse entre o Executivo de base urbana versus um Legislativo de raízes rurais. O impasse teria sido conseqüência imperiosa de um conflito político caracterizado pela dispersão de recursos entre atores radicalizados, que impossibilitou o desenvolvimento adequado do sistema, acarretando uma crise de paralisia decisória. Indo de encontro ao pensamento de Celso Furtado, o mesmo autor questiona que nunca ficou provado de maneira conclusiva que o Legislativo, mesmo com a maioria de seus membros eleitos em áreas rurais, "houvesse sido consistentemente reacionário e hostil às propostas modernizantes oriundas do Executivo". Afirma também que outra tese, ainda a ser demonstrada, "é o pretendido caráter progressista dos sucessivos Executivos brasileiros, algo que permanece suposto mais que confirmado". SANTOS, Wanderley Guilherme dos. Sessenta e quatro: anatomia da crise. São Paulo: Vértice, 1986, p.22 e 20. 
pelas forças que se assenhorearam do poder a partir de 1964 foi debilitar o Congresso através de sucessivas depurações nos seus quadros, de maneira a extinguir qualquer oposição ao projeto autoritário em implantação, coibir a emergência de quadros desviantes, extorquir a sua capacidade de legislar autonomamente ou de exercer efetiva função fiscalizadora e malbaratar qualquer prerrogativa importante dos parlamentares. ${ }^{63}$

Por sua vez, o processo de transição política no Brasil caracterizou-se pela continuidade. Os traços e os atores políticos do ancien régime perduraram ocupando diversos loci de poder. Inicialmente, tentou-se demonstrar a continuidade da instituição militar no evoluir da transição, observando-se que, no Brasil, sob uma perspectiva comparada, era o caso mais acentuado. ${ }^{64}$ Depois, cuidou-se também de acentuar a continuidade dos atores políticos civis e as suas lealdades, ${ }^{65} \mathrm{com}$ a conclusão de que "comparativamente esta continuidade é ainda maior no tocante ao pessoal civil governante, os 'notáveis' daquele regime". ${ }^{66}$

Por conta da lentidão e da continuidade dos atores políticos do passado, perdurou, inclusive, um modus faciendi de fazer política mais afeito a uma sociedade oligárquica, a permanência de um estilo intimamente vinculado às formas tradicionais de ação política,

${ }^{63}$ Durante o regime militar, o Congresso Nacional foi fechado por três vezes. A primeira foi decretada em 1966 pelo presidente Humberto de Alencar Castelo Branco. Ante a resistência de congressistas, sob a presidência da Câmara de Adauto Lúcio Cardoso, o coronel Meira Matos, comandando tropa do Exército, invadiu e fechou o prédio do Congresso. Em 20 de outubro de 1966, foi baixado o Ato Complementar n. 23, decretando recesso do Congresso dessa data até 22 de novembro. Ver LINHARES, Marcelo. O governo Castello Branco. Fortaleza: ABC Fortaleza, 1999. Na segunda vez, que perdurou até outubro de 1969, o Ato Complementar n. 38, de 13 de dezembro de 1968, editado pelo presidente Costa e Silva, estabeleceu: "Art. $1^{\circ}$. Nos termos do art. $2^{\circ}$ e seus parágrafos, do Ato Institucional $\mathrm{n}^{\circ} 5$, de 13 de dezembro de 1968, fica decretado o recesso do Congresso Nacional, a partir desta data". BRASIL. Ato Complementar n. 38, de 13 de dezembro de 1968. Disponível em: 〈http://www.senado.gov.br/legislacao>. Acesso em: 6 jun. 2008. Na terceira, durante o governo do general Ernesto Geisel, o Ato Complementar $n$. 102, de $1^{\text {o }}$ de abril de 1977, decretou o fechamento do Congresso, e o Ato Complementar $\mathrm{n}^{\mathrm{o}} 103$, de 14 de abril do mesmo ano, decretou: "Art. 1 ${ }^{\circ}$. Fica suspenso, a partir de 15 de abril de 1977, o recesso do Congresso Nacional decretado pelo Ato Complementar $n^{\circ} 102$, de $1^{\circ}$ de abril de 1977". BRASIL. Ato Complementar n. 102, de $1^{\circ}$ de abril de 1977. Disponível em: 〈http://www.senado.gov.br/legislacao>. Acesso em: 6 jun. 2008. Sobre o Poder Legislativo durante o autoritarismo-burocrático, ver, entre outros, MENDES, Cândido (Org.). O legislativo e a tecnocracia. Rio de Janeiro: Imago/Conjunto Universitário Cândido Mendes, 1975; ABRANCHES, Sérgio. O processo legislativo brasileiro: conflito e conciliação na política brasileira. Dissertação (Mestrado em Ciências Sociais). Brasília, Universidade de Brasília, 1973; ABRANCHES, Sérgio; SOARES, Gláucio Ary Dillon. As funções do legislativo. Revista de Administração Pública, Rio de Janeiro, n.7, p.73-98, 1973; MORAES, Filomeno. A separação de poderes no Brasil pós-88: princípio constitucional e práxis política. In: SOUZA NETO, André P. de; BERCOVICI, Gilberto; MORAES, Filomeno; LIMA, Martônio M.

${ }^{64}$ STEPAN, Alfred C. Os militares: da abertura à Nova Republica. Rio de Janeiro: Paz e Terra, 1986.

${ }^{65}$ O’DONNELL, Guillermo. A transição é um imenso pastiche. Senhor, São Paulo, n.335, p.5-13, 18 ago. 1987.

${ }^{66}$ O’DONNELL, Guillermo. Hiatos, instituições e perspectivas democráticas. In: REIS, Fábio Wanderley; O’DONNELL, Guillermo (Org.). A democracia no Brasil: dilemas e perspectivas. São Paulo: Vértice/RT, 1988, p.61. 
isto no país que, em algumas dimensões, era o mais moderno da América Latina. ${ }^{67}$ Ademais, na conjuntura pré-constituinte, acentuou-se que "o Congresso parece ser o lugar em que mais se condensam, e de maneira mais visível, as características mencionadas", isto é, um estilo predominantemente prebendalista. ${ }^{68}$

Assim, em relação ao autoritarismo-burocrático instalado em outros países da América Latina, se se considerou como vantagem adicional brasileira o fato de não ter sido eliminado o Congresso Nacional, tal juízo se modificou com o tempo. ${ }^{69}$ A propósito, Guillermo O’Donnell acrescenta:

[...] esta especificidade do Brasil pareceria melhorar ainda mais as suas perspectivas de consolidação democrática, já que a subsistência e posterior revitalização daquelas instituições dariam um marco institucional para processar melhor e com menos incertezas do que nos casos em que esse marco foi suprimido, os múltiplos conflitos e incertezas de ambas as transições. Nos casos de descontinuidade abrupta, essas instituições devem ser reinventadas por uma classe política que carece de experiência, ou que leva um bom tempo sem interagir nos contextos institucionais próprios da democracia. ${ }^{70}$

Destarte, a continuidade do pessoal político do regime autoritário passou a constituir um dos fatores do "paradoxo do êxito" "11 no que concerne à consolidação democrática brasileira. E, de outra parte, contribuiu para a tendência à autarquização que o Congresso Nacional ocupou nas décadas seguintes. ${ }^{72}$

${ }^{67}$ Ibid., 1988, p.72-90.

${ }^{68}$ Ibid., 1988, p.82.

${ }^{69}$ Para uma visão comparativa, ver, principalmente, O’DONNELL, Guillermo; SCHMITTER, Philippe (Ed.). Transições do regime autoritário. São Paulo: Vértice,1988a; e O’DONNELL, Guillermo; SCHMITTER, Philippe (Ed.). Transição do regime autoritário: primeiras conclusões. São Paulo: Vértice/RT, 1988 b.

${ }^{70}$ Ibid., 1988b, p.57-58.

${ }^{71}$ O’DONNELL, Guillermo. Transições, continuidades e alguns paradoxos. In: REIS, Fábio Wanderley; O’DONNELL, Guillermo (Org.). A democracia no Brasil: dilemas e perspectivas. São Paulo: Vértice/RT, 1988, p.60. Guillermo O’Donnell pondera que “as graves dificuldades enfrentadas pela consolidação democrática no Brasil, embora não exclusivamente, são devidas, paradoxalmente, ao relativo sucesso econômico e à baixa repressividade do regime burocrático-autoritário precedente, bem com a algumas características específicas desse regime e sua transição conseqüente. Um segundo argumento [...] é que os fatores que sustentam aquele paradoxo por um lado expressam e pelo outro tendem a reforçar algumas características que, embora possam ser observadas em outros países, aparecem em grau extremo no Brasil: imensas desigualdades sociais combinadas com um formidável dinamismo econômico e com padrões extremamente arcaicos e repressivos de autoridade, inclusive os que vinculam Estado e sociedade e as diversas classes e setores sociais entre si”. O’DONNELL, Guillermo, op. cit., 1988, p.56-57.

${ }^{72}$ Como anota Renato Lessa: "O fato é que o Congresso Nacional manteve-se como locus político durante a ditadura e acabou por hospedar o ato final de sua dissolução, em 1985. A singularidade não dispensa um lado sombrio: o parlamento que subsiste e sobrevive ao autoritarismo tem como marca a distância política e existencial para com o mundo além de si próprio. Em outros termos, um dos legados dos anos autoritários à democracia no Brasil foi o da autarquização do Legislativo, que viria a ser exponenciada nas décadas seguintes.” LESSA, Renato. Apresentação. In: PILATTI, Adriano. A Constituinte de 1987-1988: progressistas, conservadores, ordem econômica e regras do jogo. Rio de Janeiro: PUC Rio; Lumen Juris, 2008, p.XI. 
Como anota Adriano Pilatti, o processo constituinte foi "processo decisório de caráter extraordinário -, protagonizado por representantes que acumulavam mandato para o trato da política ordinária - deputados e senadores eleitos em cada Estado da Federação", ${ }^{73}$ cujos mandatos só poderiam ser abreviados por decisão própria. Ademais,

[...] o Processo Constituinte de 1987-1988 foi procedimento formal parlamentar, cujas decisões formais cabiam exclusivamente a atores parlamentares, através da observância de procedimentos tipicamente parlamentares, no âmbito de uma instituição parlamentar constituída: a atuação e a interferência de grupos de pressão, movimentos sociais, grupos econômicos, órgãos de formação de opinião pública e quaisquer outros atores extraparlamentares, institucionais ou não, passava necessariamente pelo filtro mundo parlamentar, seu ethos e suas formas. ${ }^{74}$

Assim, apesar do "paradoxo do êxito", o Congresso Nacional, transmutado em Congresso Constituinte, formularia certamente o consenso mais importante da história político-constitucional brasileira, a realização da Constituição de 1988.

\subsection{O debate sobre os limites dos poderes do Congresso Constituinte}

O debate em torno da necessidade de convocação de uma Assembléia Constituinte ganhou densidade tanto no Congresso Nacional como em foros importantes da sociedade civil. A convocação de uma Assembléia Constituinte foi inserida posteriormente no “Compromisso com a Nação", documento-base da Aliança Democrática (AD). ${ }^{75}$ Tal documento priorizava a necessidade de proceder-se à reorganização institucional do país, tendo como horizonte uma nova constituição, conforme foi reiterado no discurso de Tancredo Neves no Congresso, após a escolha pelo Colégio Eleitoral, em 15 de janeiro de 1985.

O debate sobre os limites da reforma constitucional e, posteriormente, sobre os limites da Assembléia Constituinte, permeou o processo que vai da sua convocação até a feitura da Constituição. A idéia da Assembléia Constituinte foi colocada inicialmente como mecanismo de controle do regime autoritário, como um recurso do MDB, como tática para confrontar o Executivo.

\footnotetext{
${ }^{73}$ PILATTI, Adriano. A Constituinte de 1987-1988: progressistas, conservadores, ordem econômica e regras do jogo. Rio de janeiro: PUC Rio; Lumen Juris, 2008, p. 12.

${ }^{74}$ Ibid., 2008, p. 12.

${ }^{75}$ O compromisso da Aliança Democrática veio a lume em 7 de agosto de 1984. Foram seus signatários: Ulysses Guimarães, presidente do PMDB; Tancredo Neves, governador de Minas Gerais; Antônio Aureliano Chaves de Mendonça, vice-presidente da República; e Marcos Maciel, senador por Pernambuco.
} 
Depois, a tentativa de alargamento do escopo da Assembléia Constituinte foi recuperada por grupos radicais dentro do PMDB e pelos partidos de esquerda, tentativa contra qual, já no Congresso Constituinte, se insubordinou principalmente o grupo de parlamentares que se compuseram o Centro Democrático (Centrão). ${ }^{76}$ Tentou-se um projeto de decisão em que se estabelecia a necessidade de a Assembléia manifestar-se sobre a Constituição vigente, para mantê-la tão somente naquilo que pudesse assegurar "a regularidade do período que antecederá a promulgação da nova Constituição". Queria-se assim: 1. restrição ao máximo da possibilidade do exercício da função legislativa pelo presidente da República através de decretos-lei; 2. aos senadores eleitos em 1982, assegurar-se-ia, tão-somente, o direito de voz na discussão da nova Constituição, visto que, no entender do projeto, não houvera outorga de poderes constituintes originários, mas tãosomente derivados ou reformacionais; 3. o projeto não confirmava, pela Constituição Federal (art. 158), a criação do estado de emergência, alterando a disciplina deste e do estado de sítio. Previa ainda confirmar o presidente da República, remetendo a duração do seu mandato para as disposições transitórias da nova constituição, mas colocando como seu objetivo legal, em primeiro lugar, o presidente da constituinte e, em seguida, o presidente do Supremo Tribunal Federal. Por fim, dispunha que a Assembléia Constituinte chamasse o poder legislativo ordinário a si, não permitindo a existência paralela de um poder fundado no sistema constitucional do autoritarismo. ${ }^{77}$

\footnotetext{
${ }^{76}$ Segundo Ronaldo Baltar, "o Centrão chegou a reunir 320 parlamentares no momento da revisão do regimento interno logo após o encerramento dos trabalhos da Comissão de Sistematização. O grupo de parlamentares organizou-se em torno de um projeto alternativo ao projeto do Relator da Comissão. [...] No entanto, o maior destaque da atividade de Centrão, ao longo do primeiro e segundo turnos de votação, foi a ação articuladora do núcleo formado em torno de parlamentares como os Deputados Rubem Medina, PFLRJ, Paes Landim, PFL-PI, Luiz Eduardo, PFL-BA, Ricardo Fiúza, PFL-PE e Roberto Cardoso Alves, PMDB-SP. Coordenado por um grupo de parlamentares, o Centrão desempenhou a tarefa de organizar o conjunto de votações favoráveis à limitação do papel do Estado na ordem econômica, na maioria dos casos com mais agilidade do que as lideranças partidárias incumbidas desta tarefa”. BALTAR, Ronaldo, op. cit., 1996, p.168. Por sua vez, Renato Lessa chama a atenção para o menosprezo que os componentes do Centrão dirigiam aos aspectos doutrinários e normativos do processo constituinte, observando: "Para o assim chamado Centrão - a reaglutinação da maioria governista e conservadora na Constituinte - o debate constitucionalista e normativo reduz-se a princípios designados como 'retóricos' e 'filosóficos'. Escusa dizer que a concepção que possuíam a respeito de que 'retórica' e 'filosofia' significam é, para dizer de modo leve, imperita e associada à idéia de especulação inconseqüente. Nas emendas que apresentou, o Centrão não propôs nenhuma alteração ou rejeição a respeito do desenho dos princípios fundamentais que orientam normativamente a Carta. A exceção ficou por conta do parágrafo único do artigo $1^{\circ}$, que fazia menção ao exercício direto do poder pelo povo, idéia sempre explosiva, ao ponto de se fazer notar mesmo pelos que não conferem nenhuma atenção às idéias. [...]". LESSA, Renato. A Constituição brasileira de 1988 como experimento de filosofia pública: um ensaio. In: OLIVEN, Ruben George; RIDENTI, Marcelo; BRANDÃO, Gildo Marçal (Org.). A Constituição de 1988 na vida brasileira. São Paulo: Aderaldo \& Rothschild Editores; Anpocs, 2008, p.370.

77 JOBIM, Nelson. Documento: Jobim e seu projeto de maioridade. Senhor, São Paulo, n.308, p.3-5, 10 fev. 1987. Para um inventário de razões jurídicas e políticas contrárias à argumentação do projeto de decisão do
} 
O inspirador do "projeto de decisão", ${ }^{78}$ o deputado Nelson Jobim (PMDB-RS), reforçando a idéia de que o Congresso Constituinte se afirmasse como poder não como competência, aduzia que

O conteúdo deste projeto de decisão corporifica e explicita, claramente, um fato político básico: a Assembléia, convocada pela Emenda Constitucional $n^{\circ} 26$, assume-se, iniludivelmente, como poder constituinte originário, rompendo com qualquer exegese que nela pretenda ver um poder constituinte derivado e dependente do sistema constitucional de 1967. Será falso afirmar que nossa Assembléia, porque foi convocada dentro do bojo do sistema constitucional anterior, através de uma emenda à Constituição de 1967, não se pode ter como efetivamente livre e soberana.

Ao ser aceita essa afirmação como verdadeira, estaríamos a admitir que somente atos revolucionários poderiam dar ensejo à emergência do poder constituinte originário. Seria reconhecer, então, que o poder constituinte originário somente se explicaria com o colapso do sistema anterior e nunca pela via da transição pacífica.

É exatamente esse o desafio que a história política brasileira põe a nós, membros da Assembléia: assumirmos nossa condição de constituintes com poderes originários ou nos perder nos meandros das regras produzidas pelo poder autoritário que deu ao sistema vigente. ${ }^{79}$

A propósito, uma das polêmicas a respeito dos poderes constituintes, se deu entre Saulo Ramos, e o deputado Bernardo Cabral (PMDB-AM), relator do Congresso Constituinte. Para Saulo Ramos, a Assembléia Nacional Constituinte possuía, na verdade, poderes constituintes de segundo grau, reformacionais:

Não há a menor dúvida de que a Assembléia Nacional Constituinte instalada no Brasil, em 1987, é derivada, e que os seus poderes são secundários, o que vale dizer que ela tem poderes de reforma, e que, por mais gerais que sejam, não se revestem de força e autoridade suficientes para permitir deliberações sobre o que não poderia o Congresso decidir por simples emenda. ${ }^{80}$

Já para Bernardo Cabral, a Assembléia detinha "soberania e liberdade irrestritas" e originalidade, os seus poderes eram realmente constituintes, hauridos da "manifestação popular":

então deputado Nélson Jobim (PMDB-RS), ver RAMOS, Saulo. A assembléia constituinte: o que pode o que não pode: natureza, extensão e limitações de seus poderes. Rio de Janeiro: Alhambra, 1987.

78 Algum tempo depois, o Regimento Interno da Assembléia Nacional Constituinte-RIANC (Resolução n. 2 , de 24 de março de 1987) estabeleceu: "os projetos de decisão destinam-se a sobrestar medidas que possam ameaçar os trabalhos e as decisões soberanas da Assembléia Nacional Constituinte, necessitando ter o apoiamento de 1/3 (um terço) dos Constituintes, e serão encaminhados à Comissão de Sistematização, que, num prazo de 5 (cinco) dias, emitirá parecer prévio, sendo arquivado definitivamente o projeto que dela receber parecer contrário. Caso tenha parecer favorável, a decisão final será proferida pelo Plenário, por maioria absoluta de votos, em dois turnos de discussão e votação" (art. 59, § $7^{\circ}$ ).

${ }^{79}$ JOBIM, Nelson, op. cit., 1987.

${ }^{80}$ RAMOS, Saulo, op. cit., 1987, p.11. 


\begin{abstract}
A Assembléia Nacional Constituinte de 1987 não se originou de ruptura da ordem jurídica. Ela se assegurou de soberania e liberdade irrestritas, em razão da manifestação popular, única fonte legítima de poder, que se consagrou nos votos das urnas de 1986. A ruptura dar-se-á, por isso, com a promulgação da nova Constituição, quando em verdade estaremos a sair da excepcionalidade institucional para a plenitude do Estado de Direito, pois encerrado o período de transição que gênio político brasileiro construiu como meio para se atingir a normalidade democrática. Não por outra razão, esta será uma Constituição analítica, por força da necessidade de assegurar todos os instrumentos e salvaguardas para a consecução dos objetivos políticos, sociais e econômicos do povo brasileiro. ${ }^{81}$
\end{abstract}

Evidentemente, a afirmação dos poderes do Congresso Constituinte não era um problema de torneio de juridicidade, senão um torneio político, o qual, politicamente, se encaminhou durante os dois anos dos trabalhos constituintes.

\title{
4.9 A retirada de alguns "entulhos autoritários"
}

O caráter de "transição por transação", que marcou a derrocada do autoritarismo, fez com que, ao longo de vários anos, mudanças político-constitucionais acontecessem, caracterizando o processo de mudança constitucional como de longo prazo. Um conjunto de reformas na legislação, ou mesmo nenhuma mudança legislativa, paulatinamente, afastou alguns dos "entulhos autoritários".

\subsubsection{A liberdade de imprensa}

Um fator digno de nota diz respeito aos meios de comunicação. A atuação em relação aos meios de comunicação punha os responsáveis pela veiculação de notícias, textos e publicações sob as sanções da Lei n. 5.250, de 9 de fevereiro de 1967, ${ }^{82}$ do Decreto-lei n. 972, de 17 de outubro de 1969, ${ }^{83}$ da Lei de Segurança Nacional, ${ }^{84}$ além do AI-5. ${ }^{85}$ Agora, "o governo não edita legislação nem pratica qualquer ato formal pela liberdade de imprensa. Apenas orientações e ordens aos operadores da censura" ${ }^{86}$

${ }^{81}$ CABRAL, José Bernardo. O poder constituinte. Brasília: Câmara dos Deputados - Coordenação de Publicações, 1988, p.39-40.

${ }^{82}$ BRASIL. Lei n. 5.250, de 9 de fevereiro de 1967. Disponível em: 〈http://www.senado.gov.br/legislacao〉. Acesso em: 20 abr. 2008.

${ }^{83}$ BRASIL. Decreto-lei n. 972, de 17 de outubro de 1969. Disponível em: <http://www.senado.gov.br/legislacao>. Acesso em: 10 abr. 2008.

${ }^{84}$ A "lei" de Segurança Nacional evoluiu por meio dos seguintes diplomas: Decreto-lei n. 314, de 13 de março de 1967 (Castello Branco), alterado pelo Decreto-lei n. 510, de 20 de março de 1969 (Costa e Silva); Decreto-lei n. 898, de 29 de setembro de 1969 (Junta Militar); Lei n. 6.620, de 17 de dezembro de 1978 (Ernesto Geisel); Lei n. 7.170, de 14 de dezembro de 1983 (João Figueiredo).

85 "Denúncias, prisões e processos eram comuns. Evidentemente, os cortes e a burocracia implicavam significativos prejuízos econômicos para os atingidos. Mutatis mutandi, a censura agia de forma idêntica 


\subsubsection{A liberdade de organização partidária}

O autoritarismo atuou de forma substancialmente danosa em relação ao sistema partidário-eleitoral, extinguindo os partidos criados ao longo da redemocratização que se seguiu ao Estado Novo e que demonstravam indicadores concretos de institucionalização. ${ }^{87}$

Mas as eleições de 1974 trouxeram novamente à ordem do dia a preocupação com os partidos. Os resultados dessas eleições, apresentando a supremacia do MDB nas grandes cidades, apesar da manutenção dos constrangimentos criados pelo autoritarismo, devolveu às casas legislativas certa margem de influência no sistema político, ocasionou a revalorização do processo eleitoral e imprimiu novo alento à vida partidária no país. A emergência do processo eleitoral com certo grau de competitividade, pela primeira vez desde as eleições de outubro de 1965, inicia nova quadra da vida política brasileira. ${ }^{88}$ Assim, se o bipartidarismo surgiu da necessidade de um novo sistema, leal ao regime autoritário, ${ }^{89}$ a sua evolução e transformação se regeriam, entretanto, por uma lógica própria, que acabaria por incompatibilizá-lo com a ordem política que presidira as suas origens. Na verdade, o processo político levara, paulatinamente, os partidos a desempenhar um importante papel na derrocada do autoritarismo e no aprofundamento do processo de transição.

em relação ao teatro, à literatura, às letras de músicas populares, às artes plásticas e ao cinema. Até a bibliografia de alguns cursos universitários foi atingida". COUTO, Ronaldo Costa. História indiscreta da ditadura e da abertura: Brasil: 1964-1985. Rio de Janeiro: Record, 1999, p.169.

${ }^{86}$ COUTO, Ronaldo Costa. História indiscreta da ditadura e da abertura: Brasil: 1964-1985. 2. ed. Rio de Janeiro: Record, 1999, p.170.

${ }^{87}$ Ver, principalmente, SOUZA, Maria do Carmo Campello de. Estado e partidos políticos no Brasil (1930 a 1946). São Paulo: Alfa-Ômega, 1976; LIMA JR., Olavo Brasil. Os partidos políticos brasileiros - a experiência federal e regional. Rio de Janeiro: Edições Graal, 1983.

88 "Depois de tantos anos de duro condicionamento político-militar à manifestação do pensamento e da vontade dos cidadãos (que levou ao aumento do voto branco e do voto nulo, como é sabido) criara-se uma espécie de consciência coletiva política que, em vez de extinta, estava silenciosa, à espreita de uma oportunidade segura para manifestar-se. À medida que a campanha eleitoral foi-se desenvolvendo (apesar das restrições à livre expansão que ela manteve, [...] tornou-se mais e mais visível que havia uma trepidação entre os eleitores; e que essa trepidação correspondia à movimentação de correntes persistentes de definição de oposições políticas e não a um simples ritual de homologação ou de recusa do voto, que às vezes a situação impõe aos eleitores como forma mais inteligente de resposta a situações sem saída". CARDOSO, Fernando Henrique; LAMOUNIER, Bolívar. Introdução. In: (Coord.). Os partidos e as eleições no Brasil. Rio de Janeiro: Paz e Terra, 1975, p.9-10.

${ }^{89}$ Para uma revisão da questão partidária no período autoritário, ver, entre outros, DINIZ, Eli. Transição, partidos e regimes políticos: algumas considerações. In: CAMARGO, Aspásia; DINIZ, Eli (Org.). Continuidade e mudança no Brasil da Nova República. São Paulo: Vértice; Rio de Janeiro: Iuperj, 1989, p.84-108; LAMOUNIER, Bolívar. O ‘Brasil Autoritário’ revisitado: o impacto das eleições sobre a Abertura. In: STEPAN, Alfred, op. cit., 1988; REIS, Fábio Wanderley. O eleitorado, os partidos e o regime autoritário. In: SORJ, Bernardo; ALMEIDA, Maria Hermínia Tavares (Org.). Sociedade e política no Brasil pós-64. São Paulo: Brasiliense, 1983, p.62-86. 
Sobretudo desde 1979, um conjunto importante de mudanças institucionais passou a ocorrer, tanto no que diz respeito ao regime político e ao deslocamento do eixo governooposição, quanto ao sistema partidário-eleitoral, com a criação de normas mais liberais e o surgimento de novos partidos.

A Lei n. 6.767, de 20 de dezembro de 1979, ${ }^{90}$ modificando dispositivos da Lei $n$. 5.682, de 21 de julho de 1971 (Lei Orgânica dos Partidos Políticos), ${ }^{91}$ extinguiu os partidos, cancelando-lhes os registros e criando blocos até o registro e funcionamento de novos partidos. ${ }^{92}$ A motivação da nova legislação atendeu, em boa medida, a estratégia do regime em decadência de dividir a oposição e, assim, ter continuidade no processo de transição. Contudo, o processo político adquiriu dinâmica própria, tornado-se, mais e mais, se torna, alheio aos desideratos daquele regime.

Posteriormente, já na Nova República, foi editada a Emenda à Constituição no 25 , de 15 de maio de 1985, que estabeleceu que "é livre a criação de partidos políticos". Ultrapassando-se o retorno controlado ao pluripartidarismo permitido pela reforma de 1979, que teve como principais organizações o Partido Democrático Social (PDS) e o PMDB, sucessores, respectivamente, da Arena e do MDB, ocorreu a ampliação do espectro pluripartidário, com a legalização, inclusive, dos partidos comunistas e a revogação dos limites à formação de novos partidos. ${ }^{93}$

90 BRASIL. Lei n. 6.767, de 20 de dezembro de 1979. Disponível em: <http://www.senado.gov.br/legislacao>. Acesso em: 20 abr. 2008.

${ }^{91}$ BRASIL. Lei n. 5.682, de 21 de julho de 1971. Disponível em: 〈http://www.senado.gov.br/legislacao>. Acesso em: 20 abr. 2008.

${ }^{92}$ Entre outros dispositivos, a Lei estabeleceu: “do nome constará obrigatoriamente a palavra partido com os qualificativos, seguidos da sigla, esta correspondente às iniciais de cada palavra, não sendo permitida a utilização de expressões ou arranjos que possam induzir o eleitor a engano ou confusão"; "é vedado a um partido adotar programa idêntico ao de outro registrado anteriormente"; "ficam extintos os partidos criados como organizações, com base no Ato Complementar $\mathrm{n}^{\circ}$ 4, de 20 de novembro de 1965, e transformados em partidos de acordo com a Lei $\mathrm{n}^{\mathbf{0}} 4.740$, de 15 de julho de 1965, por não preencherem, para seu funcionamento, os requisitos estabelecidos nesta Lei"; "durante a presente legislatura e até o registro e funcionamento dos partidos, os parlamentares reunir-se-ão em blocos, sobre cuja organização e atividade disporão, através de ato próprio, as Mesas do Senado Federal, da Câmara dos Deputados, das Assembléias Legislativas e das Câmaras Municipais; "os blocos [...] serão constituídos dos filiados a um mesmo partido em organização, vedado ao parlamentar transferir-se para outro bloco". BRASIL. Lei n. 6.767, de 20 de dezembro de 1979, op. cit., 2008.

93 Além da eliminação do princípio da fidelidade partidária para fins de perda de mandato e das novas regras para a formação de partidos políticos, a EC n. 25, de 15 de maio de 1985, procedeu a substanciais mudanças na "constituição política" vigente (a Carta de 1969 e as suas emendas), realizando, assim, uma ampla reforma política. Entre as suas disposições estão: 1. aumento do número de deputados (até 487) e diminuição da idade para ser eleito (18 anos); 2. o Distrito Federal passou a ter três senadores e oito deputados federais; 3. restabelecimento das eleições, "por sufrágio universal e voto direto e secreto", para presidente e vice-presidente da República; 4. necessidade de, para ser eleito, o candidato obter maioria 


\subsection{O sistema partidário-eleitoral em 1986}

Embora substancialmente alterada por uma série de dispositivos constitucionais, leis e decretos-leis, a moldura normativa do processo partidário-eleitoral, em que foram escolhidos os constituintes em 1986, coube a dois instrumentos jurídicos básicos: a Lei n. 4.737, de 15 de julho de 1965 (Código Eleitoral), ${ }^{94}$ e a Lei n. 5.682, de 21 de julho de 1971 (Lei Orgânica dos Partidos Políticos).

Para melhor compreensão das mutações normativas por que passou o sistema partidário-eleitoral desde 1979 até as vésperas das eleições de 1994, o conjunto de mecanismos que foi introduzido na regulação dos partidos e eleições pode ser distribuído em três escaninhos: 1. a fixação ou ampliação de limites para o exercício da cidadania eleitoral; 2. as decisões que afetaram o processo eleitoral e a organização partidária; 3. as decisões que alteraram a representação política.

Deve ser ressaltado também que, pelo menos, três aspectos cristalizados por tais mudanças legislativas foram de crucial importância para a volta do país à democracia política: 1. o restabelecimento das eleições diretas para governador, a partir de 1982, e para prefeitos das capitais, a partir de 1985; 2. a autorização para a criação de partidos nacionais, que fugia ao figurino bipartidário traçado pelo Ato Complementar n. 4/65; ${ }^{95} 3$. o estabelecimento do voto facultativo para o analfabeto (1985) e para os menores entre dezesseis e dezoito anos de idade.

No período, conservou-se o registro eleitoral obrigatório para as pessoas com idade compreendida entre dezoito e setenta anos e, facultativamente, para os maiores de setenta

absoluta de votos, não computados os em branco e os nulos; 5. introdução de um segundo turno, se nenhum candidato obtivesse maioria absoluta na primeira votação, concorrendo os dois candidatos mais votados e podendo se dar a eleição por maioria simples; 6 . direito dos analfabetos ao alistamento e ao voto;

7. introdução da cláusula de barreira ("Não terá direito a representação no Senado Federal e na Câmara dos Deputados o Partido que não obtiver o apoio, expresso em votos, de 3\% (três por cento) do eleitorado, apurados em eleição geral para a Câmara dos Deputados e distribuídos em, pelo menos, 5 (cinco) Estados, com o mínimo de $2 \%$ (dois por cento) do eleitorado de cada um deles"); 8. restabelecimento da autonomia dos municípios, com eleições diretas para os que em se situassem em capitais e ou fossem considerados de interesse da segurança nacional; 9. vedação da sublegenda e permissão de coligação partidária nas eleições de 15 de novembro de 1985; 9. modificação do sistema eleitoral ("distrital misto") introduzido em 1982. BRASIL. Constituição (1967) Emenda Constitucional no 25 de 15 de maio de 1985. Disponível em: <http://www.presidencia.gov.br/legislacao>. Acesso em: 20 abr. 2008.

94 BRASIL. Lei n. 4.737, de 15 de julho de 1965. Disponível em: <http://www.presidencia.gov.br/legislacao>. Acesso em: 20 abr. 2008.

95 BRASIL. Ato Complementar n. 4, de 20 de novembro de 1965. Disponível em: <http://www.senado.gov.br/legislacao>. Acesso em: 6 jun. 2008. 
anos, ampliando-se esse direito para os maiores de dezesseis e menores de dezoito anos e analfabetos. No que diz respeito aos partidos políticos, assistiu-se no período ao desenrolar de um processo de progressiva e paulatina abertura para a sua criação. Desde 1978 momento em que se extinguiram as duas siglas criadas pela legislação do regime militar, Arena e MDB - até a promulgação da Constituição de 1988, as normas relativas ao sistema partidário-eleitoral caminharam sempre no sentido da abertura para a criação de partidos, criando-se um estatuto extremamente permissivo. ${ }^{96}$

Por outro lado, o sistema caminhou com igual hesitação no que se refere às exigências do funcionamento dos partidos políticos. A Emenda Constitucional $n^{\circ}$ 11/78 fixava a necessidade de filiação de, pelo menos, dez por cento de representantes na Câmara dos Deputados e do Senado Federal, que tivessem, como fundadores, assinado seus atos constitutivos, concomitante com o apoio, expresso em votos, de cinco por cento do eleitorado, que houvesse votado na última eleição geral para a Câmara dos Deputados, distribuídos, pelo menos, por nove Estados, com o mínimo de três por cento em cada um deles, sendo considerada nula a votação do partido que não satisfizesse tal requisito.

No que se refere ao registro individual de candidatos para as eleições proporcionais à Câmara dos Deputados e Assembléias Legislativas, um partido podia registrá-los em quantidade igual ao número de lugares a preencher mais a metade, completada a fração (art. 92, a, do Código Eleitoral). O aparato normativo em discussão modificou substancialmente as regras partidárias elaboradas na vigência do regime militar, estabelecendo, inclusive, completa ausência de sanção por mudança de partido e igual ausência de mecanismos que vinculassem os políticos a compromissos programáticos e organizacionais mínimos. Nesse aspecto, caminhou-se em sentido totalmente contrário ao período militar, à medida que foi revogada a fidelidade partidária, instituída pelo art. 152 da Constituição de 1969.

\subsection{As eleições para o Congresso Constituinte}

\footnotetext{
${ }^{96}$ No que concerne ao sistema eleitoral dos deputados federais (e estaduais e vereadores), de 1979 em diante, caminhou-se de modo hesitante entre a instituição, via inspiração do Executivo militar, do sistema distrital misto (majoritário e proporcional), e a manutenção do sistema proporcional de lista aberta, introduzido no país em 1932. O sistema distrital misto chegou mesmo a ser adotado constitucionalmente em 1982, todavia, foi revogado pela Emenda Constitucional $n^{\circ}$ 25/85. De resto, mantiveram-se, no geral, as linhas estabelecidas pelo Código Eleitoral de 1965.
} 
A natureza do poder constituinte e as suas competências específicas parecem ter resultado das conversações estabelecidas entre os dirigentes da Aliança Democrática e os altos escalões militares, sobretudo, os não comprometidos com as manobras continuístas de parte do grupo do presidente João Batista de Figueiredo. Conforme destacado pela imprensa na época, tal pacto foi definitivamente concluído num encontro entre Tancredo Neves e o general Leônidas Gonçalves, e comportava o compromisso assumido pelo chefe da Aliança Democrática de se abster de qualquer iniciativa suscetível de abalar a estabilidade de organismos essenciais do poder de Estado, a começar pelas Forças Armadas. Em contrapartida, seria garantida a posse de Tancredo Neves como presidente da República. Tal acordo envolveria a manutenção do estatuto constitucional das Forças Armadas, assim como a natureza do próprio processo constituinte, com a rejeição à Assembléia "exclusiva", em que os "radicais" pudessem inflar os "revanchismos". ${ }^{97}$

Na campanha para as eleições de 15 de novembro de 1986, se acentuou a escolha dos governadores, tudo sob a euforia do Plano Cruzado I, responsável pela transitória política econômica de estabilização monetária, de expansão da produção e do consumo interno, e de freio na escalada inflacionária. PMDB e PFL, formando a Aliança Democrática, foram os grandes vitoriosos. Como de praxe, sobretudo as eleições para governador, a segunda vez que aconteciam diretamente desde a edição do AI-2, em 1965, acabaram por lançar uma cortina de fumaça sobre as eleições para os parlamentares constituintes, tanto senadores como deputados federais. O resultado foi a vitória do PMDB nas eleições de 21 dos 22 Estados.

Do total de 72 senadores e 487 deputados federais, o PMDB e o PFL, reunidos, alcançavam quase oitenta por cento dos membros do Congresso Constituinte, enquanto os partidos chamados progressistas (PT, PDT, PSB, PC do B e PCB) somavam apenas 9,5\%.98 Assim, se parecia que a elaboração constitucional seria tarefa relativamente fácil para a perspectiva conservadora, tal não aconteceu, pois os partidos progressistas conseguiram aprovar muitas das suas demandas. ${ }^{99}$

\footnotetext{
${ }^{97}$ MORAES, João Quartim de. O poder constituinte e a força. Estudos Avançados, São Paulo, v.3, n. 7, p.67-86, 1989.

98 RODRIGUES, Leôncio Martins. Quem é quem na constituinte: uma análise sócio-política dos partidos e deputados. São Paulo: OESP/Maltese, 1987; KINZO, Maria D’Alva Gil. Quadro partidário e a Constituição. In: LAMOUNIER, Bolívar (Org.). De Geisel a Collor: o balanço da transição. São Paulo: Sumaré; Idesp, 1990, p.105-134.

99 SOUZA, Celina. Federalismo e descentralização na constituição de 1988: processo decisório, conflitos e alianças. Dados - Revista de Ciências Sociais, Rio de Janeiro, v.44, n.3, p.515, 2001. De fato, as eleições
} 


\subsection{Regras de funcionamento}

A EC n. 26/1985, que convocou a Assembléia Nacional Constituinte, atribuindo-lhe o caráter de "livre e soberana", dispôs sobre a reunião da mesma, unicameralmente, na sede do Congresso Nacional. Dispôs, também, que a aprovação do texto constitucional se daria em dois turnos de discussão e votação, pela maioria absoluta dos constituintes.

Diferentemente das Assembléias Constituintes de 1891 e 1934, a inaugurada em 1987 não possuía um anteprojeto em torno do qual pudesse desenvolver os seus trabalhos. Por conta disso, a feitura do Regimento Interno da Assembléia Nacional Constituinte $\left(\right.$ RIANC) ${ }^{100}$ adquiriu importância política acentuada. ${ }^{101}$

Promulgado em 24 de março de 1987, nele determinava-se que haveria 24 subcomissões, que, no segundo momento, formariam oito comissões, ${ }^{102}$ as quais, por fim, desembocariam numa Comissão de Sistematização (CS). ${ }^{103}$ As decisões seriam, então, submetidas ao plenário, com duas rodadas de votações nominais.

Previa-se que as representações partidárias teriam líderes e vice-líderes, indicados pelas respectivas bancadas, com assento na Assembléia Nacional Constituinte. Os vicelíderes seriam indicados pelos respectivos líderes, na proporção de um para oito membros

para a Assembléia Nacional Constituinte trouxeram os seguintes resultados: na Câmara dos Deputados, o PMDB ficou com 53\% dos lugares, seguido do PFL, com 24\%. No Senado, dos 72 senadores, 45 eram do PMDB (63\% do total) e 15 do PFL (21\%). Por conseguinte, a "situação", isto é, a Aliança Democrática, ficou com aproximadamente dois terços do Congresso, "sobrando o outro terço para ser dividido entre a fragmentada 'oposição', composta por dez partidos, entre os quais o PDS, o mais forte deles, possui apenas 7\% do total de parlamentares (33 deputados e sete senadores)". Assim, esquematicamente, o sistema partidário brasileiro, decorrente das eleições de 1986, poderia ser descrito: "um partido grande (o PMDB), um partido médio (o PFL), quatro partidos pequenos (o PDS, o PDT, o PTB e o PT), e seis micropartidos (o PL, o PDC, o PC do B, o PCB, o PSB e o PMB)". RODRIGUES, Leôncio Martins. Quem é quem na Constituinte: uma análise sócio-política dos partidos e deputados. São Paulo: OESP - Maltese, 1987, p.25.

${ }^{100}$ BRASIL. Regimento Interno da Assembléia Nacional Constituinte. Brasília: Câmara dos Deputados, Coordenação de Publicações, 1987.

101“'Oficialmente, o chamado Centrão surgiu à luz do dia com a publicação de um manifesto no dia 11 de novembro de 1987, apoiado por 311 assinaturas. Constituído o bloco conservador, o passo seguinte seria derrubar o Regimento Interno da ANC e moldá-lo aos interesses do grupo, com o objetivo final de anular o Projeto da Comissão de Sistematização. Dentro dessa estratégia, haveria necessidade de 'brecar' os trabalhos da ANC, o que foi feito através da alteração do cronograma previamente estabelecido". SILVA, José Gomes. Buraco negro: reforma agrária na Constituinte de 1987/88. Rio de Janeiro: Paz e Terra, 1989, p.156.

${ }^{102}$ I - Comissão da Soberania e dos Direitos e Garantias do Homem e da Mulher; II - Comissão da Organização do Estado; III - Comissão da Organização dos Poderes e Sistema de Governo; IV - Comissão da Organização Eleitoral, Partidária e Garantia das Instituições; V - Comissão do Sistema Tributário, Orçamento e Finanças; VI - Comissão da Ordem Econômica; VII - Comissão da Ordem Social; Comissão da Família, da Educação, Cultura e Esportes, da Ciência e Tecnologia e da Comunicação.

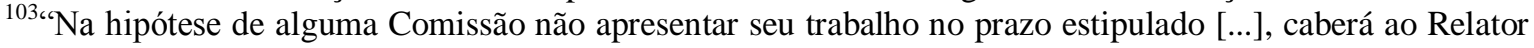
da Comissão de Sistematização a elaboração do mesmo, obedecido o prazo estabelecido no caput do art. 19" (art. 14, § $4^{\circ}$ - RIANC). 
da bancada, ou fração. Ao líder se permitia, em caráter preferencial e independentemente de inscrição, discutir matéria da ordem do dia e encaminhar votação, obedecidos os prazos e condições regimentalmente estabelecido, além de, entre outras atribuições, indicar os representantes do seu partido nas comissões.

O RIANC estabelecia que as votações poderiam ser realizadas pelos processos simbólicos, nominal ou secreto, entretanto, as matérias constitucionais somente seriam votadas pelo processo nominal. ${ }^{104}$

Admitiam-se propostas vindas de fora do Congresso Constituinte. Entre os habilitados, estavam os Legislativos estaduais e municipais, o Judiciário ${ }^{105}$ e os cidadãos, ${ }^{106}$ estes pela via das emendas populares, que deveriam ser assinadas por, no mínimo, 30.000 eleitores, sob a responsabilidade de, pelo menos, três entidades da sociedade civil.

Ademais, cada uma das 23 Subcomissões deveriam destinar de cinco a oito reuniões para audiência de entidades representativas de segmentos da sociedade, devendo, ainda, durante o prazo destinado aos seus trabalhos, receber as sugestões encaminhadas à Mesa ou à Comissão.

A cada constituinte ficava facultado assistir às reuniões de todas as Comissões e Subcomissões, discutir o assunto em debate pelo prazo por elas estabelecido, sendo-lhe

\footnotetext{
${ }^{104}$ RIANC - “Art. 67. O processo nominal será feito pela chamada dos Constituintes, utilizando-se listagem especial de votação, elaborada em ordem alfabética. $\S 1^{\circ}$. As chamadas para as votações nominais começarão numa votação pelo início da lista e na outra pelo final, e assim alternadamente na mesma ou na sessão seguinte. [...]"

105، Às Assembléias Legislativas, Câmara de Vereadores e aos Tribunais, bem como às entidades representativas de segmento da sociedade, fica facultada a apresentação de sugestões contendo matéria constitucional, que serão remetidas pelo Presidente da Assembléia às respectivas Comissões" (art. 13, § 11 - RIANC).

${ }^{106}$ RIANC - "Art. 24. Fica assegurada [...] a apresentação de proposta de emenda ao Projeto de Constituição, desde que subscrita por 30.000 (trinta mil) ou mais eleitores brasileiros, em listas organizadas por, no mínimo, 3 (três) entidades associativas, legalmente constituídas, que se responsabilizarão pela idoneidade das assinaturas, obedecidas as seguintes condições: I - a assinatura de cada eleitor deverá ser acompanhada de seu nome completo e legível, endereço e dados identificadores de seu título eleitoral. II - a proposta será protocolizada perante a Comissão de Sistematização, que verificará se foram cumpridas as exigências estabelecidas neste artigo para sua apresentação; III - a Comissão se manifestará sobre o recebimento da proposta, dentro de 48 (quarenta e oito) horas da sua apresentação, cabendo, da decisão denegatória, recurso ao Plenário, se interposto por 56 (cinqüenta e seis) Constituintes, no prazo de 3 (três) sessões, contado da comunicação da decisão à Assembléia; IV - a proposta apresentada na forma deste artigo terá a mesma tramitação das demais emendas, integrando sua numeração geral, ressalvado o disposto no inciso $\mathrm{V}$ deste artigo; V - se a proposta receber, unanimemente, parecer contrário da Comissão, será considerada prejudicada e irá ao Arquivo, salvo se for subscrita por um Constituinte, caso em que irá a Plenário no rol das emendas de parecer contrário; VI - na Comissão, poderá usar da palavra para discutir a proposta, pelo prazo de 20 (vinte) minutos, um de seus signatários, para esse fim indicado quando da apresentação da proposta; VII - cada proposta, apresentada nos termos deste artigo, deverá circunscrever-se a um único assunto, independentemente do número de artigos que contenha; VIII - cada eleitor poderá subscrever, no máximo 3 (três) propostas".
} 
vedado o direito de voto, salvo na Comissão ou Subcomissão da qual fosse membro. Ademais, até trinta dias a partir da promulgação do RIANC, os constituintes poderiam oferecer sugestões para a elaboração do Projeto de Constituição, as quais seriam encaminhadas pela Mesa às Comissões pertinentes.

\subsubsection{Conflitos e consensos na Comissão de Sistematização}

Com 93 membros, a Comissão de Sistematização foi o estágio mais importante do processo constituinte, com todos os partidos ali representados. ${ }^{107}$

A primeira grande disputa travada na Comissão de Sistematização se relacionou com a escolha do relator. Pimenta da Veiga (PMDB-MG) era o favorito de Mário Covas, líder do PMDB, todavia, acabou eleito o deputado Bernardo Cabral (PMDB-AM). A presidência coube ao senador Afonso Arinos de Melo Franco (PFL-RJ). Em virtude das pressões para a conclusão dos trabalhos, foram criadas, posteriormente, duas vice-presidências e entregues a Fernando Henrique Cardoso (PMDB-SP) e Jarbas Passarinho (PDS-PA).

\footnotetext{
107،Além das Comissões referidas neste artigo, haverá uma Comissão de Sistematização, integrada inicialmente por 49 (quarenta e nove) membros e igual número de suplentes, a qual terá sua composição complementada com os Presidentes e Relatores das demais Comissões e os Relatores das Subcomissões, assegurada a participação de todos os partidos com assento na Assembléia” (art. 13, $\S 1^{\circ}$ - RIANC). Em manifestação recente, José Sarney assim se refere à Comissão de Sistematização: "A Constituinte de 1988 quis dar um golpe dentro da própria Constituinte. Criou a comissão de sistematização, que era composta por 90 (sic) congressistas. Esses 90 (sic) podiam decidir pela metade, 47 pessoas podiam decidir a matéria. Mas, para derrubar o que a comissão de sistematização queria, tinha que ter maioria absoluta no plenário. A matéria votada ali era considerada acabada. Houve uma reação. Como podíamos ter uma Constituição que podia ser votada por 47 pessoas apenas? Houve uma mudança do regimento no qual diz 'não, toda matéria tem que ser votada aqui dentro do plenário'. [...]”. E verbera a Comissão de Sistematização, porque "eles achavam que essa comissão dos 90 ia fazer um mandato de quatro anos", enfatizando: "um dos maiores erros que cometi na vida foi ter ido para a televisão e ter dito: 'Eu aceito o mandato de cinco anos'. Porque coloquei no debate o que eles queriam. A Constituinte girou em torno do debate do mandato do presidente". FOLHA DE SÃO PAULO, São Paulo, p.A17, 27 ago. 2008. Mauro Benevides (PMDB$\mathrm{CE}$ ), vice-presidente da Assembléia Constituinte, referindo-se aos momentos mais preocupantes durante o funcionamento da Assembléia Constituinte, anota que, além do episódio da modificação regimental, para atender a pressão do Centro, "outro momento delicado foi quando, diante da seqüência de inserções de direitos sociais na Constituição - como licença-maternidade, licença-paternidade e outros direitos assegurados aos trabalhadores - o presidente José Sarney [...] demonstrou sua apreensão. Ele receava a sobrecarga de responsabilidades que, em sua opinião, poderia acarretar a ingovernabilidade do país. A advertência candente do presidente Sarney, feita em cadeia nacional de rádio e televisão, teve ampla repercussão junto aos constituintes e à opinião pública. Isso obrigou Ulysses a, também através de uma cadeia nacional, defender a soberania do poder constituinte. Esse foi sem dúvida um dos momentos mais dramáticos vividos naquela época. Mas serviu para assegurar a continuidade dos trabalhos com a aquiescência, ou a implícita aquiescência, do presidente Sarney, que terminou entendendo que as propostas da Constituinte não tinham o potencial de acarretar ônus exagerados para o erário". ENTREVISTA de Mauro Benevides à Agência Senado. Disponível em: <http://www2.camara.gov.br/internet/constituicao20anos>. Acesso em: 9 out. 2008.
} 
Inicialmente, a Comissão de Sistematização consolidou as matérias aprovadas pelas comissões temáticas. Em junho de 1987, o relator apresentou um anteprojeto, que recebeu emendas, e ambos foram votados. O relatório aprovado, em julho de 1987, foi denominado "Projeto de Constituição". Na seqüência, a Comissão de Sistematização realizou mais rodadas de trabalho, resultando, sucessivamente, o "Primeiro Substitutivo da Comissão de Sistematização" (agosto de 1987), o "Segundo Substitutivo da Comissão de Sistematização" (setembro de 1987) e o "Projeto de Constituição (A), da Comissão de Sistematização" (novembro de 1987).

\subsubsection{O consenso originado das sessões plenárias e das votações nominais}

Como última etapa dos trabalhos constituintes, as matérias foram submetidas ao Plenário, presidido e relatado, respectivamente, por Ulysses Guimarães e Bernardo Cabral. Pela ordem, todos os constituintes apreciaram as matérias em duas rodadas de votação, com o texto submetido, então, a uma Comissão de Redação Final.

As sessões plenárias se constituíram de 1.021 votações nominais em dois turnos. Mais de $95 \%$ do texto final da Constituição já havia sido negociado quando começaram as votações nominais. ${ }^{108}$ Observe-se que os dois turnos de votação em plenário apresentaram características distintas. No primeiro, cabiam quaisquer mudanças, com os trabalhos organizados a partir do Projeto da Comissão de Sistematização, que recebeu milhares de emendas, dentre as quais as que pretendiam a substituição na íntegra o "Projeto de Constituição (A)". O texto resultante constituiu o denominado "Projeto de Constituição (B)".

No segundo turno, votaram-se as emendas apresentadas ao Projeto "B" (nesta etapa, as emendas só poderiam ter caráter supressivo), do que resultou o "Projeto de Constituição (C)", em setembro de 1988. Visando à correção de erros e à realização de aperfeiçoamentos indispensáveis, o projeto foi submetido à Comissão de Redação, com a apreciação das últimas emendas do relator-geral e as apresentadas pelos constituintes, tudo visando a adequar a redação do texto aprovado no segundo turno. Chegou ao "Projeto de Constituição (D) - Redação Final”, em setembro de 1988. Finalmente, em 5 de outubro de 1988, promulgou-se a Constituição, a oitava do Brasil.

\footnotetext{
${ }^{108}$ SOUZA, Celina, op. cit., 2001; COELHO, João Gilberto Lucas; OLIVEIRA, Antônio Carlos de. A nova constituição: avaliação do texto e perfil dos constituintes. Rio de Janeiro: Revan, 1989.
} 


\title{
4.13 Interpretações sobre o trabalho constituinte
}

Um conjunto de interpretações foi formulado sobre o texto produzido pelo Congresso Constituinte de 1987/1988. Umas sugerem a conseqüência de uma cultura política conciliatória; outras, a "perda da capacidade decisória", vez que as forças políticas estavam demasiadamente fragmentadas. ${ }^{109}$ Outras mais viram o efeito direto da impossibilidade de construção de um consenso entre as principais forças políticas durante a Assembléia Nacional Constituinte. ${ }^{110}$ Vislumbrou-se, também, um problema de "soberania reduzida" e de "forte coerção do Presidente e dos militares". ${ }^{111}$ Por fim, também se destacou a ausência de consolidação estrutural ou a fragilidade dos partidos políticos brasileiros. ${ }^{112}$ Mais recentemente, e utilizando-se da perspectiva neo-institucionalista, vieram à luz explicações que vêem o texto constitucional de 1988, sobretudo, como o resultado de um conjunto de procedimentos definidos durante a Assembléia Nacional Constituinte. ${ }^{113}$

Como acentua Sandra Gomes, ao estudar o impacto das regras de organização do processo legislativo no comportamento dos parlamentares constituintes de 1987/1988,

\begin{abstract}
A definição das regras internas no início da Assembléia Nacional Constituinte favoreceu um trabalho descentralizado de organização dos trabalhos legislativos em comissões e subcomissões, ao mesmo tempo em que centralizou o processo de votação em uma única comissão que não espelhava a representação do plenário. Tal organização se refletiu no tamanho e no conteúdo substantivo do Primeiro Projeto de Constituição, pois esse conjunto de procedimentos acabou permitindo a inserção de vários pontos no Projeto de Constituição que não refletia a preferência majoritária das forças políticas na Assembléia Nacional Constituinte. $[\ldots]^{114}$
\end{abstract}

${ }^{109}$ SOUZA, Amaury de; LAMOUNIER, Bolívar. A feitura da nova Constituição: um reexame da cultura política brasileira. In: LAMOUNIER, Bolívar (Org.), op. cit., 1990.

${ }^{110}$ BRUNEAU, Thomas C. Constitutions and democratic consolidation: Brazil in comparative perspective. In: ETHIER, Diane (Ed.). Democratic transition and consolidation in Southern Europe, Latin America and Southeast Asia. London: MacMillan, 1990, p.173-196; BRUNEAU, Thomas C. Brazil's political transition. In: HIGHLEY, John; GUNTHER, Richard (Ed.), op. cit., 1992, p.257-280.

${ }^{111}$ FLEISCHER, David V. The Constituent Assembly and the transformation strategy: attempts to shift political power in Brazil from the President to Congress. In: GRAHAM, Larry S.; WILSON, Robert H. (Ed.) The political economy of Brazil: public policies in an era of transition. Austin: University of Texas Press, 1990, p.210-258.

${ }^{112}$ KINZO, Maria D’Alva Gil. O quadro partidário e a Constituinte. In: LAMOUNIER, Bolívar (Org.), op. cit., 1990; MARTÍNEZ-LARA, Javier. Building democracy in Brazil: the politics of constitutional change, 1985-95. New York: Saint Martin's Press, 1996.

${ }^{113}$ GOMES, Sandra. O impacto das regras de organização do processo legislativo no comportamento dos parlamentares: um estudo de caso da Assembléia Nacional Constituinte (1987-1988). Dados - Revista Brasileira de Estudos Sociais, Rio de Janeiro, v.49, n.1, p.193-224, 2006; PILATTI, Adriano. A Constituinte de 1987-1988: progressistas, conservadores, ordem econômica e regras do jogo. Rio de Janeiro: PUC Rio; Lúmen Júris, 2008.

${ }^{114}$ GOMES, Sandra. O impacto das regras de organização do processo legislativo no comportamento dos parlamentares: um estudo de caso da Assembléia Nacional Constituinte (1987-1988). Dados - Revista Brasileira de Estudos Sociais, Rio de Janeiro, v.49, n,1, p.192-224, 2006, p.195. 
Todavia, a aprovação de um novo Regimento Interno, em janeiro de 1988, foi a resposta encontrada pelas forças políticas descontentes com aspectos substantivos do Projeto. Assim,

[...] a aprovação desse segundo Regimento Interno fez com que o processo constituinte praticamente recomeçasse do zero, atrasando ainda mais a programação original. Por causa dos altos custos de aprovação impostos pelo novo processo deliberativo, após a reforma do regimento, uma solução centralizada ao redor dos líderes partidários tornou-se necessária. Novamente, as regras reformadas também tiveram um impacto no documento final. ${ }^{15}$

Segundo Adriano Pillatti, todavia, mesmo com as mudanças das regras do jogo constituinte, gerou-se, afinal, "uma Constituição Cidadã que saberia melhor ao paladar reformista". Assim é que

[...] a maioria conservadora existente no Plenário não bastou para, por si só, garantir a aprovação de um texto que refletisse plenamente suas expectativas e preferências, não foi capaz de impor o 'seu' projeto à minoria progressista. Ainda uma vez, surpresas ocorreram na definição dos conteúdos do novo texto constitucional. A contra-ofensiva conservadora iniciada durante os trabalhos da Comissão de Sistematização, avolumada pelos descontentamentos com as decisões procedimentais e substantivas ali verificadas, e acelerada no final de seus trabalhos em função dos resultados obtidos pelos progressistas em questões nevrálgicas para o partido da ordem, logrou reformar o Regimento, mas não logrou sepultar totalmente as alterações do status quo do Projeto de Constituição (A). Para além dos números de votantes, outros fatores determinariam a heterogeneidade dos resultados finais. O Congresso e o Processo Constituintes, concebidos e formatados para produzir uma Constituição 'palatável' ao conservadorismo, produziram uma Constituição Cidadã que saberia melhor ao paladar reformista. ${ }^{116}$

Segundo Florestan Fernandes, que salienta "a incorporação da iniciativa popular" no processo constituinte,

A incorporação da iniciativa popular como uma fonte de produção das leis
constitui o elemento mais avançado que se conseguiu conquistar na elaboração
do regimento da Assembléia Nacional Constituinte. Ponto alto do projeto de
constituição do professor Fábio Konder Comparato, a iniciativa popular e o
referendo receberam forte apoio externo, principalmente da Ordem dos
Advogados do Brasil e do Plenário Pró-Participação Popular na Constituinte. No
projeto de resolução do PT e de outros partidos de esquerda e entre os
constituintes radicais do PMDB as duas reivindicaçães encontraram acolhida. O
regimento interno aprovado não foi tão longe quanto se pretendia.

O senador Fernando Henrique Cardoso deu cobertura favorável à iniciativa popular, embora sem atender a alguns desdobramentos desejados; e manteve-se firme na defesa das posições aceitas. A resistência surpreendente de uma parte de constituintes experimentados e de renomados constitucionalistas, bem como o

${ }^{115}$ Ibid., 2006, p.195-196.

${ }^{116}$ PILATTI, Adriano, op. cit., 2008, p.229-230. 
torpedeamento por parte de correntes mais conservadoras de vários partidos não impediram a aprovação das inovações. [... $]^{117}$

De fato, na produção da "Constituição Cidadã que saberia melhor ao paladar reformista", uma variável não pode deixar de ser considerada: a participação popular. Tal participação ocasionou, entre outros, o fato de 122 movimentos populares dirigirem emendas ao Congresso Constituinte, assinadas por mais de 12 milhões de eleitores, e 83 foram discutidas. ${ }^{118}$

${ }^{117}$ FERNANDES, Florestan. O uso da iniciativa popular. O Povo, Fortaleza, p.7, 13 abr. 1987.

${ }^{118}$ MICHILLES, Carlos. Cidadão constituinte: a saga da emendas populares. Rio de Janeiro: Paz e Terra, 1989; BARROSO, Pérsio Henrique. Constituinte e constituição: participação popular e eficácia constitucional (1987-1997). Curitiba: Juruá, 1999; SALGADO, Eneida Desiree. Constituição e democracia: tijolo por tijolo em um desenho (quase) lógico: vinte anos de construção do projeto democrático brasileiro. Belo Horizonte: Fórum, 2007. Principais eventos da ANC relativos às emendas populares: Ao longo de fevereiro/87: Decide-se que não haveria anteprojeto. $\mathrm{O}$ texto será construído a partir dos trabalhos das 24 subcomissões. Sugestões populares já somam mais de 40 mil. 03/02/87: Delegação do Movimento Pró-Participação Popular na Constituinte entrega proposta de inclusão da "iniciativa popular"; 19 e 20/02/87: Reunião, em Brasília, de plenários, comitês e movimentos próparticipação popular na Constituinte. 27/03 a 06/05/87: Recebimento de 11.989 sugestões apresentadas por constituintes e entidades da sociedade civil; 07/04 a 25/05/87: Subcomissões Temáticas realizam 192 audiências públicas, com os mais variados grupos sociais; 16/06/87: Lançamento da campanha nacional de apoio às emendas populares. 11/07/87: Marcha sobre o Congresso, organizada pela UDR; 15/07 a 13/08/87: Apresentação de 20.791 emendas ao anteprojeto de Constituição, entre as quais 122 populares; 17/07/87: Dia Nacional de Mobilização para a coleta de assinaturas das emendas populares, coordenado pela Articulação Nacional de Entidades para a Mobilização Popular na Constituinte; 12/08/87: Ato público, em Brasília, para a entrega das emendas populares. 13/08/87: Fim do prazo para a apresentação de emendas. Ver PRINCIPAIS eventos da ANC em 1987. Disponível em: <http://www2.camara.gov.br/constituicao20anos>. Acesso: em 9 out. 2008. 


\title{
5 EM BUSCA DA CONSTITUIÇÃO ECONÔMICA
}

\author{
Mesmo que não seja a Constituição dos nossos sonhos, \\ certamente será a mais democrática.
}

Mário Covas

\subsection{Introdução}

Este capítulo analisa, com intuito comparativo, a construção do texto constitucional, observando nomeadamente o da Comissão Provisória de Estudos Constitucionais, e dos projetos emanados do próprio Congresso Constituinte, e o texto constitucional dirigente de 1988, no que se refere à "constituição econômica".

A história constitucional republicana mostra diversidade relativamente aos modelos, propostas e anteprojetos apresentados às Assembléias Constituintes, ou dela derivados. A primeira Constituinte republicana recebeu um projeto pronto e acabado, inclusive, já dotado das cláusulas pétreas atinentes à federação e à república. A Constituinte de 1933/1934 recebeu também um projeto, formulado pela Subcomissão do Itamarati. Em 1946, a Assembléia Constituinte foi substancialmente inicial, visto que, durante o Estado Novo, não existiam partidos políticos legais, o Poder Legislativo havia sido suprimido nos níveis federal, estadual e municipal, a sociedade civil fora inibida e o interregno entre a queda do Estado Novo e a abertura dos trabalhos constituintes fora exíguo. A própria sociedade civil, apesar das limitações próprias do seu tempo, no manifestar-se, participou ativamente da formulação de projetos, planos e propostas, pelo menos em dois momentos do evoluir constitucional brasileiro, a saber, nas conjunturas das constituintes de $1823 \mathrm{e}$ 1933/1934.

O Congresso Constituinte de 1987-1988 recebeu diversos influxos diretos ou indiretos, entre outros, o anteprojeto da Comissão Constitucional de Estudos Provisórios e o anteprojeto assumido pelo Partido dos Trabalhadores (PT). Além do mais e decorrentes dos trabalhos do Congresso Constituinte, acabaram por vir à tona os projetos A, B e C e D. 


\subsection{A agenda da transição e a constituição econômica}

A par da reordenação jurídico-política do Estado, os anseios de reordenação econômica e social do país, como parte das "dívidas" (a "externa", a "interna", a "social" e "política") de que falava Teotônio Vilela, ${ }^{1}$ estavam no horizonte que se buscava com a democratização. Tancredo Neves deu o tom da preocupação com o desenvolvimento, quando ressaltou que

devemos ter a consciência de que o mundo se contrai diante de árdua competição internacional. Acentua-se a luta pelo domínio de mercados, pelo controle de matérias-primas, pela hegemonia política. As ideologias, tão fortes no século passado e na primeira metade do século XX, empalidecem, frente a um novo nacionalismo [e], fenômeno típico do desenvolvimento industrial e da expansão do capitalismo, surge nova realidade supranacional nas grandes corporações empresariais. Aparentemente desvinculadas de suas pátrias de origem, tais organizações servem, fundamentalmente, a seus interesses. ${ }^{2}$

Por isso, "ao lado da ordem constitucional, que é tarefa prioritária", haveria

[...] que cuidar da situação econômica. A inflação é a manifestação mais clara da desordem na economia nacional. Iremos enfrentá-la desde o primeiro dia.

Não cairemos no erro, grosseiro, de recorrer à recessão como instrumento deflacionário. Ao contrário: vamos promover a retomada do crescimento, estimulando o risco empresarial e eliminando, gradativamente, as hipertrofias do egoísmo e da ganância. O ritmo de nossa ação saneadora dependerá unicamente da colaboração que nos prestarem os setores interessados. Contamos, para isso, com o patriotismo de todos. ${ }^{3}$

1 FEHLBERG, Carlos. Teotônio Vilela, o senador que tentou mudar o Brasil. Disponível em: <http://www.politicaparapoliticos.com.br〉. Acesso em: 22 maio 2008. Teotônio Vilela já em 1975 salientava "pelo menos três pontos que precisam ser preservados e ampliados": 1. a soberania da nação; 2. a dignidade do ser humano, que compreende o direito aos bens essenciais, ao emprego, à saúde, à educação, à moradia e à vigência plena do Estado de Direito; 3. as riquezas do país, como seus recursos naturais, seu parque industrial, sua infra-estrutura física. Ibid. A evolução do Estado demonstrava: "Evoluímos da situação inicial, em que o mandonismo local se opunha ao Estado, para a situação intermediária, de arranjo entre as duas forças (chamada por Victor Nunes Leal de coronelismo), e daí para a situação final de mandonismo do Estado através da força, do arbítrio, do clientelismo, do fisiologismo. Cresceu o Estado sem se tornar público. O problema central da democratização hoje talvez seja fazer do Estado coisa pública, democratizá-lo. Um dos meios de conseguir este objetivo pode ser a descentralização política". CARVALHO, José Murilo de. A luta pela Re(s)pública. Jornal do Brasil, Rio de Janeiro, Caderno B/Especial, p.2, 4 set.1988.

2 Ibid., 1998.

${ }^{3}$ Discurso de Tancredo Neves no Congresso Nacional, após a escolha pelo Colégio Eleitoral, em 15 de janeiro de 1985. In: BONAVIDES, Paulo; ANDRADE, Paes de. História constitucional do Brasil. Brasília: Paz e Terra, 1989, p.797. Noutro registro, Oscar Dias Corrêa perguntava: "Mudar o modelo, para qual modelo? Não se diz em que consistirá essa mudança, sua extensão, alcance e profundidade. Pretendese criar um regime mais estatizante, socialismo de Estado? Que se explicite detidamente. Mais de uma vez temos perguntado: Para qual modelo, novo ou diferente? Socialista? De que tipo, com quais características, expressa e objetivamente delineadas: Coletivista? À moda soviética, ou de algum "satélite"? Comunista? À chinesa? Ou outra? Impõe-se a formulação expressa de rumos, miudamente especificados, caracterizados. Qual a solução para os problemas fundiários? Para a propriedade do campo e a urbana? Aboli-la? 
Para tanto, a política econômica deveria buscar o "pleno emprego" como norte da retomada do crescimento, pois "retomar o crescimento é criar empregos". Assim, "toda a política econômica" do novo governo estaria "subordinada a esse dever social. Enquanto houver, neste País, um só homem sem trabalho, sem pão, sem teto e sem letras, toda a prosperidade será falsa". Ademais, em contraponto ao discurso hegemônico do autoritarismo-burocrático, que tendia a ver o desenvolvimento social como função do crescimento econômico, vislumbrava-se, agora, a autonomia entre "desenvolvimento econômico" e "desenvolvimento político":

\begin{abstract}
Cabe acentuar que o desenvolvimento social não pode ser considerado mera decorrência do desenvolvimento econômico. A Nação é essencialmente constituída pelas pessoas que a integram, de modo que cada vida humana vale muito mais do que a elevação de um índice estatístico. Preservá-la constitui portanto um dever que transcende a recomendação de caráter econômico, tão indeclinável quanto a defesa das nossas fronteiras. Nessas condições temos de reconhecer e admitir, como objetivo básico da segurança nacional, a garantia de alimento, saúde, habitação, educação e transporte para todos os brasileiros. ${ }^{4}$
\end{abstract}

Sem rupturas no modo de produção, o capitalismo brasileiro, sem perda de perspectiva das novas configurações que se enxergavam no plano internacional, deveria ter como parâmetro a busca do "bem-estar":

\begin{abstract}
O bem-estar que pretendemos para a sociedade brasileira deve assentar-se sobre a livre iniciativa e a propriedade privada. Exatamente por isso adotaremos medidas que venham a democratizar o acesso à propriedade, e a proteção às pequenas empresas. A defesa do regime de livre iniciativa não pode ser confundida, como muitos o fazem, com a proteção aos privilégios de forças econômicas e financeiras. Defender a livre iniciativa e a propriedade privada é defendê-las dos monopólios e do latifúndio. ${ }^{5}$
\end{abstract}

De outra parte, a doutrina reclamava de "todo um elenco de assuntos ausentes aos textos constitucionais brasileiros", entregue "a tratamento arbitrário, com os mais conhecidos prejuízos para o país, enquanto que as Cartas Magnas de países cuja realidade assemelha-se à brasileira, já os consignaram de maneira explícita". ${ }^{6}$ Entre tais assuntos, estavam o tratamento a ser dado ao capital estrangeiro, a caracterização do que deva ser

Socializá-la? Redividi-la? Em que bases? Quais os princípios reguladores da relação empresa-operário, empresa-Estado, empresa-coletividade? Como consubstanciá-la em texto expresso? Participação do trabalhador na vida da empresa: apenas nos lucros, ou também na gestão? E a apropriação dos resultados, ou assunção dos riscos e prejuízos? Como se comportará o Estado em face da atividade econômica: espectador, agente, partícipe, gestor, programador, controlador, senhor? [...]". CORRÊA, Oscar Dias. A crise da constituição, a constituinte e o Supremo Tribunal Federal. São Paulo: RT, 1986, p.19-20.

${ }^{4}$ Discurso de Tancredo Neves no Congresso Nacional, após a escolha pelo Colégio Eleitoral, em 15 de janeiro de 1985. In: BONAVIDES, Paulo; ANDRADE, Paes de, op. cit., 1989, p.798.

5 Ibid., 1989, p.798.

6 SOUZA, Washington Peluso Albino de. O direito econômico no discurso constitucional. Revista Brasileirade Estudos Políticos, Belo Horizonte, n. 60/61, p.294, 1985. 
considerado empresa nacional, estrangeira ou multinacional, o problema da obtenção de empréstimos pelo país, bem como o investimento, além da tecnologia e da sua transferência, do apoio e incentivo à formação de recursos humanos.

Em relação ao constitucionalismo do regime militar, Washington Peluso Albino de Souza argumentava mais que "não se registram ali, nem mesmo referências às bases político-econômicas de enfrentamento do problema e muito menos a instrumentos legais ou judiciais para tanto". ${ }^{7}$ Assim,

[...] Do mesmo modo, dispositivos que já figuraram em nosso discurso constitucional anterior, como o da nacionalização de bens de estrangeiros, e que dele foram retirados, constituem hoje o que há de mais moderno e importante nos regimes jurídicos dos países. Os autores europeus, afeitos a um sistema acentuadamente conservador neste particular, refletindo a realidade atual em que se encontram aqueles próprios países no relacionamento econômico e financeiro internacional, tomam o assunto como uma autêntica 'revolução' e exaltam o 'direito das nacionalizações' como a demonstração da passagem de um direito 'in statu morendi' para um 'in statu nascendi', ao ponto de figurar na própria Carta dos Direitos e Deveres Econômicos dos Estados. ${ }^{8}$

Ademais, a anarquia ou falta de coerência jurídica também era registrada por Washington Peluso Albino de Souza, que atribuía ênfase à necessidade da "presença do Direito Econômico no discurso constitucional", com

[...] uma Constituição que atenda às exigências da ordem jurídica brasileira, tão tumultuada e comprometida com a pletora de instrumentos legais emitidos durante decênios seguidos, cheia de contradições, de intenções arbitrárias, de oposição aos efetivos interesses econômicos do cidadão e da coletividade, das empresas e da própria Nação, não pode mais eximir-se de uma referência explícita ao Direito Econômico, sob pena de assumir deliberadamente a posição de adotar o mesmo estado de coisas e de permitir a continuidade dos expedientes predatórios da economia nacional, como um todo, e prejudiciais à economia privada do cidadão, em particular. A presença do Direito Econômico no discurso constitucional impõe-se como a única maneira de torná-lo atual, eficiente e consentâneo com a realidade brasileira. ${ }^{9}$

A seu tempo, Fábio Konder Comparato via na Constituição de 1969 "limites intransponíveis para a realização de uma verdadeira mudança de estruturas", sobretudo o limite decorrente do "sistema de propriedade", inclusive, com a confusão voluntária do controle empresarial com o direito de propriedade, que cumpre distinguir e cuja realidade normativa deveria ser modificada.

\footnotetext{
${ }^{7}$ Ibid., 1985, p.294.

${ }^{8}$ Ibid., 1985, p.295.

${ }^{9}$ Ibid., 1985, p.319.
} 
[...] A propriedade classicamente é um direito sobre coisas, e o poder de controle é sobretudo um poder sobre pessoas. Essa confusão leva ao ponto em que o controlador que deve exercer uma função é considerado, sobretudo, ou exclusivamente, como um proprietário. E, portanto quando ele deve ser afastado por razões de absoluta necessidade social, o único remédio é a desapropriação. Então se coloca no mesmo nível o infeliz proprietário de uma única casinha de residência, situado num terreno onde vai passar uma linha de metrô, e o titular do poder de controle sobre um império industrial. Esse último, toda vez que se fala em mudar o regime de propriedade, invoca sagrados princípios de defesa da pessoa humana e, em caráter superior, da propriedade como um resguardo da dignidade da pessoa humana. É evidente que, sem uma modificação do regime de propriedade, tornando possível a desapropriação sem a estrita garantia de indenização pelo valor venal da coisa expropriada, é impossível haver reforma agrária, é impossível haver reforma urbana. ${ }^{10}$

Verberando a Constituição de 1946, o mesmo autor considerava que "ela era ruim nos capítulos referentes à ordem social", pois "não atacava as fontes de poder, que sempre nos mantiveram numa situação de extrema desigualdade social". ${ }^{11}$ A seu ver, a Nova República tinha um projeto de retorno a 1946, “e isto nos é apresentado, até pelos comunistas, como sendo um avanço histórico. Ou seja, recuamos 40 anos no tempo e isso nos é apresentado como um avanço histórico". ${ }^{12}$

Ademais, vislumbrava na sistemática de um Congresso Constituinte, e não de uma Assembléia Geral Constituinte, um empecilho para as mudanças estruturais de que se necessitava, vinculando "poderes constituintes ao Congresso" e não "modificação no Estatuto da Propriedade", "nem propriedade agrária nem urbana" e não "modificação do sistema econômico":

[...] o terror atual dos homens no poder é que se estabeleça um sistema de elaboração da Constituição livre dos seus controles, porque eles sabem, por experiência, que não se pode dar o poder ao povo. Essa discussão sobre a Constituinte não é adjetiva, como dizem alguns preciosos ridículos. Ela é puramente substantiva, porque todos sabem que, ao se atribuir poderes constituintes ao Congresso, não haverá modificação no Estatuto da Propriedade, e, portanto, nem reforma agrária nem reforma urbana. E que não haverá modificação do sistema econômico, no sentido do planejamento, a favor da supressão das desigualdades sociais. Enfim, que todo o sistema de poder continuará como está. ${ }^{13}$

${ }^{10}$ COMPARATO, Fábio Konder. A constituinte do nada mudou (entrevista). Senhor, São Paulo, n.239, p.6, 16 out. 1985.

${ }^{11}$ Ibid., 1985, p.4.

${ }^{12}$ Ibid., 1985, p.4.

${ }^{13}$ Ibid., 1985, p.4. De igual modo, a "oportunidade de se estabelecer, no novo texto constitucional, um sistema de governo capaz de assegurar aos indivíduos que constituem a nação aquilo que os sistemas anteriormente experimentados jamais lhes proporcionaram - condições iguais para cada um prosperar segundo seu próprio talento e esforço, em clima de verdadeira liberdade, a salvo do arbítrio do poder instituído", era também reivindicada por defensores do liberalismo econômico, como MAKSOUD, Henry. Apresentação, op. cit., 1986, p.9. 
Por isso, "a futura Constituição brasileira, para ter um mínimo de legitimidade a sustentá-la, deve assentar-se na realidade brasileira, construída ao longo da história, e dar satisfação à grande exigência nacional: o desenvolvimento sócio-econômico do país", ${ }^{14}$ pois

\begin{abstract}
O ponto de partida é a idéia de que o desenvolvimento representa uma situação de desequilíbrio constante e dinâmico entre classes, setores e regiões do país, de modo a produzir múltiplas e crescentes desigualdades. O desenvolvimento aparece, assim, como o processo de eliminação desses desequilíbrios, pela combinação da capacidade de crescimento econômico com a instauração da igualdade básica de condições de vida. Não se trata, pois, de uma noção exclusivamente econômica, ligada ao aumento da renda nacional, ou à simples modernização tecnológica. Ele abrange as condições básicas de vida em sociedade, as quais dizem respeito, obviamente, às exigências biológicas elementares - alimentação, saúde e preservação do meio ambiente -, mas também às de ordem cultural e política, como a educação e as liberdades fundamentais. ${ }^{15}$
\end{abstract}

\title{
5.3 O anteprojeto do PT
}

$\mathrm{O}$ anteprojeto do $\mathrm{PT}^{16}$ parte da perspectiva de que o subdesenvolvimento não se confunde com uma situação qualquer de atraso econômico, mas representa estado permanente de desequilíbrio social, caracterizado pela desigualdade crescente de condições de vida, entre classes, setores econômicos e regiões. Ademais, "não obstante o eventual crescimento econômico global e o progresso técnico, acaba sempre reproduzindo, no interior de suas fronteiras, a mesma situação de dominação e exploração, característica da vida internacional". ${ }^{17}$

Assim, tendo em consideração que, no país, como os índices de desigualdade social estão entre os mais elevados do mundo, a organização das políticas públicas deve visar à instauração da igualdade fundamental concernente às condições básicas de vida - saúde pública, alimentação, educação e instrução, trabalho e habitação -, como condições mínimas para "uma vida digna e feliz, finalidade de toda organização de poderes" (art. 1).

${ }^{14}$ COMPARATO, Fábio Konder. Muda Brasil! Uma constituição para o desenvolvimento democrático. 4. ed. São Paulo: Brasiliense, 1987, p.15.

${ }^{15}$ Ibid., 1987, p.16.

${ }^{16}$ De autoria do jurista Fábio Konder Comparato, o anteprojeto foi assumido pelo PT. Ver COMPARATO, Fábio Konder, op. cit., 1987. Em discurso na Assembléia Nacional Constituinte, o então deputado Luiz Inácio Lula da Silva ressaltou: "O Partido dos Trabalhadores apresentou, em março de 1987, um Projeto de Constituição que não era, de forma alguma, um projeto socialista. Era o Projeto de Constituição nos parâmetros permitidos pelo capitalismo, mas entendíamos que, com o nosso projeto, poderíamos, mesmo dentro do sistema capitalista, minorar o sofrimento da classe trabalhadora brasileira". ANAIS DA ASSEMBLÉIA NACIONAL CONSTITUINTE, 23 set. 1988, p.14.313.

${ }^{17}$ COMPARATO, Fábio Konder, op. cit., 1987, p.55. 
No documento em análise, o eixo central da ordenação econômica e social é o planejamento, implicando a periódica fixação de objetivos gerais a serem atingidos e a mobilização de toda a sociedade para a consecução de tais objetivos. Assim, “os principais setores da atividade econômica não devem se desenvolver de modo irracional, arbitrário e egoísta, mas de forma harmônica e disciplinada, para a realização dos grandes objetivos, que a própria sociedade aceita e considera como metas obrigatórias". ${ }^{18}$

Destarte, trata-se de planejamento imperativo, como mecanismo para a sociedade brasileira não entregar à “'mão muito visível' dos interesses particulares a realização do desenvolvimento nacional", formulando-se, ao contrário, como

atribuição legal dos centros de poder, organizados e consentidos de acordo com
os ditames constitucionais. A democracia social não é apenas o regime do
consentimento popular para a designação dos governantes; ela é, também, o
regime de legitimação de todo o poder - político, econômico e social - pela sua
aptidão a satisfazer da comunidade nacional. ${ }^{19}$

Atribuiu-se grande atenção à execução dos planos de desenvolvimento. Previu-se, inclusive, a hipótese de intervenção federal nos Estado "em razão do descumprimento, pelas autoridades estaduais, do dever fundamental de cooperação com a União Federal, na realização dos interesses nacionais, notadamente quanto à execução do plano nacional de desenvolvimento, caso o conflito não possa ser resolvido pelo Judiciário" (art. 196, III). De igual modo, previu-se a intervenção no município (art. 202, III).

Afirma ainda Fábio Konder Comparato que, "especialmente na Parte relativa à ordem econômica e social, timbrou-se em eliminar todas as disposições ditas programáticas e em reduzir o conjunto normativo a regras capazes de impulsionar a transformação da sociedade". ${ }^{20}$

O anteprojeto introduz "sensíveis modificações em relação ao direito vigente", no que diz respeito ao regime de propriedade, “copiado de países que seguiram evolução bem diferente da do nosso", por entender que "um dos grandes obstáculos ao desenvolvimento nacional tem sido o regime da propriedade". Acentuando o "princípio de que a propriedade existe para satisfação dos interesses do próprio titular" e é "uma das garantias de proteção à dignidade da pessoa humana, desde que limitada aos bens indispensáveis à realização

\footnotetext{
${ }^{18}$ Ibid., 1987, p.55.

${ }^{19}$ Ibid., 1987, p.55.

${ }^{20}$ Ibid., 1987, p.27 e 54.
} 
dessa finalidade", pois, “em si mesma, não tem a propriedade nenhuma função social: não é um poder atribuído para a satisfação dos interesses de terceiros". ${ }^{21}$

De tal entendimento, exsurgem duas conseqüências básicas, a saber, a propriedade, enquanto garantia de proteção à pessoa humana, não pode ser suprimida ou sacrificada aos interesses sociais, porque a dignidade da pessoa humana é o primeiro e mais fundamental valor social e, nas hipóteses em que ela não é condição da dignidade da pessoa humana, a propriedade privada deve ceder o passo à realização dos interesses sociais, com indenização limitada, ou mesmo sem indenização alguma, no caso de abuso manifesto.

Ao tratar da garantia da "liberdade de iniciativa empresarial" (art. 213), o anteprojeto não a está erigindo, absolutamente, em liberdade fundamental da pessoa humana, mas apenas reconhecendo que ela representa um instrumento útil e mesmo necessário à defesa dos interesses dos consumidores (e não dos próprios concorrentes, portanto). Logo, a atividade empresarial do Estado, em concorrência com as empresas particulares, tem o fim exclusivo de suplementar a iniciativa privada deficiente no atendimento desses mesmos interesses. Como a concorrência empresarial é mero instrumento de defesa dos consumidores, impõe-se ao Poder Público a exploração das atividades consideradas de interesse público, tanto no setor de prestação de serviços, quanto nos de produção e distribuição de bens, nas quais o regime de competição não traz benefícios ao consumidor (art. 214).

No que se refere à atividade econômica de estrangeiros, deve estar jungida: 1. à submissão à autorização federal da instalação de qualquer empresa sob controle estrangeiro, bem como a das alienações a pessoas domiciliadas no exterior, ou controladas por estas, do controle de empresas já instaladas no país; 2. à facilitação do ingresso no país e a permanência, temporária ou definitiva, de estrangeiros dotados de competência técnica ou científica.

Em suma, o anteprojeto afirma o princípio de que é dever do Estado regular a atividade econômica, em todos os setores, a fim de preservar o poder aquisitivo da moeda nacional, bem como proteger os interesses dos consumidores, o equilíbrio ecológico, a saúde, a segurança e a moralidade públicas (art. 217).

${ }^{21}$ Ibid., 1987, p.56. 


\subsection{O anteprojeto da Comissão Provisória de Estudos Constitucionais e a "constituição econômica"}

O anteprojeto da Comissão Provisória de Estudos Constitucionais, tendo em conta o constitucionalismo anterior e em relação à "constituição econômica", inovou substancialmente. Algumas dessas inovações quanto à forma, podem ser observadas quando, entre outras, propõem "títulos" autônomos, um para "a ordem econômica" e outro para "a ordem social", fugindo à tradição do constitucionalismo brasileiro, que, a partir de 1934 e seguindo-se em 1946, 1967 e 1969, manteve a técnica de um título relativo à "ordem econômica e social".

Agora, como proposta importante, transmutou-se a problemática do "trabalho"22 da ordem econômica para a ordem social, apresentando parâmetros modernos e alargando programas existentes, ou inovando no que diz respeito à esfera a ser constitucionalizada como ordem social. Assim, passa-se a ver no "trabalho" mais um direito fundamental, com todos os consectários de tal entendimento, do que um mero "fator de produção".

$\mathrm{Na}$ verdade, o anteprojeto não é infenso ao capitalismo, à livre iniciativa e à propriedade privada, devendo "o exercício da atividade econômica, seja qual for seu agente, está subordinado ao interesse geral". Quer, pois, a "ordem econômica" fundamentada na "justiça social e no desenvolvimento", com o fito de "assegurar a todos uma existência digna" (art. 316). Para tanto, pretende que a atividade econômica seja ordenada nos seguintes princípios: a valorização do trabalho; a liberdade de iniciativa; a função social da propriedade e da empresa; a harmonia entre as categorias sociais de produção; o pleno emprego; a redução das desigualdades sociais e regionais; o fortalecimento da empresa nacional; e o estímulo às tecnologias inovadoras e adequadas ao desenvolvimento nacional.

Assim, "a atividade econômica será realizada pela iniciativa privada", todavia, "resguardada a ação supletiva e reguladora do Estado, bem como a função social da

\footnotetext{
${ }^{22}$ Entre os aspectos inovadores em relação à matéria, destacam-se a duração (máximo de quarenta horas semanais); obrigatoriedade de medidas que visem a eliminar ou reduzir a insalubridade dos locais de trabalho; permissão de trabalho da mulher nas indústrias insalubres; fixação em quatorze anos da idade mínima para o trabalho; obrigatoriedade de manutenção de creches para os filhos de seus empregados até um ano de idade, e de escola-maternal para os de até quatro anos; fixação de o mínimo de dois terços de empregados brasileiros nas empresas, salvo as micro e as familiares; participação nos lucros e participação no faturamento; obrigatoriedade de participação dos empregados na direção da empresa; vedação da prescrição durante a relação de emprego; direito de greve; autonomia sindical.
} 
empresa", repita-se, tanto a iniciativa privada, principal, como ação supletiva e reguladora do Estado, devendo subordinar-se ao "interesse geral".

No que diz respeito ao capital estrangeiro, o anteprojeto houve por bem em estabelecer os princípios a regê-lo, a saber, "a função supletiva do capital estrangeiro", o "regime especial" relativo à remessa de lucros, incidência de juros, entre outros aspectos, a proibição às pessoas físicas e jurídicas do acesso à propriedade de terras em que se localizem minas e jazidas. Ademais, o anteprojeto determinava a nacionalização dos bancos (art. 327, par. ún.).

Por sua vez, o anteprojeto estabeleceu um conceito de "empresa nacional" - que é aquela que, ao mesmo tempo tenha capital controlado por brasileiros, seja constituída no Brasil e possua aqui sua sede e o seu centro decisório - cercado de cuidados e limitações (art. 323).

Há que observar também o especial destaque dado ao planejamento, estabelecendo "planejamento imperativo para o setor privado". Este deverá visar ao atendimento das necessidades coletivas, à eliminação das diferenças regionais e setoriais, ao estímulo do crescimento da riqueza e da renda, à justa distribuição dessa riqueza e dessa renda, harmonizando também "o desenvolvimento econômico com a preservação do equilíbrio ecológico e da qualidade do meio ambiente" (art. 324, § $2^{\circ}$ ).

A seu tempo, o art. $324, \S 1^{\circ}$, almejou o planejamento realizado com a participação de pessoas jurídicas de direito público, comissões especiais, organizações profissionais e entidades de classe.

Ademais, pretendeu-se, com uma série de requisitos, que a propriedade rural pudesse alcançar a sua função social, de tal modo como toda propriedade. No que diz respeito à propriedade rural, estaria ela "condicionada pela sua função social", o que se alcançaria à medida que se assegurasse aos que nela trabalhem e às suas famílias "nível adequado de vida", "a manutenção adequada dos equipamentos comunitários", a "exploração racional da terra" e a observância das normas reguladoras das relações trabalhistas (art. 331).

No que se refere à propriedade territorial urbana, o proprietário de terreno deverá dar-lhe "utilização socialmente adequada, sob pena de desapropriação por interesse social, mediante prévia e justa indenização em dinheiro), ou de "incidência de medida de caráter 
tributário (art. 337). Acresce-se que, em relação à propriedade urbana, o anteprojeto (art. $139, \S 2^{\circ}$ ) dispunha que o imposto sobre a propriedade predial e territorial urbana adquiriria a qualidade de imposto sobre o patrimônio, com alíquota progressiva "em função de número de imóveis do mesmo contribuinte", ou de sanção punitiva em razão do “tempo decorrido sem utilização socialmente adequada no caso de imóveis construídos".

Por fim, o anteprojeto tem preocupação com os monopólios estatais. Largueia o monopólio da União Federal no que concerne ao petróleo, que passa a abranger "a refinação, o processamento, o transporte marítimo e em condutos”. Dá maior dimensão também ao monopólio do gás natural. Além do mais, dispõe que a pesquisa, a lavra, o enriquecimento, a industrialização e o comércio de minérios necessários e matérias fósseis (art. 330) pertencem à União Federal.

\subsubsection{Avaliação do anteprojeto}

O texto final do anteprojeto foi avaliado como "uma vitória do grupo heterogêneo que juntou socialistas, social-democratas, católicos com fortes preocupações sociais e liberais", ${ }^{23}$ principalmente por conta de duas evidências, a saber, as fortes críticas que o texto recebeu dos membros considerados "conservadores" e o afastamento do secretário geral da Comissão. ${ }^{24}$ Em relação ao "modelo econômico", ressaltou-se que "em pelo menos um momento ficou nítida na Comissão a divisão entre 'progressistas' e 'conservadores'. Foi quando se discutiu, em maio, o modelo econômico que se queria para o país".

\footnotetext{
O relatório final do grupo, defendido pelo advogado Alberto Venâncio Filho, previa um papel preponderante para a iniciativa privada na ordenação econômica do país. O texto foi completamente alterado em votações tensas no plenário e os chamados 'conservadores' foram seguidamente derrotados. Voto vencido em pontos importantes como reforma agrária, monopólio da União, capital estrangeiro e dívida externa, Venâncio abandonou as discussões, pediu demissão e só retornou depois dos apelos de Afonso Arinos e outros membros. O texto final aprovado amplia o monopólio da Petrobrás, prevê a possibilidade de desapropriação de empresas rurais para fins de reforma agrária, condiciona o direito à propriedade rural à sua função social, restringe investimentos de capital estrangeiro e afirma outros pontos que provocaram a crítica, por parte dos
}

\footnotetext{
${ }^{23}$ A COMISSÃO, sob fogo cruzado. Folha de São Paulo - Guia da Constituinte, op. cit., p.3.

${ }^{24}$ Manoel Gonçalves Ferreira Filho diz que a Constituição de Portugal de 1976 foi "a grande fonte inspiradora da Comissão", acrescentando que, "sem dúvida, desde a Independência, nenhum documento jurídico brasileiro mais seguiu o saber lusitano do que o anteprojeto em exame". FERREIRA FILHO, Manoel Gonçalves, op. cit., 1987, p.4. Para uma análise da influência do constitucionalismo português dos anos 70 no processo constituinte brasileiro, ver, entre outros, TAVARES, Ana Lucia de Lyra. A Constituição brasileira de 1988: subsídios para os comparatistas. Revista de Informação Legislativa, Brasília, n.109, p.71-108, 1991.
} 
'conservadores', de 'xenófobo', 'intervencionista' e 'socializante'. Com efeito, o texto aumenta a ação do Estado na economia. ${ }^{25}$

Evidentemente, outros prospectos se apresentavam no escambo em que se tornou o momento constituinte. A Constituição Federal vigente estabelecia que a atividade econômica seria desenvolvida prioritariamente pela iniciativa privada, destinando ao Estado uma função suplementar, quando fosse indispensável à segurança nacional ou para organizar setor que não pudesse ser desenvolvido com eficácia no regime de competição e livre iniciativa (art. 163, caput).

A Igreja Católica achava que a economia deveria ser planejada, dando-se prioridade ao atendimento das necessidades básicas da população, com a adoção de mecanismos capazes de superar a desproporção entre os setores populacionais em relação à participação nos frutos do trabalho. O trabalho deveria ter prioridade sobre o capital e a sua divisão deveria favorecer a ascensão política, econômica, social e cultural.

A Federação das Indústrias do Estado de São Paulo (FIESP) entendia que a atividade econômica deveria organizar-se dentro do respeito à liberdade de iniciativa, à propriedade privada dos meios de produção e aos direitos dos trabalhadores. Regendo-se pelas leis de mercado, a economia caberia fundamentalmente às empresas privadas, com o estímulo, o apoio e a fiscalização do Estado. Reservas de mercado admitir-se-iam tão somente para atender ao desenvolvimento de setores não suficientemente desenvolvidos e, mesmo assim, por prazo certo. Os monopólios estatais só se dariam por razões de segurança nacional. Por sua vez, os lucros das empresas se distribuiriam apenas entre os seus acionistas.

O PT, que tinha o seu próprio projeto de Constituição, sustentava que, tendo em vista a superação das desigualdades sociais básicas e a melhoria constante das condições de vida da população, será objeto de planejamento, em níveis nacional, regional e estadual. As leis e atos do Executivo não podem contrariar diretrizes dos planos de desenvolvimento, sob pena de invalidade. A liberdade de iniciativa será garantida em função do interesse dos consumidores e o Estado só poderá fazer concorrência para suplementar as deficiências da iniciativa privada no atendimento a esses interesses. Cabe ao Estado regular a atividade econômica, em todos os setores, para preservar o poder aquisitivo da moeda nacional e proteger os interesses dos consumidores. O monopólio púbico será criado por lei federal,

${ }^{25}$ A COMISSÃO, sob fogo cruzado. Folha de São Paulo - Guia da Constituinte, op. cit., p.3. 
estadual ou municipal. Depende de autorização do governo federal a instalação de empresa sob controle de pessoas domiciliadas no exterior.

\subsubsection{Balanço geral do anteprojeto}

Poder-se-iam sumariar as principais linhas de orientação da Comissão Provisória de Estudos Constitucionais, no que diz respeito à "constituição econômica" e, conseqüentemente, em relação também à propriedade e ao contrato, nas seguintes:

Tributação: instituição de imposto federal sobre a propriedade de bens móveis de caráter suntuário e de imposto determinado em função inversa da utilização e da produtividade das terras, para promover a reforma agrária. Atribui-se competência ao Município para instituir impostos sobre venda a varejo, locação de bens móveis e arrendamento mercantil e de imposto progressivo em função do número de imóveis do mesmo contribuinte e de sua não utilização (art. 139), além de poder instituir contribuição de custeio de obra ou serviço resultante do uso do solo urbano (art.133, III, d).

Papel do Estado na economia: ao Estado cabe estabelecer normas para o planejamento da atividade econômica do país, com a iniciativa privada condicionada à “ação supletiva e reguladora do Estado, bem como a função social da empresa" (art. 318, 319 e 324$)$.

Reforma agrária: cabe ao Poder Público a promoção e criação de condições de acesso do trabalhador à propriedade da terra economicamente útil (art. $331, \S 2^{\circ}$ ), podendo o proprietário de imóvel urbano compelido a lhe dar utilização socialmente adequada (art. $337)$.

Dívida externa: limitam-se em três por cento ao ano os juros sobre a dívida externa. As taxas de juros praticadas serão determinadas pelas oscilações do mercado internacional (art. 12 do título IX), além de caber ao Congresso Nacional a análise da legitimidade da dívida externa (art.13 do título IX).

Trabalho: retorno da estabilidade no emprego, combinado com o Fundo de Garantia por Tempo de Serviço (FGTS) (art. 343, XVI). Deverá haver em cada empresa um fundo a ser aplicado na construção de moradias e em serviços assistenciais com controle paritário de patrões e empregados (art. 370). 


\subsection{Perfil dos deputados constituintes em relação à "constituição econômica"}

Leôncio Martins Rodrigues, desenvolvendo pesquisa sobre o perfil políticoideológicos dos constituintes eleitos para a Câmara dos Deputados, particularmente no que diz respeito à preferência dos deputados por sistema econômico, desenvolvido a partir de um intervalo em que se contemplasse de um "mínimo de participação do Estado na economia a um máximo de estatização, com o desaparecimento do setor privado nos principais setores produtivos", encontrou os seguintes resultados:

1. Liberais (favoráveis a um mínimo de intervencionismo do Estado) - 40\%;

2. Social-democratas (favoráveis a um equilíbrio entre a participação do Estado e a da iniciativa privada) - $39 \%$;

3. socialistas moderados (favoráveis a um predomínio do Estado, mas sem eliminação da economia de mercado) - 15\%;

4. socialistas extremados (favoráveis à eliminação do capital privado e à estatização dos principais meios de produção) $-6 \%{ }^{26}$

Destarte, a análise das opiniões dos deputados diante das três questões que constituem as linhas de clivagem das principais correntes políticas do mundo contemporâneo possibilitou, de antemão, a visão de uma Câmara de Deputados na qual, em princípio, as facções de centro-esquerda conquistaram mais da metade dos lugares e as facções de direita eram formalmente inexistentes. ${ }^{27}$

A análise dos constituintes sobre a perspectiva partidária apontou-lhes, em linhas gerais, as seguintes características:

\footnotetext{
${ }^{26}$ RODRIGUES, Leôncio Martins. Quem é quem na constituinte: uma análise sócio-política dos partidos e deputados. São Paulo: OESP - Maltese, 1987, p.107. Segundo a mesma pesquisa, a auto-definição dos deputados, no que concerne à posição no espectro político-ideológico assim resultou: direita radical - 0\%; direita moderada ou centro-direita $-6^{\circ}$; centro - 37\%; esquerda moderada ou centro-esquerda - 52\%; esquerda radical - 5\%. Ibid., 1987, p.103. Coordenada pelo cientista político Leôncio Martins Rodrigues, a pesquisa em tela foi patrocinada por O Estado de São Paulo e pela Editora Maltese, e considerou tãosomente os constituintes eleitos para a Câmara dos Deputados.

27 ،[...] Assim, a julgar pelas disposições manifestadas pelos deputados entrevistados, no tocante ao sistema econômico, a atual composição da Câmara de Deputados vai no sentido da aceitação de um intervencionismo estatal de tipo corporativo, que não elimine mas controle e reduza as atividades econômicas privadas, limitando as prerrogativas da propriedade do capital em nome de certos objetivos sociais e nacionais fixados pela coletividade, ou seja, pelo Estado, ou mais exatamente, pelas elites políticas que controlam o poder”. RODRIGUES, Leôncio Martins, op. cit., 1987, p.127.
} 
1. o desmonte da idéia de que o principal partido de oposição ao regime militar, o PMDB, foi o grande vencedor no Congresso Constituinte, ${ }^{28}$ já que a eles se filiaram muitos ex-integrantes do PDS, partido de sustentação do regime anterior, mostrando, portanto, a presença de figuras vinculadas ao antigo regime nos dois partidos - PMDB e PFL - que sustentaram a Nova República;

2. o Congresso Constituinte contou com $49 \%$ de novos parlamentares, índice semelhante aos de outras legislaturas;

3. no que se refere à experiência política anterior, apenas $24,2 \%$ dos parlamentares não a possuíam. Dos que possuíam experiência política, $54 \%$ haviam sido vereadores, prefeitos, deputados estaduais e governadores, mostrando a presença de um número considerável de políticos com ligações próximas e recentes tantos com as esferas subnacionais como com o regime anterior;

4. pesquisas mostraram que os membros do Congresso Constituinte eram conservadores em questões de ordem e valores morais, mas progressistas nos temas socioeconômicos. ${ }^{29}$

$\mathrm{Na}$ verdade, o grau de heterogeneidade dos constituintes, aliado ao caráter "transição por transação", apontava duas perspectivas para o processo decisório constituinte: a) acordos entre grupos com afinidades ideológicas, confrontando conservadores e progressistas; b) acordos entre grupos ideologicamente adversários, gerando consenso em certas questões e deixando para o futuro as decisões em que este não pudesse ser alcançado. $^{30}$

\subsection{A ordem econômica no debate constituinte-parlamentar}

Ainda no início dos trabalhos constituintes, o deputado José Santana (PFL-MG) acentuava que "um dos grandes males do nosso País, que seguramente contribuiu para levá-lo à problemática atual, é a excessiva tutela estatal exercida sobre a economia”, pois, "sem receio de exagerar, podemos dizer que hoje existe maior intervenção estatal sobre a economia brasileira que em muitos países comunistas. Enquanto a própria União Soviética procura estimular algumas formas de iniciativa privada, através da 'Glasnost', abertura, no

${ }^{28}$ Sobre as raízes do PMDB, ver, entre outros, KINZO, Maria D’Alva Gil. Oposição e autoritarismo: gênese e trajetória do MDB (1966-1979). São Paulo: Idesp/Vértice, 1988; NADER, Ana Beatriz. Autênticos do MDB: semeadores da democracia. São Paulo: Paz e Terra, 1998. Sobre Ulysses Guimarães, ver GUTEMBERG, Luiz. Moisés: codinome, Ulysses Guimarães: uma biografia. São Paulo: Companhia das Letras, 1994.

${ }^{29}$ SOUZA, Celina. Federalismo e descentralização na constituição de 1988: processo decisório, conflitos e alianças. Dados - Revista de Ciências Sociais, Rio de Janeiro, v.44, n.3, p.513-560, 2001; e SOUZA, Celina. Constitutional engineering in Brazil: the politics of federalism and decentralization. London: Macmillan Press, 1997. Ver também RODRIGUES, Leôncio Martins, op. cit., 1987.

${ }^{30}$ SOUZA, Celina, op. cit., 2001. Para a autora, no que concerne ao item $b$, foi crucial o papel do deputado Ulysses Guimarães, presidente do Congresso Constituinte, na administração dos conflitos e na formação dos consensos. 
Brasil o que se assiste é a progressiva introdução do Estado em todos os setores da economia, trazendo consigo o nepotismo, a incompetência, a inidoneidade". E propunha:

Em consonância com suas funções de ordenadora da nova sociedade brasileira, caberá à Assembléia Nacional Constituinte prover para que seja evitado o avanço e intervenção do Estado na ordem econômica e na autonomia, reduzindo também os níveis atuais em que isso ocorre. O princípio da liberdade de iniciativa deverá ser gravado no Capítulo da Ordem Econômica e Social, deixando-se claro que o nosso regime econômico é o da economia de mercado, avesso à ação inexorável da férrea mão estatal que hoje administra desde a vida sindical até as taxas de juros.

Caberá, portanto, à Constituinte fixar meios e mecanismos para que o Governo, face visível do Estado, seja efetivamente tradutor e intérprete da vontade do povo, e não o tutor dos abusos e desvirtuamentos. É preciso incentivar os agentes promotores do desenvolvimento, que são exatamente as empresas privadas. E será também preciso retornar o Estado ao exercício de suas próprias e hoje negligenciadas funções de promotor da educação, saúde, segurança, saneamento e justiça, entre outras. ${ }^{31}$

Já se aproximando o final dos trabalhos constituintes, num balanço do conteúdo da "ordem econômica" no texto constitucional em preparo, o deputado Divaldo Suruagy

(PFL-AL) declarava:

[...] o Título da Ordem Econômica, com a ressalva dos excessos que todos reconhecem e que ainda podem ser corrigidos, é um texto que atende à média das aspirações de todas as correntes políticas, partidárias e ideológicas representadas no Plenário da Assembléia. Não podemos nos esquecer que um texto constitucional votado em Assembléia Nacional Constituinte não é nem pode ser obra apenas das maiorias nela representadas, mas deve, ao contrário, ser fruto da transação possível entre a maioria e minorias como de resto tem sido a tônica da Constituinte a que todos aqui integramos. ${ }^{32}$

[...] todos concordam em que os investimentos externos, sob a forma de capital de risco, ainda são indispensáveis para o processo de desenvolvimentos do País. As discordâncias residem entre os que entendem que tais investimentos devem ser seletivos, restritos a áreas a serem definidas pelo Estado, e regulados no que respeita à remessa de lucros, e aqueles que, em posição diametralmente oposta, não desejam qualquer forma de restrição em relação ao capital nacional. A solução adotada pelo texto constituinte é, em meu entender, uma solução de compromisso. O que o Plenário terminou decidindo é um meio termo entre as duas posições radicais. Aceitamos o capital de risco com garantias de repatriamento, como, aliás, o Brasil vem fazendo desde 1962, mas estabelecemos, por via constitucional, uma distinção tanto no que se refere a áreas excluídas de suas atividades, quanto no que respeita ao tratamento diferenciado que, em relação a esses capitais, devem merecer as empresas nacionais. ${ }^{33}$

\footnotetext{
${ }^{31}$ Discurso do deputado José Santana (PFL-MG). ANAIS DA ASSEMBLÉIA NACIONAL CONSTITUINTE, 13 maio 1987, p.1.892.

${ }^{32}$ Discurso do deputado Divaldo Suruagy (PFL-AL). ANAIS DA ASSEMBLÉIA NACIONAL CONSTITUINTE, 3 jun. 1988, p.11.016.

${ }^{33}$ Ibid., 1988, p.11.015.
} 
Divaldo Suruagy ressaltou também que "não se modificou substancialmente o modelo econômico em vigor no país, não havendo, portanto, razão para pessimismo ou receio de novas ameaças do capital estrangeiro". Também via continuidade no que concerne à decisão do Plenário em relação à ordem econômica, à presença do Estado no setor produtivo e à questão disso decorrente, que é o papel reservado às estatais, às empresas privadas nacionais e às empresas multinacionais, em relação ao mercado.

Destacou:

Não vejo modificações radicais no modelo vigente. Tradicionalmente, o Estado atua em áreas em que a escala de recursos necessários não pode ser atendida pelo capital nacional. Ou naqueles em que, por questões de segurança, a presença do capital internacional de risco não é considerada conveniente. ${ }^{34}$

Nas últimas décadas, no entanto, a presença do Estado no setor produtivo se expandiu muitas vezes desnecessariamente, a despeito das limitações de todos os textos constitucionais anteriores, que sempre tentaram, embora sem sucesso, conter a sua ação, subordinando-a ao interesse estratégico da segurança nacional. $\mathrm{O}$ texto aprovado pela Constituinte continua admitindo a presença do Estado em todas essas áreas, mas procurou opor um controle efetivo à possibilidade de ampliação da presença das estatais em setores que podem ser atendidos pela iniciativa privada, ao estabelecer que a criação de órgãos da Administração Indireta ou de suas subsidiárias passa a depender de prévia e expressa aprovação do Congresso. ${ }^{35}$

Por fim,

Quanto à última das questões relevantes, que foi a definição de empresa nacional, creio que a solução encontrada atende a um imperativo dos interesses nacionais na medida em que, indistintamente, se consideram empresas brasileiras aquelas que aqui estão instaladas e são organizadas sob a vigência das leis do País. E, distintamente, se consideram empresas brasileiras de capital nacional aquelas que têm maioria do controle acionário nas mãos de brasileiros residentes no País.

O deputado Odacir Soares (PFL-GO) contra-argumentava em relação ao pretenso xenofobismo do novo texto, entendendo que havia mais a preocupação de absorção dos aportes tecnológicos por parte dos brasileiros contra a prioridade dos capitais estrangeiros com o lucro. Entendendo que, na raiz dos conflitos que se davam no Congresso Constituinte, estava fundamentalmente "na opção por um determinado modelo de desenvolvimento que está o divisor da águas no imenso caudal das ideologias”, constatava que

\footnotetext{
${ }^{34}$ Ibid., 1988, p. 11.015 .

${ }^{35}$ Ibid., 1988, p. 11.015.

${ }^{36}$ Ibid., 1988, 11.016.
} 
a estruturação da atividade econômica em nosso País continua fundada na livre iniciativa, assegurando-se a manutenção da propriedade privada, que deverá ter função social, e a livre concorrência. Ao autorizar a qualquer pessoa o exercício da atividade econômica, o texto constitucional ressalva a defesa do consumidor e do meio ambiente, garantindo o tratamento favorecido para as empresas nacionais de pequeno porte e tendo em vista a redução das desigualdades regionais e sociais com a busca permanente do pleno emprego.

Na verdade, é, basicamente, o que já existe em termos de legislação ordinária. Não procedem, portanto, os reclamos daqueles insatisfeitos que teimam em ver na Constituinte um xenofobismo que ela não adotou. Contudo, é preciso o suporte da lei para termos tranqüilidade no processo de abertura da nossa economia às empresas e capitais externos. Deles, sem dúvida, o interesse maior é o lucro enquanto, para nós, o objetivo será sempre os aportes tecnológicos e recursos financeiros indispensáveis ao nosso desenvolvimento. ${ }^{37}$

O parlamentar vê o novo texto constituinte, inclusive, como salvaguarda, "no instante em que o Governo se vê às voltas com um processo de desestabilização da nossa economia", pelo que o Congresso Constituinte "aproveitou-se para estabelecer os fundamentos de uma redefinição do papel do Estado no domínio econômico", tendo em conta o fato de "outras economias, em processo de desenvolvimento como a nossa, estarem, da mesma forma, vivenciando o problema e promovendo constantes e arrojadas transformações". Enfim, "reconheceu-se competência do Estado para a dinamização econômica, seja por meio da sua atividade reguladora, seja pela capacidade que tem de articular investimentos e mobilizar poupanças".

Concluímos, portanto, que a atividade econômica em nosso País foi objeto de uma minuciosa e responsável reflexão onde a soberania nacional e o compromisso com o futuro ditaram os rumos de uma estruturação racional, lógica e condizente com as necessidades do momento. ${ }^{38}$

Um dos temas mais disruptivos dos que se feriram no Congresso Constituinte foi o da ordenação do sistema financeiro. Para o deputado Olívio Dutra (PT-RS), "o crédito para ter direcionamento social, o dinheiro que circula nos bancos, [...] para ter função social, tem que estar sob o controle do Estado, permeado pela sociedade", exigindo-se, para tanto, "estatização completa e definitiva do sistema financeiro como um todo". ${ }^{39}$ No mesmo sentido, e noutra vertente partidária, o deputado João da Mata (PFL-BA) comunicava o encaminhamento de "proposta à Assembléia Nacional Constituinte, dando a competência exclusiva ao Estado para a exploração dos serviços bancários", por conta do "drama da

\footnotetext{
${ }^{37}$ Discurso do deputado Odacir Soares (PFL-AL). ANAIS DA ASSEMBLÉIA NACIONAL CONSTITUINTE, 3 jun. 1988, p.11.019.

${ }^{38}$ Ibid., 1988, p.11.019.

${ }^{39}$ Discurso do deputado Olívio Dutra (PT-RS). ANAIS DA ASSEMBLÉIA NACIONAL CONSTITUINTE, 27 fev. 1987, p.618.
} 
espoliação dos bancos privados em relação à economia nacional”. Ressaltava o constituinte:

[...] precisamos, sim, assegurar uma sistemática válida, que dê condições à iniciativa privada, principalmente aos setores da agropecuária, à indústria e aos setores de serviço, para que planejem as suas atividades em curto, médio e longo prazo, mas que isso só pode evidentemente acontecer se viermos a limitar as atividades do setor bancário, que hoje tem sido, sem nenhuma dúvida, a grande preocupação da economia nacional. ${ }^{40}$

Logo no início dos trabalhos constituintes, outra questão ferida foi a do meio ambiente. O deputado Joaquim Francisco (PFL-PE) acentuava ser necessário que,

[...] na forma da proposta da Comissão Afonso Arinos, assuma o Estado a proteção do meio ambiente e a melhoria da qualidade de vida; que preserve a garantia da utilização adequada dos recursos naturais, o equilíbrio ecológico, a proteção da fauna e da flora, o combate à poluição e erosão e a redução dos riscos de catástrofes naturais e provocadas pelo desenvolvimento industrial (inclusive nuclear).

\section{$[\ldots]$}

Também que a criação ou ampliação de indústrias suscetíveis de causar dano à vida e ao meio ambiente dependam da prévia autorização do Congresso Nacional; que sejam vedadas em todo o Território Nacional as práticas que afetem a vida e o meio ambiente ou que ponham em risco espécies em extinção, como a baleia; declarar que a floresta Amazônica é patrimônio nacional, só podendo ser utilizada dentro de condições que assegurem sua preservação e riqueza florestal e ambiental. ${ }^{41}$

No mesmo diapasão, manifestava-se o deputado Eraldo Tinoco (PFL-BA):

Deve consagrar definitivamente o princípio da soberania, não apenas soberania política, assegurada desde a independência e mantida pelas instituições nacionais, mas também soberania no campo econômico, através de mecanismo de estímulo de desenvolvimento científico e tecnológico, capaz de situar o Brasil entre as nações mais prósperas do mundo.

Urge disciplinar, de maneira firme e adequada, a exploração de nossas reservas naturais. Sem desprezo pela ecologia e especialmente sem sacrifícios da maioria para o benefício de poucos. ${ }^{42}$

A questão do monopólio estatal do petróleo também veio à tona. Tal problema, bem como o dos contratos de riscos, arregimentou figuras tradicionais da defesa do monopólio estatal, como Barbosa Lima Sobrinho, além de representantes de entidades classistas. O

\footnotetext{
${ }^{40}$ Discurso do deputado João da Mata (PFL-PB). ANAIS DA ASSEMBLÉIA NACIONAL CONSTITUINTE, 29 abr. 1987, p.1.535.

${ }^{41}$ Discurso do deputado Joaquim Francisco (PFL-PE). ANAIS DA ASSEMBLÉIA NACIONAL CONSTITUINTE, 2 abr. 1987, p.1055.

${ }^{42}$ Discurso do deputado Eraldo Tinoco (PFL-BA). ANAIS DA ASSEMBLÉIA NACIONAL CONSTITUINTE, 8 maio 1987, p.1.771.
} 
deputado Paulo Ramos (PMDB-RJ) registra "a preocupação e o desejo de verem reacesa a luta em defesa do monopólio estatal do petróleo e contra os contratos de risco" e relembra os constituintes quanto ao dever de lutar "em defesa dos nossos recursos naturais não renováveis". ${ }^{43}$

Para Albano Franco (PMDB-SE), senador e presidente da Confederação Nacional da Indústria (CNI), cumpria fundamentalmente limitar o papel do Estado, pois, se "ninguém defende hoje em dia o laissez-faire", também, "certamente, ninguém advoga o dirigismo". Cumpre observar que "os próprios países socialistas que tinham tanto ceticismo em relação à livre iniciativa estão, a um só tempo, todos eles entregues ao mais frenético programa de privatização da economia", muito mais "que nós - capitalistas - que temos mais de 50\% da economia dependente do Estado e que, em 10 anos, não conseguimos privatizar sequer $1 \%$ do capital das empresas estatais". Assim,

[...] O excessivo peso do Estado na Economia [...] é um dos sérios entraves a ser superado. A Constituição não fará milagres, mas pode ajudar muito. Ela estabelecerá os limites do poder público no sistema produtivo. Do meu ponto de vista, luto para garantir o máximo de liberdades àqueles que desejam produzir com seus próprios recursos. Não desejo um Estado tutor ou protetor, não desejo, tampouco, um Estado interventor e autoritário. Almejo, simplesmente, um Estado regulador e mediador. ${ }^{44}$

Afirmando ser, "por formação", contrário às "formas de intervencionismo e a favor das decisões responsáveis”, manifestava-se

[...] contra incluir na Constituição princípios que são melhor tratados na lei ordinária. Este é o caso do monopólio do exercício profissional (art.12, IV); da intromissão de terceiros na vida privada das instituições (art.12, IX, a); da limitação arbitrária do uso da propriedade (art.12, XIII, d). Da mesma maneira, sou contra a interferência no comando das empresas (art.17, IV, d) e a favor da liberdade de ação de seus responsáveis. No exercício dessa liberdade, eles respondem pelos acertos e pelos erros. ${ }^{45}$

Ademais, entendia inconcebível, também,

[...] ver o Estado querendo regular os bens dos trabalhadores. Aceitar o Governo controlando os salários, por exemplo, é admitir os trabalhadores submetidos ao Estado. E tem sido o Estado o mantenedor do status quo dos trabalhadores. A história recente tem mostrado não ser a empresa privada a inibidora das

\footnotetext{
${ }^{43}$ Discurso do deputado Paulo Ramos (PMDB-RJ). ANAIS DA ASSEMBLÉIA NACIONAL CONSTITUINTE, 10 abr. 1987, p.1.225.

44 Discurso do deputado Albano Franco (PMDB-SE). ANAIS DA ASSEMBLÉIA NACIONAL CONSTITUINTE, 10 abr. 1987

${ }^{45}$ Ibid., 1987.
} 
conquistas sociais. Quem aceita o controle do Estado sobre os salários aceita implicitamente o atrelamento dos sindicatos ao Governo. ${ }^{46}$

Assestando as baterias contra a busca de mecanismos de proteção aos trabalhadores, Albano Franco perguntava e respondia:

Ora, é essa a sociedade que queremos? Certamente não. A sociedade almejada é uma sociedade mais livre e justa, mais solta e que, antes de seguir as leis dos homens, seja capaz de seguir as leis da natureza. Os artificialismos nunca funcionaram. Ao contrário, querer impor estabilidade (art. 13, I), jornada de trabalho (art.13, XV) e reajustes salariais (Art. 13, V) pela via da Constituição é desacreditar na sociedade e na capacidade negociadora dos homens. É reforçar sua condição de dependentes do 'Grande-Pai' - o Estado. ${ }^{47}$

Em relação ao capital estrangeiro e à internacionalização da economia, acentuava:

O trato do capital estrangeiro entre nós deve se nortear assim, por princípios realistas. Sou visceralmente contra qualquer tipo de entreguismo. Assim como abomino a xenofobia e o isolacionismo. Por isso, no trato do capital estrangeiro sou a favor de uma regra muito simples: associação sempre; desnacionalização, nunca! É só isso. Dessa maneira, estaremos respeitando e fazendo respeitar os princípios da soberania e da liberdade, não se justifica, pois, fechar a porta à empresa estrangeira a priori. Toda empresa que para cá deseja vir a trabalhar conosco será bem-vinda. Entretanto, querer vir para simplesmente explorar, não! Querer vir beneficiar de condições especiais, não! Chegou o momento de elas compreenderem que a sua prosperidade daqui para frente dependerá de copropriedade. Todos nós queremos vencer juntos. Essa é a maneira civilizada de convivermos no mundo moderno. Todo o resto é resquício do capitalismo selvagem. $^{48}$

Olívio Dutra (PT-RS) fazia o contraponto a Albano Franco:

Temos defendido a maior presença do Estado na economia. E fazemos isto porque temos entendimento de que o Estado é que deve ter maior presença na economia, na regulamentação da vida de todo nós; deve ser um Estado, por sua vez, permeado pela sociedade civil, o Estado, profunda e radicalmente, democratizado, não o Estado do técnico-burocrata, militar, e sim o Estado em que os governantes sejam controlados pelos governados. Este Estado tem responsabilidade social enorme e, por isso, deve estar presente nas atividades de interesse coletivo e de interesse público, como é o caso do sistema financeiro. ${ }^{49}$

Reforçando o ponto de vista defendido no início dos trabalhos constituintes, Olívio Dutra, insistia no problema do sistema financeiro, pois

[...] O crédito tem de ter uma função social, o microempresário, o pequeno comerciante, o pequeno produtor rural, a população, o trabalhador independente e autônomo precisam ter acesso rápido e desburocratizado e barato ao crédito.

\footnotetext{
${ }^{46}$ Ibid., 1987.

${ }^{47}$ Discurso do senador Albano Franco (PMDB-AL). ANAIS DA ASSEMBLÉIA NACIONAL CONSTITUINTE, 12 ago. 1987, p.4.274-4276.

${ }^{48}$ Ibid., 1987, p.4.274-4276.

${ }^{49}$ Discurso do deputado Olívio Dutra (PT-RS). ANAIS DA ASSEMBLÉIA NACIONAL CONSTITUINTE, 27 fev. 1987, p.618
} 
Para que isso aconteça o sistema financeiro tem que ser estatizado, os bancários de todo o País - e sou um deles, eventualmente aqui representando não só os bancários como outros setores de trabalhadores nesta Constituinte -, os bancários, junto com a população, há muito tempo reivindicamos isto. Os funcionários do Banco do Brasil, os funcionários dos bancos de economia mista, dos bancos de desenvolvimento regional, os funcionários do Banco Central têm realizado convenções, congressos - e nesta última semana estiveram reunidos aqui mesmo em Brasília - não apenas para defender corporativamente os seus direitos e seus interesses, como para apontar propostas que vão no rumo de que o sistema financeiro brasileiro está servindo apenas a um grupo minoritário de capitalistas, de banqueiros, com interesses encravados não apenas no sistema financeiro e também no latifúndio, e com interesses associados com o capital internacional. Para que este sistema financeiro garantia, inclusive, uma postura digna do nosso País diante dos credores internacionais no trato da dívida externa, este sistema tem que ser estatizado. [...] No nosso País a agudização da privatização do sistema financeiro está sendo discutida fora deste Congresso. A privatização de bancos públicos, a diminuição de bancos estatais está sendo articulada pelos banqueiros privados e com lobbies dentro do Executivo brasileiro, sem o conhecimento do Congresso, sem o conhecimento da Nação. A ligação dessa privatização do setor financeiro brasileiro está ligada com a subordinação da política brasileira, com relação aos credores externos da nossa dívida pública. ${ }^{50}$

O deputado Sotero Cunha (PDC-RJ) exigia "medidas inadiáveis para debelar um desvio crucial em nossa economia: a estatização", pois "chegamos aos anos 80 com 70\% de nossa economia estatizada, e vivemos hoje um capitalismo de Estado que sufoca a economia nacional não lhe permitindo grande agilidade". Ressaltava que,

[...] Muito embora saibamos que setores da economia nacional, como o energético (PETROBRÁS, ELETROBRÁS e NUCLEBRÁS) e o de telecomunicações (TELEBRÁS, Empresa Brasileira de Correios e Telégrafos e RADIOBRÁS) devam continuar a ser gerenciados por empresas do Governo, não é mais admissível a presença do Estado nos outros setores da atividade econômica do País.

\section{$[\ldots]$}

O Partido Democrata Cristão exige a privatização do desenvolvimento nacional e, com exceção feita às companhias que atuam nas áreas de energia e de telecomunicações, reclama a desestatização de todas as empresas públicas. ${ }^{51}$

A deputada Myrian Portella (PDS-PI) ressaltava: “É tempo de se renovar o conceito de propriedade. Ele já não mais limita o poder do Estado. Pelo contrário. O Estado há de intervir no regime da propriedade para manter a paz social, satisfazer os interesses coletivos e, deste modo, democratizá-la". Sobretudo, acentuava a "preocupação pelo homem urbano. São muitos os graves problemas enfrentados pelos habitantes da cidade.

\footnotetext{
${ }^{50}$ Discurso do deputado Olívio Dutra (PT-RS). ANAIS DA ASSEMBLÉIA NACIONAL CONSTITUINTE, 15 ago. 1987, p.4.436-4.437.

${ }^{51}$ Discurso do deputado Sotero Cunha (PDC-RJ). ANAIS DA ASSEMBLÉIA NACIONAL CONSTITUINTE, 27 ago. 1987, p.4.980.
} 
Aparentemente diversos, eles, no entanto, se relacionam e, em nosso entender, tudo começa pelo uso do solo urbano".52

O deputado José Santana (PFL-MG) chamava a atenção para "a excessiva tutela estatal exercida sobre a economia", ressaltando existir "maior intervenção estatal sobre a economia brasileira que em muitos países comunistas". Por sua vez, o parlamentar vinculava o "ideal democrático da sociedade pluralista, aberta, justa, centrada no respeito ao indivíduo cujo mérito deve premiar", à "eliminação da tutela tecnocrática do Estado", e à implantação de uma verdadeira economia de mercado em que floresça a livre iniciativa". Assim,

[...] Em consonância com suas funções de ordenadora da nova sociedade brasileira, caberá à Assembléia Nacional Constituinte prover para que seja evitado o avanço e intervenção do Estado na ordem econômica e na autonomia, reduzindo também os níveis atuais em que isso ocorre. O princípio da liberdade de iniciativa deverá ser gravado no Capítulo da Ordem Econômica e Social, deixando-se claro que o nosso regime econômico é o da economia de mercado, avesso à ação inexorável da férrea mão estatal que hoje administra desde a vida sindical até as taxas de juros. ${ }^{53}$

A seu tempo, o deputado Jalles Fontoura (PFL-GO) alertava para "o repensamento da Ordem Econômica no momento constituinte", visto que da "formulação dos princípios que direcionam dependerá a estabilidade do sistema constitucional que viermos a promulgar, a eficácia das normas inseridas na parte relativa à Ordem Social - direitos individuais e a própria vigência da Carta Magna". Cabia, assim, a "mais apurada análise e decisão do Congresso Constituinte" referentemente à "liberdade de iniciativa, a intervenção do Estado no domínio econômico, o papel do capital internacional e o regime constitucional da propriedade", fazendo-se, porém, que a "liberdade de iniciativa seja temperada pela demanda social" e "harmonizada com a função social da empresa" ${ }^{54} J a ́$ o deputado Raimundo Bezerra (PMDB-CE) ressaltava:

Somos daqueles que não apóiam a livre participação de empresas estrangeiras em atividades essenciais ou que fazem concorrência a firmas nacionais eficientes, principalmente quando vêm tentar desalojar congêneres brasileiros que, com reconhecida competência, prestam inestimáveis serviços à nação e oferecem milhares de empregos. Somos apologistas em uma guerra sem trégua

\footnotetext{
${ }^{52}$ Discurso da deputada Myrian Portella (PDS-PI). ANAIS DA ASSEMBLÉIA NACIONAL CONSTITUINTE, 10 abr. 1987, p.1.881-1.882.

${ }^{53}$ Discurso do deputado José Santana (PFL-MG). ANAIS DA ASSEMBLÉIA NACIONAL CONSTITUINTE, 13 maio 1987, p.1.882.

${ }^{54}$ Discurso do deputado Jalles Fontoura (PFL-GO). ANAIS DA ASSEMBLÉIA NACIONAL CONSTITUINTE, 14 maio 1987, p. 1.944-1.945.
} 
na defesa destes mercados já servidos ou a serem servidos por empresas nacionais.

Para tal deputado, "as multinacionais, nos países subdesenvolvidos, em parte por suas nocivas participações, com raríssimas exceções, usam e abusam de artifícios e meios, nem sempre éticos e legais, para alcançarem seus objetivos". ${ }^{55}$ Por sua vez, o deputado Paulo Delgado profligava:

Na subcomissão de Princípios Gerais da Ordem Econômica foram feitos acordos por membros do maior Partido, que se dizia mudancista, com os setores mais reacionários da sociedade brasileira, vinculados aos interesses internacionais e que levaram à aprovação de um relatório que mutila a concepção de monopólio de petróleo na sociedade e que muda o slogan da campanha 'O petróleo é nosso' para 'O petróleo é deles'. Termina, praticamente, o limite para a atuação de empresas mineradoras dentro do país, internacionaliza a exploração do subsolo. ${ }^{56}$

Como acentua o senador Jarbas Passarinho, sobre a propriedade, "esta é, decisivamente, uma questão que nos divide. Divide-nos ideologicamente, sobretudo", encarecendo:

[...] Não tenho a menor veleidade de convencer, aqui, aos marxistas, nem aos capitalistas, nem aos capitalistas do laissez-faire que fazem da propriedade privada uma vaca sagrada. Devemos ter nesta Constituinte a possibilidade, exatamente, de declarar que a propriedade privada tem uma função social e a ela deve estar correlacionada. O que não é cabível é que se dê com a mão esquerda aquilo que se tira com a direita. [...] A propriedade é um direito natural. Já estava inscrito entre os princípios da Revolução Francesa. $[\ldots]^{57}$

O senador pedessista insubordinava-se em relação aos princípios correlacionados pela Comissão de Sistematização, vocalizando o temor de se estivesse dando a “oportunidade a um Governador ou Prefeito de baixos sentimentos de desapropriar, por interesse social - na verdade, interesse pessoal - a propriedade alheia", propondo "não fechar questão agora, não apoiar aquilo que é na verdade uma restrição, mas abrir a oportunidade para que nós, em seguida, nos entendamos e cheguemos a uma conclusão a favor daquilo que queremos". ${ }^{58}$

O deputado Fernando Gasparian (PMDB-SP) preocupava-se com a "acumulação de uma grande dívida externa". Reconhecendo que "o Brasil conseguiu, durante os vinte anos

\footnotetext{
${ }^{55}$ Discurso do deputado Raimundo Bezerra (PMDB-CE). ANAIS DA ASSEMBLÉIA NACIONAL CONSTITUINTE, 21 maio 1987, p. 2.083.

${ }^{56}$ Discurso do deputado Paulo Delgado (PT-MG). ANAIS DA ASSEMBLÉIA NACIONAL CONSTITUINTE, 27 maio 1987, p.2.215.

${ }^{57}$ Discurso do senador Jarbas Passarinho (PDS-PA). ANAIS DA ASSEMBLÉIA NACIONAL CONSTITUINTE, 10 jan. 1988, p.7.133.

${ }^{58}$ Ibid., 1988, p.7.133.
} 
de regime autoritário, dentro de um capitalismo selvagem, algum desenvolvimento" lançava a invectiva segundo a qual "o País teria conseguido igual desenvolvimento, se os governos tivessem agido com mais correção, com menos corrupção e houvessem aplicado os recursos em investimentos produtivos". Tal desenvolvimento "teve, também, uma grande falha, ou seja, fez com que a distribuição de rendas no País se deteriorasse em muito, de tal forma que ainda hoje o salário mínimo real, por exemplo, é muito menos do que o anterior a 1964".

O mesmo chamava a atenção, na oportunidade, ser necessário "elaborar uma Constituição que possibilite o desenvolvimento social do País, evidentemente dentro de um capitalismo, porque no campo ainda se vive o feudalismo, mas na cidade existe o capitalismo do regime autoritário, que devemos transformar" para "a necessidade de fazermos com que o sistema financeiro do País ajude a construir o capitalismo no Brasil, porque este sistema financeiro é cartorial e de socialização de prejuízos, e significa um capitalismo sem risco". ${ }^{59}$

O deputado Florestan Fernandes (PT-SP) via na crise econômica da conjunta um elemento benfazejo no sentido de influenciar o Congresso Constituinte:

[...] tem-se falado que a conjuntura econômica é um elemento adverso ao funcionamento de uma Assembléia Nacional Constituinte e que interfere negativamente nas perspectivas de que a Assembléia Nacional Constituinte possa preencher suas funções nesse contexto de aguçamento das contradições sociais, econômicas e políticas.

Ao contrário do que se diz, o agravamento da conjuntura é um elemento positivo para o funcionamento da Assembléia Nacional Constituinte e, de outro lado, não é possível separar a crise de conjuntura da crise de estrutura. As duas crises estão superpostas. A crise de conjuntura é de superfície, que reflete a situação mais grave do Brasil, que vem desde o passado colonial, da herança deixada pela Velha República oligárquica, pela ditadura do Estado Novo e pela recente ditadura militar.

Portanto, nunca se pode falar na conjuntura sem pensar na estrutura, e não se pode também avaliar a crise de conjuntura sem pensar no que ela representa, em virtude de elementos que são intrínsecos à própria estrutura da economia, da sociedade e da cultura.

Os problemas mais graves do Brasil dizem respeito à sua estrutura social, econômica e política. São esses elementos que tornam muito difícil, para nós, modernizar as instituições, termos um sistema democrático de governo e, também, um Legislativo independente, cioso de sua autonomia e capaz de enfrentar o Executivo, capaz de ombrear-se com o Judiciário, capaz de funcionar

\footnotetext{
${ }^{59}$ Discurso do deputado Fernando Gasparian (PMDB-SP). ANAIS DA ASSEMBLÉIA NACIONAL CONSTITUINTE, 8 ago. 1987, p.4.088.
} 
como órgão, o nervo que vincula o Estado às necessidades fundamentais da Nação. [...] ${ }^{60}$

O deputado José Serra (PMDB-SP), encaminhando a votação de emenda apresentada pelo constituinte Nelson Friedrich, pretendia maiores graus de liberdade para a presença do capital estrangeiro no sistema financeiro. Entendendo que tal emenda contrariava "os interesses nacionais e as conveniências de uma política nacional de desenvolvimento", ressaltava:

[...] sua emenda é equivocada. Em primeiro lugar, é preciso ter claro que o texto aprovado, a partir de uma emenda de fusão, é bastante restritivo com relação à presença de capital estrangeiro no sistema financeiro, pois ó permite a participação do capital estrangeiro em função de interesse nacional ou em função de acordos internacionais. Portanto, não há liberdade para a entrada de capital estrangeiro no sistema financeiro, aliás, como não existe hoje. Hoje, o Banco Central não dá autoridade para que o capital estrangeiro possa participar de bancos comerciais, sem que isto envolva o princípio da reciprocidade. As únicas exceções são quando envolvem questões de reciprocidade. $\mathrm{O}$ sistema financeiro já é bastante fechado é muito importante ter claro isso. Por outro lado, é importante também entender que a atual legislação, inclusive, não permite que a participação do capital estrangeiro num banco superior a 30\%. Paradoxalmente, a emenda apresentada pelo Constituinte Nelson Friedrich vai permitir, por exemplo, que o Citibank tenha $49 \%$ das ações com direito a voto, de um grande banco no Brasil. Na verdade, ela é até menos restritiva do que a situação atual de outra forma, essa questão de bancos estrangeiros é sempre tratada com muito cuidado. Lembro que no México, no Peru e na França, quando os bancos foram nacionalizados e estatizados não o foram os bancos estrangeiros. Por que isso? Porque essa medida fatalmente iria afastar desses países as instituições financeiras que funcionam no exterior. O Brasil tem muitos bancos no exterior, onde capta, em dinheiro, cerca de três vezes mais do que os bancos estrangeiros captam aqui dentro. Muitos dizem ser empréstimo interbancário, mas não se trata apenas de empréstimo interbancário. Dois bilhões de dólares são captados á vista. Temos, por exemplo, acordos com a Espanha, com a Argentina, de trocas de agências de bancos. Isto ficará inviabilizado, e estaremos perdendo um instrumento de desenvolvimento nacional, que é a presença de bancos brasileiros, inclusive do Banco do Brasil, no exterior. Esse dado é realmente essencial. A presença de bancos brasileiros no exterior é importante para o comércio e expansão da nossa economia, e fatalmente haverá o princípio da reciprocidade, que será aplicado. Muitos dirão que essa reciprocidade, hoje, não é bem regulada. Dá-se de maneira desigual. Eu diria que isso é verdade. Por isso, inserimos no texto constitucional que a lei deverá regulamentar isso. Inclusive, estamos proibindo, nas Disposições Transitórias, que haja qualquer expansão de capital estrangeiro, a não ser dentro dos princípios fixados. [.... ${ }^{61}$

\footnotetext{
${ }^{60}$ Discurso do deputado Florestan Fernandes (PT-SP). ANAIS DA ASSEMBLÉIA NACIONAL CONSTITUINTE, 20 fev.1987, p. 371.

${ }^{61}$ Discurso do deputado José Serra (PMDB-SP). ANAIS DA ASSEMBLÉIA NACIONAL CONSTITUINTE, 12 maio 1988, p. 10.369. A divisão do PMDB em questões como a definição do mandato presidencial e do sistema de governo, com a derrota dos líderes da ala mais à esquerda, acarretou, entre outros fatos, afastamento do senador Mário Covas (PMDB-SP) da liderança do PMDB na Assembléia Nacional Constituinte e a criação do Partido da Social Democracia Brasileira (PSDB), em junho de 1988. Neste mês, o PSDB, tendo como presidente o senador Mário Covas e como secretário-geral Euclides Scalco, estreou no Congresso Constituinte. A bancada reunia, então, 45 constituintes, advindos do PMDB (38), do PFL (4), do PSB (1), do PDT (1) e do PTB (1). Ver FLEISCHER, David V.; MARQUES, Jales R. PSDB: de facção a partido. Brasília: Instituto Teotônio Vilela, 1999.
} 
Para o deputado Pedro Canedo (PFL-GO), “é princípio básico para uma democracia social e participativa a fixação de regras que possibilitem a garantia do sistema de mercado, com total liberdade por parte do cidadão na escolha e opção de bens e serviços, com preceitos éticos de inteiro respeito ao consumidor". Logo, "é condenável [...] o apelo intervencionista muito em voga nos dias próximos passados e atuais, que terminou por inibir em parte a criatividade individual".

É preciso deixar como tarefa à iniciativa privada tudo aquilo que não seja função do Governo. Ao Governo cabe cuidar da saúde preventiva, educação, saneamento, nutrição, habitação e segurança pública. Do restante deveria retirarse, estimulando a iniciativa privada. Não se compreende um Governo que explora hotéis, vende dentifrícios através da Cobal ou da SAB, aluga casas e apartamentos e se mete em tudo quanto é lugar onde não foi chamado nem é necessário. ${ }^{62}$

Reconhecendo que a iniciativa privada brasileira, embora não tivesse "capacidade e capital para alguns empreendimentos", estaria "preparada para a quase totalidade das atividades econômicas do País", encarecia:

À ameaça da crescente estatização deve contrapor-se um movimento coordenado
de incentivo à atuação da iniciativa privada, como meio e forma de o País
reencontrar-se com seu destino e sua história. Se o setor privado conseguiu livrar
o Brasil da dependência total do petróleo, será também capaz de colaborar
intensamente no sentido de que venhamos a ter, brevemente, uma economia
forte, pujante, como parte de um mundo moderno. É preciso, porém, que o
Governo faça a sua parte contendo os seus gastos, vendendo as suas muitas
empresas e contendo a inflação que cresce como um monstro ameaçador. O
desnecessário e o supérfluo devem ser banidos da vida nacional, com o
envolvimento e a liberação do setor privado. ${ }^{63}$

No final, a crítica mais acerba aos resultados da Assembléia Nacional Constituinte, no que tange à "constituição econômica", veio do Partido dos Trabalhadores, que, inclusive, recusou-se a aprovar o texto final produzido. Em discurso na Assembléia Nacional Constituinte, Luiz Inácio Lula da Silva ressaltou sobre o anteprojeto:

O Partido dos Trabalhadores apresentou, em março de 1987, um Projeto de Constituição que não era, de forma alguma, um projeto socialista. Era o Projeto de Constituição nos parâmetros permitidos pelo capitalismo, mas entendíamos que, com o nosso projeto, poderíamos, mesmo dentro do sistema capitalista, minorar o sofrimento da classe trabalhadora brasileira. Passados 18 meses, é importante reconhecer que não apenas o Partido dos Trabalhadores como outras forças progressistas aqui, nesta Casa, se empenharam 24 horas por dia, de segunda a domingo, para que pudéssemos hoje estar votando esta Constituição.

\footnotetext{
${ }^{62}$ Discurso do deputado Pedro Canedo (PFL-GO). ANAIS DA ASSEMBLÉIA NACIONAL CONSTITUINTE, 16 dez. 1987, p.6.154.

${ }^{63}$ Ibid., 1987, p.6.154.
} 
O Partido dos Trabalhadores fez um estudo minucioso, através da sua bancada e da sua direção, e chegou à conclusão de que houve alguns avanços na Constituição; de que houve avanços na ordem social, de que houve avanços na questão do direito dos trabalhadores, mas foram avanços aquém daquilo que a classe trabalhadora esperava acontecesse aqui, na Constituinte. ${ }^{64}$

Embora avaliasse que a Constituinte proporcionara avanços, o representante do PT criticava a falta de ousadia no que tange à "essência da propriedade privada". Por via de conseqüência,

[...] o Partido dos Trabalhadores [...] vem aqui dizer que vai votar contra esse texto, exatamente porque entende que, mesmo havendo avanços na Constituinte, a essência do poder, a essência da propriedade privada, a essência do poder dos militares continua intacta nesta Constituinte.

Ainda não foi desta vez que a classe trabalhadora pôde ter uma Constituição efetivamente voltada para os seus interesses. Ainda não foi desta vez que a sociedade brasileira, a maioria dos marginalizados, vai ter uma Constituição em seu benefício. ${ }^{65}$

Em razão da falta de "sensibilidade de entender que não basta, efetivamente, democratizar um povo nas questões sociais, mas é preciso democratizar nas questões econômicas", Luiz Inácio Lula da Silva afirmava a posição contrária do PT ao texto constitucional em construção:

[...] imaginava que os Constituintes, na sua grande maioria, tivessem, pelo menos, a sensibilidade de entender que não basta, efetivamente, democratizar um povo nas questões sociais, mas é preciso democratizar nas questões econômicas. Era preciso democratizar na questão do capital. E a que questão do capital continua intacta. Patrão, neste País, vai continuar ganhando tanto dinheiro quanto ganhava antes, e vai continuar distribuindo tão pouco quanto distribui hoje.

É por isto que o Partido dos Trabalhadores vota contra o texto e, amanhã, por decisão do nosso diretório - decisão majoritária - o Partido dos Trabalhadores assinará a Constituição, porque entende que é o cumprimento formal da sua participação nesta Constituinte. ${ }^{66}$

\subsection{A construção da "constituição econômica" no texto constitucional}

Com alguns riscos de simplificação, pode-se dizer que a Assembléia, em boa medida, se dividia entre "progressistas" e "conservadores".

\footnotetext{
${ }^{64}$ Discurso do deputado Luiz Inácio Lula da Silva (PT-SP). ANAIS DA ASSEMBLÉIA NACIONAL CONSTITUINTE, 23 set. 1988, p.14.313.

${ }^{65}$ Ibid., 1988, p.14.313.

${ }^{66}$ Ibid., 1988, p.14.314. Em manifestação recente sobre os vinte anos da Constituição Federal, Luiz Inácio Lula da Silva considerou que "o PT chegou ao Congresso com uma proposta de Constituição pronta e acabada que, se fosse aprovada, certamente seria muito mais difícil governar do que hoje. Como um partido de oposição que nunca havia chegado ao poder, tínhamos soluções mágicas para todas as mazelas do país". FOLHA DE SÃO PAULO, São Paulo, p. A4, 5 out. 2008.
} 
Mas, afinal, em que consiste tal distinção? Certamente conservadores e progressistas se distinguem pelo pertencimento aos dois grandes grupos políticos que se formaram durante a transição brasileira, que, em termos partidários mais remotos, originaram-se, respectiva e fundamentalmente, na Arena e no MDB.

O grupo progressista, com origem no MDB, cresceu durante a transição, à medida que a coalizão contra o autoritarismo se expandia e as regras de organização partidária tornavam praticamente impossível a subsistência do figurino bipartidário. ${ }^{67}$ Esse grupo se expandiu significativamente com o processo de liberalização durante o regime militar e formou uma aliança crucial com dissidentes do partido do governo, o que permitiu que a chapa Tancredo Neves e José Sarney, para presidente e vice-presidente da República, respectivamente, derrotasse o candidato do governo, em 1985, no Colégio Eleitoral.

\subsubsection{O embate entre os "liberais" e os "intervencionistas"}

Na Subcomissão de Princípios Gerais, foi vitorioso o bloco alinhado com a economia pura de mercado, derrotados, todavia, com o desenrolar do processo constituinte. O relator e os sub-relatores das comissões temáticas, e não os respectivos presidentes, participariam da Comissão de Sistematização.

Roberto Campos (PDS-MT), referindo-se ao embate entre "liberais" e “intervencionistas", dá notícia da formação de um bloco alinhado com a economia de mercado.

\footnotetext{
Graças a uma boa articulação orquestrada em parte por Afif Domingos (PL-SP), conseguimos formular um elenco de emendas apresentadas individualmente que, somadas, compunham um capítulo com predominância da linha de economia de mercado. Essa proposta acabou prevalecendo sobre a do relator, Virgildásio de Senna, que perfilhava uma ideologia nacional-estatizante. [...].. ${ }^{68}$
}

Segundo ainda Roberto Campos, manobra política do presidente da Assembléia, o deputado Ulysses Guimarães, anulou a vitória na Subcomissão de Princípios Gerais.

Derrotado o relator, seria de se esperar, como de praxe, sua renúncia, seguida pela designação de um novo relator. Consultado sobre a matéria regimental, Ulysses Guimarães decidiu pela desnecessidade da renúncia do relator, o que viria, de futuro, a causar problemas, de vez que, como já foi dito, só o relator e

${ }^{67}$ MORAES, Filomeno. Ceará: o subsistema partidário e o retorno ao multipartidarismo. In: LIMA JR., Olavo Brasil de (Org.). Sistema partidário brasileiro. Rio de Janeiro: FGV, 1997, p.35-72.

${ }^{68}$ CAMPOS, Roberto. Lanterna na popa - memórias. Rio de Janeiro: Topbooks, 1994. p. 1.189. 
os sub-relatores das comissões temáticas, e não os respectivos presidentes, participariam da Comissão de Sistematização. [... $]^{69}$

O resultado foi, afinal, a predominância de um texto de compromisso entre a "livre iniciativa" e o "valor social do trabalho". Da atitude de Ulysses Guimarães, o mesmo Roberto Campos relata que, "como resultado, Virgildásio de Senna e Severo Gomes viriam a representar, na fase de sistematização, várias propostas que desvirtuaram a linha liberal e privatista vitoriosa na Subcomissão de Princípios Gerais". ${ }^{70}$

Já na etapa da Comissão de Sistematização, tomou-se caminho diferente errático. Assim é que, por conta dos caminhos que o Congresso Constituinte tomava, em especial no que concerne à duração do mandato do presidente da República, além das medidas contrárias a interesses de vários segmentos empresariais, criou-se, então, o Centrão, que tinha como objetivo precípuo enfrentar as supostas tendências esquerdistas do Congresso Constituinte. ${ }^{71}$ Segundo Roberto Campos,

${ }^{69}$ Ibid., 1994, p. 1.189.

70 Ibid., 1994, p. 1.1189. As idéias de Roberto Campos - privatização, desregulamentação e liberalização comercial - acabaram por ser derrotadas na Assembléia Constituinte. Mas, como observa Reginaldo Teixeira Perez: “[...] verifica-se uma alteração na agenda nacional já no início do governo Collor. Observando o período em retrospecto, Campos reconhece: 'Credite-se a Collor e a Zélia o terem inserido irreversivelmente na agenda do país e no discurso político, até então medíocre e covarde, os temas modernizantes da privatização, da desregulamentação e da liberalização comercial'". PEREZ, Reginaldo Teixeira. Pensamento político de Roberto Campos. Rio de Janeiro: FGV, 1999, p.223. Apesar de - como afirma Roberto Campos - ter possibilitado a privatização, a desregulamentação e a liberalização comercial na agenda pública, a vitória de Fernando Collor de Mello não pôs em prática o projeto da burguesia vocalizado durante a Assembléia Constituinte. Como diz Brasilio Sallum Jr.: "É verdade que as derrotas na Assembléia Constituinte e irresolução das crises herdadas no começo dos anos 80 pareceram ser compensadas pela vitória do candidato à Presidência da República mais identificado com a guinada empresarial na direção da liberalização e internacionalização da economia. Foi, no entanto, uma vitória de Pirro. Ela se deu ao preço da desagregação do sistema partidário, que produzira a Nova República, identificado, em demasia, com a perpetuação da crise e com a ausência de reformas na sociedade e do Estado. Além disso, o candidato vitorioso, Fernando Collor de Mello, apesar das afinidades doutrinárias, não tinha vinculação orgânica com a sociedade civil que se aburguesara. Não foi ela que o elegeu. Foi, pelo contrário, graças ao seu carisma, que ela se salvou, por pouco, da vitória de Luiz Inácio Lula da Silva, que representara, exatamente, o que a burguesia mais temia, o aprofundamento, não controlado, dos processos de democratização da sociedade”. SALLUM JR., Brasilio. Crise e transição política: da distensão à Nova República. Tese (Livre-docência). São Paulo, Faculdade de Filosofia, Letras e Ciências Humanas da Universidade de São Paulo, 1995, p.157. Posteriormente, a tentativa de desmanche da "constituição econômica" e da "constituição social" de 1988 foi vista como "os vencidos estão passando a vencedores. O 'Centrão' recupera seu ideário constitucional e fá-lo prevalecer nas reformas em andamento. Fernando Henrique Cardoso vinga-se da derrota sofrida para relator da Constituinte, e se transforma no relator da deformação da obra do poder constituinte originário. [...]”. SILVA, José Afonso da. Poder constituinte e poder popular: estudos sobre a Constituição. São Paulo: Malheiros, 2007, p.13-14.

${ }^{71}$ A propósito da criação do Centrão, Saulo Ramos observa: "Foram tempos agitados aqueles da Constituinte. O país levou o maior susto, quando Afonso Arinos, Senador pelo Rio de Janeiro e inegavelmente um grande jurista, fez um discurso na Assembléia, sustentando que a Constituinte tinha liberdade absoluta para alterar as instituições, sem nenhuma vinculação jurídica com o passado ou com o Direito Constitucional, e que as limitações impostas à Constituinte derivada eram velharias na doutrina”. Todavia, “[...] Sarney comprovou que realmente entendia dos dois assuntos: de Direito Constitucional e de política. Em uma 
O texto coordenado pela Comissão de Sistematização, antes de passar ao Plenário, adquiriu um viés intervencionista e estatizante. É que o bloco nacionalpopulista, apesar de minoritário, revelou maior articulação e combatividade.

Como reação a esse texto, os parlamentares de visão mais liberal organizaram um bloco suprapartidário que viria a ser apelidado de Centrão. ${ }^{72}$

Inicialmente, a Comissão de Sistematização consolidou as matérias aprovadas pelas comissões temáticas. Em junho de 1987, o relator apresentou um anteprojeto, que recebeu emendas, e ambos foram votados. O relatório aprovado, em julho de 1987, foi denominado "Projeto de Constituição". Na seqüência, a Comissão de Sistematização realizou mais rodadas de trabalho, resultando, sucessivamente, o "Primeiro Substitutivo da Comissão de Sistematização" (agosto de 1987), o "Segundo Substitutivo da Comissão de Sistematização" (setembro de 1987) e o "Projeto de Constituição (A), da Comissão de Sistematização" (novembro de 1987).

Afinal, se os progressistas, em regra, foram mais bem-sucedidos nas subcomissões e comissões temáticas, na Comissão de Sistematização tiveram que negociar com as forças conservadoras.

O projeto Hércules, do Grupo dos $32,{ }^{73}$ foi entregue ao relator-geral Bernardo Cabral em 13 de agosto de 1987. Continha 227 artigos, acrescido dos 32 concernentes ao Ato das

\footnotetext{
semana, conseguiu mudar tudo. Provocou a criação de uma poderosa bancada de constituintes, que passou a ser chamada de Centrão, acabou com os poderes da Comissão do Senador Fernando Henrique, e Bernardo Cabral foi defenestrado da relatoria da Constituinte. O novo relator passou a ser o engenheiro, geólogo e Deputado José Lins, do Ceará [...].” RAMOS, Saulo. Código da vida. São Paulo: Planeta do Brasil, 2007, p.209 e 216. Mauro Benevides (PMDB-CE) considera que crucial "foi o momento em que o grupo liderado pelo deputado Roberto Cardoso Alves e denominado Centrão anunciou formalmente que se ausentaria do processo de elaboração da Carta Magna, se não fosse processada uma reforma regimental que teria que respeitar algumas cláusulas impostas pelo bloco. Era uma forma que o bloco tinha de se contrapor a quaisquer alternativas socializantes ou esquerdizantes que pudessem ser oferecidas naquele momento pelos senadores e deputados constituintes. O Regimento da Constituinte tinha sido elaborado por Fernando Henrique Cardoso. Quando houve essa imposição do Centrão, Ulysses me designou para flexibilizar o Regimento e atender, senão totalmente, mas em grande parte, à proposta do Centrão. Afinal, elaboramos esse Regimento exigindo que qualquer matéria somente fosse aprovada com 280 votos dos senadores e deputados constituintes. ENTREVISTA de Mauro Benevides à Agência Senado. Disponível em: <http://www2.camara.gov.br/internet/constituicao20anos>. Acesso em: 9 out. 2008.

${ }^{72}$ CAMPOS, Roberto, op. cit., 1994, p.1.189.

${ }^{73}$ O Projeto Hércules foi coordenado pelo senador José Richa (PMDB-PR). Observa José Gomes da Silva: “[...] Grupos como o dos 32, capitaneado pelo senador José Richa (PMDB/PR), articularam o chamado 'Projeto Hércules', uma tentativa de compor progressistas (sobretudo os do PMDB) com correntes menos conservadoras dos outros partidos. Da mesma forma atuaram ativamente, nesse estágio, os números lobbies que se movimentavam na ANC, seja de entidades de classe, de grupos empresariais ou despachantes avulsos monitorando interesses muito especiais. Pelo seu prestígio e pelos desdobramentos políticos que acarretou, é preciso mencionar a ingerência militar [...]”. SILVA, José Gomes. Buraco negro: reforma agrária na Constituinte de 1987/88. Rio de Janeiro: Paz e Terra, 1989, p.131. A respeito do Grupo dos 32 e do Grupo do Consenso, diz Adriano Pilatti: "Tendo como figuras mais proeminentes José Richa (PMDB), Virgílio Távora (PDS), Adolfo de Oliveira (PL) e Sandra Cavalcanti (PFL), o Grupo dos
} 
Disposições Transitórias. Inovava em relação ao projeto da Comissão de Sistematização, contendo as seguintes inovações:

- definia como empresa brasileira de capital estrangeiro a pessoa jurídica, com sede e direção no Brasil, que não atendesse aos requisitos da definição de empresa nacional;

- no tocante aos monopólios da União, acrescentava o reprocessamento dos minerais nucleares, e eliminava a possibilidade de 'contratos de risco' com empresas privadas para a prospecção e exploração de petróleo e gás natural;

- na definição da função social da propriedade rural, estabelecia o requisito de efetivo aproveitamento racional, eliminando a possibilidade, constante do Projeto da Comissão, de o requisito ser satisfeito se o imóvel estivesse em curso de ser racionalmente aproveitado;

- a indenização em títulos, paga pela desapropriação, perdia a garantia de correção monetária e o acréscimo de juros legais, previstos pelo Projeto da Comissão;

- caberia à lei definir a aceitação dos títulos da dívida agrária, o que, segundo o texto do Projeto da Comissão, seria garantido diretamente pela constituição;

- no tocante às concessões de rádio e TV, somente a outorga destas seria necessariamente submetida ao Congresso, mas poderia haver a aprovação por decurso de prazo, caso o Congresso não se manifestasse tempestivamente;

- quanto às renovações de concessões e ao exame das concessões em curso, o Congresso poderia examinar o ato, sempre que julgar conveniente.

- o Conselho Nacional de Comunicação teria composição paritária de representantes do Legislativo e do Executivo;

- o texto garantia o prazo certo para as concessões: dez anos para emissoras de rádio e quinze anos para as de TV, sendo que o cancelamento poderia ser suspenso e revisto pelo Judiciário. ${ }^{74}$

Em 26 de agosto, o relator deu à luz o primeiro Substitutivo, com 305 artigos e outros 69 de Disposições Transitórias, denominando-o Projeto Cabral 1. Em relação à "constituição econômica", o novo texto, no que concerne ao Anteprojeto e ao Projeto de Constituição, mantinha: “ - a exploração privada dos serviços de telecomunicações; - a

32 reunia os autodefinidos moderados do PMDB e modernos dos partidos conservadores com o propósito expresso de encontrar soluções de consenso para os temas polêmicos, alem da óbvia intenção de partilhar influência com os líderes partidários, o relator e seu auxiliares. Com as mesmas motivações e integrado por progressistas do PMDB, modernos do PFL e membros dos partidos de esquerda, articulara-se também a Comissão Interpartidária ou Grupo do Consenso, cuja porta-voz mais constante era o progressista Euclides Scalco (PMDB), secundado por Lúcio Alcântara. Ambos os grupos preparavam propostas alternativas e, às vésperas do término do prazo para emendas ao Projeto, reuniram-se seguidamente em conjunto". PILATTI, Adriano. A Constituinte de 1987-1988: progressistas, conservadores, ordem econômica e regras do jogo. Rio de Janeiro: PUC Rio; Lúmen Júris, 2008, p.157.

${ }^{74}$ Utilizo-me, em relação ao Projeto Hércules e aos subseqüentes, em transcrição abaixo, da sistematização procedida por PILATTI, Adriano, op. cit., 2008, capítulos 5 e 7. 
definição do mercado interno como patrimônio nacional; - a definição de empresa nacional tecnológica."

Mas, o Projeto Cabral 1 modificava substancialmente, quer por influência do Projeto Hércules, que por influência do Grupo do Consenso, ${ }^{75}$ além de remeter muitos temas polêmicos para legislação infraconstitucional espinhosos para o legislador ordinário:

- restringia a brasileiros a titularidade das empresas de capital nacional e incorporava o conceito de empresa brasileira de capital estrangeiro;

- eliminava a preferência no acesso a créditos públicos subvencionados em favor das empresas nacionais e a exigência de igualdade de condições para o tratamento preferencial na aquisição de bens e serviços pelo Poder Público;

- ampliava a reserva, em favor das empresas nacionais, de todo aproveitamento de potenciais de energia hidráulica (com exceção dos de capacidade reduzida), bem como para toda pesquisa e lavra de minerais;

- incluía no monopólio da União a importação e a exportação de petróleo e gases, bem como o reprocessamento de minérios nucleares e a proibição de 'contratos de risco';

- condicionava o direito de propriedade rural, e não apenas o uso desta, ao cumprimento de função social, mas deixava para a lei a definição dos requisitos;

- poderia ser desapropriada toda propriedade que não cumprisse sua função social, e não apenas a improdutiva;

- eliminava a incidência de juros legais sobre os títulos indenizatórios das desapropriações, mas mantinha a correção monetária, passando ao legislador ordinário a decisão sobre a utilização desses títulos;

- somente as benfeitorias úteis e necessárias seriam indenizadas em dinheiro, excluídas as chamadas 'voluptuárias' (piscinas, quadras esportivas, obras suntuárias, etc.);

- garantia a presença do proprietário, ou perito deste, na vistoria que precederia a desapropriação;

- previa a concessão judicial imediata da imissão da posse do imóvel em favor da União, ou no máximo em noventa dias, caos o juiz não o fizesse;

- mesmo se o juiz entendesse que a propriedade cumpria sua função social, a desapropriação seria mantida, mas o pagamento de todo valor da indenização teria que ser feito em dinheiro;

- no tocante às concessões de rádio e TV, o texto do Hércules era quase totalmente incorporado, com pequenas alterações. ${ }^{76}$

\footnotetext{
${ }^{75}$ Sobre o Grupo do Consenso, ver nota 63.

${ }^{76}$ Ver nota 73.
} 
Em 18 de setembro, o relator apresentou o $2^{\circ}$ Substitutivo, ou Cabral 2, com 264 artigos e outros 72 de Disposições Transitórias. O texto manteve do Cabral 1 os direitos trabalhistas, a possibilidade de exploração privada dos serviços de telecomunicação, o Cabral 2 apresentava também as seguintes diferenças relevantes em relação ao Cabral 1:

- restabelecia a definição de empresa nacional do Projeto, eliminando a restrição de sua titularidade a brasileiros e estendendo-a às pessoas físicas em geral;

- proibia o legislador ordinário de estabelecer qualquer outra discriminação entre empresas em razão da nacionalidade de origem do capital, além das previstas pelo constituinte para fortalecer o capital nacional e melhorar suas condições de competitividade;

- estabelecia que as áreas prioritárias para reforma agrária seriam fixadas em decreto do Poder Executivo;

- em vez de correção monetária, previa cláusula de preservação do valor real dos títulos indenizatórios das desapropriações;

- não mais definia o mercado interno como parte integrante do patrimônio nacional, e voltava a exigir igualdade de condições para a aquisição preferencial de bens e serviços tecnológicos de empresas nacionais;

- restringia a exigência de controle tecnológico para a definição de empresas nacionais aos setores nos quais a tecnologia de ponte fosse fator determinante de produção;

- restabelecia a exigência de apreciação necessária pelo Congresso Nacional dos atos de outorga e de renovação de concessão de rádio e TV, mas em regime de urgência;

- exigia que a não renovação de concessão fosse aprovada pela maioria absoluta do Congresso Nacional. ${ }^{77}$

Como observa José Gomes da Silva,

A gestação do Cabral 2 foi marcada por intensas negociações, pressões de toda origem e pelo aparecimento de blocos estruturados de constituintes defendendo posições definidas. Este último fato mostra a importância que esta etapa adquiriu na dinâmica do processo constituinte. Para a opinião pública, a movimentação que o Cabral 2 ocasionou chegou a dar a impressão de que qualquer decisão

\footnotetext{
${ }^{77}$ Para a construção deste tópico, vali-me do estado-da-arte dos estudos político-constitucionais. Além de PILATTI, Adriano, op. cit., 2008, vali-me também das contribuições de SILVA, José Gomes. Buraco negro: reforma agrária na Constituinte de 1987/88. Rio de Janeiro: Paz e Terra, 1989; SOUZA, Celina, op. cit., 2001; SOUZA, Celina. Constitutional engineering in Brazil: the politics of federalism and decentralization. London; Macmillan Press, 1997; PILATTI, Adriano, op. cit., 2008; BALTAR, Ronaldo, op. cit., 1996; SOUZA, Márcia Teixeira de. O processo decisório na Constituição de 1988: práticas institucionais. Lua Nova - Revista de Cultura e Política, São Paulo, n.58, p.37-59, 2003; FEITOSA, Raymundo Juliano. Finanças públicas e tributação na Constituinte: 1987/1988. Rio de Janeiro: América Jurídica, 2003.
} 
nesse nível estava selando os destinos da proposição, tal o empenho que foi colocado a esta altura dos debates. $[\ldots . .]^{78}$

A votação dos textos-base dos Títulos VII e VIII ocorreu em 28 de outubro. Neste dia foram votados os textos-base de todos os Títulos ainda não votados (IV a IX), ressalvados os destaques. Semelhantemente às votações dos outros Títulos do Projeto Cabral 2, a aprovação dos textos-base do Título VII se deu por unanimidade (72 votos) e do Título VIII por 72 a 2. As divergências eram deixadas para as votações dos destaques. Decidido o Título VII, em 28 de outubro, e em 9 de novembro iniciada a votação dos destaques, durante oito meses - de 27 de janeiro a 22 de setembro de 1988, transcorreu a fase derradeira do esforço constituinte.

Nesse lapso, que se inicia com as votações em Plenário e se conclui com a votação do Projeto de Constituição (D), o Centrão apresentou o seu manifesto, conseguindo, em seguida, derrubar o RIANC e moldá-lo aos seus, tudo com o objetivo derrubar o Projeto da Comissão de Sistematização. Em relação à "constituição econômica", apresentou substitutivos que, em suma, propunham:

- designação de empresa brasileira para as constituídas pelas leis brasileiras, com sede e administração no país, a elas assegurado tratamento preferencial nos fornecimentos ao Poder Público;

- designação de empresa brasileira de capital nacional para aquelas cujo controle social de capital votante estivesse, diretamente ou indiretamente, sob a titularidade de pessoas físicas domiciliadas no país ou do Poder Público;

- exigência de lei complementar para conceder às empresas brasileiras de capital nacional tratamento diferenciado consistente apenas em proteção e benefícios especiais temporários para desenvolver atividades estratégicas para a defesa nacional ou imprescindíveis ao desenvolvimento tecnológico;

- exploração privativa de energia hidráulica e minerais, por brasileiros e empresas brasileiras de capital nacional, apenas nas faixas de fronteira e nas terras indígenas;

- embora mantivesse em linhas gerais os monopólios da União sobre petróleo, hidrocarbonetos fluidos e minérios nucleares, excluía desses monopólios o gás natural, a distribuição de petróleo e derivados e a proibição dos 'contratos de risco';

- subordinação apenas ao uso da propriedade rural ao cumprimento, nos termos da lei, da função social, caracterizada pelo aproveitamento adequado, pela exploração de modo a preservar o meio ambiente e favorecer o bem-estar do proprietário e dos trabalhadores e pela observância das disposições gerais que regulam as relações de trabalho - desaparecia a exigência de cumprimento simultâneo dos requisitos;

${ }^{78}$ SILVA, José Gomes, op. cit., 1989, p.131. 
- exigência de prévia aprovação do plano e do orçamento do assentamento pela autoridade competente para que as desapropriações pudessem ser realizadas, bem como reintrodução da exigência de processo administrativo, com vistoria do imóvel na presença do proprietário ou de representante;

- manutenção das indenizações em títulos da dívida agrária com cláusula de preservação do valor real, resgatáveis em até vinte anos a partir do segundo, cuja utilização seria definida em lei;

- indenização de todas as benfeitorias em dinheiro;

- impossibilidade de desapropriação não só de pequenos e médios imóveis rurais, desde que os proprietários não possuíssem outro, mas também das propriedades produtivas;

- manutenção do procedimento contraditório especial, de rito sumário, para o processo judicial de desapropriação, fixado em lei complementar;

- supressão dos conteúdos sobre controle tecnológico nacional, sobre mercado interno, sobre tratamento diferenciado para concessão de incentivo, compras e acesso ao mercado interno no setor de tecnologia;

- manutenção de competência do Executivo para outorga e renovação de concessões de emissoras de rádio e TV;

- manutenção da exigência de maioria absoluta para o Congresso decidir sobre a não renovação de concessões;

- manutenção do prazo de 10 anos para concessão de emissoras de rádio e 15 anos para as de TV;

- manutenção de exigência de decisão judicial para o cancelamento das concessões;

- manutenção da instituição, pelo Congresso, de um Conselho Nacional de Comunicação, como seu órgão auxiliar nessas questões, composto paritariamente por membros do Legislativo e do Executivo;

- possibilidade de exploração privada dos serviços de telecomunicações. ${ }^{79}$

A dinâmica do Congresso Constituinte trouxe, em seguida, sucessivas derrotas para o Centrão já no primeiro turno das votações em Plenário. No segundo turno, as derrotas se repetiram, com a aprovação da "constituição econômica" vigente no Brasil, nas suas linhas gerais, até o momento.

\footnotetext{
${ }^{79}$ Ver nota 73.
} 


\section{ESTADO DE BEM-ESTAR, DESENVOLVIMENTO E DIREITOS SOCIAIS}

[...] la relación entre el Estado y la sociedad civil constituirá el más importante problema, tanto en lo teórico como en lo práctico, de la política del Occidente. $[\ldots]$

Hermann Heller

\subsection{Introdução}

Este capítulo analisa a instituição de um Estado Democrático e Social de Direito, estabelecido na constituição dirigente oriunda do processo constituinte de 1987/1988. A articulação entre Estado democrático, desenvolvimento econômico e direitos sociais, busca pelos constituintes, logrou, "ao revés do que dizem os seus inimigos", a promulgação da "melhor das Constituições brasileiras de todas as nossas épocas constitucionais", como disse Paulo Bonavides. ${ }^{1}$

De fato, contraditoriamente, a "constituição econômica" contida no texto constitucional de 1988 é, de um lado, motivação maior para a crítica, e do outro, se assiste à sua durabilidade, apesar das ameaças constantes.

\subsection{Economia, mercado, propriedade e constituição}

Expulso da França por uma ordem de deportação expedida por Guizot, diz Karl Marx que, em Bruxelas, teve de continuar os seus estudos de economia política iniciados em Paris. O "resultado geral" a que chegou e que, uma vez obtido, serviu de fio condutor aos seus estudos pode assim se resumir: "na produção social da sua vida, os homens contraem relações determinadas necessárias e independentes da sua vontade", que "correspondem a uma determinada fase de desenvolvimento das suas forças produtivas materiais". Ademais,

\footnotetext{
${ }^{1}$ BONAVIDES, Paulo. Teoria constitucional da democracia participativa. São Paulo: Malheiros, 2001, p.204.
} 
“o conjunto dessas relações de produção forma a estrutura econômica da sociedade, a base real sobre a qual se levanta a superestrutura jurídica e política”, com o modo de produção da vida material condicionando "o processo da vida social, política e espiritual em geral". Assim é que "as formas de Estado não podem ser compreendidas por si mesmas nem pela chamada evolução do espírito humano, mas se baseiam, pelo contrário, nas condições materiais de vida cujo conjunto Hegel resume, seguindo o precedente dos ingleses e franceses do século XVIII, sob o nome de 'sociedade civil', e que a anatomia da sociedade civil precisa ser procurada na economia política". ${ }^{2}$

Não exclusivamente, mas nomeadamente, de Marx para cá, as inter-relações entre o substrato econômico da sociedade e a superestrutura jurídico-política têm sido objeto de acirradas pelejas doutrinárias, com os contendores se dividindo entre os que vêem no "jurídico-político" mero reflexo da vida econômica e outros que apregoam a total autonomia de um e outro, para não falar das múltiplas tomadas de posição que se situam no continuum economia e direito, mercado e Estado, racionalidade econômica e racionalidade jurídico-política.

Decerto, a sociedade que se forma nos escombros da derrocada feudal, com a sua formação econômica, o seu aparato jurídico-racional e o seu Estado (nacional), tem, entre as novidades, a predisposição para o lucro, a veleidade da soberania contratual ${ }^{3}$ e o individualismo privatista, que adquirem uma racionalidade nunca vista. Afinal, segundo Max Weber, o impulso para o "ganho", a "ânsia do lucro", não está exclusivamente jungido ao capitalismo. ${ }^{4}$ De fato, o que caracteriza a ação econômica capitalista é "se basear na expectativa de lucro através da utilização das oportunidades de troca, isto é, nas possibilidades (formalmente) pacíficas de lucro". ${ }^{5}$ De fato, a busca do lucro já existia entre os povos antigos e medievos, mas é na modernidade que se aprestam os instrumentos para

${ }^{2}$ MARX, Karl. Prefácio à "Contribuição à Crítica da Economia Política". In: ; ENGELS, Friedrich. Obras escolhidas. São Paulo: Alfa-Ômega, [s/d.], v.1. p.301.

${ }^{3}$ Como observa Eros Roberto Grau, "o princípio da liberdade de contratar é instrumental do princípio da propriedade privada dos bens de produção. A atuação do Estado sobre o domínio econômico, por isso mesmo, impacta de modo extremamente sensível sobre o regime jurídico dos contratos". GRAU, Eros Roberto. A ordem econômica na Constituição de 1988. 10. ed. São Paulo: Malheiros, 2005, p.94.

4 “'O impulso para o 'ganho', a ‘ânsia do lucro', de lucro monetário, de lucro monetário o mais alto possível, não tem nada a ver com o capitalismo. Esse impulso existiu e existe entre garçons, médicos, cocheiros, artistas, prostitutas, funcionários corruptos, soldados, ladrões, cruzados, jogadores e mendigos - ou seja em toda espécie e condições de pessoas, em todas as épocas de todos os países da terra, onde quer que, de alguma forma, se apresentou, ou se apresenta, uma possibilidade objetiva para isso". WEBER, Max. A ética protestante e o espírito do capitalismo. 4. ed. São Paulo: Pioneira, 1985, p.4.

${ }^{5}$ Ibid., 1985, p.5. 
torná-lo a base da nova sociedade, que, nas suas marchas e contramarchas, passa a ser uma "sociedade de mercado".

Evidentemente, as misérias do economicismo devem ser esconjuradas, mas não deixa de ter alguma razão o ponto de vista de que mais do que autônomos os compartimentos sociais são mesmo interdependentes e, no mínimo, exercem uns sobre os outros efeitos reflexos.

\subsubsection{O mercado como instituição jurídica}

Que o mercado é uma instituição jurídica, parece não haver dúvida. ${ }^{6}$ Como instituição social deita raízes na historicidade e na formação das estruturas de poder que acompanham a emergência e a evolução da sociedade capitalista. Assim, o mercado não é uma instituição espontânea, natural - não é um locus naturalis - mas uma instituição que nasce graças a determinadas reformas institucionais, operando com fundamento em normas jurídicas que o regulam, o limitam, o conformam; é um locus artificialis, segundo Natalino Irti. $^{7} \mathrm{E}$ visa a atingir ordem, com a conseqüente regularidade, previsibilidade, calculabilidade de comportamentos, que dependem, em grande medida, de normas jurídicas gerais, impessoais, uniformes, integradas nacionalmente (e quiçá internacionalmente) num território. Como afirma Eros Roberto Grau: “[...] O mercado apenas resiste às contradições do capitalismo na medida em que é ordenado e conformado

\footnotetext{
${ }^{6}$ De modo geral, apesar de o vocábulo "mercado" estar generalizada na ação dialógica mesmo de pessoas comuns, há mal-estar quer no âmbito da ciência econômica, quer no nos arraiais do Direito em relação a esse desconhecido. Já se observou que "é curioso que a literatura de economia e história econômica contenha tão pouca discussão sobre a instituição central em que se fundamenta a economia neoclássica - o mercado". NORTH, Douglass. Markets and other allocation systems in History: the challenge of Karl Polanyi. Journal of European Economic History, Roma, n.6, p.710, 1977. De igual modo, Ronald Coase dá conta de que, "embora os economistas reivindiquem estudar o mercado, na teoria econômica moderna o próprio mercado tem um papel ainda mais à sombra que a firma", pois, de modo geral, os economistas contemporâneos interessam-se apenas pela "determinação dos preços de mercado", mas a "discussão sobre a praça de mercado (market place) desapareceu inteiramente". Assim, o mercado como fato histórico e localizado geograficamente, composto por entidades vivas, encarnadas, em suma, como instituição - não apenas como mecanismo geral de coordenação -, tende permanentemente a ser ofuscado. "Quando os economistas falam de estrutura de mercado, isso não tem nada a ver com o mercado como instituição, mas se refere a coisas como o número de firmas, a diferenciação de produtos [...] sendo a influência das instituições sociais, que facilitam as trocas, completamente ignorada", reforça o mesmo Ronald Coase. COASE, Ronald. The firm, the market and the law. Chicago: Chicago University Press, 1988, p.7-8. Por seu turno, Maria Rosaria Ferrarese aduz, quando trata de "il mercato ed i suoi significati", que, "più usati dagli economisti", todavia, com exceção de Karl Polanyi, "non corrisponde uma parallela attenzioni tributata nella letteratura a tale concetto". FERRARESE, Maria Rosaria. Diritto e mercato. Torino: G. Giappiachelli, 1992, p.17.

${ }^{7}$ Ver IRTI, Natalino. L'ordine giuridico del mercato. 4. ed. Roma/Bari: Laterza, 2001.
} 
pela mão visível do Estado, instrumentada por um direito por ele posto, comprometido com a preservação dos mercados, a serviço da fluência da circulação mercantil". ${ }^{8}$

Resumindo a complexa interação entre o "jurídico" e o "econômico", entre o Estado e o mercado, evidentemente com o Estado regulando o mercado, pode-se dizer: 1. a sociedade capitalista é essencialmente jurídica e nela o direito atua como mediação específica e necessária das relações de produção que lhes são próprias; 2. tais relações de produção não poderiam estabelecer-se nem poderiam reproduzir-se sem a forma de direito positivo, direito posto pelo Estado; tal direito posto pelo Estado surge para disciplinar os mercados. ${ }^{9}$

Afinal, Thomas Hobbes já observava que os indivíduos, antes de constituída a sociedade e o Estado, viviam num "estado de natureza", estabelecendo verdadeira "guerra que é de todos os homens contra todos" e partilhando "nenhum prazer na companhia dos outros". Mas, por meio de um contrato social, afastaram o "medo e perigo da morte violenta". ${ }^{10}$ Assim, "fora dele (do Estado) ninguém tem assegurado o fruto dos seus labores; nele, todos o têm garantido. Finalmente: fora dele, assistimos ao domínio das paixões, da guerra, do medo, da miséria, da imundície, da solidão, da barbárie, da ignorância, da crueldade; nele, ao domínio da razão, da paz, da segurança, das riquezas, da decência, da sociedade, da elegância, das ciências e a benevolência". ${ }^{11}$ Sem o Estado, "a vida do homem é solitária, sórdida, embrutecida e curta". ${ }^{2}$

De modo geral, podem-se descrever os atores econômicos em termos de bounded rationality e oportunismo, mas não dotados de uma lógica superior que tudo vê e tudo preside. Nas palavras de Luiz Gonzaga de Mello Belluzzo, "seria uma insanidade, no mundo moderno e complexo, tentar substituir os preceitos e a força da lei pela presunção de virtude auto-alegada por qualquer grupo social ou, pior ainda, por aqueles que ocupam circunstancialmente o poder". ${ }^{13}$ Também Karl Polanyi já alertara que, "se se deixasse a

\footnotetext{
${ }^{8}$ GRAU, Eros Roberto, op. cit., 2005, p.505. Paula Forgioni, por sua vez, enfatiza que "ao direito compete preservar o mercado (i.e., a fluência das relações econômicas), viabilizando o 'jogo' mediante um sistema que procura levar ao respeito de suas regras”. FORGIONI, Paula A. Contrato de distribuição. São Paulo: RT, 2005, p.207.

${ }^{9}$ GRAU, Eros Roberto, op. cit., 2005.

${ }^{10}$ HOBBES, Thomas. Leviathan. London: Penguin Classics, 1985.

${ }^{11}$ HOBBES, Thomas. Do cidadão. São Paulo: Martins, 1992, p.178.

${ }^{12}$ HOBBES, Thomas, op. cit., 1985, p. 186.

${ }^{13}$ BELLUZZO, Luiz Gonzaga de Mello. Ensaios sobre o capitalismo no século XX. São Paulo: Unesp; Campinas: Unicamp, 2004, p.138.
} 
economia de mercado desenvolver-se de acordo com as suas próprias leis, ela criaria grandes e permanentes males. ${ }^{14}$

Ademais, não se pode olvidar que T. H. Marshall, no seu ensaio clássico, já acentuava a existência, no interior mesmo das democracias modernas, de uma tensão permanente - "uma guerra" - entre o princípio da igualdade implícito no conceito de cidadania e a desigualdade inerente ao sistema capitalista e à sociedade de classes. ${ }^{15}$ Até para que o mercado subsista, cumpre levar em consideração que tal sobrevivência depende de uma racionalidade que não seja a da singela lucratividade, a da simples maximização de lucros, a qualquer custo.

\subsubsection{Constituição econômica ${ }^{16}$ e “autonomia” do Estado}

Uma das características do desenvolvimento do Estado capitalista na Europa Ocidental e nos Estados Unidos, principalmente após a Segunda Guerra, foi a "autonomia" na implantação de projetos políticos, autonomia tal que influenciou o percurso das mudanças sociais. ${ }^{17}$

No que diz respeito à conformação do Estado latino-americano, é de suma importância ressaltar que as relações sociais, econômicas e políticas peculiares em que está envolvido dão lugar a experiências estatais também peculiares concernentes à sua autonomia. ${ }^{18}$ Sobretudo nos países de capitalismo mais avançado, o Estado alcançou um

${ }^{14}$ POLANYI, Karl. A grande transformação: as origens da nossa época. 5. ed. Rio de Janeiro: Campus, 2000, p.161. "A produção é a interação do homem e da natureza. Se este processo se organizar através de um mecanismo auto-regulador de permuta e troca, então o homem e a natureza têm que ingressar na sua órbita, têm que se sujeitar à oferta e à procura, isto é, eles passam a ser manuseados como mercadorias, como bens produzidos para venda." Ibid., 2000, p.162.

15 Ver MARSHALL, T. H. Citizenship and social class and other essays. Cambridge: Cambridge University Press, 1950.

${ }^{16}$ Ver, entre outros, MOREIRA, Vital. Economia e constituição: para o conceito de constituição económica. 2. ed. Coimbra: Coimbra Editora, 1979; BEARD, Charles Austin. An economic interpretation of the Constitution of the United States. Mineolo - New York: Dover Publications, 2004; BERCOVICI, Gilberto. Estado de exceção econômico e a periferia do capitalismo. Separata do Boletim de Ciências Económicas, Coimbra, n.XVLII, 2004; e BERCOVICI, Gilberto. Constituição econômica e desenvolvimento: uma leitura a partir da Constituição de 1988. São Paulo: Malheiros, 2005; COMPARATO, Fábio Konder. O indispensável direito econômico. Revista dos Tribunais, São Paulo, n.353, p.14-26, 1965; GRAU, Eros Roberto, op. cit. 2005; TOJAL, Sebastião Botto de Barros. Constituição dirigente de 1988 e o direito à saúde. In: MORAES, Alexandre de (Coord.). Os 10 anos da Constituição Federal. São Paulo: Atlas, 1999, p.33-44; SOUZA, Washington Peluso Albino de. Teoria da constituição econômica. Belo Horizonte: Del Rey, 2002.

17 Ver ANDERSON, Perry. Balanço do neoliberalismo. In: SADER, Emir: GENTILI, Pablo (Org.). Pósneoliberalismo: as políticas sociais e o Estado democrático. São Paulo: Paz e Terra, 1995, p.9-23

${ }^{18}$ Como observa John Sudarsky, tratando da Colômbia, "la discusión sobre la relación entre el Estado y la sociedad ha girado en torno de la autonomía de la acción del primero en lo que se refiere a la relación 
papel desenvolvimentista, embora sempre muito distante do envolvimento social e do grau de autonomia logrado nos países desenvolvidos. Na verdade, o welfare state, no dizer de David Marquand, "razoavelmente a maior realização da civilização européia neste século", ${ }^{19}$ ficou circunscrito, de algum modo, aos países do Noroeste do mundo e a mais um ou outro país fora de tal quadrante.

No Brasil, em particular, a emergência do autoritarismo-burocrático, em 1964, acarretou a ruína do Estado populista, com a sua veleidade desenvolvimentista, dando lugar, então, à busca da integração no sistema de capitalismo transnacionalizado, com a derrocada dos mecanismos de integração social que, bem ou mal, estavam em curso. ${ }^{20}$

\subsection{A ordem econômica nas constituições brasileiras}

Alguma normatização a respeito do que se denominaria depois, com variações, de “ordem econômica e social” está presente no Brasil desde a primeira constituição (ver projeto da Assembléia de 1823), ${ }^{21}$ que estatuiu "a inviolabilidade dos Direitos Civis, e Políticos dos Cidadãos Brasileiros”, tendo "por base a liberdade, a segurança individual, e a propriedade, "garantida pela Constituição do Império, pela maneira seguinte", entre outros direitos e garantias: "Nenhum gênero de trabalho, de cultura, indústria, ou comércio

entre clases y sobre cómo el Estado es o no instrumento de hegemonía de las clases dominantes, ya sean capitalistas o burocráticas. Sin embargo, en el caso latinoamericano, aunque estas discusiones se han replicado, se han introducido algunos temas adicionales relacionados con la forma particular que esta dominación ha tomado, en buena medida herencia de la forma inicial de conquista y dominación española durante la Colonia (Wiarda, 1974). Para el caso que nos atañe, el colombiano, la literatura en general ha resaltado la naturaleza bloqueada en el acceso al centro que ha mantenido una élite, catalogando el régimen político como oligárquico [...], neopatrimonial [...] y aún consociacional [...]; ya la sociedad como clientelista". SUDARSKY, John. El eslabonamiento entre el estado y la sociedad en la perspectiva de la nueva constitución colombiana. Perfiles Latinoamericanos, México-DF, n.1, p.85-131, 1991.

${ }^{19}$ MARQUAND, David. Reinventando o federalismo: a Europa e a esquerda. In: MILIBAND, David (Org.). Reinventando a esquerda. São Paulo: Editora da Unesp, 1997, p. 275.

${ }^{20}$ Entre outras, duas compreensões, contrárias reciprocamente, da autonomia do Estado brasileiro sob o populismo, merecem destaque. Para uma, “depois de 1930, [...] estabelece-se uma solução de compromisso de novo tipo, em que nenhum dos grupos participantes do poder (direta ou indiretamente) pode oferecer as bases da legitimidade do Estado: as classes médias, porque não possuem autonomia política frente aos interesses tradicionais em geral, os interesses cafeeiros porque foram deslocados do poder político sob o peso da crise econômica, os setores menos vinculados à exportação, porque não se encontram vinculados aos centros básicos da economia. Em nenhum desses casos, os interesses sociais e econômicos particulares, podem servir de base para a expressão política dos interesses gerais". WEFFORT, Francisco Corrêa. O populismo na política brasileira. Rio de Janeiro: Paz e Terra, 1978, p. 50. Para a outra, “[...] este Estado pautou sua atuação não como árbitro e mediador entre as frações dominantes, porém, mais que isso, impôs, ao aproveitar-se das fissuras existentes entre as frações dominantes, um projeto que se dirigiu para a constituição de um núcleo industrializante fundamental e que, neste processo, ultrapassou inclusive aos interesses imediatos das classes dominantes agrárias e mesmo da burguesia industrial, formulando um projeto que garantia e preservava a expansão capitalista no Brasill”. ANTUNES, Ricardo. Classe operária, sindicatos e partido no Brasil. São Paulo: Global, 1982, p.70.

${ }^{21}$ RODRIGUES, José Honório. A Assembléia Constituinte de 1823. Petrópolis: Vozes, 1974. 
pode ser proibido, uma vez que não se oponha aos costumes públicos, à segurança, e saúde dos Cidadãos" (art. 179, XXIV). ${ }^{22}$

Por sua vez, a Constituição de 1891 comportou vários dispositivos que tratavam da propriedade, da indústria, do comércio, do transporte, das finanças e, inclusive, do desenvolvimento das letras, artes e ciências, bem como a imigração, a agricultura, a indústria e comércio.

Em primeiro lugar, assegurou "a brasileiros e a estrangeiros residentes no País a inviolabilidade dos direitos concernentes à liberdade, à segurança individual e à propriedade", considerando que "o direito de propriedade mantém-se em toda a sua plenitude, salva a desapropriação por necessidade ou utilidade pública, mediante indenização prévia" e que "as minas pertencem aos proprietários do solo, salvas as limitações que forem estabelecidas por lei a bem da exploração deste ramo de indústria" (art. 72, caput e $\S 17$ ).

Ademais, tratou do "direito da União e dos Estados de legislarem sobre a viação férrea e navegação interior", a ser regulado por lei federal, restringindo a navegação de cabotagem a navios nacionais (art. 13, caput e par. ún.).

Entre as competências exclusivas da União, estava a de decretar "direitos de entrada, saída e estadia de navios, sendo livre o comércio de cabotagem às mercadorias nacionais, bem como às estrangeiras que já tenham pago impostos de importação", competindo-lhe, "privativamente", a "a instituição de bancos emissores" (art. $7^{\circ}, 2^{\circ}$, e $\S 1^{\circ}, 1^{\circ}$ )

Em relação ao Congresso Nacional, como competência privativa, cabia-lhe regular o comércio internacional, bem como o dos Estados entre si e com o Distrito Federal", incumbindo-lhe, também, "mas não privativamente", "animar no País o desenvolvimento das letras, artes e ciências, bem como a imigração, a agricultura, a indústria e comércio, sem privilégios que tolham a ação dos Governos locais" (art. 34, 5º e art. 35, caput e $2^{\circ}$ ).

A matéria voltou, agora com pompa e circunstância, no constitucionalismo dos anos 30. Na esteira das inovações trazidas pelas Constituições do México (1917), ${ }^{23}$ Alemanha

\footnotetext{
${ }^{22}$ BRASIL. Constituição (1824). Constituição Política do Império do Brasil. Disponível em: <http://www.presidencia.gov.br/legislacao>. Acesso em: 10 jan. 2008.

${ }^{23}$ A Constituição de 1917 inaugura nova tendência no Direito Constitucional, realizando um turning point no entendimento acerca da propriedade, que passa a ter em vista a idéia-força da justiça social. Dois anos depois, a Constituição de Weimar, reconhecendo os deveres que lhe são concernentes, estatuiu que "a
} 
(1919) e Espanha (1931), o constituinte brasileiro de 1933/1934 inseriu no texto constitucional, no atinente à ordem econômica, a necessidade da sua valoração a partir dos "princípios da Justiça e as necessidades da vida nacional, de modo que possibilite a todos existência digna". Por conseguinte, “dentro desses limites, é garantida a liberdade econômica", ${ }^{24}$ positivando-se o comando segundo o qual "os Poderes Públicos verificarão, periodicamente, o padrão de vida nas várias regiões do País" (art. 115). ${ }^{25}$

propriedade obriga" e que "seu uso constituirá, também, um serviço para o bem comum" (art. 153, in fine). Todavia, persistem reservas, ainda nos dias de hoje, em relação à Constituição do México de 1917, que, embora de repercussão reduzida, foi a pioneira no trato da questão. Manoel Gonçalves Ferreira Filho aduz que, "há quem conteste essa primazia (da Constituição de Weimar), apontando a anterioridade da Constituição mexicana de 1917. Este documento, sem dúvida, antecipa-se no reconhecimento de direitos sociais, como educação (art. $3^{\circ}$ ), na previsão de uma reforma da estrutura agrária (art. 27) etc. Todavia, nela inexiste sequer um esboço de tratamento sistemático da atividade econômica". FERREIRA FILHO, Manoel Gonçalves. Direito constitucional econômico. São Paulo: Saraiva, 1990, p.4. Recentemente, Gilmar Ferreira Mendes et al. também aduzem: "É necessário ressaltar e pôr em relevo a questão do Princípio da função social da propriedade que veio a ser apresentado, pela primeira vez, na Constituição Federal do Brasil de 1934 como sendo uma nova tendência a respeito da atividade econômica e social [...]. Na verdade, a primeira constituição a apresentar um bloco sobre esse assunto foi a Constituição alemã de Weimar (1919) e veio a ser imitada por algumas Constituições, como a nossa de 1934". MENDES, Gilmar Ferreira et al. Curso de direito constitucional. São Paulo: Saraiva, 2007, p.1.290.

${ }^{24}$ Entre outros limites à liberdade econômica, configuravam-se:

“Art. 131 - É vedada a propriedade de empresas jornalísticas, políticas ou noticiosas a sociedades anônimas por ações ao portador e a estrangeiros. Estes e as pessoas jurídicas não podem ser acionistas das sociedades anônimas proprietárias de tais empresas. A responsabilidade principal e de orientação intelectual ou administrativa da imprensa política ou noticiosa só por brasileiros natos pode ser exercida. A lei orgânica de imprensa estabelecerá regras relativas ao trabalho dos redatores, operários e demais empregados, assegurando-lhes estabilidade, férias e aposentadoria".

"Art. 132 - Os proprietários, armadores e comandantes de navios nacionais, bem como os tripulantes na proporção de dois terços pelo menos, devem ser brasileiros natos, reservando-se também a estes a praticagem das barras, portos, rios e lagos".

"Art. 133 - Excetuados quantos exerçam legitimamente profissões liberais na data da Constituição, e os casos de reciprocidade internacional admitidos em lei, somente poderão exercê-las os brasileiros natos e os naturalizados que tenham prestado serviço militar ao Brasil; não sendo permitido, exceto, aos brasileiros natos, a revalidação de diplomas profissionais expedidos por institutos estrangeiros de ensino".

"Art. 135 - A lei determinará a percentagem de empregados brasileiros que devam ser mantidos obrigatoriamente nos serviços públicos dados em concessão, e nos estabelecimentos de determinados ramos de comércio e indústria".

"Art. 136 - As empresas concessionárias ou os contratantes, sob qualquer título, de serviços públicos federais, estaduais ou municipais, deverão:

a) constituir as suas administrações com maioria de diretores brasileiros, residentes no Brasil, ou delegar poderes de gerência exclusivamente a brasileiros;

b) conferir, quando estrangeiros, poderes de representação a brasileiros em maioria, com faculdade de substabelecimento exclusivamente a nacionais".

“Art 137 - A lei federal regulará a fiscalização e a revisão das tarifas dos serviços explorados por concessão, ou delegação, para que, no interesse coletivo, os lucros dos concessionários, ou delegados, não excedam a justa retribuição do capital, que lhes permita atender normalmente às necessidades públicas de expansão e melhoramento desses serviços". BRASIL. Constituição (1937). Constituição dos Estados Unidos do Brasil. Disponível em: <http://www.presidencia.gov.br/legislacao>. Acesso em: 10 jan. 2008.

25 Ibid., 2008. Se a necessidade de proteção do economicamente fraco, por intermédio do Estado, ganhou terreno com o constitucionalismo do século XX, observe-se que, já na primeira metade do século XIX, "a Revolução Francesa de 1848 e sua Constituição reconheceram efetivamente o primeiro dos 'direitos econômicos e sociais': o direito ao trabalho, impondo ao Estado a obrigação de dar meios ao desempregado de ganhar o seu pão", e que "a afirmação in abstracto desse direito [...] já se encontrava na Declaração jacobina de 1793”. FERREIRA FILHO, Manoel Gonçalves. Curso de direito constitucional. 34. ed. São 
Tirante a de 1988, a problemática da ordem econômica foi mais detalhadamente posta na Constituição outorgada que inaugurou o Estado Novo, em 1937. Embora considere que, "na iniciativa individual, no poder de criação, de organização e de invenção do indivíduo, [...] funda-se a riqueza e a prosperidade nacional”, o texto constitucional restringia tal iniciativa individual e tal poder de criação, de organização e de invenção do indivíduo aos "limites do bem público". Em contrapartida, prescrevia "a intervenção do Estado no domínio econômico", legitimando-a "para suprir as deficiências da iniciativa individual e coordenar os fatores da produção, de maneira a evitar ou resolver os seus conflitos e introduzir no jogo das competições individuais o pensamento dos interesses da Nação, representados pelo Estado". Ademais, dispôs o texto constitucional que a intervenção no domínio econômico poderia ser mediata e imediata, a revestir-se da forma de controle, de estímulo ou de gestão direta (art. 135). ${ }^{26}$ Para um dos seus apologistas,

\begin{abstract}
$\mathrm{Na}$ ordem econômica, a corporação reflete, na sua estrutura, nos processos do seu funcionamento e nos objetivos que por meio dela se pretende realizar, exatamente tudo aquilo que o Estado autoritário tem por finalidade alcançar no conjunto da vida nacional. Da verificação deste fato deduz-se que a organização corporativa da economia é, no regime atual, não apenas aconselhada por iniludíveis imperativos de convivência técnica na coordenação das atividades empenhadas na produção e na distribuição da riqueza. Ao lado dessas injunções de natureza econômica atuam ainda decisões motivadas de ordem política, derivadas dos postulados básicos da organização estatal. ${ }^{27}$
\end{abstract}

Observando a atuação do New Deal de Franklin Delano Roosevelt, Azevedo Amaral também ponderava:

\footnotetext{
Paulo: Saraiva, 2008, p.295. Ainda nos primeiros anos revolucionários, Maximilien de Robespierre, no discurso que dirigiu à Convenção, em 2 de dezembro de 1792, já falava num "direito à subsistência", com a necessidade de distribuição de gêneros de primeira necessidade, aduzindo: "Falar aos representantes do povo dos meios de prover sua subsistência não é apenas falar-lhes do mais sagrado de seus deveres; é também falar-lhes do mais precioso de seus interesses. Pois sem dúvida estes se confundem com aqueles. Não é apenas a causa dos cidadãos indigentes que desejo advogar, mas também a dos próprios proprietários e comerciantes". ROBESPIERRE, Maximilien de. Discursos e relatórios na Convenção. Rio de Janeiro: Eduerj; Contraponto, 1999, p.45.

${ }^{26}$ No Brasil, a intervenção estatal no domínio econômico esteve sempre presente por meio de diversos mecanismos, independentemente de uma economia eminentemente agrícola ou industrial. Como ressalta Alberto Venâncio Filho: "Considerando ainda que durante a vida colonial e todo o Império podemos perceber uma predominância do poder privado sobre o poder público, teremos, então, o quadro das características do Estado brasileiro como moldura do exame da intervenção no domínio econômico". Ademais, "a própria predominância do poder privado sobre o poder público representou, em muitos casos, a utilização da máquina estatal para a defesa de interesses privados [...]". VENANCIO FILHO, Alberto. A intervenção do Estado no domínio econômico: o direito público econômico no Brasil. Rio de Janeiro: FGV, 1968, p.35. A propósito, ver, também, DUARTE, Nestor. A ordem privada e a organização política nacional. Brasília: Ministério da Justiça, 1997; LEAL, Victor Nunes. Coronelismo, enxada e voto: o município e o regime representativo no Brasil. 2. ed. São Paulo: Alfa-Ômega, 1975.; FAORO, Raimundo. Os donos do poder: formação do patronato político brasileiro. 10. ed. São Paulo: Globo; Publifolha, 2000. 2v.;HOLANDA, Sérgio Buarque de. Raízes do Brasil. 26. ed. São Paulo: Companhia das Letras, 1995.

${ }^{27}$ AMARAL, Azevedo. O Estado autoritario e a realidade nacional. Brasília: UnB, 1981, p.152.
} 
[...] assistimos ao início de uma fase nova da evolução das instituições democráticas. Como o Presidente Roosevelt observava no discurso pronunciado em julho de 1936 no Congresso do Partido Democrático, da etapa da democracia puramente política passamos neste momento para a da democracia econômica. Em outras palavras, a órbita dos fenômenos atinentes à produção e à distribuição da riqueza torna-se o campo de aplicação de princípios de ordem e de sistematização, envolvendo forçosamente um ajustamento das liberdades desfrutadas pelo indivíduo na ordem econômica às necessidades superiores dos interesses da coletividade nesse setor. A inevitabilidade de uma adaptação dos direitos individuais aos imperativos de uma organização econômica racional está sendo reconhecida no país onde mais pura é ainda a fé nos postulados ortodoxos do regime democrático. $[\ldots]^{28}$

Ímpetos liberal-econômicos fizeram com que a Constituição de 1946 retrocedesse em matéria de ordem econômica, quando comparada ao constitucionalismo dos anos 30 . Aquele texto constitucional apenas estabeleceu, parcimoniosamente, que

a ordem econômica deve ser organizada conforme os princípios da justiça social, conciliando a liberdade de iniciativa com a valorização do trabalho humano [e que] a todos é assegurado trabalho que possibilite existência digna. O trabalho é obrigação social (art. 145). ${ }^{29}$

As constituições editadas no período da ditadura iniciada em 1964, as de 1967 e 1969, foram bem intervencionistas no que atine à constituição econômica formal. Para a Constituição de 1967 ,

a ordem econômica tem por fim realizar a justiça social, com base nos seguintes princípios: I - liberdade de iniciativa; II - valorização do trabalho como condição da dignidade humana; III - função social da propriedade; IV - harmonia e solidariedade entre os fatores de produção; V - desenvolvimento econômico; VI repressão ao abuso do poder econômico, caracterizado pelo domínio dos mercados, a eliminação da concorrência e o aumento arbitrário dos lucros (art. 167).

Por sua vez, a Constituição outorgada de 1969, juntando "ordem econômica e social", atribuiu-lhe "por fim realizar o desenvolvimento nacional e a justiça social", com base nos mesmos princípios arrolados no texto de 1967, alterando apenas "os fatores de produção" por "categorias sociais de produção" (item IV) e acrescentando o item VI, que se eleva à categoria de princípio a "expansão das oportunidades de emprego produtivo" (art. 160).

\footnotetext{
${ }^{28}$ Ibid., 1981, p.154.

29 “O art. 145 constitui mera recomendação. Frágil a sanção para a infração dele. Os legisladores, que a ele não obedeçam, escapam a qualquer restrição legal. Mas o princípio, por si, é útil, principalmente na parte final do artigo em que se concretiza a programática constitucional. Todo ele serve à interpretação do sistema jurídico e afasta que as leis com tais fins se tenham por inconstitucionais, o que de certo modo é sanção”. MIRANDA, Pontes de. Comentários à Constituição de 1946. Op. cit., v. IV. p. 462:
} 
A seu tempo, os constituintes de 1987/1988, realizando uma constituição realmente dirigente, atribuíram à "ordem econômica, fundada na valorização do trabalho humano e na livre iniciativa", um rol de fins e objetivos, para

\begin{abstract}
assegurar a todos existência digna, conforme os ditames da justiça social, observados os seguintes princípios: I - soberania nacional; II - propriedade privada; III - função social da propriedade; IV - livre concorrência; V - defesa do consumidor; VI - defesa do meio ambiente;30 VII - redução das desigualdades regionais e sociais; VIII - busca do pleno emprego; IX - tratamento favorecido para as empresas brasileiras de capital nacional de pequeno porte ${ }^{31}$ (art. 170).
\end{abstract}

Por fim, o parágrafo único do art. 170, repetiu com alterações semânticas - “é assegurado a todos o livre exercício de qualquer atividade econômica, independentemente de autorização de órgãos públicos, salvo nos casos previstos em lei" - o unicamente estatuído em matéria de ordem econômica pela primeira Constituição brasileira.

Destarte, "se o mal da Constituição de 1946, como o da Constituição de 1934 e da Constituição de 1937, é o mesmo da Constituição de Vaimar: não ter fins precisos, se bem que a crítica mais apanhe a de 1946", ${ }^{32}$ a Constituição de 1988 estabeleceu os "objetivos fundamentais da República Federativa do Brasil", nomeadamente, a saber, I - construir uma sociedade livre, justa e solidária; II - garantir o desenvolvimento nacional; III erradicar a pobreza e a marginalização e reduzir as desigualdades sociais e regionais; IV promover o bem de todos, sem preconceitos de origem, raça, sexo, cor, idade e quaisquer outras formas de discriminação. De fato, desde a Constituição de 1934, diz ainda Pontes de Miranda, a

liberdade econômica não é a priori. A Constituição só a garante até onde não exijam que seja restringida os princípios de justiça social - digamos distributiva - e o interesse nacional. Duas raias, uma de ordem social, ligada ao bem do povo, e outra de ordem nacional. [embora] não cria sanção ao que apenas ordena, é sem direitos subjetivos que tornem eficiente o texto e sem a rigidez que lhe emprestaria o Estado de fins precisos.

Todavia, corrige-se,

${ }^{30}$ Redação dada pela EC n. 42, de 19 de dezembro de 2003: "VI - defesa do meio ambiente, inclusive mediante tratamento diferenciado conforme o impacto ambiental dos produtos e serviços e de seus processos de elaboração e prestação; [...]”. BRASIL. Constituição (1988). Emenda Constitucional n. 42, de 19 dezembro de 2003. Disponível em: <http://www.presidencia.gov.br/legislacao>. Acesso em: 20 abr. 2008.

${ }^{31}$ Redação dada pela EC n. 42/2003: "IX - tratamento favorecido para as empresas de pequeno porte constituídas sob as leis brasileiras e que tenham sua sede e administração no País". Ibid, op. cit., 2008.

${ }^{32}$ MIRANDA, Pontes de. Comentários à Constituição de 1946. 2. ed. Rio de Janeiro: Max Limonad, 1953. v. IV, p.467. 
no sentido socialístico, o mal da igualdade somente político-jurídica; isto é, pretende-se chegar à boa solução, que é a de haver a igualdade nas duas dimensões sociais, Direito e Política, e também havê-la, salvo certas garantias, e atendendo à irrealizabilidade completa, na dimensão econômica. ${ }^{33}$

A partir do reconhecimento de que na nova Constituição estão retratadas, de um lado, as desigualdades imensas, a degradação urbana, a deterioração do meio ambiente, o estágio patrimonialista do Estado, e, de outro, os ideais de emancipação econômica, cultural, científica, política e social, Modesto Carvalhosa sintetizou muito bem o documento realizado pelo esforço constituinte de 1987/1988:

[...] Há, com efeito, na Carta de 1988 uma afirmação da nacionalidade do plano do indivíduo e da comunidade que acaba sendo a marca desse documento histórico. Retoma-se, através dele, as velhas lutas pela independência econômica e das tecnologias nacionais. E, nesse particular há uma clara 'reprise' dos ideais da década de 50, de defesa da produção nacional na sua tentativa de ocupação dos espaços e setores estratégicos e modernos, a ponto de apresentar-se a Carta, no capítulo da ordem econômica, como um instrumento da soberania nacional. $[\ldots]^{34}$

A propósito, e recuperando J. J. Gomes Canotilho,

poderá ser abusivo rastrear 'normas revolucionárias' na Constituição brasileira. Mas elas lá estão a marcar a narratividade emancipatória: direito dos trabalhadores à participação nos lucros ou resultados desvinculada da remuneração e participação, embora excepcional, na gestão da empresa [...], a usucapião pro labore [...], a cobrança de taxas de juros reais sujeita ao limite de doze por cento ao ano, considerando-se a cobrança acima desse limite como crime de usura. ${ }^{35}$

${ }^{33}$ Ibid., 1953, p.467.

${ }^{34}$ CARVAlHOSA, Modesto. A Carta de 1988 e os 200 anos do constitucionalismo. Folha de São Paulo, São Paulo, p.A-3, 20 set. 1988.

35 CANOTILHO, J. J. Gomes. Videoconferência - 21/02/02 - UFPR (J. J. Gomes Canotilho e Grupo das Jornadas da Fazenda Cainã). In: COUTINHO, Jacinto Nelson de Miranda (Org.). Canotilho e a constituição dirigente. Rio de Janeiro: Renovar, 2003, p.57. Sobre "normas revolucionárias" no constitucionalismo brasileiro, convém atentar para a observação de Luiz Werneck Vianna: "No Brasil nunca houve, de fato, uma revolução, e, no entanto, a propósito de tudo fala-se dela, como se a sua simples invocação viesse a emprestar animação a processos que seriam melhor designados de modo mais corriqueiro. Sobretudo, aqui, qualificam-se como revolução movimentos políticos que somente encontram a sua razão de ser na firme intenção de evitá-la, e assim se fala em Revolução da Independência, Revolução de 1930, Revolução de 1964, todos acostumados a uma linguagem de paradoxos em que a conservação, para bem cumprir o seu papel necessita reivindicar o que deveria consistir no seu contrário a revolução. Nessa dialética brasileira em que a tese parece estar sempre se autonomeando como representação da antítese, evitar a revolução tem consistido, de algum modo, na sua realização". VIANNA, Luiz Werneck. A revolução passiva: iberismo e americanismo no Brasil. 2. ed. Rio de Janeiro: Revan, 2004, p.43. No discurso de abertura dos trabalhos do Congresso Nacional, o presidente do Supremo Tribunal Federal realçou a "vocação conciliadora" brasileira: "Ao instalar-se esta Assembléia Constituinte, chega-se ao termo final do período de transição com que, sem ruptura constitucional, e por via da conciliação, se encerra o ciclo revolucionário". Discurso de José Carlos Moreira Alves em $1^{\circ}$ de fevereiro de 1987. In: BONAVIDES, Paulo; ANDRADE, Paes de. História constitucional do Brasil. Brasília: Paz e Terra, 1989, p.819-826. No que concerne ao disposta no art. 192, § $3^{\circ}$, da Constituição, que estipulou o teto da taxa de juros em $12 \%$ ao ano e foi retirado do texto constitucional pela Emenda $\mathrm{n}^{\circ} 40$, de 2003 , 


\title{
6.4 Direito de propriedade
}

Não há como olvidar que, no século XX, o Estado passou por transformações importantes, entre as quais, o seu papel em relação à função social da propriedade. Tal função, reconhecida na Constituição do México de 1917 e na Constituição de Weimar (1919), foi contemplada no constitucionalismo brasileiro a partir de 1934. Desde então, caracterizou-se por novos padrões, que não possuíam o constitucionalismo revolucionário do século XVIII nem os movimentos conservadores e românticos do século XIX. ${ }^{36}$

O constitucionalismo brasileiro está, assim, concorde com as transformações que, nas sociedades capitalistas, mudaram o estatuto da propriedade, reconhecendo-a como direito humano. Tal reconhecimento dá à propriedade privada a função de proteção pessoal, envolvendo os que já são proprietários e os que são carentes de tal direito para a subsistência. Como adverte Fábio Konder Comparato,

\begin{abstract}
Nem toda propriedade privada constitui um direito fundamental da pessoa humana, a merecer, por isso, uma proteção constitucional, [pois] seria, com efeito, evidente contra-senso que essa qualificação fosse estendida ao domínio sobre um latifúndio improdutivo, ou sobre uma gleba urbana não utilizada ou subutilizada, em cidades com sérios problemas de moradia popular. Da mesma sorte, é da mais elementar evidência que a propriedade do bloco acionário, com o qual se exerce o controle de um grupo empresarial, não pode, sem ofensa à razão jurídica, ser incluída na categoria dos direitos humanos. ${ }^{37}$
\end{abstract}

Enquanto a propriedade é encarada como instrumento, como uma garantia da subsistência individual e familiar, tem uma função individual, isenta da função social, limitada tão somente pelo poder de polícia estatal, que estaria relacionada com o art. $5^{\circ}$, XXII, da CF. Estando a propriedade relacionada com os bens de produção, tem-se, então, não um direito de propriedade, mas uma propriedade-função. Por conseguinte, perde a

observa Gilberto Bercovici: “[...] Dois dias após a promulgação da constituição, em 7 de outubro de 1988 foi publicado o Parecer da Consultoria-Geral da República SR n ${ }^{\circ} 70$, de 6 de outubro de 1988, que entendia o art. 192, § $3^{\circ}$, como não auto-aplicável, dependendo, portanto, de legislação regulamentadora. Este parecer foi aprovado pelo Presidente da República de então, adquirindo, assim, caráter normativo. O parecer da Consultoria Geral da República foi secundado por vários outros de juristas que contestavam a possibilidade de aplicação imediata do referido dispositivo". BERCOVICI, Gilberto. Estado intervencionista e constituição social no Brasil: o silêncio ensurdecedor de um diálogo entre ausentes. In: SOUZA NETO, Cláudio Pereira; SARMENTO, Daniel; BENENBOJM, Gustavo (Coord.). Vinte anos da Constituição Federal de 1988. Rio de Janeiro: Lumen Juris, 2009, p.734.

${ }^{36}$ Ver CARBONELL, Miguel. Zagrebelsky y el uso de la Historia por el derecho constitucional. In: ZAGREBELSKY, Gustavo. Historia y constitución. Buenos Aires: Trotta, 2005.

${ }^{37}$ COMPARATO, Fábio Konder. Direitos e deveres fundamentais em matéria de propriedade. In: AMARAL JÚNIOR, Alberto; PERRONE-MOISÉS, Cláudia (Org.). O cinqüentenário da Declaração Universal dos Direitos do Homem. São Paulo: Edusp, 1999, p.382. 
condição de direito e passa à de dever, conforme estabelecido no art. 170, III, da CF. A propósito, afirma ${ }^{38}$

[...] quanto à inclusão do princípio da garantia da propriedade privada dos bens
de produção entre os princípios da ordem econômica, tem o condão de não
apenas afetá-los pela função social - conúbio entre os incisos II e III do art. 170 -
mas, além disso, de subordinar o exercício dessa propriedade aos ditames da
justiça social e de transformar esse mesmo exercício em instrumento para a
realização do fim de assegurar a todos existência digna. ${ }^{39}$

É importante acentuar que a CF relativizou a propriedade privada, mas não deu azo à sua expropriação injustificada e arbitrária, nem à coletivização. Afinal, os "valores sociais do trabalho e da livre-iniciativa" constituem também fundamento do Estado constitucional brasileiro. Nem somente o trabalho, nem somente a livre-iniciativa, mas "os valores sociais do trabalho $e$ da livre-iniciativa".

A rigor, o princípio da função social e a propriedade como direito humano têm como meta, além de conceder legitimidade jurídica à propriedade privada, tornando-a associativa, construtiva e solidária, e, por conseguinte, resguardar a diretividade da CF, tendo em vista a consecução dos "objetivos fundamentais da República Federativa do Brasil”, a saber: I - construir uma sociedade livre, justa e solidária; II - garantir o desenvolvimento nacional; III - erradicar a pobreza e a marginalização e reduzir as desigualdades sociais e regionais; IV - promover o bem de todos, sem preconceitos de origem, raça, sexo, cor, idade e quaisquer outras formas de discriminação (art. $3^{\circ}$ ).

De fato, o problema fundamental da Constituição Federal de 1988, no que concerne à propriedade, fundamentalmente à distribuição de terras, à reforma urbana e à reforma agrária, é de concretização constitucional. Assim, como pondera Gilberto Bercovici, “a prática política e o contexto social favorecem uma concretização restrita e excludente dos dispositivos constitucionais" e, "não havendo concretização da Constituição enquanto mecanismo de orientação da sociedade, ela deixa de funcionar enquanto documento legitimador do Estado". No limite, "na medida em que se amplia a falta de concretização

\footnotetext{
${ }^{38}$ Segundo José Afonso da Silva, "os conservadores da constituinte [...] insistiram para que a propriedade privada figurasse como um dos princípios da ordem econômica, sem perceber que, com isso, estavam relativizando o conceito de propriedade, porque submetendo-o aos ditames da justiça social, de sorte que se pode dizer que ela só é legítima enquanto cumpra uma função dirigida à justiça social". SILVA, José Afonso da. Curso de direito constitucional positivo. 17. ed. São Paulo: Malheiros, 2000, p.786.

${ }^{39}$ GRAU, Eros Roberto, op. cit., 2005, p.247. Ver também MORAES, Filomeno. Entre a liberdade e a solidariedade: a propriedade como direito humano. In: RODRIGUES, Francisco Luciano Lima (Org.) Estudos de direito constitucional e urbanístico: em homenagem à prof ${ }^{a}$ Magnólia Guerra. São Paulo: RCS, 2007, p.171-191.
} 
constitucional, com as responsabilidades e respostas sempre transferidas para o futuro, intensifica-se o grau de desconfiança e descrédito no Estado, seja como poder político ou como implementador de políticas públicas". ${ }^{40}$

\subsection{A "constituição econômica" e as emendas constitucionais}

No que se refere à "ordem econômica" e, fundamentalmente, aos "princípios gerais da atividade econômica", ao longo dos vinte anos da $\mathrm{CF} / 88,{ }^{41}$ houve modificações nos arts. 170, IX, 171, 176, 177 e 178. As emendas (6, 7, 8, 9 e 19/98) vieram à luz durante o primeiro quadriênio do presidente Fernando Henrique Cardoso, com exceção das trazidas pelas ECs n's. 33/2001, 42/2003 e 49/2006.

Por meio do art. 170, IX, com a nova redação dada pela Emenda à Constituição ${ }^{\circ}$ 6/95, favoreceram-se as "empresas de pequeno porte constituídas sob as leis brasileiras e que tenham sede e administração no Brasil" em substituição às "empresas brasileiras de capital nacional de pequeno porte", conforme constava do texto constitucional. Por sua vez, o art. 171 foi totalmente revogado pela Emenda Constitucional $n^{\circ}$ 6, de 15 de agosto de $1995 .^{42}$

A EC n. 6 alterou ainda aqueles que poderiam efetuar a pesquisa e lavra dos recursos minerais, assim como aproveitar dos seus potenciais, modificando "empresa brasileira de

${ }^{40}$ BERCOVICI, Gilberto. Constituição econômica e desenvolvimento: uma leitura a partir da Constituição de 1988. São Paulo: Malheiros, 2005, p.168.

41 Entre outros estudos que abordam a evolução constitucional, ver MELO, Marcus André. Reformas constitucionais no Brasil. Rio de Janeiro: Revan; Brasília: Ministério da Cultura, 2002; MAUÉS, Antonio Gomes Moreira (Org.). Constituição e democracia. São Paulo: Max Limonad, 2001; SOUZA NETO, Cláudio Pereira; SARMENTO, Daniel; BENENBOJM, Gustavo (Coord.). Vinte anos da Constituição Federal de 1988. Rio de Janeiro: Lumen Juris, 2009; OLIVEN, Ruben George; RIDENTI, Marcelo; BRANDÃO, Gildo Marçal (Org.). A Constituição de 1988 na vida brasileira. São Paulo: Aderaldo \& Rothschild Editores; Anpocs, 2008.

42 “Art. 171. São consideradas: I - empresa brasileira a constituída sob as leis brasileiras e que tenha sua sede e administração no País; II - empresa brasileira de capital nacional aquela cujo controle efetivo esteja em caráter permanente sob a titularidade direta ou indireta de pessoas físicas domiciliadas e residentes no País ou de entidades de direito público interno, entendendo-se por controle efetivo da empresa a titularidade da maioria de seu capital votante e o exercício, de fato e de direito, do poder decisório para gerir suas atividades. $\S 1^{\circ}$ - A lei poderá, em relação à empresa brasileira de capital nacional: I - conceder proteção e benefícios especiais temporários para desenvolver atividades consideradas estratégicas para a defesa nacional ou imprescindíveis ao desenvolvimento do País; II - estabelecer, sempre que considerar um setor imprescindível ao desenvolvimento tecnológico nacional, entre outras condições e requisitos: a) a exigência de que o controle referido no inciso II do "caput" se estenda às atividades tecnológicas da empresa, assim entendido o exercício, de fato e de direito, do poder decisório para desenvolver ou absorver tecnologia; b) percentuais de participação, no capital, de pessoas físicas domiciliadas e residentes no País ou entidades de direito público interno. $\S 2^{\circ}-\mathrm{Na}$ aquisição de bens e serviços, o Poder Público dará tratamento preferencial, nos termos da lei, à empresa brasileira de capital nacional". BRASIL. Constituição (1988). Emenda Constitucional $\mathrm{n}^{\mathrm{o}}$ 6, de 15 de agosto de 1995. Disponível em: <http://www.presidencia.gov.br/legislacao>. Acesso em: 20 abr. 2008. 
capital nacional” para "empresa constituída sob as leis brasileiras de capital nacional”. Pela Emenda Constitucional n ${ }^{\circ}$ 9, de 9 de novembro de 1995, alterou-se o art. 177. Assim, se "a questão do monopólio do Brasil foi definida, de início, a partir da concessão de monopólio à Sociedade de Economia Mista de Petróleo Brasileiro S.A.- Petrobrás, para as atividades definidas nos incisos I e IV a que se refere essa Emenda", agora, "configurou-se assim a quebra do monopólio da Petrobrás para tais atividades, embora mantendo o monopólio da União que passava a abrir à concorrência as atividades ali definidas”. Além dessas concessões se estenderem também a outras empresas estatais ou privadas, "combinando-se com os efeitos da revogação do art. 171, abria-se à empresa estrangeira a sua participação já oferecida no $\S 2^{\circ}$, pelas bases para o fornecimento dos derivados de petróleo em todo o território nacional e condições de contratação", assim como de "existência do "órgão regulador do monopólio da União', segundo modelo neoliberal da 'regulação', com a criação de agências reguladoras (Agência Reguladora de Petróleo - ANP)" ${ }^{43}$

Em relação ao art. 178, a EC n. 7, de 15 de agosto de $1995,{ }^{44}$ cuidou de retirar a norma que estabelecia a predominância dos armadores nacionais e navios de bandeira e registros brasileiros e dos países importadores ou exportadores. O artigo passou a estabelecer que, nas ordenações do transporte aéreo, aquático e terrestre, sejam observados no transporte internacional os acordos firmados com a União, atendendo o princípio da reciprocidade. Restou ainda um parágrafo único em que ficaram estabelecidas as condições em que o transporte de mercadorias, na cabotagem, e a navegação interior poderão ser feitos por embarcações estrangeiras.

O art. 192, modificado por meio da Emenda ${ }^{\circ}$ 13, de 21 de agosto de 1996, recriou as bases da política securitária disposta pelo constituinte originário. ${ }^{45}$

\footnotetext{
${ }^{43}$ SOUZA, Washington Peluso Albino de, op. cit., 1985, p.524.

${ }^{44}$ BRASIL. Constituição (1988). Emenda Constitucional $\mathrm{n}^{\circ}$ 7, de 15 de agosto de 1995. Disponível em: <http://www.presidencia.gov.br/legislacao>. Acesso em: 20 abr. 2008.

45 Redação original: "Art. 192. O sistema financeiro nacional, estruturado de forma a promover o desenvolvimento equilibrado do País e a servir aos interesses da coletividade, será regulado em lei complementar, que disporá, inclusive, sobre: I - a autorização para o funcionamento das instituições financeiras, assegurado às instituições bancárias oficiais e privadas acesso a todos os instrumentos do mercado financeiro bancário, sendo vedada a essas instituições a participação em atividades não previstas na autorização de que trata este inciso; II - autorização e funcionamento dos estabelecimentos de seguro, previdência e capitalização, bem como do órgão oficial fiscalizador e do órgão oficial ressegurador; III as condições para a participação do capital estrangeiro nas instituições a que se referem os incisos anteriores, tendo em vista, especialmente: a) os interesses nacionais; b) os acordos internacionais. IV - a organização, o funcionamento e as atribuições do Banco Central e demais instituições financeiras públicas e privadas; V - os requisitos para a designação de membros da diretoria do Banco Central e demais instituições financeiras, bem como seus impedimentos após o exercício do cargo; VI - a criação de fundo
} 
Por fim, a Emenda Constitucional n ${ }^{\circ} 19$, de 4 de junho de 1998, entre outros aspectos, dispõe que a lei estabelecerá estatuto jurídico para as empresas públicas, sociedades de economia mista e todas as suas subsidiárias que explorem atividade econômica de produção ou comercialização de bens ou prestação de serviços. Tal lei deverá dispor acerca da sua função social e formas de fiscalização pelo Estado e sociedade, sujeição ao regime próprio das empresas privadas, exigência de licitação, constituição e funcionamento dos conselhos de administração e fiscal com a participação dos acionistas minoritários, dos mandatos, da avaliação de desempenho e da responsabilidade dos seus administradores aspectos. ${ }^{46}$

\subsection{O Estado brasileiro e a CF/88}

Já se disse que "a verdade é que pelo menos dois terços da hipertrofia do Estado brasileiro de hoje se devem aos mesmos Campos, Delfins e Simonsens", que passaram a criticá-lo. ${ }^{47}$ De fato, o Brasil pós-1964 tornou-se exemplo de Estado com muito

ou seguro, com o objetivo de proteger a economia popular, garantindo créditos, aplicações e depósitos até determinado valor, vedada a participação de recursos da União; VII - os critérios restritivos da transferência de poupança de regiões com renda inferior à média nacional para outras de maior desenvolvimento; VIII - o funcionamento das cooperativas de crédito e os requisitos para que possam ter condições de operacionalidade e estruturação próprias das instituições financeiras. $\S 1^{\circ}$ - A autorização a que se referem os incisos I e II será inegociável e intransferível, permitida a transmissão do controle da pessoa jurídica titular, e concedida sem ônus, na forma da lei do sistema financeiro nacional, a pessoa jurídica cujos diretores tenham capacidade técnica e reputação ilibada, e que comprove capacidade econômica compatível com o empreendimento. $\S 2^{\circ}$ - Os recursos financeiros relativos a programas e projetos de caráter regional, de responsabilidade da União, serão depositados em suas instituições regionais de crédito e por elas aplicados. $\S 3^{\circ}$ - As taxas de juros reais, nelas incluídas comissões e quaisquer outras remunerações direta ou indiretamente referidas à concessão de crédito, não poderão ser superiores a doze por cento ao ano; a cobrança acima deste limite será conceituada como crime de usura, punido, em todas as suas modalidades, nos termos que a lei determinar”. BRASIL. Constituição (1988). Constituição da República Federativa do Brasil. Disponível em: 〈http://www.presidencia.gov.br/legislacao〉. Acesso em: 5 out. 2008. Redação dada pela EC n. 13: "Art. 192. O sistema financeiro nacional, estruturado de forma a promover o desenvolvimento equilibrado do País e a servir aos interesses da coletividade, em todas as partes que o compõem, abrangendo as cooperativas de crédito, será regulado por leis complementares que disporão, inclusive, sobre a participação do capital estrangeiro nas instituições que o integram. (Redação dada pela Emenda Constitucional $n^{\circ}$ 40, de 2003) I - (Revogado). II - (Revogado). III - (Revogado) a) (Revogado) b) (Revogado). IV - (Revogado). V -(Revogado). VI - (Revogado). VII - (Revogado). VIII (Revogado). § $1^{\circ}$ - (Revogado). § $2^{\circ}$ - (Revogado). § $3^{\circ}$ - (Revogado)". BRASIL. Constituição (1988). Emenda Constitucional n. 13, de 21 de agosto de 1996. Disponível em: <http://www.presidencia.gov.br/legislacao>. Acesso em: 20 abr. 2008.

46 BRASIL. Constituição (1988). Emenda Constitucional n. 19, de 4 de junho de 1998. Disponível em: <http://www.presidencia.gov.br/legislacao>. Acesso em: 20 abr. 2008.

${ }^{47} \mathrm{Na}$ verdade, "a Constituição de 1988 recebe o Estado estruturado sob o regime militar (1964-1985), ou seja, o Estado reformado pelo PAEG (Plano de Ação Econômica do Governo) de Roberto Campos e Octávio Gouveia de Bulhões (1964-1967), responsáveis pela atual configuração do sistema monetário e financeiro, com a criação do Banco Central do Brasil (Lei n ${ }^{\circ} 4.595$, de 31 de dezembro de 1964), do sistema tributário nacional (Emenda Constitucional $\mathrm{n}^{\mathrm{o}} 18$, de $1^{\circ}$ de dezembro de 1964), do sistema tributário nacional (Emenda Constitucional $\mathrm{n}^{\circ} 18$, de $1^{\circ}$ de dezembro de 1965, e Código Tributário Nacional, Lei $\mathrm{n}^{\circ}$ 5.172, de 25 de outubro de 1966) e da estrutura administrativa, por meio da reforma 
intervencionismo e quase nenhum bem-estar. Ao fim e ao cabo, o esforço constituinte se efetivou no sentido de intervir para proporcionar o bem-estar e de, dotando o Estado brasileiro mecanismos interventivos, prestar a distribuição de benefícios. Se os neoliberais insistiam na idéia da necessidade de reformar o Estado, os social-democratas, os liberaldemocratas e a esquerda instavam na idéia da necessidade de reformar a sociedade. ${ }^{48}$ Os objetivos contidos no art. $3^{\circ}$ e os princípios contidos no art. 170 pretendem ambas as reformas, do Estado e da sociedade. Com o refazimento do Estado, dar-se-ia substância às políticas públicas, reconstruir-se-ia a administração pública, possibilitar-se-ia a democratização da sociedade, enfim, promover-se-iam os valores democráticos do ponto de vista político, social e econômico e os valores republicanos.

\subsection{O "mal-estar da Constituição" e as "incertezas epistêmicas da directividade constitucional"}

Promulgado a Constituição Federal, em 5 de outubro de 1988, de logo começou a vir à tona o que se denominou de "mal-estar da Constituição" e de "incertezas epistêmicas da directividade constitucional". ${ }^{49}$

O texto constitucional, posto como ponto de consenso para a retirada do "obstáculo fundamental para a construção de um Estado que promova o desenvolvimento" foi vocalizado como o verdadeiro obstáculo fundamental aos novos barbarismos, com a exponenciação do anti-Estado. Com certeza, "o desenvolvimento envolve a normalidade contínua, tendo por pressuposto o antecedente dos trinta anos de consenso keynesiano" e "o núcleo do sistema democrático está na normalidade e na sua continuidade".

implementada pelo Decreto-Lei no 200, de 25 de fevereiro de 1967, que exige gestão 'empresarial' dos órgãos administrativos, ressuscitada por Bresser Pereira trinta anos depois". BERCOVICI, Gilberto. Estado intervencionista e constituição social no Brasil: o silêncio ensurdecedor de um diálogo entre ausentes. In: SOUZA NETO, Cláudio Pereira; SARMENTO, Daniel; BENENBOJM, Gustavo (Coord.). Vinte anos da Constituição Federal de 1988. Rio de Janeiro: Lumen Juris, 2009, p.732-733.

${ }^{48}$ WEFFORT, Francisco Corrêa. Não ao apartheid social. Folha de São Paulo, São Paulo, p.A-3, 14 out. 1989. Observa Oscar Dias Corrêa: "No Estado autoritário que sucedeu ao AI-5, por mais que vigesse a letra da Constituição de 1969 - de definição visceralmente neoliberal - acentuou-se, desmesuradamente, a intervenção estatal e o governo passou a controlar [...], no mínimo, 70\% das atividades econômicas nacionais, direta ou indiretamente, agindo de modo amplo e, por que não o dizer, indiscriminado, instável e desorganizado, sobre toda essa atividade, em todos os campos. De tal sorte que, quando os ventos liberais recomeçaram a soprar, um dos grandes problemas foi, e é, o da liberalização da economia, que o Estado se acostumou a manobrar e controlar, mas que não tem mais como centralizar, agora, sem afrontar as conveniências políticas, que passaram a exigir a conformidade aos textos liberais vigentes. [...]". CORRÊA, Oscar Dias. A crise da constituição, a constituinte e o Supremo Tribunal Federal. São Paulo: RT, 1986, p.28-29.

49 Ver Prefácio em CANOTILHO, J. J. Gomes. Constituição dirigente e vinculação do legislador: contributo para a compreensão das normas constitucionais programáticas. 2. ed. Coimbra: Coimbra Editora, 2001. 
Mas, como afirma Gilberto Bercovici, os tempos que advieram não são de normalidade,

o que existe é um estado de exceção econômico permanente a que está submetida a periferia do capitalismo [e], a partir da recente supremacia de idéias como auto-regulação e soberania do mercado, volta à atualidade o pensamento de Carl Schmitt, que define como soberano quem decide sobre o estado de exceção. ${ }^{50}$

De fato, no conflito entre o poder localizado no território nacional e o poder planetário da economia mundial, os constituintes brasileiros de 1987/1988 preferiram o primeiro, optando pelas bases da construção de um Estado nacional à globalização e à interconstitucionalização. Os constituintes que produziram o texto de 1988 estão concordes com aquela definição segundo a qual o Estado é "un conjunto de instituciones y relaciones sociales (La mayor parte de lãs cuales son sancionadas por el sistema legal de esse mismo estado) que normalmente penetra y controla el território y los habitantes que este conjuto pretende delimitar geográficamente $[. .]. "{ }^{51}$

Evidentemente, o incorrer no "estado de exceção econômica" faz com que a tríplice dimensão do Estado nacional, a saber, um conjunto de burocracias, um sistema legal e uma ordem geral, com previsibilidade das relações sociais, percam "eficacia del estado qua

${ }^{50}$ BERCOVICI, Gilberto. Estado de exceção econômico e a periferia do capitalismo. Separata do Boletim de Ciências Econômicas, Coimbra, n.XVLII, 2004b, p.3-4. Evidentemente, como observa Marcelo Neves, "a sociedade mundial de hoje é multifacetada e possibilita a aplicação do esquema 'centro e periferia' em vários níveis". Assim, "a distinção entre modernidade central e periférica é analiticamente frutífera, na medida em que, definindo-se a complexificação social e o desaparecimento de uma moral material globalizando como características da modernidade, constata-se que, em determinadas regiões estatalmente delimitadas (países periféricos), não houve a efetivação adequada da autonomia sistêmica de acordo com o principio da diferenciação funcional e nem mesmo a criação de uma esfera intersubjetiva autônoma fundada numa generalização institucional da cidadania, que ocorre em outras regiões estatalmente organizadas (países centrais). $\mathrm{O}$ fato de haver graus diversos quanto à diferenciação funcional exigida pela complexidade social e quanto à construção da cidadania como exigência do desaparecimento da moral hierárquico-material pré-moderna, não invalida o potencial dos conceitos de modernidade central e modernidade periférica [...]". NEVES, Marcelo. A constitucionalização simbólica. São Paulo: Acadêmica, 1994, p.148-149. Sobre o estado de exceção, não é ocioso pensar com Paulo Arantes: “[...] Trinta anos gloriosos de consenso keynesiano, crescimento econômico e padrão dólar-ouro varreram para debaixo do tapete a memória da exceção. Ou melhor, empurraram-na para a periferia, terra de ninguém mesmo, na qual vegetou rotineiramente, durante todo o período, preciosa contribuição para o conforto moral da metrópole. Até que as coisas começam a mudar, mais ou menos a partir da virada dos anos 70 para os anos 80. O consenso se desmanchou, a sociedade do pleno emprego foi desmantelada, as modernizações periféricas, abortadas. [...]”. ARANTES, Paulo. Extinção. São Paulo: Boitempo, 2007, p.156. De modo geral, “[...] deve-se observar que a reflexão sobre o estado de exceção e sobre a ditadura acompanha todo o pensamento moderno e está presente, por exemplo, em Rousseau [...], que também prevê, em situações de crise particularmente aguda, e sempre com referência à Roma antiga, o recurso a uma ditadura de duração 'brevíssima', cujos termos em nenhum caso poderiam ser prolongados. [...]”. LOSURDO, Domenico. Democracia ou bonapartismo: triunfo e decadência do sufrágio universal. Rio de Janeiro: UFRJ; São Paulo: Unesp, 2004, p.108-109.

51 O’DONNELL, Guillermo, op. cit., 2006, p.19. "Sin embargo, a diferencia de Weber, no postula que la coerción o violencia practicada por el estado deba ser legítima”, diz O’Donnell ainda. Ibid., 2006, p.19. 
conjunto de burocracias", a "efectividad del estado qua sistema legal" e a "credibilidad del estado". 52

\title{
6.8 Constituição econômica e constituição financeira
}

Criando contradição entre a ordem constitucional inaugurada em 1988 e as políticas do Estado brasileiro, o "mundo que nos pegou de surpresa" teve as suas conseqüências no Brasil também. Fernando Henrique Cardoso resumiu bem o estado de espírito de parte das elites brasileiras, ${ }^{53}$ quando afirma que "[...] a Constituição votada nasceu a destempo: era estatizante e corporativa, e isso às vésperas da queda do Muro de Berlim e das viradas anticorporativistas de boa parte das próprias esquerdas mundiais". ${ }^{44}$

De fato, se a ordem econômica intervencionista e dirigente da Constituição de 1988 continua sendo a "jóia da coroa", as vicissitudes do processo legislativo constitucional e políticas públicas acabaram por isolar os

\begin{abstract}
seus instrumentos financeiros, cuja efetividade é medida em si mesma, sem qualquer relação com os objetivos da política econômica estatal ou da ordem econômica constitucional. A Lei de Responsabilidade Fiscal e a insana proposta de emenda constitucional instituindo o déficit nominal zero são meios de excluir o orçamento da deliberação pública, garantindo metas de política monetária muitas vezes impostas de fora e em favor de interesses econômicos privados, que desejam uma garantia sem risco para seus investimentos ou para sua especulação financeira. $^{55}$
\end{abstract}

A implementação da ordem econômica e da ordem social da Constituição de 1988 ficaram restritas, assim, às obras orçamentárias e financeiras do Estado. A constituição financeira de 1988 foi, deste modo, 'blindada'. A Lei de

52 Ibid., 2006, p.20. Ressalta Guillermo O’Donnell que “en mi investigación actual, parece claro que los estados latinoamericanos, con las excepciones ya mencionadas, fracasan seriamente en estas tres dimensiones: eficacia, efectividad y credibilidad" e "esto, por supuesto, no es nuevo. Sin embargo, es una cruel paradoja que estos defectos del estado no hayan mejorado (y que, no en pocos, hayan empeorado) bajo gobiernos democráticamente electos". Principalmente, por conta do "fuerte peso a la furia antiestatista expresada en las políticas económicas (llamadas) neo-liberales que han prevalecido en las dos últimas décadas, o sea aproximadamente el mismo periodo de democracia en muchos nuestros países". Ibid., 2006, p.21.

53 Já se observou que "o maquiavelismo de máfia das elites urdira uma sinistra cilada para o movimento democrático: uma vez que o centro político resistia ao seu deslocamento para a direita - a prova foi o texto final da Constituição -, assumiu-se o objetivo da sua implosão". VIANNA, Luiz Werneck. A transição: da Constituinte à sucessão presidencial. Rio de Janeiro: Revan, 1989, p.69.

${ }^{54}$ CARDOSO, Fernando Henrique. A arte da política: a história que vivi. 3. ed. Rio de Janeiro: Civilização Brasileira, 2006, p.109. Saulo Ramos, quando trata das dissensões entre o governo Sarney e o Congresso Constituinte, observa a "desconstitucionalização" que seria levada a efeito sob os governos de FHC: “[...] lhe reconheço um mérito: em seu governo, promoveu reformas constitucionais, corrigindo os erros mais grosseiros da Constituição, que foram por ele defendidos na Constituinte [...]". RAMOS, Saulo. Código da vida. São Paulo: Planeta do Brasil, 2007, p.228.

${ }^{55}$ BERCOVICI, Gilberto; MASSONETO, Luís Fernando. A constituição dirigente invertida: a blindagem da constituição financeira e a agonia da constituição econômica. Separata do Boletim de Ciências Económicas, Coimbra, 2006, p.17. 
Responsabilidade Fiscal apenas complementa este processo, ao vedar a busca do pleno emprego e a implementação de outra política financeira. Neste processo, é importante ressaltar a edição da Lei $\mathrm{n}^{\circ} 10.028$, de outubro de 2000 , que, dentre várias medidas draconianas, tipifica como crime a promoção do déficit público. ${ }^{56}$

De fato, o discurso que ganhou importância vocaliza que a constituição dirigente das políticas públicas e dos direitos sociais prejudica os interesses nacionais, ao provocar crises econômicas, déficit público e “ingovernabilidade". Por sua vez, a constituição dirigente invertida, isto é, "a constituição dirigente das políticas neoliberais de ajuste fiscal" ${ }^{57}$ é vista como algo positivo para a credibilidade e a confiança do país junto ao sistema financeiro internacional. Como afirma Gilberto Bercovici, “esta, a constituição dirigente invertida, é a verdadeira constituição dirigente, que vincula toda a política do Estado brasileiro à tutela estatal da renda financeira do capital, à garantia da acumulação de riqueza privada". ${ }^{58}$ Mas, se como queria Montesquieu, cabe pôr, momentaneamente, véus sobre a liberdade, assim como se escondem as estátuas dos deuses, ${ }^{59}$ a conotação agora é diferente, tem a veleidade da continuidade.

\subsection{Balanço dos vinte anos}

Apesar das limitações constantes do ato convocatório do Congresso Constituinte, como diz Dalmo de Abreu Dallari, “o resultado de seu trabalho ficou mais próximo das aspirações dos progressistas e democratas do que das preferências conservadoras dos

\footnotetext{
${ }^{56}$ Ibid., 2006, p.17-18.

${ }^{57}$ Ibid., 2006, p.19.

${ }^{58}$ Ibid., 2006, p.19. A propósito: "Como conseqüência, o direito financeiro, antes voltado à organização do financiamento público da economia capitalista e a promoção de políticas de bem-estar social, teve seu conteúdo profundamente modificado. Mais especificamente, o direito financeiro, antes voltado à ordenação da expansão material do sistema mundial a partir do paradigma keynesiano, deu lugar a um complexo normativo voltado à organização da expansão financeira do processo sistêmico de acumulação [...]." Ademais, "[...] o fundo público continuou sendo o pressuposto do financiamento da acumulação de capital. No entanto, a "dolarização generalizada do sistema de crédito" e a manifestação de um povo e peculiar padrão de riqueza no capitalismo contemporâneo alteraram substancialmente a natureza deste processo. Diferentemente do que ocorrera na ordem do segundo pós-guerra, a camada capitalista do mundo dos negócios, localizada no entrelaçamento das redes de poder e capital do sistema mundial, passou a comandar a expansão do capital [...], impondo uma adaptação dos ordenamentos jurídicos nacionais, a partir das expectativas dos detentores da riqueza mundial”. Ibid., 2006, p.22.

59 "J'avoue pourtant que l'usage des peuples les plus libres qui aient jamais été sur la terre me fait croire qu'il y a des cas où il faut mettre, pour un moment, un voile sur la liberté, comme l'on cache les statues des diex”. MONTESQUIEU. De l'esprit des lois, I. Paris: Éditions Gallimard, 1995, p.402.
} 
oligarcas e autoritários", porque foi a que recebeu "maior influência do povo em sua elaboração" ${ }^{60}$ Ademais,

[...] Uma conseqüência da ampla mobilização do povo no momento da Constituinte e de sua influência nas decisões foi a garantia de seu conteúdo democrático, muito evidente pelos princípios expressamente afirmados em normas constitucionais, assim como pelo grande número de artigos relacionados com os direitos humanos e suas garantias. ${ }^{61}$

No Brasil, passados vinte anos da conclusão do esforço constituinte, e apesar do rol de emendas constitucionais que configuram a vontade de abrir-se a economia ao mercado internacional, a CF continua dirigente e, por conseguinte, vinculando o legislador. Como diz Eros Roberto Grau, o "seu cerne", identificado "fundamentalmente nos preceitos dos seus arts. $3^{\circ}, 1^{\circ}$ e 170 , resta intocado". ${ }^{62}$

Tudo isto, apesar do discurso dos fundamentalistas da religião do mercado, que insistem em pôr a constituição dirigente das políticas públicas e dos direitos sociais como fonte dos males do país, causadora última das crises econômicas, do déficit público e de uma tal "ingovernabilidade", invertendo-a em favor da busca de uma "constituição

${ }^{60}$ DALLARI, Dalmo de Abreu. Constituição resistente. In: MORAES, Alexandre de (Coord.). Os 10 anos da Constituição Federal. São Paulo: Atlas, 1999, p.49. Em discurso por ocasião da promulgação da Constituição, em 5/10/1988, Ulysses Guimarães avaliou a participação no processo constituinte nos seguintes termos: "O enorme esforço é dimensionado pelas 61.020 emendas, além de 122 emendas populares, algumas com mais de um milhão de assinaturas, que foram apresentadas, publicadas, distribuídas, relatadas e votadas no longo trajeto das subcomissões à redação final. A participação foi também pela presença, pois diariamente cerca dez mil postulantes franquearam, livremente, as onze ao enorme complexo arquitetônico do Parlamento, na procura dos gabinetes, comissões, galeria e salões. Há, portanto, representativo e oxigenado sopro de gente, de rua, de praça, de favela, de fábrica, de trabalhadores, de cozinheiras, de menores carentes, de índios, de posseiros, de empresários, de estudantes, de aposentados, de servidores civis e militares, atestando a contemporaneidade e autenticidade social do texto que ora passa a vigorar. Como o caranguejo, guardará para sempre o bramido das ondas de sofrimento, esperança e reivindicações de onde proveio". Discurso do deputado Ulysses Guimarães em 5/10/1988. DIÁRIO DA ASSEMBLÉIA NACIONAL CONSTITUINTE, Brasília, p.14.380, 5 out. 1988. Em balanço sobre os vinte anos da Constituição Federal, Luiz Inácio Lula da Silva nota: "Acredito que fizemos uma Constituição extremamente avançada. É bem possível que a principal razão disso tenha sido a participação popular, como jamais houve na história deste país. Eu lembro das milhares de pessoas que circulavam dentro da Câmara e do Congresso Nacional, fazendo reuniões com todos os líderes, entregando cartas e propostas, fazendo pressão". FOLHA DE SÃO PAULO, São Paulo, p. A4, 5 out. 2008.

${ }^{61}$ DALLARI, Dalmo de Abreu. In: MORAES, Alexandre de (Coord.), op. cit., 1999, p.53. Segundo Luiz Werneck Vianna, convocada a Constituinte, "pela primeira vez na história republicana faz-se possível a democratização do público com suas numerosas agências de intervenção sobre os domínios do econômico e do social". VIANNA, Luiz Werneck, op. cit., 1989, p.11. Por sua vez, Gisele Cittadino observa que, afinal, definindo objetivos do Estado, pela primeira vez no Brasil, uma constituição "orientou a compreensão e interpretação do ordenamento constitucional pelo critério do sistema de direitos fundamentais. Em outras palavras, a dignidade humana, traduzida no sistema de direitos constitucionais, é vista como o valor essencial que dá unidade de sentido à Constituição Federal". CITTADINO, Gisele. Pluralismo, direito e justiça distributiva: elementos da filosofia constitucional contemporânea. 3. ed. Rio de Janeiro: Lumen Juris, 2004, p.13. Ver também CASTRO, Carlos Roberto Siqueira. A constituição aberta e os direitos fundamentais: ensaios sobre o constitucionalismo pós-moderno e comunitário. Rio de Janeiro: Forense, 2003.

${ }^{62}$ GRAU, Eros Roberto, op. cit., 2005, p.366. 
dirigente das políticas neoliberais de ajuste fiscal" ${ }^{63}$ é vista como algo positivo para a credibilidade e a confiança do país junto ao sistema financeiro internacional. Esta, a constituição dirigente invertida, é a verdadeira constituição dirigente, que vincula toda a política do Estado brasileiro à tutela estatal da renda financeira do capital, à garantia da acumulação de riqueza privada.

Importante a ressaltar é que na deliberação constituinte há um modelo econômico de bem-estar, acobertado, inclusive, de modificações que o desnaturem, embora compatível com mudanças que a dinâmica social e política exigirem e apto a concretizá-las. No limite, tal modelo poderá levar à "adequação do Brasil ao relógio do Ocidente moderno" ${ }^{64}$ e evitar que o Brasil se torne "terra natal da exceção sem regra". ${ }^{65}$

Os desafios da sua eficácia jurídica e social continuam a desafiar o engenho e arte, diante, das tendências à desconstitucionalização e da desregulamentação, com a mudança para a contratualização, que, em grande medida, antes mais, agora menos talvez, perpassaram os anos 90 e seguintes. De fato, os "tempos difíceis", pois

Tradicionalmente, as leis de emergência interferiam nas liberdades políticas e econômicas, particularmente o direito de propriedade: ou seja, limitavam-se os direitos individuais tendo em vista o bem-estar coletivo. Hoje, dá-se o contrário: a utilização atual dos poderes de emergência caracteriza-se por limitar os direitos da população em geral para garantir a propriedade privada e a acumulação capitalista. $^{66}$

A crítica, segunda a qual a constituição dirigente tinha veleidades de substituir a política, já caiu por terra. ${ }^{67} \mathrm{~A}$ rigor, a constituição dirigente sujeita a política a fundamentação constitucional. De outra parte, afigura-se digna de nota a admoestação de Guillermo O’Donnell, segundo a qual,

Pese a todo, el estado es el único lugar institucional donde los derechos de ciudadanía pueden ser inscriptos y de hecho implementados por aquellos muchos - que en nuestros países han logrado la ciudadanía política por la vía del régimen democrático, pero que en la práctica carecen de muchos derechos civiles básicos, para no mencionar derechos sociales. Hay muy poca ciudadanía sin un estado que incluya un democrático y efectivo imperio de la ley y un

${ }^{63}$ BERCOVICI, Gilberto; MASSONETO, Luís Fernando, op. cit., 2006, p.22.

${ }^{64}$ CARVALHO, Maria Alice Rezende. Uma reflexão sobre a civilização brasileira. In: VIANNA, Luiz W. A revolução passiva: iberismo e americanismo no Brasil. 2. ed. Rio de Janeiro: Revan, 2004. p.7.

65 ARANTES, Paulo, op. cit., 2007, p.165.

${ }^{66}$ BERCOVICI, Gilberto, op. cit., 2004b, p.7.

${ }^{67}$ Ver BERCOVICI, Gilberto, op. cit., 2005; GRAU, Eros Roberto, op. cit. 2005; CARBONELL, Miguel, op. cit., 2005. 
conjunto de burocracias que opere en la dirección de garantizar y/o ayudar a que los respectivos derechos sean efectivos. ${ }^{68}$

Enfim, a "constituição econômica" vazada no texto constitucional de 1988 configura-se como a expressão verdadeira do seu caráter dirigente. O mundo do dever-ser aponta, pois, caminhos para o mundo do ser, Estado e sociedade, tendo como objetivo a alcançar uma ordem econômico-social que, a despeito da convivência com o capitalismo, possibilite que todos convivam na conformidade dos ditames da justiça social.

${ }^{68}$ O’DONNELL, Guillermo, op. cit., 2006, p.22. Ver também DUPAS, Gilberto. Tensões contemporâneas entre o público e o privado. São Paulo: Paz e Terra, 2003. 


\section{CONCLUSÃO}

Confesso que as mais das iguarias com que vos convido são alheias, mas o guisamento delas é de minha casa.

Frei Amador Arrais

Nos últimos tempos, a idéia de poder constituinte foge da teorização convencional dos juristas, passando, inclusive, para outras esferas investigativas da inteligentsia. Assim, alargam-se as bases teóricas do poder constituinte, com o seu afastamento das limitações formalistas abeberadas, sobretudo, na influência francesa, e com a conseqüente busca de vertentes explicativas mais amplas.

A condução do processo constituinte de 1987/1988, fugindo das mãos do governo, inclusive, do estamento militar ainda com muita influência, da exclusividade de grupos ou classes, corporações, e refugiando-se na esfera do "político", permitiu que a incerteza se descolasse na direção da construção de um texto constitucional democrático e progressista. De fato, se há não normas "revolucionárias" na Constituição Federal de 1988, a "narratividade emancipatória" está presente, tendo na "constituição econômica" um dos seus pontos nodais.

A "constituição econômica" inscrita na Constituição Federal de 1988 possibilita que se afirme que o esforço constituinte de 1987/1988 rompeu com o paradigma, segundo o qual nunca houve manifestação do poder constituinte do povo. Obviamente, se avançou consideravelmente no sentido de possibilitar um salto de qualidade no constitucionalismo nacional.

Decididamente, o último fato constituinte transcende, pela primeira vez na história brasileira, o caráter elitista que, de maneira geral, caracterizou as demais manifestações constituintes. De um lado, um conjunto de fatores ocasionou a abertura de frações das elites para uma visão mais ampla da problemática do país, reentronizando a preocupação com a "nação". Do outro lado, o "povo" - que ingressou no cenário político-constitucional 
a partir dos anos 30 e que, desde então, buscou a autonomia e cuja busca foi interrompida pela ruptura autoritário-burocrática em 1964 - rearticula-se durante a transição para a democracia.

Durante o processo constituinte, o setor popular é verdadeiramente partícipe, assistindo-se a momento de efervescência política extremamente importante em torno do Congresso Constituinte. Se a sociedade se moldara menos em uma estrutura de classes a empreender a luta pelos seus interesses, e mais na configuração de corporações, a diferença, agora, é que tais corporações cortam verticalmente o tecido da sociedade civil organizada. De maneira efetiva, o processo constituinte é marcado pelas reivindicações de corporações das classes dominantes e das classes subalternas, dos empresários e dos empregados, dos funcionários públicos, dos diversos entes federativos, dos militares e dos civis.

Sem dúvida, a ideologia dominante é a capitalista, nas suas diversas manifestações, maximalistas ou minimalistas, mais afeitas ao despotismo na fábrica, no latifúndio e na banca, ou mais preocupadas com o bem-estar, ou simplesmente conscientes de que o Estado capitalista é, na falta de melhor expressão, garante de burgueses e proletários. O modo de produção capitalista não foi ameaçado, sequer, esteve em jogo. Todavia, a tentativa de compatibilidade dos "valores sociais do trabalho e da livre iniciativa" (CF, art. $\left.1^{\circ}, I V\right)$ e a busca de uma "ordem econômica, fundada na valorização do trabalho humano e na livre iniciativa", com o fim de "assegurar a todos existência digna, conforme os ditames da justiça social" (CF, art. 170, caput), representam uma mudança qualitativa no processo político-constitucional nacional.

Evidentemente, as normas constitucionais que melhor representam a continuidade do passado com o presente e do presente com o futuro são as normas de princípios. Vivenciase, pois, a partir de 1988, um texto constitucional que se insere num modelo de constituição dirigente, ao mesmo tempo em que possibilita a espontaneidade da vida social como a competência para assumir a direção política. No que atine à "constituição econômica", tais normas de princípios já tem uma longa caminhada no constitucional nacional. Poder-se-ia dizer que tudo começou com o anteprojeto da Subcomissão do Itamarati, nos anos 30, estatuídas as suas diretrizes, em seguida, no texto constitucional de 1934. 
Nas duas últimas décadas, sob a vigência da Constituição Federal de 1988, transformações ocorreram no capitalismo, com a desconstituição do padrão regulatório keyenesiano, a expansão dos mercados, a relativização do Estado, muito mais no plano da constituição econômica real do que da constituição econômica jurídica. A Constituição Federal, promulgada em 5 de outubro de 1988, pouco tempo em seguida se trouxeram à baila o "mal-estar da Constituição" e as "incertezas epistêmicas da directividade constitucional".

De fato, ganhou vida o discurso segundo o qual a constituição dirigente das políticas públicas, dos direitos sociais, da função social da propriedade, do equilíbrio entre o valor social do trabalho e da livre iniciativa, da ordem econômica baseada na justiça social, promovia o desencontro com interesses nacionais. Ademais, teria o condão de fomentar as crises econômicas e produzir a ingovernabilidade, invertendo, por conseguinte, a vontade de constituição de 1987/1988 na "constituição dirigente das políticas neoliberais de ajuste fiscal".

Todavia, os acontecimentos internacionais parecem indicar a precariedade da veleidade neoliberal diante da crise que ganhou terreno nos últimos tempos, a apontar para a insanidade de substituir a racionalidade coletiva simplesmente pelas leis da economia de mercado. A conclusão inevitável dos novos tempos aponta, por sua vez, para o necessário fortalecimento do Estado nacional.

No Brasil, se a nossa fortuna tem sido a pluralidade e a diferença - de grupos sociais, de interesses, de ideologias, de projetos, a nossa virtù é a realização constitucional, tudo no sentido de tornar efetivos os objetivos fundamentais de "construir uma sociedade livre, justa e solidária", "garantir o desenvolvimento nacional", "erradicar a pobreza e a marginalização e reduzir as desigualdades sociais e regionais" e "promover o bem de todos, sem preconceitos de origem, raça, sexo, cor, idade e quaisquer outras formas de discriminação".

Como suma das sumas, pode-se dizer que se tem no texto constitucional de 1988, uma constituição dirigente econômica e social, incólume depois de vinte anos, um instrumento capaz de contribuir para o alcance dos objetivos fundamentais da Republica Federativa do Brasil, a saber, o desenvolvimento econômico, a sociedade de bem-estar e a democracia política 
Por fim, não é ocioso lembrar que se sabe, desde pelo menos Nicolau Maquiavel, "[...] gli è tanto discoto da come se vive a como si doverebbe vivere, che colui che lascia quello chi si fa per quello che si doverrebbe fare, impara più presto la ruína che la perservazione sua". ${ }^{1}$ Ademais, ao se tratar de processo constituinte, originário ou derivado, e de realização constitcional, está-se a tratar de esfera fundamentalmente política, não inoportuna a exortação de Max Weber, segundo a qual "a política é como a perfuração lenta de tábuas duras. Exige tanto paixão como perspectiva". Além do que, e "certamente, toda a experiência história confirma a verdade - que o homem não teria alcançado o possível se repetidas vezes não tivesse tentado o impossível". ${ }^{2}$

\footnotetext{
${ }^{1}$ MACHIAVELLI, Nicolò. Il principe. Milano: Feltrinelli, 2004. p. 164.

${ }^{2}$ WEBER, Max. Ciência e política: duas vocações. 16. ed. São Paulo: Cultrix, 2000. p. 123-124.
} 


\section{REFERÊNCIAS}

ABRANCHES, Sérgio. O processo legislativo brasileiro: conflito e conciliação na política brasileira. Dissertação (Mestrado em Ciências Sociais). Brasília, Universidade de Brasília, 1973.

Presidencialismo de coalizão: o dilema institucional brasileiro. Dados Revista de Ciências Sociais, Rio de Janeiro, v.31, n.1, p.5-34, 1988.

; SOARES, Gláucio Ary Dillon. As funções do legislativo. Revista de Administração Pública, Rio de Janeiro, n.7, p.73-98, 1973.

ACKERMAN, Bruce. We the people. Cambridge-Massachusetts; London: The Belknap Press of Harvard University Press, 1993.

. Neo-federalism? In: ELSTER, Jon; SLAGSTAD, Rune. Constitutionalism and democracy. Cambridge: Cambridge University Press, 1993. p.153-193.

AGAMBEN, Giorgio. Estado de exceção. São Paulo: Boitempo, 2004.

ALEIXO, José Carlos Brandi. Introdução. In: BRASIL. Senado Federal. A constituição que não foi: história da emenda constitucional n.1, de 1969. Brasília: Senado Federal, 2002. p.15-29.

ALENCAR, José de. Discursos parlamentares. Brasília: Câmara dos Deputados, 1977.

ALMEIDA, Martins de. Brasil errado: ensaio político sobre os erros do Brasil como país. Rio de Janeiro: Civilização Brasileira, 1932.

ALMINO, João. Os democratas autoritários: liberdades individuais, de associação política e sindical na Constituição de 1946. São Paulo: Brasiliense, 1980.

Era uma vez uma constituinte: lições de 1946 e questões de hoje. São Paulo: Brasiliense, 1985. 
O processo político na Constituinte de 1987. In: FORTES, Luiz Roberto Salinas; NASCIMENTO, Milton Meira do (Org.). A constituinte em debate. São Paulo: Sofia Editora Seaf, 1987. p.77-82.

ALVES, Alaor Caffé. Estado e ideologia: aparência e realidade. São Paulo: Brasiliense, 1987.

AMADO, Gilberto. Gilberto Amado, discursos parlamentares. Brasília: Câmara dos Deputados, 1979.

Eleição e representação. Brasília: Senado Federal, 1999.

Grandes discursos 2. Brasília: Instituto Tancredo Neves, 1988.

AMADO, Jorge. Vida de Luís Carlos Prestes: o cavaleiro da esperança. Rio de Janeiro: Livraria Martins Editora, 1945.

AMARAL, Azevedo. O Estado autoritário e a realidade nacional. Brasília: UnB, 1981. ANDERSON, Perry. Lineages of the absolutist state. London: NLB, 1974.

Balanço do neoliberalismo. In: SADER, Emir; GENTILI, Pablo (Org.). Pósneoliberalismo: as políticas sociais e o Estado democrático. São Paulo: Paz e Terra, 1995. p.9-23.

ANDRADE, José Carlos Vieira de. Os direitos fundamentais na Constituição Portuguesa de 1976. Coimbra: Almedina, 1987.

ANTUNES, Ricardo. Classe operária, sindicatos e partido no Brasil. São Paulo: Global, 1982.

ARANTES, Paulo. Departamento francês de ultramar: estudos sobre a formação da cultura filosófica uspiana. São Paulo: Paz e Terra, 1994.

. Extinção. São Paulo: Boitempo, 2007.

ARAÚJO, Caetano Ernesto Pereira de; MACIEL Eliane Cruxên Barros de Almeida. A comissão de alto nível: história da emenda constitucional $n^{\circ} \cdot 1$, de 1969. In: BRASIL. 
Senado Federal. A constituição que não foi: história da emenda constitucional n.1, de 1969. Brasília: Senado Federal, 2002. p.31-83.

ARAÚJO, Cícero. Apresentação. In: BERCOVICI, Gilberto. Constituição e estado de exceção permanente: atualidade de Weimar. São Paulo: Azougue Editorial, 2004. p.9-17.

ARCHER, Renato. Prefácio. In: HIPPOLITO, Lúcia. De raposas e reformistas: o PSD e a experiência democrática brasileira, 1945-1964. Rio de Janeiro: Paz e Terra, 1985. p.19-20.

ARENDT, Hanna. Men in dark times. New York: Harcourt, 1967.

ARMITAGE, John. História do Brasil. Rio de Janeiro: Tecnoprint Gráfica, 1965.

AZEVEDO, José Afonso de Mendonça. Elaborando a constituição nacional: atas da Subcomissão elaboradora do anteprojeto 1932/1933. Brasília: Senado Federal, Conselho Editorial, 2004. p.XI-XXV.

BAETA, Hermann Assis. O monopólio do Congresso. In: MAKSOUD, Henry (Ed.). Constituinte independente e apartidária. São Paulo: Visão, 1986. p.26-29.

BAGEHOT, Walter. The English constitution. Oxford: Oxford University Press, 2001.

BALEEIRO, Aliomar. Alguns andaimes da constituição. Rio de Janeiro: Livraria Principal, 1950.

A constituinte e a Constituição Federal de 1946. In: BALEEIRO, Aliomar; LIMA SOBRINHO, Barbosa. A Constituição de 1946. Brasília: CED, 1987. p.1-13.

Constituições brasileiras: 1891. Brasília: Senado Federal; CEE/MCT, 2001.

BALTAR, Ronaldo. Empresariado, transição e o papel do Estado na ordem econômica e social. Tese (Doutorado em Sociologia). São Paulo, Faculdade de Filosofia, Letras e Ciências Humanas da Universidade de São Paulo, 1996.

BANNING, Lance. Jefferson \& Madison: three conversations from the Founding. Madison: Madison House, 1995.

BARBOSA, Rui. Pensamento e ação de Rui Barbosa. Brasília: Senado Federal, 1999. 
BARBOSA, Vivaldo. Dois equívocos rondam nossa constituinte. In: MAKSOUD, Henry (Ed.). Constituinte independente e apartidária. São Paulo: Visão, 1986. p.130-132.

BARELLI, Walter. Sintonia com vontade popular marcou Comissão. Folha de São Paulo - Guia da Constituinte, São Paulo, p.25, 19 set. 1986.

BARRETO, Alvaro Augusto de Borba. Representação das associações profissionais no Brasil: o debate dos anos 1930. Revista de Sociologia e Política, Curitiba, n.22, p.119$133,2004$.

BARROSO, Pérsio Henrique. Constituinte e constituição: participação popular e eficácia constitucional (1987-1997). Curitiba: Juruá, 1999.

BASBAUM, Leoncio. Uma vida em seis tempos. São Paulo: Alfa-Ômega, 1976.

BASTOS, Aurélio Wander. A Ordem dos Advogados e o Estado democrático no Brasil. Tese (Doutorado em Ciência Política). Rio de Janeiro, Instituto Universitário de Pesquisas do Rio de Janeiro, 2007.

BEARD, Charles Austin. An economic interpretation of the Constitution of the United States. Mineolo - New York: Dover Publications, 2004.

BELLAMY, Richard; CASTIGLIONE, Dario. Introduction: constitutions and politics. In: (Ed.). Constitutionalism in transformation: European and theoretical perspectives. Oxford: Blackwell Publishers, 1996. p.1-4.

BELLUZZO, Luiz Gonzaga de Mello. Ensaios sobre o capitalismo no século XX. São Paulo: Unesp; Campinas: Unicamp, 2004.

BENEVIDES, J. M. Corrêa de Sá e. Análise da constituição política do Império do Brasil. São Paulo: Tipografia King, 1890.

BENEVIDES, Maria Victoria de Mesquita. A UDN e o udenismo: ambigüidades do liberalismo brasileiro, 1945-1965. Rio de Janeiro: Paz e Terra, 1981.

BERBEL, Márcia Regina. Deputados do Brasil nas Cortes Portuguesas de 1821-22. Novos Estudos Cebrap, São Paulo, n.51, p.189-202, 1998. 
BERCOVICI, Gilberto. A problemática da constituição dirigente: algumas considerações sobre o caso brasileiro. Revista de Informação Legislativa, Brasília, n.142, p.35-51, 1999.

A constituição dirigente e a crise da teoria constitucional. In: SOUZA NETO, Cláudio Pereira de; BERCOVICI, Gilberto; MORAES, Filomeno; LIMA, Martonio Mont'Alverne Barreto. Teoria da constituição: estudos sobre o lugar da política no direito constitucional. Rio de Janeiro: Lumen Juris, 2003. p.75-150.

Constituição e estado de exceção permanente: atualidade de Weimar. São Paulo: Azougue Editorial, 2004a.

Estado de exceção econômico e a periferia do capitalismo. Separata do Boletim de Ciências Económicas, Coimbra, n.XVLII, 2004 b.

Constituição econômica e desenvolvimento: uma leitura a partir da Constituição de 1988. São Paulo: Malheiros, 2005.

O poder constituinte do povo no Brasil: um roteiro de pesquisa sobre a crise constituinte. In: COUTINHO, Jacinto Nelson de Miranda; LIMA, Martonio Mont'Alverne Barreto (Org.). Diálogos constitucionais: direito, neoliberalismo e desenvolvimento em países periféricos. Rio de Janeiro: Renovar, 2006. p.215-224.

Soberania e constituição: para uma crítica do constitucionalismo. São Paulo:

Quartier Latin, 2008.

. Estado intervencionista e constituição social no Brasil: o silêncio ensurdecedor de um diálogo entre ausentes. In: SOUZA NETO, Cláudio Pereira; SARMENTO, Daniel; BENENBOJM, Gustavo (Coord.). Vinte anos da Constituição Federal de 1988. Rio de Janeiro: Lumen Juris, 2009. p.725-738.

; MASSONETO, Luís Fernando. A constituição dirigente invertida: a blindagem da constituição financeira e a agonia da constituição econômica. Separata do Boletim de Ciências Económicas, Coimbra, 2006.

BIERRENBACH, Flávio. Quem tem medo da constituinte? Rio de Janeiro: Paz e Terra, 1986. 
BOBBIO, Norberto. Destra e sinistra: ragioni e significati di una distinzione politica. Roma: Donzelli, 1994.

Teoria geral da política: a filosofia política e as lições dos clássicos. Rio de Janeiro: Campus, 2000.

. O futuro da democracia. 9. ed. Rio de Janeiro: Paz e Terra, 2004.

et al. O marxismo e o Estado. 2. ed. Rio de Janeiro: Graal, 1979.

BODIN, Jean. Los seis libros de la república. 3. ed. Madrid: Editorial Tecnos, 1997.

BONAVIDES, Paulo. Constituinte e constituição: a democracia, o federalismo, a crise contemporânea. 2. ed. Fortaleza: Ioce, 1987.

. Do Estado liberal ao Estado social. 6. ed. São Paulo: Malheiros, 1996.

..Teoria constitucional da democracia participativa. São Paulo: Malheiros, 2001.

. Curso de direito constitucional. 18. ed. São Paulo: Malheiros, 2006.

; ANDRADE, Paes de. História constitucional do Brasil. Brasília: Paz e Terra, 1989.

; AMARAL Roberto. Textos políticos da História do Brasil. 3. ed. Brasília: Senado Federal, Conselho Editorial, 2002. 10 v.

BORJA, Célio. Introdução. In: URUGUAI, Visconde de. Ensaio sobre o Direito Administrativo. Brasília: Ministério da Justiça, 1997.

BORON, Atilio A. Filosofia política marxista. São Paulo: Cortez; Buenos Aires: Clacso, 2003.

BRAGA, Sérgio Soares. Quem foi quem na Assembléia Constituinte de 1946: um perfil sócio-econômico e regional da Constituinte de 1946. Dissertação (Mestrado em Ciência Política) - Departamento de Ciência Política, Campinas-SP, Universidade Estadual de Campinas, 1996. 2 v. 
(Org.). Luiz Carlos Prestes; o constituinte, o senador (1946-1948). Brasília: Senado Federal, Conselho Editorial, 2003.

BRASIL, Joaquim Francisco de Assis. Idéias políticas de Assis Brasil. Brasília: Senado Federal; Rio de Janeiro: FCRB, 1990. 3v.

Da democracia representativa na república (antologia). Brasília: Senado Federal, 1998.

BROSSARD, Paulo. Ainda é tempo. Brasília: Senado Federal, 1978.

BRUNEAU, Thomas C. Constitutions and democratic consolidation: Brazil in comparative perspective. In: ETHIER, Diane (Ed.). Democratic transition and consolidation in Southern Europe, Latin America and Southeast Asia. London: MacMillan, 1990. p. 173-196.

Brazil's political transition. In: HIGHLEY, John; GUNTHER, Richard (Ed.).

Elites and democratic consolidation in Latin America and Southern Europe. Cambridge: Cambridge University Press, 1992. p.257-280.

BURDEAU, Georges. Traité de science politique. Paris: LGDJ, 1950. t.III.

O Estado. São Paulo: Martins Fontes, 2005.

BURKE, Edmund. Reflexões sobre a revolução em França. 2. ed. Brasília: UnB, 1998.

BURLAMAQUI, Jean-Jacques. The principles of natural and political law. Indianapolis-Indiana: Liberty Fund, 2006.

CABRAL, João C. da Rocha. Código Eleitoral da República dos Estados do Brasil. 3. ed. Rio de Janeiro: Freitas Bastos, 1934.

CABRAL, José Bernardo. O poder constituinte. Brasília: Câmara dos Deputados Coordenação de Publicações, 1988.

CAMARGO, Aspásia. Prefácio. In: GOMES, Angela Maria de Castro (Coord.). Regionalismo e centralização política: partidos e constituinte nos anos 30. Rio de Janeiro: Nova Fronteira, 1980. p.15-17. 
; DINIZ, Eli (Org.) Continuidade e mudança no Brasil da Nova República.

São Paulo: RT, 1989.

CAMPOS, Francisco. O Estado nacional: sua estrutura, seu conteúdo ideológico. Brasília: Senado Federal, Conselho Editorial, 2001.

CAMPOS, Roberto. O Poder Legislativo e o desenvolvimento. In: MENDES, Cândido (Org.). O legislativo e a tecnocracia. Rio de Janeiro: Imago/Conjunto Universitário Candido Mendes, 1975. p.31-41.

Lanterna na popa - memórias. Rio de Janeiro: Topbooks, 1994.

CANECA, Frei Joaquim do Amor Divino. Frei Joaquim do Amor Divino Caneca. Organização e introdução de Evaldo Cabral de Melo. São Paulo: Ed. 34, 2001.

CANOTILHO, J. J. Gomes. Direito constitucional. 5. ed. Coimbra: Livraria Almedina, 1992.

Constituição dirigente e vinculação do legislador: contributo para a compreensão das normas constitucionais programáticas. 2. ed. Coimbra: Coimbra Editora, 2001 .

Videoconferência - 21/02/02 - UFPR (J. J. Gomes Canotilho e Grupo das Jornadas da Fazenda Cainã). In: COUTINHO, Jacinto Nelson de Miranda (Org.). Canotilho e a constituição dirigente. Rio de Janeiro: Renovar, 2003.

. "Brancosos" e interconstitucionalidade: itinerários dos discursos sobre a historicidade constitucional. Coimbra: Almedina, 2005a.

- O Estado adjetivo e a teoria da constituição. Revista Latino-americana de Estudos Constitucionais, Belo Horizonte, n.5, p.139-154, 2005b.

CARBONELL, Miguel. Zagrebelsky y el uso de la Historia por el derecho constitucional. In: ZAGREBELSKY, Gustavo. Historia y constitución. Buenos Aires: Editorial Trotta, 2005. p.9-24.

CARDOSO, Fernando Henrique. Autoritarismo e democratização. Rio de Janeiro: Paz e Terra, 1975. 
Brasil: caminhos da transição. Folha de São Paulo (Folhetim), São Paulo, p.3, 29 mar. 1981.

A constituinte: desafio e alternativa. Opinião, São Paulo, p. 2, 5 jan. 1986.

A arte da política: a história que vivi. 3. ed. Rio de Janeiro: Civilização Brasileira, 2006.

; FALETTO, Enzo. Dependência e desenvolvimento na América Latina. Rio de Janeiro: Zahar, 1970.

; LAMOUNIER, Bolívar. Introdução. In: CARDOSO, Fernando Henrique; LAMOUNIER, Bolívar (Coord.). Os partidos e as eleições no Brasil. Rio de Janeiro: Paz e Terra, 1975. p.9-13.

CARNEIRO, Levi. Pela nova constituição. Rio de Janeiro: A. Coelho Branco Filho (Editor), 1936.

CARONE, Edgard. A república velha (evolução política). São Paulo: Difel, 1971. A república velha (instituições e classes sociais). 4. ed. Rio de Janeiro: Difel, 1978. A república nova (1930-1937). Rio de Janeiro: Difel, 1976.

CARPIZO, Jorge. La constitución mexicana de 1917. 2. ed. México-DF: Unam, 1973.

CARVALHO, Maria Alice Rezende. Uma reflexão sobre a civilização brasileira. In: VIANNA, Luiz Werneck. A revolução passiva: iberismo e americanismo no Brasil. 2. ed. Rio de Janeiro: Revan, 2004. p.7-37.

CARVALHO, José Murilo de. Os bestializados. São Paulo: Companhia das Letras, 1987. A luta pela $\operatorname{Re}(s)$ pública. Jornal do Brasil, Rio de Janeiro, Caderno B/Especial, p. 2, 4 set. 1988.

A construção da ordem: a elite política imperial; Teatro de sombras: a política imperial. 2. ed. Rio de Janeiro: UFRJ; Relume-Dumará, 1996. 
CARVAlHO, Manuel Emílio. E. Gomes de. Os deputados brasileiros nas Cortes Gerais de 1821. Brasília: Senado Federal, Conselho Editorial, 2003.

CARVALHO, Orlando. Ensaios de sociologia eleitoral. Belo Horizonte: RBEP, 1958.

CARVAlHOSA, Modesto. A Carta de 1988 e os 200 anos do constitucionalismo. Folha de São Paulo, São Paulo, p.A-3, 20 set.1988.

CASTEL, Robert. Les metamorphoses de la question sociale: une chronique du salariat. Paris: Fayard, 1995.

CASTELLO BRANCO, Carlos. Os militares no poder. Rio de Janeiro: Nova Fronteira, 1979. v. III.

Liberar sem transferir poder (entrevista). IstoÉ, São Paulo, n.265, p.68-70, 20 jan. 1982.

CASTRO, Araújo. A reforma constitucional. Rio de Janeiro: L. Ribeiro, 1924.

CASTRO, Carlos Roberto Siqueira. A constituição aberta e os direitos fundamentais: ensaios sobre o constitucionalismo pós-moderno e comunitário. Rio de Janeiro: Forense, 2003.

CAVALCANTI, João Barbalho Uchôa. Constituição Federal brasileira, 1891: comentada. Brasília: Senado Federal, Conselho Editorial, 2002.

CAVALCANTI, Temístocles Brandão. À margem do anteprojeto. Rio de Janeiro: Irmãos Pongetti, 1933.

CHACON, Vamireh. Vida e morte das constituições brasileiras. Rio de Janeiro: Forense, 1987.

CHAGAS, Carlos. 113 dias de angústia: impedimento e morte de um presidente. Porto Alegre: L\&PM, 1979.

CHAUÍ, Marilena; NOGUEIRA, Marco Aurélio. O pensamento político e a redemocratização do Brasil. Lua Nova - Revista de Cultura e Política, São Paulo, n.71, p. 173-228, 2007. 
CHILCOTE, Ronald H. The Brazilian Communist Party. New York: Oxford University Press, 1974.

CITTADINO, Gisele. Pluralismo, direito e justiça distributiva: elementos da filosofia constitucional contemporânea. 3. ed. Rio de Janeiro: Lumen Juris, 2004.

COASE, Ronald. The firm, the market and the law. Chicago: Chicago University Press, 1988.

COELHO, João Gilberto Lucas; OLIVEIRA, Antônio Carlos de. A nova Constituição: avaliação do texto e perfil dos constituintes. Rio de Janeiro: Revan, 1989.

COLLIER, David (Org.). O novo autoritarismo na América Latina. Rio de Janeiro: Paz e Terra, 1982.

COMPARATO, Fábio Konder. O indispensável direito econômico. Revista dos Tribunais, São Paulo, n.353, p.14-26, 1965.

Um quadro institucional para o desenvolvimento democrático. In: JAGUARIBE, Hélio et al. Brasil, sociedade democrática. Rio de Janeiro: José Olympio, 1985. p.393-432.

A constituinte do nada mudou (entrevista). Senhor, São Paulo, n.239, p.6-8, 16 out. 1985 .

- Função social da propriedade dos bens de produção. Revista de Direito Mercantil, São Paulo, n.63, p.71-89, jul./set. 1986.

- Muda Brasil! Uma constituição para o desenvolvimento democrático. 4. ed. São Paulo: Brasiliense, 1987.

. Direito empresarial: estudos e pareceres. São Paulo: Saraiva, 1990.

. Direitos e deveres fundamentais em matéria de propriedade. In: AMARAL JÚNIOR, Alberto; PERRONE-MOISÉS, Cláudia (Org.). O cinqüentenário da Declaração Universal dos Direitos do Homem. São Paulo: Edusp, 1999. p.377-384.

CONSTANT, Benjamin. Escritos de política. São Paulo: Martins Fontes, 2005. 
CORRÊA, Oscar Dias. A crise da constituição, a constituinte e o Supremo Tribunal Federal. São Paulo: RT, 1986.

CORREA, Serzedello. A revisão constitucional. Rio de Janeiro: Companhia Lithotypographia, 1904.

COUTINHO, Amélia; GUIDO, Maria Cristina. Geisel, Ernesto. In: ABREU, Alzira Alves et al. (Coord.). Dicionário histórico-biográfico brasileiro pós-1930. 2. ed. Rio de Janeiro: FGV; CPDOC, 2001. v.III. p.2.510-2.522.

COUTINHO, Jacinto Nelson de Miranda (Org.). Canotilho e a constituição dirigente. Rio de Janeiro: Renovar, 2003.

COUTO, Ronaldo Costa. História indiscreta da ditadura e da abertura: Brasil: 19641985. 2. ed. Rio de Janeiro: Record, 1999.

CUNHA, Paulo Ferreira. Para uma história constitucional do direito português. Coimbra: Almedina, 1995.

D’ARAúJO, Maria Celina; CASTRO, Célio. Ernesto Geisel. 4. ed. Rio de Janeiro: Editora FGV, 1977.

DAHL, Robert A. How democratic is the American Constitution? New Haven and London: Yale Nota Bene, 2003.

DALlARI, Dalmo de Abreu. Constituição e constituinte. 2. ed. São Paulo: Saraiva, 1984.

Constituição resistente. In: MORAES, Alexandre de (Coord.). Os 10 anos da

Constituição Federal. São Paulo: Atlas, 1999. p.45-60.

. O futuro do Estado. São Paulo: Saraiva, 2001.

DELGADO, Lucília de Almeida Neves. PTB: do getulismo ao reformismo, 1945-1964. São Paulo: Marco Zero, 1989.

DEIRÓ, Eunápio. Fragmentos de estudos da história da Assembléia Constituinte do Brasil. Brasília: Senado Federal, Conselho Editorial, 2006. 
DINIZ, Eli. Transição, partidos e regimes políticos: algumas considerações. In: CAMARGO, Aspásia; DINIZ, Eli (Org.). Continuidade e mudança no Brasil da Nova República. São Paulo: Vértice; Rio de Janeiro: Iuperj, 1989. p.84-108.

DOLHNIKOFF, Miriam. Introdução. In: SILVA, José Bonifácio de Andrada e. Projetos para o Brasil. Organização de Miriam Dolhnikoff. São Paulo: Companhia das Letras; Publifolha, 2000. p.3-14.

DRAIBE, Sonia. Rumos e metamorfoses: Estado e industrialização no Brasil, 1930-1960. 2. ed. Rio de Janeiro: Paz e Terra, 2004.

DUARTE, José. A Constituição de 1946. Exegese dos textos à luz dos trabalhos da Assembléia Constituinte. Rio de Janeiro: Imprensa Nacional, 1947. 3v.

DUARTE, Nestor. A ordem privada e a organização política nacional. Brasília: Ministério da Justiça, 1997.

DUGUIT, Léon. La separación de poderes y la Asamblea Nacional de 1789. Madrid: Centro de Estudios Constitucionales, 1996.

DULLES, John W. F. Castello Branco, o presidente reformador. Brasília: UnB, 1983. Sobral Pinto: a consciência do Brasil. Rio de Janeiro: Nova Fronteira, 2001.

DUMONT, Louis. Essays on individualism: modern ideology in anthropological perspective. Chicago: University of Chicago Press, 1986.

DUPAS, Gilberto. Tensões contemporâneas entre o público e o privado. São Paulo: Paz e Terra, 2003.

DUVERGER, Maurice. Institutions politiques et droit constitutionnel. 12. ed. Paris: PUF, 1970.

ELIAS, Norbert. O processo civilizador. Rio de Janeiro: Jorge Zahar, 1994.

ENCINAR, José Juan Gonzalez et al. El proceso constituyente. Enseñanzas a partir de cuatro casos recientes: España, Portugal, Brasil y Chile”. Cadernos do Idesp, São Paulo, n.37, 1991. 
ENGELS, Friedrich. Prefácio à terceira edição alemã. In: MARX, Karl. O 18 Brumário e cartas a Kugelmann. 3. ed. São Paulo: Paz e Terra, 1977. p.11-13.

ENGLUND, Steven. Napoleão: uma biografia política. Rio de Janeiro: Jorge Zahar Editor, 2005.

ENTREVISTA de Mauro Benevides à Agência Senado. Disponível em: <http://www2.camara.gov.br/internet/constituicao20anos>. Acesso em: 9 out. 2008.

FAORO, Raymundo. Constituinte: a verdade e o sofisma. In: SADER, Emir (Org.). Constituinte e democracia no Brasil de hoje. São Paulo: Brasiliense, 1985. p.7-16.

Os donos do poder: formação do patronato político brasileiro. 10. ed. São Paulo: Globo; Publifolha, 2000. 2v.

A república inacabada. São Paulo: Globo, 2007.

FARIA, José Eduardo. A crise constitucional e a restauração da legitimidade. Porto Alegre: Sergio Antonio Fabris Editor, 1985.

Os direitos humanos e o dilema latino-americano às vésperas do século XXI.

Boletim da Sociedade Brasileira de Direito Internacional, São Paulo, n. 93/94, p.43-60, 1994.

Depoimento. In: SCHUBSKY, Cássio (Org.). Estado de direito já!: os trinta anos da Carta aos Brasileiros. São Paulo: Lettera.doc, 2007. p.100-110.

FAUCHER, Philippe. Políticas de ajuste ou erosão do Estado no Brasil? Dados - Revista de Ciências Sociais, Rio de Janeiro, v.36, n.3, p. 393-418, 1993.

FEHLBERG, Carlos. Teotônio Vilela, o senador que tentou mudar o Brasil. Disponível em: <http://www.politicaparapoliticos.com.br>. Acesso em: 22 maio 2008.

FEITOSA, Raymundo Juliano. Finanças públicas e tributação na constituinte: 1987/1988. Rio de Janeiro: América Jurídica, 2003.

FERNANDES, Florestan. O uso da iniciativa popular. O Povo, Fortaleza, p. 7, 13 abr. 1987. 
A percepção popular da Assembléia Nacional Constituinte. Estudos Avançados, São Paulo, v.2, n.2, p.86-88, 1988.

Que tipo de República? 2. ed. Rio de Janeiro: Globo, 2007.

FERRARESE, Maria Rosaria. Diritto e mercato. Torino: G. Giappiachelli Editore, 1992.

FERRAZ JR., Tercio Sampaio. Constituinte: assembléia, processo, poder. São Paulo: RT, 1985.

. Uma constituinte "lenta, gradual e segura". In: FORTES, Luiz Roberto Salinas; NASCIMENTO, Milton Meira do (Org.). A constituinte em debate. São Paulo: Sofia Editora Seaf, 1987. p.241-251.

FERREIRA, Gabriela Nunes. Centralização e descentralização no Império: o debate entre Tavares Bastos e Visconde de Uruguai. São Paulo: Editora 34/Departamento de Ciência Política da USP, 1999.

FERREIRA, Manoel Rodrigues. A evolução do sistema eleitoral brasileiro. Brasília: Senado Federal, Conselho Editorial, 2001.

FERREIRA FILHO, Manoel Gonçalves. A democracia possível. 3. ed. São Paulo: Saraiva, 1976.

Nova perspectiva do processo constitucional. Revista Brasileira de Estudos Políticos, Belo Horizonte, n. 60/61, p.127-145, 1985.

. O anteprojeto dos notáveis. São Paulo: Saraiva, 1987

. Direito constitucional econômico. São Paulo: Saraiva, 1990.

O poder constituinte. 5. ed. São Paulo: Saraiva, 2007.

Curso de direito constitucional. 34. ed. São Paulo: Saraiva, 2008.

FINNER, S. E. The history of government: empires, monarchies and the modern State. Oxford:Oxford University Press, 1997. v. III.

FIORI, José Luís; MEDEIROS, Carlos (Org.). Polarização mundial e crescimento. Petrópolis: Vozes, 2001. 
FISHLOW, Albert. Some reflections on post-1964 Brazilian economic policy. In: STEPAN, Alfred (Ed.). Authoritarian Brazil: origins, policies, and future. New Haven and London: Yale University Press, 1973. p.69-118.

FIX-ZAMUDIO, Hector. La evolución del derecho internacional de los derechos humanos en las constituciones latino-americanas. In: TRINDADE, Antônio Augusto Cançado; VOLIO, Lorena González (Comp.). Estudios Básicos de Derechos Humanos II. San José-Costa Rica: IIDH, 1995. p.51-66.

FLEISCHER, David V. The Constituent Assembly and the transformation strategy: attempts to shift political power in Brazil from the President to Congress. In: GRAHAM, Larry S.; WILSON, Robert H. (Ed.) The political economy of Brazil: public policies in an era of transition. Austin: University of Texas Press, 1990. p.210-258.

; MARQUES, Jales R. PSDB: de facção a partido. Brasília: Instituto Teotônio Vilela, 1999.

FLORES, Alberto Vivar. El liberalismo constitucional en la fundación del Imperio brasileño. Revista Electrónica de Historia Constitucional, Oviedo-Espanha, n.6, 2005. Disponível em: <http://hc.rediris.es/06/articulos>. Acesso em: 10 set. 2007.

FLORY, Thomas. El juez de paz y el jurado en el Brasil imperial. México-DF: Fondo de Cultura Económica, 1996.

FOLHA DE SÃO PAULO, São Paulo, p.A17, 27 ago. 2008.

FOLHA DE SÃO PAULO, São Paulo, p. A4, 5 out. 2008.

FORGIONI, Paula A. Contrato de distribuição. São Paulo: RT, 2005.

Análise econômica do Direito: paranóia ou mistificação? In: COUTINHO, Jacinto Nelson de Miranda; LIMA, Martonio Mont'Alverne Barreto (Org.). Diálogos constitucionais: Direito, neoliberalismo e desenvolvimento em países periféricos. Rio de Janeiro: Renovar, 2006. p.419-442.

FRANCO, Afonso Arinos de Melo. Curso de direito constitucional brasileiro. Rio de Janeiro: Forense, 1960. v. II. p.189. 
História e teoria dos partidos políticos no direito constitucional brasileiro. 2 . ed. São Paulo: Alfa-Ômega, 1974.

. Um estadista da República. Rio de Janeiro: Nova Aguilar, 1976.

A constituinte instituída. Revista de Ciência Política, Rio de Janeiro, v.1, n.1, p. 3-17, 1982.

FRANCO, Gustavo. Prefácio. In: BARBOSA, Rui. O papel e a baixa do câmbio: um discurso histórico, 1891. Rio de Janeiro: Reler, 2005. p.9-33.

FREIRE, Felisbelo. História constitucional da República dos Estados Unidos do Brasil. Rio de Janeiro: Typ. Aldina, 1895. 3v.

FREITAS, Décio. O homem que inventou a ditadura no Brasil. 3. ed. Porto Alegre: Sulina, 1999.

FRIEDMAN, Milton. Essays in positive economics. Chicago: University of Chicago Press, 1953.

; FRIEDMAN, Rose. Free to choose: a personal statement. New York: Harcourt Brace Jovanovich, 1980.

FURTADO, Celso. O Brasil ou os entraves ao desenvolvimento. Paz e Terra, Rio de Janeiro, n.4, p.174-175, 1967.

A fantasia organizada. Rio de Janeiro: Paz e Terra, 1985.

A fantasia desfeita. Rio de Janeiro: Paz e Terra, 1989.

. Brasil - A construção interrompida. 2. ed. Rio de Janeiro: Paz e Terra, 1992.

GARGARELLA, Roberto. As pré-condições econômicas do autogoverno político. In: BORON, Atilio A. Filosofia politica: controvérsias sobre a civilização, império e cidadania. Buenos Aires: CLACSO; São Paulo: Departamento de Ciência Política da USP, 2006. p.279-294.

GASPARI, Elio. A ditadura encurralada. São Paulo: Companhia das Letras, 2004. 
GIAVARINA, Valmor. Constituinte originária e instituída. Disponível em: <http://www.valmorgiavarina.adv.br>. Acesso em: 25 jan. 2003.

GIDDENS, Anthony. Para além da esquerda e da direita. O futuro da política radical. São Paulo: Unesp, 1996.

O Estado-nação e a violência. São Paulo: Edusp, 2001.

GiOvannetti, Evaristo Netto. A bancada do PCB na Assembléia Constituinte de 1946. São Paulo: Novos Rumos, 1986.

GOLDTHORPE, John H. (Ed.). Order and conflict in contemporary capitalism: studies in the political economy of Western European nations. Oxford: Clarendon Press, 1988.

GOMES, Angela Maria de Castro. Introdução. In: (Coord.). Regionalismo e centralização política: partidos e constituinte nos anos 30. Rio de Janeiro: Nova Fronteira, 1980. p.41-131.

A representação de classes na Constituinte de 1934. In: (Coord.).

Regionalismo e centralização política: partidos e constituinte nos anos 30 . Rio de Janeiro: Nova Fronteira, 1980. p.427-491.

Confronto e compromisso no processo de constitucionalização (1930-1935).

In: FAUSTO, Boris (Org.). História geral da civilização brasileira: sociedade e política (1930-1964). 2. ed. Rio de Janeiro: Difel, 1983. 3v. p.7-75.

. (Coord.). Regionalismo e centralização política: partidos e constituinte nos anos 30. Rio de Janeiro: Nova Fronteira, 1980.

GOMES, Sandra. O impacto das regras de organização do processo legislativo no comportamento dos parlamentares: um estudo de caso da Assembléia Nacional Constituinte (1987-1988). Dados - Revista Brasileira de Estudos Sociais, Rio de Janeiro, v.49, n.1, p.193-224, 2006.

GOYARD-FABRE, Simone. Os princípios filosóficos do direito político moderno. São Paulo: Martins Fontes, 1999.

GRAU, Eros Roberto. A constituinte e a constituição que teremos. São Paulo: RT, 1985. 
A ordem econômica na Constituição de 1988. 10. ed. São Paulo: Malheiros, 2005.

GUTEMBERG, Luiz. Moisés: codinome, Ulysses Guimarães: uma biografia. São Paulo: Companhia das Letras, 1994.

HABERMAS, Jürgen. A crise de legitimação do capitalismo tardio. Rio de Janeiro: Tempo Brasileiro, 1980.

HAGGARD, Stephen; KAUFMAN, Robert. The politics of economic adjustments: international constraints, distributive politics and the State. Princeton: Princeton University Press, 1992.

HAMBLOCH, Ernest. Sua majestade o presidente do Brasil: um estudo do Brasil constitucional (1889-1934). Brasília: UnB, 1981.

HAMILTON, Alexander; MADISON, James; JAY, John. The federalist papers. New York: Signet Classics, 2003.

HAYEK, Friedrich von. The road to serfdom. London: Routledge \& Paul Kegan, 1979.

HELLER, Hermann. Teoría del Estado. Buenos Aires: Fondo de Cultura Económica, 1992.

HELÚ, Jorge Sayeg. El constitucionalismo social mexicano. México: Fondo de Cultura Económica, 1972.

HILTON, Stanley. Oswaldo Aranha: uma biografia. Rio de Janeiro: Objetiva, 1994.

HIPPOLITO, Lúcia. De raposas e reformistas: o PSD e a experiência democrática brasileira, 1945-1964. Rio de Janeiro: Paz e Terra, 1985.

HIRSCHMAN, Albert. A mudança para o autoritarismo na América Latina e a busca de suas determinantes econômicas. In: COLLIER, David (Org.). O novo autoritarismo na América Latina. Rio de Janeiro: Paz e Terra, 1982. p.65-100.

HOBBES, Thomas. Do cidadão. São Paulo: Martins Fontes, 1992. 
HOBSBAWM, Eric. The age of extremes: A history of the world, 1914-1991. New York: Pantheon Books, 1994.

O novo século: entrevista a Antonio Polito. São Paulo: Companhia das Letras, 2000.

HOLANDA, Sérgio Buarque de. Raízes do Brasil. 26. ed. São Paulo: Companhia das Letras, 1995.

HORTA, Raul Machado. Direito constitucional. 2. ed. Belo Horizonte: Del Rey, 1999.

HUTTON, Will; GIDDENS, Anthony (Ed.). Global capitalism. New York: The New Press, 2001.

IRTI, Natalino. L’ordine giuridico del mercato. 4. ed. Roma/Bari: Laterza, 2001.

JAGUARIBE, Hélio et al. Brasil, sociedade democrática. Rio de Janeiro: José Olympio, 1985.

JASMIM, Marcelo. Francisco Campos e a crítica das constituições liberais. CaxambuMG: paper apresentado durante o XXV Encontro Anual da Associação Nacional de PósGraduação e Pesquisa em Ciências Sociais - Anpocs, 2001.

JELLINEK, George. Teoría general del Estado. México-DF: Fondo de Cultura Económica, 2000.

JOBIM, Nelson. Documento: Jobim e seu projeto de maioridade. Senhor, São Paulo, n.308, p.3-5, 10 fev. 1987.

KAUFMAN, Robert. The politics of economic adjustments: international constraints, distributive politics and the State. Princeton: Princeton University Press, 1992.

KELSEN, Hans. A competência da assembléia nacional constituinte de 1933/34. Revista Trimestral de Direito Público, São Paulo, n.9, p.5-8, 1995.

Teoria geral do Direito e do Estado. 5. ed. São Paulo: Martins Fontes, 2005. Teoria pura do direito. 7. ed. São Paulo: Martins Fontes, 2006. 
KETCHAM, Ralph (Ed.). The anti-federalist papers and the constitutional Convention debates. New York: Signet Classics, 2003.

KINZO, Maria D’Alva Gil. Oposição e autoritarismo: gênese e trajetória do MDB (19661979). São Paulo: Idesp/Vértice, 1988.

Quadro partidário e a Constituição. In: LAMOUNIER, Bolívar (Org.). De Geisel a Collor: o balanço da transição. São Paulo: Sumaré; Idesp, 1990. p.105-134.

KORPI, Walter. The democratic class struggle. London: Routledge \& Kegan Paul, 1983.

KUGELMAS, Eduardo. Pimenta Bueno, o jurista da Coroa. In: SÃO VICENTE, José Antônio Pimenta Bueno, Marquês de. José Antônio Pimenta Bueno, Marquês de São Vicente. Organização e introdução de Eduardo Kugelmas. São Paulo: Ed. 34, 2002. p.1949.

LACERDA, Carlos. Depoimento. 3. ed. Rio de Janeiro: Nova Fronteira, 1987.

Na Tribuna da Imprensa: crônica sobre a Constituição de 1946. Rio de Janeiro: Nova Fronteira, 2000.

LAFER, Celso. O sistema político brasileiro. São Paulo: Perspectiva, 1975.

LAMENATZ, John Petrov. Man and society: a critical examination of some important social and political theories from Machiavelli to Marx. London: Longman, 1963.

LAMOUNIER, Bolívar. Formação de um pensamento político autoritário. In: FAUSTO, Boris (Org.). História geral da civilização brasileira: sociedade e instituições (18891930). Rio de Janeiro: Difel, 1977. 2v. p.343-374.

. Os trabalhos da "Comissão Afonso Arinos". In: FORTES, Luiz Roberto Salinas; NASCIMENTO, Milton Meira do (Org.). A constituinte em debate. São Paulo: Sofia Editora Saef, 1987. p.83-99.

. "O Brasil Autoritário" revisitado: o impacto das eleições sobre a abertura. In: STEPAN, Alfred. Democratizando o Brasil. São Paulo: Paz e Terra, 1988. p. 83-124.

LANE, Jan-Erik. Constitutions and political theory. Manchester and New York: Manchester University Press, 1996. 
LASSALLE, Ferdinand. A essência da constituição. Rio de Janeiro: Liber Juris, 1995.

LEAL, Aurelino de Araújo. História constitucional do Brasil. Brasília: Senado Federal, Conselho Editorial, 2002.

LEAL, Hamilton. História das instituições políticas do Brasil. Rio de Janeiro: Imprensa Nacional, 1962.

LEAL, Victor Nunes. Coronelismo, enxada e voto: o município e o regime representativo no Brasil. 2. ed. São Paulo: Alfa-Ômega, 1975.

. Problemas de direito público e outros problemas. Brasília: Ministério da Justiça, 1997.

LESSA, Pedro. A reforma constitucional. Rio de Janeiro: Brasileira Lux, 1925.

LESSA, Renato. A invenção republicana. 2. ed. Rio de Janeiro: Topbooks, 1999.

Apresentação. In: PILATTI, Adriano. A Constituinte de 1987-1988: progressistas, conservadores, ordem econômica e regras do jogo. Rio de Janeiro: PUC Rio; Lumen Juris, 2008. p.XI-XIII.

A constituição brasileira de 1988 como experimento de filosofia pública: um ensaio. In: OLIVEN, Ruben George; RIDENTI, Marcelo; BRANDÃO, Gildo Marçal (Org.). A Constituição de 1988 na vida brasileira. São Paulo: Aderaldo \& Rothschild; Anpocs, 2008. p.363-395.

LEVINE, Robert M. Pais dos pobres? O Brasil da era Vargas. São Paulo: Companhia das Letras, 2001.

LIMA, Hermes. O espírito da Constituição de 1946. In: INSTITUTO DE DIREITO PÚBLICO E CIÊNCIA POLÍTICA. Estudos sobre a Constituição brasileira. Rio de Janeiro: FGV, 1954. p.11-18.

Travessia: memórias. Rio de Janeiro: José Olympio, 1974.

LIMA, Martonio Mont'Alverne Barreto. Judiciário e Estado no Brasil: tribunais superiores e juízes na formação do Estado brasileiro. Revista da Escola Superior do Ministério Público do Distrito Federal e Territórios, Brasília, n.6, p.171-199, 1995. 
; BERCOVICI, Gilberto. Entrevista com Friedrich Müller. Seqüência - Revista do Curso de Pós-Graduação em Direito da UFSC, Florianópolis, n.51, p.9-30, 2005.

LIMA, Oliveira. O movimento da Independência: 1821-1822. 6. ed. Rio de Janeiro: Topbooks, 1997.

LIMA JR., Olavo Brasil. Os partidos políticos brasileiros - a experiência federal e regional. Rio de Janeiro: Graal, 1983.

. Instituições políticas democráticas. Rio de Janeiro: Jorge Zahar Editor, 1997.

LIMA SOBRINHO, Barbosa. A presença de Alberto Torres: sua vida e pensamento. Rio de Janeiro: Civilização Brasileira, 1968.

O direito eleitoral e a Constituição de 1946. In: BALEEIRO, Aliomar; LIMA SOBRINHO, Barbosa. A Constituição de 1946. Brasília: CED, 1987. p.15-31.

LINHARES, Marcelo. O governo Castello Branco. Fortaleza: ABC Fortaleza, 1999.

LINZ, Juan. Prefácio à segunda edição. In: TRINDADE, Hélgio. O integralismo (o fascismo brasileiro na década de 30). 2. ed. Rio de Janeiro: Difel, 1974. p.VII-XVII.

- Lições da Espanha para a democracia: o pacto do rei e as tramas brasileiras.

Jornal do Brasil, Rio de Janeiro, Caderno B/Especial, p.1, 15 maio 1983.

; STEPAN, Alfred. Problems of democratic transition and consolidation.

Baltimore: John Hopkins Press, 1996.

LOCKE, John. Second treatise of government. Indianapolis-Indiana: Hackett Publishing Company, 1980.

LOEWENSTEIN, Karl. Brazil under Vargas. New York: Macmillan, 1942.

Teoría de la constitución. 2. ed. Barcelona: Editorial Ariel, 1976.

LOSURDO, Domenico. Democracia ou bonapartismo: triunfo e decadência do sufrágio universal. Rio de Janeiro: UFRJ; São Paulo: Unesp, 2004.

Contra-história do liberalismo. Aparecida-SP: Idéias \& Letras, 2006. 
LOVE, Joseph L. A república brasileira: federalismo e regionalismo (1889-1937). In: MOTA, Carlos Guilherme (Org.). Viagem incompleta: a experiência brasileira (15002000): a grande transação. São Paulo: Senac, 2000. p.123-160.

LUNO, Antonio-Enrique Perez. Derechos humanos, estado de derecho y constitución. 9. ed. Madrid: Tecnos, 2005.

MACHIAVELLI, Nicolò. Il principe. Milano: Feltrinelli, 2004.

MADEIRA, Luís Carlos. Os limites do poder. In: MAKSOUD, Henry (Ed.). Constituinte independente e apartidária. São Paulo: Visão, 1986. p.101-103.

MAKSOUD, Henry. Apresentação. In: MAKSOUD, Henry (Ed.). Constituinte independente e apartidária. São Paulo: Visão, 1986. p.7-15.

MALBERG, R. Carré de. Teoría general del Estado. México-DF: Fondo de Cultura Económica, 2001.

MANDEVILLE, Bernardo. La fábula de las abejas o los vicios privados hacen la prosperidad pública. México: Fondo de Cultura Económica, 2001.

MANGABEIRA, João. Em torno da constituição. São Paulo: Nacional, 1934.

Idéias políticas de João Mangabeira. Brasília: Senado Federal; Rio de Janeiro: FCRB, 1980. 3 v.

Rui: o estadista da República. Brasília: Senado Federal, Conselho Editorial, 1999.

MANIN, Bernard. The principles of representative government. Cambridge: Cambridge University Press, 1997.

MARQUAND, David. Reinventando o federalismo: a Europa e a esquerda. In: (Org.). Reinventando a esquerda. São Paulo: Unesp, 1997. p.273-294.

MARSHALL, T. H. Citizenship and social class and other essays. Cambridge: Cambridge University Press, 1950. 
MARTÍN, Carolina Jiménez. Momentos, escenarios y sujetos de la producción constituyente. Aproximaciones críticas al proceso constitucional de los noventa. Análisis Político, Bogotá, n.58, p.132-156, 2006.

MARTÍNEZ-LARA, Javier. Building democracy in Brazil: the politics of constitutional change, 1985-95. New York: Saint Martin's Press, 1996.

MARX, Karl. Prefácio à "Contribuição à crítica da economia política". In:

ENGELS, Friedrich. Obras escolhidas. São Paulo: Alfa-Ômega, [s.d.]. v.1. p.300-303.

MAUÉS, Antonio Gomes Moreira. Poder e democracia: o pluralismo na Constituição de 1988. Porto Alegre: Síntese, 1999.

(Org.). Constituição e democracia. São Paulo: Max Limonad, 2001.

MAXIMILIANO, Carlos. Comentários à constituição brasileira. 3. ed. Porto Alegre: Globo, 1929.

MAXWELL, Kenneth. Por que o Brasil foi diferente? O contexto da independência. In: MOTA, Carlos Guilherme (Org.). Viagem incompleta: a experiência brasileira (15002000): formação: histórias. São Paulo: Senac, 2000. p.177-195.

MCILWAIN, Charles Howard. Constitutionalism, ancient and modern. Ithaca: Cornell University Press, 1947.

MEDEIROS, Borges de. O Poder Moderador na república presidencial. Brasília: Senado Federal, Conselho Editorial, 2004.

MELO, Marcus André. Reformas constitucionais no Brasil. Rio de Janeiro: Revan; Brasília: Ministério da Cultura, 2002.

MELLO, Barão Homem de. A Constituinte perante a História. Brasília: Senado Federal, 1996.

MELLO, Evaldo Cabral de. A outra Independência: o federalismo pernambucano de 1817 a 1824. São Paulo: Editora 34, 2004.

MENDES, Cândido. A inconfidência brasileira: A nova cidadania interpela a constituinte. Rio de Janeiro: Forense-Universitária, 1986. 
(Org.). O Legislativo e a tecnocracia. Rio de Janeiro: Imago/Conjunto Universitário Candido Mendes, 1975.

MENDES, Gilmar Ferreira et al. Curso de direito constitucional. São Paulo: Saraiva, 2007.

MÉNDEZ, Juan E. et al. Democracia, violência e injustiça: o não-Estado de Direito na América Latina. São Paulo: Paz e Terra, 2000.

MICELI, Sergio. Carne e osso da elite política brasileira pós-1930. In: FAUSTO, Boris (Org.). História geral da civilização brasileira: sociedade e política (1930-1964). 2. ed. Rio de Janeiro: Difel, 1983. 3v. p.557-596.

MICHILLES, Carlos. Cidadão constituinte: a saga da emendas populares. Rio de Janeiro: Paz e Terra, 1989.

MILIBAND, David (Org.). Reinventando a esquerda. São Paulo: Unesp, 1997.

MIRANDA, Jorge. Teoria do Estado e da constituição. Rio de Janeiro: Forense, 2002.

MIRANDA, Pontes. Comentários à Constituição da República dos E. U. do Brasil. Rio de Janeiro: Editora Guanabara, [s.d.]. 2 t.

Comentários à Constituição de 1946. 2. ed. Rio de Janeiro: Max Limonad, 1953. v. IV.

Comentários à Constituição de 1967. São Paulo: RT, 1967. t. I.

MIRKINE-GUETZÉVICH, B. As novas tendências do direito constitucional. São Paulo: Nacional, 1933.

MONTESQUIEU. De l'esprit des lois. Paris: Éditions Gallimard, 1995. 2 v.

MORAES, Filomeno. As constituintes brasileiras: retrospectiva e tendência. DN Cultura, Fortaleza, n.156, p.4-5, 29 set. 1985.

. Direitos e garantias fundamentais e a realidade brasileira. In: TRINDADE, Antônio Augusto Cançado (Ed.). A incorporação das normas internacionais de 
proteção dos direitos humanos no Direito brasileiro. San José-Costa Rica, IIDH; ACNUR; CIVC; CUE, 1996. p.471-484.

. Ceará: o subsistema partidário e o retorno ao multipartidarismo. In: LIMA JR., Olavo Brasil de (Org.). Sistema partidário brasileiro. Rio de Janeiro: FGV, 1997. p.3572.

A construção democrática. Fortaleza: UFC/Casa de José de Alencar, 1998a.

O processo partidário-eleitoral no Brasil: a literatura revisitada. Revista Brasileira de Estudos Políticos, Belo Horizonte, n.86, p.49-84, 1998 b.

A separação de poderes no Brasil pós-88: princípio constitucional e práxis política. In: SOUZA NETO, André Pereira de; BERCOVICI, Gilberto; MORAES, Filomeno; LIMA, Martonio Mont'Alverne Barreto. Teoria da constituição: estudos sobre o lugar da Política no Direito Constitucional. Rio de Janeiro: Lumen Juris, 2003. p.151197.

A Constituição do Brasil de 1988 e a reforma política. In: XIMENES, Fernando; MORAES, Filomeno (Coord.). Direito constitucional contemporâneo: estudos em homenagem ao Professor Paulo Bonavides. Belo Horizonte: Del Rey, 2005. p.173-187.

. Poder. In: BARRETTO, Vicente de Paulo (Coord.). Dicionário de Filosofia do Direito. São Leopoldo-RS: Unisinos; Rio de Janeiro: Renovar, 2006. p.640-642.

Entre a liberdade e a solidariedade: a propriedade como direito humano. In: RODRIGUES, Francisco Luciano Lima (Org.). Estudos de direito constitucional e urbanístico: em homenagem à prof ${ }^{a}$ Magnólia Guerra. São Paulo: RCS, 2007. p.171-191.

; LIMA, Martonio Mont'Alverne Barreto. Partidos políticos y elecciones: la Justicia Electoral en la construcción de la democracia brasileña. In: EMMERICH, Gustavo Ernesto (Coord.). Ellos y nosotros: democracia y representación en el mundo actual. México-DF: Demos, 2006. p.213-230.

MORAES, João Quartim de. O poder constituinte e a força. Estudos Avançados, São Paulo, v.3, n.7, p.67-86, 1989. 
MORAES FILHO, Evaristo de. O problema do sindicato único no Brasil: seus fundamentos sociológicos. 2. ed. São Paulo: Alfa-Ômega, 1978.

MOREIRA, Vital. Economia e constituição: para o conceito de constituição económica. 2. ed. Coimbra: Coimbra Editora, 1979.

MOSCA, Gaetano. La clase política. México-DF: Fondo de Cultura Económica, 1992.

MÜLLER, Friedrich. Prefácio. In: SOUZA NETO, Cláudio Pereira de; BERCOVICI, Gilberto; MORAES, Filomeno; LIMA, Martonio Mont'Alverne Barreto. Teoria da constituição: estudos sobre o lugar da Política no Direito Constitucional. Rio de Janeiro: Lumen Juris, 2003. p.XI-XIII.

Fragmento (sobre) o poder constituinte do povo. São Paulo: RT, 2004.

NABUCO, Joaquim. Um estadista do Império. 5. ed. Rio de Janeiro: Topbooks, 1997. v. I NADER, Ana Beatriz. Autênticos do MDB: semeadores da democracia. São Paulo: Paz e Terra, 1998.

NEGRETTO, Gabriel L. The durability of constitutions in changing environments: explaining constitutional replacements in Latin America. Working Paper (Kellog Institute), n.350, Indiana-Indianopolis, 2008.

NEGRI, Antonio. O poder constituinte: ensaio sobre as alternativas da modernidade. Rio de Janeiro: DP\&A, 2002.

NEGRI, Antonio; HARDT, Michael. O trabalho de Dioniso: para a crítica do Estado pósmoderno. Juiz de Fora: UFJF; Pazulin, 2004.

NEVES, Lúcia Maria Bastos Pereira das. Corcundas e constitucionais: a cultura política da Independência (1820-1822). Rio de Janeiro: Revan; Faperj, 2003.

NEVES, Marcelo. A constitucionalização simbólica. São Paulo: Acadêmica, 1994.

NOBRE, Freitas. Constituinte. Rio de Janeiro: Paz e Terra, 1978.

NOGUEIRA, Octaciano. A Constituinte de 1946. Getúlio, o sujeito oculto. São Paulo: Martins Fontes, 2005. 
NORTH, Douglass. Markets and other allocation systems in History: the challenge of Karl Polanyi. Journal of European Economic History, Roma, p.703-716, 1977.

NUNES, António José Avelãs. Neoliberalismo e direitos humanos. Rio de Janeiro: Renovar, 2003a.

. Os sistemas económicos: o capitalismo - génese e evolução. Coimbra: Serviço de Acção Social da Universidade de Coimbra, 2003 b.

A filosofia social de Adam Smith. Boletim de Ciências Econômicas (separata), Coimbra, v. XLIX, 2005.

NUNES, José Castro. Jornada revisionista: os rumos, as idéias, o ambiente: estudo crítico da constituição. Rio de Janeiro: Almeida Marques, 1924.

O’DONNELL, Guillermo. Modernización y autoritarismo burocrático. Buenos Aires: Paidós, 1972.

As forças armadas e o Estado autoritário no Cone Sul da América Latina. Dados - Revista de Ciências Sociais, Rio de Janeiro, v.24, n.3, p.277-304, 1981.

A transição é um imenso pastiche. Senhor, São Paulo, n.335, p.5-13, 18 ago. 1987.

Transições, continuidades e alguns paradoxos. In: REIS, Fábio Wanderley; O’DONnElL, Guillermo (Org.). A democracia no Brasil: dilemas e perspectivas. São Paulo: Vértice/RT, 1988. p.41-71.

. Hiatos, instituições e perspectivas democráticas. In: REIS, Fábio Wanderley; O’DONNELL, Guillermo (Org.). A democracia no Brasil: dilemas e perspectivas. São Paulo: Vértice/RT, 1988. p.72-90.

Análise do autoritarismo burocrático. Rio Janeiro: Paz e Terra, 1990.

Delegative democracy? Working Paper (Kellog Institute), n.172, IndianaIndianopolis, 1992.

Otra institucionalización. La Política - Revista de Estudios sobre el Estado y la Sociedad, Buenos Aires, n.2, p.5-27, 1996. 
Pensamientos retrospectivos sobre el Estado, la democratización y la democracia. In: EMMERICH, Gustavo Ernesto (Coord.). Ellos y nosotros: democracia y representación en el mundo actual. México-DF: Demos, 2006. p.17-22.

- Disonancias: críticas democráticas a la democracia. Buenos Aires: Prometeo Libros, 2007.

O’DONNELL, Guillermo; SCHMITTER, Philippe (Ed.). Transições do regime autoritário. São Paulo: Vértice/RT, 1988. 3v.

- Transição do regime autoritário: primeiras conclusões. São Paulo:

Vértice/RT, 1988.

OLIVEIRA, Francisco de. Crítica à razão dualista. O ornitorrinco. São Paulo: Boitempo, 2003.

OLIVEN, Ruben George; RIDENTI, Marcelo; BRANDÃO, Gildo Marçal (Org.). A Constituição de 1988 na vida brasileira. São Paulo: Aderaldo \& Rothschild; Anpocs, 2008 .

ORDOÑEZ, Jaime; VÁZQUEZ, Enrique (Org.). Derechos económicos y desarrollo en América Latina. San José - CR: IIDH, 1991.

PACHECO, Pedro Mercado. El análisis económico del derecho: una reconstrucción teórica. Madrid: Centro de Estudios Constitucionales, 1994.

PAIM, Antonio. História do liberalismo brasileiro. São Paulo: Mandarim, 1998.

PAINE, Thomas. Rights of man. New York: Penguin Books, 1984.

PEREIRA, L. C.; MARAVALL, J. M.; PRZEWORSKI, Adam. Economic reforms in new democracies. Cambridge: Cambridge University Press, 1993.

PEREIRA, Osny Duarte. Que é a constituição (crítica à Carta de 1946 com vistas às reformas de base). Rio de Janeiro: Civilização Brasileira, 1964.

Constituinte (Anteprojeto da Comissão Arinos). Brasília: UnB, 1987. 
PEREZ, Reginaldo Teixeira. Pensamento político de Roberto Campos. Rio de Janeiro: FGV, 1999.

PILATTI, Adriano. A constituinte de 1987-1988: progressistas, conservadores, ordem econômica e regras do jogo. Rio de Janeiro: PUC Rio; Lumen Juris, 2008.

PILLOUER, Arnaud Le. Les pouvoirs non-constituants des assemblées constituantes: essai sur le pouvoir instituant. Paris: Dalloz, 2005.

POCOCK, John Greville Agard. The machiavellian moment. 2. ed. Princeton: Princeton University Press, 2003.

POLANYI, Karl. A grande transformação: as origens da nossa época. 5. ed. Rio de Janeiro: Campus, 2000.

POLETTI, Ronaldo. A constituição de 1934. Brasília: CED, 1987.

PORTO, Walter Costa. Prefácio. In: CAVALCANTI, João Barbalho Uchôa. Constituição federal brasileira, 1891: comentada. Brasília, Senado Federal, Conselho Editorial, 2002. p. XI-XX.

Prefácio. In: AZEVEDO, José Afonso de Mendonça Elaborando a constituição nacional: atas da Subcomissão elaboradora do anteprojeto 1932/1933. Brasília: Senado Federal, Conselho Editorial, 2004. p. XI-XXV.

PRADO, Ney. Os notáveis erros dos notáveis da Comissão Provisória de Estudos Constitucionais. Rio de Janeiro: Forense, 1987.

PRZEWORSKI, Adam. Estado e economia no capitalismo. Rio de Janeiro: RelumeDumará, 1995.

QUINTELLA, Sérgio F. A ordem econômica e social na constituinte. Folha de São Paulo - Guia da Constituinte, São Paulo, p.25, 19 set. 1986.

RAMOS, Saulo. A assembléia constituinte: o que pode o que não pode: natureza, extensão e limitações de seus poderes. Rio de Janeiro: Alhambra, 1987.

Código da vida. São Paulo: Planeta do Brasil, 2007. 
RÁO, Vicente. Mirkine-Guetzévitch e sua obra. In: MIRKINE-GUETZÉVICH, B. As novas tendências do direito constitucional. São Paulo: Nacional, 1933. p.7-16.

REALE, Miguel. Por uma constituição brasileira. São Paulo: RT, 1985.

. Liberdade e democracia (em torno do anteprojeto da Comissão Provisória de Estudos Constitucionais). São Paulo: Saraiva, 1987.

REIS, Fábio Wanderley. O eleitorado, os partidos e o regime autoritário. In: SORJ, Bernardo; ALMEIDA, Maria Hermínia Tavares (Org.). Sociedade e política no Brasil pós-64. São Paulo: Brasiliense, 1983. p.62-86.

Constituição, pacto e poder ou de uma constituição a outra melhor, com engenho e sorte. Revista Brasileira de Ciências Sociais, São Paulo, n.1, [s.p.], 1986.

RIBEIRO, Paulo de Tarso Ramos. Constituinte e decisão jurídica: os paradoxos da legitimação institucional. Dissertação (Mestrado em Direito). São Paulo, Faculdade de Direito da Universidade de São Paulo, 1989.

RIVERA, José Antonio Aguilar. En pos de la quimera. Reflexiones sobre el experimento constitucional atlántico. México-DF: CIDE; Fondo de Cultura Económica, 2000.

ROBESPIERRE, Maximilien de. Discursos e relatórios na Convenção. Rio de Janeiro: Eduerj; Contraponto, 1999.

RODRIGUES, José Honório. A Assembléia Constituinte de 1823. Petrópolis: Vozes, 1974.

RODRIGUES, Leôncio Martins. O PCB: os dirigentes e a organização. In: FAUSTO, Boris (Org.). História geral da civilização brasileira: sociedade e política (1930-1964). 2. ed. Rio de Janeiro: Difel, 1983. v.3. p.443.

Quem é quem na constituinte: uma análise sócio-política dos partidos e deputados. São Paulo: OESP-Maltese, 1987.

RODRIGUEZ, Ricardo Vélez. Castilhismo: uma filosofia da República. Brasília: Senado Federal, Conselho Editorial, 2000.

RODRIGUES, José Honório. A Assembléia Constituinte de 1823. Petrópolis: Vozes, 1974. 
ROSA, Virgínio Santa. A desordem: ensaio de interpretação do momento. Rio de Janeiro: Schmidt, 1932.

O sentido do tenentismo. Rio de Janeiro: Schmidt, 1933.

ROURE, Agenor de. Formação constitucional do Brasil. Rio de Janeiro: Tipografia do Jornal do Comércio, 1914.

A constituinte republicana. Rio de Janeiro: Imprensa Nacional, 1920. 2 v.

ROUSSEAU, Jean-Jacques. Du contrat social précédé de discours sur l'économie politique et de Du contrat social première version et suivi de fragments politiques. Paris: Éditions Gallimard, 1964.

RUFFÍA, Paolo Biscaretti di. Introducción al derecho constitucional comparado. México-DF: Fondo de Cultura Económica, 1975.

SADER, Emir; GENTILI, Pablo (Org.). Pós-neoliberalismo II: que Estado para a democracia? Petrópolis: Vozes, 2001.

SAGUIR, Julio. ¿Unión o secesión?: los procesos constituyentes en Estados Unidos (1776-1787) y Argentina (1810-1862). Buenos Aires: Prometeo Libros, 2007.

SALDANHA, Nelson. Formação da teoria constitucional. Rio de Janeiro: Forense, 1983.

O poder constituinte. São Paulo: RT, 1986.

Prefácio. In: VARELA, Alfredo. Direito constitucional brasileiro: reforma das instituições nacionais. Brasília: Senado Federal, Conselho Editorial, 2002. p. XI-XX.

SALES, Manuel Ferraz de Campos. Da propaganda à presidência. Brasília: UnB, 1983.

SALGADO, Eneida Desiree. Constituição e democracia: tijolo por tijolo em um desenho (quase) lógico: vinte anos de construção do projeto democrático brasileiro. Belo Horizonte: Fórum, 2007. 
SALLUM JR., Brasilio. Crise e transição política: da distensão à Nova República. Tese (Livre-docência). São Paulo, Faculdade de Filosofia, Letras e Ciências Humanas da Universidade de São Paulo, 1995.

- Metamorfoses do Estado brasileiro no final do século XX. Revista Brasileira de Estudos Sociais, São Paulo, v.18, n.52, p.36-54, 2003.

SANTOS, Boaventura de Sousa. Pela mão de Alice: o social e o político na pósmodernidade. São Paulo: Cortez, 1995.

SANTOS, Fabiano. Escolhas institucionais e transição por transação: sistemas políticos de Brasil e Espanha em perspectiva comparada. Dados - Revista de Ciências Sociais, Rio de Janeiro, v.43, n.4, p.637-669, 2000.

SANTOS, Rogerio Dultra dos. Francisco Campos e os fundamentos do constitucionalismo antiliberal no Brasil. Dados - Revista de Ciências Sociais, Rio de Janeiro, v.50, n.2, p. 281-323, 2007.

SANTOS, Wanderley Guilherme dos. Ordem burguesa e liberalismo político. São Paulo: Duas Cidades, 1978a.

Poder e política: crônicas do autoritarismo brasileiro. Rio de Janeiro: Forense Universitária, $1978 b$.

Cidadania e justiça: a política social na ordem brasileira. Rio de Janeiro: Campus, 1979.

Sessenta e quatro: anatomia da crise. São Paulo: Vértice, 1986.

- Fronteiras do Estado mínimo: indicações sobre o híbrido institucional brasileiro. In: VELLOSO, João Paulo dos Reis (Coord.). O Brasil e as reformas políticas. Rio de Janeiro: José Olympio, 1992. p.49-94.

O paradoxo de Rousseau: uma interpretação democrática da vontade geral. Rio de Janeiro: Rocco, 2007. 
SÃo VICEnTE, José Antônio Pimenta Bueno, Marquês de. José Antônio Pimenta Bueno, Marquês de São Vicente: organização e introdução de Eduardo Kugelmas. São Paulo: Ed. 34, 2002.

SARTORI, Giovanni. Engenharia constitucional: como mudam as constituições. Brasília: Ed. UnB, 1996.

SCHMITT, Carl. Teoría de la constitución. Madrid: Alianza Editorial, 1992.

SCHNEIDER, Hans Peter. Democracia y constitución. Madrid: Centro de Estudios Constitucionales, 1991.

SCHUBSBY, Cássio (Org.). Estado de direito já!: os trinta anos da Carta aos Brasileiros. São Paulo: Lettera.doc, 2007.

SCHWARZ, Roberto. Ao vencedor as batatas. São Paulo: Duas Cidades; Ed. 34, 2000.

SERVA, Mário Pinto. Problemas da constituinte. São Paulo: Casa Siqueira Sales Oliveira, 1933.

SHARE, Donald; MAINWARING, Scott. Transitions from above: democratization in Brazil and Spain. Indiana-Indianopolis: Kellogg, 1984.

SIEYÈS, Emmanuel. Qu'est-ce que le tiers état? Genève: Librairie Droz, 1970.

SILVA, Hélio. 1945: porque depuseram Vargas. Rio de Janeiro: Civilização Brasileira, 1964.

1934 - A constituinte. Rio de Janeiro: Civilização Brasileira, 1969.

1931 - Os tenentes no poder. 2. ed. Rio de Janeiro: Civilização Brasileira, 1972.

; CARNEIRO, Maria Cecília Ribas. A lei e a revolta, 1934-1936. São Paulo: Três, 1975.

SILVA, José Afonso da. Curso de direito constitucional positivo. 17. ed. São Paulo: Malheiros, 2000. 
Poder constituinte e poder popular: estudos sobre a Constituição. São Paulo: Malheiros, 2002.

SILVA, José Bonifácio de Andrada e. Projetos para o Brasil. Organização de Miriam Dolhnikoff. São Paulo: Companhia das Letras; Publifolha, 2000.

SILVA, José Gomes. Buraco negro: reforma agrária na Constituinte de 1987/88. Rio de Janeiro: Paz e Terra, 1989.

SILVA, Maria Beatriz Nizza da. Prefácio. In: NEVES, Lúcia Maria Bastos Pereira das. Corcundas e constitucionais: a cultura política da Independência (1820-1822). Rio de Janeiro: Revan; Faperj, 2003. p.13-14.

SKINNER, Quentin. The foundations of modern political thought. Cambridge: Cambridge University Press, 1978. 2v.

SMITH, Adam. Inquérito sobre a natureza e as causas da riqueza das nações. 3. ed. Lisboa: Fundação Calouste Gulbenkian, 1999. 2 v.

Teoria dos sentimentos morais, ou ensaio para uma análise dos princípios pelos quais os homens naturalmente julgam a conduta e o caráter, primeiro de seus próximos, depois de si mesmos, acrescida de uma dissertação sobre a origem das línguas. São Paulo: Martins Fontes, 2002.

SMITH, William; ACUÑA, Carlos H. T.; GAMARRA, Eduardo (Ed.). Latin American political economy in the age of neo liberal reform: theoretical and comparative perspectives for the 1990s. New Brunswide: Transaction Press, 1994.

Democracy, markets, and structural reform in Latin America: Argentina, Bolivia, Brazil, Chile and México. New Brunswide: North-South Center/Transaction Press, 1994.

SOARES, Gláucio Ary Dillon. Sociedade e política no Brasil. Rio de Janeiro: Difel, 1973.

SODRÉ, Alcindo. A gênese da desordem. Rio de Janeiro: Schmidt, 1933. 
SOLA, Lourdes (Org.). Estado, mercado e democracia: Política e economia comparadas. São Paulo: Paz e Terra, 1993.

SOLON, Ari Marcelo. Um texto de Kelsen sobre o Brasil. Revista Trimestral de Direito Público, São Paulo, n.9, p.8-11, 1995.

SOUSA, Octavio Tarquinio de. História dos fundadores do Império do Brasil. Rio de Janeiro: José Olympio, 1957. $10 \mathrm{v}$.

SOUZA, Amaury de; LAMOUNIER, Bolívar. A feitura da nova constituição: um reexame da cultura política brasileira. In: LAMOUNIER, Bolívar (Org.). De Geisel a Collor: o balanço da transição. São Paulo: Sumaré; Idesp, 1990. p.81-104.

SOUZA, Braz Florentino Henriques de. Do Poder Moderador: ensaio de Direito Constitucional contendo a análise do título V, capítulo I, da constituição política do Brasil. Brasília: Senado Federal, 1979.

SOUZA, Celina. Federalismo e descentralização na constituição de 1988: processo decisório, conflitos e alianças. Dados - Revista de Ciências Sociais, Rio de Janeiro, v.44, n.3, p.513-560, 2001.

. Constitutional engineering in Brazil: the politics of federalism and decentralization. London: Macmillan Press, 1997.

SOUZA, Márcia Teixeira de. O processo decisório na Constituição de 1988: práticas institucionais. Lua Nova - Revista de Cultura e Política, São Paulo, n.58, p.37-59, 2003.

SOUZA, Maria do Carmo Campello de. Estado e partidos políticos no Brasil (1930 a 1946). São Paulo: Alfa-Ômega, 1976.

SOUZA, Washington Peluso Albino de. O direito econômico no discurso constitucional. Revista Brasileira de Estudos Políticos, Belo Horizonte, n. 60/61, p.271-319, 1985.

Teoria da constituição econômica. Belo Horizonte: Del Rey, 2002.

SOUZA NETO, Cláudio Pereira; SARMENTO, Daniel; BENENBOJM, Gustavo (Coord.). Vinte anos da Constituição Federal de 1988. Rio de Janeiro: Lumen Juris, 2009. 
STEPAN, Alfred. Os militares: da abertura à "Nova República". Rio de Janeiro: Paz e Terra, 1986.

SUNSTEIN, Cass R. Republic.com 2.0. Princeton: Princeton University Press, 2007.

SUDARSKY, John. El eslabonamiento entre el Estado y la sociedad en la perspectiva de la nueva constitución colombiana. Perfiles Latinoamericanos, México-DF, p.85-131, 1991

TAVARES, Ana Lucia de Lyra. A constituição brasileira de 1988: subsídios para os comparatistas. Revista de Informação Legislativa, Brasília, n.109, p.71-108, 1991.

TAVARES, André Ramos. Curso de direito constitucional. São Paulo: Saraiva, 2002. . Direito constitucional econômico. 2. ed. São Paulo: Método, 2006.

TEMER, Michel. Entrevista. In: DINES, Alberto; FERNANDES JR., Florestan; SALOMÃO, Nelma (Org.). Histórias do poder: 100 anos de política no Brasil. São Paulo: Ed. 34, 2000. v.2.

TELles JR., Goffredo. A Constituição, a Assembléia Constituinte e o Congresso Nacional. São Paulo: Saraiva, 1986.

O povo e o poder. 2. ed. Porto Alegre: Juarez de Oliveira, 2006.

Carta aos Brasileiros. In: SCHUBSBY, Cássio (Org.). Estado de direito já!: os trinta anos da Carta aos Brasileiros. São Paulo: Lettera.doc, 2007. p.21-34.

TOJAL, Sebastião Botto de Barros. Constituição dirigente de 1988 e o direito à saúde. In: MORAES, Alexandre de (Coord.). Os 10 anos da Constituição Federal. São Paulo: Atlas, 1999. p.33-44.

TORRES, Alberto. A organização nacional. 4. ed. São Paulo: Nacional; Brasília: UnB, 1982.

TORRES, João Camilo de Oliveira. A democracia coroada: teoria política do Império do Brasil. Rio de Janeiro: José Olympio, 1957.

Os construtores do império. São Paulo: Nacional, 1968. 
TORRE-SCHAUB, Marthe. Essai sur la construction juridique de la categórie de marché. Paris: LGDJ, 2002.

TRINDADE, Hélgio. O integralismo (o fascismo brasileiro na década de 30). 2. ed. Rio de Janeiro: Difel, 1979.

UNIVERSIDADE DE BRASÍLIA. A revolução de 30: textos e documentos. Brasília: $\mathrm{UnB}, 1982$.

URICOECHEA, Fernando. A formação do Estado brasileiro no século XIX. Dados Revista de Ciências Sociais, Rio de Janeiro, n.14, p.85-109, 1977.

O minotauro imperial. Rio de Janeiro: Difel, 1978.

URUGUAI, Visconde de. Ensaio sobre o direito administrativo. Brasília: Ministério da Justiça, 1997.

VALENZUELA, J. Samuel. La constitución de 1980 y el inicio de redemocratización en Chile. Working Paper (Kellog Institute), n.242, Indianopolis-Indiana, set. 1997.

VALS, Luiz Fernando Montenegro. Brossard: 80 anos na história política do Brasil. Porto Alegre: Artes e Ofícios, 2004.

VALlaDARES, Benedicto. Tempos idos e vividos. Rio de Janeiro: Civilização Brasileira, 1966.

VALENTIM, Alexandre. Os sentidos do império: questão nacional e questão colonial na crise do antigo regime português. Porto: Afrontamento, 1993.

VARELA, Alfredo. Direito constitucional brasileiro: reforma das instituições nacionais. Brasília: Senado Federal, Conselho Editorial, 2002.

VARGAS, Getulio. A nova política do Brasil. Rio de Janeiro: José Olympio, 1938. v.I III.

VASCONCELOS, Arnaldo. Teoria pura do direito: repasse crítico de seus principais fundamentos. Rio de Janeiro: Forense, 2003. 
VASCONCELOS, Zacarias de Góes e. Zacarias de Góes e Vasconcelos. Organização e introdução de Cecília Helena de Salles Oliveira. São Paulo: Ed. 34, 2002.

VENANCIO FILHO, Alberto. A intervenção do Estado no domínio econômico: o direito público econômico no Brasil. Rio de Janeiro: FGV, 1968.

VIANNA, Luiz Werneck. Liberalismo e sindicato no Brasil. Rio de Janeiro: Paz e Terra, 1976.

Travessia: da abertura à constituinte. Rio de Janeiro: Taurus, 1986.

A transição: da Constituinte à sucessão presidencial. Rio de Janeiro: Revan, 1989.

A revolução passiva: iberismo e americanismo no Brasil. 2. ed. Rio de Janeiro: Revan, 2004.

VIANNA, Oliveira. O idealismo na constituição. Rio de Janeiro: Terra de Sol, 1927.

Instituições políticas brasileiras. Belo Horizonte: Itatiaia/USP/UFF, 1987. v.1.

WEBER, Max. A ética protestante e o espírito do capitalismo. 4. ed. São Paulo: Pioneira, 1985.

Ciência e política: duas vocações. 16. ed. São Paulo: Cultrix, 2000.

. Economía y sociedad. 15. ed. Buenos Aires: Fondo de Cultura Económica, 2004.

WEFFORT, Francisco Corrêa. O populismo na política brasileira. Rio de Janeiro: Paz e Terra, 1978.

Não ao apartheid social. Folha de São Paulo, São Paulo, p.A-3, 14 out. 1989.

WIRTH, John D. A política do desenvolvimento na era de Vargas. Rio de Janeiro: FGV, 1973.

WOLKMER, Antônio Carlos. Constitucionalismo e direitos sociais no Brasil. São Paulo: Acadêmica, 1989. 
ZAGREBELSKY, Gustavo. Historia y constitución. Madrid: Editorial Trotta, 2005.

ZIPPELIUS, Reinhold. Teoría general del Estado. 2. ed. México-DF: Editorial Porrúa/Unam, 1989.

\section{TEXTOS NORMATIVOS, ANAIS E OUTRAS FONTES}

ANAIS DA ASSEMBLÉIA NACIONAL CONSTITUINTE. Brasília: Senado Federal, 1994. $25 \mathrm{v}$.

BRASIL. Anteprojeto constitucional, elaborado pela Comissão Provisória de Estudos Constitucionais. Diário Oficial, Brasília, Suplemento especial ao n. 185, 26 set. 1986.

Ato Complementar n. 4, de 20 de novembro de 1965. Disponível em: <http://www.senado.gov.br/legislacao>. Acesso em: 6 jun. 2008.

Ato Complementar n. 38, de 13 de dezembro de 1968. Disponível em: <http://www.senado.gov.br/legislacao>. Acesso em: 6 jun. 2008.

Ato Complementar n. 102, de n. 102, de $1^{\text {o }}$ de abril de 1977. Disponível em: <http://.senado.gov.br/legislacao>. Acesso em: 6 jun. 2008.

Ato Institucional n. 1, de 9 de abril de 1964. Disponível em: <http://www.senado.gov.br/legislacao>. Acesso em: 10 jan. 2008.

Ato Institucional n. 5, de 13 de dezembro de 1968. Disponível em: <http://www.senado.gov.br/legislacao>. Acesso em 10 jan. 2008.

Constituição (1824). Constituição Política do Império do Brasil. Disponível em: <http://www.presidencia.gov.br/legislacao>. Acesso em: 10 jan. 2008.

Constituição (1891). Constituição da República dos Estados Unidos do

Brasil. Disponível em: <http://www.presidencia.gov.br/legislacao>. Acesso em: 10 jan. 2008 . 
Constituição (1934). Constituiçãa da República dos Estados Unidos do

Brasil. Disponível em: 〈http://www.presidencia.gov.br/legislacao>. Acesso em: 10 jan. 2008 .

Constituição (1937). Constituição dos Estados Unidos do Brasil. Disponível em: <http://www.presidencia.gov.br/legislacao>. Acesso em: 10 jan. 2008.

Constituição (1937). Lei Constitucional n. 9, de 28 de fevereiro de 1945. Disponível em: <http://www.senado.gov.br/legislacao>. Acesso em: 10 jan. 2008.

. Constituição (1937). Lei Constitucional n. 13, de 12 de novembro de 1945. Disponível em: <http://www.senado.gov.br/legislacao>. Acesso em: 10 jan. 2008.

Constituição (1937). Lei Constitucional n. 15, de 26 de novembro de 1945. Disponível em: <http://www.senado.gov.br/legislacao>. Acesso em: 10 jan. 2008.

Constituição (1946). Constituição dos Estados Unidos do Brasil. Disponível em: <http://www.presidencia.gov.br/legislacao>. Acesso em: 10 jan. 2008.

Constituição (1967). Constituição da República Federativa do Brasil.

Disponível em: <http://www.presidencia.gov.br/legislacao>. Acesso em: 10 jan. 2008.

Constituição (1967). Emenda Constitucional n. 1, de 17 de outubro de 1969.

Disponível em: <http://www.presidencia.gov.br/legislacao>. Acesso em: 10 jan. 2008.

Constituição (1967). Emenda Constitucional n. 8, de 14 de abril de 1977.

Disponível em: <http://www.senado.gov.br/legislacao>. Acesso em: 10 jan. 2008.

Constituição (1967). Emenda Constitucional n. 11, de 13 de outubro de 1978.

Disponível em: <http://www.senado.gov.br/legislacao>. Acesso em: 15 jan. 2008.

. Constituição (1967). Emenda Constitucional n. 22, de 29 de junho de 1982.

Disponível em: <http://www.senado.gov.br/legislacao>. Acesso em: 5 jan. 2008.

Constituição (1967). Emenda Constitucional n. 25, de 15 de maio de 1985.

Disponível em: <http://www.presidencia.gov.br/legislacao>. Acesso em: 20 abr. 2008.

Constituição (1967). Emenda Constitucional n. 26, de 27 de novembro de 1985. Disponível em: <http://www.senado.gov.br/legislacao>. Acesso em: 5 jan. 2008. 


\section{. Constituição (1988). Constituição da República Federativa do Brasil.}

Brasília: Senado Federal, 1988.

\section{. Constituição (1988). Constituição da República Federativa do Brasil.}

Disponível em: <http://www.presidencia.gov.br/legislacao>. Acesso em: 5 out. 2008.

. Constituição (1988). Emenda Constitucional n. 6, de 15 de agosto de 1995.

Disponível em: <http://www.presidencia.gov.br/legislacao>. Acesso em: 20 abr. 2008.

. Constituição (1988). Emenda Constitucional n. 7, de 15 de agosto de 1995.

Disponível em: <http://www.presidencia.gov.br/legislacao>. Acesso em: 20 abr. 2008.

. Constituição (1988). Emenda Constitucional n. 8, de 15 de agosto de 1995.

Disponível em: <http://www.presidencia.gov.br/legislacao>. Acesso em: 20 abr. 2008.

Constituição (1988). Emenda Constitucional n. 9, de 9 de novembro de agosto de 1995. Disponível em: <http://www.presidencia.gov.br/legislacao>. Acesso em: 20 abr. 2008 .

Constituição (1988). Emenda Constitucional n. 13, de 21 de agosto de 1996.

Disponível em: <http://www.presidencia.gov.br/legislacao>. Acesso em: 20 abr. 2008.

Constituição (1988). Emenda Constitucional n. 19, de 4 de junho de 1998.

Disponível em: <http://www.presidencia.gov.br/legislacao>. Acesso em: 20 abr. 2008.

Constituição (1988). Emenda Constitucional n. 33, de 11 de dezembro de 2001. Disponível em: <http://www.presidencia.gov.br/legislacao>. Acesso em: 20 abr. 2008.

Constituição (1988). Emenda Constitucional n. 42, de 19 dezembro de 2003.

Disponível em: <http://www.presidencia.gov.br/legislacao>. Acesso em: 20 abr. 2008.

Constituição (1988). Emenda Constitucional n. 49, de 8 de fevereiro de 2006.

Disponível em: <http://www.presidencia.gov.br/legislacao>. Acesso em: 20 abr. 2008.

Decreto n. 1, de 15 de novembro de 1889. Disponível em: <http://www.senado.gov.br/legislacao>. Acesso em: 10 abr. 2008. 
Decreto n. 510, de 22 de junho de 1890. Disponível em: <http://www.senado.gov.br/legislacao>. Acesso em: 10 abr. 2008.

. Decreto n. 511, de 23 de junho de 1890. Disponível em: <http://www.senado.gov.br/legislacao>. Acesso em: 10 abr. 2008.

- Decreto n. 848, de 11 de outubro de 1890. Disponível em: <http://www.senado.gov.br/legislacao>. Acesso em: 10 abr. 2008.

. Decreto n. 19.398, de 11 de novembro de 1930. Disponível em: <http://www.senado.gov.br/legislacao>. Acesso em: 10 abr. 2008.

. Decreto n. 20.076, de 24 de fevereiro de 1932. Disponível em: <http://www.senado.gov.br/legislacao>. Acesso em: 10 abr. 2008.

- Decreto n. 21.402, de 14 de maio de 1932. Disponível em: <http://www.senado.gov.br/legislacao>. Acesso em: 10 abr. 2008.

- Decreto n. 22.040, de $1^{\text {o }}$ de novembro de 1932. Disponível em: <http://www.senado.gov.br/legislacao>. Acesso em: 10 abr. 2008.

. Decreto n. 22.364, de 17 de janeiro de 1933. Disponível em: <http://www.senado.gov.br/legislacao>. Acesso em: 10 abr. 2008.

Decreto n. 22.621 de 5 abril de 1933. Disponível em: <http://www.senado.gov.br/legislacao>. Acesso em: 10 abr. 2008.

. Decreto n. 22.653, de 20 de abril de 1933. Disponível em: <http://www.senado.gov.br/legislacao>. Acesso em: 10 abr. 2008.

- Decreto n. 22.696, de 11 de maio de 1933. Disponível em: <http://www.senado.gov.br/legislacao>. Acesso em: 10 abr. 2008.

- Decreto n. 91.450, de 18 de julho de 1985. Disponível em: <http://www.senado.gov.br/legislacao>. Acesso em: 10 abr. 2008.

. Decreto-lei n. 7.474, de 18 de abril de 1945. Disponível em: <http://www.senado.gov.br/legislacao>. Acesso em: 10 abr. 2008. 
- Decreto-lei n. 7.586, de 28 de maio de 1945. Disponível em: <http://www.senado.gov.br/legislacao>. Acesso em: 10 abr. 2008.

. Decreto-lei n. 972, de 17 de outubro de 1969. Disponível em: <http://www.senado.gov.br/legislacao>. Acesso em: 10 abr. 2008.

- Decreto-lei n. 1.541, de 14 de abril de 1977. Disponível em: <http://www.senado.gov.br/legislacao>. Acesso em: 10 jan. 2008.

. Lei n. 4.737, de 15 de julho de 1965. Disponível em: <http://www.presidencia.gov.br/legislacao>. Acesso em: 20 abr. 2008.

. Lei n. 5.250, de 9 de fevereiro de 1967. Disponível em: <http://www.senado.gov.br/legislacao>. Acesso em: 20 abr. 2008.

. Lei n. 5.682, de 21 de julho de 1971. Disponível em: <http://www.senado.gov.br/legislacao>. Acesso em: 20 abr. 2008.

- Lei n. 6.339, de $1^{\mathrm{o}}$ de julho de 1976. Disponível em: <http://www.senado.gov.br/legislacao>. Acesso em: 10 jan. 2008.

. Lei n. 6.767, de 20 de dezembro de 1979. Disponível em: <http://www.senado.gov.br/legislacao>. Acesso em: 20 abr. 2008.

Discurso de posse na presidência da República (Emílio Garrastazu Médici).

Brasília: Departamento de Imprensa Nacional, 1969.

Regimento Interno da Assembléia Nacional Constituinte. Brasília: Câmara dos Deputados, Coordenação de Publicações, 1987.

DIÁRIO DA ASSEMBLÉIA NACIONAL CONSTITUINTE, Brasília, p.14.380, 5 out. 1988.

FOLHA DE SÃO PAULO - Guia da Constituinte, São Paulo, 19 set. 1986.

FRANCE. Déclaration (1789). Déclaration des droits de l'homme y du citoyen. Disponível em: <http://www.assemblee-nationale.fr/histoire/dudh/1789.asp>. Acesso em: 8 abr. 2008. 
ANEXOS 


\section{ANEXO A \\ Mensagem do Presidente José Sarney propondo a convocação da ANC Mensagem no 48, de 1985-CN ( $n^{\circ} 330 / 85$, na origem)}

Excelentíssimos Senhores Membros do Congresso Nacional:

É com a mais profunda confiança no discernimento e na vocação do povo brasileiro, para organizar-se pacificamente em regime de liberdade e justiça, que proponho a Vossas Excelências a convocação da Assembléia Nacional Constituinte.

Compromisso histórico firmado no curso do movimento cívico que congregou brasileiros de todas as condições, com o propósito de democratizar a sociedade e o Estado, é a convocação da Assembléia Nacional Constituinte ato de coragem e fé.

De coragem, porque pressupõe, por parte de cada indivíduo que constitui a comunhão nacional, a disposição de submeter ao escrutínio da Nação direitos e situações, quantas vezes duramente conquistados, para vê-los disciplinados por novas regras, de conteúdo e alcance não conhecidos, que se espera mais justas, equânimes e conformes ao ciclo histórico que reponta no presente e se projeta em um futuro de extensão desconhecida.

Ato de fé é a convicção da Constituinte, porque todos os anseios e temores do futuro repousam, afinal, na confiança que cada cidadão deposita nos sentimentos de seus irmãos, de procurarem, juntos, uma lei fundamental que a todos proporcione os bens necessários à vida digna, vivida em paz e uberdade.

O compromisso, antes aludido, de convocação da Assembléia Nacional Constituinte, de par com os traços de generosa confiança e incontida esperança que o exornam, singulariza-se pelo fato de estar em plena vigência uma ordem jurídica e suas instituições políticas e civis, cujo império se estenderá até o momento em que for promulgada a nova Constituição. Até lá, e sob pena de instalar-se o caos normativo, que a ninguém aproveitaria, é necessário respeitar a lei que temos e modificá-la segundo os processos por ela própria admitidos, para que a vontade de alguns não seja erigida em mandamento supremo de todos.

Da inelutável necessidade de manter e operar as instituições governativas vigentes, harmonizando-as à imperiosa aspiração de instaurar outras mais livres e justas, resulta o texto que ora submeto à deliberação dos Senhores Membros do Poder Legislativo da União. Por isso, nele se prevê a investidura de poder constituinte pleno nos Deputados Federais e senadores escolhidos pelo sufrágio do povo brasileiro. Evitando tutelar o órgão de tão alta atribuição, a Proposta de Emenda limita-se a prover quanto à direção das sessões de instalação e eleição Presidente da Assembléia Nacional Constituinte e a indicar que ela funcione na sede do Congresso Nacional, como corpo único, sem a divisão própria do sistema bicameral. Este, contudo, subsistirá nos trabalhos da Legislatura, enquanto Poder constituído e segundo as normas constitucionais em vigor.

E, finalmente, fixa a duração da $1^{a}$ Sessão Legislativa da $48^{a}$ Legislatura para promulgação da nova Constituição, e o quórum da maioria absoluta, que determinará a adoção do projeto e das emendas respectivas.

Cumpro o dever assumido com a Nação pela Aliança Democrática. A Assembléia Nacional Constituinte realizará, sem dúvida, o grande e novo pacto nacional, que fará o País reencontrar-se com a plenitude de suas instituições democráticas.

Espero que, de agora, a sociedade se mobilize para criar a mística da Constituição, que é o caminho de Estado de Direito.

Palácio do Planalto, Brasília, aos 28 de junho de 1985.

- José Sarney. 


\section{Proposta de Emenda à Constituição no 43, de 1985}

Convoca a Assembléia Nacional Constituinte

Art. $1^{\circ}$ Os Membros da Câmara dos Deputados e do Senado Federal, sem prejuízo de suas atribuições constitucionais, reunir-se-ão, unicameralmente, em Assembléia Nacional Constituinte, livre e soberana, no dia 31 de janeiro de 1987, na sede do Congresso Nacional.

Art. $2^{\circ} \mathrm{O}$ Presidente do Supremo Tribunal Federal instalará a Assembléia Nacional Constituinte e dirigirá a sessão de eleição do seu Presidente.

Art. $3^{\circ} \mathrm{O}$ Projeto de Constituição será promulgado no curso da primeira Sessão Legislativa da $48^{\text {a }}$ Legislatura, depois de aprovado, em dois turnos de discussão e votação, pela maioria absoluta dos Membros da Assembléia Nacional Constituinte.

Fonte: DCN, 8 de agosto de 1985, p. 1.228-1.233. 


\begin{abstract}
ANEXO B
EMENDA CONSTITUCIONAL No 26

Convoca Assembléia Nacional Constituinte, e dá outras providências

As Mesas da Câmara dos Deputados e do Senado Federal, nos termos do artigo 49 da Constituição Federal, promulgam a seguinte emenda ao texto constitucional:
\end{abstract}

Art. $1^{\circ}$ Os Membros da Câmara dos Deputados e do Senado Federal reunir-se-ão, unicameralmente, em Assembléia Nacional Constituinte, livre e soberana, no dia $1^{\circ}$ de fevereiro de 1987, na sede do Congresso Nacional.

Art. $2^{\circ} \mathrm{O}$ Presidente do Supremo Tribunal Federal instalará a Assembléia Nacional Constituinte e dirigirá a sessão de eleição do seu Presidente.

Art. $3^{\circ}$ A Constituição será promulgada depois da aprovação de seu texto, em 2 (dois) turnos de discussão e votação, pela maioria absoluta dos Membros da Assembléia Nacional Constituinte.

Art. $4^{\circ}$ É concedida anistia a todos os servidores púbicos civis da Administração Direta e Indireta e militares, punidos por atos de exceção, institucionais ou complementares.

$\S 1^{\circ}$ É concedida, igualmente, anistia aos autores de crimes políticos ou conexos e aos dirigentes e representantes de organizações sindicais e estudantis, bem como aos servidores civis ou empregados que hajam sido demitidos ou dispensados, por motivação exclusivamente política, com base em outros diplomas legais.

$\S 2^{\circ} \mathrm{A}$ anistia abrange os que foram punidos ou processados pelos atos imputáveis previstos no "caput" deste artigo, praticados no período compreendido entre 2 de setembro de 1961 e 15 de agosto de 1979.

$\S 3^{\circ}$ Aos servidores civis e militares serão concedidas as promoções, na aposentadoria ou na reserva, ao cargo, posto ou graduação a que teriam direito se estivessem em serviço ativo, obedecidos os prazos de permanência em atividade, previstos nas leis e regulamentos vigentes.

$\S 4^{\circ}$ A Administração Pública, à sua exclusiva iniciativa, competência e critério, poderá readmitir ou reverter ao serviço ativo o servidor público anistiado.

$\S 5^{\circ} \mathrm{O}$ disposto no "caput" deste artigo somente gera efeitos financeiros a partir da promulgação da presente Emenda Constitucional, vedada a remuneração de qualquer espécie, em caráter retroativo.

$\S 6^{\circ}$ Excluem-se das presentes disposições os servidores civis ou militares que já se encontravam aposentados, na reserva ou reformados, quando atingidos pelas medidas constantes do "caput" deste artigo.

$\S 7^{\circ}$ Os dependentes dos servidores civis e militares abrangidos pelas disposições deste artigo já falecidos farão jus às vantagens pecuniárias da pensão correspondente ao cargo, função, emprego, posto ou graduação que teria sido assegurado a cada beneficiário da anistia, até a data de sua morte, observada a legislação específica.

$\S 8^{\circ}$ A Administração Pública aplicará as disposições deste artigo, respeitadas as características e peculiaridades próprias das carreiras dos servidores públicos civis e militares, e observados os respectivos regimes jurídicos.

Art. $5^{\circ}$ A alínea "c", do $\S 1^{\circ}$, do artigo 151 , da Constituição passa a vigorar com a seguinte redação: 
“c) a inelegibilidade do titular efetivo ou interino de cargo ou função cujo exercício possa influir para perturbar a normalidade ou tornar duvidosa a legitimidade das eleições, salvo se se afastar definitivamente de um ou de outro no prazo estabelecido em lei, o qual não será maior de 9 (nove) meses, nem menor de 2 (dois) meses, anteriores ao pleito, exceto os seguintes, para os quais fica assim estipulado:

1 - Governador e Prefeito: 6 (seis) meses;

2 - Ministro de Estado, Secretário de Estado, Presidente, Diretor, Superintendente de órgão da Administração Pública Direta ou Indireta, incluídas as fundações e sociedades de economia mista: 9 (nove) meses; quando candidato a cargo municipal: 4 (quatro) meses;

3 - ocupante de cargo previsto no número anterior, se já titular de mandato eletivo: 6 (seis) meses".

A Mesa da Câmara dos Deputados:

Ulysses Guimarães - Presidente.

Carlos Wilson $-1^{\circ}$ Vice-Presidente em exercício.

Haroldo Sanford $-2^{\circ}$ Vice-Presidente em exercício.

Epitácio Cafeteira $-1^{\circ}$ Secretário em exercício.

José Frejat $-2^{\circ}$ Secretário em exercício.

José Ribamar Machado - $3^{\circ}$ Secretário em exercício.

Orestes Muniz $-4^{\circ}$ Secretário em exercício.

A Mesa do Senado Federal:

José Fragelli - Presidente.

Guilherme Palmeira - $1^{\circ}$ Vice-Presidente.

Passos Porto $-2^{\circ}$ Vice-Presidente.

Enéas Faria $-1^{\circ}$ Secretário.

João Lobo $-2^{\circ}$ Secretário.

Marcondes Gadelha $-3^{\circ}$ Secretário.

Eunice Michiles $-4^{\circ}$ Secretário.

Fonte: BRASIL. Constituições. Disponível em: <http://www.presidencia.gov.br/legislacao〉. Acesso em: 5 out. 2008. 


\section{ANEXO C \\ MEMBROS DA COMISSÃO PROVISÓRIA DE ESTUDOS CONSTITUCIONAIS}

Afonso Arinos de Melo Franco

Alberto Venâncio Filho

Alexandre José Barbosa Lima Sobrinho

Antônio Ermírio de Morais

Bolívar Lamounier

Cândido Antônio Mendes de Almeida

Celso Monteiro Furtado

Cláudio Lacombe

Cláudio Pacheco

Clóvis Ferro Costa

Cristóvão Buarque

Edgard da Matta Machado

Eduardo Portela

Evaristo de Morais Filho

Farjardo Pereira Faria

Fernando Bastos D’Ávila

Florisa Verucci

Gilberto Freire

Gilberto de Uchôa Canto

Guilhermino Cunha

Hélio Jaguaribe

Hélio Santos

Hilton Ribeiro Rocha

João Pedro Gouveia Vieira

Joaquim Arruda Falcão Neto

Jorge Amado

Josaphat Marinho

José Afonso da Silva

José Alberto da Assumpção

José Francisco da Silva 
José Paulo Sepúlveda Pertence

José do Rego Barros Meira de Araújo

José Saulo Ramos

Laerte Ramos Vieira

Luís Eulálio de Bueno Vidigal Filho

Luís Pinto Ferreira

Mário de Souza Martins

Mauro Santayana

Miguel Reale Jr.

Nei Prado

Odilon Ribeiro Coutinho

Orlando Magalhães de Carvalho

Paulo Brossard de Souza Pinto

Raphael de Almeida Magalhães

Raul Machado Horta

Rosah Russomano

Sérgio Franklin Quintella

Walter Barelli

* Célio Borja, ao ser indicado para o Supremo Tribunal Federal, em março de 86, ficou impedido de integrar a Comissão. 


\section{ANEXO D}

\section{Comissões e Subcomissões}

I - Comissão da Soberania e dos Direitos e Garantias do Homem e da Mulher:

a) Subcomissão da Nacionalidade, da Soberania e das Relações Internacionais;

b) Subcomissão dos Direitos Políticos, dos Direitos Coletivos e Garantias;

c) Subcomissão dos Direitos e Garantias Individuais.

II - Comissão da Organização do Estado:

a) Subcomissão da União, Distrito Federal e Territórios;

b) Subcomissão dos Estados;

c) Subcomissão dos Municípios e Regiões.

III - Comissão da Organização dos Poderes e Sistema de Governo:

a) Subcomissão do Poder Legislativo;

b) Subcomissão do Poder Executivo;

c) Subcomissão do Poder Judiciário e do Ministério Público.

IV - Comissão da Organização Eleitoral, Partidária e Garantia das Instituições:

a) Subcomissão do Sistema Eleitoral e Partidos Políticos;

b) Subcomissão de Defesa do Estado, da Sociedade e de sua Segurança;

c) Subcomissão de Garantia da Constituição, Reformas e Emendas.

V - Comissão do Sistema Tributário, Orçamento e Finanças:

a) Subcomissão de Tributos, Participação e Distribuição das Receitas;

b) Subcomissão de Orçamentos e Fiscalização Financeira;

c) Subcomissão do Sistema Financeiro.

VI - Comissão da Ordem Econômica:

a) Subcomissão de Princípios Gerais, Intervenção do Estado, Regime da Propriedade do Subsolo e da Atividade Econômica; 
b) Subcomissão da Questão Urbana e Transporte;

c) Subcomissão da Política Agrícola e Fundiária e da Reforma Agrária.

VII - Comissão da Ordem Social:

a) Subcomissão dos Direitos dos Trabalhadores e Servidores Públicos;

b) Subcomissão de Saúde, Seguridade e do Meio Ambiente;

c) Subcomissão dos Negros, Populações Indígenas, Pessoas Deficientes e Minorias.

VIII - Comissão da Família, da Educação, Cultura e Esportes, da Ciência e Tecnologia e da Comunicação:

a) Subcomissão da Educação, Cultura e Esportes;

b) Subcomissão da Ciência e Tecnologia e da Comunicação;

c) Subcomissão da Família, do Menor e do Idoso.

IX - Comissão de Sistematização.

Art. 15 do Regimento Interno da Assembléia Nacional Constituinte (Resolução n o 2 , de 1987) 


\author{
ANEXO E \\ Comissão da Ordem Econômica \\ Subcomissão de Princípios Gerais, Intervenção do Estado e da Atividade Econômica \\ PMDB: Albano Franco (SE), Irapuan Costa Júnior (GO), Antônio Carlos Franco (SE), \\ Gabriel Guerreio (PA), Gil César (MG), Gustavo de Faria (RJ), Hélio Duque (PR), Ismael \\ Wanderley (RN), Marcos Lima (MG), Renato Johnsson (PR). \\ PFL: Antônio Ueno (PR), Raquel Cândido (RO), Gilson Machado (PE), Jales Fontoura \\ (GO), Rubem Medina (RJ). \\ PDS: Roberto Campos (MT). \\ PDT: Luiz Salomão (RJ). \\ PTB: Roberto Jefferson (RJ). \\ PT: Wladimir Palmeira (RJ). \\ PL: Afif Domingos (SP). \\ PSB: Beth Azize (AM). \\ Relator: Virgildásio de Senna (PMDB-BA); Presidente: Delfim Netto (PDS-SP). \\ Subcomissão da Questão Urbana e Transporte \\ PMDB: Expedito Júnior (RO), Gerson Marcondes (SP), Gedel Dantas (CE), Luís Roberto \\ Ponte (RS), Nyder Barbosa (ES), Paulo Zarzu (SP), Sérgio Naya (MG), Márcio Lacerda \\ (MT). \\ PFL: Joaquim Francisco (PE), Lael Varella (MG), Maluly Neto (SP), Manuel Castro (BA). \\ PDS: Myrian Portela (PI). \\ PTD: Noel de Carvalho (RJ). \\ Relator: José Ulisses de Oliveira (PMDB-MG); Presidente: Dirceu Carneiro (PMDB-SC). \\ Subcomissão da Política Agrícola, Fundiária e da Reforma Agrária \\ PMDB: Arnaldo Rosa Prata (MG), Benedicto Monteiro (PA); Cardoso Alves (SP), Ivo \\ Mainardi (RS); Jorge Vianna (BA); Percival Muniz (MT), Rachid Saldanha Derzi (MS), \\ Raquel Capiberibe (AP), Santinho Furtado (PR), Valter Pereira (MS), Vicente Bogo (RS). \\ PFL: Alysson Paulinelli (MG), Assis Canuto (RO), Jonas Pinheiro (MT), Victor Fontana \\ (SC). \\ PDS: Virgílio Calassi (MG). \\ PDT: Amaury Müller (RS). \\ PTB: José Egreja (SP). \\ PT: Irma Passoni (SP). \\ PDC: Mauro Borges (GO). \\ PC do B: Aldo Arantes (GO). \\ PCB: Fernando Santana (BA). \\ Relator: Oswaldo Lima Filho (PMDB-PE); Presidente: Edison Lobão (PFL-MA).
}




\section{ANEXO F}

\section{CÂMARA DOS DEPUTADOS}

\begin{tabular}{|l|c|c|}
\hline \multicolumn{1}{|c|}{ Partido } & $\mathbf{N}^{\mathbf{o}}$ & $\boldsymbol{\%}$ \\
\hline PMDB & 260 & 54,4 \\
\hline PFL & 118 & 24,2 \\
\hline PDS & 33 & 6,8 \\
\hline PDT & 24 & 4,9 \\
\hline PTB & 17 & 3,4 \\
\hline PT & 16 & 3,3 \\
\hline PCdoB & 3 & 0,6 \\
\hline PL & 6 & 1,2 \\
\hline PDC & 5 & 1,0 \\
\hline PCB & 3 & 0,6 \\
\hline PSB & 1 & 0,2 \\
\hline PSC & 1 & 0,2 \\
\hline Total & $\mathbf{4 8 7}$ & $\mathbf{1 0 0 \%}$ \\
\hline
\end{tabular}

Fonte: RODRIGUES, Leôncio Martins. Quem é quem na constituinte: uma análise sócio-política dos partidos e deputados. São Paulo: OESP/Maltese, 1987. 


\section{ANEXO G}

SENADO FEDERAL

\begin{tabular}{|l|c|c|}
\hline \multicolumn{1}{|c|}{ Partido } & $\mathbf{N}^{\mathbf{0}}$ & $\mathbf{\%}$ \\
\hline PMDB & 45 & 62,5 \\
\hline PFL & 15 & 20,8 \\
\hline PDS & 5 & 6,9 \\
\hline PDT & 2 & 1,3 \\
\hline PTB & 1 & 1,3 \\
\hline PSB & 1 & 1,3 \\
\hline PL & 1 & 1,3 \\
\hline PMB & 1 & 1,3 \\
\hline PDC & 1 & 1,3 \\
\hline Total & $\mathbf{7 2}$ & $\mathbf{1 0 0 \%}$ \\
\hline
\end{tabular}

Fonte: RODRIGUES, Leôncio Martins. Quem é quem na constituinte: uma análise sócio-política dos partidos e deputados. São Paulo: OESP/Maltese, 1987. 
ANEXO H

\section{A ORDEM ECONÔMICA NAS CONSTITUIÇÕES BRASILEIRAS}

\begin{tabular}{|c|c|c|c|c|c|c|c|}
\hline 1824 & 1891 & 1934 & 1937 & 1946 & 1967 & 1969 & 1988 \\
\hline 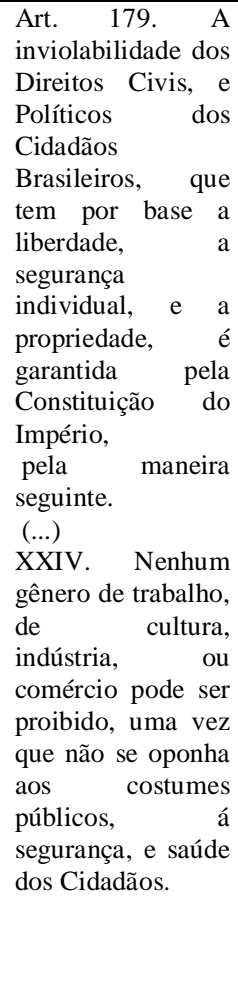 & $\begin{array}{l}\text { Art. } 35 \text { - Incumbe, outrossim, ao } \\
\text { Congresso, mas não privativamente: } \\
(\ldots) \quad 2^{\circ} \text { ) animar no País o } \\
\text { desenvolvimento das letras, artes e } \\
\text { ciências, bem como a imigração, a } \\
\text { agricultura, a indústria e comércio, } \\
\text { sem privilégios que tolham a ação } \\
\text { dos Governos locais; } \\
\text { (...) } \\
\text { Art. } 72 \text { - A Constituição assegura a } \\
\text { brasileiros e a estrangeiros } \\
\text { residentes no País a inviolabilidade } \\
\text { dos direitos concernentes à } \\
\text { liberdade, à segurança individual e } \\
\text { à propriedade, nos termos } \\
\text { seguintes: } \\
\text { (...) § } 17 \text { - O direito de propriedade } \\
\text { mantém-se em toda a sua plenitude, } \\
\text { salva a desapropriação por } \\
\text { necessidade ou utilidade pública, } \\
\text { mediante indenização prévia. } \\
\text { As minas pertencem aos } \\
\text { proprietários do solo, salvas as } \\
\text { limitações que forem estabelecidas } \\
\text { por lei a bem da exploração } \\
\text { deste ramo de indústria. }\end{array}$ & $\begin{array}{l}\text { Art. 115 - A } \\
\text { ordem } \\
\text { econômica } \\
\text { deve ser } \\
\text { organizada } \\
\text { conforme os } \\
\text { princípios da } \\
\text { Justiça as as } \\
\text { necessidades da } \\
\text { vida nacional, } \\
\text { de modo que } \\
\text { possibilite a } \\
\text { todos existência } \\
\text { digna. Dentro } \\
\text { desses limites, } \\
\text { é garantida a } \\
\text { liberdade } \\
\text { econômica. } \\
\text { Parágrafo único } \\
\text { - Os Poderes } \\
\text { Públicos } \\
\text { verificarão, } \\
\text { periodicamente, } \\
\text { o padrão de } \\
\text { vida nas várias } \\
\text { regiões do País. }\end{array}$ & $\begin{array}{l}\text { Art. } 135-\mathrm{Na} \\
\text { iniciativa individual, no } \\
\text { poder de criação, de } \\
\text { organização e de } \\
\text { invenção do indivíduo, } \\
\text { exercido nos limites do } \\
\text { bem público, funda-se a } \\
\text { riqueza e a prosperidade } \\
\text { nacional. A intervenção } \\
\text { do Estado no domínio } \\
\text { econômico só se } \\
\text { legitima para suprir as } \\
\text { deficiências da } \\
\text { iniciativa individual e } \\
\text { coordenar os fatores da } \\
\text { produção, de maneira a } \\
\text { evitar ou resolver os } \\
\text { seus conflitos e e } \\
\text { introduzir no jogo das } \\
\text { competições individuais } \\
\text { o pensamento dos } \\
\text { interesses da Nação, } \\
\text { representados pelo } \\
\text { Estado. A intervenção } \\
\text { no domínio econômico } \\
\text { poderá ser mediata e } \\
\text { imediata, revestindo a } \\
\text { forma do controle, do } \\
\text { estimulo ou da gestão } \\
\text { direta. }\end{array}$ & 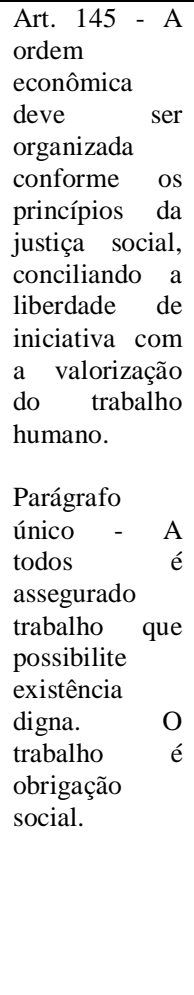 & 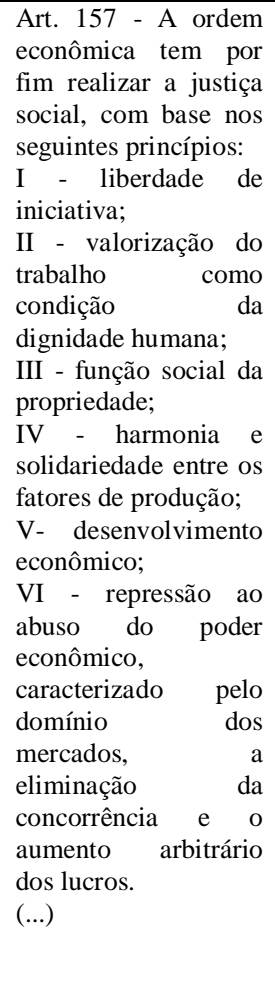 & $\begin{array}{l}\text { Art. 160. A ordem } \\
\text { econômica e social tem por } \\
\text { fim realizar }\end{array}$ & $\begin{array}{l}\text { Art. } 170 \text { A ordem } \\
\text { econômica, fundada na } \\
\text { valorização do trabalho } \\
\text { humano e na livre iniciativa, } \\
\text { tem por fim assegurar a todos } \\
\text { existência digna, conforme os } \\
\text { ditames da justiça social, } \\
\text { observados os seguintes } \\
\text { princípios: } \\
\text { I - soberania nacional; } \\
\text { II - propriedade privada; } \\
\text { III - função social da } \\
\text { propriedade; } \\
\text { IV - livre concorrência; } \\
\text { V - defesa do consumidor; } \\
\text { VI - defesa do meio ambiente; } \\
\text { VII - redução } \\
\text { desigualdades regionais } \\
\text { sociais; } \\
\text { VIII - busca do pleno emprego; } \\
\text { IX - tratamento favorecido para } \\
\text { as empresas brasileiras de } \\
\text { capital nacional de pequeno } \\
\text { porte.* } \\
\text { Parágrafo único. É assegurado } \\
\text { a todos o livre exercício de } \\
\text { qualquer atividade econômica, } \\
\text { independentemente de de } \\
\text { autorização de órgãos públicos, } \\
\text { salvo nos casos previstos em } \\
\text { lei. }\end{array}$ \\
\hline
\end{tabular}

Fonte: BRASIL. Constituições. Disponível em: <http://www.presidencia.gov.br/legislacao>. Acesso em: 5 out. 2008.

Redação dada pela EC no 42, de 19.12.2003: VI - defesa do meio ambiente, inclusive mediante tratamento diferenciado conforme o impacto ambiental dos produtos e serviços e de seus processos de elaboração e

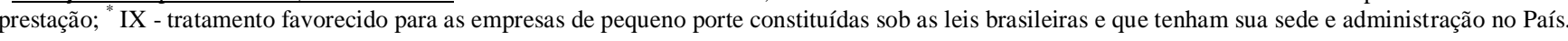

